\title{
NEGOTIATING THE NORTH
}

\section{MEETING-PLACES IN THE MIDDLE AGES IN THE NORTH SEA ZONE}

\author{
By \\ Sarah Semple, Alexandra Sanmark, \\ Frode Iversen, and Natascha Mehler
}

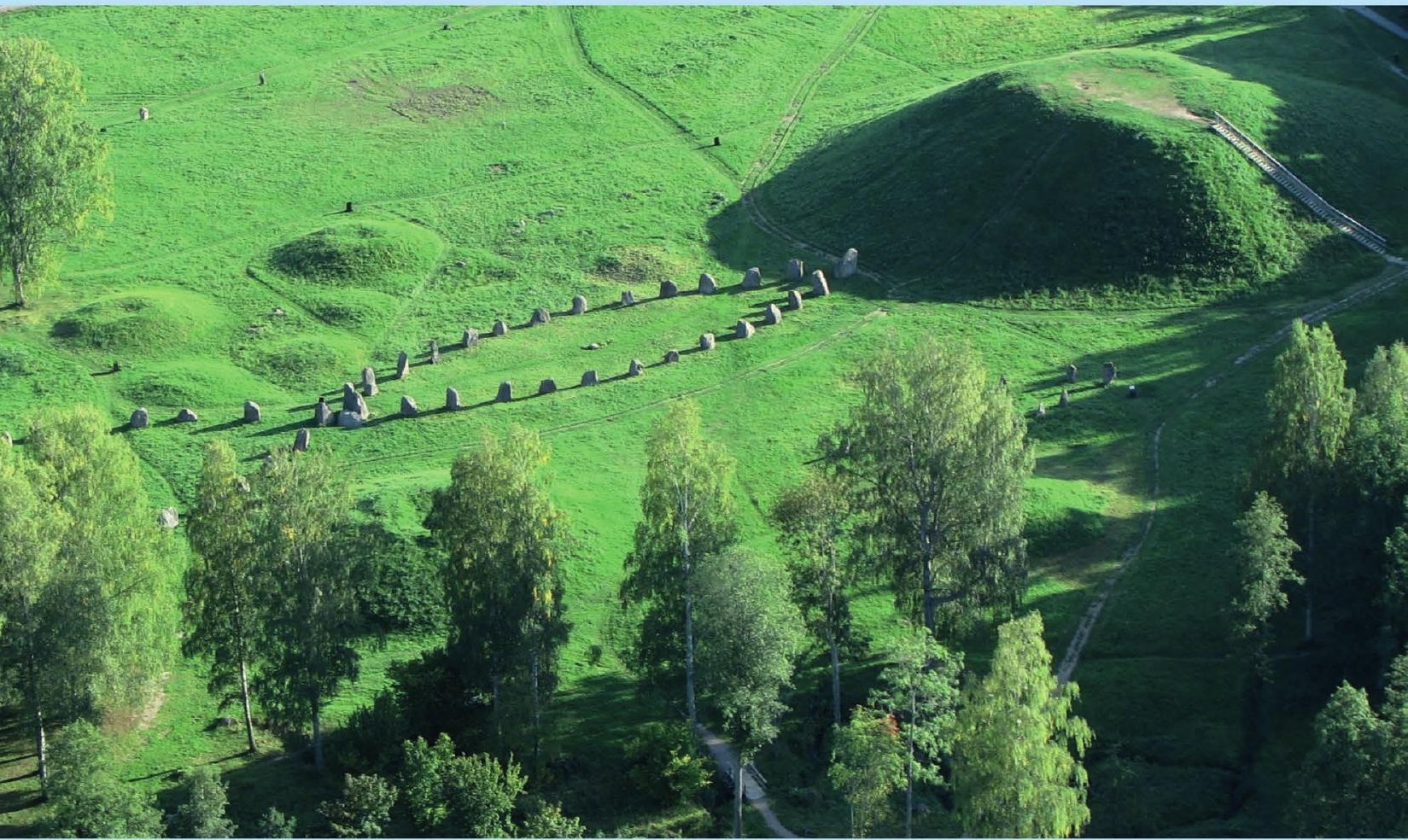

THE SOCIETY FOR MEDIEVAL ARCHAEOLOGY MONOGRAPH 4I
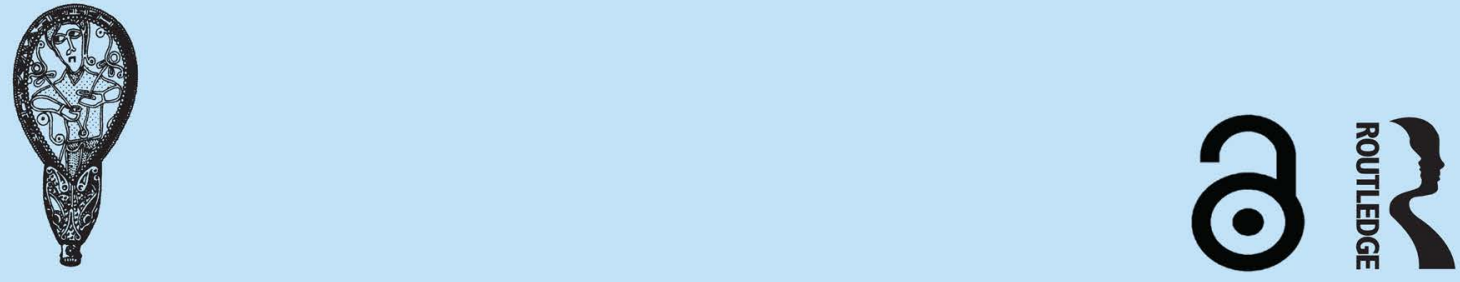


\title{
THE SOCIETY FOR \\ MEDIEVAL ARCHAEOLOGY MONOGRAPH $4 \mathrm{I}$
}

\author{
Series Editors \\ Alejandra Gutiérrez \\ Gabor THOMAS
}

NEGOTIATING THE NORTH:

MEETING-PLACES IN THE MIDDLE AGES

IN THE NORTH SEA ZONE 
First published 2021

by Routledge

2 Park Square, Milton Park, Abingdon, Oxon OX14 4RN

and by Routledge

52 Vanderbilt Avenue, New York, NY 10017

Routledge is an imprint of the Taylor \& Francis Group, an informa business

(C) 2021 Sarah Semple, Alexandra Sanmark, Frode Iversen, and Natascha Mehler; individual sections, the contributors

The right of Sarah Semple, Alexandra Sanmark, Frode Iversen, and Natascha Mehler to be identified as the authors of the editorial material, and of the authors for their individual chapters, has been asserted in accordance with sections 77 and 78 of the Copyright, Designs and Patents Act 1988.

The Open Access version of this book, available at www.taylorfrancis.com, has been made available under a Creative Commons Attribution-Non Commercial-No Derivatives 4.0 license.

Trademark notice: Product or corporate names may be trademarks or registered trademarks, and are used only for identification and explanation without intent to infringe.

British Library Cataloguing-in-Publication Data

A catalog record for this book is available from the British Library

Library of Congress Cataloging-in-Publication Data

A catalog record has been requested for this book

ISSN: 0583-9106

ISBN: 978-0-367-49311-0 (hbk)

ISBN: 978-1-003-04566-3 (ebk)

Publisher's Note

This book has been prepared from camera-ready copy provided by Sarah Semple, Alexandra Sanmark, Frode Iversen and Natascha Mehler

The Society for Medieval Archaeology

www.medievalarchaeology.co.uk

Cover: Aerial photograph of the thing site at Anundshög, the proposed early top-level assembly of Västmanland in Sweden. Photograph by Daniel Löwenborg 


\title{
NEGOTIATING THE NORTH: \\ MEETING-PLACES IN THE MIDDLE AGES IN THE NORTH SEA ZONE
}

\author{
By \\ Sarah Semple \\ Alexandra Sanmark \\ Frode IVErsen \\ and \\ Natascha Mehler
}

with

Halldis Hobæk, Marie Ødegaard and

Alexis Tudor Skinner

$202 \mathrm{I}$

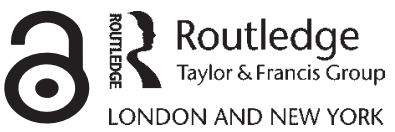


$\because$ Taylor \& Francis Taylor \& Francis Group http://taylorandfrancis.com 


\section{CONTENTS}

List of figures . . . . . . . . . . . . . . . . . . . vii Preface . . . . . . . . . . . . . . . . . . . . $x i$

Summary . . . . . . . . . . . . . . . . . . . . $x v$

Acknowledgements . . . . . . . . . . . . . . . . xvii

Abbreviations . . . . . . . . . . . . . . . . . . xviii

I Introduction. . . . . . . . . . . . . . . . . . . I

I.I Summary

I.2 Introduction

I.3 The thing

I.4 The value of studying early medieval assembly

I.5 The scope of this volume

2 Research histories . . . . . . . . . . . . . . . . . 24

2.I Summary

2.2 Genesis: Assemblies and national consciousness

2.3 Romanticism, nationalism and the thing

2.4 Research traditions I900 to present day

2.5 Conclusion

3 Methods and approaches. . . . . . . . . . . . . . 58

3.I Summary

3.2 Written sources

3.3 Mapping the thing

3.4 Limitations

4 Lawthings and inauguration sites in Scandinavia . . . . . . .7I

4.I Summary

4.2 Reconstructing the thing system in Scandinavia

4.3 The laws, law provinces and things

4.4 The provincial thing sites in Scandinavia

4.5 Royal inauguration sites in Scandinavia

4.6 Discussion

5 Landscapes of law in Norway . . . . . . . . . . . . I35

5.I Summary

5.2 Introduction

5.3 The Norwegian kingdom: The historic thing system

5.4 The Borgarthing law province

$5 \cdot 5$ Hålogaland law province

5.6 The Gulathing law province

$5 \cdot 7$ Conclusions 
6 Colonisation and control: Assembly systems in new territories . . I80

6.I Summary

6.2 Law and assembly in the Norse settlements

6.3 Iceland

6.4 Faroe Islands

6.5 Orkney and Shetland

6.6 The Danelaw

6.7 Discussion

7 Assembly and trade in Iceland and beyond . . . . . . 232

7.I Summary

7.2 Regulation and assembly in the Commonwealth Period

7.3 Regulation of trade in Iceland in the later Middle Ages

7.4 Trade and markets at the Icelandic local spring assemblies

7.5 Trade at the Icelandic general assembly of Pingvellir

7.6 The Icelandic model in context

7.7 Discussion

8 Things in the north . . . . . . . . . . . . . . 248

8.I Summary

8.2 The shadow of the past

8.3 Basic structures and beginnings?

8.4 Things in operation

8.5 Things in the landscape

8.6 Contemporary thing structures and features

8.7 Things in context

8.8 Kings, things and the church

8.9 Summary

9 Concluding thoughts . . . . . . . . . . . . . . 29I

Glossary . . . . . . . . . . . . . . . . . . . 299

Bibliography. . . . . . . . . . . . . . . . . 304

Index $\quad . \quad . \quad . \quad . \quad . \quad . \quad . \quad . \quad . \quad . \quad . \quad . \quad . \quad \cdot 34 \mathrm{I}$ 


\section{LIST OF FIGURES}

I.I Kingdoms/named political units in the north c. AD I IoO.

I.2 Late Iron-Age tribes in northern Europe, as described by Tacitus in the Ist century AD.

I.3 Altar dedicated to Mars Thincsus and the Divinity of the Emperor, discovered at Housesteads Roman fort, Northumberland, England.

I.4 Runic inscription attesting to the thing, Aspa Löt, Södermanland, Sweden.

I.5 The extent of Viking activity and interaction c. AD I IOO.

I.6 The site of Tynwald Hill, Isle of Man.

I.7 The Assembly Project research regions and the location of our investigations.

I.8 The documented terms for the different types of administrative districts across all geographic areas studied.

I.9 The documented terms for the different types of thing sites across all geographic areas studied.

2.I Jelling in Ole Worm's Danicorum Monumentorum Libri Sex published in I 643 .

2.2 The Forsa Rune Ring.

2.3 Pingvellir depicted in I79I, showing some booths.

2.4 The Stone of Destiny, used for the inauguration of English monarchs since its removal from Scone, Scotland, in I 296.

2.5 Pseudo-ancient monument at Abedare, Wales, constructed as a focus for the Gorsedd revival.

2.6 The assembly site at Árnes, Iceland.

2.7 Painting entitled 'Alping (Althing) in Session', I9th century.

2.8 The Thingstätte at Heidelberg, Germany.

2.9 The courtyard site at Leksaren at Reistad, Varhaug, Norway, was excavated by Jan Petersen I938-39. It was in use in around AD I00-600.

2.IO The arrangements at the thing. After Brink 2004a, 2 I0, fig. 9.2.

2.I I The medieval trading site of Gásir, northern Iceland, with booths and a church with circular enclosure.

2.I2 Early medieval English palace complexes associated with assembly.

3.I Norse terminologies for various things.

3.2 Example of map retrogression for Spellow Clump, East Riding, Yorkshire.

3.3 A site where excavation has revealed numerous hearths as well as standing monuments. Anundshög, Västmanland, Sweden.

3.4 LiDAR scan of the Law Ting Holm at Tingwall, Shetland.

3.5 List of attributes checked off at each site visit by The Assembly Project team.

3.6 Example of a photographic palimpsest. I 80-degrees viewshed from the thing site í Køtlum in Norðuroyar.

4.I The law provinces of Sweden and Norway with the top-level assemblies.

4.2 The extent of the Law of Uppland.

4.3 The law province of Hälsingland. 
4.4 Shifting assembly practices in Västmanland, Sweden.

4.5 Aerial photograph of the thing site at Anundshög, the proposed early toplevel assembly of Västmanland.

4.6 $3 \mathrm{D}$ reconstruction of the Anundshög-site.

4.7 The top-level assembly sites of the four lands of Hälsingland.

4.8 Map of Gamla Uppsala illustrating how the site was enclosed by a combination of the wooden monuments, watercourses and wetlands, as well as burials.

4.9 Suggested locations for the top-level thing sites of Attundaland.

4. IO Ullunda ('the grove of the god Ull'), just west of modern Enköping, Sweden.

4.I I The location of the top-level assembly at Roma, Gotland.

4.I2 Tingvalla, the top-level assembly in Värmland, Sweden.

4.I3 Law provinces of Denmark with the top-level assemblies.

4.I4 Lund, Sweden, and its surroundings.

4.I 5 Law provinces of Denmark with the top-level assemblies identified and labelled.

4.I6 St Benedict's Church, Ringsted, Denmark.

4.I7 Seven or eight coastal towns in Norway partly or wholly attracted the functions of the rural lawthing.

4.I 8 View of the Gulathing.

4.I9 Two large stone crosses may originally mark out the 'thing peace' area at the Gulathing.

4.20 Stemnebø on the nearby island of Hisarøy, Norway.

4.2 I Eide farm, Norway.

4.22 The Frostathing.

4.23 Sigar's mound.

4.24 Frösön in Jämtland, Sweden.

4.25 The Eidsivathing law province prior to c. I 250.

4.26 The location of Mora thing in relation to the three folkland units of Uppland with their respective assemblies.

4.27 Mora thing.

4.28 The royal route of the Eriksgata through medieval Sweden with the toplevel assembly sites and handover points along the route.

4.29 Denmark's landsthings, also used for inaugurations.

4.30 'The thing stones' (Tingstenene), located just outside St Benedict's Church in Ringsted, Denmark.

4.3 I Map of I 804 showing a straight road leading from the town of Hamar towards Disen and Åker, Norway. It may or may not be an old processional road.

4.32 Map of I7I2 showing the medieval jurisdiction of Hamar town.

5.I Patria or law provinces of coastal Norway: The coastal and mountain lands and the land of the Sámi.

5.2 Model showing the tiered relationships between named types of administrative unit in Norway.

5.3 The sýsla districts and the county-churches of the Borgarthing. 
5.4 The law districts c. I 200, divided into four fylkir (counties), with the thing sites mentioned in the text located.

5.5 The Borgarthing law province, divided in four law districts each with a law district thing connected to the towns or the administrative centres of Skien, Tønsberg, Oslo and Konghelle.

5.6 A detailed study of nine skipreiður in Borgarsýsla (present-day Østfold).

5.7 Thing sites in the skipreiður in Viken, Norway.

5.8 Lunde cooking-pit site under excavation, Norway.

5.9 A sequence of radiocarbon dates obtained from excavations of 30 pits at Lunde in Vestfold, Norway.

5.IO Location of the excavation of the southern mound at Haugathing, Norway.

5.I I Dates obtained from the excavation of the southern mound at Haugathing in 20I2, and those from Gansum's excavations of the northern mound in I994.

5.I 2 The thing site of Berg, in Eiker skipreiða in Oslosýsla, Norway.

5.I3 The site at Kolberg, Norway.

5.I4 Hålogaland law province.

5.I 5 The landscape of Steinsfjorden, Vestvågøy, Lofoten, Norway.

5.I6 The remains of the courtyard site of Vollmoen at Steigen, Norway.

5.I7 Approximate view from the courtyard site at Gimsøy, towards the Hoven mountain. Vikspollen in the front.

5.I 8 The Bjarkøy courtyard site.

5.I9 The three original fylkir of the Gulathing law province, with the four areas of land that made up the fjórðungar of Horðafylki.

5.20 Toponymic evidence places the assembly at Tønjum (Sygnafylki) within the settled area.

5.2 I Tingvikjo with Tingholmen, Føyno, is interpreted as a local assembly site.

6.I Map of Iceland with I7 potential assembly sites and other potential assembly sites with the background of the quarter division.

6.2 View over Pingvellir, Iceland.

6.3 A booth at Pingey, Iceland, during excavation in 2005 .

6.4 Map of Pingvellir, Iceland, with surveyed ruins and excavated areas.

6.5 Ruins of the assembly site at Hegranes, Iceland.

6.6 Alleged dómbringur at Pingeyrar, Iceland.

6.7 Resistivity survey at Pingeyrar.

6.8 Early and late assembly sites in the Faroe Islands and the six administrative sýsla districts.

6.9 The assembly site at Tórshavn on Streymoy.

6. Io Inscription at Tinganes, Tórshavn, showing the letters P and I and the year I 589 .

6.I I The assembly site at Millum Vatna on Sandoy in the Faroe Islands.

6.I 2 The Stevnuválur assembly site on Eysturoy in the Faroe Islands.

6.I3 The assembly site at í Køtlum in Norðuroyar in the Faroe Islands.

6.I 4 Thing sites in Shetland, Scotland, in their respective 'thing parishes'.

6.I 5 Thing sites in Orkney, Scotland. 
6.I6 Dingieshowe, thing site located on a narrow isthmus, Orkney, Scotland.

6.I7 The causeway at Tingwall, Shetland.

6.I 8 Law Ting Holm, Shetland, during excavation in $20 \mathrm{II}$.

6.I9 Tingwall in Orkney.

6.20 Maeshowe, the Neolithic chambered tomb that may have been the focus for the top-level thing, Orkney.

6.2 I Results of the geophysical survey at Housa Voe, Papa Stour, Shetland.

6.22 Approximate boundary of the Danelaw, highlighting the location of the Ridings of Yorkshire.

6.23 Wapentake and hundred territories in the Ridings of Yorkshire, c. Io86.

6.24 Documented assembly sites in the Ridings of Yorkshire.

6.25 Place-name attested assembly sites in the Ridings of Yorkshire.

6.26 Halikeld, one of several springs with this name south of Melmerby, North Yorkshire, associated with the eponymous wapentake.

6.27 Spell Howe depicted on the Second Edition 6-inch Ordnance Survey.

6.28 The Rudston Monolith, within the churchyard of All Saints, Rudston, East Riding of Yorkshire.

7.I Map of Iceland with spring assembly sites and trading sites of the Viking Period and Middle Ages.

7.2 Booth remains at Pingeyri in the West Fjords, Iceland.

7.3 View of the area where Vadlaping was once located, at the mouth of the River Eyjafjarðará, Iceland.

7.4 The possible remains of a jetty at Eyjafjarðará, Iceland.

7.5 View over Maríuhöfn (also known as Búðasandur), a seasonal trading site near Pingvellir, Iceland.

7.6 Plan and digital terrain model of the trading site Maríuhöfn (or Búðasandur) in Hvalfjörður, Iceland, after a geophysical survey carried out in 2015.

7.7 Digital terrain model of the ruins of Veøy, Møre and Romsdal county, Norway.

7.8 Tingwall, Shetland, and neighbouring trading sites of Laxfirth and Scalloway. 


\section{PREFACE}

The volume brings together the cumulative results of a three-year project on assembly in northern Europe. The Assembly Project was funded by Humanities in the European Research Area (HERA) and was initiated in June 2010 and completed in November 2013. Four connected strands of work were led independently by Prof. Frode Iversen (University of Oslo), Dr Natascha Mehler (University of Vienna), Dr Alexandra Sanmark (University of the Highlands and Islands) and Prof. Sarah Semple (Durham University). In addition, the project hosted three PhD studentships: Halldis Hobæk (University of Bergen), Marie Ødegaard (University of Oslo) and Tudor Skinner (Durham University). Together the team has investigated the role of assembly in the processes of kingdom creation and state formation in northern Europe. Individual Project I (IPI) (Iversen, Hobæk and Ødegaard), examined how royal power established regularised administrative systems in new subordinated provinces and conquered kingdoms in the Scandinavian homelands. IP2 (Semple and Skinner) created a historiographical basis, setting a critical context and agenda for the project. IP2 also explored the administrative patterns of authority within the Danelaw, using Yorkshire as a casestudy. $\mathrm{IP}_{3}$ (Mehler) examined the economic activities of thing sites and their effects, focusing on economic activities, such as trade and crafts at or near thing sites and $\mathrm{IP}_{4}$ (Sanmark) investigated thing organisation and assembly sites in Scandinavia and in the areas of Norse settlement and colonisation in the west. The project was hosted and administered by the University of Oslo.

Four workshops took place across 20IO-I3 (see below), involving the team and invited participants from across eight European countries: At Durham (England, UK) in January 20I I, Utstein (Norway) in November 20I I, Kirkwall, Orkney (Scotland, UK) in September 20I 2 and Hall, Tyrol (Austria) in April 20I3. Invitees were asked to share their research with the project and interim results were disseminated for discussion. Many of the papers have subsequently been published in two Special Issues of the Journal of the North Atlantic (Vol. 5, 20I3 and Vol. 8, 2015/20I6).

In addition, field investigation mostly led by Natascha Mehler and Joris Coolen took place across eight locations in the North Sea zone and involved the project team and external specialists. Combined field survey, geophysics and excavation facilitated in-depth analysis of specific sites and locales. These on-site investigations enabled the refinement of chronologies and provided insight into the locational aspects of meeting-places and associated activities. These investigations have been published as separate grey literature reports and are available online (http://www.khm.uio.no/english/research/projects/previously-projects/assemblyproject/). In some instances, the results have been published in their own right (Coolen and Mehler 20I4).

This volume offers the combined, final results, setting a broad and deep critical context. The focus is the assemblies and administrative systems of Scandinavia and Britain. We have interrogated a wide range of historical, 
cartographic, archaeological and onomastic data pertaining to early medieval and medieval administrative practices, administrative geographies and places of assembly in Norway, Sweden, Denmark, Iceland, the Faroe Islands, Scotland and in the county of Yorkshire in England which was once part of the Danelaw. Assembly in medieval Ireland was not part of our project remit and is not present in this book in terms of original research, case studies or fieldwork. Assemblies and inauguration sites and administrative levels of organisation in early medieval Ireland have been subject to a number of extensive, excellent and independent studies (e.g. Warner I988; 2004; FitzPatrick 2004a; Gleeson 201 5; 2018). Thus in this volume we acknowledge and use Irish comparanda based on this published body of work. We assess the historiography of assembly studies in Ireland alongside England and Scotland in Chapter 2 and we return to the Irish evidence in our discussion to provide context and comparison. Likewise, while evidence suggests that the thing was exported to Greenland by the Norse, our project did not undertake original on-the-ground research and fieldwork in this location. Alex Sanmark has pursued the evidence for the establishment of assembly sites on Greenland and in this book we draw on her work and the evidence from Greenland, especially in Chapter 6, to provide further context for the ways in which the thing was exported as part of the Norse colonisation of unpopulated regions.

As a team and through our workshops we have created a new level of European cooperation and by sharing our datasets and results have opened up our networks and knowledge to each other and to a broader scholarly community. This has benefitted the outcomes of the project by faciliating a transnational perspective on the early development of power structures in early medieval northern Europe and the maturation of these systems in later centuries under royal control.

Finally this is a multi-authored book that reflects the integrated work of the team. The authorage reflects the contribution of its members. Alexandra Sanmark and Frode Iversen were instrumental contributors to Chapter 4, and Chapter 5 draws primarily on the work of Frode Iversen, Marie Ødegaard and Halldis Hobæk. Chapter 6 was written by Alexandra Sanmark, Natascha Mehler and Alexis Tudor Skinner, and Chapter 7 by Natascha Mehler. Chapters I, 2 and 9 were written by Sarah Semple, and Chapter 3 by Sarah Semple and Alex Sanmark Chapter 8 was completed by Sarah Semple, Alex Sanmark and Natascha Mehler with contributions by Frode Iversen. Sarah Semple led the drafting, development, editing and completion of the volume as a whole.

TAP Workshops and Participants 20I0-I3

\section{Durham, UK. January 20 I I \\ Valorisation and rhetoric: Situating assembly studies}

John Baker, Institute for Name Studies, School for English Studies, University of Nottingham. 
Stuart Brookes, Institute of Archaeology, University College London.

Stephen Driscoll, Dept of Archaeology, University of Glasgow.

Halldis Hobæk, Dept of Archaeology, Museum of Cultural History, University of Oslo.

Frode Iversen, Dept of Archaeology, Museum of Cultural History, University of Oslo.

Natascha Mehler, Dept of Prehistory and Historical Archaeology, Vienna University.

Marie Ødegaard, Dept of Archaeology, Museum of Cultural History, University of Oslo.

Ingvild Øye, Dept of Archaeology, History, Cultural studies and Religion, University of Bergen.

Dean Paton, Dept of History and Archaeology, University of Chester.

Anne Irene Riisøy, Dept of Teacher Education, Buskerud and Vestfold University College.

Andrew Reynolds, Institute of Archaeology, University College London.

Alex Sanmark, Centre for Nordic Studies, University of the Highlands and Islands.

Sarah Semple, Dept of Archaeology, Durham University.

Tudor Skinner, Dept of Archaeology, Durham University.

\section{Utstein, Norway. November 20 I I}

Territorialisation and the migration of administrative frameworks

Orri Vésteinsson, Dept of Archaeology, University of Iceland.

Frode Iversen, Dept of Archaeology, Museum of Cultural History, University of Oslo.

Sarah Semple, Dept of Archaeology, Durham University.

Natascha Mehler, Dept of Prehistory and Historical Archaeology, Vienna University.

Nanna Løkka, Telemark University College.

Endre Elvestad, Stavanger Sjøfartsmuseum.

Ulf Jansson, Dept of Human Geography, Stockholm University.

Tudor Skinner, Dept of Archaeology, Durham University.

Ola Svensson, Linnéuniversitetet in Växjö.

Halldis Hobæk, Dept of Archaeology, Museum of Cultural History, University of Oslo.

Marie Ødegaard, Dept of Archaeology, Museum of Cultural History, University of Oslo.

Orkney. September 2012

Societal norms: Control and mediation

Alex Sanmark, Centre for Nordic Studies, University of the Highlands and Islands. Anne Irene Riisøy, Dept of Teacher Education, Buskerud University College.

Caspar Ehlers, Max-Planck-Institut für europäische Rechtsgeschichte. 
Frode Iversen, Dept of Archaeology, Museum of Cultural History, University of Oslo.

Halldis Hobæk, Dept of Archaeology, Museum of Cultural History, University of Oslo.

Katy Cubitt, Dept of History, University of York.

Marie Ødegaard, Dept of Archaeology, Museum of Cultural History, University of Oslo.

Patrick Gleeson, Dept of Archaeology, University of Cork.

Sarah Semple, Dept of Archaeology, Durham University.

Tudor Skinner, Dept of Archaeology, Durham University.

\section{Hall, Tirol, April 2013}

Economic Identities and Collective Activities

Stuart Brookes, Institute of Archaeology, University College London.

Joris Coolen, Dept of Prehistory and Historical Archaeology, Vienna University.

Elizabeth FitzPatrick, School of Geography and Archaeology, National University of Ireland, Galway.

Adolf Friðriksson, Fornleifastofnun Íslands, Reykjavík.

Frode Iversen, Dept of Archaeology, Museum of Cultural History, University of Oslo.

Natascha Mehler, Dept of Prehistory and Historical Archaeology, Vienna University.

Marie Ødegaard, Dept of Archaeology, Museum of Cultural History, University of Oslo.

Halldis Hobæk, Dept of Archaeology, Museum of Cultural History, University of Oslo.

Sarah Semple, Dept of Archaeology, Durham University.

Tudor Skinner, Dept of Archaeology, Durham University. 


\section{SUMMARY}

Assembly places and practices are fundamental to our understanding of how medieval society in Northern Europe was transformed from a network of smallscale local power structures to a competing system of large kingdoms with royally driven administrative infrastructures. Assembly was an institution present in a variety of shapes and forms in different parts of the North Sea zone in the Ist millennium $\mathrm{AD}$ and provided an arena within which authority and power could be negotiated, consolidated and extended. Assemblies varied in size and purpose. Some facilitated powerful royal theatre, some enabled dialogue between different tiers of authority; others gave voice to all individuals permitted to attend. Some took place regularly and others were one-off events, but all were intrinsic to peace-keeping and the regulation and maintenance of the laws in medieval society. Some were vital to military mustering and others served economic purposes. The origins of these gatherings are unknown; there are clear Late Iron-Age antecedents in the archaeological record and some rare mentions of late prehistoric assembly traditions in Roman accounts of territories within and beyond imperial control. Organised meetings and assemblies as a form of governance in the localities appear in the written record in various parts of early medieval northern Europe between the 6th and I 2 th centuries, often, as elements of seemingly fully formed legal and political frameworks. The focus of our project and this book is the thing: The documented Scandinavian medieval institution for governance and justice. We have also researched and explored similar institutions in Britain and tracked the export of the thing to new inhabited and uninhabited regions. Drawing on three years of research, fieldwork and collaborative and comparative work, The Assembly Project has aimed to establish a critical understanding of the role of the thing institution and its cognates in the consolidation and maintenance of collective identities and emergent polities and kingdoms in Scandinavia and other Northern European regions. Our team, including researchers and $\mathrm{PhD}$ students from the UK, Norway and Austria have collaborated on three broad objectives:

- To understand how authority was articulated in landscape terms in the medieval North, and to explore the bottom-up and top-down processes that resulted in local mechanisms for consensus and control,

- To create a cohesive account of the development of administrative systems within early- and late-medieval Britain and Europe, taking account of the impacts and effects of Norse colonisation in several regions,

- To assess how assemblies were valorised in European perceptions in the early modern and modern era, and how certain viewpoints were promoted then and now. 
Our methods and combined results are set out in the chapters that follow. By undertaking comparative work across eight regions, using a strict methodological framework and a common Geographic Information System (GIS), we have been able to open up the question of the emergence of complex society in Northern Europe to broader and deeper scrutiny. The project has allowed us to understand far more precisely how assemblies and their place in administrative frameworks helped facilitate the emergence of complex political units in Europe, enabling authorities to maintain and govern them. Some 20 papers and two themed journal volumes, three completed $\mathrm{PhD}$ projects, as well as this book, represent the results of our dialogues, workshops, research and field investigations. 


\section{ACKNOWLEDGEMENTS}

The project has been well served by a wide range of collaborators and we are grateful to numerous organisations and individuals. In the first instance we would like to thank all those who have participated in elements of the project and shared data or offered constructive input in terms of research and fieldwork: Símun V. Arge, Føroya Fornminnissavn (Faroe Islands National Heritage), Orri Vésteinsson, Háskoli Î́slands, Adolf Friðriksson, Fornleifastofnun Íslands, Mjöll Snæsdóttir, Fornleinfastofnun Íslands, Val Turner, Shetland Amenity Trust, Brian Smith, Shetland Museum and Archives, Ian Tait, Shetland Museum and Archives, Joris Coolen, Zentrum für baltische und skandinavische Archäologie Schleswig, Ronny Weßling, Department of Prehistory and Historical Archaeology, University of Vienna, Mathias Hensch, Schauhütte Regensburg, Ingvild Øye, Department of Archaeology, History, Cultural Studies and Religion, University of Bergen, Karen Ørbog Oftedal, Vestfold Fylkeskommune, Julie Karina Øhre Askjem, Vestfold Fylkeskommune, Terje Gansum, Vestfold Fylkeskommune, Ludwig Bolzmann Institute for Archaeological Prospection and Virtual Archaeology, Norsk Institutt for Kulturminneforskning (NIKU), Sofie Scheen Jahnsen, Martin Baar-Dahl, Ronny Kvarsnes, Hege Skalleberg Gjerde.

We would also like to thank the following specialists for commenting on draft articles and text for this volume: Stuart Brookes, Institute of Archaeology, University College London; Thomas Lindkvist, Professor Emeritus, Department of Historical Studies, University of Gothenburg; Helle Vogt, Centre for Studies in Legal Culture, University of Copenhagen; Orri Vésteinsson, Háskoli Î́slands, University of Iceland; and Símun V. Arge, Føroya Fornminnissavn, Faroe Islands National Heritage. We also thank our two peer-reviewers, Dr Tom Moore, Durham University, and Dr David Griffiths, Oxford University, for their extensive and insightful comments that greatly helped us strengthen the volume.

We would also like to thank Knut Paasche, Ludwig Bolzmann Institute for Archaeological Prospection and Virtual Archaeology, Norsk Institutt for Kulturminneforskning; EDINA and the Ordnance Survey, and Fredrik Sundman for permission to reproduce images in this volume. Illustrations in the following chapters have been created by Brian Buchanan, Tudor Skinner, Joris Coolen and Yvonne Beadnell and are acknowledged accordingly. The index to the volume was prepared by Pam Scholefield.

Finally we would like to offer our thanks to the Humanities in the European Research Area for the funding that enabled our project and resulted in a lasting collaboration between the team and many of those attending our workshops. We additionally thank the National Environmental Research Council (NERC) and the Airborne Research and Survey Facility for a grant that provided us with LiDAR data of the Tingwall valley, Shetland, in 20 I . 


\section{ABBREVIATIONS}

References:

$\mathrm{AB}$

Akts no st hist

ASC

ÄV

B

Caesar

CL

DD

DF

DI

DL

DN

DRW

Egs

F

Flat.

Fornsök

G

Germania

GL

HE

$\mathrm{HH}$

Aslak Bolts jordebok (Jørgensen I997).

Aktstykker til de norske stondermøders historie I548-I66I, vol I (Johnsen I929).

Anglo-Saxon Chronicle (Swanton 2000).

The Older Law of Västergötland (Holmbäck and Wessén 1946).

Borgartings eldre kristenrett (Halvorsen and Rindall 2008).

Caesar. The Conquest of Gaul (Handford I95I).

Chronicon Lethrense (Gertz I9I7-18).

Diplomatarium Danicum, Det danske sprog- og litteraturselskab (I938).

Diplomatarium Faeroense: Føroyskt fodnbrcevasavn I (Jakobsen I907).

Diplomatarium Islandicum (I8 57-I972).

The Law of Dalarna (Holmbäck and Wessén 1936).

Diplomatarium Norvegicum (I 846).

Deutsches Rechtswörterbuch (I9I2).

Egils saga Skallagrimssonar (Jónsson I886-88).

The Law of the Frostathing (Larson I935).

Flateyjarbok: En samling af Norske Konge-sagaer (Vigfússon and Unger I 860-68).

The Archaeological Sites and Monuments database of The National Heritage Board in Sweden <http://www.raa.se/cms/fornsok/start.html> [accessed May 2016].

The Law of the Gulathing (Larson 1935).

Tacitus. Germania (Rives I999).

Gutalagen (Holmbäck and Wessén I943).

Historia Ecclesia Gentis Anglorum (Sherley-Price I968).

Hist Archbishops H-B Adam of Bremen. History of the Archbishops of Hamburg-Bremen (Tschan 2002).

$\mathrm{Hkr}$ Heimskringla, Snorri Sturlasson (Hollander 1964).

$\mathrm{HL}$ The Law of Hälsingland (Holmbäck and Wessén 1940).

$\mathrm{J}$ Jordabalken: Regulations regarding land.

KLNM Kulturhistorisk Leksikon for Nordisk Middelalder (Andersson and Granlund 1956-78).

L Rural Law of Magnus the Law-mender, Lagabøtes Landslov Old Norse edition: Den nyere Lands-Lov, utgiven av Kong Magnus Haakonsson. NgL II, I-I 78 (Taranger I9I5).

LoF Lover og forordningar I 536-I605 (Winge I988).

M Manheldgsbalken: Regulations regarding murder.

MEL The Law of Magnus Eriksson (Holmbäck and Wessén 1962).

MGH MGH Scriptores, Vita Lebuini antiqua (Hofmeister 1976 [I926-34]). 
NG

$\mathrm{NgL}$

NgL I

NgL II

NgL III

NgL IV

NHD

NLR

NRR

NRJ

ÖG

PAS

R

RB

RN

$\mathrm{S}$

Saxo

S1

SD

SDHK

SL

SmL

SRD

Sö

$\mathrm{Tj}$

U

UL

VL

YVG

Other:

Lat.

MDan

ME

MGerm

Norske Gaardnavne oplysninger samlede til brug ved matrikelens revision I-XIX (I 833-99).

Norges gamle Love indtil I387, I-5 (series editors Keyser, Munch, Storm and Hertzberg I 846-1895).

Norges gamle love indtil I387, I (Keyser I 846).

Norges gamle love indtil I387, II (Keyser and Munch I 848).

Norges gamle love indtil I387, III (Keyser and Munch I 849).

Norges gamle love Indtil 1387 , IV (Storm I885).

Norske Herredags-Dombøger Første til Fjerde Rokke I893-1959 (Thomle et al. I966-72).

Norske lensrekneskapsbøker I 548-67, vol I-7, Riksarkivet 1937-43, Oslo.

Norske Rigs-Registranter, vol I-2 (Lange et al. I86I-9I).

Norske Regnskaber og Jordebøger fra det I6. de Aarhundrede, vol I-4 (Huitfeldt-Kaas I887-I906).

The Law of Östergötland (Holmbäck and Wessén I933).

Portable Antiquities Scheme, United Kingdom, <www.finds.org.uk> [accessed April 2017].

Rättlösabalken [pr: prologue].

Biskop Eysteins Jordebok (Den røde Bog), Fortegnelse over det geistlige gods i Oslo Bispedømme omkring Aar I400 (Huitfeldt-Kaas I879).

Regesta Norvegica I-I I (I989-2016).

Sawyer number. Online catalogue of Anglo-Saxon Charters <www. esawyer.org.uk> [accessed April 20I7] (see also Sawyer I968).

Saxo Grammaticus. Gesta Danorum (Friis-Jensen and Fisher 2015).

Slagmålsbalken: Regulations regarding fights.

Shetland Documents, I, II95-I 579 (Ballantyne and Smith I994; I999).

Diplomatarium Suecanum <https://sok.riksarkivet.se/sdhk> [accessed August 2016].

The Law of Södermanland (Holmbäck and Wessén I940).

The Law of Småland (Holmbäck and Wessén I946).

Scandinavian Runic-text Database, Samnordisk runtextdatabas, <http:// www.nordiska.uu.se/forskn/samnord.htm8> [accessed August 20I6].

Södermanland, Sweden (used in reference to entries in the SRD).

Tjuvbalken: Regulations regarding thieves.

Uppland, Sweden.

The Law of Uppland (Holmbäck and Wessén I933).

The Law of Västmanland (Holmbäck and Wessén I936).

Younger Law of Västergötland (Holmbäck and Wessén I946).

Latin

Middle Danish

Middle English

Middle German 


$\begin{array}{ll}\text { MIr } & \text { Middle Irish } \\ \text { MNorw } & \text { Middle Norwegian } \\ \text { MSw } & \text { Middle Swedish } \\ \text { Mod Dan } & \text { Modern Danish } \\ \text { Mod Engl } & \text { Modern English } \\ \text { Mod Faroese } & \text { Modern Faroese } \\ \text { Mod Germ } & \text { Modern German } \\ \text { Mod Icel } & \text { Modern Icelandic } \\ \text { Mod Norw } & \text { Modern Norwegian } \\ \text { Mod Sw } & \text { Modern Swedish } \\ \text { ODan } & \text { Old Danish } \\ \text { OE } & \text { Old English } \\ \text { OFranc } & \text { Old Frankish } \\ \text { OIcel } & \text { Old Icelandic } \\ \text { OIr } & \text { Old Irish } \\ \text { ON } & \text { Old Norse } \\ \text { ONorw } & \text { Old Norwegian } \\ \text { OSw } & \text { Old Swedish } \\ \text { OW } & \text { Old Welsh } \\ \text { r. } & \text { reign }\end{array}$




\section{CHAPTER I INTRODUCTION}

\section{I.I SUMMARY}

This chapter introduces the volume and reviews current core knowledge regarding the development of the thing. This is set against a brief contextual overview of the major changes of the Ist millennium AD in the North Sea world. Our research aims and questions are introduced and the value of studying medieval assembly is discussed along with the approaches and methods that have proved successful in recent times. Relevant terminologies and classifications are also explained.

\section{I.2 INTRODUCTION}

At the end of the Ist millennium AD, some 20 major supra-regional kingdoms existed across Europe (Leciejewicz and Valor 2007, 70) (Figure I.I). Some of these were loosely defined and some would change and disappear, but at this time three existed in Scandinavia: Norway, Sweden and Denmark. Across the North Sea, Anglo-Saxon England had emerged as a unified entity in resistance to the extension of Danish power (Hadley 2008). Scotland was divided: Alba existed as a political entity, but northern and western parts of Scotland were under Norse rule (Driscoll 2002, 33-39). In the west of Scotland, the Norse lost authority during the I 2 th and I 3 th centuries, while the Northern Isles remained part of the Norwegian kingdom until the mid-I 5 th century (Crawford I987; 20I3; Imsen 20I4). In Ireland, the rise of numerous powerful dynasties such as the Uí Néill had resulted by Io०० in some ten over-kingdoms (Edwards I990, 8), while six survived in Wales (Redknap 2000, fig 27).

Many of these kingdoms were governed using systems in which assembly-both royal and popular - was integral to the processes of negotiation, achieving consensus and exercising authority. Assemblies took many forms: they could comprise 'national' gatherings, exemplified by the Icelandic althing, or might be discriminatory in terms of membership, like the Anglo-Saxon royal council or (OE) witan (Loyn I984, IOII02). These gatherings might encompass fairs, sport, and serve ecclesiastical purposes as well as political and legal ends (Barnwell 2003, I). In early medieval Ireland a three-fold hierarchy of kings is suggested as early as the $5^{\text {th }}$ century AD (Gleeson 20I5, 33; Ó Corráin 20IO, 284-286), served at each level or scale in the hierarchy by a place associated with inauguration and a locus of assembly (Gleeson 2017a). The (OIr) óenach, possibly the most important type of gathering within this system, convened by the king on 'royal land/estates', functioned as a political assembly and market-fair, with games and horse-racing (Byrne I973, 30-3I). Equivalent popular 


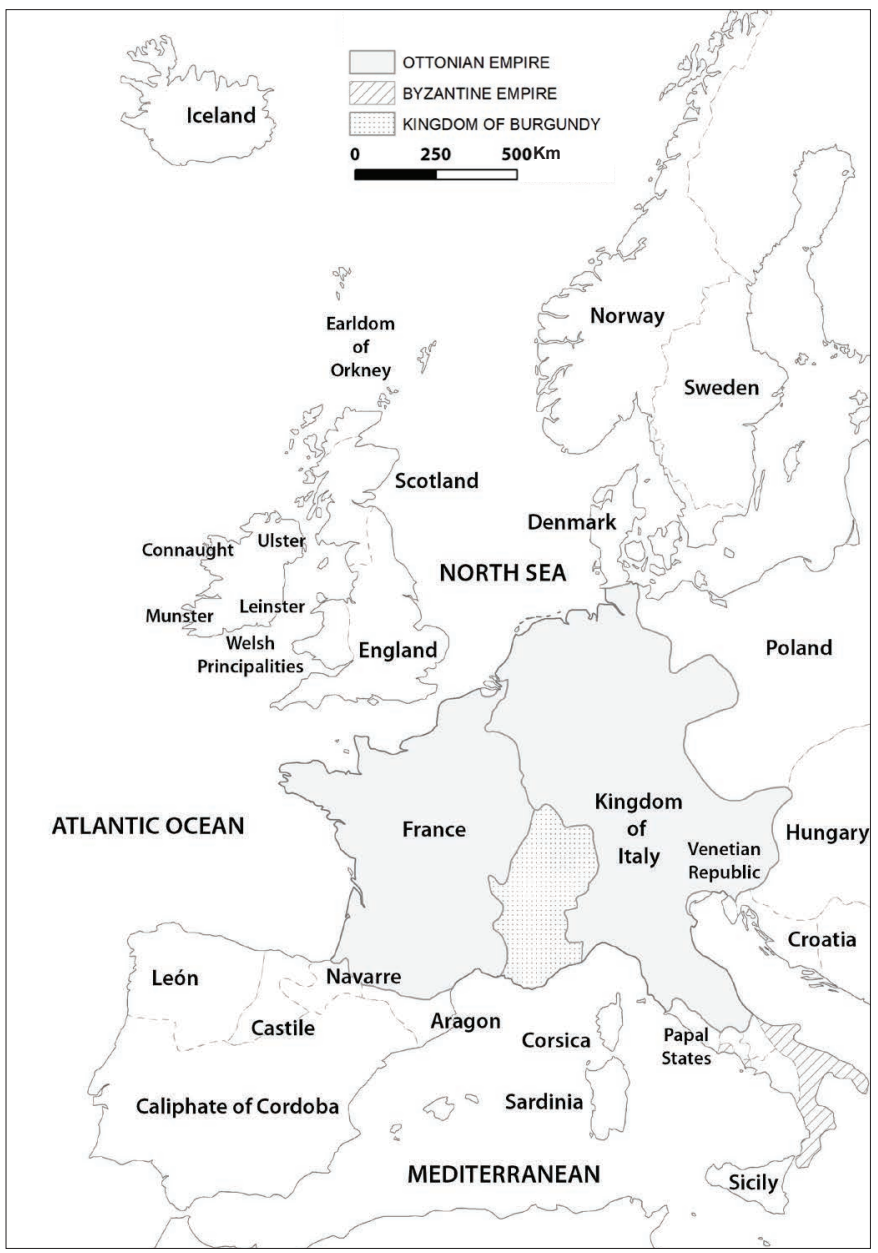

FIGURE I.I Kingdoms/named political units in the north $c$. AD IO००. Map drawn by Tudor Skinner.

and provincial conventions elsewhere include the meetings of the Anglo-Saxon shire and the Scandinavian thing (Barnwell 2004, 234), all of which served freemen, landholders and aristocrats. In England, the shire court was composed, in name at least, of the freemen of the shire and was presided on by earls and bishops, but dealt with affairs of the community including land claims and the collection of geld (Loyn I984, I38-I40). The more frequent hundred court in England served the localities, dealing with the vast majority of routine business, in particular the hearing and settling of disputes (Loyn I984, I40-I4I).

Assembly was intimate to the land-holding systems of a region. Traditionally the English hundred meeting served a hundred, a unit considered to represent a district of around Ioo/I 20 hides of land (Anderson I934, 2), with a hide thought to equate to 
around I 20 acres and represent 'the land farmed by, and supporting, a peasant family' (Faith I 999, 238-239). Notably the Welsh word cantref, for the divisions relevant to the administration of law in medieval Wales, is also thought to derive in part from the Old Welsh for 'a hundred'. The Irish (OIr) trícha-cét or 'thirty-hundreds' is argued convincingly as a land-holding unit of considerable antiquity in Ireland (Cotter 2005, 308), although multiple assembly sites on occasion suggest a 'sub-trícha-cét' structure as well (Gleeson 2015, 37). The (OFranc) mallus in Francia, which belonged to the same family of meeting, was an assembly that served the centena (Lat.) or 'bundred' and dealt with issues of theft, reclamation of property and even 'instances of homicide' (Barnwell 2004, 242). While some consider the mallus to have functioned as a 'legal court' (Murray I986; I988), the evidence in fact points to a broader portfolio, with consideration of criminal and civil matters, the witnessing of transactions and the making of public announcements (Barnwell 2004, 234-235).

The equivalent secular institution for assembly and justice in Scandinavia was the thing: a 'multi-functional venue for discussion and determination of any matter of communal concern' (Vogt and Esmark 2013, I 52). The thing was instrumental to the acceptance of new kings and the regulation of political and economic relations between the king and the people. By I I 50, a regulatory thing system existed in Scandinavia that, in common with the administrative framework in late Anglo-Saxon England and 6th17 th-century Francia, was multi-tiered with at least two, if not three, levels of activity (see Chapters 4 and 5). The thing is intimately connected to land-holding and land division. At the local level in Norway, Denmark and Sweden, the bundred or (ON) herað, ${ }^{\mathrm{I}}$ skipreiður and skiplagh units all had their own assembly site. In Norway, there were also regional assemblies for the $(\mathrm{ON})$ fylki (county) and $(\mathrm{ON})$ priðjungsping and fjóroungsping that served respectively, the thirds and quarters of the fylki. ${ }^{2}$

In addition, in many of these regions, assemblies were also held as part of king-making processes. The great royal sites in Ireland, such as Tara (Co. Meath) and Rathcrogan (Co. Roscommon) appear in the medieval literature as places of inauguration ritual and assembly, while rites involving outdoor inauguration rituals can be tracked in Ireland right through to the I6th and I7th centuries (FitzPatrick 2004a). In Scotland, important centres such as Dunadd and Scone may have been used for these kinds of meeting, particularly by the Ioth and I Ith centuries (Driscoll I998; O'Grady 20I8). In England we know that by the late Anglo-Saxon era, public outdoor events, assembly and ceremony were central to exercising power including inauguration rituals (Barrow 200I; Roach 20I3; Semple 20I3). Royal inaugurations were a specific kind of assembly in medieval Scandinavia and the physical relevance and proximity of inauguration sites to the thing is more pronounced than in other regions. This is evident in the correspondence, at least in some areas, between the medieval locations of top-level provincial assemblies and places of inauguration (see Chapter 4). Sometimes direct relationships are evident with inauguration taking place at the medieval landsthing or, as in Sweden, where inauguration sites were linked to top-level thing sites by designated routes used for royal itineraries and travel

I (ON) herað has been translated as hundred, as it was a local adminstrative unit equivalent to the English bundred although the herað did not refer to Ioo units of land.

2 This was not the case, however, for the Borgarthing area in Norway where, it seems, the quarter thing represented the smallest or lowest level of administration (see Chapter 5). 
(Chapters 4 and 6; Sanmark 2009). In Ireland 'assembly' refers to a suite of 'royal' places active in the Iron-Age and medieval eras (Gleeson 20I8, IOI). These might be royal caputs, popular assemblies or inauguration sites, and sometimes a place might fulfill all of these functions, but more often than not these different meeting-place functions were spatially discreet (Gleeson 20I8, IOI). Inauguration sites are thus explored in this book alongside provincial assembly and administrative structures, but in line with our focus on the thing, we examine evidence for inauguration sites in Scandinavia within our research on the emergence and development of administrative systems and meeting-places.

Traditionally, the study of assembly and the administrative structures and land-holding arrangements they served, has taken place within national scholarly discourse (see Chapter 2). Studies of power and territorial arrangements in early medieval Ireland have, for example, largely been explored in isolation from similar work on England, with arrangements in each viewed as separate traditions (although see FitzPatrick 2004a, 5I-52; Gleeson 2018, IO0-IO4). Conversely, the assemblies and administrative arrangements of Francia and Anglo-Saxon England and the thing system in Scandinavia have been compared and argued to represent systems rooted in the Germanic-speaking societies of the Late Iron-Age and Migration period (see Chapter 2). Others have proposed, however, that the Frankish centena may owe much more to 'the military and administrative life of the Roman province taken over by Merovingian kings...' (Murray I988), while Romano-British land-holding structures are posited, in a recent discussion, as an instrumental factor in the shape of Anglo-Saxon systems of administration (Oosthuizen 2016). Even in Ireland, recent scholarship has begun to point to a potential for imperial influences in early medieval strategies of power and lordship in the early medieval era (Gleeson 201 5, 37).

These scholarly tensions and divisions often reflect different schools of thought and cultural preconceptions of assembly and administration as 'indigenous' to a particular region or set of peoples. Some ideas arise particularly out of the prominent and problematic place of assembly, governance and law in I9th- and early 2othcentury historical and antiquarian studies, which considered assembly conventions as intrinsic to the rise of early political and national identities (see Chapter 2). Similarities of arrangements, terminologies and conventions were once thought to suggest a common Germanic root for the thing, the hundred, the mallus etc. and the administrative arrangements they served. Assemblies were presented as 'folkmoots', '...in which the democratic instincts of free Germanic peoples were given full expression' (Loyn I984, IOI; and this volume Chapter 2). In these schools of thought, assembly was considered a late prehistoric Iron-Age development, attested in the writings of Roman historians who made mention of the use of large decision-making gatherings by the inhabitants of territories beyond the Roman frontiers (see Pantos and Semple 2004 b, II-I 8). As time has passed, however, this academic position has changed in some national discourses. As early as I906-I3, for example, there were concerns about connecting royal councils and other formalised modes of assembly in early medieval societies with the Tacitean 'folk-moot' (Liebermann I898-I9I6). In England, as a result, scholarship has tended to favour discussions of operation and process, rather than conjecture on the pre- or proto-historic origins of the open-air assembly (see Wormald I999, 24-28; and Chapter 2). 
In considering the regulatory assemblies of the Early Middle Ages in Northern Europe, however, it must be remembered that the archaeological record demonstrates that gatherings and assemblies operated as mechanisms within emerging complex arrangements in prehistory in many regions of the world. Traditions of temporary gatherings at set places in the landscape existed in hunter-gatherer, pastoral and agricultural societies. Set landmarks, such as stone outcrops, offered 'predictable, immovable' places for mobile hunter-gatherer populations to assemble at and return to (Miller et al. 20I8). In south-eastern Arabia, where mobility and temporary sites were a feature throughout late prehistory, sites like Saruq al-Hadid attest to large temporary meeting-places operating over the longue durée for the purpose of exchange and production (Weeks et al. 2018; Wilkinson 2003, I08). The so-called megasites of the 4th millennium BC in the Ukraine, such as Nebelivka, operated as massive temporary seasonal settlements with gatherings of thousands of households for suprahousehold level collaboration and activity, production and ritual action, military and political purposes (Nebbia et al. 2018). To this we might add the tradition of causewayed enclosures in Neolithic Europe, where ditched enclosures were created in the landscape for group and seasonal activities, for example the so-called Sarup sites in Denmark, located in elevated places, central to farming communities and used, perhaps for gatherings and ritual action (Andersen 2004, I4-I6). More than merely locations for seasonal trade, exchange or ritual, however, it is clear that temporary gatherings could play a significant catalytic role in territorial development, with meetings both connecting and diversifying communities, providing opportunities for cooperation and alliance that might drive growing political complexity (Reynolds 20I8; Semple 20I8; Swenson 20I8). Assemblies could play regulatory roles as well, setting and enforcing modes of behaviour within and across communities (Ugwuanyi and Schofield 2018).

One of the key problems in the study of assembly practices in the Early Middle Ages in Europe, therefore, is a lack of recognition of the deeper timeframe in which gatherings have proved instrumental in emergent complex societal structures. Another limitation is the treatment of assembly in geographic isolation. The hundred meeting or the thing, for example, tend to be discussed as a novel phenomenon of the Late Iron-Age to early medieval eras, confined to some Northern European societies. If we look a little deeper in time, however, prehistorians working on the European Iron Age have been arguing for quite some time for similar principles and have been drawing on some of the same, difficult, Roman written accounts pertaining to IronAge communities beyond imperial frontiers. In the European Iron Age meeting and gathering processes are evident in the archaeological record. The development of oppida in Gaul, for example, while traditionally connected with the implementation and control of large-scale production, is a phenomenon now considered symptomatic of a new 'technology of power' (Fernández-Götz 20I4a, 379-380). Such sites hosted large open spaces that could house fairs, assemblies and religious ceremonies (FernándezGötz 20I2). At Titelberg in Luxembourg for example, the excavated evidence suggests fairs and markets, probably seasonally and religiously timetabled, throughout the Ist century BC (Fernández-Götz 20I2; 20I4a, 379-380). Oppida were also places for assembly and negotiation. Julius Caesar's account of the Gallic Wars implies their use for large group assemblies and decision-making meetings resulting, for example, 
in the election of leaders (Caesar. Bello Gallico VII, 33, 55, 63). The imperial influence on these populations is also evident. The establishment of oppida with large public spaces, and in the Gallo-Roman period, structures interpreted as voting installations, similar to those found in Italian cities, is demonstrative of the importing of imperial ideas of space, consensus and governance (Fernández-Götz 20I2; 20I4a; 20I4b). At Corent in France, the Gallo-Roman oppida ultimately developed into a centre with urban functions, a market, temple and Roman-style theatre etc. Excavations produced evidence of an earlier timber theatre, dating to the ist and 2nd centuries $\mathrm{BC}$, which in size, form and design is argued to be more appropriate to public gatherings and assembly (Poux 20I2, I77-I9I). Here the evidence may attest to an intersection between existing Iron-Age traditions of assembly and Roman styles of assembly architecture. In southern Britain, around the same time, evidence suggests that extensive and complex polyfocal landscapes were performing similar assembly functions (Moore 20I2; Moore et al. 2013). Multiple enclosures and ditches were created that related to both animal management and, potentially, the management of human engagement, activity and experience. As areas used for large seasonal congregations, rather like the kinds of ceremonial gathering places in Ireland (Newman 2007); ditches, routes and monuments may have directed and managed gatherings in terms of human and animal movement and experience (Moore 20I 2). Such monument complexes are suggested as indicators of the more fluid social structures of Late Iron-Age Britain, symptomatic of the kinds of negotiations necessary to a mobile and seasonally driven society, reliant on animal resource, but at the same time representative of an important development in the staging of power as larger social groups formed (Moore 2012; Moore et al. 2013).

The types of assembly organisation examined in this volume are therefore not unique to Scandinavia, nor indeed early medieval Europe, rather the opposite. Assembly plays a part in all societies, literate and non-literate, in varying formats (see Fenger I999, 52; Malinowski I926; Sanmark 20I7a, 4-6). While the more structured locations and formats for assemblies in terms of political and ritual roles in Late Iron-Age Gaul were perhaps influenced by imperial formats, as congruent Iron-Age traditions demonstrate in England, the demands of a mobile and seasonally-driven population could prompt similar processes that carried a distinctive architecture and function.

The largest body of written evidence for the Scandinavian thing as an administrative and legal institution is medieval to late medieval in date, but is considered to build on long-standing legal traditions and oral law, which over time were subject to continuous development and change. T J Chevral (T L Thurston), in particular, has argued in regards to Denmark for increased complexity in the Iron Age, with the assembly as a pivotal component, initially in the regulation of elite power, but by the Viking Age, significant to the development of elite control and influence over law (Thurston 200I). Chevral draws, as others have, on the accounts by Roman writers to establish the long pedigree of assembly in Denmark and its strength as a mediating force on rulership in the Iron Age (Thurston 200I, 88, 45-48, 52). As discussed above, the Bello Gallico describes the assemblies that Caesar learned of while campaigning in Gaul in the mid-Ist century BC, but his accounts also describe assemblies to the north, beyond the northern frontiers of the Roman Empire. The text describes how the Suebi, when threatened by the Romans at a crossing on the Rhine, 
called a concilium (Lat.), which was their tradition, and ordered the evacuation of the local populace (Caesar. Bello Gallico IV, 2). A century later, another Roman text was set down that described the activities and lives of the Germanic peoples inhabiting the regions beyond the frontier between the Rhine, Vistula and Danube (Tacitus. Germania) (Figure I.2). In Germania, Publius Cornelius Tacitus describes elements of legal custom, including fines imposed by the assembly. The source also describes how designated principes (Lat.) (perhaps chieftains) (Schulze 2004, 3I), were appointed at these gatherings to uphold the law and that they could decide on minor matters, but were expected to defer major disputes to the assembly (Germania XI). In a later chapter, delegates representing kin-groups living between the rivers Elbe and Oder are described as annually meeting outdoors in a sacred grove (Germania IV, IX). While Germania is a text that must be treated with caution given its Roman pedigree (Pagán 20I2; Rives I999), it is a well established and accepted source in Scandinavian scholarship for the Iron Age (Thurston 200I, 45). Scholars argue for its accuracy in terms of information on artefacts, and social structures (Hedeager I992), and consider it an ethnography for the peoples beyond the Roman frontier in the Netherlands, Germany, Belgium and southern Scandinavia (Thurston 200I, 45-46). These sources are without question important, but should not be seen as an exact and homogenous representation of Iron-Age society. The hints of early formal mechanisms for group decision-making at an early point in northern regions, however, remain important.

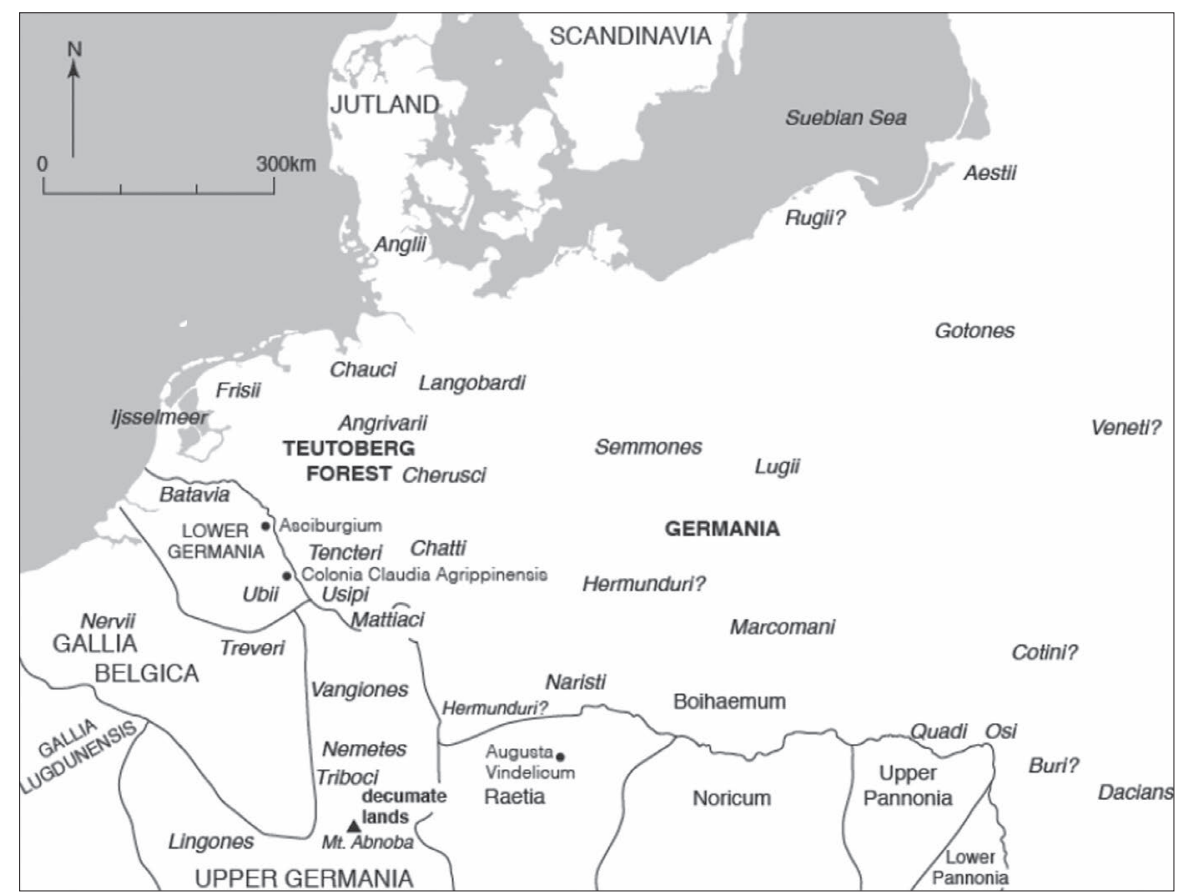

FiguRE I.2 Late Iron-Age tribes in northern Europe, as described by Tacitus in the Ist century AD. Drawn by Yvonne Beadnell. After Mattingly I970, Map 3. 
The case for the early development of the thing institution and linkage to these Late Iron-Age assembly sites is compelling if the linguistic origins and usage of the word ping are taken into account. Ping exists in all of the Old Germanic languages including Old Norse; it can be translated as 'a gathering in a certain place, at a certain time' (Hellquist 1980, 974; Iversen 2013) and shares a common root with the gothic word peihs which meant both 'time' and 'to constrict' (Bjorvand and Lindeman 2007, I I 5 I-52). In Francia the main official presiding at the mallus in the 6 th/ 7 th centuries was termed (OFranc) thunginus; a word that some consider may share a relationship with ping (Barnwell 2004, 243-244), although others dispute this. In England, (OE) ping had an early usage too, appearing in the 7 th-century laws of Hlothere and Eadric (Pantos 2004a). An even earlier indirect usage of the term apparently occurs in a $3 \mathrm{rd}$ century inscription on an altar from Housesteads Roman Fort in Cumbria (Wenskus I984, 443; Iversen 20I3, IO-I I). This can be translated as 'To the god Mars Thincsus and the two Alaisiagae, Beda and Fimmilena, and the divine spirit of the emperor, the German tribesmen from Tuihantis willingly and deservedly fulfill their vow' (Ireland 2009, I 84) (Figure I.3). The dedication is by soldiers from the current area of Twenthe in the eastern Netherlands and Thincsus (Thincso Lat.) appears to be a reference to a hybrid deity, suggested (along with Beda and Fimmilena) as protectors of the thing (Gutenbrunner I936, 24-40). Later sources, relating to Neustria, Austria and Saxony and East Frisia, including place-names and written accounts demonstrate usage of the Old Germanic term ping (Talbot I954). This accumulated evidence for shared assembly terminologies within the regions north of the Roman frontier, and their use by several Germanic-speaking groups, implies the thing may well have been an early and familiar facet of life for these Late Iron-Age populations.

Whether the shire in England, the (OIr) óenach in Ireland and the thing in Scandinavia and all other comparable emerging administrative structures of the Ist millennium $\mathrm{AD}$ had their origins in similar Iron-Age assembly traditions remains uncertain. The deciding factor that differentiates the types of assemblies evident in the early medieval record from the gatherings attested in late prehistory by archaeological evidence or Roman written accounts, is the greater regulatory role of early medieval meetings and the hierarchical frameworks they operated in. Late prehistoric assemblies, in the few documentary accounts that survive, seem to have been concerned with group decisions with regional and supra-regional implications, such as electing leaders, debating military action or even evacuating regions (see above). By contrast, early medieval assemblies in the localities by the end of the Ist millennium $\mathrm{AD}$, such as the shire and hundred, thing, were distinctive in that they operated within structures linked to local, supra-local and regional land divisions. They played, in these capacities, an instrumental legal role in keeping the peace and upholding customary law and regulating local activity.

These differences could, of course, be an artifice of documentary survival. The early medieval assembly is far better documented, appearing in a burgeoning number of written sources, which are frequently connected to legal activity (see below). Its more precise modes of operation, at local and supra-local levels, and the hierarchical assembly frameworks that existed, are, potentially, simply better recorded than the operations of any potential prehistoric forerunners. Distinctions, therefore, between the assemblies operating in the immediate centuries $\mathrm{BC}$ and $\mathrm{AD}$ outside the Roman 


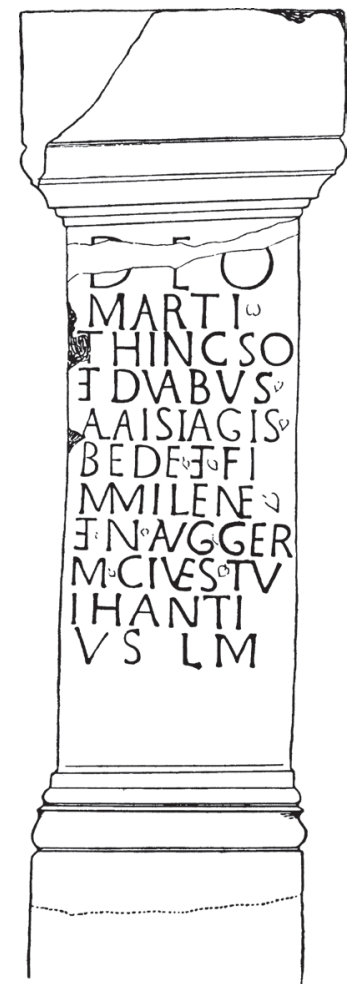

FiguRE I.3 Altar dedicated to Mars Thincsus, the Alaisiagae, and the Divinity of the Emperor, discovered at Housesteads Roman fort, Northumberland, England. Roman Inscriptions of Britain no. I 593. CC BY 4.0 .

frontiers and within conquered provinces, and the prescribed regulatory activities of the hundred or thing in northern Europe by the end of the Ist millennium AD, may lie largely in the sharp inequality of surviving written accounts. It is worth remembering in this context that in the brief accounts we have, Tacitus does attribute legal power to the assemblies of Germania, describing the assembly as competent to hear and pass judgement on criminal charges (Germania XII). He also describes how elected officials at the assembly then administered justice in 'the districts and villages' (Germania XII).

The limited evidence, however, means it is simply not possible to equate the concilia (Lat.) described by Caesar or Tacitus with the Scandinavian or Germanic medieval thing, and it is perhaps imprudent to try. The varying types of late prehistoric assembly discussed above are strongly rooted in the lifestyles and lifeways of the communities that used and developed them and they are demonstrably different in terms of locales, architecture and function. Such large decision-making events play well with the assertion that Late Iron-Age societies were more heterarchical in nature and elite power was regulated and restrained by the collective power of the ordinary populace (Thurston 200I; 20I0). Early medieval populations will have been equally influenced by their landscapes and lifeways, leading to similar kinds of variation in assembly protocol and setting. The relatively rapid development in certain regions in the Ist millennium $\mathrm{AD}$ of named kingdoms attests to the emergence of more 
complex socio-political structures. This complexity may have resulted in a burgeoning bureaucracy with assembly becoming more structured and regulatory to serve, rather than moderate, elite needs.

\section{I.3 THE THING}

The early centuries of the Ist millennium AD were a time of significant change in northern Europe. The collapse of Roman authority and large-scale movements of people in the $4^{\text {th }}$ and $5^{\text {th }}$ centuries created a de-stabilising effect. Massive environmental impacts, arguably resulting in significant social and ideological changes, also seem to have been caused by a major volcanic disaster around the mid6th century (Gräslund and Price 20I2). In this period of uncertainty, disruption, displacement and competition, mechanisms for justice and consensus may have been particularly necessary and rapidly adapted or adopted at local levels. As these upheavals began to dissipate, elites campaigned to win larger and more extensive territories in the regions around the North Sea. In the 6th to 8th centuries, chiefdoms and large kingdoms were established governed by dynastic lineages. The command of larger territories with a multiplicity of smaller groupings required new ruling strategies on the part of kings and chiefs. Law-making and enforcement appear at this time in writing: part of the ideological package that seems to have accompanied these elite groups, with the first early medieval laws committed to writing at the orders of leaders of new confederacies and kingdoms. These codes are largely concerned with keeping the peace and dispute settlement and some of the first assemblies mentioned in the form of regional or local regulatory meetings appear in these written documents underscoring an integral relationship between the development of assembly and law.

Lex Salica (the earliest Frankish civil law code) was created around AD 486-507 'for the sake of keeping peace' among the Franks and their leaders (Vauchez and Lapidge 2000, I50; Wormald I999, 40). The first Visigothic law code set down c. AD 466-484, provides an amalgam of earlier laws made by Theoderic I c. AD 4I9-45I (Wormald I999, 40), while the Lex Romana Burgundionum can be placed in the early 6th century (Wormald I999, 38). While these codes owe a debt to a desire for romanitas on the part of the early barbarian kings, the centrality of feud and feud resolution in these codes is argued to make them irrefutable products of the Germanic world (Wormald I999, 39). In Francia, the laws of Clovis (Lex Salica) attest to the business of the mallus as early as the 6th century (Barnwell 2004, 233-244). In England, the very first written laws of the 6th century, attributed to King Æthelberht of Kent [AD 550-6I6/589-6I6] (HE ii, 5; trans Wormald I999, 29) with improvements and additions from Hlothere (AD 673-685) and Eadric (AD 685-686), include in their regulations the need for keeping the peace at an assembly. It is not until the Ioth century, however, that the regular arrangements in England of the shire and hundred courts are fully described (Loyn I984, I33, I40).

In Scandinavia, the setting down of law in writing occurred far later, beginning in the IIth or I2th centuries, although surviving manuscripts date above all from the I3th century onwards. Just like their European counterparts, however, the Scandinavian peoples without doubt held long established oral legal traditions that influenced their first written laws (contra Sjöholm I988 and I990; see instead Bagge 
I989; Brink 2002; Helle 200I; Stein-Wilkeshuis I998; Sanmark 2004, I33-I46). The early mentions of the thing in Scandinavian written sources appear in skaldic poetry, which dates broadly to c. AD 900-I 400 (Myrvoll 20I4). Among the earliest references is the $(\mathrm{ON})$ vápnapingi-the weapon thing-cited in Lausavisur. The poem is attributed to the Icelandic skald, Egil Skallagrimsson (c. AD 900-983) (Jónsson I9I2, 44). Runic inscriptions also provide testament to the existence of the thing as early as the I Ith century (Semple and Sanmark 20I3) (Figure I.4) and by I I 5O, administrative documents describe the existence of the regulatory thing system in Norway, Denmark and Sweden with at least three levels of activity (see Chapters 4 and 5). The laws, legislation and assembly practices recorded in the High Middle Ages in Scandinavia are argued to evolve from these earlier arrangements (Brink 2002; Stein-Wilkeshuis I998), testifying to the evolution of an 'indigenous' and long-lived insular legal and assembly system in Scandinavia across the Ist to 2nd millennia AD (Brink 2004a, 206).

The later export of the thing to other territories created new dynamics and influences and may well have changed how law and the thing operated. The colonisation by the Norse of the coastal margins of the North Atlantic and Irish Sea occurred in the last centuries of the Ist millennium (see Barrett 2004; Crawford I987) (Figure I.5). Place-name and documentary evidence from these regions suggests that Scandinavian law and the thing institution were implemented in these new regions. But these were often populated places, that hosted existing modes of local organisation and assembly. In the Danelaw, for example, a portion of northern and eastern England, was ceded to Danish control in c. 878 (see Hadley 2008); this Danelaw had legal autonomy (Whitelock I979, 435-436) and was divided into wapentakes or local law districts (ON vápnatak, 'taking of weapons') served by things. Not only does this help in corroborating the existence of an evolving legal and assembly system in the Scandinavian homelands, the process of exportation also demonstrates the way in which the thing was introduced into some regions where legal systems were already in place. In eastern England, the new Scandinavian legal and administrative system was imposed on existing populations and arrangements (Hadley 2008, 375; Stenton I97I, 504-505). As later chapters will show, the pre-existing administrative pattern seems to have had an influential effect in shaping the new framework, suggesting perhaps that there was significant enough synergy with existing administrative arrangements to allow an easy superimposition (see Skinner 2014; and Chapter 6).

In contrast, Iceland was a largely uninhabited landscape when Norse colonisation began in the 9th century (Sigurðsson 2008b, 57I-572). By the Ioth century a pattern of administrative organisation was in place, and a central assembly, the althing, had been founded at Pingvellir (Sigurðsson 2008b, 572-573). Iceland's medieval legislation had strong Norwegian links and Iceland became part of Norway in I 262 (Dennis et al. I980, I; Imsen 2015). It provides some of the richest written source material for early legal arrangements and practices in the form of the laws of Grágás, 'The Book of Settlements' and the sagas. Establishing relationships between these written accounts and on-the-ground archaeological evidence for assembly is somewhat more challenging. Many antiquarians made claims regarding visible features - both natural and human altered-linking them with named places and people in the early written accounts (see Chapters 2, 6 and 7). Many of these identifications of sites and features are now in question (Friðriksson and Vésteinsson I992; Friðriksson 1994). 


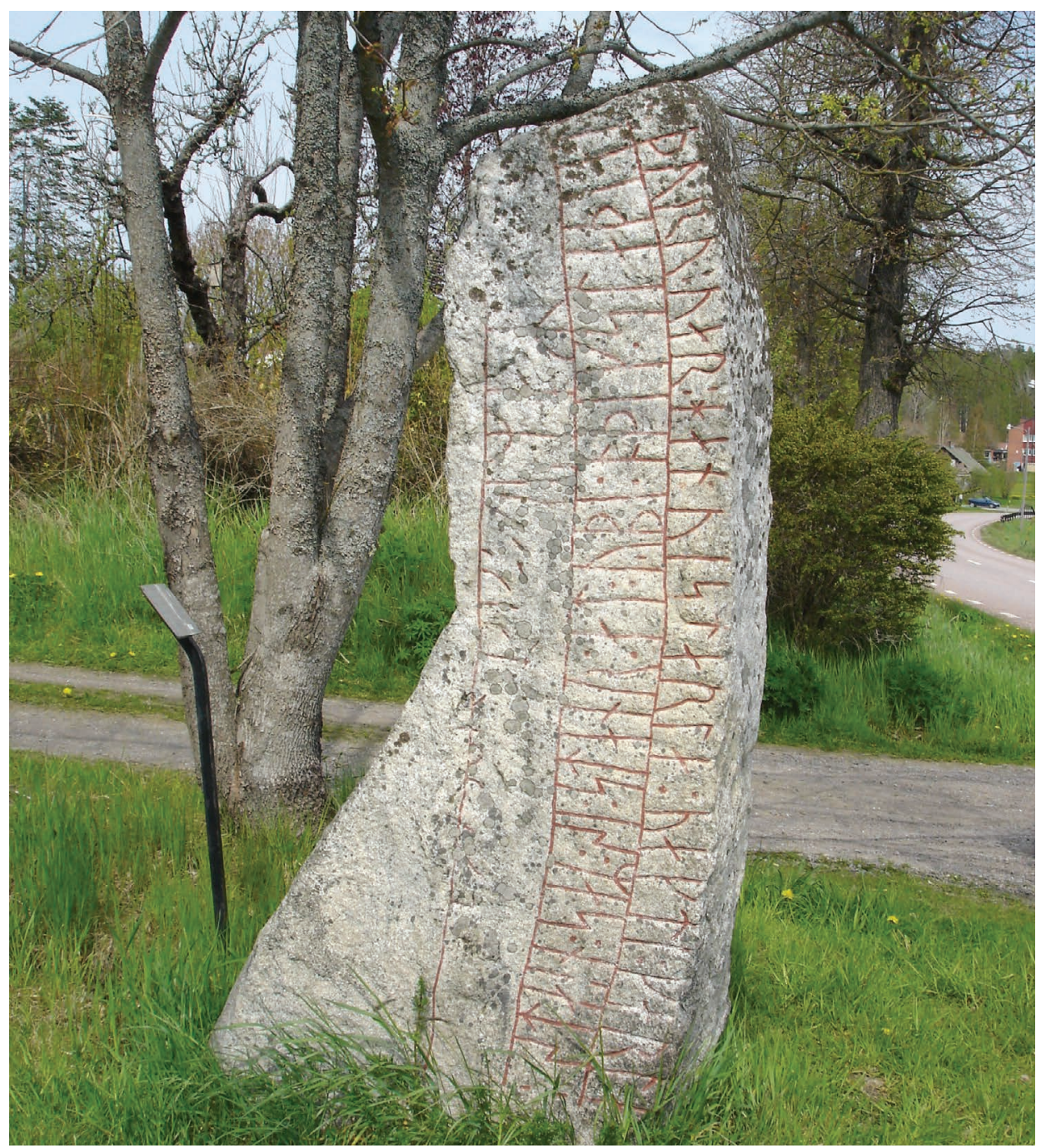

FIGURE I.4 Runic inscription attesting to the thing, Aspa Löt, Södermanland, Sweden. Photograph by Alexandra Sanmark.

\section{Sö 137}

\$A pura : raispi : stin : $\mathrm{p}-$-si at : ubi : buanti : sin

\B : stain : saR:si : stanr : at : ybi : o pik*stapi : at II : puru : uar : han : uestarla : uakti : karla II [sa par] * sunr pap * traknasuatau(k)i(f)maR[sua]

\A Pora rceispi stcein $p[a n n]$ si at $\varnothing p i$, boanda sinn.

\B Stceinn saRsi standr at Øpi a pingstaði at Poru ver. Hann vestarla veknti(?) karla, sa paR sunR pað...

\A Póra raised this stone in memory of CEpir, her husbandman.

\BThis stone stands in memory of CEpir, on the assembly place in memory of Póra's husband. He armed(?) (his) men in the west. The son saw this there... 


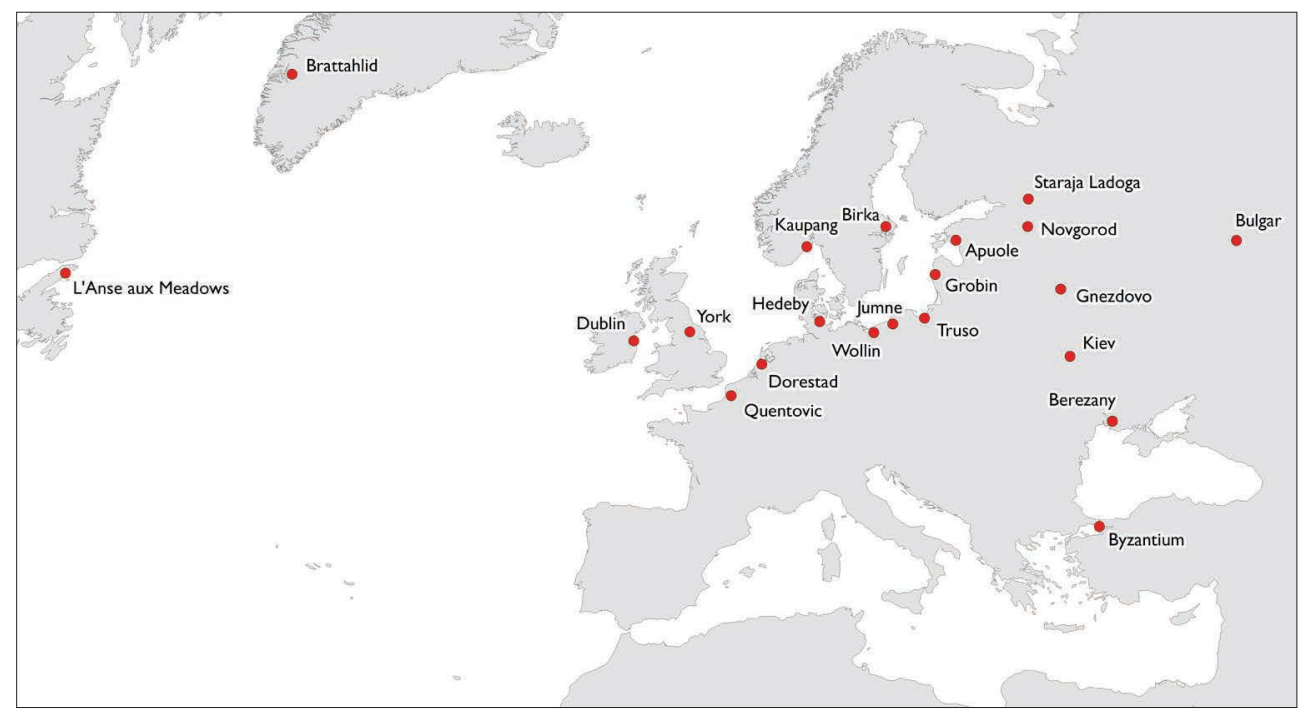

FiguRE I.5 The extent of Viking activity c. AD I IOo, marked out by important trading centres and sites. Map by Tudor Skinner.

Similar types of 'assembly' site are identified in Greenland. Here written accounts intimate similar practices of assembly in the I 4 th century, and at least two sites can be suggested as seasonal things (Sanmark 2010).

In Scotland, the thing system seems to have been introduced across all areas of Norse settlement during the 9th to I 2 th centuries. Place-name evidence above all, shows that thing sites were present in the Northern Isles of Orkney and Shetland, Caithness, Ross, Dumfries and the Hebrides (Sanmark 20I7b). The societies that emerged in Orkney, Shetland, the Faroe Islands, Greenland and Iceland were called (ON) skattland (also skattland in modern usage), tributary lands subordinate to the Norwegian king. The term skattland is first recorded in the time of King Magnus the Law-Mender ( $\mathrm{AD}$ I 238-I280), but it is likely that tributes were taken long before this time (Sigurðsson 20I0, 62; Wærdahl 2006; 20II, 69-7I). Little is known about early legislation in Orkney, Shetland and the Faroes, but medieval documents show that Norwegian law applied in the Faroes in the I 2 th and 13 th centuries and the situation was most likely the same for the other islands. On-the-ground identification of thing sites in these different island groups occurred as early as the I9th century (see Chapter 2), but little detailed written source material survives and there is limited precise knowledge of when such places became operational and how they functioned (see Chapter 6).

The thing was also exported to Ireland. In Dublin, Thingmote/Thing Mount or the 'thing motte' attests to Norse organisation, and place-names suggest that at least two other assemblies existed, outside Wexford and Cork respectively (Duffy I 997; 2005; Sanmark 20I7a, 250). On the Isle of Man, in the middle of the Irish Sea, the well known site of Tynwald Hill and additional thing names also attest to 
the implementation of Norse arrangements on the island (Darvill 2004) (Figure I.6). Norse presence along the western seaboard also resulted in the establishment of thing sites such as Thingwall on the Wirral peninsula and its counterpart across the Mersey River in West Derby hundred, Lancashire (see Fellows-Jensen I993 for discussion of thing place-names).

The thing is thus a complex and lasting phenomenon. Its origins are potentially deep, but evidence is limited and imprecise until the IIth and I 2 th centuries. Its export, however, as early as the Ioth century, to new regions and its widespread presence and survival suggest it was an effective mechanism of regulation. By the High Middle Ages, chiefs, kings, land-holders, and churchmen would have found it essential to participate in meetings where the majority of routine legal business that concerned their affairs was conducted. Assembly in the localities largely survived until the Late Middle Ages in Scandinavia, after which royal regulation ended traditional patterns of local governance. Yet some assembly sites in northern Europe seem to have survived or were revived as meeting-sites. One of the most famous of these is the annual assembly held at Tynwald Hill on the Isle of Man, mentioned above, which is recorded in medieval documents and still takes place today (Darvill 2004).

\section{I.4 THE VALUE OF STUDYING EARLY MEDIEVAL ASSEMBLY}

Despite all indications that assembly and gatherings have played an important role in northern Europe since prehistory, studying medieval assembly provides significant challenges. Archaeologically, the assembly and the systems it served are hard to actualise. The early written accounts often provide little indication that meeting-places were formally arranged in a tangible way that might be discovered archaeologically. Indeed the mentions of river crossings and forest groves in the Roman sources signal quite the opposite. In England, where (OE) ping can be identified in place-names and seems to have had an early usage (Pantos 2004a), the place-names refer to natural features such as the $(\mathrm{OE})$ feld, hills or wood pasture (see Pantos 2004a; Semple 2013, 90-9I). Periodic gatherings of people, lasting a number of days, out in the open landscape, are unlikely to have left behind rich, diagnostic material remains. And yet there are some remarkable and interesting findings. The monumentalising of thing sites (Sanmark and Semple 20II); the appropriation of ancient features as meeting loci (Baker and Brookes 2013 b; Semple 2013); and the regular choice of certain types of location as ideal assembly places such as fords and crossroads (Sanmark 2009) - are all choices evident in different parts of northern Europe. Despite the apparent ephemeral nature of an 'assembly', it seems that conscious actions in terms of the choice of location and its enhancement led in many cases to the physical creation and maintenance of such places in ways that marked them out in the past and might render them locatable in the present (Sanmark and Semple 2008).

Archaeology has begun to value the potential of ephemeral human activities and events for creating powerful new discourses on the transient elements of human experience, for example festivals, peace camps, homeless shelters (e.g. Claassen 20I I; Petersen I994; Schofield 2000; White 2013; Zimmerman 2013). Ephemeral material culture can be used to create compelling counter-narratives (see Schofield 2000; 

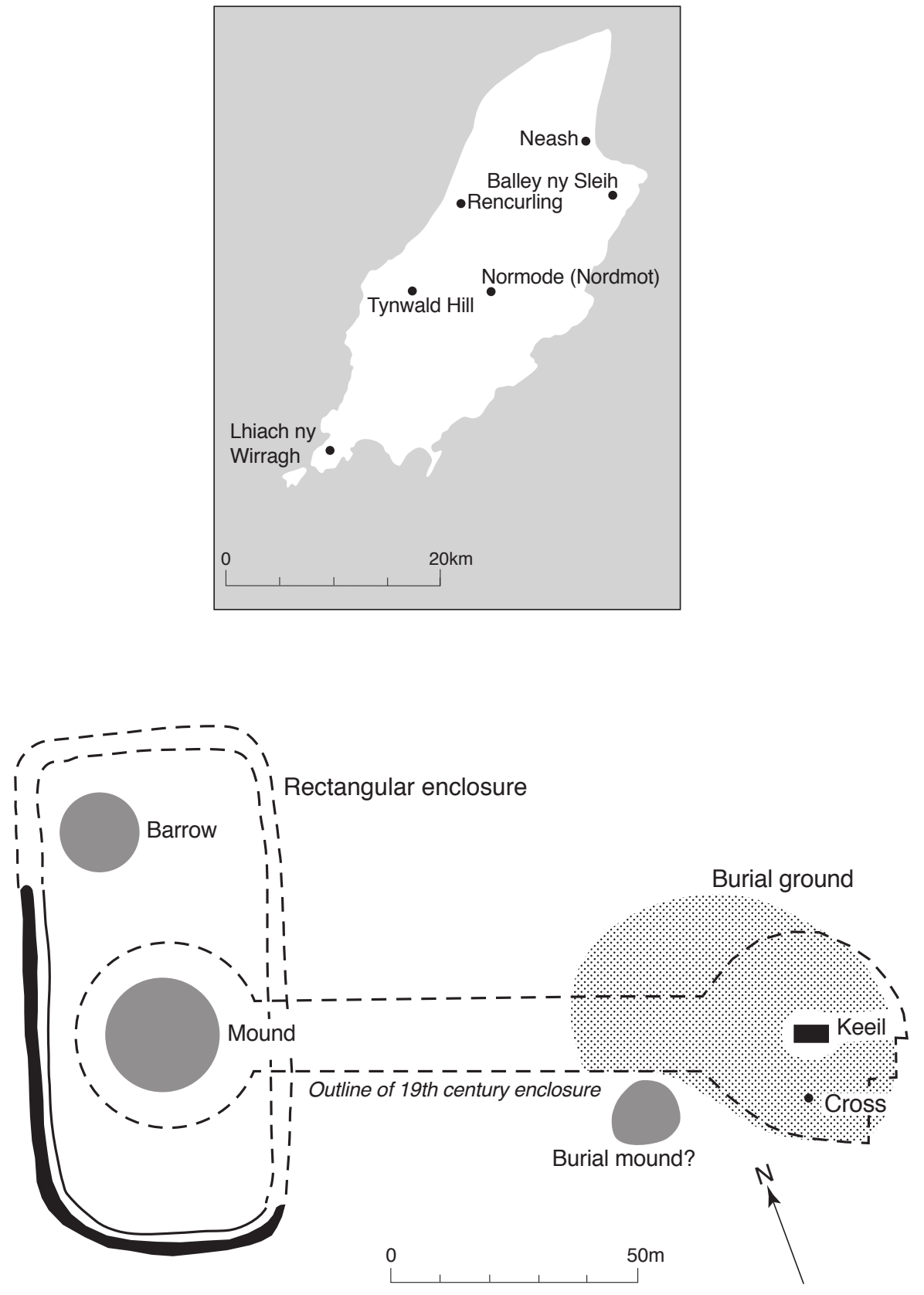

Figure I.6 The site of Tynwald Hill, Isle of Man. Drawn by Yvonne Beadnell after Darvill 2004, fig I0.3 and fig I0.5. 
Zimmerman and Welch 20II), uncovering marginalised and poorly documented sectors, such as youth subculture (Schofield 2000) or protest groups (Fiorato 2009, I42-I46; Vareka and Symonds 20II). Seasonal and temporary gatherings provide opportunities, to behave outside norms (Costello 20I 8), or, for a time, to participate in a new broader collective identity (Swenson 2018). The processes of meeting and negotiation can result in alliances that merge and temporarily unify different groups (Nebbia et al. 2018). Regular and scripted meetings can also serve to reinforce existing identities and behaviours, through cyclical and seasonal repetition and regulated activity (Sanmark 20I5; Ugwuani and Schofield 20I8). As a result, gatherings can be powerful territorialising agents, driving alliances and new group identities. Our project has taken the view that the study of early assembly structures is not only potentially instrumental to understanding the processes of kingdom formation on the ground, but that there could be significant methodological value in developing approaches and models for the archaeology of temporary gatherings and political and administrative landscapes within a proto-historical framework. Such models might be valuable and applicable to the study of increased complexity in a-historic societies.

More broadly, legal culture is largely pursued via text-based research and yet a rich archaeology exists, including places connected to the enactment of law such as courts, prisons and gallows sites, while evidence for consensual governance can include administrative demarcations or boundaries and designated meeting-places (Smith and Reynolds 20I4). While gatherings of people may leave only ephemeral low-density traces (Baker and Brookes 20I5), meeting-places, through their landscape situation and location, and their antecedent as well as contemporary archaeology, can inform on how assembly places were demarcated and sited within a broader network (Sanmark and Semple 2008; 2010; Semple and Sanmark 2013). There is a potential to explore and map the emerging theatrical architecture of nascent legal systems: interrogating their physical potential for shaping the action of meetings, court proceedings, royal events and punishment (Baker and Brookes 20I 5; Sanmark 20I 5; Semple and Sanmark 2013). By studying the morphology of thing sites-the chosen places, the monuments reused or raised and built - there is the potential to investigate how communities and elites signalled their authority and how the architecture of the assembly was organised with this in mind and even then how this operated as a stage for the performance of public ritual (see Sanmark 20I 5; Semple 20I3; 20I8).

As Chris Wickham has argued, 'continuity and radical change' describe $\mathrm{AD} 400-800$ and the greatest changes of all may have been 'in the form of the state' (2005, I 2). Assembly in early medieval Europe was an activity with many actors - a forum in which people and groups considered they had a voice and could challenge or obtain justice or debate key decisions. These were places and systems that underpinned the development of medieval kingdoms: theatres within which collective identity was consolidated and power could be called to account. The archaeology of assembly, consequently, can offer a powerful counter-narrative to the traditional, topdown models, informing on how mechanisms of governance may have emerged at a grass roots level.

Finally, our macro-scale northern European perspective on assembly, in terms of location, networks, administrative frameworks and practices, provides an 
opportunity to model the role of meetings as agents of change in emerging social and legal complexity. In these ways, we can elicit some of the material narratives that accompany the processes of heterarchical and hierarchical development and the arrival of kingship, justice and statehood-valuable worldwide in the study of complex societies (Brookes and Reynolds 20II; Fukuyama 20II; Semple 20I8; Thurston 200I; 20I0).

\section{I.5 THE SCOPE OF THIS VOLUME}

The emergence and development of the thing as an administrative instrument in Scandinavia and other parts of northern Europe in the Early to High Middle Ages is the central theme of this volume. The thing by AD Iooo was a formalised and exported administrative mechanism. It was regulatory and instrumental in lawmaking and king-making; and at least in Scandinavia until the $\mathrm{I}_{3}$ th century, even the king was not exempt from law. Beyond the Scandinavian homelands and colonised regions, equivalent systems existed, that differed in detail, but retained assembly as a pre-eminent aspect of regional and local government. It is the flexibility of the assembly that may have made it indispensable, as Barnwell argues, to 'the brokering of power in the earlier Middle Ages'. They could be shaped by hierarchical and nonhierarchical political communities as vehicles for arriving at authoritative solutions to specific needs' (Barnwell 2004, 5).

The time frame explored in this book, AD 400-I 500, and the geographic scope (encompassing Norway and the Faroes, Sweden, Denmark, Iceland, Norse Scotland and eastern England), facilitates the investigation of the development of assembly, lawmaking and administrative systems during the upheavals of the Ist millennium AD and the colonising processes evident in the North Atlantic from the 9th century onwards. The focus on the thing means that neither the medieval administrative arrangements of Ireland, non-Norse Scotland, nor Wales feature in detail in the discussions presented here. Assembly practices and administrative systems in Ireland have been subject to recent extensive study. In this volume we acknowledge and use Irish and Scottish comparanda based on the existing body of published work. We assess the historiography of assembly studies in Ireland alongside England and Scotland in Chapter 2 and we return to the Irish evidence in our discussion chapters to provide context and comparison. Another omission is Greenland. Our project did not pursue extensive original research and fieldwork in this country, but our team has published separately on the potential assembly sites related to Norse colonisation in these lands. Evidence from Greenland is mentioned and drawn on in some chapters but only for comparison. We have taken $\mathrm{AD} 400$ to I 500 as our temporal scope and the provincial and local-level assemblies as the major concern. We aim to explore the momentum of collective power as a formative element of early governmental systems in Scandinavia and Britain and the North Sea world in medieval times.

The hard-to-define nature of an assembly and the elusive and difficult material evidence (Barnwell 2003, I; Sanmark and Semple 2008; 2010; Semple and Sanmark 20I3) have acted as a deterrent to archaeologically driven research. The study of sites and systems within the context of the early medieval and medieval landscape has the potential, however, to inform on attributes of complex societies, peer polity 


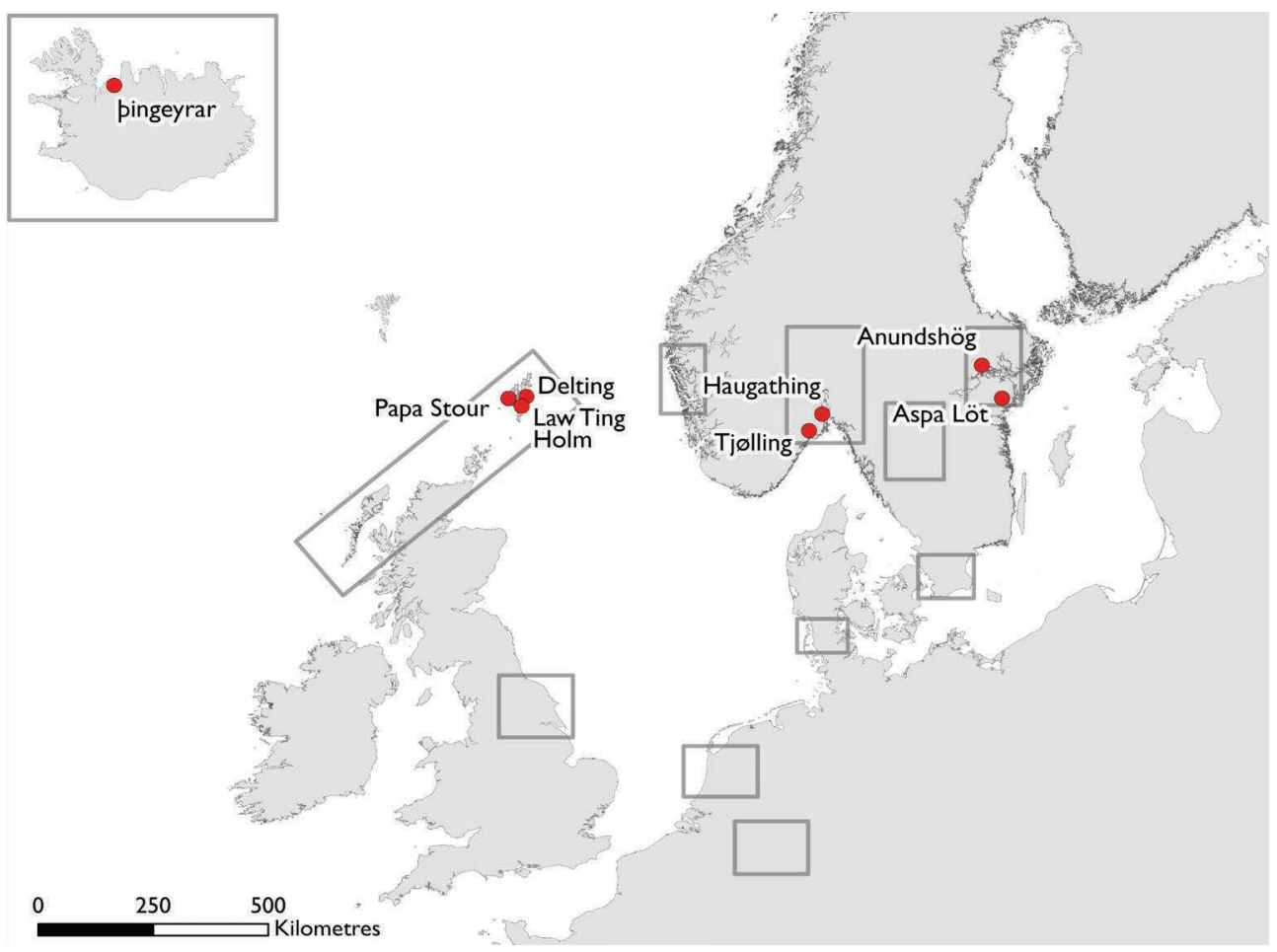

Figure I.7 The Assembly Project: The research regions, with case-study areas marked out and the locations of field investigations identified and named. Map by Tudor Skinner.

interactions, identity creation and kingdom-formation processes. By drawing together a dataset that is the sum of its parts, we give equal value to written and archaeological evidence, to place-names and to topographic information. Only by using these together can a full narrative on thing development be elicited from a composite of fragmentary and challenging source material.

In our research, we have combined research and fieldwork across eight separate regions (Figure I.7). This includes a core area comprising the modern countries of Norway, Sweden and Denmark. Here we explore and chart the processes of collective consensus versus elite rhetoric, forged through place and landscape. Our investigation takes in some of the earliest evidence from archaeological, as well as documentary accounts, of designated provincial assemblies and charts the development of the thing and the administrative systems it served right through the Middle Ages. Research and fieldwork in Iceland, the Faroe Islands as well as the Northern Isles of Orkney and Shetland and the Ridings of Yorkshire in the Danelaw, has facilitated investigation of the imposition of assembly, law-making and administrative systems within colonised lands. Here we explore how systems of administration were exported, how they influenced existing populations and regulations and how law, legality, and assembly were maintained. Selected case-study areas were chosen for in-depth research in 
Orkney, Shetland, the Faroes, Iceland and north-east England, the latter comprising a landscape-led exploration of assembly and administration in the Ridings of Yorkshire (Skinner 20I4).

Throughout we chart the traditions and evolution of systems of assembly in these regions, assessing their longevity within the changing landscape and seascape of the North Atlantic and ultimately explore their final legislative and political demise in the dawn of early modern Europe. By situating detailed comparisons within a more general framework, we also consider the connections between the assembly phenomenon and kingdom-formation processes. Linked to this are questions of how agent these regular meetings were, what role they played in the processes of territorialisation and kingdom expansion, and conversely whether they held any regulating power over elite and royal authorities.

The value of studying early places of gathering and consensus and how these changed offers the chance to understand the varied archaeological signatures for political development in a proto-historic framework. This has wider value and can contribute more broadly to understanding the material signatures of power and consensus in other parts of the world in pre- and proto-history. We therefore reflect on the material evidence and consider what the driving mechanisms and natural stimulants might be for places and processes of consensus, how more formal systems might emerge and what material evidence attests to the increasing complexity of local systems of governance?

\section{Terminologies}

A significant challenge for any volume drawing on evidence from eight countries is the need for common terminologies. The complexity is compounded here by the use of early documentary sources, place-name and linguistic evidence from several different regions. In many instances, the location of sites or the earliest form of systems is attested in documents where the Old Norse, Old Swedish, Old Norwegian, Old Icelandic or Old English, offers key information.

In order to achieve a common clarity across the chapters, modern word or name terms are used. In some cases, for example thing, the modern term is used across Norwegian, Danish, Swedish, Icelandic and English and so this is the term employed throughout the volume. Thing is italicised to emphasise its application as an administrative term, separate from its modern English usage for an inanimate material object in general. The same is true of hundred, landsthing, lawthing and sysselthing etc. in that these are modern terms for antique units, but are understood or used across the majority of countries in question and are thus italicised throughout.

Where a specific modern Norwegian, Danish or Swedish or indeed Icelandic term is used, the term is given in italics. In instances where it is necessary to distinguish the modern language in use, the abbreviations pre-empt the word in parentheses. These are explained in the list of abbreviations given at the beginning of the book. In many cases the original Old Norse, Old Norwegian, Old German, Old Icelandic is used. These terms are included in bold and not in italics and abbreviations pre-empt the word in parenthesis to indicate the language. Some terms also appear for the first time in medieval documents and these medieval words are given in the book in bold 
and not in italics but are again pre-empted abbreviations in parenthesis to indicate the language. All abbreviations are explained in the list given at the beginning of the book. If a translation is offered of either a modern or ancient term, this follows in ordinary script in quote marks, e.g. (Mod Dan) herredsting (ODan herritzting, 'a local thing'). Latin terms are also rendered in bold and not in italics and are followed by (Lat.). All specialist terms used in the volume are included and explained in the glossary.

\section{Hierarchies of assembly}

Another challenge, indeed one of the research remits of the project that informs this book, has been to compare different systems of governance in different regions. These systems are documented at different times, evolved in different ways and demonstrate great variety. In order to mine more deeply into the common mechanisms driving administrative processes and assembly making, some parity is needed in how the levels of assembly are classified and compared within the volume. As set out in the opening to this chapter, the 'provincial' assembly or thing provides a focus. As we have already seen, it is difficult to make a clear classification of a simple 'provinciallevel' institution. In Anglo-Saxon England, the shire and the hundred handled matters from the localities. The mallus in Francia seems to have been similar. The term thing in Scandinavia was used to refer to the legal institution, the meeting and the meetingsite and was applied to a variety of supra-regional to local meeting-types operating at different hierarchical levels. The higher-level thing, for example, seems to have been broadly equivalent to the shire assembly in England and the (OIr) óenach in Ireland, but a lower level thing might be more characteristic of the scale and remit of the English hundred or (OIr) túath-scale assemblies in Ireland (Gleeson 2018, I03). While strikingly similar systems are present in Norway, Denmark and Sweden and the lands colonised by the Norse, the number of 'levels' within the administrative hierarchy can vary, as can the names used to refer to both the units of administration and the names for the assemblies that served them.

To facilitate better comparison therefore, the terms 'top-level', 'regional' and 'local' are used to distinguish three basic tiers of authority operating across medieval Scandinavia. Top-level refers to regions of jurisdiction and assemblies operating at the highest provincial level for example the lawthing, althing and landsthing. Figure I.8 sets out this classification for the administrative districts, sorting named types of administrative units into broad top-level, regional and local units of division. As we will see in the chapters that follow, regions differed in their complexity in terms of unit size and hierarchy, but where comparisons are made, these broader terms of division enable cross-regional discussion. Likewise, Figure I.9 sets out the names for the meetings themselves, sorting these again into a hierarchy of assemblies, serving the divisions of top-level, regional and local. It must be stressed that this was not a legal hierarchy in the modern sense of the word, as the top-level thing was not necessarily the supreme assembly in every respect, but served larger areas than regional- and local-level meetings or things. To some extent, these different types of thing worked in parallel, as demonstrated in Chapter 4. In terms of the top-level assembly sites, the greatest variation in terminology is found in Sweden, where terms 


\begin{tabular}{|c|c|c|c|}
\hline $\begin{array}{l}\text { Geographical } \\
\text { area }\end{array}$ & $\begin{array}{l}\text { Top-level } \\
\text { district name }\end{array}$ & $\begin{array}{l}\text { Regional } \\
\text { district names }\end{array}$ & $\begin{array}{l}\text { Regional to local } \\
\text { district names }\end{array}$ \\
\hline Norway & $\begin{array}{l}\text { lögsókn (law- } \\
\text { district) }\end{array}$ & fylki (county) & $\begin{array}{l}\text { herað, skipreiða, fjórðungr, priðjungr (a third } \\
\text { of a fylki/skipreiða), (a quarter of a fylki/ } \\
\text { skipreiða) }\end{array}$ \\
\hline Denmark & $\begin{array}{l}\text { land } \\
\text { lögsögn (law- } \\
\text { district) }\end{array}$ & No evidence & herað \\
\hline Sweden & $\begin{array}{l}\text { land } \\
\text { laghsagha } \\
\text { folkland }\end{array}$ & No evidence & $\begin{array}{l}\text { herað, hundari, skiplagh. In Gotland the } \\
\text { parishes served as a form of thing district }\end{array}$ \\
\hline Faroes & No evidence & No evidence & Name unknown \\
\hline Iceland & No evidence & $\begin{array}{l}\text { Name unknown, } \\
\text { but these existed for } \\
\text { a very short time }\end{array}$ & $\begin{array}{l}\text { Name unknown, but herað and hreppr units } \\
\text { existed too }\end{array}$ \\
\hline Greenland & No evidence & No evidence & No evidence \\
\hline Norse Scotland & No evidence & No evidence & $\begin{array}{l}\text { Hints of herað divisions, fjórðungar } \\
\text { ('quarters') and áttungar ('eighths') (Orkney } \\
\text { and Shetland). } \\
\text { In Shetland the parishes served as thing } \\
\text { districts }\end{array}$ \\
\hline
\end{tabular}

FigURE I.8 The documented terms for the different types of administrative districts across all geographic areas studied. Due to the scarcity of sources, changes over time and regional differences, the details of this table can be debated, but the intention is to provide a general overview of the different units and their place in the assembly hierarchy. It is important to note that the units by the same name do not necessarily represent areas of the same size and dignity in the different geographical areas.

such as folklandsthing, lawthing and 'the thing of all Geats' are found. Despite these variations, the overall thing organisation was in essence the same across the kingdom. In the I4th century and the time of Magnus Eriksson's Law, however, all top-level assembly seems to have gone under the name of landzping ('thing of the land') (MEL, I:I) This term was also used for the top-level assemblies in Denmark, while in Norway, they were termed lawthing (lögthing). A lawthing was a representative assembly where royal law was introduced and enforced. Many of these top-level assembly sites were also used for royal election and inauguration ceremonies (see Section 4.5). In Iceland and Norse Greenland, the top-level assembly was called althing and kept this name despite these areas being integrated into the Norwegian kingdom in the I260s (Helle 200I, 30-32; Imsen 20I4). At the local level in Norway, Denmark and Sweden, as noted above the hundred or (ON) herað, skipreiður and skiplagh units all had their own assembly site. In Norway, there were also regional assemblies for the $(\mathrm{ON})$ fylki (county) and the $(\mathrm{ON})$ priðjungsping and fjórðungsping or 'third-thing' and 'quarter-thing', responsible respectively for the thirds and quarters of the fylki, but in some and not all regions. 


\begin{tabular}{|c|c|c|c|}
\hline Geographical area & Top-level assembly & Regional assembly & Local assembly \\
\hline Norway & lögping (lawthing) & fylkisping & $\begin{array}{l}\text { heraðsping, skipreiðuping, } \\
\text { priðjungsping ('third- } \\
\text { things'), fjórðungsping } \\
\text { ('quarter things') }\end{array}$ \\
\hline Denmark & lögping (lawthing) & No evidence & heraðsping \\
\hline Sweden & $\begin{array}{l}\text { landzping (landsthing), } \\
\text { folklandzping ('thing of } \\
\text { the folkland'), aldra gøta } \\
\text { ping ('thing of all Geats'), } \\
\text { Lionga ping etc. }\end{array}$ & No evidence & $\begin{array}{l}\text { heraðsping, skiplaghsping, } \\
\text { hundarisping? }\end{array}$ \\
\hline Faroes & $\begin{array}{l}\text { alping (althing), } \\
\text { lögping (lawthing) }\end{array}$ & No evidence & Name unknown \\
\hline Iceland & alping (althing) & $\begin{array}{l}\text { fjórðungsping ('quarter } \\
\text { things'), reformed into the } \\
\text { fjórðungsdómar held at the } \\
\text { althing }\end{array}$ & $\begin{array}{l}\text { várping and leiðir ('spring' } \\
\text { and 'autumn' things) }\end{array}$ \\
\hline Greenland & alping (althing) & No evidence & No evidence \\
\hline Norse Scotland & lögping (lawthing) & No evidence & Name unknown \\
\hline
\end{tabular}

FIGURE I.9 The documented terms for the different types of thing sites across all geographic areas studied. Due to the scarcity of sources, changes over time and regional differences, the details of this table can be debated, but the intention is to provide a general overview of the different types of things and their place in the assembly hierarchy.

It is important to note that assemblies carrying the same name do not necessarily represent areas of the same size and dignity in the different geographical areas.

\section{Chaper-by-chapter outline}

A critical assessment of assembly scholarship within the Scandinavian core area of study and comparative regions has provided an initial basis for study (Chapter 2). Thing sites appear in some of the most prominent political and religious discourses of the early modern era, appropriated by nationalist agendas in the I 9 th and early 20 th centuries. In order to decouple our project's methods from long-held traditions and perceptions, a critical historiography has been an essential stage, serving to provide evidence for the later re-appropriation and re-invention of assembly long after the demise of the thing. In Chapter 3, we set out our methodology and approach and outline how and where research took place. Using the intensive regional research and field investigation that flowed from the project, we have attempted to create a fresh understanding of evidence for the development of gathering places and thing sites in the core lands of Norway, Denmark and Sweden. The top-level thing serving the highest and largest provincial-level units are considered in Chapter 4 , in terms of historical sources, archaeological and topographic evidence, and compared, and contrasted with evidence for places of inauguration. Here the primary concentration is on documentary accounts. Starting with these, the size, scope and hierarchy of 
administrative units is reconstructed for Norway, Denmark and Sweden. Using topographic and archaeological evidence, where possible the physical reality is explored of both the systems of administration and the assemblies that served them. Retrogressive methods are also used to determine a model for how units and their meeting-sites developed in the Early to High Middle Ages. Norway provides an intensive case study in Chapter 5. Using case studies located in eastern and western Norway (Vestlandet and Viken), close attention is given in Chapter 5 to the shape and size of the different levels of unit, where meetings were held and how emerging systems were linked in to other functions in the early medieval landscape. Here topographic survey and historical accounts, alongside archaeological interventions, are brought together in a deeper interrogation of the potential early origins of some Norwegian units of law and administration and differences are identified in the archaeological character and earliest evidence of operation of the Norwegian units and meetinglocations from Swedish and Danish counterparts.

A major opportunity in studying the provincial thing has been to track its export to colonised regions. Using additional areas for in-depth study we have explored the administrative arrangements imposed in inhabited and uninhabited regions and used interdisciplinary study to delineate the patterns of meeting-sites and administrative systems established or appropriated by the Norse. Studies of Iceland, the Northern Isles of Scotland and the Faroes and the English county of Yorkshire, once part of the Danelaw, feature in Chapter 6. We have sought to explore and compare this evidence with the core Scandinavian territories, to establish how authority was articulated in landscape terms and how ideas of control and consensus were transferred and established.

Iceland represents an example of how exported systems were planted in an uninhabited landscape. Exploration of the evidence for assemblies mapped and considered against communication networks and places of trade, serve to show how systems of control emerged in Iceland in the first centuries of Norse colonisation. In Chapters 6 and 7, the evidence from Iceland is considered in the context of other colonised areas, but also on its own terms with especial reference to connections with trade. Across all the regions, our research has taken into account where assemblies took place and how sites and locations were enhanced, modelled and eventually moved or relocated. We have, where possible, also considered who attended such meetings and what the composition was of the audiences and attendees at these events.

Not only does this book offer the first detailed consideration of the thing as an institution in Norse society, it more broadly charts and de-contextualises the mechanisms of consensus in the late prehistoric and early medieval North, focusing on their emergence, development, formalisation and demise. An 'archaeology' of assembly is debated, and modes of display and power are also interrogated in relation to increasingly complex political structures. In our final chapter we reflect on all regions, and consider how assembly processes and places served to shape the political developments in early Europe and how the assembly lingered on as a powerful motif in political discourses linked to the emergence of national identities in more recent times. 


\section{CHAPTER 2 RESEARCH HISTORIES}

\section{I SUMMARY}

Academic and popular discussion of assembly most often begins with the words of Tacitus, historian and Senator of the Roman Empire (c. AD 56-II7). European scholarship, both prehistoric-focused and historical, has repeatedly returned, for over six centuries, to his descriptions of open-air assemblies in Germania and the words of other Roman writers. The manuscript was recovered in the I 5 th century, when the increasing accessibility of classical texts and art triggered new concepts of the past (Díaz-Andreu 2007, 35). This chapter explores how the concept of the early popular assembly is appropriated and reimagined from the early modern era to the present, and how the open-air 'folk-moot', of the kind described by Tacitus, became embedded in antiquarian, Romantic and nationalist conceptions of ancient custom and a panGermanic identity. The focus is Scandinavian scholarly traditions, but British and Irish scholarship is compared, to demonstrate the power of assembly and assembly places in different national discourses and the similarities and exceptions in their treatment. The chapter takes the discussion right up to the present to demonstrate how differences in approach and interpretation in modern scholarship reflect the national and transnational discourses developed in the past.

\subsection{GENESIS: ASSEMBLIES AND NATIONAL CONSCIOUSNESS}

\section{Runes, stones and kings: Scandinavian antiquarianism}

The Renaissance spurred radical changes in European thinking, particularly on history and human development. Descent and ancestry emerged as predominant concerns, particularly in terms of determining rightful claims to land and territory (Díaz-Andreu 2007, 35). The modern regions that now make up Scandinavia were not under Roman authority, instead they formed part of Germania Inferia and lay north of the imperial frontier. Literate modes also arrived later in Scandinavia. NonChristian beliefs and practices survived until at least the Ioth century (Sanmark 2004). As a result, the antiquarians of Scandinavia, instead of valorising a Roman past, turned towards the material remains of the prehistoric and medieval eras and the surviving medieval texts in their search for the distinctive nature of Scandinavian identity and the emergence of its kingdoms (Díaz-Andreu I995, 42; Schnapp I993, I 56-I65). Some of the first Scandinavian medieval histories were refined and printed in the I6th and I7th centuries, such as Saxo's Gesta Danorum in I 5 I4 [c. I 200] and Snorri Sturluson's Chronicle of the Kings of Norway as Norske kongers Chronica 
in 1633 [c. I230], providing a crucial non-biblical frame of reference for the first antiquarian writers (Iversen 20I2, 300-30I). Antiquarian attention often focused on the sites and monuments that featured in these medieval narratives, for example the site of Jelling in Denmark was captured in a series of richly detailed engravings in I 59I (Klindt-Jensen I975, I4-I 5; Pedersen 2006, 287-29I, 288; Schnapp I993, I 56-I77, esp. I 56-I 59) (Figure 2.I). This place of burial, its royal authorship attested in written sources and in surviving, on-site, runic inscriptions, was not acknowledged at the time as a location of assembly, but the site became the 'birth certificate of Denmark' (Pedersen 2006, 283), emblematic of nationhood for centuries. Likewise Gamla Uppsala in Sweden, also recognised now as an important location of early elite power and assembly, featured prominently in antiquarian works, achieving a singular status as a result of accounts, by Adam of Bremen and Snorri Sturluson, of cultic and royal activity at the site (Hollander I999, 3 I 5; Tschan 2002, Book IV, Ch. 27, 207-208).

Travel and the recording and drawing of monuments were customary (Brackmann 2OI2, I 20). Chorography, a genre of illustrative, descriptive narrative, used to map regions and districts, wove together elements of antiquarianism, place-name research and natural and legal history (Helgerson I992, I05-I48). It is noticeable that the old medieval administrative patterns in many European regions continued to define the

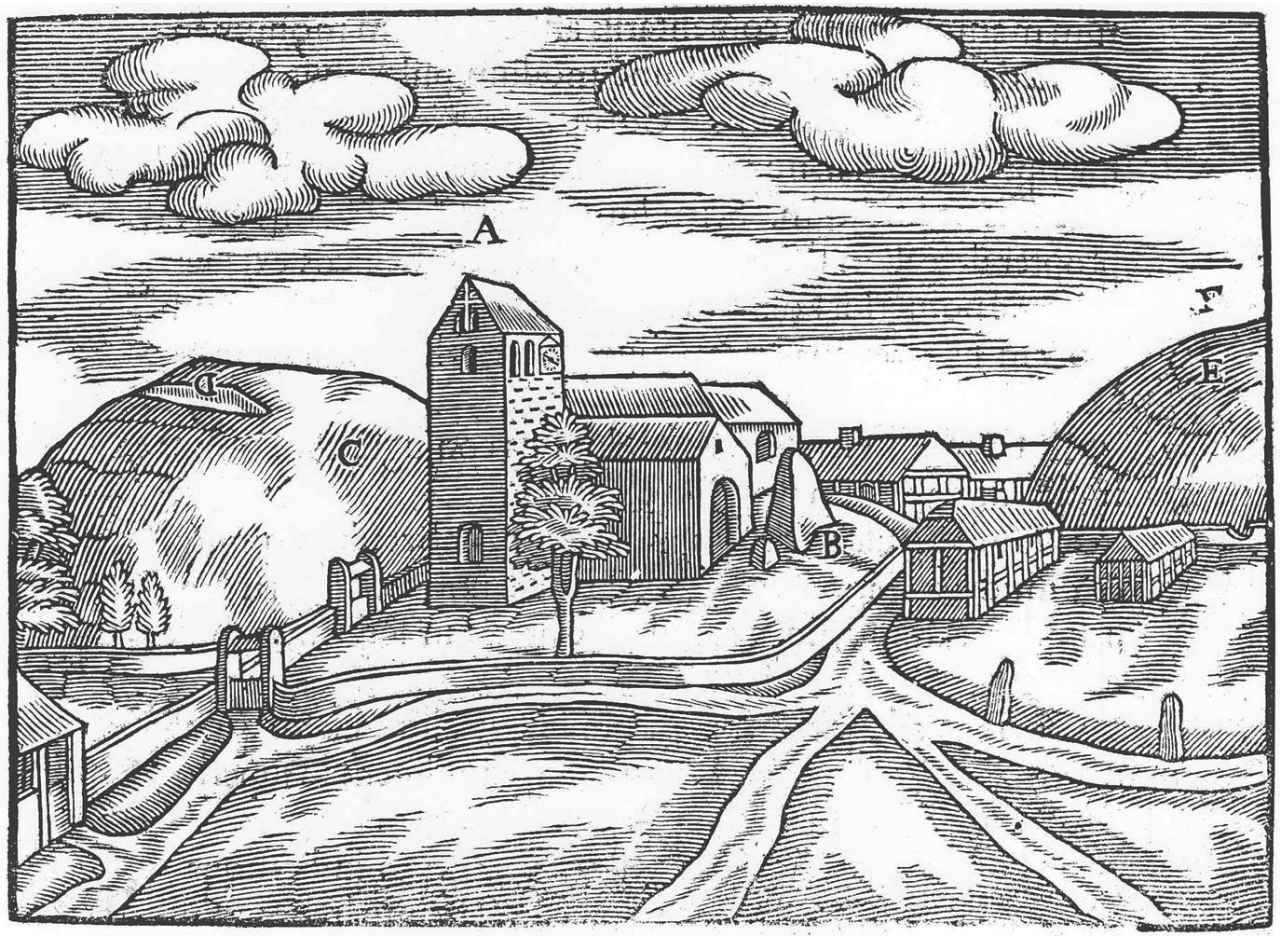

Figure 2.I Jelling in Ole Worm's Danicorum Monumentorum Libri Sex published in I643. Wikimedia. CC BY 2.o. 
land-holdings and the activity of the gentry and elite, and structure their experiences. The 'histories' that antiquarians penned on their realms are often organised along these ancient principles (see Sweet 2004, 210). John Leland in England, for example, used hundredal organisation to structure his itineraries (Smith I906-Io; Skinner $20 \mathrm{I} 4,3 \mathrm{I})$. It is important to acknowledge too that in Scandinavia in the I6th century, assembly traditions and the thing-term were still operating and would operate for even longer in Iceland and the Faroes. Assembly practices also continued in Ireland, and hundred and shire courts remained operational in Tudor England.

Historia de Gentibus Septentrionalibus (I 555 ) by Olaus Magnus (c. I490-c. I 557) provides one of the earliest historical and chorographical accounts of the north, and both Saxo and Adam of Bremen feature large in his writings (see Fisher et al. I999, I $85, \mathrm{n}$. OM 3:4, I; I 86, n. OM 3:6, 2 and 4). It is interesting that alongside his use of medieval accounts and descriptions of winds, seas, animals, inscribed stones and ancient burial places (see for example Magnus I 5 55, Book I, Chs 29, 30 and 3I), Magnus included the discussion of contemporary legal practices that survived in his time. He emphasised their ancient origins (XIV, Chs I7-24), including the use of open-air meetings on islands or 'elevated, flat places among the forests' and noted how these meeting traditions were still strictly maintained in the localities (Book XIV, Ch. I7).

The growth of antiquarianism in the I6th and I 7 th centuries took place against a backdrop of political rivalry between Denmark and Sweden (Díaz-Andreu 2007, 35-36). Two very significant antiquarians emerged at this time: Johan Bure (1568I652) and Ole Worm (I 588-I655). Bure served the Swedish royal house and Worm the Danish-Norwegian monarchy (Klindt-Jensen I975, I5-24), but together they were responsible for introducing systematic survey to Scandinavian research (KlindtJensen I975, I59; Nordbladh 2002, I43-I45). Like Olaus Magnus, each touched independently on legal institutions and things by referencing a variety of material phenomenon that attested to the distinctive and ancient nature of Scandinavian legal tradition. Bure undertook the first corpus of Swedish runic inscriptions (I 599-?), which included a number of rare inscriptions on rune-stones attesting to a thing site (SRD: U 2 I 2, Sö I 37, U 225 and Sö I 96; U 668, Sö 33; see Sanmark 20 I 7a, 9) (Figure I.4). The first engraving of the 'Forsa Rune Ring' (Forsaringen) inscription also appeared at this time in Bure's Runakenslones lerespan (I 599) (although a translation was only published in I700 by Olof Celsius; Brink I996; 2008, 28) (Figure 2.2). Ole Worm went a step further and featured thing sites in his early and impressively systematic surveys. Under the double monarchy of Denmark and Norway, Worm embarked on a programme of survey, using rural deans and vicars to collect information on monuments and antiquities known within their parishes (Randsborg I994, I36). He devoted an entire chapter to Jelling in the Monumenta Danicorum (c. I643) and in the same volume, harnessed the terminology of the classical world to classify data, enlisting the Latin term fora to account for thing sites (Worm I643, 4).

Magnus, Bure and Worm notably were travelling and writing at a time when traditional, open-air assemblies were still active in some rural areas. The local/ regional units of the $(\mathrm{ON})$ fjorðungr, the $(\mathrm{ON})$ skipreiða and the $(\mathrm{ON})$ herað remained in operation as structuring divisions with new early modern name forms, and meetings continued in rural localities. It is often with the demise of customs or institutions that intense interest is generated in preserving or researching them 


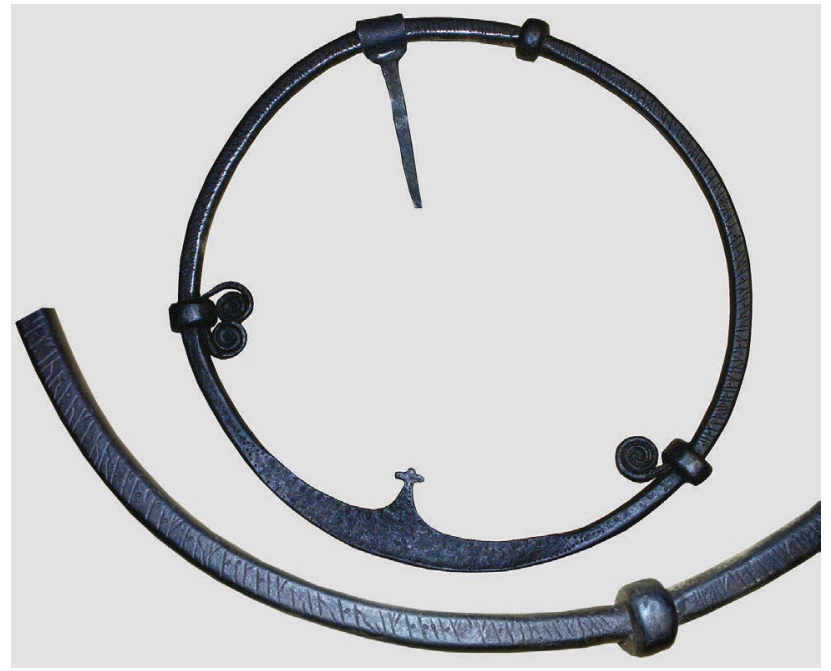

FIgURE 2.2 The Forsa Rune Ring. Image by Sven Rosborn. CC BY-SA 3.0.

(Morgan I983, 43-44). As later chapters will demonstrate, increased royal regulation gradually removed the power of the thing, and by the I6th and 17 th centuries, these antiquarians were recording outdoor assembly traditions that were slowly slipping from use. The legal system of provincial assemblies or things became subject to intense regulation under Kristian IV of Denmark-Norway (I 588-I648). Though passionate about his realm and its history (Skovgaard-Petersen 2002), Kristian fundamentally changed the shape of legal jurisdiction in Norway. His actions removed and replaced virtually all local legal arrangements and roles, changing the ancient rules on representation at the thing and so lessening its jurisdictional power (Hallanger and Brandt I 855 , XVIf). In Sweden, while the ancient units of division survived, the sites of meetings were usually relocated in the High and Late Middle Ages to towns or churches (see Sanmark 2009). The situation was similar in remote regions, although there are instances of extreme longevity. Two sites stand out, Pingvellir in Iceland and Tinganes in Tórshavn, Faroes, which both remained in use. Tinganes is still the site of the parliament, which is held in wooden buildings just above the rocky outcrop identified as the assembly location. In the skattlands, thing meetings occasionally survived until the I 7 th century (see below); in Iceland, the last althing at Pingvellir, took place in I799 and an I8th-century image depicts well maintained and actively used buildings (usually termed booths) (Pórðarson I92 I-22) (Figure 2.3). In the I743 Danish monument survey that covered Denmark-Norway, Faroe Islands, and Iceland, questionnaires were sent out by the government to obtain a better record of sites and monuments: notably question 43 asked specifically about thing site locations (Røgeberg 2003-8). This may reflect a desire to capture information about local practices in remote areas and, perhaps, testifies to a royal interest in controlling and regulating surviving local assemblies. It also underlines, however, the slow demise of the thing sites as a result of central control: their inclusion in the mid-I 8th century in the monument survey signals their ongoing rural survival, but also their classification alongside ancient monuments and antiquities. 


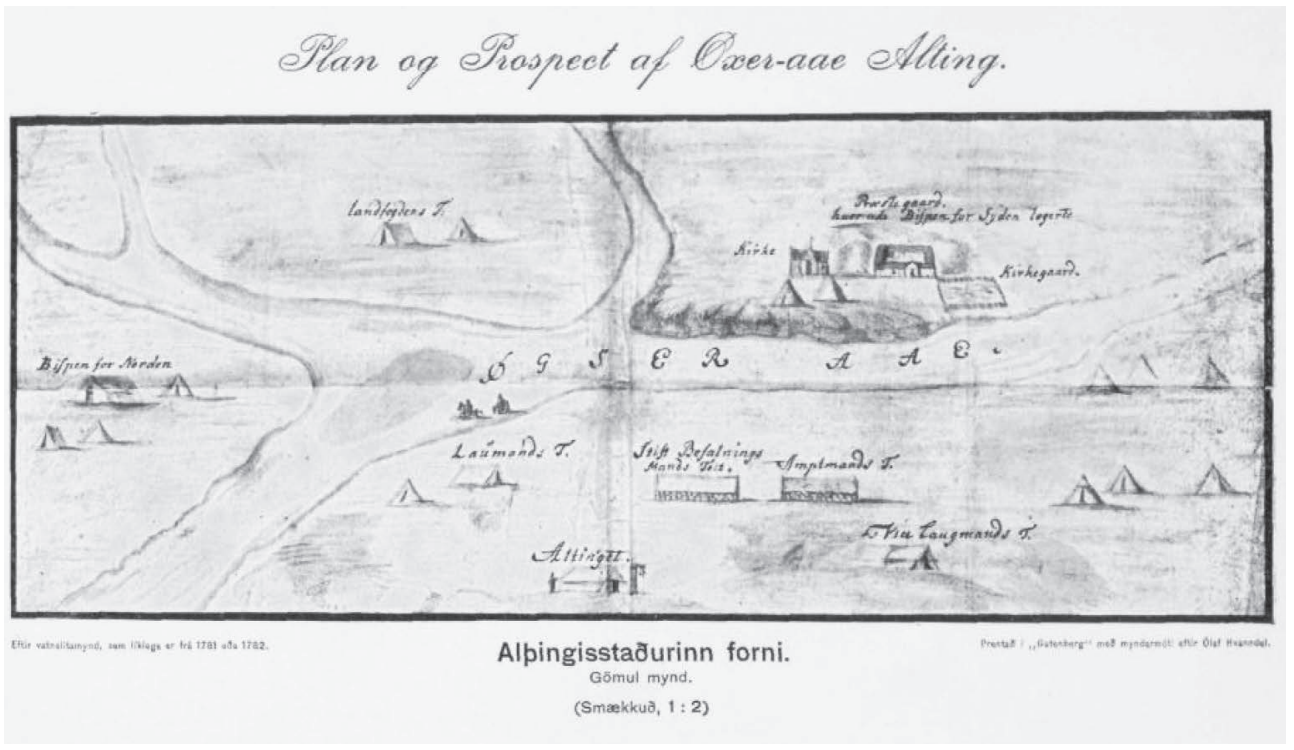

Figure 2.3 Pingvellir depicted in I79I, showing some booths. Reproduced from Pórðarson I92I-22, I07-IO8.

\section{Beyond Scandinavia: Britain and Ireland}

Each country or region has its own trajectories of antiquarian study and the insular political dynamics in each creates strikingly different routes for how assembly practices were researched and valorised. In England, discussions on the origin and development of the hundredal system appear as early as the I 2 th century in the writings of William of Malmesbury who describes it as a system of collective responsibility (Skinner 20I4, 30). Malmesbury's assertion that King Alfred [AD 847/9-899; 87I886] was responsible for its creation was picked up by other medieval chroniclers, but the Dialogus de Scaccario, a late I2th-century 'Dialogue concerning the Exchecquer', is perhaps most telling. This document, in a statement about the hundred, gives the response that 'The country people know it better'. The implication is the hundred was a useful rural tradition but one of uncertain origins and functions (FitzNeal et al. 1902, I08-I09; Skinner 20I4, 3I). By the time of Henry VIII, it is interesting that a manual was needed, published as guidance on the chairing of hundredal sessions. As Tudor Skinner has argued, 'there is a nagging sense that these institutions [bundred, shire and county courts] were... simultaneously familiar and obscure' in the High Middle Ages (20I4, 32). Courts and meetings still functioned, but knowledge of the origins and development of the administrative divisions and meeting arrangements was hazy and partly mythologized. In practical terms, meetings in the localities must still have relied heavily on oral memory and tradition in terms of location and practice.

The Reformation, however, placed a new emphasis on proving the distinctive nature of English identity, language and law, as protestant thinkers and writers sought 
to vindicate the break with Rome. The discovery of Old English revealed documents that preserved the earliest English laws and the political activities of the Anglo Saxons (Lutz 2000, I). Archaionomia, sive de priscis Anglorum legibus libri published in I 592 by William Lambarde (I536-I60I) argued for the origins of the English legal system 'in Saxon laws and administrative arrangements' (Lambarde I 592, 9, I 5, 2 I; see also Wormald I999, 7). Notably Lambarde argued that units of administration such as the Kentish lathes were likely to represent ancient patterns of jurisdiction (I 592, I 8-20). Most revealing of all is William Camden's Britannia (I 586), where the author draws a connection between the Saxon hundredal system and the assemblies described by Tacitus in Germania (Pantos and Semple 2004b, I4; Skinner 2014, 32-33). This idea was picked up and developed by other writers, notably Henry Spelman, a learned specialist in English law (Handley 2004). Lambarde, Camden and Spelman were all members of the newly founded Society of Antiquaries, which flourished in the reign of Elizabeth (Schuyler I946, 9I-92). Their writings belie a desire to establish a clear English tradition of law and administration with Anglo-Saxon roots, but also to establish connections with Germanic tradition, and in the case of Spelman, acknowledge Roman assembly practices as well (see Spelman I664; Skinner 20I4, 32-33). The influence of these thinkers and writers was profound. A century later, the philosopher and lawyer Montesquieu (I689-I755) held up the English system of government as ideal: a 'beautiful system' that could be traced directly back to the woods of Germania described by Tacitus (Montesquieu I75 I, I, I75, I77).

As nationalism developed in the 16 th to 17 th centuries, the Germanic past took on an increased importance (Hobsbawm I990, 33; MacDougall I982; Polikov I974, 77-90). Concepts of the 'nation = state = people', with common definitions sought in linguistics, historical accounts, material remains and even local customs and folklore, became familiar antiquarian territory (Hobsbawm I990, I4-45). Tacitus' descriptions of a primitive and early communal assembly had a universal appeal to those supporting absolutist or republican causes (Pantos and Semple 2004b, I4). From French Protestantism (Hill I958, 58), to English Parlimentarian thinkers and writers like John Seldon (I 584-I654), these centuries witnessed many attempts to connect the free representative institutions described in Germania with national accounts of political development (see Pantos and Semple 2004b, I4; Skinner 20I4, 33-34).

It is within this context that we can place evidence for, conversely, the attrition and loss of Gaelic customs of assembly in Ireland (FitzPatrick 2004a, I3). From the I540s one of strategies of Tudor rule in Ireland was the banning of traditional inauguration ceremonies and Gaelic titles (FitzPatrick 2004b, 2I3). In Ireland, the seminal 'royal' places or old historic centres like Tara have been a pre-eminent focus in research, but assembly places were located at a remove from sites of inauguration. The (OIr) óenach (óenaig pl.) is a term that derives from a root word meaning 'one', and connotes a concept of unification and these meetings may have operated as the principal assemblies of the Irish kingdoms (Gleeson 2018). They operated as fairs and included legal proceedings, games and sports, and seem to have operated as provincewide assemblies perhaps on a par with the shire assemblies of Anglo-Saxon England (Gleeson 2018, I03; Simms I987, 62). These gatherings, however, declined in the 9th century, and the functions were appropriated by the Christian Church (Simms I 987,62 ). During the Ioth to I 2 th centuries, however, both the major ceremonial 
and inauguration sites and principal assemblies became heavily mythologized in Ireland through the growth in popularity of the (MIr) dindshenchas (a genre of text that celebrated the lore of places) (Gleeson 20I7a). These texts valorised inauguration sites, royal meeting-places and popular assemblies, embedding them in memory and legend and securing their seminal place in the medieval stories of ancient kings and kingdoms (Gleeson 2017a, 76; 2018). By the time of the Nine Years War (I 594-1603), such powerful attachments were a threat to English rule. The traditional assembly sites or 'old historic centres' became a focus of contestation, used strategically by Irish leaders as places of muster, gathering and military encounter (FitzPatrick 2004b, 2 I 5). A claim of national leadership, for example, by Aodh Ó Néill in I 599, followed by some success against the English, culminated in a victory assembly on the Hill of Tara, Co. Meath (FitzPatrick 2004b, 2I7). As a result, the Tudor administration vilified and banned outdoor assembly as seditious. Edmund Spenser in I 596 in $A$ View of the Present State, associated them with the 'scum of loose people', describing how the Irish made use of 'great assemblies... upon a Rath or hill... to parly about matters and wrongs' (Renwick I970, 77). In defiance, some antiquarian works on Ireland valorised the old historic centres. In Geoffrey Keatings' History of Ireland, which drew on the dinschendas or medieval lore as a primary element (c. I570I644; see Waddell 2005, 27-39), Tara, Emain Macha and Uisneach, the great royal inauguration, ceremonial and gathering places, were used alongside stories of noble characters to create an heroic account of an emergent Irish Catholic nation (Waddell 2005, 34-35). This was a rarity, however, and antiquarian efforts in Ireland in the I 8 th and I9th centuries became predominantly focused instead, on prehistoric remains and the traces of early Christianity (FitzPatrick 2004a, I3; Hutchinson I987, 49, II8-II9). By the first decade of the I7th century, the traditional Gaelic royal assembly culture ceased, although sites were returned to in later centuries for the purposes of rebellion and protest (FitzPatrick 2004b, 222-223).

Gaelic practices of inauguration using mounds, stones, stone thrones and carved footprints in stone are present as well in Scottish assembly traditions. Within the midIst millennium AD, fortified sites seem to have operated as central places. In western Scotland, Dalriadic power seems to have been predicated on a number of defended sites that took advantage of prominent natural rocky outcrops; these may have been tribute centres and nodes in broader royal itineraries (Nieke and Duncan I988, II). One of these, Dunadd, is thought to have been associated with inauguration and thus assembly, with activity focused on a rock near the summit of the site where the shape of a human foot is carved out (Nieke and Duncan I988, I6). Other examples of stone-carved footprints near royal sites are known in Dalriada and beyond (Nieke and Duncan I988, I6). More generally, Leslie Alcock has argued such forts represent the seat of kings and centres of royal power ( $1988,3 \mathrm{I})$. The use of the Latin term urbs for a number of these centres in western and eastern Scotland has led Geoffrey Barrow to argue that large units of land centred on these forts may have been the forerunner of the medieval shires and thannages of medieval Scotland (Barrow 1973, 66-67). In terms of the medieval and antiquarian interest, the Stone of Destiny provides an insightful example (Figure 2.4). Believed to have been used for inauguration rituals before and during the $\mathrm{I} 2$ th and $\mathrm{I} 3$ th centuries, in which a new king had to stand or sit upon the stone to be received as rightful ruler (Aitchison 2000, 98-105), the 


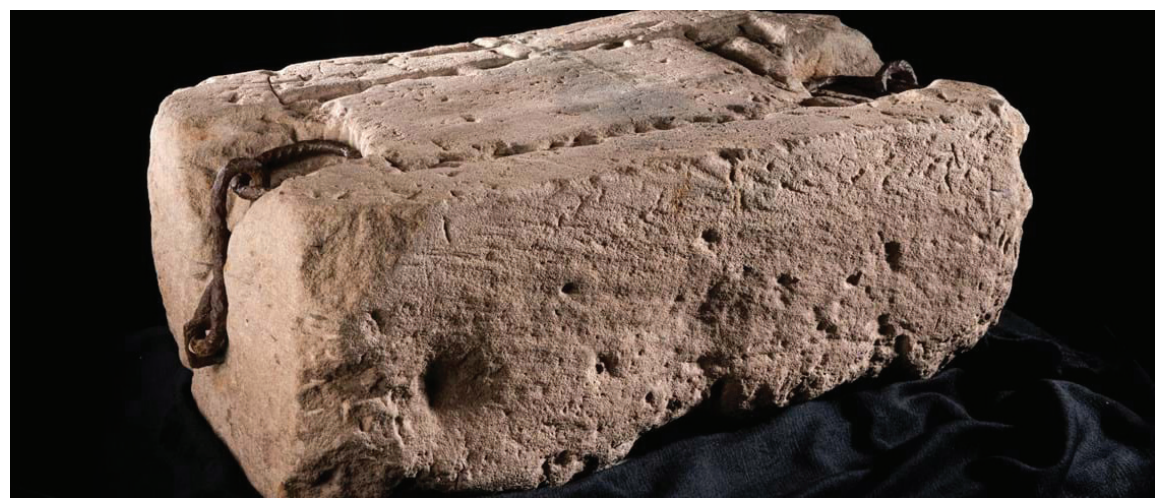

FIGURE 2.4 The Stone of Destiny, used for the inauguration of English monarchs since its removal from Scone, Scotland, in I 296. Reproduced with permission from Historic Environment Scotland.

stone was perhaps boxed within a wooden throne by the time of Alexander III's inauguration (FitzPatrick 2004b, I 53). In I 296, the stone was removed by the English during the First Scottish War of Independence and relocated to London where it has been used for every subsequent coronation of an English British Monarch since 1707 until its return to Scotland in I996. As in Ireland, the practices of using stone seats, mounds and sites with carved footprints as places for inauguration and assembly, persisted, or was perhaps reinvented, in parts of Scotland in the Late Middle Ages, for example in the rituals associated with the inauguration of the Lord of the Isles at Finlaggan, Islay, which used a large flagstone carved with a single footprint (Aitchison 2000, 98; FitzPatrick 2004b, 240).

It is interesting to note that in Elizabethan England the rituals of Scottish kingship and its symbols were in some cases embraced: the Stone of Scone features in William Camden's Britannia ( 1586 ) and John Speed's The History of Great Britaine (I6I I). Camden, however, republished the incendiary I 2th-century account by Gerald of Wales of Gaelic king-making rituals (1602). Irish writers met this with a fierce defence: Keating and others refuted that such coarse rituals could have taken place. In Keating's work, however, he listed the major inauguration sites and explored the detail of the ceremonies and ritual symbols that accompanied these events (FitzPatrick 2004a, 25). Within the context of Keating's popularised account of the antiquity and civilized ancestry of Ireland, it seems pertinent that he chose to reimagine the ancient rite known as Feis Temro or the Feast of Tara as a formal assembly or gathering: 'for the establishing of laws and regulations in Ireland in his [king and law-giver Ollamh Fodhla] time' (Waddell 2005, 27-29).

\section{Summary}

When comparing the ways in which assembly and inauguration traditions eventually ended and were picked up to greater and limited extents in the first 


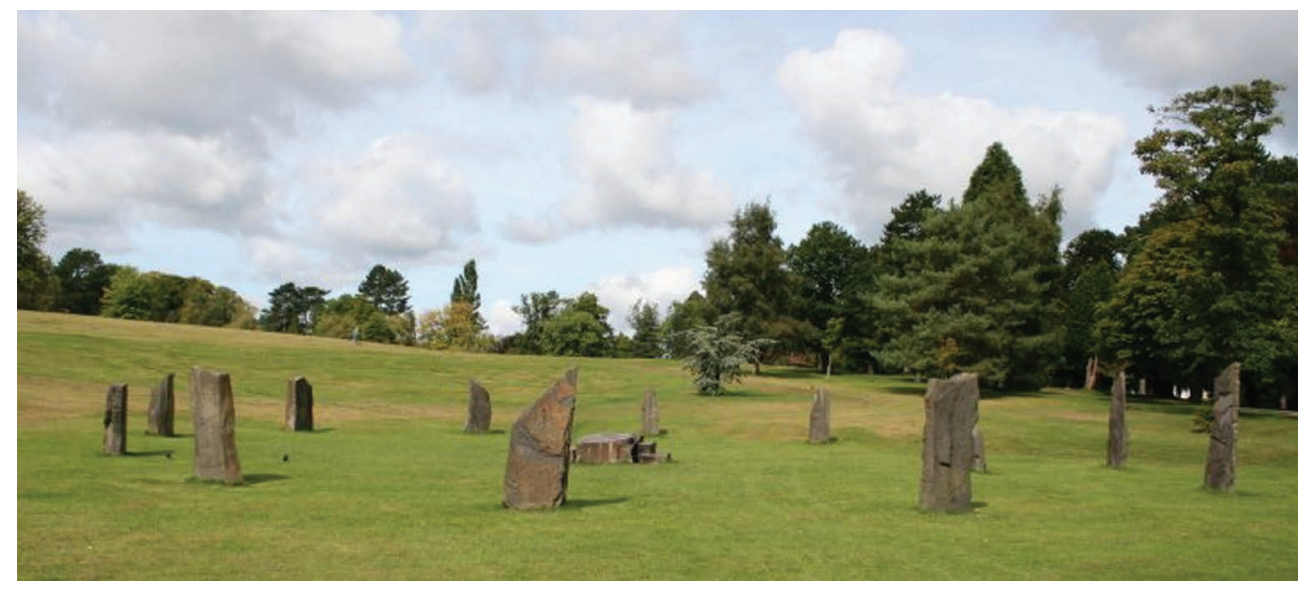

Figure 2.5 Pseudo-ancient monument at Abedare, Wales, constructed as a focus for the Gorsedd revival. Photograph by Darren Wyn Rees at Abedare Blog. CC BY-SA 4.o.

antiquarian studies and publications, it is clear that early medieval assembly practices and places continued to carry power in the Middle Ages, as symbols of tradition and rightful authority. They were essential in the staging of legitimate power, but deployed as well in the creation of new invented political narratives. Antiquarian writers, often encountering these practices in their twilight, chose to valorise or demonise them, either portraying them as elements of the noble cultural and indigenous traditions of the past, or as seditious and uncouth barbaric activities that should be eradicated. Even in the I6th and I 7 th centuries, they were seen as culturally contingent, rooted in the perceived prehistoric, ethnic and cultural differences that were thought to shape particular peoples and kingdoms.

An extraordinary final vignette can be found in the wholesale invention of assembly traditions in Wales a century or so later. In line with the growth of antiquarian claims by different nationalities for the ancient nature of their royal or legal and political institutions, Edward Williams (I747-I 826) undertook a virtual wholesale invention of the Welsh past, creating a medieval Order of Bards, keepers and teachers of a tradition of mystical belief (Hutton I993, I39-I42). Mixing pseudo-medieval ritual and Celtic traditions and prehistoric and medieval emblems, Williams invented monumentalised places of assembly, created as theatrical settings for rituals connected to his Welsh nationalist revival. Some of these sites survive today (Figure 2.5). Drawing on prehistoric monuments and symbols, these sites were intended to instil a common and stronger sense of national identity through their invented settings and ritual action.

\subsection{ROMANTICISM, NATIONALISM AND THE THING}

While the seeds of nationalism lie in the Renaissance in Western Europe (Silberman 1982), the relationship between archaeology and nationalism became 
far more intense and explicit in the I9th century (Kohl and Fawcett I995, Io; DíazAndreu 2007, 57-58). Archaeology was established institutionally in its own right as European powers became expansionist and vied for control of assets in the Americas, Asia and Africa (Hobsbawm I990, I4-45). The advent of the Romantic Movement played a crucial part in stimulating and sustaining nationalism but also spurred a growth of interest in the late prehistoric/medieval era. The Middle Ages provided the earliest written sources of kings and dynastic rule and the literary 'darkness' of the first centuries of the Ist millennium $\mathrm{AD}$, its inscrutability and primitive nature expressed through rare accounts like Germania, were attractive to the Romantic movement in their suggestion of a simpler, noble age.

The need to create distinctive national histories drew antiquarians to the same pool of sources: Tacitus, the sagas, laws and texts surviving in early Germanic languages and early 'histories' and chronicles etc. For ambitious states such as Germany and Italy, who sought to unify diverse peoples and polities, linguistic identification was a primary means of claims to nationality, spurred by the development of vernacular literatures (Hastings I997, 20-27), but historical evidence and material culture inevitably played their part (Sweet 2004; Content and Williams 2010). Smaller polities, either claimed commonalities in order to become part of a greater nation, or fiercely sought to demonstrate their distinctive nature through languages and customs (Hastings I997, 96-I23). The I9th century was a time of philological discovery, with revelations of a shared Indo-European language (Aarsleff I983, I I 5-I65). It was also a time when intense interest in early Germanic law also took hold.

\section{Law and nationalism and the thing}

German scholarship is unsurpassed in this era for publications on medieval Germanic law. An early protagonist was Jacob Grimm (I785-I863) (Wormald I999, IO-II). Along with his contemporaries, Grimm was convinced of an early primal 'Germanic' law. He played a significant part in the creation of the Historische Rechtsschule (German Historical School of Jurisprudence), which departed from ideas of natural law, and in the spirit of the Romantic age considered law equal to the customs, language and traditions of the people. Such an approach allowed the conflation of sources from different places and times, as long as they were perceived to stem from a common, ancient shared 'ethnicity' (for all above, see Wormald I999, I I-I2). The result was a system of Germanic law, concocted 'by boiling up evidential ingredients from allotments as diverse as Tacitean Rome and Snorri Sturlasson's Iceland' (Wormald I999, I2). One cannot underestimate, however, the wide and long-lasting impact of their core conceptions of a shared early basis for language, custom, religion and law.

Although nationalism was felt universally across the Nordic states, the unsteady nature of the union between Sweden and Norway in the late I 9th century (Hillström 2010, 604), promoted the valorisation of insular traditions. Initiatives such as the Nordiska muséet, 'The Nordic Museum', and the open-air museum Skansen, by Artur Hazelius (I833-I90I), put an emphasis on Swedish history and folk culture (Bohman I997, 2I), while Yngvar Nielsen (I843-I9I6), embarked on creating a new and separate Norwegian museum tradition showcasing the oldest cultural development of 
Norway (Shetelig I944, I9I-I95). Legal and assembly traditions had a major role all in these arguments for ancient pre-eminence. P A Munch, for example, a Norwegian historian, made strong arguments for the distinctive nature of the Norwegian legal system and its divisions, arguing these had a pre-Christian origin (Munch I 849, I3). Similar sentiments perhaps were at work in the creation in I 840 of a regional estate assembly for Iceland by Christian VIII, who asked if it 'should not bear the name Alpingi... meet at Pingvellir and have the same organisation as the old assembly' (cited in Hálfdanarson 2000, I 5 , no. 33). The thing institution became a prized attribute in claims for ancient primacy: Jón Jónsson Aðils wrote of the Icelandic Commonwealth Period 'Wherever we look, we find evidence of a society so rich, so beautiful, so splendid, that it compares to no other society in former times but to the one of ancient Greece at its highest stage of development...' (Aðils I903, 238, quoted in Friðriksson I994, 5-6).

A number of Danish and Icelandic antiquarians, among them Daniel Bruun (I 856-I93 I), Kristian Kaalund (I844-I9I9), Brynjúlfur Jónsson (I838-I9I4) and Sigurður Vigfússon ( I 828-92), embarked on a more systematic approach to identifying assembly sites and their architectural remains in the landscape at the time. These researchers were strongly motivated by the written accounts and sagas (e.g. Friðriksson and Vésteinsson I992; Friðriksson I994, I05-I46; 20II). Such endeavours were of course fraught with errors, as Adolf Friðriksson has so vividly identified (1994). Features described in medieval law and literature as $(\mathrm{ON})$ dómhringar, $(\mathrm{ON})$ dómr 'court, judgement' and (ON) hringur 'circle', were sought out and identified on the ground as physical monuments, although these enclosures are now considered, in the main, to have served other purposes (Friðriksson and Vésteinsson I992, 27-28; see too Friðriksson I994; 20I I, 346; Vésteinsson 2006b) (Figure 2.6). Our own results have revealed the frailties in these I9th-century excursions. Our survey of the remains recorded and excavated in 1896 by Daniel Bruun and associated with the Vaðlaping (Bruun I987, I80-I8I; Kaalund I877-82, I25-I28), revealed instead that these structures are the remains of a farm. The ruins recorded and excavated by Bruun are typical for an Icelandic farm building and no traces of characteristic assembly structures such as booths were found. Most archaeological work focused on Pingvellir (in Iceland), where surveys and excavations were carried out in the second part of the I9th century (Bell 2010; Friðriksson et al. 2005).

Early I9th-century curiosity regarding meeting-sites inevitably arose elsewhere. Such evidence, if located, could underpin desired contemporary political connections and in Shetland, for example, these ancient sites were valorised as dual evidence of early law and Scandinavian-Scottish descent. Hibbert discussed thing sites in a Description of the Shetland Islands in I 822, drawing heavily on the Icelandic sources and comparing Tingwall in Shetland with Pingvellir in Iceland. An important facet of Hibbert's work, intimate to the early work on Iceland, was to identify and characterise things. His failing, like his Icelandic and Danish counterparts, was to draw on a rich repertoire of prehistoric monuments, re-inventing these as thing sites based on their circular shape and form (Hibbert I 822, 278; I83 I; see also Skinner 2014, 44).

The drawing of closer connections with Scandinavia by these island communities articulated their differences to Britain, countering the traditional antiquarian emphasis on the historic unity of England and Scotland (Sweet 2004, 227). Scotland had no 


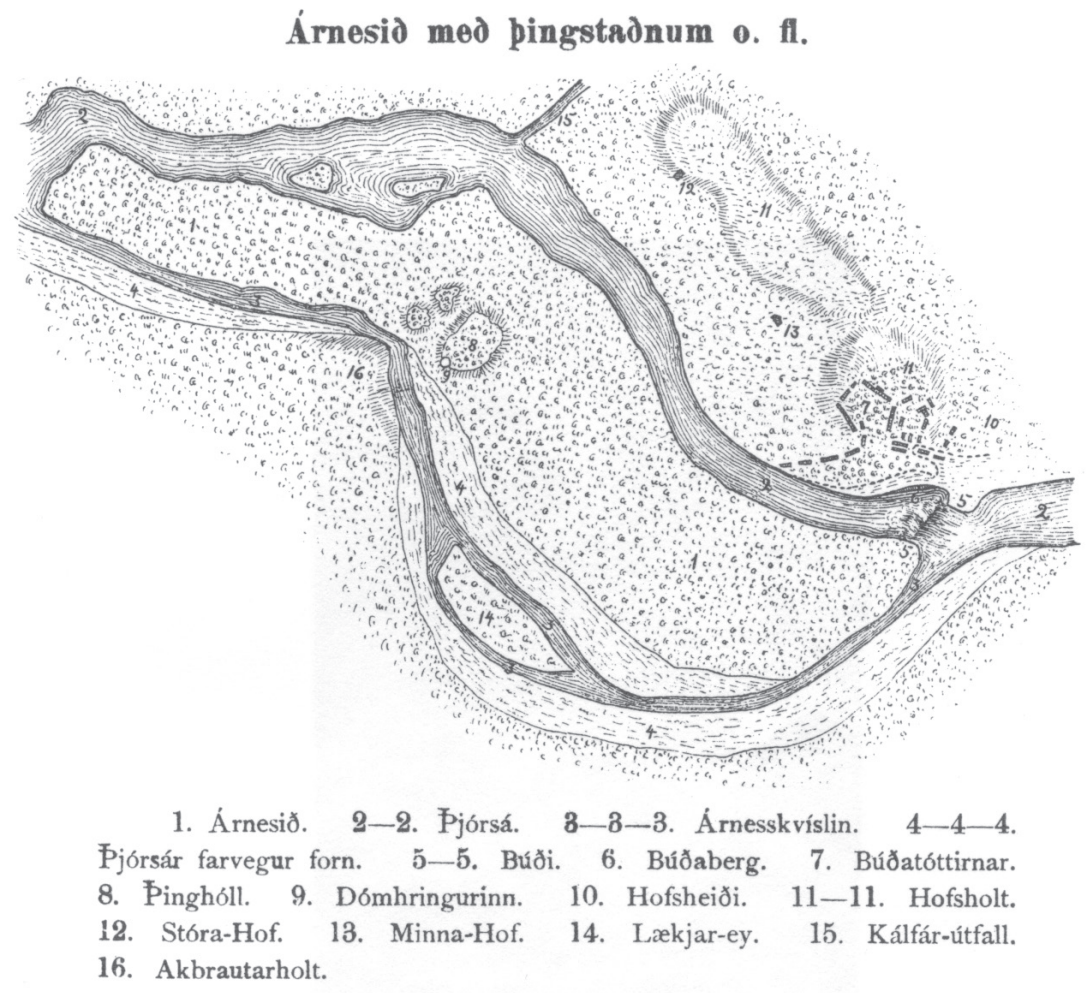

FiguRE 2.6 The assembly site at Árnes, Iceland, showing a court circle (no. 9). Drawing by Brynjólfur Jónsson. Reproduced from Jónsson I 894, I 2.

Anglo-Saxon constitution to rival that of England, but George Barry, who wrote a history of the Orkney Islands in I805, argued the inhabitants were descended from Icelanders, who displayed a wisdom which 'among a barbarous people, has seldom been equalled, and never surpassed, in forming themselves into a regular republic' (Sweet 2004, 227).

\section{English nationalism and legal history}

The second half of the I9th century saw continued growth in historical commentary on early law. The legacy of the Rechtsschule was broadly felt. Frederic William Maitland, a correspondent with counterparts in universities across the North Sea wrote of the 'tons of books concerning legal history which Germany produced in the I9th century...' (The Laws of the Anglo-Saxons; Fisher I9II, 462-463). German legal historian Konrad von Maurer (I 823-I902) wrote extensively about Norway (I907) and the constitution of Iceland during the Commonwealth Period (Maurer I 874), guided heavily by the surviving medieval literature. Heinrich 
Brunner, whose prolific publication record marks the climax of the Historiche Rechtsschule argued, in Deutsche Rechtsgeschichte for these shared teutonic legal institutions and in a separate paper stressed the value of Anglo-Saxon law as 'vernacular... and free of Roman "taint"' (Wormald I999, I 5-16, citing Maitland I 889, 66-67 and Brunner I908, 8). In England, historians like William Stubbs, in personal correspondence with Rechtsschule protagonists (Wormald I999, I3), claimed 'a native or at least common Germanic' legal inheritance (Stubbs I874, I, 97-IO5, I I4-I I 5; Wormald I999, I4), tracing the origins of the bundred to the 'folk districts' established by Germanic migrants in the 5 th and 6th centuries (Stubbs I 874, 77, IO3-IO4) and linking the pagi (Lat.) of Tacitus with the English hundred, the Frankish mallus and the herað of Scandinavia (Stubbs I874, I03; Skinner 2014, 3538). These views were echoed by his contemporary F W Maitland who argued for similar links (Maitland I908, 44; MacCotter 2008, I09-I24; Skinner 20 I4, 38 ).

Another Anglo Saxonist profoundly influenced by the Rechtsschule was John Mitchell Kemble, a scholar of philology and law, and well travelled on the continent with a deep knowledge of 'Germanic' antiquities; he was also a correspondent of Jacob Grimm (Williams 2006, 3, 5-6). The English assembly for Kemble was without question rooted in the pan-Germanic past, and could be recognised in the legal institutions of his own day (Kemble I 849, I, 240). He preferred Grimm's arguments for an early systems of free households or 'Marks' that over time coalesced into larger units - the (OE) ga or shire-which in turn formed the building blocks from which the first kingdoms emerged (Grimm I828, 36, 53; Kemble I849, 47; Skinner 2014, 34-35 for overview). The ga or gau would gather the 'markmen' at 'a ping, placitum or court' (Kemble 1849,74$)$. His definition of (OE) ping is strikingly familiar to recent conceptions of the convergence of cult and kingship at the Scandinavian thing (e.g. Brink 2004a; 2013): 'the lands necessary for the site and the maintenance of a temple, the supply of beasts for sacrifice, and the endowment of a priest or priests: perhaps also for the erection of a stockade or fortress, and some shelter for the assembled freemen in the ping' (Kemble I 849, I, 74; Skinner 20I4, 35-36).

In this climate of correspondence and shared interests, the 'folk-moot' or 'primitive' assembly recorded by Tacitus retained its primacy as evidence of enduring relationships between Germanic-speaking groups and a shared history of early democratic and free institutions. Such emotions are clearly evident in the work of Laurence Gomme (I853-I9I 5), a librarian, historian of technology and a folklorist, correspondent of Kemble and Grimm. Gomme drew on an extensive repertoire of sources, from the Anglo-Saxon laws to the medieval literature of Scandinavia, as well as folklore, in authoring Primitive Folk-Moots or Open Air Assemblies in Britain (I 880). Another expert of the time whose research has endured the test of time far more successfully than Gomme's is Felix Liebermann. Liebermann had been tutored by experts of the Rechtsschule (Wormald I999, 20-24) and in 1883 he impressed Brunner and von Maurer sufficiently to receive a commission to compile a corpus of Anglo-Saxon law. His work encapsulates the drive to compile and merge early sources from across the 'Germanic' spectrum; as Wormald identifies, 'his objective was recovery of the common Germanic', and thus he privileged Icelandic and Scandinavian evidence over Carolingian sources, and he conceived of the Anglo-Saxon assembly as an institution with its roots firmly in the late prehistoric era: 
It therefore existed in heathen times, and the same venerable author [Bede] adduces another instance from pagan Northumbria. These two archaic examples of the national gemot had their precursor in that hypothetical assembly, without which the continental forefathers of the English cannot be conceived; and what Tacitus tells us about early Germany seems indeed to survive in the functions of the assembly six hundred years later (Liebermann I9I3, 3).

For Liebermann, the open-air meeting was the oldest form of early assembly, and in this, he concurred with Laurence Gomme. They believed it had its roots on the Germanic continent and that the English parliament could count the late prehistoric assembly as 'one of its parents' (Liebermann I9I3, 43-44, 90). Liebermann, however, was keen to point out that different assembly practices may have evolved and that some, like the royal council or (OE) witan, may have developed separately and were different to the (OE) folcmóte 'popular assembly' (I9I3).

\section{The recovery of Gaelic tradition}

In line with Romanticism in Scandinavia and England, it is in the early I9th century that Irish assembly practices and royal inauguration received detailed attention. The Gaelic Revival, prompted by growing nationalism, resulted in a growth in interest in Irish language, literature, history and folklore. In the I 7 th and $\mathrm{I} 8$ th centuries the predominent focus of antiquarian interest, as in Scandinavia, had been on surviving prehistoric monuments and remains, with a heavy emphasis at times on attributing old works of all kinds to 'the Danes', indicative perhaps of the strong and long-term influence of Ole Worm's publications on the antiquarians beyond Scandinavia (Waddell 2005, 4I, 47-49). Charles O'Connor, a renowned historian, acknowledged his interests in Rath Croghan, 'the place of Election and Inauguration of our Provincial Kings' (Waddell 2005, 66-67), and the royal sites appeared briefly as well at this time in other works and in historical cartography (Andrews 1986, 38, fig 3; Waddell 2005, 67). It is in the surviving I 8th and I9th century travelogues, however, that the Romantic attraction of legendary sites connected with kingship and assembly is attested (FitzPatrick $2004 \mathrm{~b}, 27$ ). These record stones and rocky outcrops, thrones and mounds, attesting to the richness of local folklore attached to ancient places (FitzPatrick 2004b, 27). This was enhanced in the I9th century in the context of the Celtic revival, which involved artists and writers identifying and embracing connections with the Celtic people in parts of pre-Christian and early Christian Europe (McAteer 2015). It is within this I9th-century context that the Ordnance Survey of Ireland was established and this greater investment in cartography led to a research interest in place-names (Waddell 2005, 97-99). The work of John O'Donovan in Ireland can be set within this context. He was recruited to the first Ordinance Survey in I 830 to address the task of mapping place-names and antiquities and later became Professor of Celtic Languages at Queen's University. O'Donovan gathered an extraordinary compendium of information on inauguration customs, the sites themselves and the folklore relating to these places (FitzPatrick 2004a, I 5; Waddell 2005, 98-99). O'Donovan's county-by-county work laid a foundation for future study, opening up the potential for archaeological enquiry (FitzPatrick 2004b, 26). Many believe that 
the Ordnance Survey marked a beginning for Irish archaeology as discipline (Waddell 2005, I03). In the I930s, George Petrie surveyed the Hill of Tara and published his results $(1839,224-232)$. The exploration of monuments and sites, survey and mapping and the study of linguistics developed side-by-side and led to the publication of detailed explorations of other important royal complexes such as Carnfree in Co. Meath (Waddell 2005, I I4). As in Scandinavia and England, in Ireland and Scotland, a greater emphasis on recording, mapping and survey proved vital in capturing information on royal sites, places of inauguration and other potential assembly locales. Joseph Anderson compiled information on many antiquarian publications, and his work and others tended to valorise the distinctiveness of the Iron Age in Scotland (I 886). These individuals and organisations strove to achieve an empiric basis of information, but did so against a I9th- to early 2oth-century background of religious and political division that sought to determine differences based on national, political and religious values and, in the end, racial distinctions (Waddell 2005, I 59-I65).

\section{Summary}

By the turn of the 2oth century, the ebb and flow of correspondence and shared ideals between the scholars of early language, law and antiquities had thus come firmly down on the side of a common ancient, 'Teutonic' origin for the thing and its 'Germanic' cognates, the Anglo-Saxon moot and the Frankish mallus. The place of the open-air meeting or 'parliament' in Romantic consciousness was sealed despite the more pragmatic and constitutional concerns of historians like Stubbs, Maitland and Brunner. Pan-Scandinavianism may have played its part in stimulating the broader use of medieval Scandinavian sources and new discoveries in Iceland in a search for the ancient thing. Lending itself neatly to arguments for a distinctive pan-Germanic cradle of human advancement, separate from the Roman and classical worlds, the thing was used to create distinct and powerful arguments for the political strength and ancient superiority of the allied 'Germanic' speaking, and racially connected, nationalities of northern Europe. Romantic and antiquarian interests also developed in the royal sites of Ireland and Scotland. Emphasis, however, within the Celtic schools of antiquarianism, was often the folklore and textual survivals that attested to the importance of the sites as ancient seats of kingship, inauguration and ceremony, thus emphasising the deep roots and traditions of independent rulership and political autonomy.

\subsection{RESEARCH TRADITIONS I9O0 TO PRESENT DAY}

An emphasis in survey, recording and systematic study and cataloguing of archaeological phenomena and place-names is common to many regions in the late I 9 th and early 20 th centuries. In the new century, Sweden witnessed a surge in national Romanticism: 'National Romantics believed that national identity was central to their program of individual freedom, social harmony, symbiosis with nature and the preservation of indigenous traditions' (Facos I998, 3). The essence of Swedishness was commensurate with rural life and nature and instilled in the settlements, natural landscape and rural populace or 'folk' that held 'primordial' links with the 
past (Facos I998, 4). Such drivers resulted in the emergence of a strong academic interest in the localities, and, as part of this, place-name and assembly studies and a focus on mapping early local administrative arrangements rose in popularity. There was a move to undertake detailed recording in the localities, listing medieval thing sites and at times locating them on the ground (see below). These methodological changes mirrored a similar growth of interest elsewhere. In England, the 'optimistic imperialism' of the end of Victoria's reign had sparked renewed interest in Englishness and thus the English countryside (Gerrard 2003; Hingley 2008) which gave rise to a renewed interest in place-names.

\section{Catalogues and place-names}

Although interest in place-names can be traced as early as the I6th century (Spittal and Field I990, 3), place-name studies emerged as a distinctive tradition in the I 9 th century (see, for example, Gomme I 880, I98-259), and in the early 2oth century moved into a new empiric era. In England place-name studies found a new rigour with the founding of the English Place-Name Society in I923, which with its programme of survey and publication, provided an 'organisational sophistication' that would result in the exceptional, if incomplete, coverage we have today in terms of English habitative names and toponyms (Ryan 20I I, 6-7). The hundred and wapentake were used as structuring elements and volume by volume, this administrative focus resulted in the definition of attributes that might constitute an assembly place (Skinner 20I4, 46-56). From Allen Mawer onwards, authors noted characteristics such as positions in neutral areas, or on commons or parish boundaries, good communications, distinctive features such as trees, mounds, forts or clearings, and good views. Such ideas have remained strikingly influential, shaping locational work on identifying assembly sites right into the present (e.g. Baker and Brookes 201 5 ; Pantos 2002; see also later sections here and Chapter 3 ).

A new era of transnational collaboration also emerged. Eilert Ekwall was a scholar who capitalised on the striking similarities in mentality and intellectual drive in the English and Swedish schools. Ekwall was Swedish and Professor of English at Lund University and a foremost scholar in English place-name studies publishing perhaps most notably his Dictionary of English Place-Names (I960). His work with the English Place-Name Society and Alan Mawer and Frank Stenton in the I920s-3os opened up an important dialogue in place-name studies between philologists in Scandinavia and Britain (von Feilitzen I96I). One of the most important contributions to the study of local units and assembly places was made by his student and successor at Lund, Olof Arngart (previously Anderson) (Kristensson 1997). The position of these two scholars, working between Scandinavian and English scholarly traditions in the early part of the 2oth century cannot be underestimated and almost certainly accounts for the shared approaches that emerged. Olof Arngart is notable for producing one of the most definitive sources for assembly studies in England, which continues to shape current work. The three volumes of English HundredNames (Anderson I934; I939a; I939b) remain the only comprehensive study of the names of hundreds and wapentakes in England, and within this, Arngart identified potential locations for the hundred meeting-places. Together with the English Place- 
Name series, the volumes set in motion long-held methods for seeking out meetingsites within hundred or wapentake units.

Firstly, the unit name was considered the primary clue to location. Salmonsbury hundred in Gloucestershire for example, indicated that the original meeting-place for the hundred was the Iron-Age fort carrying the name Salmonsbury (OE) burh 'fort' (Smith I964-65; see also Pantos 2002, 306-307). In fact, local meetings at Salmonsbury are recorded as late as the I8th century (O'Neill I977), demonstrating some veracity to the method. A range of factors was then drawn upon to corroborate such identifications. Problems arose when associations were made between a unit name and a modern toponym or habitative place-name. Indications, for example in medieval documents, of meetings at Burcheleiam in Skyrack wapentake in West Yorkshire, were assumed by Anderson to refer to the modern surviving Burley in Wharfedale 'which for several reasons would be a good meeting-place' (see Skinner 2014, 52-56; and also Anderson I934, 22-23). More suspect still are instances when Arngart could not make a connection between a unit name and a feature, and medieval documentation was also absent; in these circumstances, Arngart simply selected 'appropriate' sites of assembly based on accepted characteristics for such places (Skinner 20I4, 52-56).

In Sweden, after a predominance of research that had focused on the written evidence, the I920s-40s saw the production of a number of significant catalogues of administrative units and assembly sites. While these took place-names extracted from medieval and late-medieval documents as their starting point and relied on documents of a contemporary age for additional evidence, several of these publications included careful drawings and plans of some meeting-sites, marking-out standing stones and runic monuments (see summary in Sanmark 2009, 207). Fridolf Wildte, in particular, in a study of prehistoric and early medieval thing sites in Sweden, identified features such as law circles and meeting-mounds, stone settings and rune-stone attestations to thing sites (1926). He also noted a likely connection with marketing and trade (Wildte I926, 2I3-2I4). These publications offer some of the first on-the-ground identifications of sites, and are cautious in their use of place-name and runic evidence. These writers also drew on unpublished and antiquarian accounts, sometimes reproducing earlier images of sites (e.g. Nordén I938). Between the I920s and I940s, catalogues, that were created province by province with a local focus, located and characterised sites using diplomas and place-names (Ahlberg I946a; I946b; Lindqvist I927, 43-44; Turén I939; Wildte I926; I93 I). Things were variously connected by these writers to cultic activities, guilds, sports and competitions and marketing (e.g. Schück I926, I70).

The first similar mapping of thing sites in Norway was carried out by Alexander Bugge (I920). Interestingly Bugge, like Jens Worsaae before him, emphasised the importance of Scandinavian influences on English administrative systems, and Scandinavian administrative practices in the Danelaw (Bugge 1904, 325; see also Worsaae I 852, I 59-I63). Bugge used a different methodology. He recognised that the name of wapentake units in the Scandinavian homelands and in the Danelaw often contained a personal appellation and argued that where a personal name was taken for a district, the assembly was likely held at the residence of the named individual or chief (Bugge 1904; see overview in Skinner 2014, 55-56). This idea features as well in Ekwall's work, and is proposed by Mawer and Anderson (Skinner 20I4, 55-56). 
The idea of a shared, ancient Germanic inheritance still exerted a strong influence. Meeting-places were often discussed in terms of enduring foci, where assemblies had been held since pre-Christian times (Bugge I920; Schledermann I974). To a degree these surveys testify to the filtering down of Romantic and nationalist ideas to local scholarship. These individuals were mapping early local systems of governance, arguing for insular and yet ancient traditions, often based on written and documentary sources, especially the sagas and medieval literature. Nevertheless, these publications remain an important source of information on thing sites mentioned in medieval documents. Little attempt was made however to distinguish any kind of chronology, the existence of these places was sufficient as testimony of the ancient nature of local administration (e.g. Bugge I920, I IO; Bull I924, I43; I92 I, 64).

At the same time, some scholars worked on categorising and recording the early units or districts. In Norway, Tunberg in particular worked to distinguish the meaning, purpose and distribution of the (ON) herað, hundred (r) (I9II, 79-86). Units were debated in terms of their origin, for example whether the $(\mathrm{ON})$ skipreiða division was a Danish model (e.g. Bull I920, 50; Hertzberg I9I4, 247; Indrebø I935, 259), or introduced from Western Norway by King Haakon the Good [AD 920-96I] under influence from Britain (Steinnes I929, 63-65). Together these publications denote insularity in scholarship and a competitive edge in terms of national sentiment. Many were eager to claim the first and earliest evidence for law and government. It is in these accounts, however, that local legal scholarship developed a landscape element.

\section{National Socialism and the concept of the thing}

In Germany by the I930s, the thing had found a firm place in the ideology of National Socialism, but the origins of the Third Reich's interest in things stemmed from the German Romantic nationalism of the I 9 th century. The völkische movement can be characterised as a set of ethno-nationalistic beliefs that emerged in relation to ideas of commonalities created by blood and race bound up with a reaction against industrialisation (Mosse I964; Pietikäinen 2000, 524-525). Rooted in the political theory of the enlightenment, this movement believed in the essential freedom of primitive Germanic society and a Germanic golden age (Mosse I964, I-2). Folk songs and Germanic customs and symbols were revived and the movement stressed the importance of nature and landscape, often holding open-air festivals (Mosse I964, 67-87). Inevitably, the thing found a prominent place. A national festival in I 832 at Hambach, Germany, for example, was organised to coincide with the supposed time of year when the Germanic thing had been held, and in 1907 a theatre in the Hartz Mountains in Germany was created for the staging of specially written plays reflecting völkische philosophy (Mosse I964, 67-87, 80-84). The thing was conceived as an expression of a pure and free primitive society, romantic notions innocently captured in paint by William Gershom Collingwood in Alping (Althing) in Session in I897 (Figure 2.7).

One of the many plays conceived with national themes and ideologies to emerge from this movement was the Deutsche Passion 1933 which premiered in Heidelberg in I934. This was the first play to be given the generic title Thingspiel, or 'Thing play' (Fischer-Lichte 2005, I22). Drawing on the concept of the Germanic thing, 


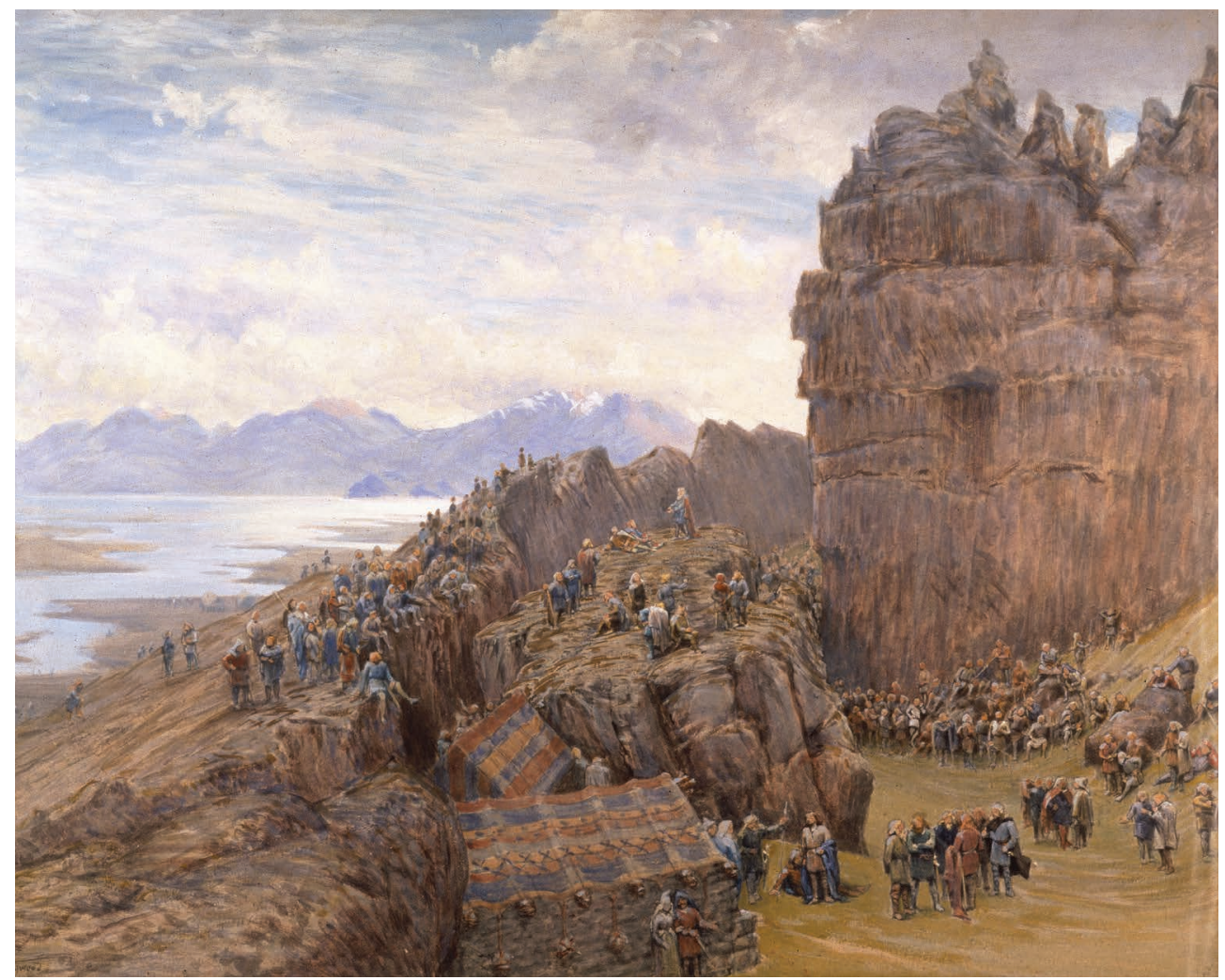

Figure 2.7 Oil on canvas entitled 'Alping (Althing) in Session', by William Gershom Collingwood, c. I 897. (C) The Stapleton Collection/Bridgeman Images.

this new genre of performance was concieved as 'a "people's... liturgy"... [and] the "monumental pulpit whence National Socialism will be preached" (Walter Tiessler)' (Fischer-Lichte 2005, I28). Thing plays or Thingspiele were developed in the I930s under the Third Reich as a new form of drama (Niven 2000, 55 ). They were situated in the open air, sometimes within groves, and often in dramatic locations with direct visual association with both ancient monuments and First World War memorials or commemorative sites. By 1934 the movement was at its peak, active sites included Halle and Holzminden, and some 20 further sites were under construction (FischerLichte 2005, I42-I43). Heidelberg is the most well known of all the Thingplätze or Thingstätten. The open-air theatre was constructed on a distinctive hill hosting a prehistoric fort, two Roman-period temples and an early medieval monastery (Figure 2.8). The monumental seating area and stage was, in part, classically inspired, but the open-air situation drew on other influences. As the architect of the thing movement, Carl Nissen, explained: 'The new Germany is again striving to leave the stone deserts of the towns... the people liberated from the politics of self-interest, finds its wonderful, symbolic expression in the wide realm of nature' 


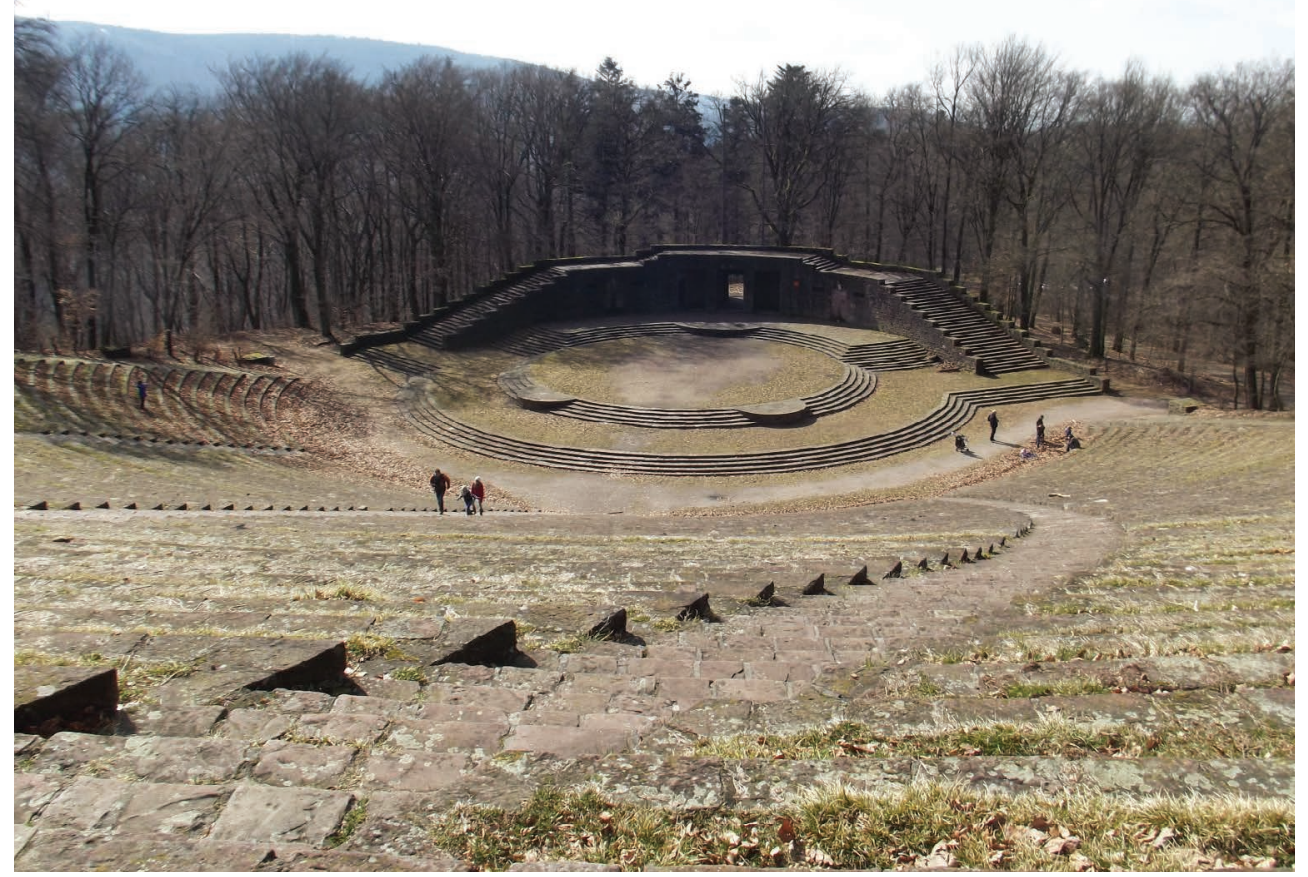

FIGURE 2.8 The Thingstätte at Heidelberg, Germany. Photograph by Sarah Semple.

(cited in Niven 2000). The inauguration of the Heidelberg thing site took place in I935 on the summer solstice (Fischer-Lichte 2005, I43). This, however, seems to have signalled the beginning of the end of the movement and while the sites continued in some use, in the same year the Ministry of Reich Propaganda shut down the mass performances and disassociated itself from the terms thing and thing site (FischerLichte 2005, I44-I45). Despite this, several researchers associated with the Third Reich planned a survey of I 5 to 20 thing sites on Iceland in 1938 , photographing the ruins and interviewing people to collect oral information (Stummann Hansen 2005). Nevertheless the movement was a failed experiment and Thingspiel proved unpopular with the German populace. Construction of the Thingstätten ceased, but many arenas were put to other uses and several survive in present use as concert arenas.

\section{Scandinavia since 1940}

The academic focus, in past and present, is generally the surviving laws and administrative records rather than evidence of the thing meetings. This is especially true of Norway where research narratives are heavily dominated by historians (e.g. Andersen I977, Ch. 22; Ersland I999, I02-105; Helle 200I; Imsen I990; Sigurðsson $2008 \mathrm{a})$. Here the legacy of historical research undertaken in the late I 9 th to early 20 th 
centuries on early legal matters has provided basis for advancements in knowledge in the 20 th century. In the I970s in particular, older studies and models were revived. A number of republications occurred, including Aschehoug's Constitution of Denmark and Norway until I8I4 (I866), in a compendium of selected texts by Norwegian historians (e.g. Holmsen and Simensen I967). Per Sveaas Andersen also made several important contributions, drawing on the literary and saga material (1974; I977). Edvard Bull's thesis dealing with the governance and judicial kingdoms as well as the thing institution was republished as Lov, rett og statsstyre (Law, justice and rule of state) again by Holmsen and Simensen (1970), alongside Ebbe Hertzberg's work on the thing institution (Hertzberg and Brandt I 874) retitled as 'Den ældste norske process' ('The oldest Norwegian lawsuit') (Holmsen and Simensen I970, 27-36) and also, crucially perhaps, Absalon Taranger's work on royal power and administration and the thing. This reissuing of key historical discussions marks a time in the I970s when a more intensive research focus emerged on ideas of early governance in Norway, the emergence of chieftainly power and the thing institution. The Gulathing, the medieval law province of western Norway and the region from where the medieval Norwegian kingdom is held to have been established and expanded in the Viking Age, has long dominated discussions (Helle 200I; Krag 2008, 646-647). The provincial or regional units of medieval administration-the skipreiður-have also received significant attention (see Ersland 2000). In both instances, research has largely focused on the age of these law provinces and the regional units and how such administrative divisions may have operated together. Some have considered the military capacities and functions of the regional level divisions. While the judicial and socio-political functions of Norwegian administration have been extensively discussed, the precise locations and physical aspects of assembly sites, and indeed their archaeology have largely been ignored.

A type-site that has long occupied researchers, however, in terms of its potential relationship to early legal arrangements, is the so-called courtyard sites of Norway (Mod Norw tunanlegg). These were first documented in $\mathrm{I} 86 \mathrm{I}$ as a result of the discovery of Dysjane, Tu-ridge in Stavanger (Nicolaysen I 862-66, 30I). These often semi-circular complexes of bow-sided long houses were categorised as a type-site or monument in the I930s (Grimm and Stylegar 2004, III) (Figure 2.9), when several were investigated by Jan Petersen and Oddmund Møllerop (Møllerop I957; I97I; Petersen I936; 1938). Petersen and Møllerop identified these as a settlement type predating single farms. Ottar Rønneseth argued these sites were in border regions between resource zones and may have acted as gathering places for special purposes including judicial, cultic and military functions (1959, 68-74). In line with favoured military interpretations for the early regional units, Lund suggested, however, that these sites represented military barracks 'at the most eminent contemporary political centres' (Lund I965, 288-310). It is notable that alongside the reissuing of publications on early legal matters in the I970s, research interest in courtyard sites also intensified. Lund's excavations were republished by Johansen and Søbstad in I978. While these sites had long been thought of as potential meeting or mustering places they were characterised as things even in the I9th century (Nicolaysen I862-66, 30I) and the linkage to the thing institution is an interpretation that has survived and has been revisited again in present scholarship. Some sites, like Dysjane, lie close to the site 


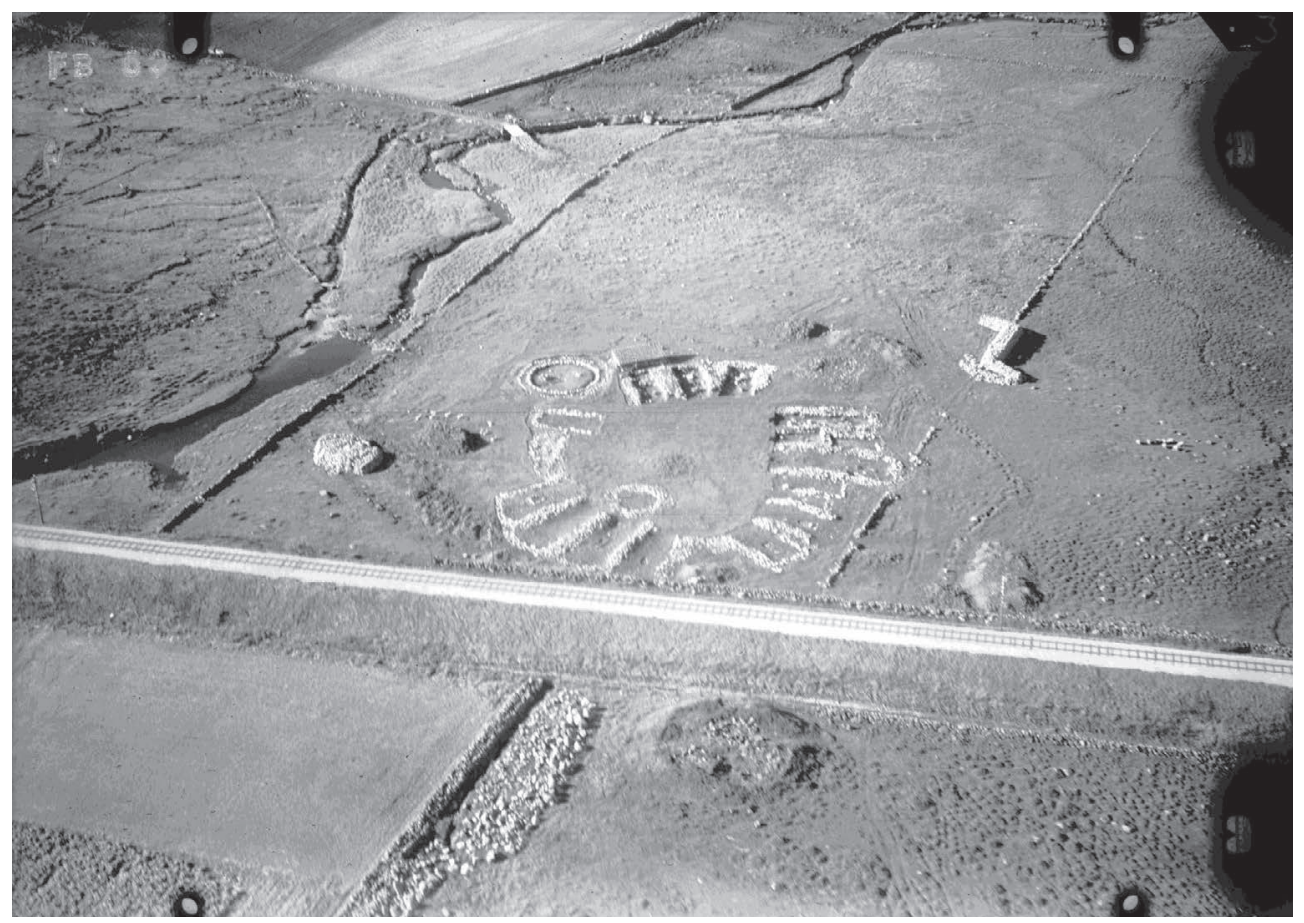

Figure 2.9 The courtyard site at Leksaren at Reistad, Varhaug, Norway, was excavated by Jan Petersen in I938-39. It was in use in around AD I00-600. Photograph by Hærens Flyvåpen, Archaeological Museum, Stavanger. CC BY-NC-ND 3.o.

of a medieval thing (Grimm 2010, 9), additional information which has sustained arguments for their role as regional things, active in the mid-Ist millennium (Iversen 20I5a; 20I 5 d; Storli 20IO, I37-I38).

More broadly across Scandinavia, another type of site that has prompted speculation are 'central places', where a range of ritual, judicial and elite functions may have taken place. These are identified in Scandinavia through rich assemblages of material including Roman items and imports (Jørgensen 2003, 204). Many different aspects are wrapped into the 'central place' bundle, however, and these sites can have markedly different characteristics (see for example Jørgensen's arguments for five separate kinds of 'central place': 2003, I75-176). The association with assembly or gathering is largely conjectural, based on the evidence for multi-functionality and cultic practices (e.g. Uppåkra, Sweden, Larsson 2007, I 5; or Borg in Lofoten, Herschend I998, I85; see comments by Skinner 2014, 89-90). Like courtyard sites however, a close relationship with a medieval thing can be suggested in a few instances (see also Ødegaard 2018a). Recent discoveries near the large emporia of Kaupang in Norway have identified a hall and a thing site at Tjølling, suggestive of dispersed 'central area' surrounding the trading site in southern Norway (Ødegaard 20 I 5; Skre 2007). 


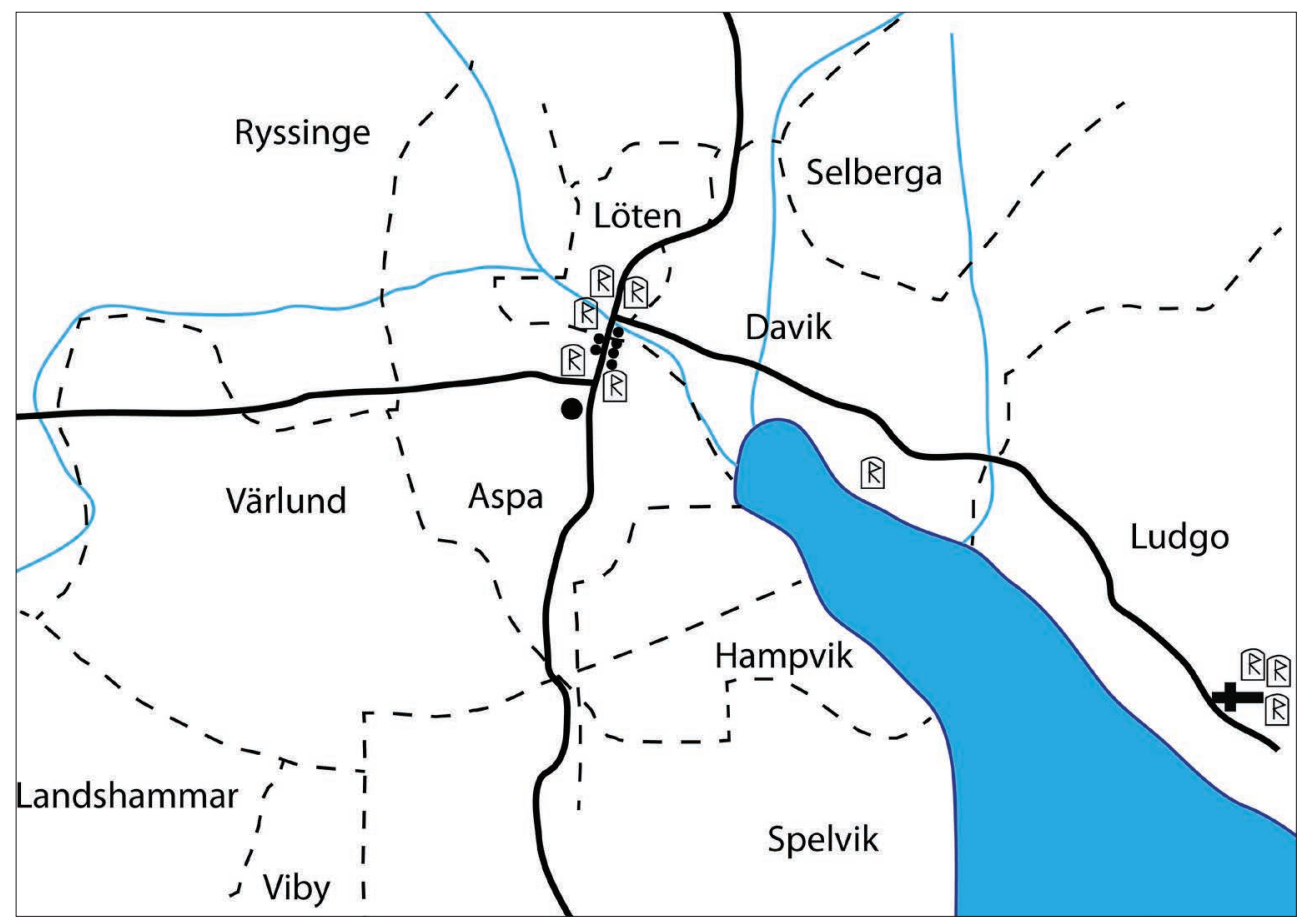

Figure 2.IO The arrangements at the thing. After Brink 2004a, 2 IO, fig. 9.2.

Connections between law, cult, power and the thing have also been intensively explored in Scandinavia by Stefan Brink. Together with Mats G Larsson he has pressed forward a characterisation of thing locations using place-names and medieval documents, and topographic and archaeological information (Brink 200I; 2002; $2004 \mathrm{a} ; 2004 \mathrm{~b})$. Although the work rests mainly on Swedish evidence, a number of sites can be shown to have 'large mounds, a concentration of rune-stones and a close connection with crossings between roads by land or water' (Larsson I998, 64 I). Such arrangements, especially in relation to an ancient road like the royal Eriksgata seem to represent the material essence of a Viking thing (Brink 2004a, 209) (Figure 2.IO).

This model has been tested out with fieldwork by Alexandra Sanmark and Sarah Semple, largely in Sweden. Field survey and excavation at Aspa Löt in Södermanland, Sweden, (Sanmark and Semple 2008, 250) and later at Anundshög, Västmanland, Sweden (Sanmark and Semple 20IO; 20II; Semple and Sanmark 20I3), has demonstrated investment in certain places that are attested in place-name sources, runic inscriptions and medieval documents as thing sites that operated in the I Ith and I 2 th centuries. Evidence for purpose-built mounds, stone rows and rows of timber posts, all suggest extensive development of these monumental complexes in the Viking Age. At Aspa Löt, the site seems to have been 'created', in the Viking Age/late roth and early I Ith centuries, while at Anundshög, a site of long-term activity was enhanced with the addition of standing stones, a rune-stone and a row of massive timber posts 
(Sanmark and Semple 20II). Sanmark has linked both sites to the medieval royal route Eriksgata, arguing that this investment in the Viking Age represents evidence for the itinerancy of royal power and the need for different communities to command thing sites along the royal route (Sanmark 2009).

Sanmark and Semple's work is distinctive in that it combines the use of placenames, medieval documents and runic inscriptions with desktop assessment, field survey, geophysical prospection and excavation, thus critically characterising the site and its locality. Recent discoveries of a massive row of posts flanking a route in to Gamla Uppsala in Sweden, complementing evidence of massive hall buildings and specialised production (Beronius Jörpeland et al. 20I3), underscores the findings at Anundshög, Västmanland (Sanmark and Semple 20I I; Semple and Sanmark 20I3). Recent discoveries at Jelling in Denmark of a large, fenced enclosure surrounding the well known central area marked by the mounds, rune-stones and church (Holst et al. 20I3; Randsborg 2008), suggests that monumentalised routes and enclosures may have been common aspects of display at Viking-Age things.

In the skattlands, archaeological and historical study has been relatively limited, with the exception of Iceland. Here, Adolf Frioriksson has demonstrated the illusory nature of some of the commonly described characteristics of Icelandic assembly sites such as 'court circles' ( I 994, I09). Booths, often used in Iceland as a signal for assembly sites, might equally indicate merely a rural settlement or trading place or as local-level meetings (Friðriksson I994, I43; Vésteinsson 2013, I I9-I22) (Figure 2.I I). Faroese Viking-Age and medieval assemblies have not been subject to such detailed study, but their locations have been mapped, using a composite of information drawn from I 7 th-century court books and place-name evidence (Thorsteinsson 2012).

\section{Britain and Ireland}

In Ireland and Scotland, the so-called 'royal' sites have featured prominently in archaeological discourse since the early 2oth century (see Fenwick et al. 2006; FitzPatrick 2004a; Lynn 2003, I27; Warner I988; 2004; for Scotland, see Driscoll I $998 ; 2002 ; 2004)$. In contrast to other regions, field research has been much more prolific, for example at Tara (Newman I997), but the medieval written accounts and place-names remain the 'way in' for landscape-based assessment. Interpretations in Ireland have remained strongly informed by the written evidence from Annals and the (MIr) dindshenchas or 'lore of places' (see for example Macalister and Lloyd I929 on Uisneach; and Lynn 2003 on Navan). In Scotland, the emphasis has been on the royal sites as central places, as well as possible sites of inauguration, such as Dunadd, Forteviot and Scone (Alcock I988; Driscoll I998; 2004). Notably researchers have sought to draw connections between Irish and Scottish traditions, noting the multiperiod significance of historic places of power such as Tara and Scone (Newman I997; I998; Driscoll I998), and the striking relationships in aspects of inauguration such as mounds and stone-carved footprints (Alcock 1988; Driscoll I998; FitzPatrick 2004a). Interestingly Norse influences on the assembly practices and sites of Ireland and Scotland are acknowledged but have only been pursued more fully in recent years (Fitzpatrick 2004b, 45-52). Excavations at the Thingmote or Thingmount in Dublin, likely a Ioth-century thing site, provided evidence for a possible prehistoric 
Figure 2.I I The medieval trading site of Gásir, northern Iceland, with booths and a church with circular enclosure. Photograph by Ronny Weßling and Natascha Mehler (C) HaNoA Project.

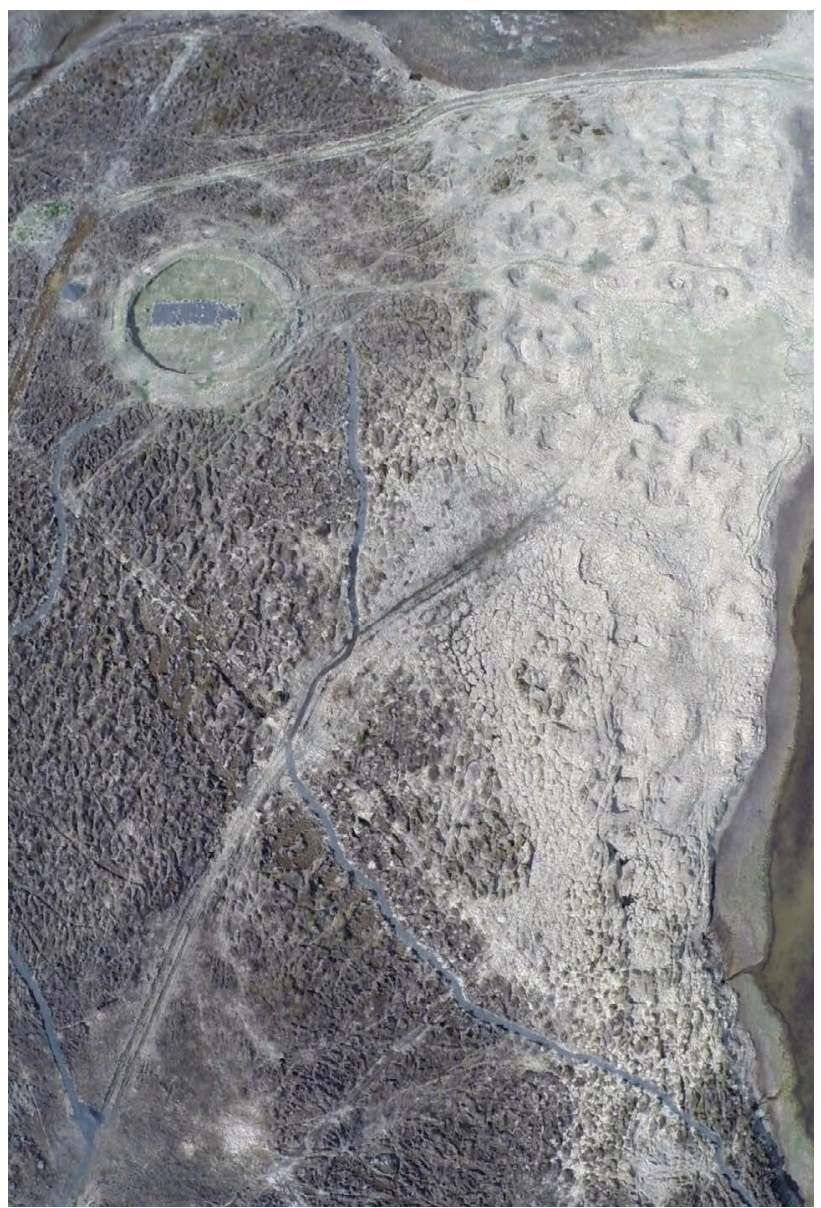

mound either levelled and replaced or appropriated with a large flat-topped and stepped mound associated with evidence for burials of Viking date (Ó Floinn I998). Thing place-names and thing mounds are also known from Scotland; excavations at Doomster Hill identified a stepped mound that, in its situation and position, may be a court mound of the 9 th century, connected to lordship traditions of the Norse Irish Sea province (Driscoll 2003, 77-8I; but see contra argument by Sanmark 20I7b). In Shetland, thing sites have been subject to research in past and present, that has valorised a distinct ancestry and political identity separate from Scotland and Britain and placed emphasis on a close association with Scandinavian practices (Coolen 2016; Smith 2009). Despite intimations of cross-national similarities and trends, and broader Scandinavian influence on the assembly practices of Britain and Ireland, archaeological studies have largely remained national in focus (but see Semple and Sanmark 20I3; Sanmark 20I7a; Gleeson 20I8; Semple 20I 8; Reynolds et al. 2019).

After the Second World War, the story in England begins with the renewal of interest in English landscape studies in the I950s and the foundation of The Society for Medieval Archaeology. A retrogressive landscape methodology emerged 
that integrated the evidence of the physical landscape palimpsest with information from early cartographic sources, documentary accounts, place-names and the built environment, to create an understanding of the development of the English medieval village and landscape (Gerrard 2003; see too Gardiner and Rippon 2007). Place-names played an important role and place-name studies began to draw the attention of archaeologists to terms suggestive of activities that could be interrogated archaeologically, for example burials, Roman remains and meeting-places (Gelling 1978). After the Second World War, ideas of an early-shared Germanic administrative inheritance were replaced with an emphasis on a distinctly English administrative development. A strong preference emerged for seeing the roth century as a time when an organised system of governance was put in place in southern England by King Alfred's successors, prompting analogous systems in the north (Loyn I974; Roffe I98I; 2007; Sawyer I998). These systems are generally acknowledged, however, to replace something less formal and more organic that operated as early as the 7 th century (Loyn I984, I40; Reynolds I999; 2009). Arguments for a pre-Christian origin for Anglo-Saxon assemblies have not been completely abandoned (Meaney I995; I997), but have fallen from common favour. Instead more recent research emphasises the locational preferences for local-level meeting-sites, pointing to the use of mounds, stones, fording places and bridges (Pantos 2002; 2004b) and distinct topographies, such as hanging promontories (Baker and Brookes 20I3 b). Sites have been shown to be multi-focal, and to lie sometimes in liminal areas at administrative boundaries (Pantos 2002; 2004b), while other regional studies suggest a centrality to meeting-places, matching the liminality of connected execution sites (Reynolds I999; 2009).

Field investigation, as in Scandinavia, is largely serendipitous, resulting from chance discoveries, commercial archaeology or prompted by documentary sources attesting to high-profile and important royal sites. Metal-detecting in England, for example, has produced evidence of large scatters of early metal finds including dress fittings and personal effects that have been termed 'productive sites' (Ulmschneider 2000; Ulmschneider and Pestell 2003). Some argue these are gathering places: fairs, trading posts and perhaps assembly sites (Naylor 2004; Pestell 20I I; but especially Ulmschneider 2000; Ulmschneider and Pestell 2003). Purposeful excavation is rare, with the discovery of 'assembly' activities merely an incidental in a broader project. Excavations at Cheddar in Somerset, and Yeavering in Northumberland, for example, were both prompted by contemporary documentary accounts attesting to royal sites or palaces, surviving medieval ruins in the case of Cheddar, and aerial photographic evidence (Rahtz I979; Hope-Taylor 1977) (Figure 2.I2). Assembly activities are considered by both excavators, but were not the primary spur for investigation. Recent field investigations at the palace sites of Sutton Courtenay in Oxfordshire and Rendlesham in Suffolk have both produced large spreads of metal finds indicative of gatherings (Hamerow et al. 2007; Hamerow and Brennan 20I 5 for Sutton Courtenay; Scull et al. 2016 for Rendlesham). At Sutton Courtenay in particular, metal finds including coins suggest marketing or meeting activity lasted longer than the timber palace complex (Hamerow et al. 2007).

By comparison, the provincial or regional level meeting-sites in England-shire, hundred and wapentake-have received even less archaeological attention. A number 
a

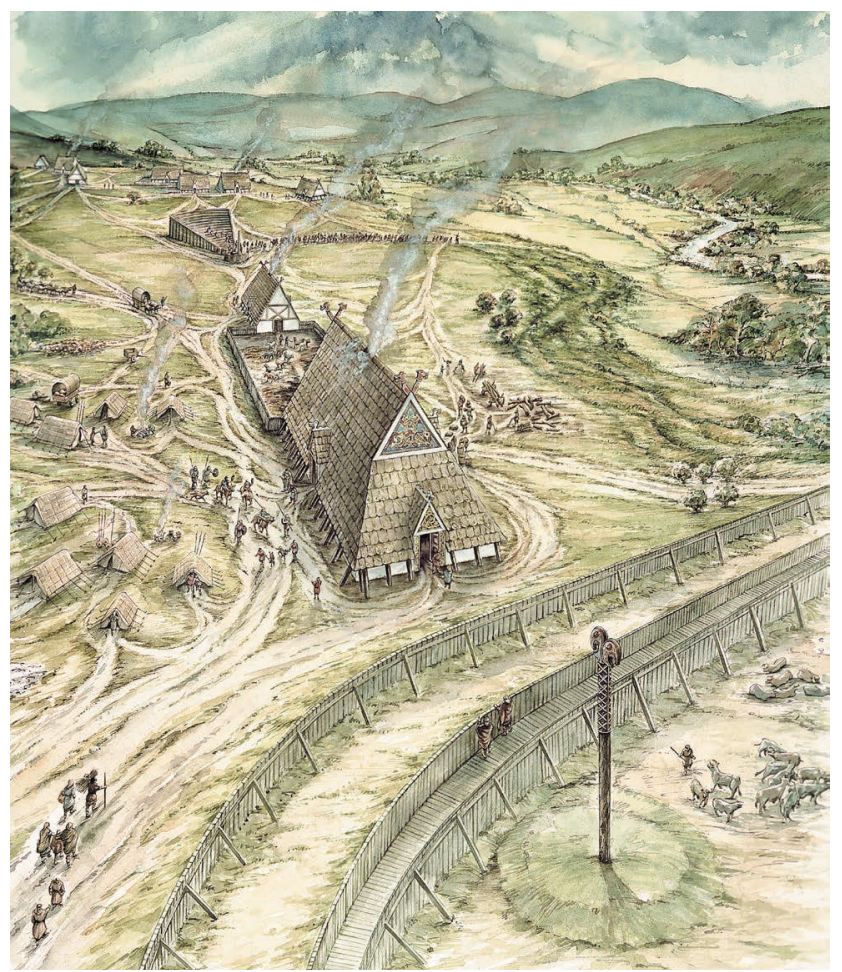

b
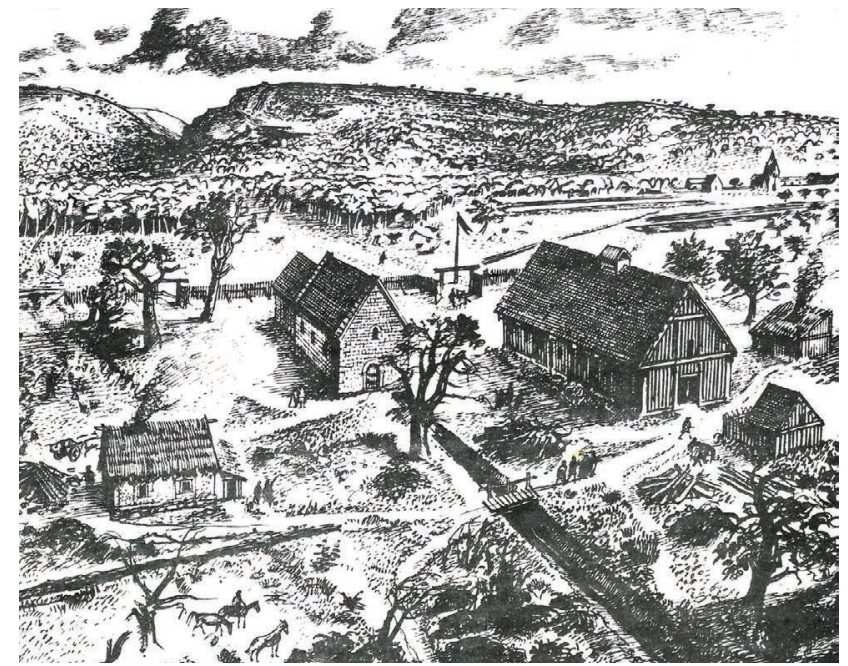

FIGURE 2.I2 Early medieval English palace complexes associated with assembly:

a) Yeavering. Northumberland, UK. Painting by Peter Dunn. Reproduced with the permission of Historic England.

b) Cheddar, Somerset, UK. Reconstruction drawing. Reproduced with the permission of Lorna Watts, from Rahtz I979, 59, fig. I4. 
of projects have targeted meeting-mounds (Adkins and Petchey I984; Sanmark and Semple 2008; 2010), revealing evidence for potentially Late Anglo-Saxon, non-sepulchral examples (Adkins and Petchey I984, 243-246), prehistoric (Sanmark and Semple 2008; 2010), and early medieval barrows (Booth et al. 20II; Brookes and Reynolds 20II). Excavations like these have produced very few metal finds. The 'signature' for assembly is therefore enigmatic, but arguably different functions and activities (and a different scale of meeting) might be expected at 'royal' or toplevel gatherings, although monuments-old or contemporary-are a feature of both (Sanmark and Semple 2008; 2010; Semple and Sanmark 2013).

Landscapes of Governance, a Leverhulme-funded project on English assembly, is currently assessing processes of assembly formation and the material signatures of meeting-places in England (Baker and Brookes 20I3a; 20I3b; 20I3C; 20I 5; Brookes 20I9). While the temporal evidence is hard to tease out, excavations like Saltwood, provide an inkling of what a regional/local assembly (equivalent to a shire-level meeting perhaps), might have looked like in the 7 th/8th centuries. Here, the people of the locality met at an old pre-Christian cemetery marked by prehistoric and early Anglo-Saxon burial mounds and stayed long enough to need hearths. They produced sufficient rubbish and waste to warrant the use of pits for disposal, and given the lack of structural evidence, they probably camped (Booth et al. 20I I; Reynolds 20I 8).

Targeted studies of individual sites have also proved effective. Two of these in Wales have significantly advanced understanding of early medieval Welsh assembly practices. At the Pillar of Eliseg, Llandysilio yn Iân, Denbighshire, excavation and detailed landscape survey has revealed that a Bronze-Age burial mound was repurposed as a place of early medieval assembly, used perhaps for seasonal fairs, mustering and other types of gathering (Edwards 2009; Murrieta-Flores and Williams 2017). Critical to this interpretation is the accessibility of the location and its relationship to patterns of movement and visibility (Murrieta-Flores and Williams 20I7). Likewise, at Bayvil, Cemais, in Pembrokeshire, another prehistoric barrow is suggested to have been a locus of early medieval assembly, prior to its use as a medieval fair site (Comeau 20I4). In both instances, as Comeau argues for Bayvil, 'the same conscious references' are present that are found elsewhere in medieval north-west Europe and the same spatial vocabulary of early medieval authority (Comeau 20I4, 28I).

In Ireland and Scotland, field research has been far more extensive, structured and targeted. In the I960s and I970s, extensive excavations took place at Navan Fort (Co. Armagh), one of the great symbolic places of kingship and provincial capitals according to medieval accounts (Newman I998). The attributes and functions of these great centres then received closer attention, with researchers noting the common presence of extensive prehistoric remains and complexes, and establishing these as criteria, including large circular enclosures, prominent mound-and-banked roadways, and signs of ritual and wealth (Wailes I982; Warner I988, 52, 67). These have been interpreted as places of ritual and ceremonial importance, used for the performance of inauguration theatre (Newman I997; I998; Warner 2004). The Irish and Scottish schools share an emphasis on the appropriation of seminal places for early medieval royal ritual. Building on Richard Bradley's work on 'the past in the past' (I987; I993), it has been proposed that prominent palimpsests of multi-period and prehistoric sites and monuments were re-appropriated as a means of legitimating royal power (Driscoll 
I998; FitzPatrick 2004a). In Scotland the phenomenon of constituting early medieval royal centres around notable prehistoric earthworks has been suggested as especially characteristic of Scotland and Ireland, and absent from the Romanised regions that later developed into Anglo-Saxon kingdoms (Driscoll I998). Other connecting factors include the presence of stone-carved footprints at inauguration sites in Ireland and Scotland as well as the use of inaugurations stones (Driscoll I998; Nieke and Duncan I988; FitzPatrick 2004b, 99-I30; Lane and Campbell 2000, 250-25 I). Such attributes have been critically interrogated by FitzPatrick who suggests that while the carved footprints and their connection to inauguration and authority may well be early medieval in date; the late-medieval inauguration traditions involving one shoe and one foot are most probably inventions of their era (FitzPatrick 2004b, I 28). The Scottish and Irish inauguration/royal sites do, however, share their multi-focal and extensive monumental backdrops as a common trope: including barrows, ring ditches but also natural rocky outcrops or springs and many of these features hold individual roles within the mythical narratives of kingship (Aitchison I994; Warner 2004). A common concern in recent discussions has been ideas of appropriation and invention, whether by early-medieval kings (Driscoll I998; O’Grady 20I4; 20I8) or medieval and late-medieval lords (FitzPatrick 2004b). Such places appear to have experienced lengthy periods of use in prehistory, but activity is episodic pointing to the symbolic appropriation of such locations in times of need (Newman I998; FitzPatrick 2004b, 68-87). Attention has also shifted to trying to understanding the broader situation of royal power and assembly in landscape terms (FitzPatrick 2004b, 4I-98; Grigg 20I 5 ; Gleeson 20I2; 20I5; 20I7a; 20I7b; 20I8; O'Grady 20I4). The great royal centres were part of a more complex contested political landscape in Ireland that involved local territorial and larger regional assemblies (Gleeson 20I7a; 20I8). Connections between popular assemblies, royal land and hunting have been claimed (FitzPatrick 20I2), which has strong resonance with Carolingian kingship and late Anglo-Saxon England too (Rollason 20I2). These larger gatherings, combined market-fairs with games and horseracing, and there is now good evidence that connects these popular and larger seasonal meetings with earthwork complexes and earlier burial and cemetery sites (Gleeson 20I 5; 20I 8). What is most striking is that increasingly, authors have come to notice the similarities rather than the distinctions in assembly traditions between Scotland, Ireland and England (FitzPatrick 2004b, 75; Gleeson 201 8, IooI04; Pantos and Semple 2004a). As Elizabeth FitzPatrick has clearly stated, there is 'no apparent basis for presuming a continuity of distinctive Irish kingship practices from late prehistory into and throughout the medieval period' (Fitzpatrick 2004b, 5I). Indeed increasingly drawn similarities between the attributes of early medieval Irish, Scandinavian and English kingship and royal ceremony suggest that 'the experience of early medieval Irish kingship was not singular' (FitzPatrick 2004b, 52; Sanmark and Semple 2008; Semple and Sanmark 2013; Gleeson 2018).

The process of revisiting and appropriating seminal places for the purpose of political or religious theatre attests to the power of such sites even in the present. Tara has continued to exert a profound agency even in modern times as symbolic of the long right of Ireland to self-governance (FitzPatrick 2004b, 225). In April 2006 Bertie Ahern, then Taoiseach of Ireland, and Tony Blair, then Prime Minister of England, met at the ancient site of Navan, Co. Armagh, to set out their plans for a 


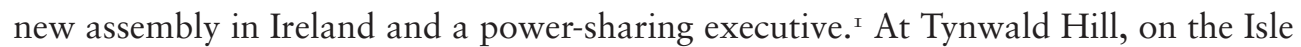
of Man, the Tynwald Court still gathers annually to commence proceedings with an open-air ceremony.

\section{Assemblies and gatherings in prehistoric archaeology}

While prehistoric archaeology is not the focus of this volume and any historiographical review is beyond the scope of this chapter, it is important to highlight how the concept of the early open-air, political/judicial assembly is explored and dealt with in prehistoric research. This is separate from the much broader and deeper permeation across prehistoric scholarship of ideas of mobility and meeting-places, sites of ritual and ceremony, production, trade and gathering. The latter are broadly evidenced in prehistoric archaeology across time and place. The evidence for short- and long-distance mobility of hunter-gatherers, pastoralists and farmers, and arguments for how central places and complexes become fixed and long-term sites of visitation for seasonal activities are well rehearsed themes. The taskscapes of the Mesolithic speak of mobility, but regular repeated visits to different camps, caves and hunting grounds, alongside evidence for settlements, created fixed places that were returned to on a seasonal basis. Enhancement to natural places, particularly watery sites, also intimates that regular visits to sacred or special locations were an important element in the cycle of movement of Mesolithic communities (Blinkhorn and Little 20I8). The monumental complexes of the Neolithic, in many parts of the world, are accepted as places where people gathered to engage in and perform a variety of activities, and these are thought in many cases to reference places significant for gathering in the Mesolithic (Ray and Thomas 20I8). In the Late Bronze Age, a range of different features suggests collective activities and gatherings: not least the emergence of pit complexes and pit alignments (Bradley 2007, 243-235). These are common to Scandinavian regions, but not confined to them, and pit clusters and pit lines are a feature as well of the Iron Age (Løvschal and Fontjin 20I8, 3-5). These are sometimes indicative of gathering and cooking and in other cases may represent traces of large-scale spectacular events, but do attest to the coming together of people for communal activities and performances (Løvschal and Fontijn 20I8). These are just some of the kinds of seasonal gathering practices we associate with prehistoric populations. It is in Iron-Age studies, however, that archaeologists have focused more predominantly on seeing evidence of gathering in terms of frameworks of power and state formation processes. Interestingly, the concept of a formalised process of assembly operational in Iron-Age and Late IronAge societies, as with early medieval archaeology, is in part prompted by the scanty mentions in Roman written accounts of conciliar activities of the indigenous IronAge populations living beyond the imperial frontiers. These ethnographic sources are described and outlined in Chapter I and the power of Tacitus' written account Germania is discussed in the opening to this chapter. In discussions of the 'Celtic' Iron Age such sources have been used alongside the archaeological evidence to describe the increased complexity of Late Iron-Age society and its development from heterarchy to

I http://news.bbc.co.uk/I/hi/northern_ireland/4890534.stm 
hierarchy (see papers in Arnold and Blair Gibson 1995). The archaeology of complex change and central places as seen in terms of oppida in Gaul and Britain has long been considered as indicative of the development of chiefdoms and early kingdoms (see Brun 1995; Haselgrove I995). The Gallo-Roman oppida in Gaul with large public spaces and structures interpreted as voting installations have been argued to represent imperial influences in the use of meetings and places of gathering in the articulation and enactment of power (Fernández-Götz 20I2; 20I4a; 20I4b). The work of T J Chevral (previously T L Thurston) on Denmark argues for assembly as a pivotal component in the regulation of elite power in the Iron Age, as demonstrative of the corporate nature of power and a move to more complex levels of organisation and authority (Thurston 200I, 44-48). There are, therefore, synergies in Iron-Age and early-medieval scholarship. On the one hand, evidence of places of seasonal gathering and assembly seem to point to increased complexity, and the use of monumentalised sites and places for such events signals perhaps an attempt a greater regulation and management of people, activities and events (Brun 1995; Moore 2012; Moore et al. 20I3). On the other, the written accounts have taken on a particularly potent role in arguments for formalised assembly mechanisms as evidence of the emergence of early chiefdoms/kingdoms and states (Poux 20I2; Thurston 200I; 20I0). Where these schools of thought intersect is in identifying the Late Iron Age as a time when more formalised ideas of assembly, judicial action and consensus emerge as part of an increasing complexity in the development of more hierarchical structures.

\section{Summary}

This is a selective overview of the more recent academic work on assemblies, administrative systems and the thing, but the outcomes from Scandinavia, Britain and Ireland are strikingly similar. The assembly remains a powerful element in historical and archaeological discourse in all countries, but the varied treatment of the topic demonstrates notable differences in approach, methods and interpretations. The panScandinavian and pan-Germanic standpoints evident at the end of the I 9 th century have persisted. In Scandinavia, a firm commitment remains to the idea of a common indigenous and ancient Scandinavian tradition of law and assembly, but scholarship now also emphasises particular national trends: some authors give primacy to the Swedish topographic evidence (e.g. Brink 2002; 2004a) and others to Norwegian medieval administrative arrangements (Helle 200I). Likewise, while commonalities have been drawn between Irish and Scottish traditions, the administration of early medieval England has been treated as a separate phenomenon with emphasis on its indigenous and 'Anglo-Saxon' nature (Loyn I984; Molyneaux 201 5; Reynolds I999; Wormald 1999). Suggestions of early pre-Christian aspects to meeting-sites and connections to early Germanic practice have been increasingly treated as dubious in English scholarship, yet late prehistoric, and therefore pre-Christian, connections have remained strong elements of discourse in Irish and Scandinavian discussions. There has been a striking insularity to scholarship overall in the post-Second World War period with cross-national and transnational comparison and discussion only reappearing in the I990s to the present. Even so, there is a reluctance to draw comparisons between evidence gathered from different places and times. 
Perhaps the most striking distinction is the varied adherence to what can be termed a 'deep-time' narrative. The late prehistoric era is considered formative in the traditions of kingship, power and assembly in Ireland (e.g. Bhreathnach 20I I; FitzPatrick 2004a; 2004b; Newman I997; Schot et al. 20I I; Warner I988; 2004). The same ideas are present in research conducted in Norway and Sweden; periodically researchers have sought to emphasis the early nature of the thing as an institution, pressing its origins back into the Iron Age and seeing a connection between cult, power and law (Brink 2002; 2004a; Ødegaard 2015; 2018a). Notably early medievalists and late prehistorians working with ideas of social complexity, assembly and early statehood in Europe draw on similar written accounts and in some cases argue for the Late Iron Age as the root point at which formalised processes of assembly and consensus and judicial regulation emerge within a move from heterarchical to hierarchical structures. Recent English scholarly viewpoints have tended to dismiss the 'deep-time' model, 'pre-Christian' connections and Migration-period origins. Instead emphasis is placed on either the 7 th century or the Ioth century as the pivotal moment for the setting down of more rigorous administrative and legal arrangements. More recently, however, it has been suggested that in England we should look to Roman/Romano-British land-holding and inheritance patterns for the beginnings of administrative and assembly arrangements (Oosthuizen 20I6).

There are issues with the deep-time model, and some scholars will find problematical any drawing of connections between medieval assembly practices and the evidence presented by Tacitus in the Ist century $\mathrm{AD}$ and other Roman writers. Archaeological evidence, however, is demonstrating that sites of popular assembly and the thing are often co-extant with earlier evidence for collective activities and gatherings (see Chapter 4; Ødegaard 20I9a; 20I9b). At Anundshög, Sweden, hearths and cooking pits suggest the use of this seasonal island as a place to gather around the Ist -3 rd century AD before it was substantially developed and monumentalised with a peak of activity in the Ioth and IIth centuries (Sanmark and Semple 20II; Sanmark 20I 5). Likewise, in Ireland there are emerging associations with prehistoric monuments and Late Iron-Age burial grounds and cemeteries (Gleeson 20I8), something apparent in some instances in early medieval England as well (Reynolds 20I8).

The questions raised are two fold: is assembly a static phenomenon, developed by late prehistoric populations, that endures unchanged in an unbroken insular pattern of activity and meaning until the late-medieval period? Alternatively, should we understand assembly as a more fluid mechanism that can emerge and change over time, disappear and reappear and vary in form and function from place to place?

The counter to these ideas of assembly and the thing as enduring and strictly maintained conventions of a great age is a research narrative that instead places an emphasis on invention, renegotiation and reuse. The royal sites of Scotland demonstrate the intentional selection of seminal places and monuments as stages for royal ceremony and power (Driscoll I988; I998; 2004). Similar arguments are made for top-level events in early medieval England (Semple 2013) and for some thing sites in Viking-Age society, especially when royal power and connections become relevant (Sanmark 2009; 20I 5). Elizabeth FitzPatrick has argued for similar processes of adaption and invention underlining regional power claims in medieval 
Ireland (2004a). While such interpretations do not preclude a deep-time element to the assembly institution, the emphasis is on the fissile nature of power, and how 'traditions' and 'places' can be appropriated or even invented to lend a legitimacy to new regimes. Field investigations suggest that these schools of thought are not mutually exclusive. The scholarly divergence apparent between the deep-time narratives of Scandinavian and Irish scholarship and the emphasis on 'renegotiation' and 'appropriation' in English, Scottish and in more recent Irish scholarship, may be more contingent on national traditions of scholarship than any archaeological reality and also relate to the variable levels of field interrogation and scientific dating of meeting-sites in different countries.

In the same way that scholarship is beginning to re-envisage assembly as something that can be reinvented and re-inscribed in the landscape as a practice, recent publications are also breaching the traditionally geographic insularity of study and drawing connections between the 'Celtic' and 'Germanic' traditions of assembly. Recent articles point to some striking northern European connections in the organisations and levels of early assembly (Gleeson 2018), the functions of popular regional assemblies (FitzPatrick 2004b, 5I-52) and the 'architecture' of meetingsites (Semple and Sanmark 20I3). Landscape and field-based studies are repeatedly revealing commonalities in assembly placement that point to the development of broader north-west European vocabularies of early medieval power (Edwards 2009; Comeau 20I4; Murrieta-Flores and Williams 20I7; Semple and Sanmark 20I3; Sanmark 20I7a; Reynolds et al. 20I9). These studies situate early medieval assembly, whether an enduring prehistoric or newly inscribed tradition, as something especially relevant to the emerging mechanisms of statehood in the nascent kingdoms of the early medieval north.

\subsection{CONCLUSION}

The motif of the early medieval, democratic outdoor assembly has proved powerful long beyond the timeframe in which such assemblies functioned. It has held a significant place in political, religious and popular discussions: regularly exploited since the I6th century to lend legitimacy to debates on political origins and identity (Pantos and Semple 2004b). The potent nature of assembly and the thing in nationalist discourses serves as a reminder that the past can be powerful and agent in the present (Hobsbawm I990). Pingvellir, in a modern era, continues to provide a venue for popular gatherings designed to reaffirm a sense of pride in Icelandic national identity (Hálfdanarson 2000). The fluidity, therefore, of how and where assembly was used, and revalorised, and used again, reveals a dynamic agency across time. Despite recent moves towards a cross-national discourse (Barnwell and Mostert 2003; Pantos and Semple 2004a; Reynolds et al. 2019), assembly and its relationship to emerging administration and law still tends to be treated within national insular contexts. Long-term 'continuity' is an argument often used to put assembly and the thing at the forefront of powerful narratives on the emergence of states and nations. Repeatedly, ancient legal evidence has been called upon to legitimate a political or ideological standpoint and the lesson must surely be that all studies of assembly are intimately bound up with politics of the time. This is a salutary warning to us in the 
present; our project and book needs to be viewed in this longue durée of scholarship, as another stage of renegotiation and interest in early forms of communal meeting and government. The insularity of national discourses has enhanced these tendencies and impeded the advancement of understanding of assembly as a general mechanism in political-formation processes. There is a lack of shared dialogue as well between early medievalists and late prehistoric specialists working towards the same ideas of complex societal development. Recent publications have begun to bridge these divides, as has our project. The transnational approach adopted and used in this book, as well as an integration of relevant late prehistoric scholarship, provides a research framework aimed at pressing forward investigation on assembly as a broader mechanism in kingdom formation processes in early northern societies.

The study of assembly has marched alongside the rise and fall in popularity of interdisciplinary approaches, for one good reason: it is very challenging to research early medieval administration, assembly practices and places from a single source of evidence. In Ireland and Scandinavia, early medieval archaeologists have always worked with written sources and place-names. In England, an initial rejection of historical sources (see Austin I990), led to a new confidence in the late I990s and a return to working within a critical, multi-disciplinary framework. In all regions, however, historical accounts have exerted most agency over the development of scholarship and a similar, if less far-reaching trend, is evident in Iron-Age studies. Field investigations have countered this, attesting to archaeological evidence for gatherings, assemblies and meetings and evidence for the selective invention and re-invention of this institution to suit the needs of different powers. Purely archaeological investigations are also problematic. Ascribing the label 'early medieval assembly place' or 'thing' because of archaeological evidence alone, is conjectural. This said, field survey, on-site visits and excavations, although rare, have generated an interesting repertoire of evidence which is beginning to signal distinct regional and local variations in the choice of location, 'architecture' and associated assemblages (Semple and Sanmark 20I3; Gleeson 20I7a; 20I8). Assembly studies for now must remain an interdisciplinary affair; the documentary and place-name records are still essential, but an integrated landscape approach (see Chapter 3 ) offers a counter to using the brief written sources simply as a window for the archaeological imagination.

This critical review of past research charts a route towards the integrated methods used in this volume (see Chapter 3). By using all sources, the method represents a critical, multi-scalar and multi-disciplinary assessment of the place and role of assembly and administrative units within localities and broader regions. Thus while this book is another stage in rethinking early administrative and legal arrangements, we have critically reflected on past research traditions to create a conscious and empiric basis for our work. Our geographic scope has allowed us to cross the national boundaries that have inhibited research on early political structures in Europe. Likewise, an interdisciplinary approach has been essential with field research as an integral element. In the chapters that follow, we move debate away from the constraints of a national focus and open up cross-European comparative, critical evaluation of how and why systems of administration and administrative networks evolved in early and later medieval European societies. 


\section{CHAPTER 3 \\ METHODS AND APPROACHES}

\section{I SUMMARY}

Taking inspiration from the last chapter, the project methods are now set out. Key written source material is identified first and then our approach to locating and mapping units is described alongside the processes of locating thing sites. The chapter considers the processes of topographic and archaeological characterisation, the use of GIS and the purposes of field survey and excavation. It concludes with a consideration of the limitations of certain categories of evidence.

\section{$3 \cdot 2$ WRITTEN SOURCES}

The pre-eminent source of information on early medieval assemblies, as Chapter 2 has elicited, has long been the written record. Histories and chronicles, laws, wills, land charters, maps and diplomas all offer important evidence of political and legal activity in the Ist and early 2 nd millennia. These sources offer chronological insight; they assist in understanding the mechanisms of the thing, and in some cases assist in identifying units and thing sites on the ground.

The earliest written sources from Scandinavia are inscriptions found on runestones that mention assemblies (see Chapter I for examples and discussion). These are dated to the late Ioth and I Ith centuries and at least some seem to have been raised, according to the inscriptions, by individuals responsible for 'making' a thing site. Of course these stone monuments may have been moved from their original location, but on the whole, the first late-medieval/early-modern 'histories', runic corpus, and national monument record, all demonstrate that rune-stones tend to occupy their original settings.

The earliest laws from Scandinavia and Iceland, in manuscript terms, are several centuries later in date. These encompass the provincial laws of Norway, Sweden and Denmark, the Icelandic law Grágás and the first 'national' laws of Scandinavia. Although they are broadly written down in the I 2 th-I 4 th centuries (Helle 200I, I II3; Strauch 20II), they almost certainly represent an amalgam of earlier and older regulations (for overviews, see Liedgren I98I; Sanmark 2004). Close exploration of the contents and language have enabled the identification of early legal elements (Brink 20II; Foote I987; Lindkvist 20I4; Mundal 200I; Sanmark 2004, I33-I45; 2006, 32-34). The Norwegian Law of the Gulathing seems to represent the earliest set of legal regulations, while the Norwegian Law of the Frostathing followed slightly later. The Icelandic law Grágás - the content of which is more obviously inspired by Christian values and norms (Mundal 200I) - is considered later still. By the $\mathrm{I} 3$ th and 
I4th centuries, kings began to replace these regional laws with a centralised legal institution (Bøe I966, 233). These 'national' laws drew heavily upon pre-existing regional legal frameworks (Ruthström 2003, II).

The Icelandic sagas are a standard and long-used resource for researching legal and administrative arrangement in Scandinavia and Iceland in the Middle Ages. The sagas survive in manuscripts dating from the 13 th and the 14 th centuries. They contain an expansive range of references to thing meetings, in relation to Scandinavia, Iceland and other colonised regions, and provide information on events and activities (Riisøy 20I3; Sundqvist 2002). Njal's saga for example, in describing numerous legal cases, reveals a significant level of legal complexity (Bagge 200I). There is very little reference, however, to actual thing sites, with some rare and well known exceptions such as Pingvellir and Gamla Uppsala (Dennis et al. I980, 57, 246; Hollander I964; I999, 3 I 5). The reliability and value of the sagas as accounts of actual events in the Viking Age is debated (e.g. Andersson and Miller I989, 3-6; Friðriksson I 994). These written accounts are much later in date, but they are thought to capture and preserve details of past institutions, events and people (Lönnroth 2008, 309-3 I0).

Eddic poetry is also an important source. The poems survive in I 3 th-century manuscripts, but they evolved over time: the $\mathrm{I} 3$ th-century versions representing the latest stage of development of ideas once circulated through oral traditions over many hundreds of years (Meulengracht Sørensen I99I). These sources date from a Christian era, but are thought to contain the vestiges of older pre-Christian myths and motifs. References to assembly and law are frequent in the poems (Løkka 20I0; 20I3, I 8-27; Riisøy 2013), and can be used to characterise perceived 'ideal' locations and functions of the thing. While the poems are set down in writing in the $\mathrm{I} 3$ th century, many argue the poems contain ideas that may relate to an older Old Norse mentality (Løkka 20I0; 20I3, I8-27; Meulengracht Sørensen I99I; Riisøy 20I3).

Perhaps most valuable of all, however, are the court records that survive from the late $13^{\text {th }}$ century, and grow in number thereafter. These pertain to all Scandinavian regions, Iceland and the Faroes, Shetland and Orkney. These are now collected into different national and regional compendiums, including the Diplomatarium Norwegicum (DN), Diplomatarium Suecanum (SDHK), Diplomatarium Islandicum, Diplomatarium Danicum (DD), Shetland Documents (SD) (Ballantyne and Smith I994; I999), and the Faroese thing books (Tingbókin) (Joensen I953; I969). They detail of the local-level assemblies, usually the hundred meetings, noting their general location. Together with place-name evidence, these are a primary and vital source for identifying places of local assembly (Hobæk 20I3; Ødegaard 20I3; 20I5; Sanmark 2009). Some of the most useful references appear in the I 7 th-century antiquarian reports/accounts from Sweden called Rannsakningarna. Although of course these date to the early modern era, they concern themselves heavily with preceding tradition, often making mention of 'ancient thing sites' and describing them in detail (e.g. Schnell and Ståhle I938).

A final category of 'written evidence' comprises place-names. Place-names survive in written documents and on medieval to modern cartographic sources but also survive in the modern landscape as well. They are a mainstay for scholarship relating to legal administration and assemblies, and are an invaluable resource (Hobæk 20I3; Ødegaard 20I3; 20I5; 20I8a; 20I8b; Skinner 20I4). When they 
survive in medieval or early modern documents that describe legal and administrative events or arrangements, they provide locational references that can be tracked down using medieval estate documents or through examination of early modern to modern cartographic sources (Baker 20II; Baker and Brookes 20I5; Pantos 2002; 2004b; Skinner 20I4).

Place-names can be useful as well in their own right. Old maps and documents and modern maps will often retain place-names that, through their etymology, appear to reference an ancient meeting-site. The Old Norse term ping 'thing' survives in place-names across Scandinavia and in the skattlands (see Chapter I and Figure 3.I). Not only do these names allow a researcher to examine the potential pattern of meeting-places in a landscape, they are useful in delivering details on the character and function of meetings. Place-names such as (ON) 'thing slope' or 'drop' such as Pingbrekka at Pórsnesping in Iceland, mentioned in Eyrbyggia saga (Whitmore 2013, I3-I4; see also Chapter 6.2); (ON) pingbýr 'thing farm', Skaun, Romerike, Norway (DN I, 486); and the term, rather than place-name $(\mathrm{ON})$ pinghús 'thing house', mentioned in the Flateyjarbók (Flat. II, 49, ln. 3I), all provide an important level of detail on-site attributes and association activities.

The Old Norse element ping, signifying 'assembly', is encountered throughout the areas studied here (Fellows-Jensen I993), but many additional terms are of value: $(\mathrm{ON})$ galgi 'gallows' is useful as an indication of locations of judicial activity (Coolen 20I6) and names that indicate places of horseracing or fighting such as (ON) skeið 'a track for horseracing or riding' (Atkin I978; see also Ødegaard 2018a). The latter can signal communal games attached to assembly events. In Iceland, place-names record specific structures or (ON) búðir 'booths' (see Chapter 7). Enclosures or temporary seating such as planks or trestles are implied for example in a range of hundred names in England, such as Worth, Kent (OE worp) 'enclosure'; Dill, Sussex (OE pille) 'plank or board'; Shamwell, Kent (OE sceamol) 'bench, trestle, stall' (Pantos $2002,77)$ and the regular survival of $(\mathrm{ON})$ vé, 'holy, sanctuary' in relation to meetingsites in Scandinavia, implies that in some cases evidence of cultic activity might have been synonymous with early gatherings (Brink 2004b, 308-3II; Vikstrand 200I, 247-248). It is also worth noting the Old English element (ge)mot, or 'meeting'. It is a relatively common assembly-attesting name in much of central and southern England (Pantos 2004a). Far fewer instances of this place-name element have been found in the Yorkshire study area, within the Danelaw, explored by our project and discussed in Chapter 6 (Skinner 20I4). Examples are known further north-west in Cumbria, such as the place-name Moota Hill which occurs twice (Smith I967, 38, II9) and in Scotland, where it was loaned synonymously to both Gaelic mód and Old Norse mót; (O’Grady 2008, I39) although again identifications are rare.

Place-names are a difficult dataset. The primary challenge is to identify a precise feature or location from a place-name. The source may be a late-medieval or earlymodern document that lists a particular meeting-place. While the name may appear on a later map, unfortunately place-names can move around, shifting along with the settlement, farm or habitation they become attached to over the course of time (Carroll 20I 2; Gardiner 20I2). Multiple place-names can also occur, attesting to more than one assembly in a single administrative unit (see Pantos 2002 on England). This might suggest a level of administrative complexity, but may also reflect the fact that 


\begin{tabular}{|c|c|c|}
\hline Old Norse & Gender & Meaning \\
\hline gangdagaping & $\mathrm{n}$ & $\begin{array}{l}\text { A thing held during the three days before Rogation Day } \\
\text { (either associated with Ascension Day or } 25 \text { April) }\end{array}$ \\
\hline haustping & $\mathrm{n}$ & Autumn assembly \\
\hline miðföstuping & $\mathrm{n}$ & A thing that takes place in the middle of a fasting period \\
\hline mótsping & $\mathrm{n}$ & $\begin{array}{l}\text { A thing that takes place at the same time as the market on Frösön, } \\
\text { Jämtland }\end{array}$ \\
\hline várping & $\mathrm{n}$ & Spring assembly \\
\hline dagping & $\mathrm{n}$ & A thing held for a specific case \\
\hline heimfaroping & $\mathrm{n}$ & Assembly at home by a person who owes somebody compensation \\
\hline manndrápsping & $\mathrm{n}$ & Manslaughter thing \\
\hline manntalsping & $\mathrm{n}$ & Assembly where the number of men for the levy fleet is counted \\
\hline refsiping & $\mathrm{n}$ & Assembly to punish culprits \\
\hline skattping & $\mathrm{n}$ & Assembly to claim tax \\
\hline skírslarping & $\mathrm{n}$ & Assembly to prove one's innocence \\
\hline skuldaping & $\mathrm{n}$ & Assembly where one pays the debts to another person \\
\hline fjórðungsping & $\mathrm{n}$ & Assembly for a quarter of a unit \\
\hline fylkisping & $\mathrm{n}$ & Assembly for a province (the fylki) \\
\hline heraðsping & $\mathrm{n}$ & Local asembly for the herað \\
\hline hreppstjórnarping & $\mathrm{n}$ & Assembly for the hreppar district \\
\hline hölfubing & $\mathrm{f}$ & Assembly for half of an area \\
\hline kirkjusóknarping & $\mathrm{n}$ & Parish assembly \\
\hline lögping & $\mathrm{f}$ & Lawthing, assembly for all the representatives of the law area \\
\hline skipreiðuping & $\mathrm{n}$ & Assembly for for the skipreiða, connected to the levy fleet \\
\hline priðjungsping & $\mathrm{n}$ & Assembly for a third of a unit \\
\hline almannaping & $\mathrm{n}$ & An ordinary local assembly \\
\hline $\begin{array}{l}\text { ályktaping, } \\
\text { lyktarping }\end{array}$ & $\mathrm{n}$ & Assembly empowered to make a final decision \\
\hline fararping & $\mathrm{n}$ & Unclear? \\
\hline fimtarbing & $\mathrm{n}$ & Assembly to be held after five days announcement \\
\hline höfuðping & $\mathrm{n}$ & A main assembly \\
\hline konungsping & $\mathrm{n}$ & Assembly held by the king \\
\hline setnaping & $\mathrm{n}$ & Final/closing assembly \\
\hline skapping & $\mathrm{n}$ & Assembly where a law is created or decided \\
\hline sóknarping & $\mathrm{n}$ & Assembly to decide on compensation \\
\hline sýslumannaping & $\mathrm{n}$ & $\begin{array}{l}\text { Assembly that the sýslumaðr holds in his sýsla three weeks after the } \\
\text { lawthing }\end{array}$ \\
\hline vápnaping & $\mathrm{n}$ & Weapon thing - inspecting equipment \\
\hline
\end{tabular}

FiguRE 3.I Norse terminologies for various things used across the area of study. There are at least 35 Old Norse words describing things of different types. Meetings are named after the cases brought to court, for example 'manslaughter thing'. At other times they are named after the administrative district they served.

A fjórðungsping was a meeting held for a quarter of a larger district. In some cases the meeting was named after the time or season in which it was held, for example a spring assembly. The actual site where meetings took place was named a pingstaðr (m), pingstöð (f), which translates as 'thing site'. 
meeting-places too were not static. As Alex Sanmark has demonstrated, new places of assembly were sometimes chosen in the High and Late Middle Ages (Sanmark 2009). To use place-names as an effective source of evidence, careful triangulation is needed between documentary sources for meetings, the units of administration, and placename evidence (Baker and Brookes 20I5).

\section{$3 \cdot 3$ MAPPING THE THING}

The mapping of medieval administrative units has a well established methodology. Medieval sources, maps and estate documents are used as a basis for the reconstruction of earlier estates and units (e.g. Cam I932; Jolliffe I937). If cartographic sources, place-names and archaeological field data are included, the landscape can be 'read' through a retrospective process of peeling back layers of information, beginning with the modern land forms and divisions, and working back to the vestiges of the medieval landscape: routes, places and boundaries (Figure 3.2). By testing evidence for medieval divisions and administrative units against natural terrain, their early form can be further corroborated and their origins investigated. In England, W G Hoskins, with Oliver Rackham and Christopher Taylor, developed this approach for multi-period landscapes, revealing how the historic landscape had developed in terms of settlement, roads, boundaries and fields (Gerrard 2003; Rippon 2004). The use of place-names and documentary sources can bring a time-depth to the early-medieval to post-medieval 'layers' within this palimpsest (Musgrove I997; Rippon 2004). Such methods are not confined to Britain, but are employed widely in European historical and archaeological research. Indeed a recent overview has distilled three methodological strands evident in applied research across Europe: retrospective, retrogressive and chronological approaches (Stahlschmidt et al. 20I7). Our work here falls within both retrospective and retrogressive methods. On the one hand, we seek to use a composite of sources to peel back the landscape layer by layer to understand the long-term development of administrative patterns and places. On the other, we are particularly interested in the reconstruction of the early medieval administrative landscapes and employ a range of sources and later documents to reconstruct of early arrangements (Stahlschmidt et al. 2017).

Using a combination of retrospective and retrogressive approaches is a standard method for identifying the names and locations of different types of administrative units. Advances in the 2oth century using this kind of approach have facilitated the reconstruction of administrative units and arrangements at a local level in Norway, Sweden and Denmark (see Chapter 2). These publications continue to provide an important basis for current work. The reconstruction of administrative territories is generally undertaken in tandem with identifying assembly locations, as the evidence for both is drawn from the same written sources. Using these approaches and a combination of medieval documentation including laws, court records and diplomas, alongside early modern maps, we have recreated the administrative geography in our core and colonised lands and we reconstruct the administrative framework in selected regions in the chapters that follow. The sources used are detailed in each chapter. Using cartographic evidence, we examine whether unit boundaries, particularly the provincial and local, have changed over time. While the environment will have 

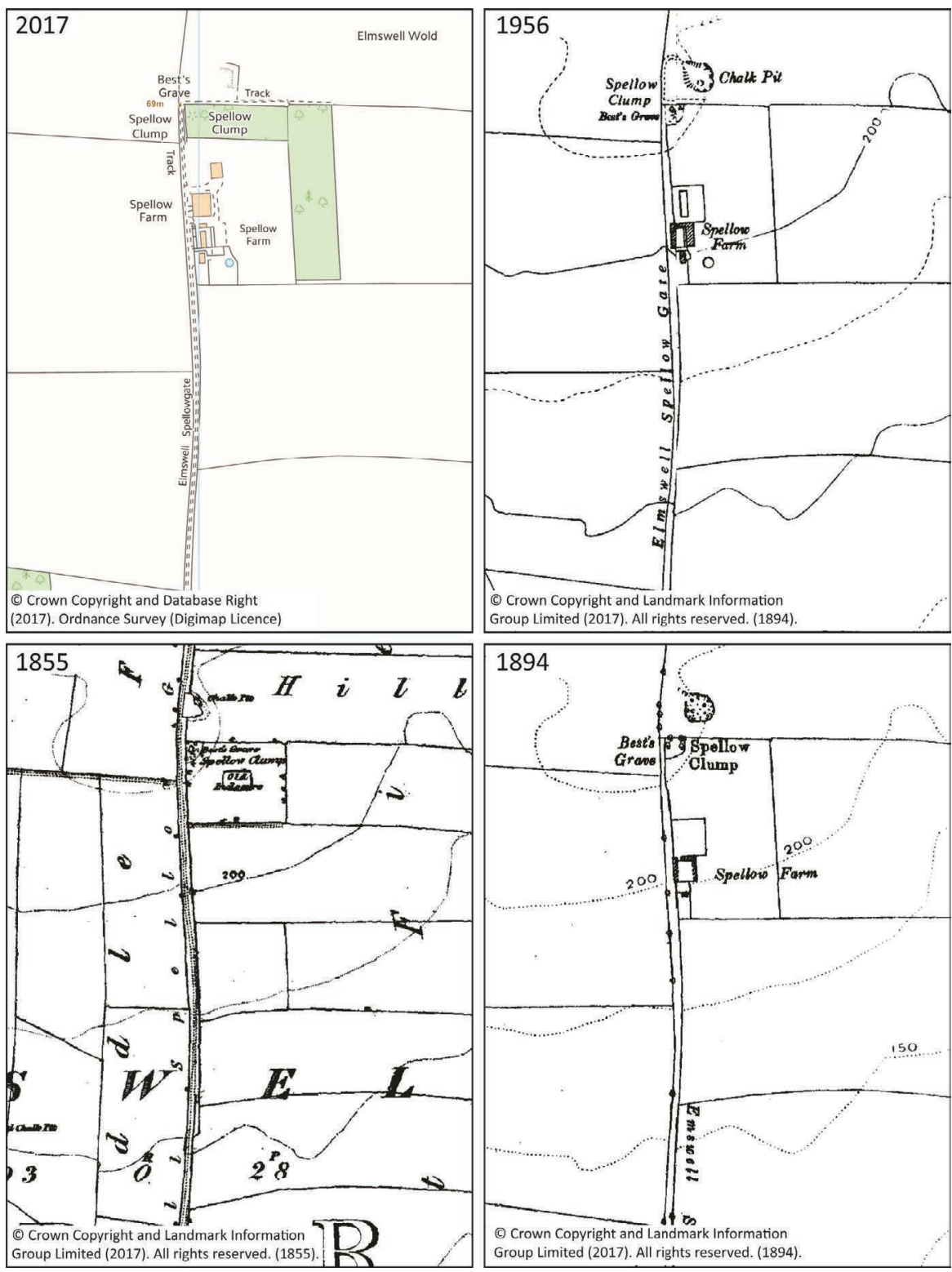

FIgURE 3.2 Example of map retrogression for Spellow Clump, East Riding, Yorkshire. From the top left working clockwise, we can track the presence of Spellow from its connection with the modern farm in 2017 to its survival in I 855 in association with an upstanding mound.

Drawn by Alex Turner. I:I0560 County Series Ist edition, Scale I:I0560; County Series Ist Revision, Scale I:I0560; National Grid I:I0 560 Ist Imperial Edition, Scale I:I0 560 ; OS VectorMap® Local, Scale I:I0000, Tiles: SE9 ${ }_{5}$ NE, TA0 ${ }_{5}$ NW, updated: I 4 December 20I6, Ordnance Survey (GB). All obtained using EDINA Historic Digimap Service, http:// digimap.edina.ac.uk, all TIFF geospatial data, all downloaded: I7.4.20I7. 
changed in terms of cultivated land, forest and water levels etc., the natural terrain can offer useful information on how the natural topography and antecedent humanmade features shaped medieval administrative units.

Locating the thing in relation to these medieval units is the next step. In tandem, therefore, with locating and mapping different levels of unit, documentary sources and place-names are used to pinpoint the meeting location. If a meeting-site is recorded in a medieval or early modern court record, the place-name or site name may not survive on early modern or modern maps. If it does survive as a habitative placename, a toponym or field-name, there is no guarantee that it marks the precise spot of a meeting-site (Gardiner 201 2; Watts et al. 2004). Medieval documentary accounts and place-names are therefore essential and used alongside topographic data. An account or place-name that identifies a meeting-site on a ridge or by a ford can be tested by exploring the terrain encompassed by the medieval unit. Archaeological survey is also vital. By considering information on prehistoric to medieval activity, prominent features, boundaries or activity areas can be identified and considered in light of the documentary and/or place-name attestations. This has proved especially effective in work on Sweden (Chapter 4), in the case studies presented on the Borgarthing, Hålogaland and Gulathing Law provinces in Norway (Chapter 5) and in the assessment of the lands colonised by the Norse (Chapter 6).

The tool used to triangulate these data is a Geographic Information System (GIS) - a means of digitally mapping, integrating and interrogating geographic and archaeological data. GIS has been used within our project to facilitate the integration of many layers of information including the medieval and early modern administrative units, topographic information on the terrain, information on historic resources and communications and archaeological data including the locations of monuments and sites. This has enabled exploratory analysis, where the translation of data into visual representations in maps allows detection of spatial patterns and relationships (Barceló and Pallarés 1996; McCormick et al. 1987; Thomas and Cook 2005, 4).

In our case-study areas, a vector-based ArcGIS has facilitated the integration of documentary and place-name information along with topographic and archaeological evidence. The sources of map data and archaeological information vary according to country and region, and these specifics are dealt with in each chapter. In broad terms, however, each strand of work has used GIS to draw together early and late medieval evidence from documentary sources and early-modern and modern cartographic sources and the information from these written accounts on provincial and local administrative arrangements has been digitally mapped using GIS. The historical development of the boundaries has been taken in to account when data for multiple time-periods survive. Elevation, geological and riverine data are then used alongside as much additional topographic data as possible to explore the landscape attributes of these regions in the early-medieval to late-medieval eras. Place-names attesting to assembly sites or activity, when they can be located with certainty, have been included. Nationally and regionally available datasets listing archaeological sites and monuments, crop marks and upstanding monuments, burials, coin finds, sculptures and rune-stones have also been introduced.

Within the GIS, these datasets have been used to map the earliest administrative units and locate certain and possible assembly and thing sites. Acknowledgement of 
differing levels of likely jurisdiction have been added, as well as probable dates, and evidence has been ranked according to its 'certain' or 'likely' status. The definition of proximate zones of assembly activity is also used as a basis for research, when precise locations for the thing are not forthcoming. It is worth adding that assembly sites frequently seem to have comprised relatively large areas and therefore researching an 'assembly area' is often more appropriate.

\section{Characterising thing sites}

Place-names are first used to assess particular common or unusual attributes. They may offer information on topographic preferences, but also provide interesting insights into structural additions and buildings at the thing location. In Södermanland in Sweden, for example, the meeting-site place-names mentioned in documents carry specific and important information: Eldasund refers to a strait; Stigtomta derives from the plural of Old Swedish stigher (road) and refers to a crossroads; and Kjula ås and Tumbo ås both refer to ridges (Sanmark 2009). These give some indication of the types of topographic feature used to denote and situate meetings.

Once place-names can be located on the ground, further research characterises the site and its immediate environs. Using the GIS and additional datasets, our project has assessed the hinterland and landscape setting of meeting-places, demonstrating where possible, relationships between the meeting-site and the natural environment and human activity (see Chapters 4-7). Early-modern and I9th-century maps offer details on fossilised land boundaries and routeways. Relationships between meetingplaces and resource zones are tested, as well as proximity to settlements, aristocratic farms and cult places etc. Relationships with earlier or contemporary archaeological evidence can provide chronological information on the inception of the meeting-site and its longevity, but also whether types of meetings existed before the formal creation of the thing. Routeway proximity is considered in the context of understanding the accessibility of sites and their likely level of operation (local, regional, etc.), and date of function. Natural features and environmental factors, such as hills or flood plains are important in modelling likely meeting-locations, while key resources, for example common upland grazing and harbours, are also powerful determining factors in assembly placement. A position in the outlands or between the cultivated land and uplands, on islands, isthmuses or river crossings can impart important information on the practical and ideological drivers for assembly placement and offer insight into networks of control over specific resources or routes.

Many assembly and thing locations are located at upstanding monuments such as burial mounds, stone settings and rows, and earth- or stone-built enclosures (Figure 3.3). Even when features do not appear physically present on the site, research using national and regional sites and monuments records and excavation archives as well as aerial photographic records can provide information on these kinds of relationship. We have used these resources in our study areas to explore the evidence for activity in the immediate and broad locality of meeting-places. In the case-study area of Yorkshire, England, data collated from the Portable Antiquities Scheme, which records all metal-detected finds, is integrated. At this intra-site level, the use of LiDAR data at one-metre resolution is also invaluable. This has become a much more 

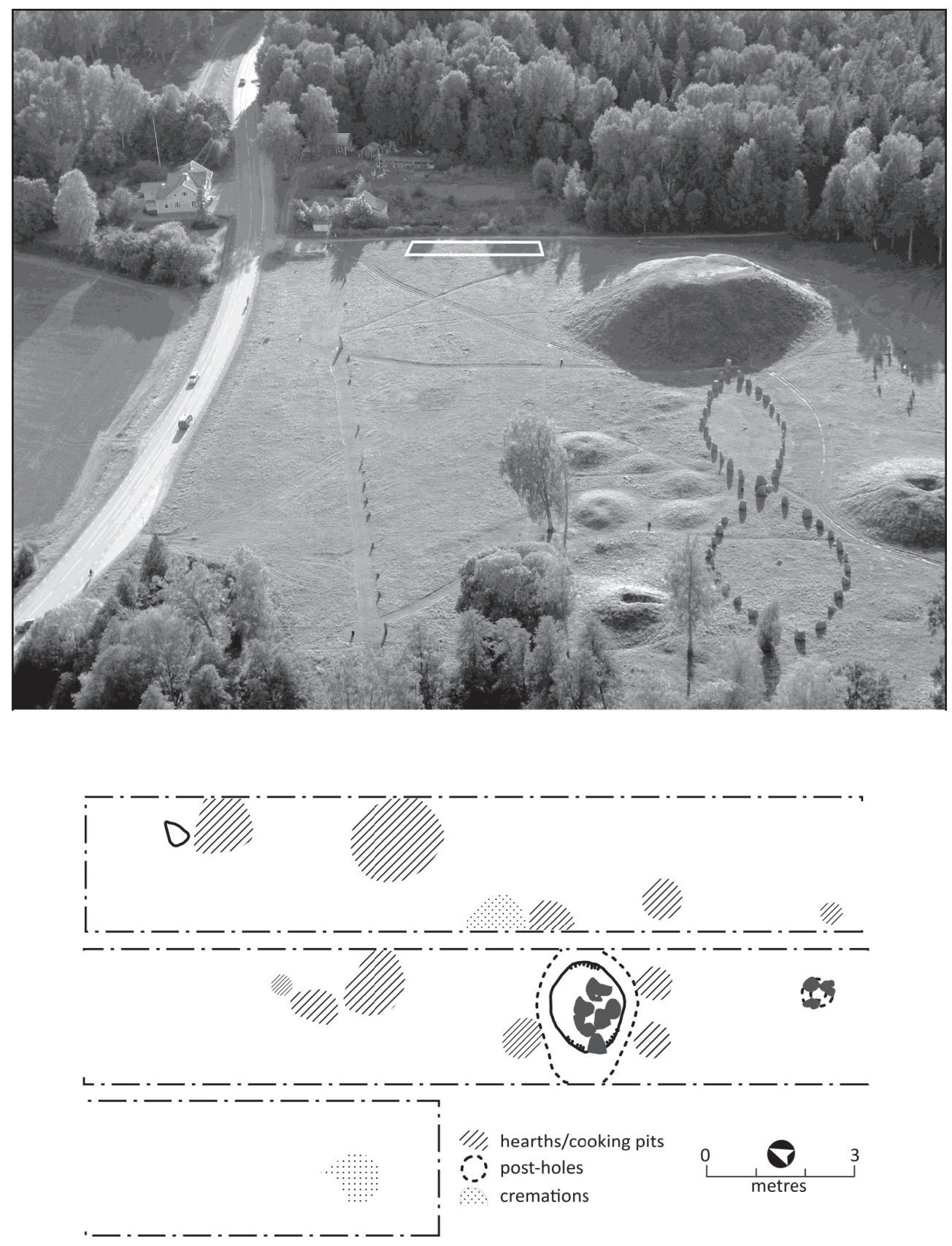

FIGURE 3.3 A site where excavation has revealed numerous hearths as well as standing monuments. Anundshög, Västmanland, Sweden. (C) Sarah Semple and Alex Sanmark. 
widely available resource and offers detailed information on landforms including upstanding earthworks and remains, even when traces are relatively ephemeral or monuments are hidden by undergrowth or woodland. LiDAR data were acquired for Shetland and have greatly aided the characterisation of on-site earthworks and features (see Chapters 6 and 7) (Figure 3.4).

Finally, following a phenomenological approach, we visited all locatable assembly sites within our study regions and assessed them in terms of the natural

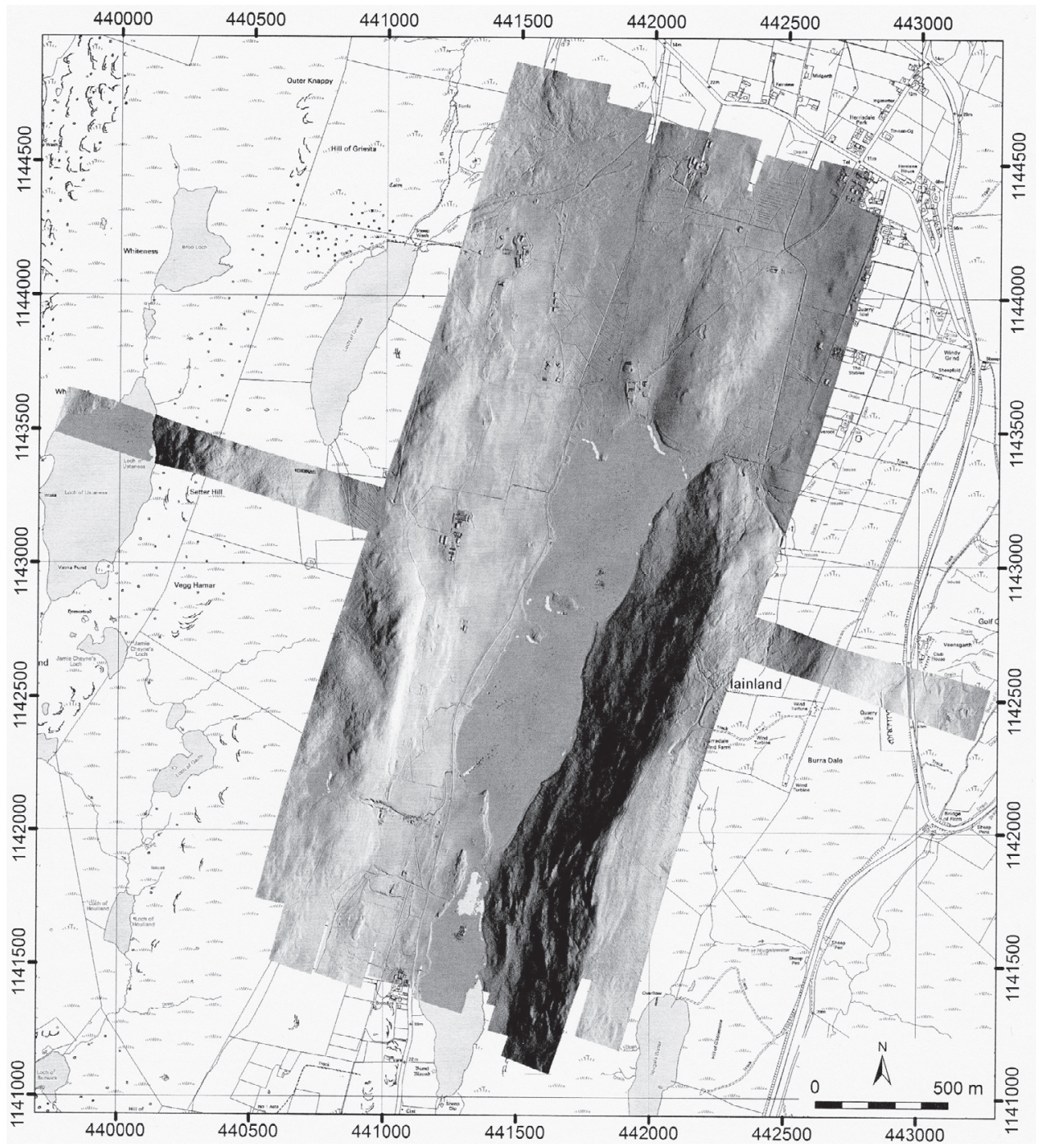

FIgURE 3.4 LiDAR scan of Law Ting Holm at Tingwall, Shetland. Image by Joris Coolen and National Environmental Research Council (NERC).

(C) The Assembly Project. 
setting, natural terrain and visible archaeological attributes. A list of designate characteristics were checked off at each site (Figure 3.5) and a field recoding proforma was completed (see Appendix 3a), GPS co-ordinates were taken at key features and a digital photographic record was produced including a $360^{\circ}$ view shed (Figure 3.6). This facilitated a critical assessment of the accuracy of the identified location and offered further useful insight on the character and attributes of the meeting-site.

FigURE 3.5 List of attributes checked off at each site visit by

The Assembly Project team.

\begin{tabular}{|l|}
\hline Location (co-ordinates) \\
\hline Information in written sources \\
\hline Date/s (from written sources or maps) \\
\hline Minor place-names indicating assembly activity \\
\hline Connection to thing place-name \\
\hline Connection to farm name linked to thing-site \\
\hline Landscape location \\
\hline Landscape character (likely pasture, wood etc.) \\
\hline Proximity to roads/communications \\
\hline Presence of monuments/archaeology \\
\hline Relationship to administrative units \\
\hline Proximity to settlement \\
\hline Proximity to church \\
\hline Proximity to recorded boundaries \\
\hline
\end{tabular}

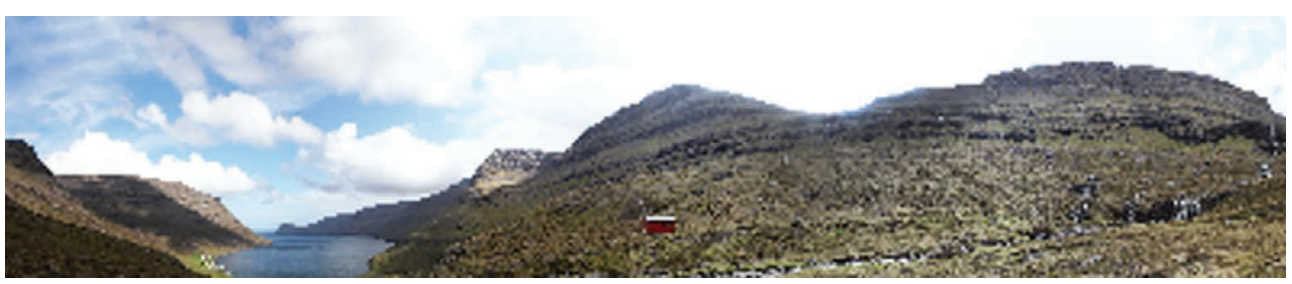

FiguRE 3.6 Example of a photographic palimpsest. I 80-degrees viewshed from the thing site í Køtlum in Norðuroyar, overlooking Árnfjarðarvík. () Fredrik Sundman.

\section{Survey and excavation}

Field investigation can offer both detail and chronological resolution. A selection of eight meeting-places has been subject to geophysical survey or excavation or both. These were chosen on the basis of five factors: the need to test sites in different regions; a desire to interrogate sites functioning in different timeperiods; good evidence for the location of the meeting-site on the ground; some indication that archaeological remains or traces might be forthcoming from placename data, aerial photographic evidence, or upstanding remains; and potential in 
terms of archaeological features and deposits. Sites were chosen in Sweden, Norway, Iceland and Shetland (see Figure I.7).

The location, terrain and underlying geology at each place dictated different survey and excavation regimes. All sites were surveyed using GPS and, where possible, LiDAR data were accessed to create a landform model (e.g. Tingwall), or digital terrain models were created based on aerial photographs taken using kites and drones. The use of geomagnetic survey as a form of prospection was only applicable at certain locations due to the high magnetic nature of the underlying geology at some sites. Based on the geological qualities, therefore, geomagnetic survey was carried out or resistivity and ground penetrating radar were applied instead.

Based on the results of the methodology described above and the geophysical prospection results, decisions were made on where to locate excavation trenches. In all instances the geophysical surveys were undertaken over relatively extensive areas in order to seek additional information on the hinterland of the meeting-place. We identified anomalies or possible key features and sampled those using relatively smallscale interventions. Given the difficulties in dating assembly sites and characterising activities that took place at meetings or the ways sites were designed or delimited (Sanmark and Semple 2008; 20I0), excavation was primarily directed towards features that might offer dating evidence, provide artefactual material or information on structural additions. Trenches were located where stratigraphy of depth might be preserved, or to test features that could contain or seal material; to sample specific areas that might have been associated with activity such as summits, platforms or mounds; and to test out any anomalies that could be hearths or cooking activity or pits where waste or charcoal might be preserved. The excavations were recorded using standard on-site paper and digital recording techniques. Charcoal-rich and organic deposits thought to be associated with temporary activities on the site were sampled for radiocarbon dating and for environmental evidence. Finds were retrieved, processed, and recorded and samples were taken where possible in the surrounding landscape to provide additional evidence on the historic environment. Each excavation has been published separately (Coolen and Mehler 20IO; 20I I; 20I4; 20I 5; Ødegaard 20I7). The field results are discussed and presented in the chapters that follow in the context of regional and comparative surveys.

\section{$3 \cdot 4$ LIMITATIONS}

The proposed methods inevitably have limitations. The reconstruction of administrative units relies on sufficient surviving documentation. Very little clearcut documentary material survives from before AD Iooo for our study regions, such as documents recording the extent, value and ownership of land or administrative, tribute or taxation structures. The majority of sources that we have are historical accounts, poetry, chronicles and sagas, all of which are distinctive and challenging, and are often late in date in their surviving form. Although this presents problems in terms of locating assemblies physically, these documents can still inform on activity at the assembly. In all regions, the units are reconstructed from the earliest available medieval and late-medieval sources, or, in the case of the Northern Isles of Scotland and the Faroes, almost exclusively based on early modern accounts. Using GIS, we 
have tested this evidence against natural and human-altered features and evidence of human activity as a means of critique, but our approach remains predicated on the assumption that such units preserve or capture the traces of pre-AD IO०० administrative geography. Likewise, although meeting-sites can be pinpointed through place-name and field-name data; we still make an assumption in some regions, that the name of a unit reflects an original meeting-site. Although corroborated in many cases by additional sources, evidence of multiple meeting-sites can be found within administrative units. It is vital, therefore, to recognise that systems were dynamic and subject to change over time.

Even as modern researchers, we are prone to some of the same failings as I9thand 2oth-century researchers. Using site visits is important, but not all archaeology is physically visible on a site. Likewise prehistoric monuments or activity near a suspected medieval thing is no assurance that these relate directly to the political or legal activity or gathering. Part of our project has been to create a critical framework of enquiry and a reflective methodology to better develop a detailed understanding of what constituted assembly units, places and activities. Archaeology and multi-scalar survey is not used within this project as a way of illustrating documentary accounts; they are employed as exploratory tools in their own right, to aid in-depth critique and statistical measurement. Standard approaches to identifying and locating units, cleaning and integrating archaeological data, on-site visits and site recording and use of remote data sources for landscape characterisation have thus ensured that our methods are as rigorous and error free as possible, offering a cohesive basis for comparative study.

The fallacies of past scholarship devoted to assembly studies in northern Europe are thoroughly aired in the previous chapter. This critical basis is used as a platform from which we have developed a transnational approach. Our geographic scope promotes comparative research across different countries, responding to recent publications that suggest assembly processes and practices were neither geographically, nor ethnically distinctive, but relate instead to the broader kingdomformation processes evident across Europe in the Late Iron-Age and early-medieval period. We have also responded to the dominant role historical documentation has played in past scholarship. In the chapters that follow, we demonstrate that the integrated methods outlined above offer the best evaluative approach for a rigorous exploration of assembly in a European perspective. 


\section{CHAPTER 4 \\ LAWTHINGS AND INAUGURATION SITES IN SCANDINAVIA}

\section{I SUMMARY}

The oldest administrative systems that can be reconstructed in Scandinavia are reviewed here, along with the top-level assembly sites in use at this time, and their potential predecessors. The major administrative divisions of Sweden, Denmark and Norway are explored first and then the provincial assembly sites within these districts are discussed (see Figures I.8 and I.9 for this classification). Topographic assessment is used to identify and explore sites in terms of their features and characteristics. Finally royal inauguration sites are reviewed. The changes that ensued in the latemedieval and early-modern periods in terms of the formation of the modern provinces within Denmark, Norway and Sweden are not discussed here, but I $3^{\text {th- }}$ and I4thcentury royal reforms are addressed.

\section{Background}

The periods preceding the Scandinavian Viking Age provide evidence of increased territorialisation and a certain level of societal and military organisation. This is demonstrated by a large body of evidence, such as the emergence and distribution of hillforts (Swedish fornborg/Norwegian bygdeborg). The hillforts have been interpreted as forming defensive systems for larger territories and chiefdoms, or for the protection of power centres by warlords (Mitlid 2004; Myhre I987b; Olausson 2008; 2009; Skre 1998, 28 5; Steuer and Hoeper 2008, 249; Ystgaard 2014, 30). The hillforts as nodal points in the landscape, as in other European regions, point to local organisation and, perhaps, as suggestefd for Gaul and Britain in earlier chapters, their use for gatherings and assembly-type activities (Ødegaard 20I5, 3 I8-3I9). In Scandinavia, hillforts are well evidenced in Sweden, but are less frequent in Norway and hardly any are known in the flat landscape of Denmark. Hillforts were in general in use from the Late Bronze Age in all areas, with a peak of activity evident in the

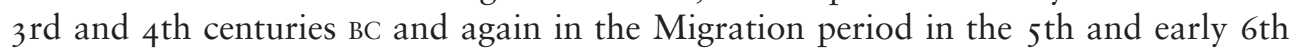
centuries AD. Most sites fell out of use around 550, and only sporadic use is recorded in the Viking and Middle Ages (Olausson 2009; Ystgaard 2014, 29-30).

The Migration period in Scandinavia has been seen as turbulent. Populations were affected by the changes in Europe prompted by the collapse of the Roman Empire which affected exchange systems and elite connections and power (Hedeager I992; 2OII; Herschend 2009, 403-404). A deteriorating climate and outbreaks of plague amplified these developments in the north (Axboe 200I; Gräslund 2007; Gräslund 
and Price 20I2, 434, 440; Iversen 20I3; 20I6; Löwenborg 20I2, I9-25; Tvauri 20I4). Previously occupied land became available, which created new opportunities for estate acquisition and powerful land-owners. Elites in the Vendel and Viking periods expressed their power in many ways, in striking forms of material culture and visible monuments in the landscape. At this time, the elite created and/or enhanced assembly sites with prominent features. These were then maintained and updated. The elite aimed to demonstrate their power and rulership by drawing on the past and their ownership of land. Thing sites, however, also involved communal efforts and activities in the same vein as the hillforts. The sites, we may assume, were created and maintained by collective efforts, while various types of evidence signal other kinds of communal activity, such as cooking pits and hearths implying the cooking and sharing of meals. Place-names and later written sources also indicate activities such as competitions, games, storytelling and to some extent trade.

\subsection{RECONSTRUCTING THE THING SYSTEM IN SCANDINAVIA}

Before towns and churches were established in the late Viking Age in Scandinavia, the thing was the most important place for social interaction and negotiation, but it did not exist in a void. Things were socially, morally and possibly religiously attached to rural communities and to the larger society. Much is still unclear regarding the formation processes of the law provinces in parts of Scandinavia and the emergence of the thing, but evidence suggests that royal strategy and a need by communities for collective security, wider interactions and even protection, all played a part (Iversen 20I5d; Sanmark 20I5). What is less well understood is whether law provinces developed organically to serve collective needs, or whether they were a development driven by elite power (Iversen 20I5d).

The primary sources for attempting a reconstruction of how the law provinces developed and the assemblies that served them are the medieval laws. These survive from a period when the concept of national unity was beginning to emerge in the three Scandinavian kingdoms, although national administrative systems were not yet in place. These sources demonstrate great variation between and within the different kingdoms in terms of administrative and legal practice, but this can be valuable in providing evidence of older frameworks and practices (Brink 20I4).

The Scandinavian administrative organisation is evident in a surviving group of documents termed the provincial laws and several associated written sources. The earliest of these date to the late I 2 th and above all the I 3 th century. Around 30 such laws are preserved from Scandinavia and Iceland. In some cases several versions of the same law survive. Latin sources from the IIth and I2th centuries refer to the Scandinavian laws as mos provinciae (Lat.) regional customs, ius terræ (Lat.) the law of the province/land, and regionis consuetudo (Lat.) regional customs (Fenger 200I, 68; Vogt 2009, 67-7I), and thus suggest the origin of these laws lies in preexisting local customs and regulations. A large number of surviving manuscripts were produced between c. I 250 and I350. Despite the proximity in date between them, it is possible to establish a rough 'stratigraphy', as some laws contain older regulations than others. All laws, however, contain a mix of regulations from different time-periods, at times conflicting, which can make them rather difficult to interpret 
(for a summary of the debate, see Sanmark 2004, I33-I45). Despite these pitfalls, close examination of the laws and related documents provides a snapshot of the administrative systems in the late I 2 th, I 3 th and I 4 th centuries. It is important to acknowledge, however, that the administrative organisation as presented in the laws may not be fully representative of the systems that existed on the ground, and to some extent, represent attempts to enforce unity from above (Hobæk 2013).

\subsection{THE LAWS, LAW PROVINCES AND THINGS}

According to the earliest laws, there were some 20 Scandinavian law provinces in the I 4 th century, and laws have been preserved from nearly all of these and in a few provinces 'older' and 'younger' versions of the laws survive (Iversen 20 I $5 \mathrm{~d}, 6$ ). Nine law provinces are known from Sweden, four from Norway and three from Denmark (a full list is published in Selberg 20I0) (Figure 4.I). Some laws were used in several law provinces, for example the Frostathing Law was used in Trøndelag, Hålogaland

Figure 4.I The law provinces of Sweden and Norway with the top-level assemblies. The location of the assembly sites and the boundaries has been mapped using medieval documents and early maps. Map by Alexandra Sanmark, Frode Iversen and Tudor Skinner, partly based on Charpentier Ljungqvist (2OI4).

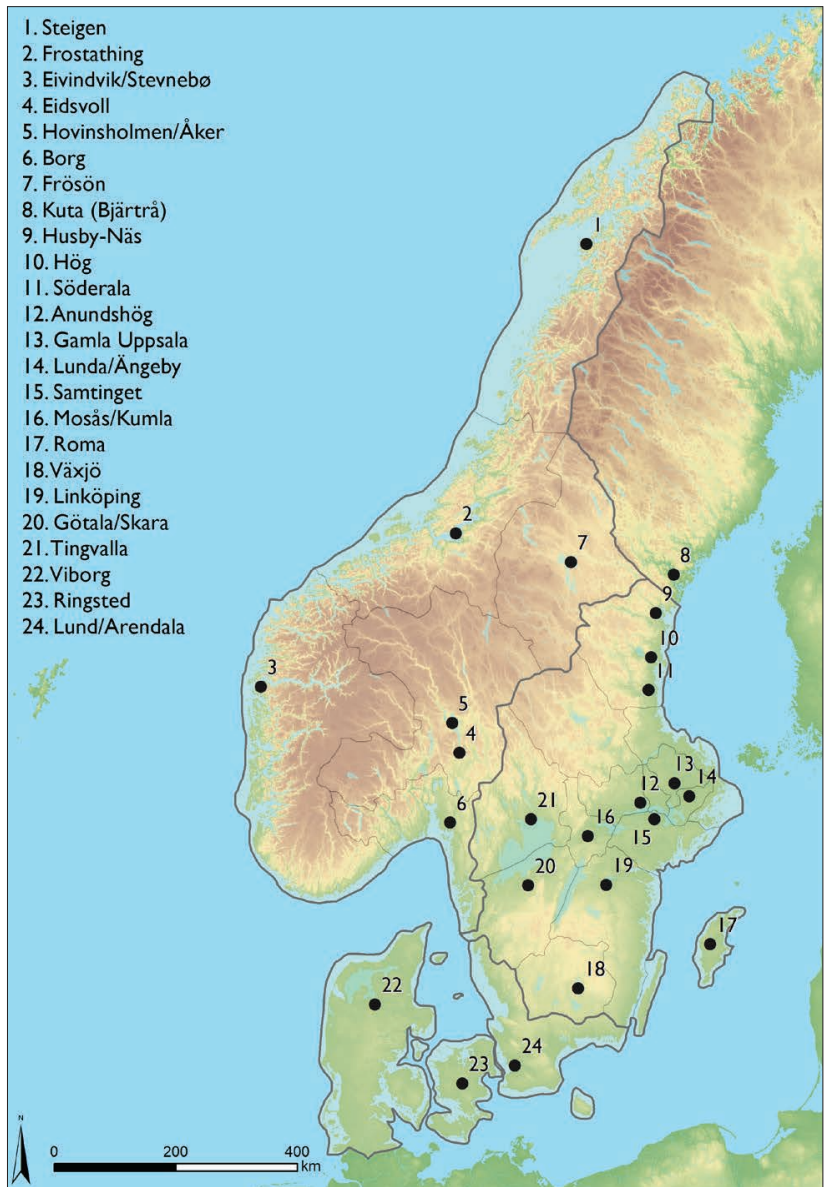


(modern Norway) and in Jämtland (modern Sweden) (Iversen 20I7d). By the time laws were being regularly written down, the Scandinavian administrative systems had been taken into royal hands and in the following centuries, further reforms were made in order to create more efficient systems, under even tighter royal control (Helle 200I, 74-75, I 55-I 56; Sanmark 2006). The large royal reforms in Norway in I 274 and Sweden in I347, by Magnus the Law-Mender and Magnus Eriksson respectively, resulted in the first rural 'national' laws (Liedgren I965; Taranger I9 I5). The Law of Magnus the Law-Mender existed in four more or less identical versions, one for each of the four law provinces (Taranger I9 I 5). They only varied in regards to the delegates' compensation for their journey to the thing meetings (Ødegaard 20 I 5, I I I). In I 274 the Laws of King Magnus the Law-Mender [r. AD I263-I 280] became applicable to the entire Norwegian kingdom (Taranger I9 I 5). In Sweden, King Magnus Eriksson's law replaced all existing provincial laws, apart from the island of Gotland which was not part of the Swedish kingdom at this time (Holmbäck and Wessén I943, GL lxxxvii; Ruthström 2003, II). Parts of the provincial laws, however, continued to be used, especially their ecclesiastical regulations, as these were absent from the new law (Liedgren 1965, 23I). In this way, the new national laws of Norway and Sweden stimulated a move to more homogeneous legal practices. The situation in Denmark was different, as the three law provinces of Jutland, Zealand and Skåne remained separate using their own laws until $\mathrm{I} 68_{3}$, while the Law of Jutland was used in connection with the royal courts (Fenger 200I, I34; Hoff I997, 20).

The laws discussed so far can all be termed rural laws: there were also specific laws for trading sites and (proto-)towns as well as other socio-economic areas. At least from the I 2 th century onwards, the trading laws were referred to as (ON) bjarkeyjarréttr, and this term gradually spread across Scandinavia. It translates as the 'law of Björkö' (Wessén I956, 657-658), most likely referring to Birka on the island of Björkö in Sweden, one of the oldest towns in Scandinavia that developed in the early 8th century (Hagland and Sandnes I997, XII; Skre 2008, 88; Wessén I956, 657-658). Further indications that large trading sites and towns had their own administrative system come from the Life of Ansgar (Vita Ansgarii), in which we are told that Birka c. AD 830 was administrated by the praefectus or 'prefect' Hergeir (Waitz I 884, 32). After consulting with his closest men, the king or chief gave Ansgar permission to proselytise (Norr and Sanmark 2008, 383; Waitz I884, 32). The earliest surviving written 'trading laws' are found in the bjarkeyjarréttr of Nidaros (Trondheim) surviving in a post-Reformation copy of a mid-I3th-century version (Hagland and Sandnes I997, IX). Specific lawmen (ON lögmaðr) appeared for towns in Norway around the same time (I260s) (Seip I934).

In addition, in 1276 a common town law was established for all four of Norway's royal towns. This royal law used the MNor vor by, meaning 'our town', implying royal control: it applied to Bergen, Oslo, Trondheim and Tønsberg (Helle 2006, I I4-II 8).

\section{Thing meetings}

Each rural law province was served by a hierarchal arrangement of assemblies, the nature of which varied between and within kingdoms. As a general rule it can be 
said that there was a single common 'top-level' thing that served each law province. The latter was then divided into smaller districts, often on two or three different levels, each served by their own thing site. It is important to note that the provincial assembly was not necessarily the supreme assembly in every respect, as the different types of thing to some extent worked in parallel with each other in an integrated framework. This was, for example, the case with the landsthing, the local thing of the hundred and the 'quarter-things' in Västergötland in Sweden (Holmbäck and Wessén I979b, LII; Rosén I965, 294). A case was brought to a court at a particular level based on two conditions: (a) when court-members could not agree on a decision, the case would be transferred to a court on a higher level, up to three times, according to Norwegian law (although this was not the case in Denmark at this time); (b) all courts seem to have had the same judicial competence, but higher ranked courts treated cases that involved people from a broader area. Although firm evidence is absent, it is probable that a local court would not make decisions or take cases concerning persons from another local thing district, but such cases would be referred to a thing that covered a wider area (Helle 200I; Taranger I 898). In Denmark, however, disputes over land were treated in the relevant district (Vogt 2005, 94-97).

According to Snorri Sturluson, the 'Law of Uppsala' had the highest authority in the kingdom of (ON) Svipjóð (in modern Sweden), where many law provinces had their own laws and their own assembly (Hollander I964, 3 I6; Saga of Olaf the Holy, Ch. 77). It seems, however, that this was only supreme in the sense that when the laws relating to different lands were contradictory, the Uppsala law and the decision of the Uppsala lawman took precedence. In this way, the Uppsala law was the Lex Superior within the kingdom. Snorri was a man of the $\mathrm{I} 3$ th century and highly skilled in law and may have had a good understanding of matters. Nevertheless, caution is needed as it is hard to ascertain which period he was referring to and whether he was describing a judicial system or a hierarchical political system.

In the Late Middle Ages, the king's court, the $(\mathrm{ON})$ réttarping, was established in Denmark, Norway and Sweden (Lerdam 200I). These courts, which heard cases from across each kingdom emerged as a type of royal council, and gradually became more regularised after c. I300. This level of court also dealt more frequently with legal issues at a national level. From I397, the king's court operated in relation to the Kalmar Union which joined the kingdoms of Norway, Sweden and Denmark under a single monarch (Lerdam 200I).

Many of the Swedish provincial laws contain regulations stating that there should only be one thing site in each hundred district and meetings should be held at 'the correct thing site' (OSw rættum thingstadh) or alternatively 'the correct and old thing site' (see e.g. Ahlberg I946a, 97-98; Holmbäck and Wessén I940, 218-219; Sanmark 2015; Turén I939, 6-7; Wildte I926, 219-220; I931, I82). This appears in documents from provinces within the Svealand region (Uppland, Södermanland, Västmanland and Dalarna), the provinces of Småland and Östergötland, but not Västergötland (Wildte I93 I, I 82). The same sentiment is reflected in later laws, such as that of Magnus Eriksson (Holmbäck and Wessén 1962, Tingmb 7 and I2, Kr Tmb 5 and 6: OSw Enskal thingsstadher i huario haeradhe wara; Emmelin I944, 94, Wildte I93 I, I74). This implies a concern with ensuring the holding of meetings at the correct location and that enduring or old meeting-sites held a certain importance 
as legitimate locations for the thing. Thing meetings did move around rather a lot, however, as documents from the I4th and I 5 th centuries from Sweden show. The nature of these assembly sites varies. Some, as this chapter and the next argue, may have had their beginnings in the Early Iron Age and were returned to at different junctures. Others seem to have been late-medieval creations, with only one or two meetings documented. The latter type tends to be more difficult to identify and define in archaeological terms.

Attempts were made to follow the regulations, but with varied success across the different provinces. A study of Södermanland in Sweden reveals that hundred thing meetings moved in terms of meeting location fairly frequently according to circumstances, making it clear that the existence of a 'correct thing site' did not necessarily mean that thing sites remained in the same place for a long time (Sanmark 2009). In Norway, however, there does seem to have been a greater degree of stability from the I2th/I 3 th centuries until c. I600. From western Norway we know that farmers living at farms with thing sites were exempt from the fleet levy or (ON) leiðangr 'tax'-one of the main taxes in medieval Norway. This was confirmed in I 579 by the king as a customary right (NRR II, 32I) and may suggest that owners of farms with a 'correct thing site' originally had some privileges or were compensated for their expenses arising from the meetings.

The (ON) herad (Mod Dan herred), hundred, was a local law district in Denmark. In the Middle Ages there were around 200 hundreds within the three law provinces. More than half of these ( I I 2) were situated in the law province of Jutland, which was the most influential district of Denmark. The hundreds are named in Valdemar's Cadastre from c. I230 and were stable entities throughout the Middle Ages, with a few additions. The hundred is thought originally to have consisted of four quarters, although divisions and mergers took place over time. The make-up of the herreder or hundreds in Denmark, during and after the Late Middle Ages, displays great variation. Mogens Lebech has studied Jutland and showed that here the hundreds were divided into both thirds and eighths, but most commonly into quarters (Lebech I935, I60). He has argued that it was the king who first organised the bundreds and revealed that they were often named after royal estates (Lebech I935, I 52). In the Law of Skåne the herred thing was referred to as 'the thing of the king' (Lebech I935, I6I). Hundred boundaries also coincided with the topography and natural divisions (Lebech I935, I6I). The bundred is considered to have had two purposes, military and judicial, but much remains unclear regarding its development (Jørgensen I92 Ia, 346).

In the Middle Ages, in Denmark, the local hundred assembly was held outdoors and a special thing site was selected by the king with the approval of the herredsmenn 'the men of the hundred'. The thing site at this time consisted of four logs serving as benches for the participants. Even though judicial power was transferred to the herredsfogde 'the judge of the local thing' in the Late Middle Ages and the general public no longer took part in the thing, the terms stokkemoend 'log men' and tingsvidne 'thing witness' continued in use in reference to those chosen to take part at the thing (Jørgensen I92 Ia; I92Ib). In Jutland in the Late Middle Ages, the participants, socalled sandemenn or 'truth men', became a fixed group, appointed by the king, while in the other Danish law provinces a system of permanent representatives did not 
exist and instead participants who gave testimony in cases were referred to as noevn 'nominated men'.

The hundreds of Denmark can be compared to the (ON) skipreiða units of the Borgarthing and Hålogaland areas in that these too were also subdivided into quarters. There were, however, significant differences. The skipreiðuping was an althing and its quarters were separate judicial areas served by their own thing. This was not the case in Denmark. The Law of Jutland certainly assumed a strict system where the bundreds were divided into quarters, but these were not thing areas in themselves, but rather areas connected to the naval defence system (ON leiðangr) (Jørgensen 1919). The men of the hundred were obliged to meet at the thing when required. It is unclear, however, if there was a general obligation to participate in the local hundred assemblies (Jørgensen $\mathrm{r} 92 \mathrm{Ib}$ ).

In Denmark, the hundred assembly had judicial rights in areas concerning local affairs. Cases of theft and rapine (ON rán) appear to have been the exclusive domain of the local thing and this institution could also issue the death sentence (Andersen 2OII, IIO). When a bundred made agreements, 24 people were needed to ratify these on behalf of the community (Jørgensen I92 Ia; I92 Ib). The hundred assembly only dealt with minor matters and larger issues were addressed at the landsthing. According to Per Andersen, the nominated men in cases of theft were not merely locally elected representatives for the hundred, but also land-owners in their own right (Andersen 20I I, I IO). In Zealand tenants could also hold the position of nominated men (ON nævn), as there were fewer land-owners here. In civil law cases there was a free choice between the different tiers of thing; people could choose where to bring their cases, probably because cases often involved people from different hundreds and there was a need for a neutral court. After the judicial power was transferred to the royal official (ON heraðsfoguti; MDan herredsfogde) in the Late Middle Ages, the participation of the men of the hundred in the legal process was reduced. In the I6th century the local assembly was made subordinate to the landsthing and (MDan) réttarthing (Jørgensen I92 Ib, 350). Until I 847 it was common to annually choose eight permanent stokkemoend or thinghørere 'thing listeners', for the hundred assembly to secure witnesses and the transparency of the legal process. In the I 7 th century (MDan) thingstuer or 'thing cottages' became more commonplace, but even during the I 8th century a few hundred assemblies were held in the open air. Through the Retsplejelov from I I April I9 16, the term herredsting or 'local hundred assembly' became obsolete (Jørgensen I92 Ib, 349-350).

Concerns are also evident in written accounts regarding the timing of assemblies. Top-level things were held at set times of the year and this was often specified in or implied by the laws (Holmbäck and Wessén I933, Ög xxviii). This idea is also found in Eddic poetry (Løkka 20I3, 20). The fixed meeting date for top-level assemblies varied in Scandinavia, but summer seems to have been preferred. According to the Law of King Magnus the Law-Mender of Norway from I274, the annual lawthing in all law provinces was held on St Botulphus mass on the I 7 th of June. ${ }^{\mathrm{I}}$ The assembly lasted as long as the cases demanded, ending only when the representatives agreed. According

I Notably in the Borgarthing area the lawthing was regularly held instead on the 28 th of June and on the following days and connected to the Feasts of St Peter and St Paul (Ødegaard 201 5, I00). 
to the earlier Gulathing Law, a slave should be set free at the Gulathing on the first Sunday of the event, indicating the proceedings could last more than a week. This regulation was taken out of the law by King Magnus Erlingsson [r. AD I I6I-II 84] in the II70s (G 4; Larson I935, 39).

For local hundred meetings, Swedish laws state that they were not to take place more frequently than every seventh day (Holmbäck and Wessén I933, Ög R I pr, xxxviii). In Skåne the hundred assemblies were expected to be held every I4 days, and there were only eight days between meetings in Jutland, according to the Law of Jutland. Hence, in theory, the hundred assembly in Sweden and Denmark met much more frequently than in Norway, but it is possible that these regulations for frequent meetings were intended as a way of timetabling meeting-events across several meeting sites to allow officials to attend, rather than a relentless calendar of almost weekly meetings at each thing. For example, the so-called Tingtavlen or 'thing calendar' appears as a contemporary appendix in the Norwegian law code of I687. This specifies three fixed dates for the local things in Norway, with one meeting in winter, summer and autumn, but only two annual meetings in northern Norway, in spring and autumn (Hallanger and Brandt I855, appendix). Within each mid-level district the set dates for the fixed local meetings varied with two- to three-day intervals so that the royal judge had time to travel from one site to another and thereby attend all the meetings in his district. For example, in Nordhordland, western Norway, the judge $(f \circ g d)$ attended I I local things in his district. In winter the meetings were held during the period 4th-26th February, in summer I 3 th June-Ist July and in autumn $4^{\text {th-3 }}$ oth October (Hallanger and Brandt I 855 , appendix).

Time seems to have been at the very essence of the thing concept (Sanmark 20I7a, I 20-I 22). As set out in Chapter I, the meaning of the term thing relates to both people and time (Bjorvand and Lindeman 2007, II5I-52; Hellquist I980, 974; Iversen 20I3, 5; Sanmark 20I5). This offers some explanation for (OSw) affkiännuping or 'extraordinary assembly', as an expression reserved for assemblies not held at the correct time and place (Holmbäck and Wessén I933, UL xxxviii, 207, fn 8a, 209, fn 36; VL R I 2:4). Affkiännuping included for example thing meetings held at someone's house, royal assemblies that were held at other sites than the correct thing site (Holmbäck and Wessén I933, UL, 209, fn 36; Wildte I93 I, I78), and probably also those called after specific incidences, such as murder. The concept of fixed and extraordinary meetings appears at a very early point in time in Tacitus' description of assemblies in Germania, where he stated that they were held 'on certain fixed days, either at new or full moon' and also that 'in the case of a sudden emergency', meetings could be called for specific purposes (Germania XI). Extraordinary meetings called (ON) boðping or bodthing also appear in Norwegian and Frisian laws and legal documents (Iversen 20I3, IO-I2) and initial evidence dates from AD IIO8 (Waitz I 886, 44). Medieval documents suggest that extraordinary assemblies were not uncommon and in this case it appears that the locations were decided according to need. One such example comes from Daga hundred, Södermanland, where King Magnus Eriksson [r. AD I3 I9-I364] held an assembly in I345. Rather than meeting at Vadsbro, the thing site of the hundred, this gathering took place at a place named Ljunga, a few kilometres from Vadsbro, where local tradition accords the place-name Kungsgatsbacken ('The slope by the royal route'), referring to a place for meetings 
with kings who were travelling the royal route named the (Mod Sw) Eriksgata (Sanmark 2009, 222-223).

\subsection{THE PROVINCIAL THING SITES IN SCANDINAVIA}

At the top-level, each law province was served by a thing. None of the medieval laws provide specific information on location. In order to reconstruct arrangements within the provincial units, late-medieval written sources are required, which offer information on later thing meetings in terms of location. In this section, the toplevel sites serving law provinces in Sweden, Norway and Denmark are identified and discussed and considered in terms of their fit and function in medieval administrative arrangements.

\section{Sweden}

Medieval Sweden had the largest number of law provinces, all with slightly varying traditions, together creating a rather complex picture. According to the Law of Magnus Eriksson there were nine law provinces (OSw laghmanz döme): Uppland, Östergötland, Öland, Västergötland, Värmland, Södermanland, Närke, Tiohärad (i.e. Värend, Njudung and Finnveden in the province of Småland), and Västmanland and Dalarna (the latter two forming one province according to this law). It seems that, by this time, each of these law provinces had a top-level assembly called the (OSw) landzping (Holmbäck and Wessén 1962, I:I) (Figure 4.2).

In the time of the provincial laws, i.e. prior to the Law of Magnus Eriksson (in content and origin, if not in terms of the date of the surviving manuscript), a total of I 2 provinces can be identified. Laws are preserved from eight of these: Västmanland, Dalarna, Hälsingland, Uppland, Tiohärad (only the ecclesiastical law), Östergötland, Gotland and Västergötland. No laws have survived from Värmland, Öland or Närke. A law for Närke, confirmed by the king, is referred to in a document dated I 330 (Holmbäck and Wessén I946, SmL xxx; Styffe I9I I, 302). Also the Värmland law is referred to in a medieval document, this one issued by the lawman of the province in I426 (Styffe I9I I, I86-I87). This law may well have been rather similar to that of Västergötland, as strong administrative connections and similarities existed between these two provinces; Värmland was for example part of the episcopal see of Skara (Styffe I9II, I87). The existence of a written provincial law for Öland is not certain and has been subject to recent debate (Andersson 20I0; Strauch 20I I).

In terms of thing organisation, the terminology used in the extant laws is varied, but the overall structure was rather similar across the kingdom of Sweden. In Västergötland, the top-level assembly was known as 'The Thing of all Geats' (Mod Sw Alla götars ting, OSw ping aldra götä), and is mentioned in both the Older and the Younger Law of Västergötland (Holmbäck and Wessén I946, ÄVG lii; S1 I, R I pr, 3:2, Tj 5:2; YVG R I,3, Tj 33). There are also some references to 'the thing' clearly referring to this very assembly (Holmbäck and Wessén I946, lii) and it seems that a thing became 'the Thing of all Geats' if the lawman was present (Wildte I926, 219). The Younger Law of Västergötland also refers to a landzping on several occasions (Holmbäck and Wessén I946, lii). In the neighbouring province of Östergötland 


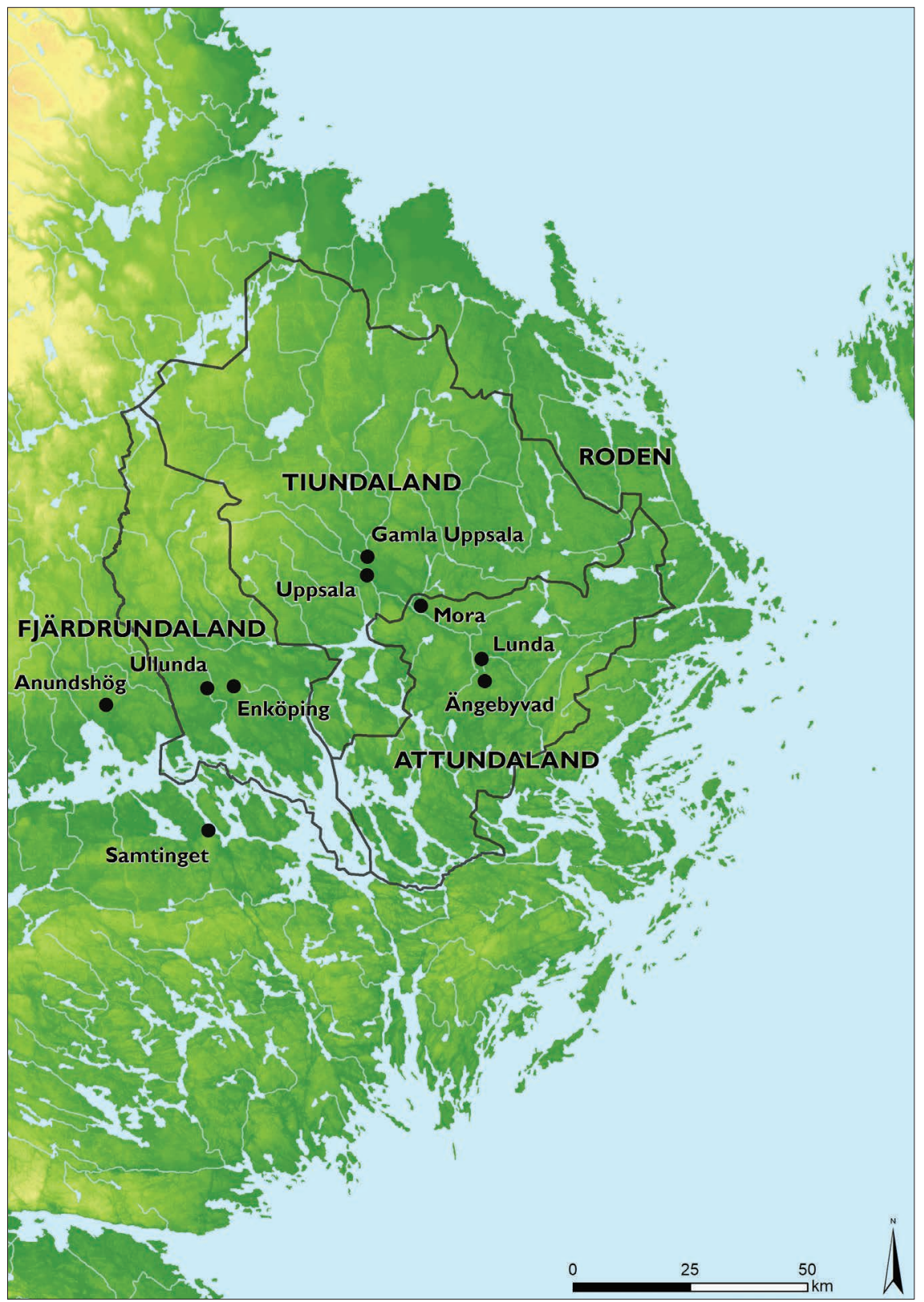

Figure 4.2 The extent of the Law of Uppland, covering not only the folkland units, but also the province of Gästrikland and the Roden area (modern Roslagen and presumably some of the islands in Lake Mälaren). The boundaries have been recreated using medieval documents and early maps. Map by Alexandra Sanmark, Brian Buchanan and Tudor Skinner. 
the top-level assembly-called Lionga thing-was referred to as a lawthing (OSw lagping) (Holmbäck and Wessén I933, ÖG xxviii, B I:2, 30:I, R 3:I, 25, 26; Styffe I 9 I I, 242). The Östergötland law extended to parts of the northern and eastern areas of the modern province of Småland and, prior to the 13 th century, possibly also the island of Öland (Holmbäck and Wessén I946, SmL lxxix; Styffe I9I I, 265-266). The Law of Magnus Eriksson stated that Öland was its own law province, but part of the see of Linköping (Holmbäck and Wessén I962, MEL I:I). The rest of modern Småland was covered by (Mod Sw) Tiohärads lag, i.e. 'The Law of Ten Hundreds (Mod Sw härad)', of which only the ecclesiastical regulations have been preserved (Holmbäck and Wessén 1946, SmL lxxv-vi)-these regulations are included in Magnus Eriksson's Law. There is no doubt that 'The Law of Ten Hundreds' once existed, and still in the early I 7 th century there was at least one copy (Holmbäck and Wessén I946, SmL lxxix). As the name suggests, this was an amalgamation of ten separate units. The law does not contain any direct references to a provincial thing, but at least one regulation hints at its existence. This regulation stated that 'people should go to the thing and hear the (OSw) laghsagha (Holmbäck and Wessén 1946, Sml 2, SL lxxxxiii-iv), where laghsagha is used in its original sense of 'the recital of the law at the thing' by the lawman. This rule could therefore be seen as a reference to a meeting for the whole area (Holmbäck and Wessén I946, $\mathrm{SmL}, 435, \mathrm{n} \mathrm{I})$. ( $\mathrm{OSw}$ ) lag was the word for the law itself but was also used for the community of people who lived by it, and for the physical area in which this community lived (Brink 2002, 99; Gurevich I985, I 57). This should be compared to the expression 'before land and lawman' which appears in other laws and is seen to refer to top-level assembly meetings (Holmbäck and Wessén I946, ÄVG Tj I I, YVG XX; I936, vl lii, xli-xlii, R 8, I4:I, I9).

On the island of Gotland the top-level assembly is referred to in the Guta saga and the Guta Law (Peel 1999; 2009, xcii). The saga refers to the assembly as (ON) gutnal ping, the meaning of which has been debated. Some have argued that this should be interpreted as the 'althing of the Gotlanders' (for a summary, see Peel 2009, $6-7,68)$. The explanation that has been most widely accepted, however, is that gutnal is a place-name denoting the 'al (sacred place) of the Gotlanders' (Lindroth I9I 5; Myrberg 2008, I38-I58; Peel I999, xxvii-xxix). Gutnal ping should therefore be translated as 'The thing of the Gotlanders' sacred place' (Myrberg 2008, I3 8-I39; Styffe I99I, 428).

In central and northern Sweden, yet further administrative variations are found, the most important of which is the 'folkland', the names of which (referred to in Latinised versions of the OSw names: Tindia, Fedundria and Atanth) are mentioned in the so-called Florence document from c. I I20 (Liedgren I959; Nilsson I998, 79; Nyberg 2008, I70), although this term does not appear in this source. The folkland was clearly an older unit that was gradually abolished, but survived in some areas into the Late Middle Ages. The three folkland units of Uppland (MSw Tiundaland, Attundaland, and Fjärdrundaland) are the most well known (Figure 4.2).

In I 296 they were brought together under the Law of Uppland. The royal confirmation of the new law clearly stated that it was based on the existing laws of the folkland (Holmbäck and Wessén I933, UL 5-6). The new law covered not only the folkland units, but also the province of Gästrikland and the Roden area 
(modern Roslagen and presumably some of the islands in Lake Mälaren) (Holmbäck and Wessén I933, UL 7, fn 3, R I3; Styffe I9II, 365-366, 376-383). There is some debate whether all of Roden or just the northern part (Mod Sw norra Roden) was under the Law of Uppland. Carl Gustaf Styffe lists the islands in Lake Mälaren under Attundalands Rodh in Uppland while the royal confirmation letter states that the law applied to norra Roden, interpreted as modern Roslagen (Holmbäck and Wessén I933, UL, 6, fn I3; Styffe I9I I, 376-386). In the Law of Uppland it is stated that this new law was accepted at a common thing. This was a meeting of the three folkland units, and may have been a one-off meeting (perhaps at Mora, see below), as there is no other evidence of a provincial thing for Uppland. Instead, the assumed pre-I 296 organisation seems to have remained in place, with a folklandsthing as the highest instance for each respective unit (Liedgren 1959; Holmbäck and Wessén I933, UL xxxix, 5-6 fn 7 and I 2, M 52, pr, I I4, J 4 pr, I32), although the folklandsthing is only mentioned on two occasions in the law (Holmbäck and Wessén I933, UL M 52, pr, I I 4, J 4 pr, I32). It is important to note that cases could be taken to the king in the highest instance (Holmbäck and Wessén I933, UL 6, xxxix), but this is most likely a late development (Sanmark 2006).

Västmanland too was classed as a folkland with a folklandsthing as the overall assembly, which is referred to directly in the law (Holmbäck and Wessén I936, M 33 pr). Its existence is also implied by the expression stating that cases could be taken before 'land and lawman' (Holmbäck and Wessén I936, VL R 8, I4:I, I9, xli-xlii; I946, YVG Tj II). Also Södermanland seems to have been a folkland, as implied by the existence of a (Mod Sw) folklandsnämnd 'the board of nominated men of the folkland' (Holmbäck and Wessén I940, SL xxxv; Liedgren I959, 47I). There is no mention in the law of a folklandsthing or a landsthing, and it has therefore been suggested that the lawman may have held meetings at the local hundred assemblies (Holmbäck and Wessén I940, SL xxxv, R I, 2:I). It is noteworthy, though, that the royal confirmation of the law from I 327 stated that 'the law and the law-book' had been announced at 'many' landsthing meetings (tha lysto the them laghum ok laghbook a magnum lanzthingum) (Holmbäck and Wessén I940, SL 4, IO-I I, fn I7; Jansson I970, 26). In addition, the existence of a market called the (OSw) samping ('common thing') suggests that a provincial assembly for Södermanland existed, consisting of several territorial units, joined under one law and a common assembly (Holmbäck and Wessén I940, SL xxxi, SL R I I, 235 fn I 25). The earliest recorded such assembly took place in Strängnäs in I360 (Styffe I9I I, 275).

The province of Dalarna was labelled a hundred, although it had its own law (Holmbäck and Wessén I936, DL xxi-xxii; Styffe I9II, 324). In the I9th century it was argued that the Law of Dalarna was merely a revision of the Law of Västmanland, but by the turn of the 2oth century it was more or less conclusively proven that this was not the case (Holmbäck and Wessén I936, DL xv-xvi). The units for judicial proceedings seem to have been the 'thirds' (OSw pripuingar, pl) (Holmbäck and Wessén I936, DL xxvi; Styffe I9II, 324) and there is no certain evidence of an assembly for the whole province. The law stated that householders could appeal against a judgement 'under the law-book', while expressions such as 'land and lawman', indicate the existence of an overall thing (Holmbäck and Wessén I936, DL R Pr 3, 5:2, xxvii). What this means is that a new thing would be called 
Figure 4.3 The law province of Hälsingland.

This consists of four units termed land:

Alir and Sunded in the modern province of Hälsingland, Medelpad and Ångermanland. Map by Alexandra Sanmark and Tudor Skinner.

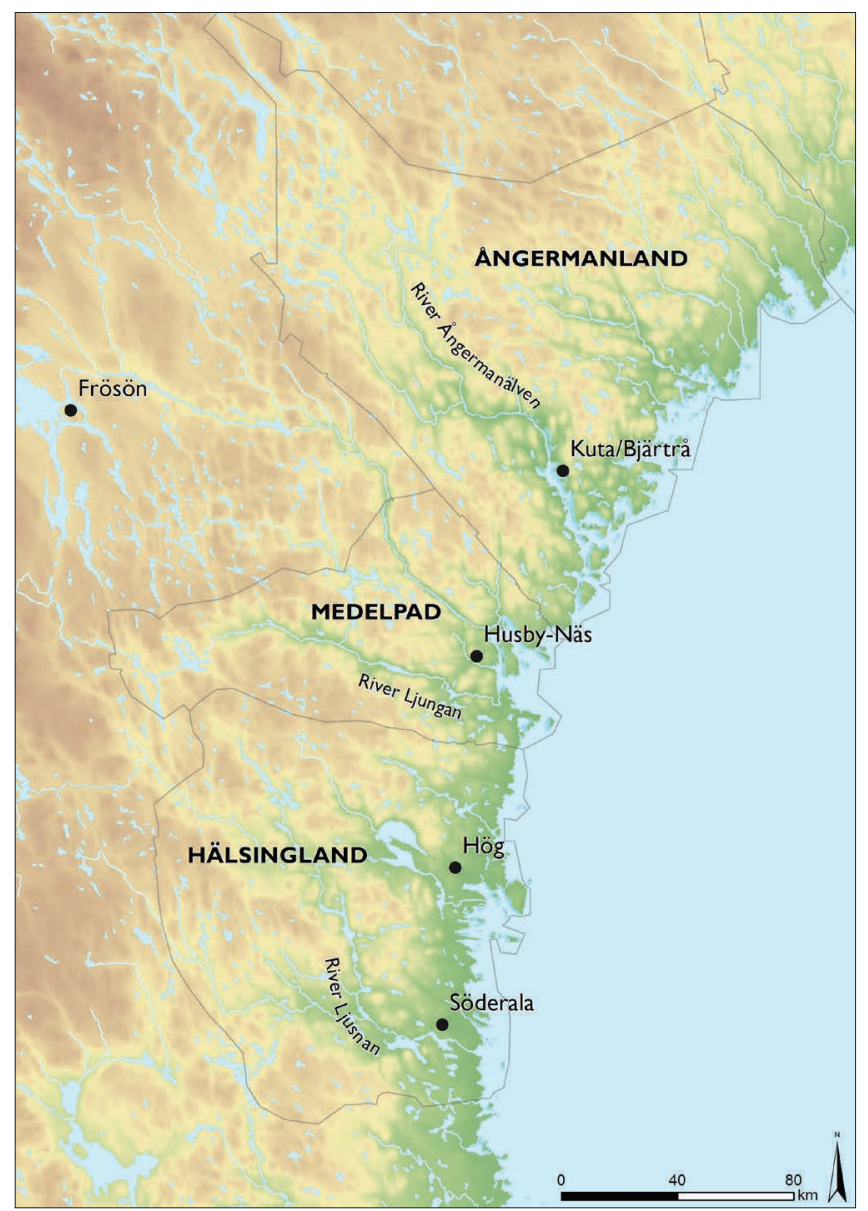

at which the law was to be consulted (Holmbäck and Wessén I936, xxvii). In I493, a landsthing is recorded, a late development of the administrative system of this province (Holmbäck and Wessén I936, DL xxvii, DD I, I 50; Styffe I9I I, 324).

The law province of Hälsingland consisted of four units termed land: Alir, Sunded, Medelpad and Ångermanland (Holmbäck and Wessén I940, HL xlvi-ii; Styffe I9I I, 386) (Figure 4.3). These 'lands' probably covered the modern province of Hälsingland as well as those of Medelpad and Ångermanland and perhaps also small parts of Västerbotten (Holmbäck and Wessén I936, HL xlv-vi and lii; Styffe I9II, 396-397). Each of these units had its own lawman and its own assembly, presumably known as landsthing, recorded at Alir (Söderala), Hög (Sunded), HusbyNäs (Medelpad) and Kuta/Bjärtrå (Ångermanland) (Holmbäck and Wessén I936, HL xlvii; Styffe I9I I, 395).

The late-medieval documents only provide the name of the place where meetings were held, so in order to locate meeting-sites, archaeological evidence and placenames have to be consulted. In this way, details of some late-medieval sites have been 
found. In many instances a shift took place in the High and Late Middle Ages, from rural assembly sites that may have been operating since late prehistory, to meetinglocations in medieval towns. One of the most interesting results is the consistency in location and site features across all areas examined; sites follow a remarkably similar pattern despite the variety of terms used in the laws to describe the top-level sites. In addition, in several cases, predecessor sites can be traced and these are often located just a few kilometres away from the known and documented location of the latemedieval thing. This pattern is found across Norway, Denmark and Sweden, although there are some striking differences between the kingdoms too, all of which will be examined below.

\section{Location, archaeology and topography}

A clear example of a shift from a place of assembly active in late prehistoric times to a new location in the medieval period is found in Västmanland (Figure 4.4). The late-medieval top-level assembly meetings were in Västerås, as recorded in I364 (SDHK 85I5) and a meeting in I3OI can be interpreted as such (VL XXXIV; Holmbäck and Wessén I936; Styffe I9II, 3I3). Västerås shows humble beginnings in the Ioth century, with some evidence of craftspeople and trade (Bäck 20I4), from which the town presumably grew. Nearby Anundshög is recorded as a thing site of Gorunda hundred from the I4th century onwards, but in view of its strong archaeological signal, it is the most likely candidate for the earlier folklandsthing (Semple and Sanmark 2013, 522-523). The archaeological evidence-hearths and cooking pits-suggests the location was used for gatherings in prehistory. It was also monumentalised with burial mounds, ship-settings, rune-stones and standing stones dating from the Early Iron Age to the Late Middle Ages (Figure 4.5). A linear monument c. I50m long-perhaps dating from the Vendel period (AD 550-790) or earlier-consisting of huge wooden posts, was added to the site, and is interpreted as a combination of an enclosure and a processional route (Figure 4.6). In addition, the royal ceremonial route known as the (Mod Sw) Eriksgata passed the site (Sanmark 201 5, 88-94, 99-103; Semple and Sanmark 2013, 522-523). The shift from this site to Västerås may have taken place in the I3th century, when the episcopal seat was founded and the cathedral was first constructed (Nilsson I998, 83). A similar relocation is suggested for Västergötland, where the top-level things ('The thing of all Geats') were held in Skara. This is documented for example in I4O2 and I409 (DD I 402070900I). Götala, a few kilometres away, has been seen as a likely earlier candidate as this name contains the $(\mathrm{ON})$ element al 'sacred place', matching the name of Gotlandic top-level thing site of Gutnalia; it lies close to two fording places and there are prehistoric burials close by, but it cannot be identified as the early meetingsite with absolute certaintly (Vikstrand 200I, I96; see discussion in Sanmark 2017a, I $52-$ I 53 ).

In the law province of Hälsingland, a shift from top-level assembly sites to towns can be traced in all four cases: Söderala to Söderhamn, Forsa to Hudiksvall, Selånger to Sundsvall and Kuta/Bjärtrå to Härnösand (Grundberg 2006, 49-50; Holmbäck and Wessén I940, HL xlvii; Styffe I9I I, 393, 395) (Figure 4.3). All sites have strong archaeological profiles, with features such as prehistoric cemeteries, harbours, and 


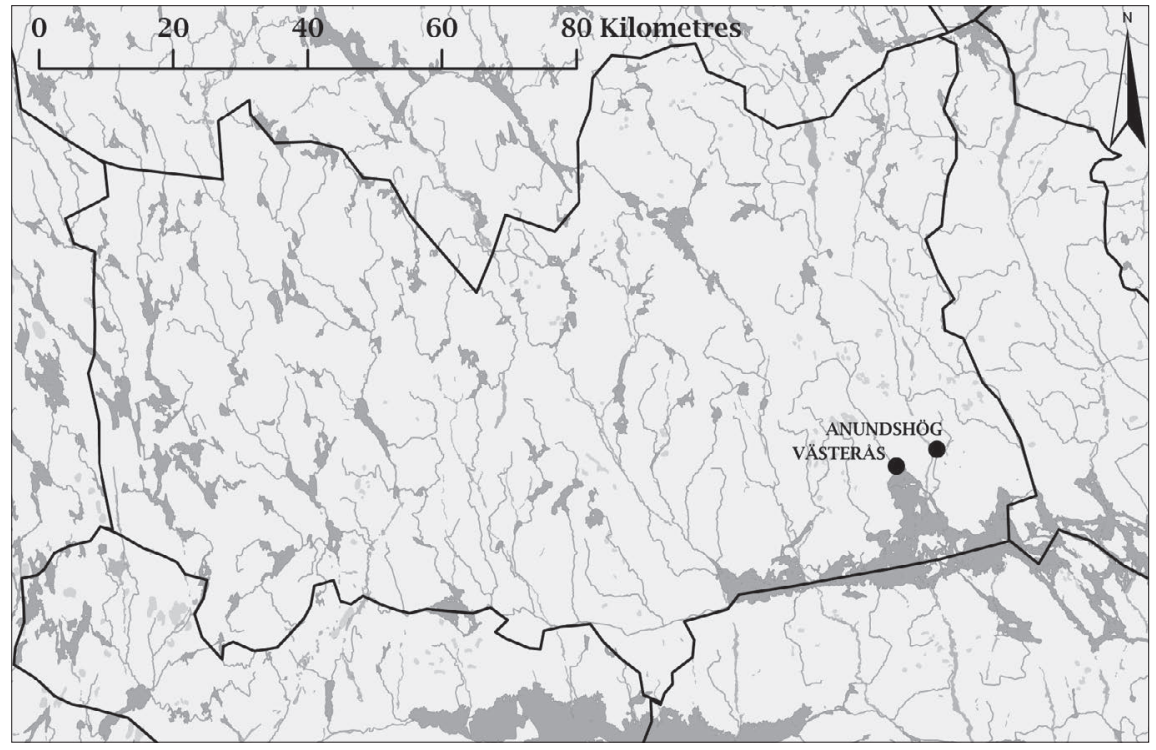

FIGURE 4.4 Shifting assembly practices in Västmanland, Sweden. Map by Alexandra Sanmark and Tudor Skinner.

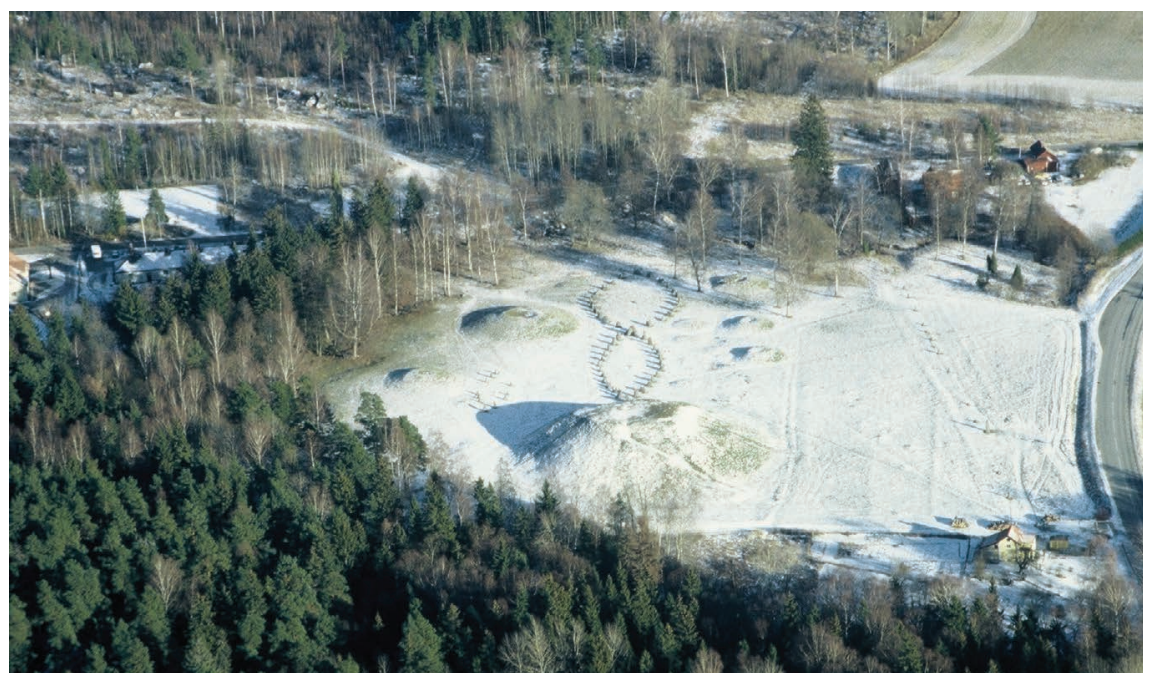

FIGURE 4.5 Aerial photograph of the thing site at Anundshög, the proposed early top-level assembly of Västmanland. This site has remains, such as one very large burial mound, smaller burial mounds, ship-settings, rune-stones and standing stones, dating from the Early Iron Age to the Late Middle Ages. Photograph by Daniel Löwenborg. Aerial photograph inspected and approved for publication by the Swedish Armed Forces, October 20I 5, FM20I 5-I 8792:2. 


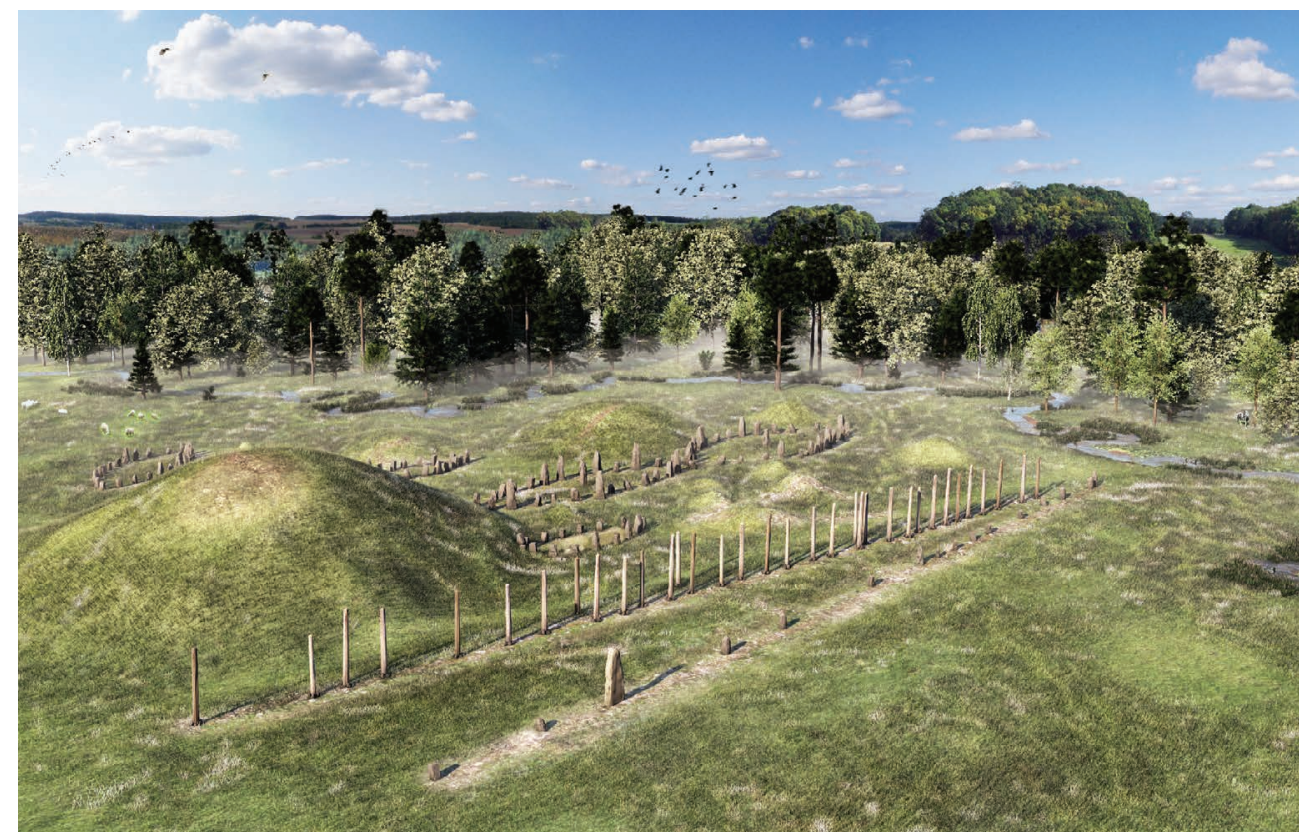

FIGURE 4.6 3 D reconstruction of the Anundshög site. In the foreground are the rune-stones and the line of standing stones, with the wooden monument just behind. Created by Framefusion in collaboration with Alexandra Sanmark and Sarah Semple.

large mounds (Sanmark 2017a, 64-88) (Figures 4.7a-d). This area of Sweden did not really develop until the late-medieval period and most towns were established in the 17 th century. Bearing in mind the vastness of this law province, we should not be surprised at the lack of a joint assembly site for all four 'lands'. It is, however, noteworthy that meetings for the modern province of Hälsingland did take place, for example in I3I4 when one is recorded at Söderala church (SDHK 26II) at which lawmen from Alir and Sunded were both present (Holmbäck and Wessén I940, HL xlvii). By the I 5 th century, landsthings for the province of Hälsingland (not the law province) were held as indicated by the landsthing at Tuna church in 1458 (Styffe I9I I, 389).

Uppland is probably the most complex law province, and a variety of sites have to be taken into consideration. The three folkland assembly sites are recorded in the Late Middle Ages: by Uppsala Cathedral (OSw Tíundaland, Mod Sw Tiundaland) (AD I29I, SDHK I5I3: in pretorio fulclandie iuxta cimiterium maioris ecclesie); Folklandstingstad (OSw Áttundaland, Mod Sw Attundaland) (Styffe I9I I, 347) and Enköping (OSw Fjathryndaland, Mod Sw Fjärdrundaland) (AD I300, SDHK I9I5; Styffe I9II, 347). The archiepiscopal seat, established in Gamla Uppsala in II64, was moved to Uppsala in around I273, when the construction of the new cathedral started. This means that when the first recorded meeting of I29I was held, the cathedral would have been in its very early stages. The cimeteria (Lat.) referred to 

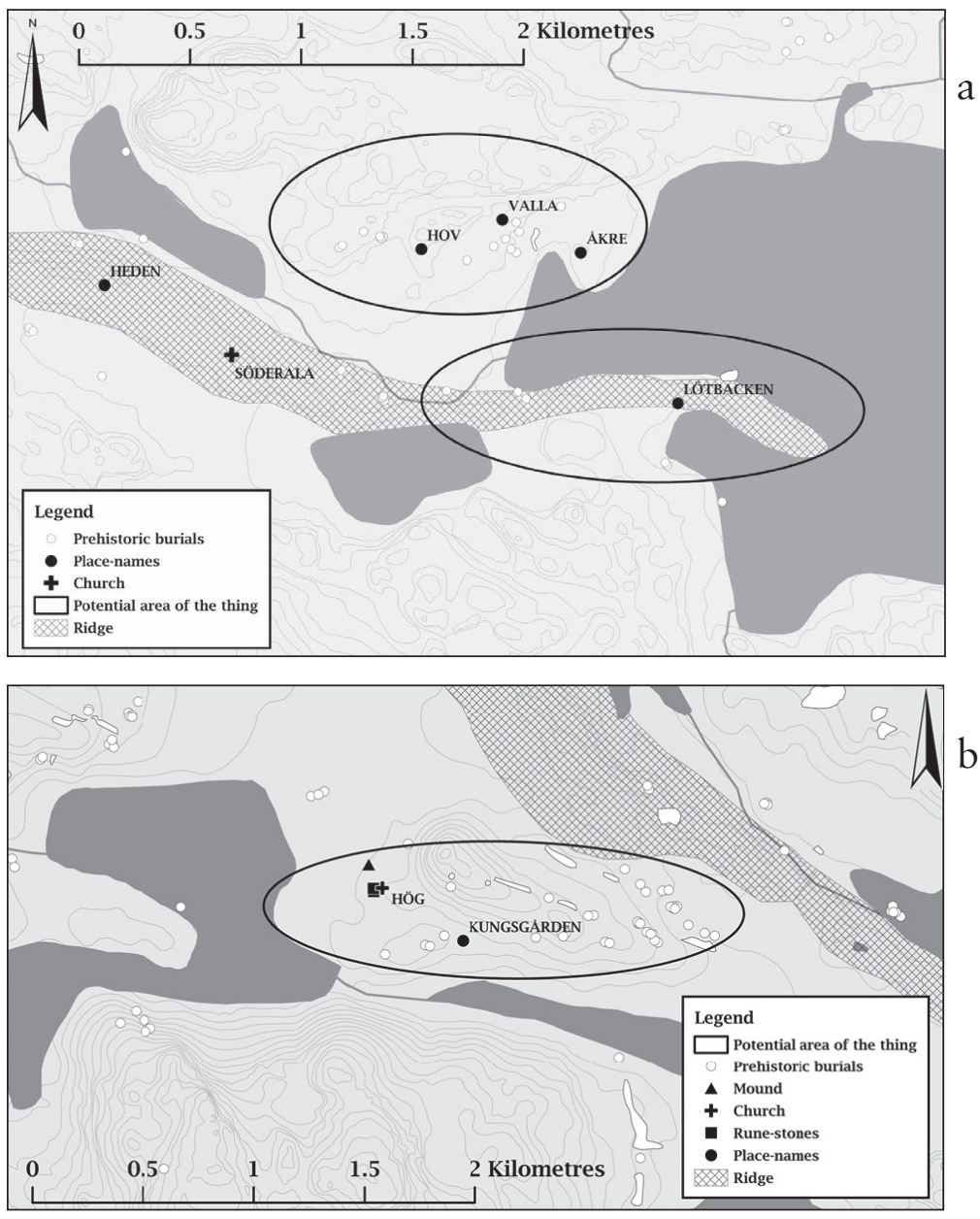

FIGURE $4.7 \mathrm{a}-\mathrm{b}$ The proposed early top-level assembly sites of the four lands of Hälsingland. Reconstructed water levels reflect those around AD Ioo० (C) Sveriges geologiska undersökning.

a) The thing site at Söderala, the proposed location of the top-level assembly for Alir. The site was in a prime geographical location by the ridge and the watercourse which connects into the River Ljusnan. A large number of prehistoric burials are found in this area. The place-names Valla, Åkre, Heden and Lötbacken are all indicative of assembly meetings, and Hov suggests a cult site. Valla, Åkre and Heden as well as Söderala and Heden are located on higher ground and are therefore the most likely spots for the assembly meetings. Large parts of the surrounding area must have consisted of wetlands. b) The thing site at Hög, the proposed location of the top-level assembly for Sunded. The site was in a prime geographical location by the ridge and a lake system which leads far into the interior of Sweden. A large number of prehistoric burials are found in this area and two Ioth-I Ith century rune-stones. The placename Kungsgården indicates the location of the royal manor. The assemblies were most likely held around Hög church where there is a large Iron-Age burial mound. This area sits on a natural elevation, which must have been almost surrounded by water and wetlands. 

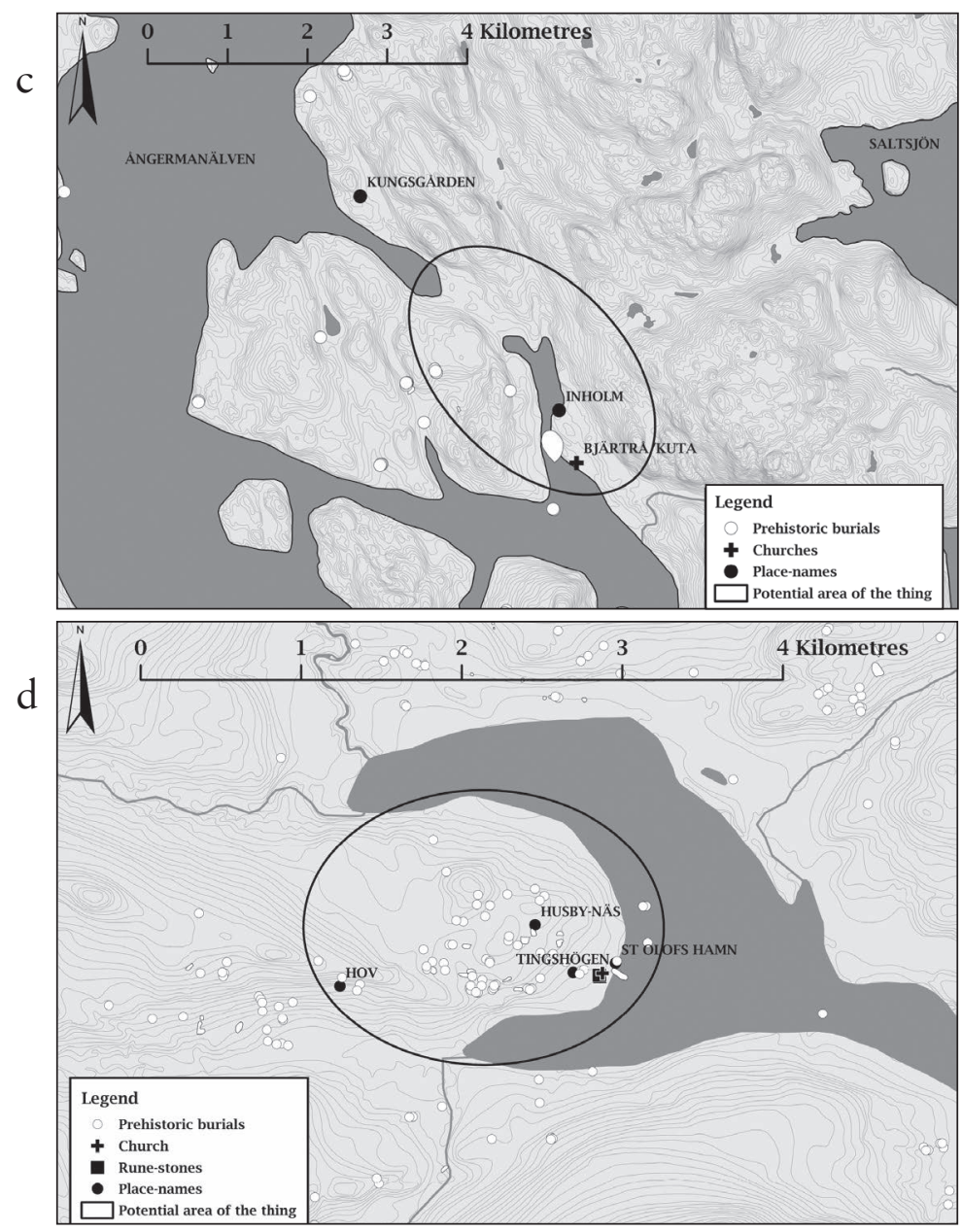

FigURE $4.7 \mathrm{c}-\mathrm{d} \quad$ c) The thing site at Kuta (Bjärtrå), the proposed location of the top-level assembly for Ångermanland in the law province of Hälsingland, Sweden. The site was in a prime geographical location on the River Ångermanälven. The place-name Kungsgården ('The royal manor') indicates royal presence, although Kuta (Bjärtrå) is generally viewed to have been the location of the late-medieval royal manor. The church and the burials are located on the highest ground in a rather low-lying area. This again is a site, where the thing site is very likely to have been surrounded by water, and it could most likely be reached from two directions. d) The thing site at Husby-Näs (Kungsnäs), Selånger, the proposed location of the top-level assembly for Medelpad. The site was in a prime geographical location by the ridge and a water route which connects into the River Ljungan. The harbour, called St Olof's hamn, formed a suitable landing place where a trading site (Mod Sw köpstad) is recorded in I428. A large number of prehistoric burials are found in the area, as well as two Ioth-I Ith century rune-stones and the place-name Hov suggests a cult site. The mound known as Tingshögen ('The thing mound') was not necessarily the focus of the assembly meetings, but is indicative of thing meetings in this area, which formed a small peninsula. Maps by Alexandra Sanmark and Tudor Skinner. 
in the document must have been the shrine of St Erik, which had been moved from the old cathedral (Sundquist I953, 94). This may also have been the site of the thing of Ulleråker hundred, recorded in I323 for the first time (Styffe I9II, 359-360; Sundquist I953, 94). As Uppsala grew, various functions seem to have been centred there. A royal manor (Mod Sw Föresäng) is documented from I 243, for example, where a lawman's thing was held in I430 (Styffe I9I I, 347).

The most likely location of the assembly meetings for Tiundaland prior to the I 3 th century is Gamla Uppsala, where according to Snorri Sturlusson 'the assembly of all Swedes' was held (Hollander I964, 3 I 5) (Figure 4.8). This site seems to have been used for assemblies from at least the 6th century onwards and was highly monumentalised like Anundshög with burials and rows of wooden posts (Beronius Jörpeland et al. 20I3; Sanmark 20I 5, 90-98).

The evidence from the other two folkland units shows a rather similar picture. Mod Sw Folklandstingstad ('The thing of the folkland') in Attundaland first appears in documents as the thing site for Seminghundra hundred in $\mathrm{I}_{3} 85$, when meetings were held by Lunda church (Beronius Jörpeland and Bäck 2003; Callissendorff I966, 244245; Emmelin I944; Styffe I9I I, 372). It has been argued that Folklandstingstad was moved to Sigtuna in the I 4 th century, but this was the market only, not the assembly (Sanmark 20I7a, I 54-I 55), but as late as I396 a royal (OSw) ræfsta ping 'a royal thing' was held here, suggesting that the site still held special status (Styffe I9I I, 372). A predecessor site can be surmised at Ängebyvad, $2 \mathrm{~km}$ to the south of Lunda church (Figure 4.9). This area has some striking assembly features: a connection with cultic place-names, a prehistoric burial ground, a rune-stone, I 2 standing stones, and a location where key communication routes converge (Brink 2004a; Sanmark 2009; 20I7a, 58-60; Sanmark and Semple 20I0). The evidence suggests a common pattern for thing sites. Locations that are topographically distinctive with evidence for activity of prehistoric date and good access to communications seem to provide the sites for medieval and earlier meetings but these were generally abandoned in the Late Middle Ages in favour of new meeting-places located near to the parish church (Sanmark 2009; 20I7a, I43-I46).

In Enköping, a similar scenario is possible. Royal assemblies were held here, for example in I409 (Styffe I9II, 347), and probably within the medieval town. A potential predecessor site is possible at Ullunda ('The grove of the god Ull'), just west of modern Enköping. The site is characterised by Iron-Age burials, rune-stones, and a fording place for the royal Eriksgata, and by the I 7 th-century thing meetings are recorded at nearby Tillinge church (Sanmark 20I7a, 6I-62; Vikstrand 200I, I77-I78) (Figure 4.IO).

The model of an early/initial phase of meeting-sites that generally encompassed earlier monumental remains, prehistoric archaeological evidence and good communications, is in some cases verified by sites that were not relocated in medieval times. At Lionga thing in Linköping, Östergötland, for example, a different scenario is evident. Here, the old thing site, which was most likely located at Stanga, remained in use in the late-medieval period. Stånga was situated just outside the medieval town, across the River Stångån from the cathedral, which dates from the I 2 th century, but where the first church was probably erected in the IIth century (Nilsson I998, 93-94; Styffe I9I I, 242). The site, which is proximate to the royal Eriksgata, has a 
Figure 4.8 Map of Gamla Uppsala illustrating how the site was enclosed by a combination of the wooden monuments, watercourses and wetlands, as well as burials. The burials were gradually added over time and they are shown here to the fullest extent they have been documented. The size of the wetlands at and around the site has been approximated on the basis of historic maps. Map by Alexandra Sanmark and Brian Buchanan.
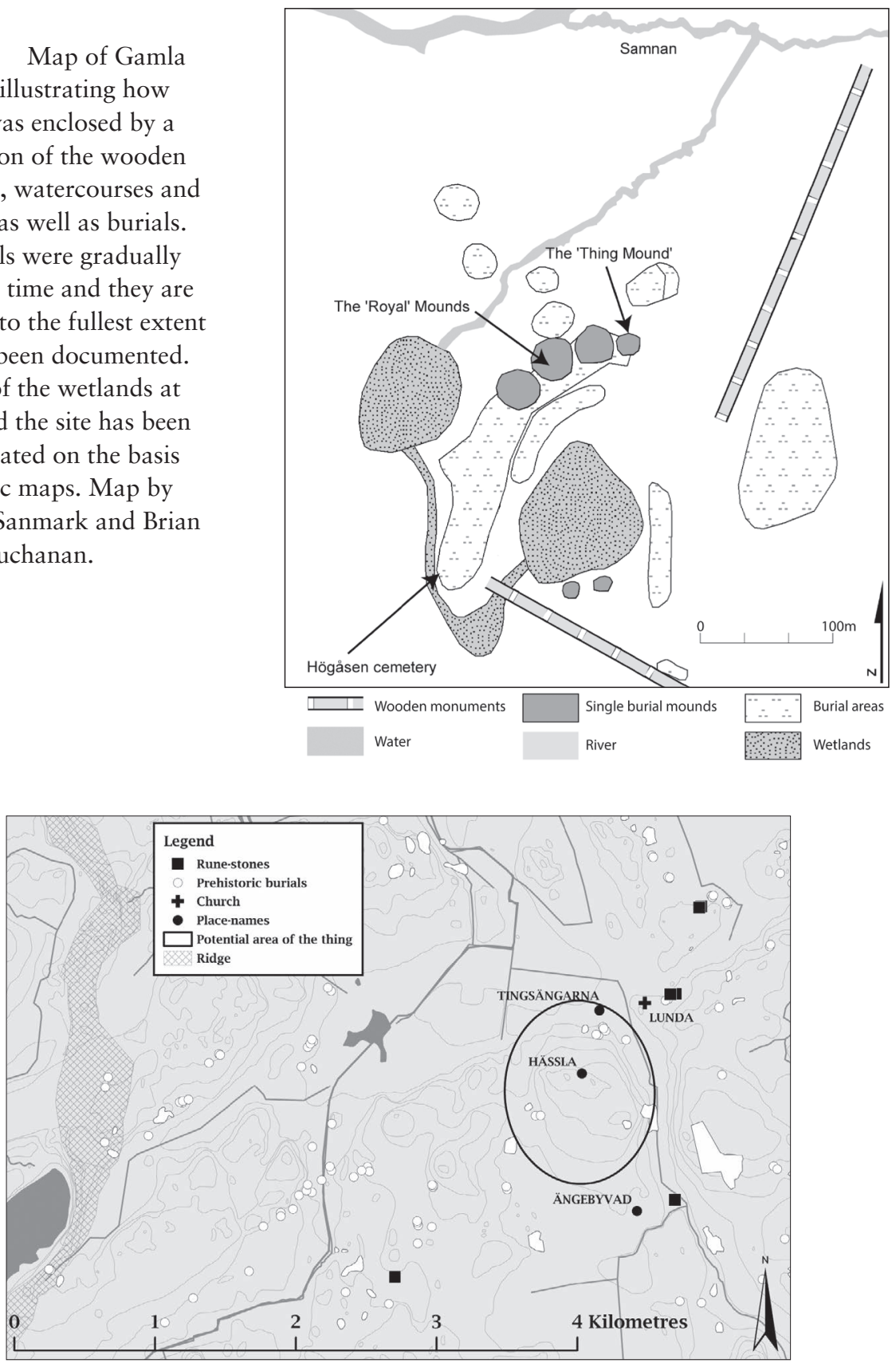

FIgURE 4.9 Suggested locations for the top-level thing sites of Attundaland: Lunda church, documented as a thing site from the I 4 th century, and its likely predecessor Ängebyvad, where a linear stone monument marks a ford across a water route. Map by Alexandra Sanmark and Tudor Skinner. 


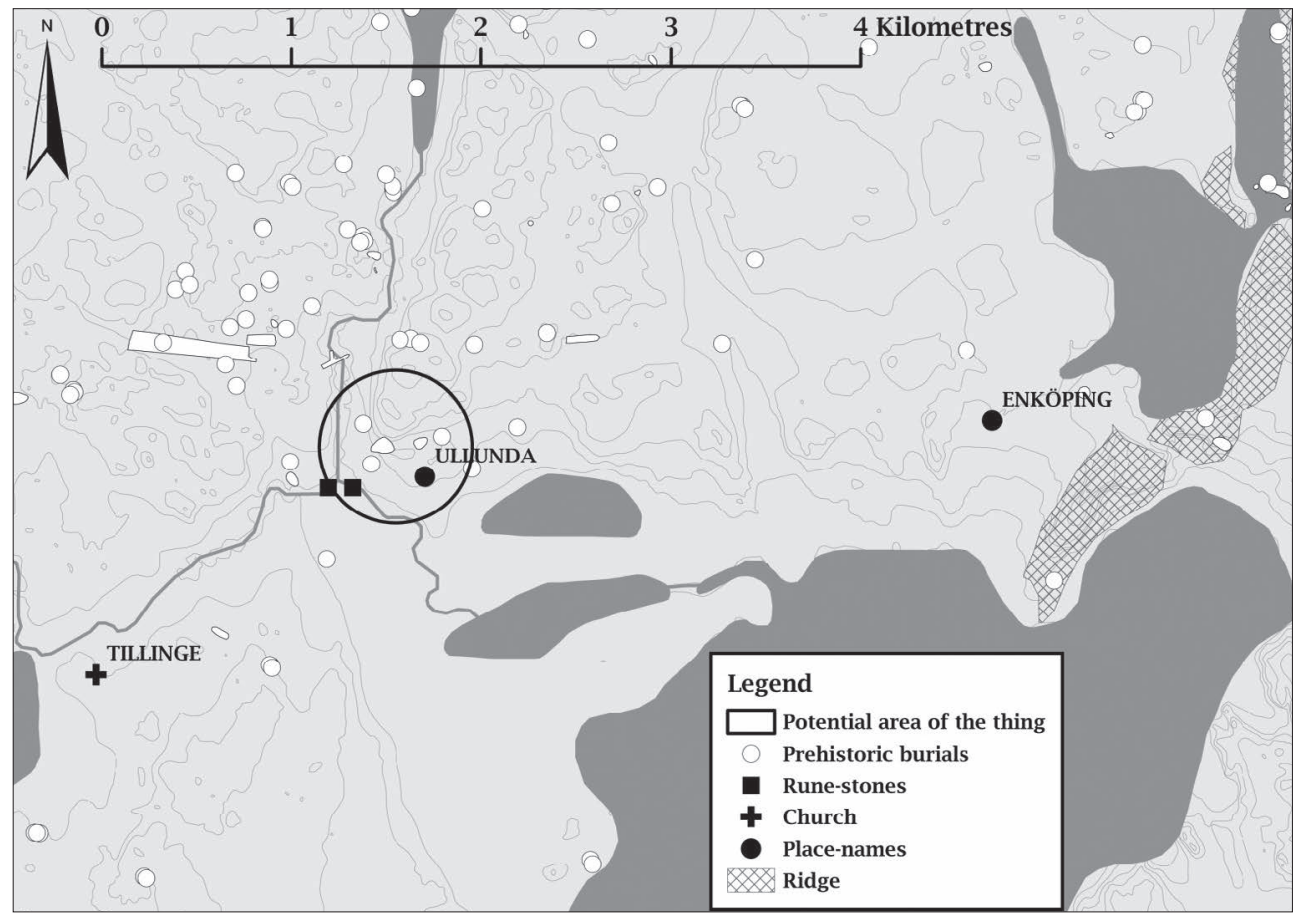

FIGURE 4.IO Ullunda ('The grove of the god Ull'), just west of modern Enköping, Sweden. Ullunda is proposed as the early top-level assembly site for the folkland and Enköping is documented as such from I300. A number of communication routes converge in this area. Enköping is situated at a ridge and an inlet in Lake Mälaren. At Ullunda, two rune-stones mark the fording place where the royal route of the Eriksgata crossed a watercourse. This area is also rich in Iron-Age burials. Reconstructed water levels reflect those around AD Iooo (C) Sveriges geologiska undersökning. Map by Alexandra Sanmark and Tudor Skinner.

9th-century ship-setting and burials dating from the 6 th $/ 7$ th century onwards. The Stångån forms the boundary between the two parts of the province, Östanstång ('East of Stång') and Västanstång ('West of Stång'), and the location of the site suggests the assembly site was used for people from the province's two parts. The name Stång (wooden post) may refer to a boundary marker, which would fit in well with an assembly site that brought people together from the provinces' two parts (Kaliff I995, I36; Wessén I92 I, 36). This site may therefore be linked to royal power and perhaps the unification of the province/small kingdom (Sanmark 2017a, 69-70).

A similar situation can be seen on the island of Gotland. The top-level assembly was held at Roma, centrally located in the middle of the island (Myrberg 2008; Styffe I9II, 428) (Figures 4.I Ia-c). This site was active far back in time, with finds of Roman denarii, Vendel-period metal-working and Viking-Age silver; a Cistercian monastery was established here in the I2th century (Nilsson I998, I26; Myrberg 2008). 


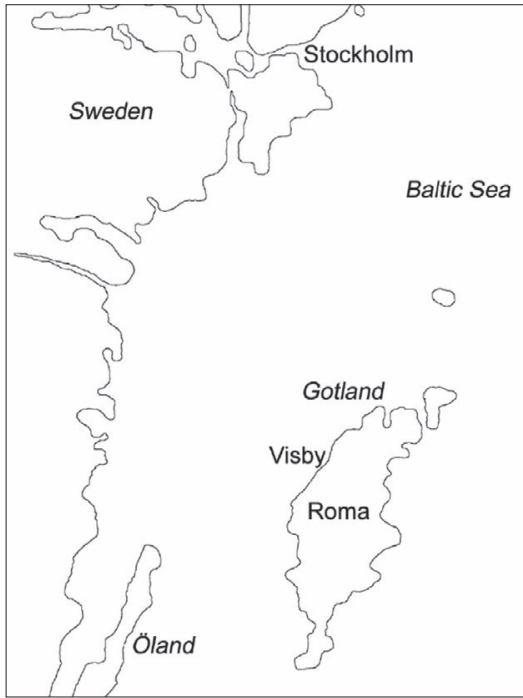

a
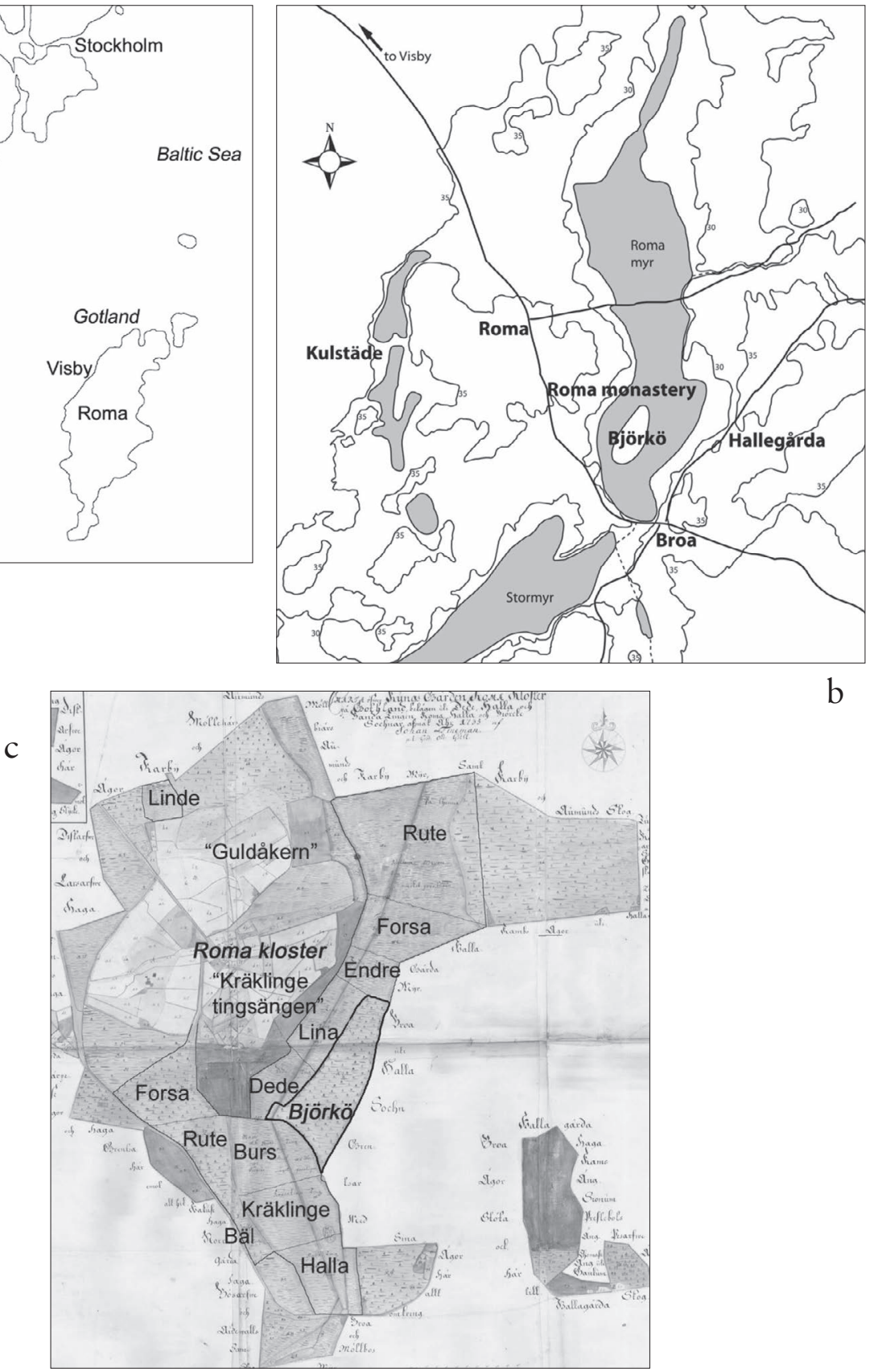

b

FIGURE 4.I I The location of the top-level assembly at Roma, Gotland:

a) the location of Gotland; b) the location of Roma with the medieval wetlands reconstructed in grey; c) the area around Roma Monastery on the I 699 taxation map-plots carrying thing place-names are marked. Reproduced with permission from Myrberg 2009. 
This site may well have been used for assemblies from the Early Iron Age and was the Gotland assembly until at least the early I7th century (AD I6I8; Styffe I9II, 428). A taxation map from I 699 shows I 3 thing names such as (Mod Sw) Linde ting and (Mod Sw) Kräklinge ting on different plots around Roma Monastery. Although caution is needed, on the basis that naming patterns like these can arise in a variety of ways, the place-names could indicate where the representatives from certain thing areas such as Linde and Kräklinge had their camps (Myrberg 2009, I04; Östergren 2004). Some thing 'units' appear twice, which might indicate extended areas or a regular system of plots for camps and grazing at this important assembly (Östergren 2004).

There are also a few areas where the top-level thing sites are late in origin, and predecessor sites are unknown. Södermanland is one such case; Strängnäs does not seem to have been a prehistoric central place and the meetings probably stem from around the time when Strängnäs became an episcopal see in the I 2 th century (Bäck 20I4, 6; Hjärne I952, I74; Jansson I970; Nilsson I998, 84). Similar situations can be envisaged for Tiohärad (Småland) and Dalarna. As mentioned above, the name Tiohärad shows that it was an amalgamation of ten separate bundreds. Värend, which comprised five of the ten hundreds, was the area which carried the most weight. The Tiohärad law province was often referred to as the (OSw) Wärinsko Laghsaghu, and the lawman as legifer Værendiæ (Lat.) (Holmbäck and Wessén I946, SmL lxxix). The I 3 th-century references to the 'provincial thing of Värend' (commune placitum Værendiæ Lat.) in Växjö should therefore most likely be interpreted as the top-level thing of Tiohärad (Holmbäck and Wessén I946, SmL lxxix). In Dalarna, on the other hand, there was an assembly for each third. A lawman's thing for the whole province is not mentioned until I493 and in the same year the first landsthing is recorded at Tuna (Holmbäck and Wesisén I936, xxvii, DD I, I 50; Styffe I9I I, 324).

For the remaining three provinces, very little is known, although Värmland is a rather interesting case. The predecessor of Karlstad, the main town of the province founded in the I6th century, was Tingvalla 'Thing field' located on an island in the River Klarälven (Wildte I926, 2I3, 226) (Figure 4.I2). At Tingvalla there was a trading site and a church was erected in the I4th century, and Tingvalla was chosen

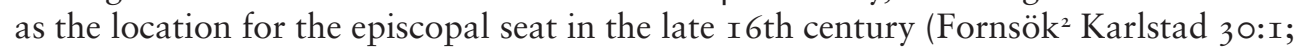
Lindström I974, 3; Nygren I934, appendix I). In I4th-century Närke, top-level assemblies (landsthings) were recorded in Mosås and Kumla and from the beginning

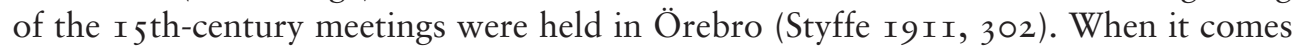
to Öland, evidence is almost completely lacking, although the place-name Fyrting ('Four things'), has been suggested as a potential assembly site for southern Öland (Jan-Henrik Fallgren pers. comm.).

One of the most striking aspects of this study is the existence of a number of examples where an older assembly place was connected with a highly monumentalised, outdoor location. These sites are notable for their access to land and water communications. Mounds were important at these sites, along with cemeteries and standing stones and ship-settings and other monumental attributes. Sometimes

2 Fornsök: The Swedish National Heritage Board's search service. This contains information on all known registered ancient remains and other cultural-historical remains in Sweden, both on land and in water. Searchable at https://app.raa.se/open/fornsok/. 


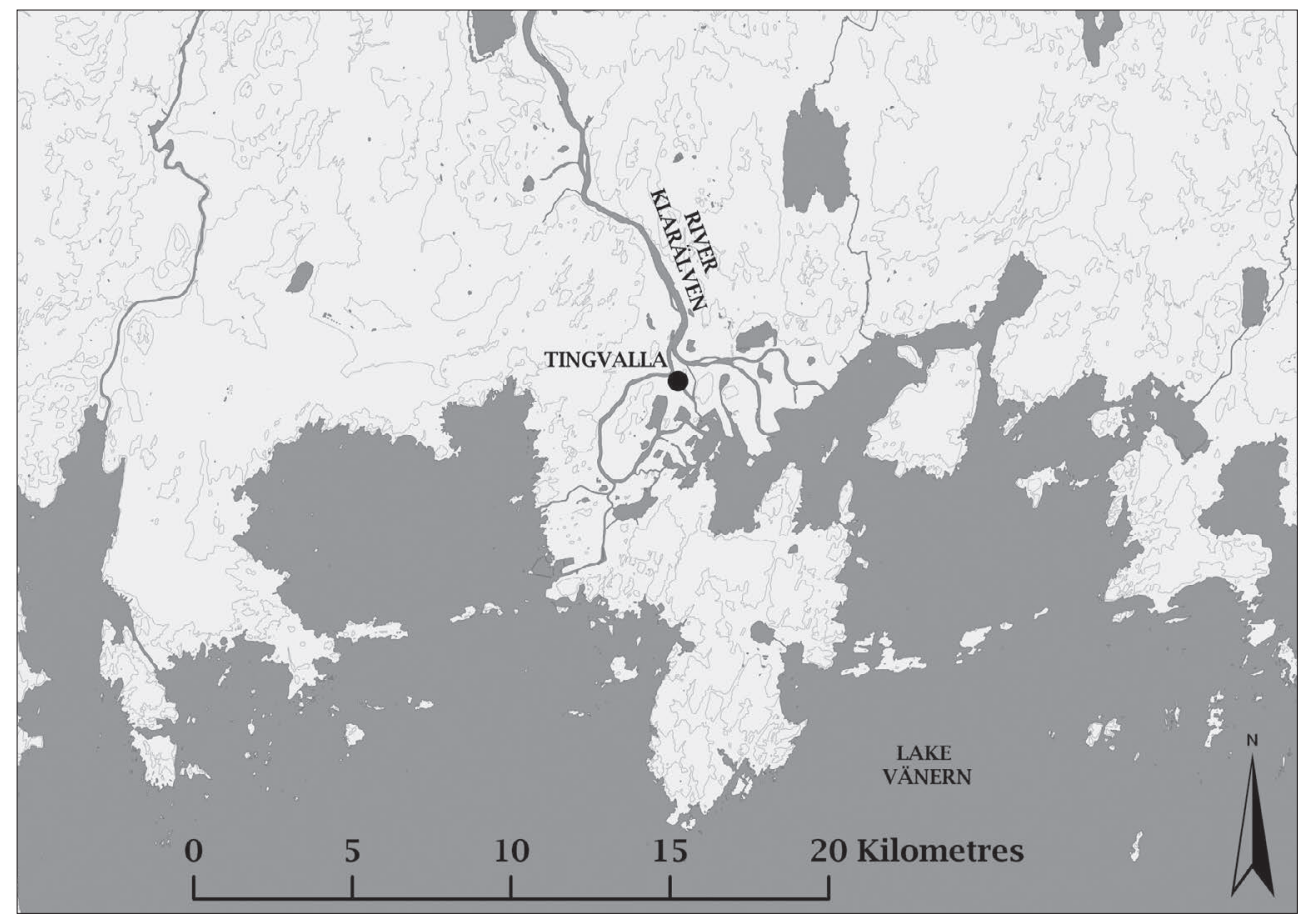

FiguRE 4.I2 Tingvalla, the top-level assembly in Värmland, Sweden, in relation to the River Klarälven, which with its many tributaries was the key communication route through the province of Värmland. Tingvalla was located at the northern end of Lake Vänern, which also connected it with the provinces

of Dalsland, Västergötland and in extension Närke. Map by Alexandra Sanmark and Tudor Skinner.

evidence for hearths and cooking pits suggests these locations were places of gathering in an earlier period. Sometimes these sites survived as meeting-places in the medieval era, but others were relocated, especially to towns. Another coincidence between ecclesiastical organisation and provincial assemblies: 6 of the I I provincial assembly sites were also medieval episcopal seats (Uppsala, Västerås, Linköping, Växjö, Strängnäs and Skara). The connection is also seen in the overlap between law provinces and bishoprics spelled out in the first chapter of the Law of Magnus Eriksson. These six towns were clearly seen as significant from the earliest Christian times, as allwith the exception of Växjö-were mentioned in the Florence document as existing (or, perhaps, planned) episcopal seats (Nilsson I998, 79). The episcopal seat of Växjö was probably established in the II60s (Nilsson I998, 82). Royal involvement seems likely, although the nature of this is rarely examined (Nilsson I998, 70-97). It is therefore interesting that top-level assembly sites and royal manors were in several cases located in close vicinity. Far from all are known, but at present royal manors have been identified in Gamla Uppsala, Linköping (Stånga), Söderala, Hög, Husby- 
Näs and Kuta (Grundberg 2006, I97-I98; Nilsson I998, 93). Another feature shared by most of the provincial assemblies is a market. The clearest examples are the (OSw) samping in Strängnäs, the folklandsthing in Attundaland, the (ON) disping in Gamla Uppsala, and in medieval Norway, the island of Frösön (Jämtland). In all of these cases, the market had the name of the old assembly meetings, even after the assemblies had ceased to exist. This may indicate that these markets were opened and closed by thing meetings at which the 'trade peace' was declared (Holm 2000). Although the evidence is somewhat circumstantial, the pattern is striking and it is possible that the annual markets with longstanding traditions in towns such as Enköping, Västerås, Uppsala, Linköping and Skara have their beginnings in earlier assembly meetings (Staf I93I, 24, 30, 72, 78, 350, 36I). This rather obvious concentration of functions over time is surprising, although it is not always possible to establish which of these came first and the pattern most likely varied between places.

\section{Denmark}

The work of T J Chevral (T L Thurston) (200I) has concentrated on evidence for state formation processes in Denmark. Thurston has reviewed and examined the broad evidence chieftains into kings and smaller polities into larger ones during the Roman to the Germanic Iron Ages (AD I-700). While the work of Thurston does not involve close inspection of the evidence for administrative arrangements and assemblies on the ground, it does draw heavily on Tacitus as an ethnographic source (Thurston 200I, 44-48). Arguments are made for a form of heterarchical organisation and re-distributive economy in the Migration period that relied on voluntary tribute with the assembly as a levelling mechanism (Thurston 200I, 47-48). By the Viking Age the assembly still acted as a regulating force on elite power, but over time Chevral argues for greater royal control (Thurston 200I, 88-90). As discussed in Chapter I, although Tacitus is an important ethnographic account, it remains challenging to connect the kinds of concilia (Lat.) described for the Ist century AD with the actual evidence for the thing which, as we will see here, is largely medieval in date.

We know from written accounts that until 1683 Denmark was divided into three law provinces: Jutland, Zealand and Skåne. In the I 3 th century the top-level landsthings of Viborg, Ringsted and Lund were the principal authorities regarding judicial matters and royal elections in their respective law provinces. Each of the areas shared law, but was subdivided into several (ON) lögsókn (Mod Dan lagsogn) 'law districts' (a subdivision of a law province), each with their own landsthing. Originally it seems that these law districts were independent law provinces, and in total I 3 landsthings and lögsókn units are known from medieval Denmark (Jørgensen I974, 238; Lerdam 200I, 203). According to Wulfstan's description in the mid-9th century, the province of Blekinge east of Skåne was subordinated to the Svear together with Möre, Öland and Gotland: (OE) pas land hyrað to Sweon or 'the land belonged to Svear' (Bately 2009; Sundqvist 2016, 4I), and was part of the Danish realm at least from I23 I, when mentioned in the cadastre of King Valdemar II [r. AD I 202-I 24I], to 1658 when lost to Sweden in conjunction with the Roskilde peace agreement.

The primary function of the Danish landsthing as described in the laws was legal. They proclaimed new laws, and were the highest authorities in their law districts. 
We cannot be sure of when the I 3 law provinces of Denmark emerged, but in I 284 the laws of Zealand were introduced in the islands of Møen, Falster and Lolland (Nielsen 1867,85 ). The Law of Skåne applied to the provinces of Skåne, Halland, Blekinge and Bornholm in the $\mathrm{I} 3$ th century, but uncertainty remains on whether it applied to the areas other than Skåne when it was first written down around I 200. The Law of Jutland was set in writing in I24I, and was introduced to the islands of Fyn and Langeland. Fyn was part of the Jutland law province at least by 1234 and was represented at the landsthing of Jutland from I 284 at the latest (Jørgensen I974, I $7-18,38-39)$. It is the documents of the I 5 th and I6th centuries that provide the richest detail on how the landsthing functioned. Before I 500 there are few written accounts. A number of letters (testimonium placiti Lat.) survive from the meetings at the landsthing of Viborg during the period I340-I4I 2 (Lerdam 200I, 95), while court records (Mod Dan dombøger) from the I 5 th century reveal that the landsthing met every two weeks, far more frequently than in Norway and most likely Sweden.

From the second half of the I 3 th century the royal (MDan) réttarthing (placitum regis justitiarium Lat.) were established (see above). After the Reformation in I 536, this became a single 'Supreme Court' that remained in place until I66I (Andersen 20IO; Lerdam 200I; Tamm 2003). The term réttarthing first appeared in the royal 'peace legislation' of $\mathrm{I} 284$, which distinguished between the king's own thing, with the king as judge, and the royal réttarthing where the (MDan) rettere (Justitarii Lat. 'judges') had legal authority on behalf of the king (Jørgensen I923). It is argued on the basis of written sources dating from after the Reformation that the king may have personally taken part in a large proportion of the decisions at the réttarthing, and that this could mirror older practices (Andersen 20I0, 305). The réttarthing seems to have evolved out of the (MDan) danehoff 'the royal court'. In an early phase the réttarthing was assembled when needed, where the king happened to be, but it eventually evolved into a regular event more often held in Copenhagen (Tamm 2003). In the Late Middle Ages and after the Reformation, matters regarding the king and nobility and regarding property were addressed at this 'Supreme Court' (Andersen 2010, 299-300). Until I66I, the king's court was the Supreme Court in the realm and also operated for the nobility in regards to cases involving life and honour (Andersen 20I0, 305 ).

In Jutland, in contrast to other areas of Denmark, an additional level of authority existed between the local assembly (ODan herritzting, 'local thing') and the landsthing (ODan lantzting): this was termed the sysselthing (ODan syzellting) (Lerdam 200I, 203). The sysselthing did not make laws or have judicial powers, but played a part in property transactions, witness statements and public announcements. It was associated with the public approval of specific matters and probate declarations. Sysselthings are well known in Norway and mentioned in Magnus the Law-Mender's law of 1274 where, in a similar fashion to their Danish equivalents, they were associated with probate announcements (L I, 7; Taranger I935). In addition, in Norway, it was the role of the sysselman (ON sýslumaðr, 'royal official on a high level') to summon people to the sysselthing and announce the result of verdicts in his sýsla within three weeks of returning from the lawthing (Taranger I935). 
Locations, archaeology and topography

As with other regions, locating the meeting-places of the landsthing is a difficult task. Some medieval documents do, however, offer insight into the thing locations, for example the location of five landsthings in the whole law province of Skåne can be suggested on the basis of written accounts (Figures 4.I3 and 4.I5). According to Saxo Grammaticus the landsthing of Skane was held at Arna vallis in the I 2 th century (Saxo XIV, II, 6), which has been identified as Linero/Arendala, $5 \mathrm{~km}$ east of Lund (Strauch 2004, 259; Svensson 20I 5, 85) (Figure 4.I4). It has been argued that 'The Market of the Three Mounds' was located east of present-day Linero on a site where remains of mounds still could be seen in the I8th and I9th centuries. According to Saxo Grammaticus the assembly was held in close vicinity of the market (Blomqvist I95 I, 90-9I; Pamp I 998, I 5). The assembly site was most likely located some I.5 km east of this market, along a pathway on a slope between the Arendala farm and the medieval Hardeberga church (Svensson 201 5, 85-86, fig. 2). Overall, this site was central to Skåne, and the Royal Road, Kungavägen between Lund and Dalby passed south of the site. The heights around Linero, Arendala and Hardeberga give a unique view of the whole plain of Lund and a runic inscription c. I348-50 placed on the northern wall in Hardeberga church reinforces this: I, Niklis Tues of Hardeberga and Knut Has. I see it all + , most likely referring to the view that the lord, Niklis Tuesson of Hardeberga (d. I350), had over his estate (Loive 20I7).

According to Saxo, in II8I the landsthing of Skåne was held in Lund itself (Saxo XV, IV, 2, 3). Lund was the seat of the archbishop and it is generally assumed

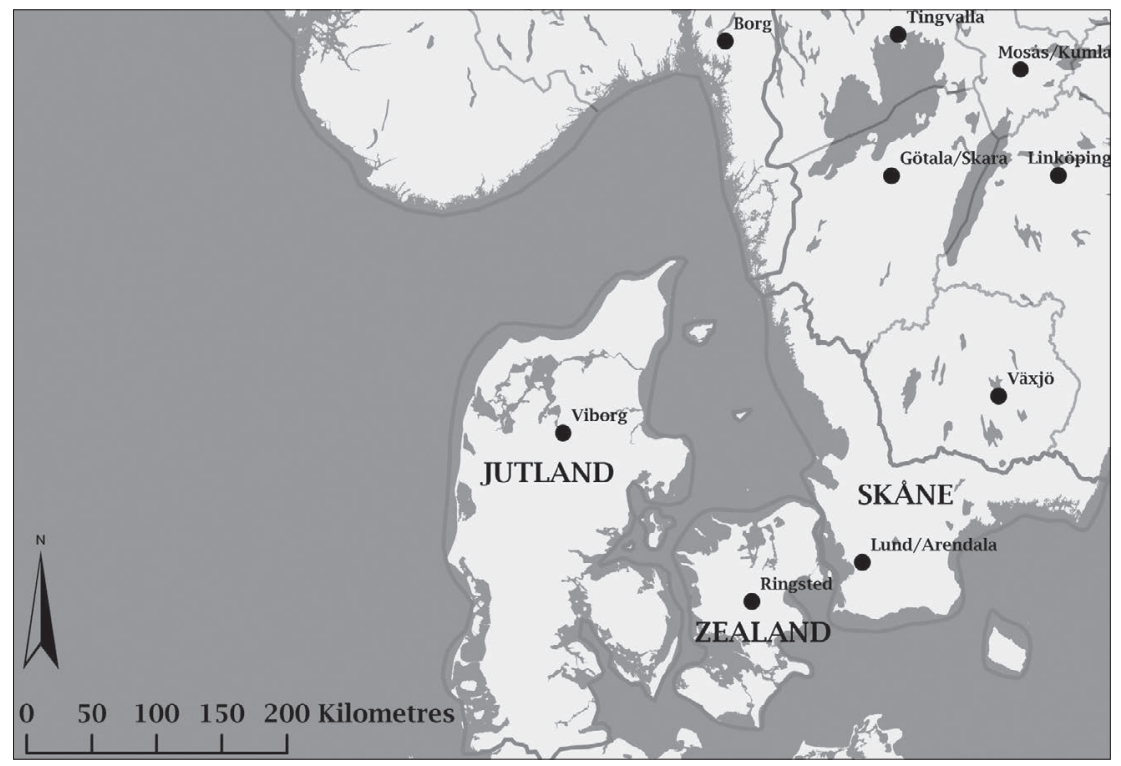

FigurE 4.I3 Law provinces of Denmark with the top-level assemblies. Drawn by Frode Iversen, Alexandra Sanmark and Tudor Skinner. 


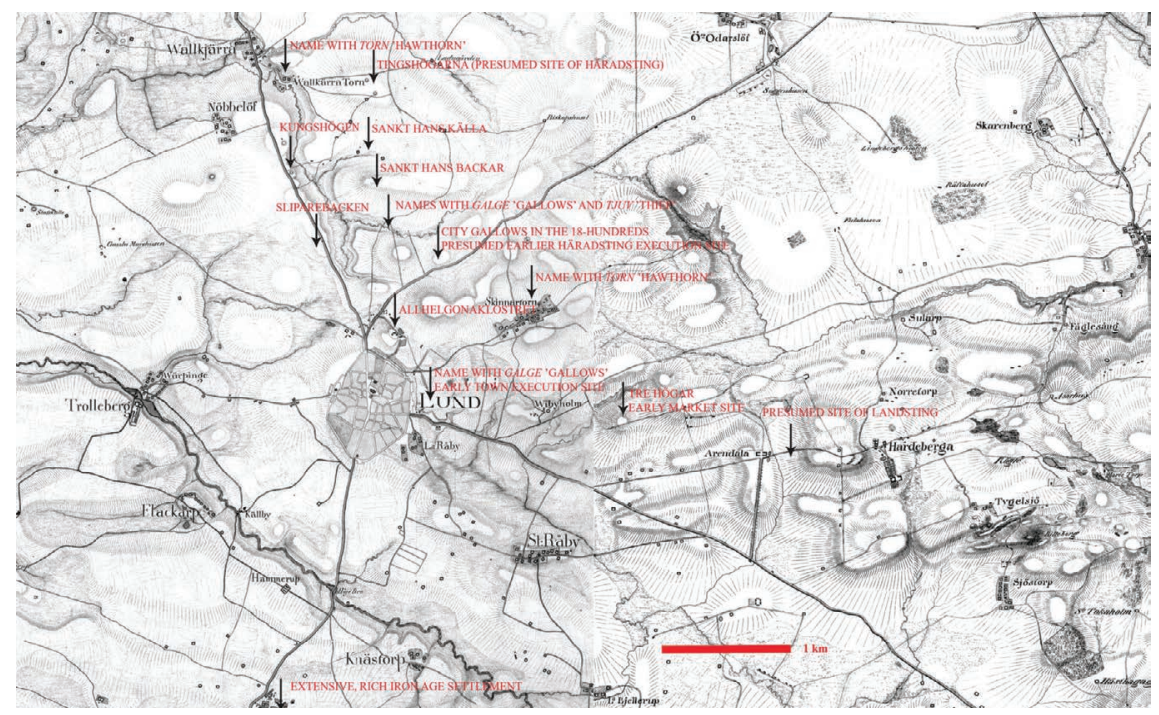

Figure 4.I4 Lund, Sweden, and its surroundings. On the plateau on the slope of which the city was located at the end of the Viking Age there are several assembly sites used for the administration of justice. The map is based on Skånska rekognoceringskartan from I 8 I 2-20. Map reproduced with permission from Svensson 201 5, 85, fig. 2.

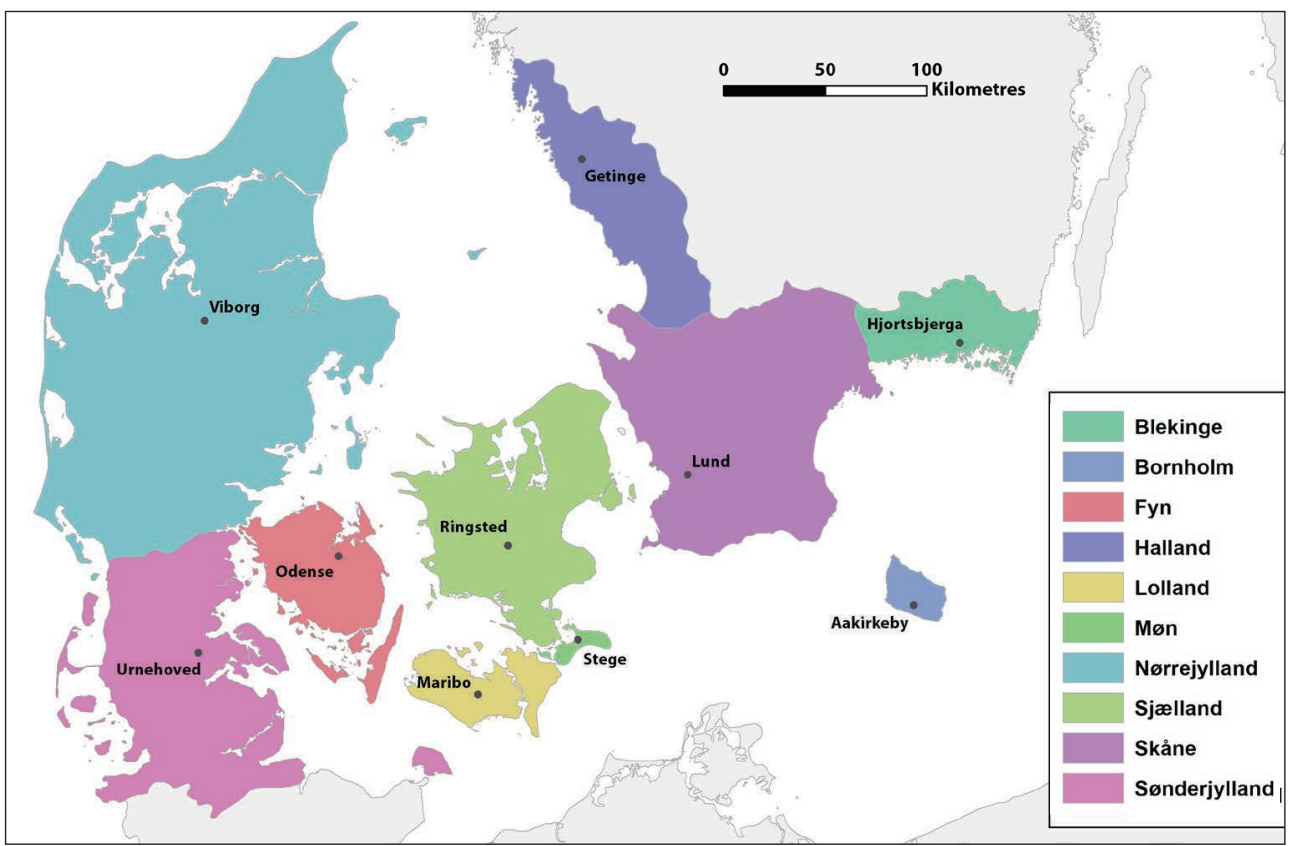

FIGURE 4.I 5 Law provinces of Denmark with the top-level assemblies identified and labelled. Map by Tudor Skinner. 
that the assembly was moved from Arendala to Lerbäckshög ('Mud brook's mound') (Blomqvist I95 I, 267). It has also been suggested that the royal inauguration of Skåne was held at Lerbäckshög as well (Svensson 2015) but evidence for this is absent. The thing sites around Lund have been discussed more thoroughly by Ola Svensson, who argues that the rural landsthing of Skåne was moved to Lund during the Early Middle Ages and was thus 'urbanised'. This follows the pattern suggested for Swedish toplevel things above (Sanmark 20I7a, I56, Ch. 6) and similar processes of relocation of the Norwegian lawthings (see Chapter 5; Iversen 20I7a; Ødegaard 2015, III). Uppåkra, a central place associated with gathering, cultic activity and production, has been discussed as a possible forerunner to Lund, which was established as a town in the roth century (Andrén I998, I37; Svensson 2015, 85), but it is uncertain what legal functions Uppåkra may have had.

Sometime after I 298 and before I589, the Halland landsthings were held at Varberg (northern Halland) and Halmstad (southern Halland) (see Jørgensen I974, 238, 505 for this and all below) (Figure 4.I5). This partition of Halland is a late occurrence, and joint landsthings for Halland (commune placitum Lat.) are known from Getinge in I 298 (SDHK I804, I805). In addition, the Knýtlingasaga (Ch. 28) from the $\mathrm{I} 3_{\text {th }}$ century mentions an important thing held in Halland at the end of the I I th century. The king came to Halland by sea and asked for horses for the further journey. The farmers of Halland would not accede to this request, and neither would they take on burdens other than those stated in the law. As the large forests of Halland were legally royal commons, the king pressed his will by threatening the farmers to take away their grazing rights for pigs in these forests. According to the saga, the most disobedient farmer who had talked against the king was killed. Getinge is situated central to Halland, some $8 \mathrm{~km}$ east of the sea, close to the main north-south road through Halland and by the navigable River Suseåen which empties into the ocean by Veka. There is a medieval church at Getinge. There were eight hundreds in Halland in the Middle Ages, and Getinge is situated close to the border of Årstad and Halmstad bundred, with five hundreds to the north and three to the south. The landsthing of Halland was joined again in 1589 , and located in Falkenberg farther north (Jørgensen 1974, 238, 505; Andersen 2010, 206).

Hjortsberga, the landsthing in Blekinge, is mentioned in I 500 (SDHK 33974) and I 505 (SD 35 I77). Here evidence is more forthcoming on the archaeological signature of the possible assembly location. We know a peace agreement was made here at the landsthing in $\mathrm{I} 505$ to protect the important trade between the provinces of Småland and Blekinge. Styffe has suggested that this meeting took place at 'Tingsslätten' ('The thing plain') near Hjortsberga (Styffe I 867, 74). Hjortsberga lies in the heart of Blekinge along major roads crossing through the landscape north-south and east-west (Figure 4.I 5). There were four local hundreds in Blekinge in the Middle Ages-Lister, Bräkne, Medelstad and Östra hundred-and Hjortsberga is located in the middle of Medelstad hundred. Hjortsberga church, according to archival evidence dating from I665, was the first church in Blekinge (Andersson I932, 245). There is archaeological evidence for a wooden church pre-dating the present stone church which was built between I 200 and I250. A large prehistoric cemetery spanning the Bronze and Iron Ages is also located by the church, with an old pathway next to it running from the coast to Småland (Anglert and Thomasson 2003, 240). The close spatial connection 
between the large burial site and the assembly site is a relationship exemplified in several regions and seems to attest to similar early processes of locating meetings in relation to prehistoric monumental and burial complexes. The establishment of a church demonstrates the centrality of the site over a long period of time and the appropriation of the place and the assembly within a new Christian framework.

Landsthings on Bornholm are mentioned in I3I9 (SD 2926) and in court records regarding land (Mod Dan landsdommer) in I448 (SD 25366). The first confirmed landsthing was held at Aa church at Aakirkeby (Hansen I969, I3, I4; Zahrtmann I934) and meetings continued to be held here until I776 when a decision was made to move the landsthing to Rønne (Zahrtmann I925, I60-I68). In addition to the landsthing, documents in the I 7 th century mention four hundred assemblies, five 'town things' and one birkething held on Bornholm. The four bundreds were named after their orientation in relation to the island: north (Nørre herred), east (Øster herred), west (Vester herred) and south (Sønder herred). It has been suggested that Tingstad in Vestermarie parish may have been an older pre-Christian landsthing (Zahrtmann 1934), but this remains uncertain. ${ }^{3}$ Aakirkeby is located central to Bornholm, and received municipal privileges in I346. A church was, however, built as a rural church c. II50. It is the largest church in Bornholm perhaps and has a large porch which some have argued was used for landsthing meetings: a meeting is documented here in I700 (Hansen I969, I; Wienberg 1993, 97). Apart from the late arrangement in Ringsted church (see below), no other evidence exists for the holding of landsthings or lawthings in churches. Instead, it can be proposed that the original location of the Bornholm landsthing was the site of Hellige Lucie kilde ('the spring of St Lucia'). This water source was named Stokkekilde ('Log spring') and according to oral tradition this name referred to the beams (Mod Dan stokkene) used during the landsthings (Kofoed I928, 4I). This site is recorded on a map from I763 as Stokke kilde/Stokke dam ('Log pond'), situated on the outskirts of the town, some $400 \mathrm{~m}$ north of the church. The area of Aakirkeby can also be argued to have a long tradition as a central place: at Bornholm a 'Sarup enclosure' (a kind of ritual meeting-site in the Neolithic) lies $2 \mathrm{~km}$ east of Aakirkeby (Nielsen et al. 20I4).

In Zealand, the later records offer a little more insight into the topographic locations of the landsthing meetings. The landsthing of Ringsted was the highest ranked in the Zealand law province. Ringsted lies in the middle of Zealand where major roads running east-west and north-south cross, and by the navigable River Suså. Ringsted had a royal mint in 1020 and a Benedictine monastery was established by Sven Estridsen before his death in 1076 (Hybel and Paulsen 2007). From I 584 to I 805 , the Zealandsfar landsthing was held in the northern Cross-arm in St Benedict's Church (Hermansen and Nørlund I936, IIO) (Figure 4.I6). A map of Ringsted from 1670 shows the location of the landsthing in the church. According to Saxo, an assembly was held outside Ringsted in the reign of King Niels [r. AD I IO4-I I 34] (Zeeberg 2005, 5, 7, I3, II8-II9). A possible location for this site and the local assembly place is south-west of the town, where traditions of a thing site were recorded in the late I9th century. There are also reports of 'large, red stones' said to

3 For further discussion of Tingstad as the site for the landsthing at Bornholm, see http://367ture.dk/site/ Tingsted/. 
be the remains of a thing cottage. A Gallow Hill (Galgebakke) was recorded in the I 7 th century (Petersen I 883; Sanmark 20I7a, 70). Landsthings are also recorded on the smaller islands south of Zealand in the High and Late Middle Ages: in Stege on Møn, in Nykøping on Falster and in Maribo on Lolland. The landsthing of Møn was mentioned in I 290 as generali placito Meonix (Lat.) where a board of I 2 nominated men (MDan nævninger) constituted a court led by a royal official (capitaneus Lat.) at Stege Castle (castri Stege Lat.) (Nielsen I 867, 85). Stege lies in the middle of the Møn island on the north side by a small channel leading to the inlocked bay of Stege Nor (Figure 4.I 5). The Stege church was built in I 200-50, and a 'church-hall' was added in the early I 5 th century making the room spacious and wide (Lorenzen I934, I 58 ). The location for any preceeding outdoor assembly, however, remains unknown. The landsthings for Falster and Lolland were joined in I650. Lolland and Falster belonged to the bishopric of Fyn (Nielsen I867, 85), and thus had a double connection, in secular affairs to Zealand law and in ecclesiastical affairs to Fyn. Møn was joined to the landsthing of Zealand from I 584 to I 635 when it was reputedly difficult to recruit judges (Andersen 20I0, 206; Jørgensen I974, 505). In I64I the outdoor Maribo landsthing on Lolland was moved to the Maribo town hall (Andersen 20II, 3I6).

The law province of Jutland had three, possibly four, landsthings, in northern Jutland, southern Jutland, on the islands of Fyn and Langeland. Viborg was the

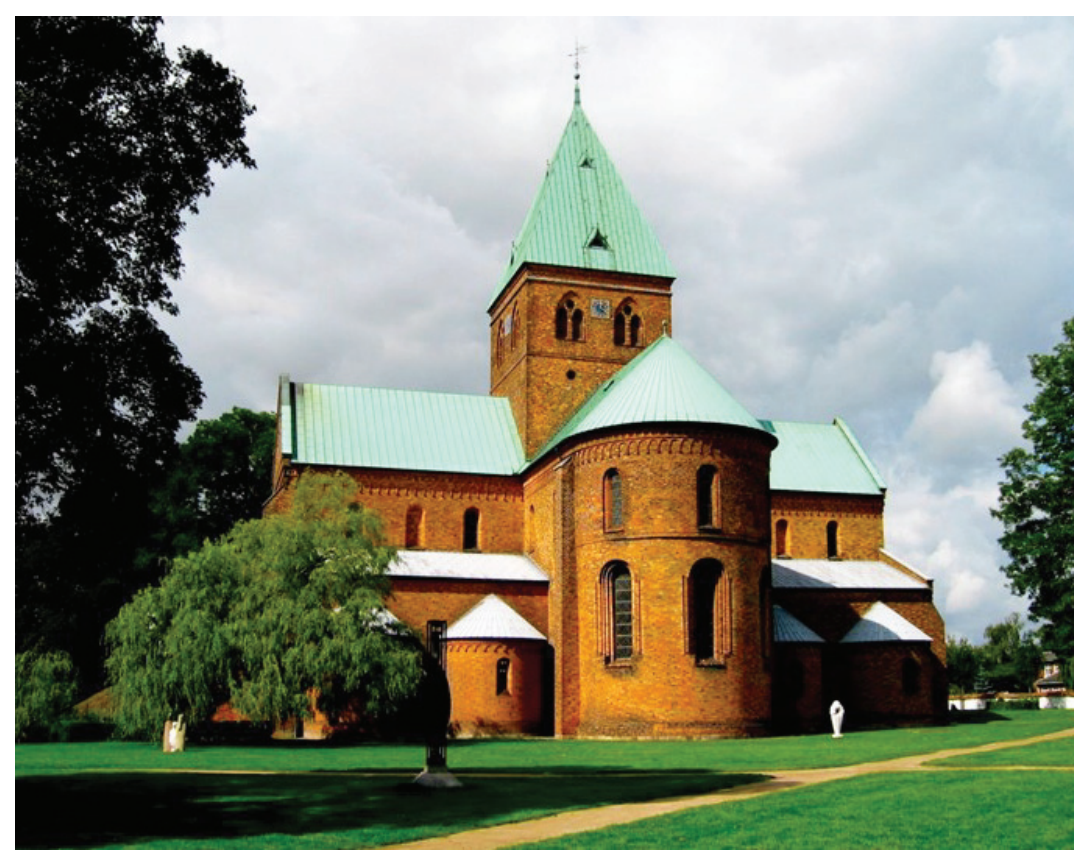

FIguRE 4.I6 St Benedict's Church, Ringsted, Denmark. Sjæellandsfar landsthing was held in the northern cross-arm congregated here in II 70 . Prior to I 584 , the exact location of the landsthing is unknown. Photograph by Mariusz Padziora. CC BY-SA 3.0. 
landsthing for northern Jutland and in c. I I 20 the English-born abbot Ælnoth of St Knuds Abbey in Odense wrote about Viborg providing an interesting account of the power of the landsthing assembly and its potential age and early functions:

\footnotetext{
People from all of Jutland gathered here often, part to negotiate common matters, part to discuss the fairness and validity of the laws, and to decide current law. What was decided among them cannot be set aside in any part of Jutland by anyone without punishment (Vitce sanctorum Danorum Ch. 23; Gertz I908-I2).
}

Ælnoth added that this place was called 'Viberg' ('sacred elevation'), 'partly on account of its high location, partly because sacrifices were held there in the old days' (Albrectsen 1984, Chs 23, 73, II9). The top-level thing for northern Jutland is recorded in Viborg at least from the time of Knut the Great [Denmark r. AD IOI 8-IO35]. Viborg seems to have held a central importance for the district of northern Jutland and was the location for medieval royal inaugurations (Hoffmann I976). Formally the top-level thing was discontinued in I806 and its exact original location is unknown, but in I 552 the king decided that the Viborg landsthing should be held in St John's Church, and later a courthouse was built (Andersen 20II, 3 I7). The earlier thing meetings could have been held in the vicinity of the purported medieval inauguration place at Viborg (Mod Dan Kongehyldingsmonumentet), located north of the cathedral. Urnehoved thing served southern Jutland and is mentioned by Saxo in conjunction with events in c. II34 (Larsen I840, 26I). The name Urnehoved may refer to a hill-slope with stony soils, but the assembly location is unknown. Southern Jutland consisted of three syssel units (Isted, Ellum and Barved) and it is generally assumed that the landsthing was located somewhere near the route through Jutland in the middle of Ellum syssel. In Langeland, the landsthing was Rudkøbing, but according to Ole Worm (I643), the landsthing had earlier been situated at Kirkeby (Nørgaard 2004). In the district of Fyn the landsthing was named Fynbo and was located at Odense at least from I363 (Lerdam 200I, 206) and may have been established in the 13 th century (Nielsen I 867,76 ). The Fynbo assembly is first mentioned in documents in I 272, and in I 279 King Erik Klipping [r. AD I 259-I 286] chose the Grey Friars church in Odense as his place of burial and this was announced at placito Fyonie (Lat.) referring to the Fyn top-level assembly (Nielsen I 867, 76). The top-level assembly for Fyn was documented in two different outdoor locations in Odense in I3 I7 and I438 (Christensen I988, I26, 57, fig. 34; Sanmark 20I7a, 247). A move inside seems to have taken place shortly after this time. According to I 5 thcentury legal documents (I443, I458, I475, and I 52I), the Fynbo assembly met at the Swortebrødhre stue ('The Hall of the Black Friars') which most likely was located on the first floor in the eastern wing of the Black Friars Monastery (Jakobsen 2008, 204, 2II). This monastery was established c. I239, and while it is not known were the Fynbo landsthing met prior to this, in 1569 the king granted a specific house for the holding of the Fynbo landsthing (Andersen 20I I, 3 I6).

The early medieval and late-medieval evidence for assembly locations is more limited than that surviving for Sweden. There are, however, synergies in the evidence. Open-air meetings were the norm initially and there are some early connections with markets. Land and water communications were important to locating an assembly, 
and elevated sites are referred to several times. A few examples suggest that mounds and prehistoric monuments and cemeteries were of relevance too in situating things. There are some examples as well where churches seem to have been established close by. Finally the same process of relocation is apparent in the late-medieval period, with some assemblies moved to urban sites and ultimately held indoors, and in a few instances meetings seem to have been resituated at churches or ecclesiastical sites. The medieval accounts do vindicate Chevral's assertion of greater elite and royal control over law and assembly in the late early medieval to medieval eras, but the archaeological and topographic detail on the ground is hard to elicit.

\section{Norway}

A more detailed exploration of the evidence for the thing in Norway is provided in Chapter 5, where the case studies of the Borgarthing, Hålogaland and Gulathing Law provinces are interrogated in terms of their locational and archaeological attributes. A summary, however, is useful here in establishing similarities and distinctions with Denmark and Sweden. As set out in Chapter I, four law provinces are thought to have existed in Norway. The law district in Norway is accepted as a subdivision of the law province and was served by its own lawthing; each of the Norwegian law provinces is thought to have been subdivided into two or three law districts. Gustav Indrebø (I935) suggested law districts were established when lawmen became royal officials in the I2th century. On the other hand, Seip was not convinced that all the lawmen from the eastern provinces participated at the (ON) höfðingifundr, 'meeting of chieftains', in Bjørgvin in I223. He believed there were even more lawmen in earlier periods, as indicated by the administrative geography stated in the $\mathrm{I} 3$ th century Historia Norwegiae, an early history of Norway (Seip I934, I2). The (ON) lögsókn 'law district' system may, however, have earlier origins and this is discussed further in Chapter 5 .

The coastal landscape of Norway in the I 2 th century was organised into four patriae or law provinces (patria Lat. sing; patriae Lat. plural). Altogether, seven or eight coastal towns in Norway partly or wholly attracted the functions of the rural lawthing. This applies to Borg, Oslo, Tønsberg, Skien, Stavanger, Bergen, Trondheim and in addition Hamar in the Eidsivathing law province and partly to Konghelle (Figure 4.I7). As described in Chapter 5, the thing at Tjølling was most likely moved to the town of Tønsberg (Ødegaard 20I9a), or split between the lawthing in this town and a lawthing in the Skien law district, established in the 13 th century and located in the town of Skien (Iversen 20I6). The changes on the western side of the Oslo fjord and the southern mountain land were the most extensive (Iversen 20I7a).

The Middle Danish term réttarthing appeared during the $15^{\text {th }}$ century and in I480 a specific Norwegian national court named the réttarthing was established which was divided into two regular commissions. This was the first step towards a High Court, a judicial level superior to the lawthing. One of the commissions was placed in Bergen and was responsible for the 'nordafjelske' (Trøndelag/western Norway); the other was situated in Oslo and responsible for the 'sønnafjelske' (the eastern and parts of southern Norway). According to two royal decrees from I 54 I and I 547 a réttarthing was held in Oslo twice a year (Paus I745, 305f; NRR I, I I 5). 
During the I6th century the court consisted of a body of lawmen, chosen members of the Norwegian Royal council (Mod Norw Det norske riksrådet), and the town councillors from Oslo or Bergen respectively, as public representatives. According to Steinar Imsen (I974b), the (Mod Norw) herredag or 'the lord's day' (a supreme court), represented a time established in I 539 for the official meeting between the king and the Council of the Realm and can be seen as a local session of the royal

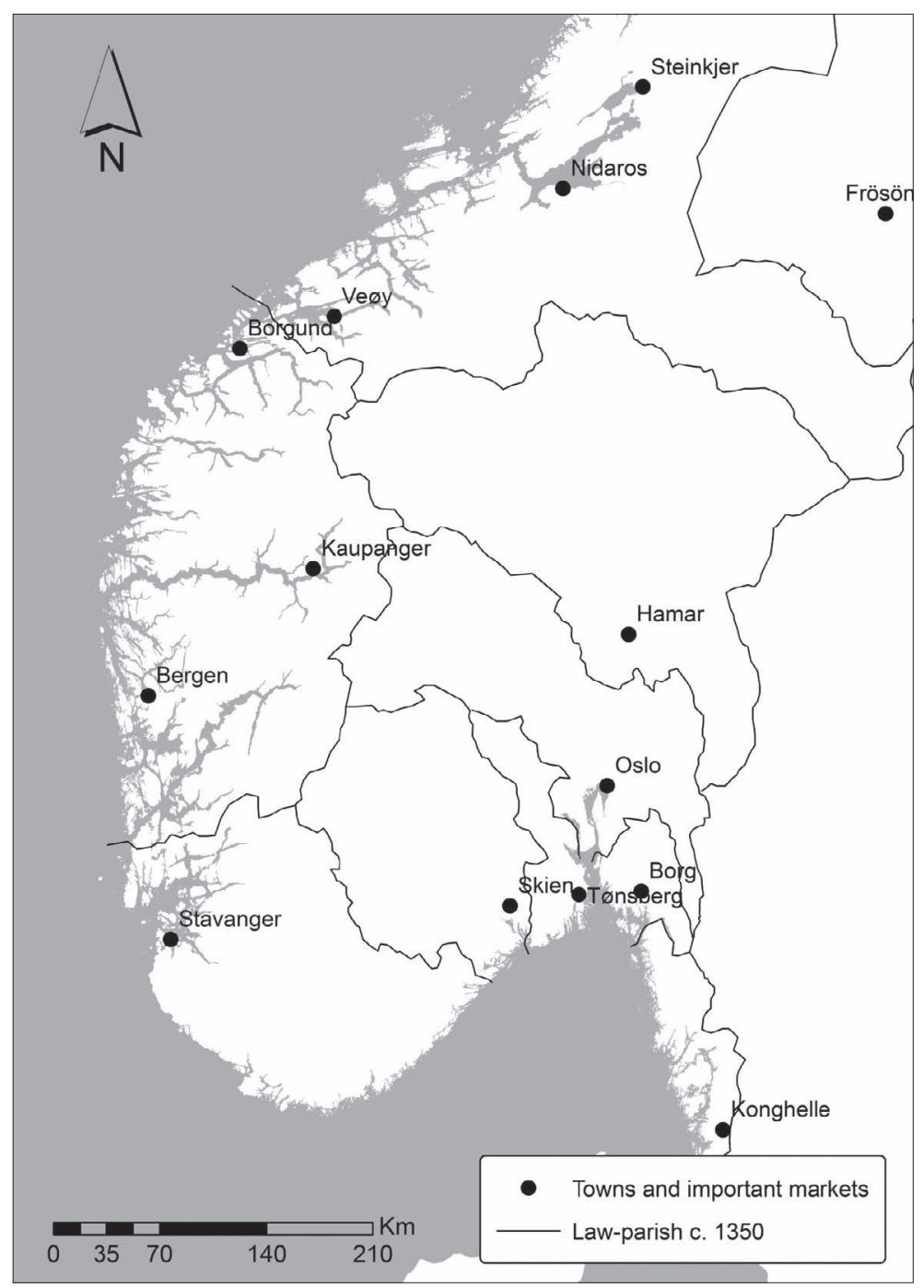

FIGURE 4.I7 Seven or eight coastal towns in Norway partly or wholly attracted the functions of the rural lawthing: Konghelle (Bohuslän, modern Sweden) but also Borg, Oslo, Tønsberg, Skien, Stavanger, Bergen, Trondheim and in addition Hamar in the Eidsivathing law area. Map by Frode Iversen. 
réttarthing, although the (Mod Norw) herredagen had several other functions apart from legislation.

Prior to these changes in the I $5^{\text {th }}$ century, royal legislative authority was implemented at the royal thing (kongething). As a court, this was associated with the Royal council (Riksrådet) and was formed during the reign of Haakon V Magnusson in the early I4th century. Here the king performed duties as the principal judge of the realm. The réttarthing predated the so-called overlagting which was introduced in the I6th century (Imsen I974C). From the overlagting appeals could be made to the itinerant royal court, which was the Supreme Court for the whole union. The réttarthing in Norway was gradually made more permanent and met several times annually, and was usually held at the same time as the lawthings of Oslo and Bergen.

In two cases it is attested that the Norwegian kings moved the location of rural lawthings from one rural place to another: the Eidsivathing and Gulathing. In one case the king established a new rural lawthing in a town at Borgarthing (Iversen 2016; Ødegaard 2015, 99-I06; Taranger I 898; I935, 29I). The most significant changes occurred, however, after I223 (Iversen 20I7a; Ødegaard 201 5, 96-99, I06-II2). It seems at this stage that rural lawthings were relocated to towns and the lawmen's role in town and countryside was amalgamated (Seip I934, I6-24) (see Chapter 5). Haakon Haakonsson's saga is the main source for the districts and lawthings in the early I200s. In this account, nine lawmen met at the $(\mathrm{ON})$ höfðingifundr, 'the meeting of the chieftains', in Bjørgvin in I223 (HH 85-95; Helle I972, 248). The subject of this important political meeting was the right to the Norwegian throne. The lawman's opinion was given considerable importance in the conflict between Haakon Haakonsson and Earl Skule, exemplifying the powerful nature of this new combined role.

Locations, archaeology and topography

As the topographic and archaeological evidence for thing locations in the Borgarthing, Hålogaland and Gulathing law provinces are explored in detail in the following chapter, this section offers just a general overview for comparison with Swedish and Danish evidence. In the province of Borgarthing, there were three rural lawthings: one in each of the two law districts (held at Foss and possibly Tjølling) and one top-level lawthing (Borg). A review of the charter evidence indicates that Aslak Petersson, the lawman in Viken, issued a charter from Foss, Bohuslän on the Wednesday after 23 June I 450 (SD 26289). Another charter was issued by the same lawman dated 25 June I444 at Foss in (Old Norw) Laghmanz stadh or 'the lawman's place' (DN XI, I78). According to the law of I604, one of the two fixed lawthings at Foss was held on the first working day after the Feast of St Hans (St John's Eve), which fits in well with both letters. Foss is centrally located in Bohuslän, and it is reasonable to assume it was both the seat of the lawman and location of the rural lawthing. This was an old assembly site: a thing by Foss church is mentioned in the I 3 th-century Sverri's saga (Ch. I67), for the year c. I200, in an account concerning a battle between King Sverre [r. AD I I 84-I 202] and his rivals during the Norwegian civil wars. While for Tjølling, written evidence of a lawthing is absent, the name, derived from (ON) pjóðalyng, 'the heath of the peoples' (Brink 2007, 63; Zoëga 2004, 
5 I2), implies that this may have been an important thing site with early origins. It is likely that Tjølling was the location of the lawthing for the area corresponding to the northern law district of the Borgarthing law province in $\mathrm{I} 223$ and served the counties of Vingulsmark, Vestfold and Grenland. Arguments in Chapter 5 associate the meetingsite at Tjølling with archaeological activity of the Iron Age and Migration period suggesting a meeting-place of substantial age and duration. In the early I Ith century a common lawthing for Ranrike and Vingulsmark/Vestfold/Grenland was established in the newly founded town of Borg, where Norway's largest river, Glomma, empties into the ocean. This is not far from the border of present-day Norway and Sweden and centrally located for both of the high medieval law districts (Ødegaard 201 5, I03-IO6, 302-309; 2019a). Details of the actual meeting location remain known.

In I223, two lawmen are recorded from the Gulathing area, one of which represented Ryfylke. This fits well with the rural lawthing territories here. In I 322 (DN I I68; RN IV I69), Ryfylke law district is comprised of Agder and Rogaland, and more tentatively, Valdres and Hallingdal. Already prior to I I 50-75, Valdres and Hallingdal were under the Gulathing Law. In the Late Middle Ages they were part of the diocese of Stavanger, indicating association to the southern law district. The extent of the Avaldsnes jurisdiction is somewhat unclear. If the valleys of Valdres and Hallingdal are included, Avaldsnes becomes a more central location in the jurisdiction. The lawthing was moved to the town of Stavanger prior to I35I (DN III, 275). Its exact location is unknown, but most likely the lawthing was held in the vicinity of Gloppe or Bø close to the royal farm of Avaldsnes, where the main sailing route along the coast went inside the large island of Karmøy (Iversen 20 I 5 b; 20I 5c; Skre 20I7).

In terms of the Gulathing itself, according to Egils' saga there was a thing held at 'Gulen' in the spring of c. 930 (Egs 56; Helle 200I, 25-27). While this saga is I 3 th century, and thus circumspect in terms of recording Ioth-century conventions, it does offer some interesting details. The case concerned a dispute between parties in the counties of Hordaland and Firda. An assembly of 36 men (lögrétta) reached a verdict in the case. This is interpreted as $\mathrm{I} 2$ men drawn from each of the fylkir (counties) of Firda, Sogn and Hordaland. Furthermore, this is used to suggest that the Gulathing law province was originally comprised of only these three fylkir (Helle 200I, 26). The Gulathing was moved to Bergen around I300 (DN I, I47) and was amalgamated with the town's lawthing. The last known date where two lawmen, one urban and one rural, were simultaneously serving in Bergen was in I 348 (DN II, 295). In I366 a lawman with the title of 'Gulathing and Bergens lawman' appeared (DN II, 387; Seip I934, 20, note I). The location of Gulathing has been widely discussed (Helle 200I, 49-64). Knut Helle has convincingly argued that it was located by the church of Eivindvik where an area of wetland together with two large stone crosses may originally mark out the area of 'thing peace' (Figures 4.I 8 and 4.I9) (Sanmark 20I7a, 76-77, IO0-IOI). The thing site was most likely moved to Eivindvik when King Haakon Haakonsson [r. AD I 2 I7-I 263] built a church there. Eivindvik hosts the only known medieval church in the area. The question remains as to where Gulathing was located prior to this move. Knut Helle argued for a primary location at Eivindvik and then a move to the nearby Floli close to a little island named Guløy (200I, 65-66). This version of the Codex Frisianus states: (ON) hann let gera kirkio i Goley norðr fra Biorgyn ok færði pangat Golaping, 'he had a church built in Guløy north 


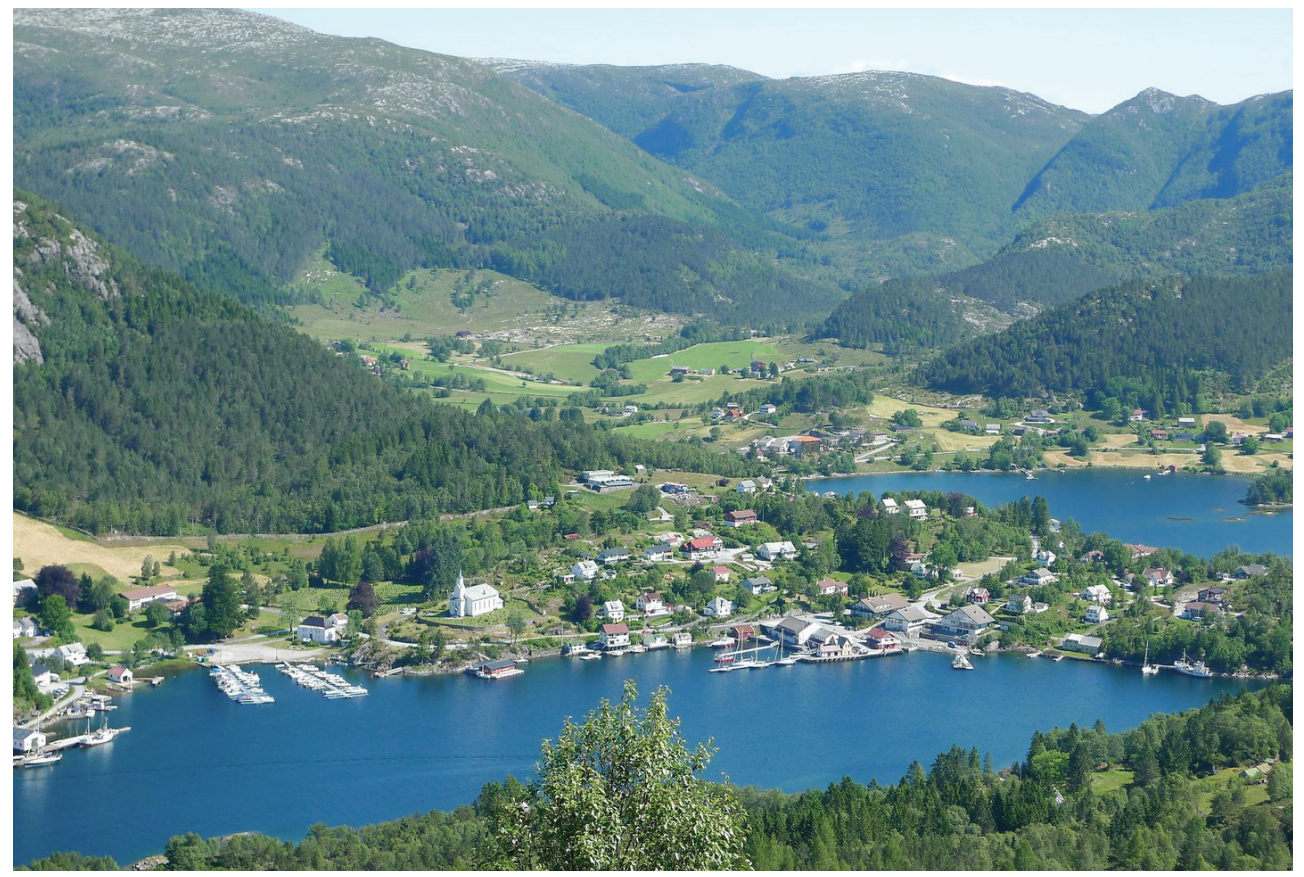

FiguRE 4.I 8 View of the Gulathing. The site of the Gulathing is thought to have been located on the plain between the foot of the slope and the medieval churchyard. Photograph by Knut S Andersen. CC BY-SA 3.0.

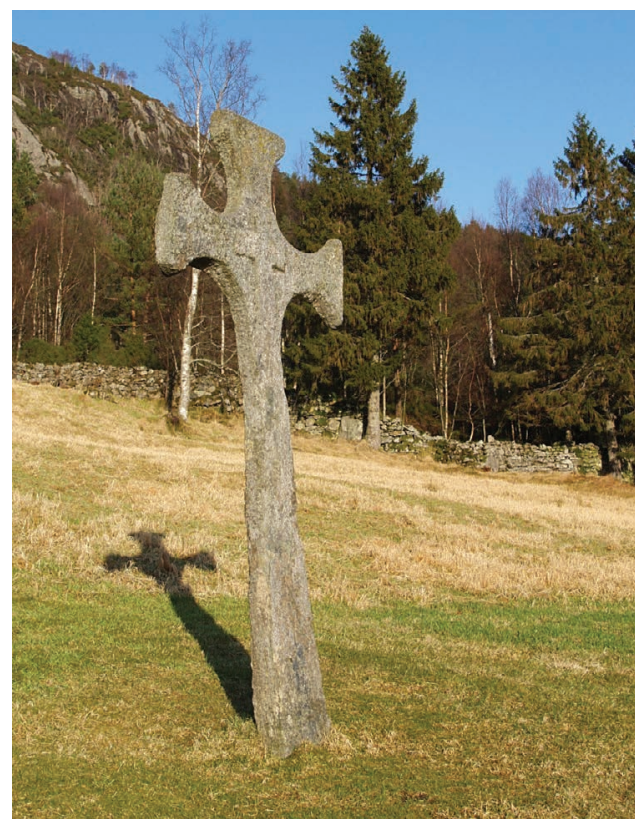

Figure 4.I9 Two large stone crosses may originally mark out the 'thing peace' area at the Gulathing. Photograph by John Erling Blad, CC BY-SA 3.o. 


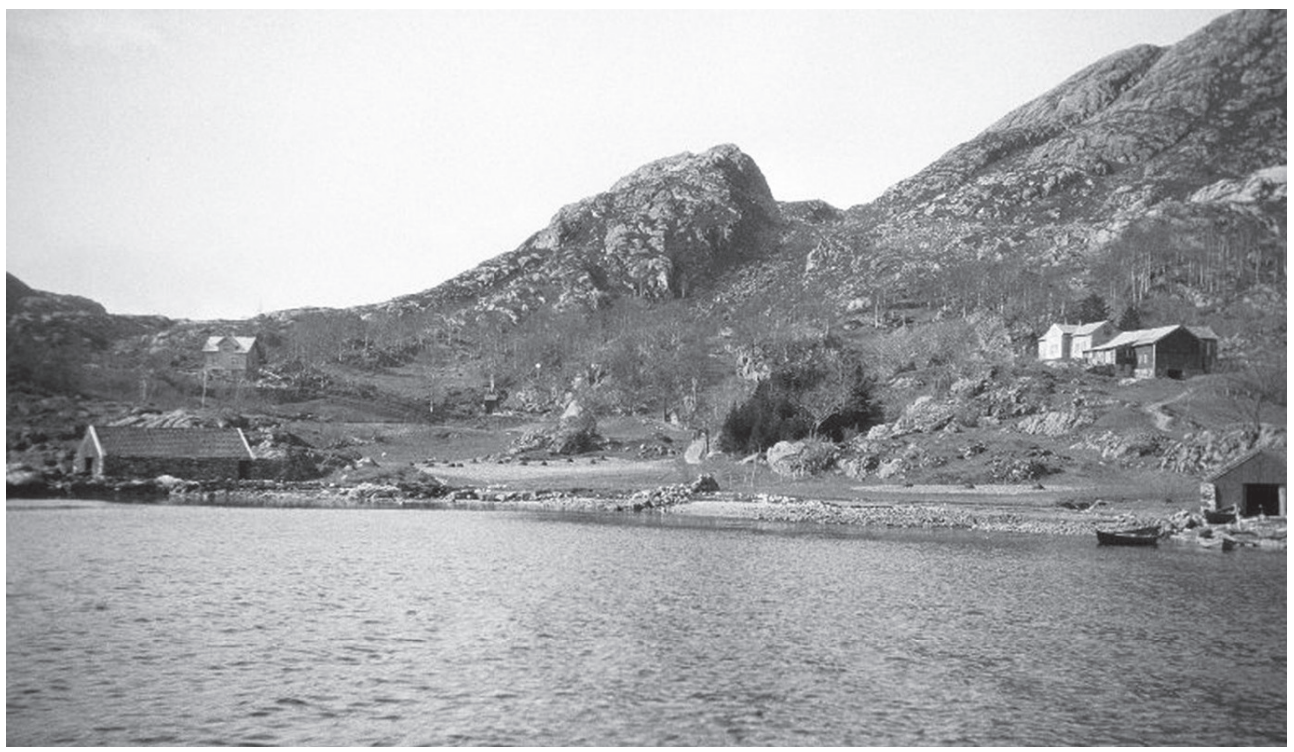

FIGURE 4.20 Stemnebø on the nearby island of Hisarøy, Norway. Photographer unknown c. I930, Fylkesarkivet Sogn og Fjordane. CC BY-SA 3.0.

of Bergen and moved the thing there (to the church)' (Unger and Drolsum I 869, Ch. 34 I, 582). (ON) I Goley, in this context probably refers to the administrative district of Guløy, which in 1567 was still referred to in written accounts as Guløe schiipreide (NLR IV, 52). Archaeological investigations in 1976 were unsuccessful in identifying a church in the vicinity of Guløy/Floli (Helle 200I, 62-66) and thus any association of this location with the early thing also remains unproven. Another candidate is Stemnebø at the nearby island of Hisarøy, $4.5 \mathrm{~km}$ west of Eivindvik (Figure 4.20). The place-name Stemnebø (Stensbo, Steffneby) is recorded in I520 (NRJ II, 506; NRJ III, 430), meaning 'assembly farm'. Its peripheral location raises questions over whether this could have been the thing site for the Guløy district, but the site perhaps served the oldest law province before its expansion from the I Ith century onwards (see Chapter 5). Hisarøy is located close to the border of the three counties that constitute the northern law district of the Gulathing, a situation perhaps indicative of its earlier central importance. A prominent mountain on the island is named Stemnebøfiellet, 'the mountain by the assembly farm'. Hisarøy is also central to the main sailing route and a royal harbour or Kongshamnen, is located in the eastern part of the island. Another candidate for the local assembly in the Gulen district is Eide farm (I $4 \mathrm{~km}$ south of Eivindvik). This holds a more central position and is associated with a range of thing place-names (Tinghaugen, Tingdalen, Tingskaret, Tingarleitet) (Helle 200I, 53) (Figure 4.2I).

In the Frostathing area there were important assemblies both at Frosta and $\varnothing y r a$. The relation between them has been extensively discussed (Iversen 20I7d). The Frostathing Law, from c. I260, describes an annual thing at Øyra (a promontory 


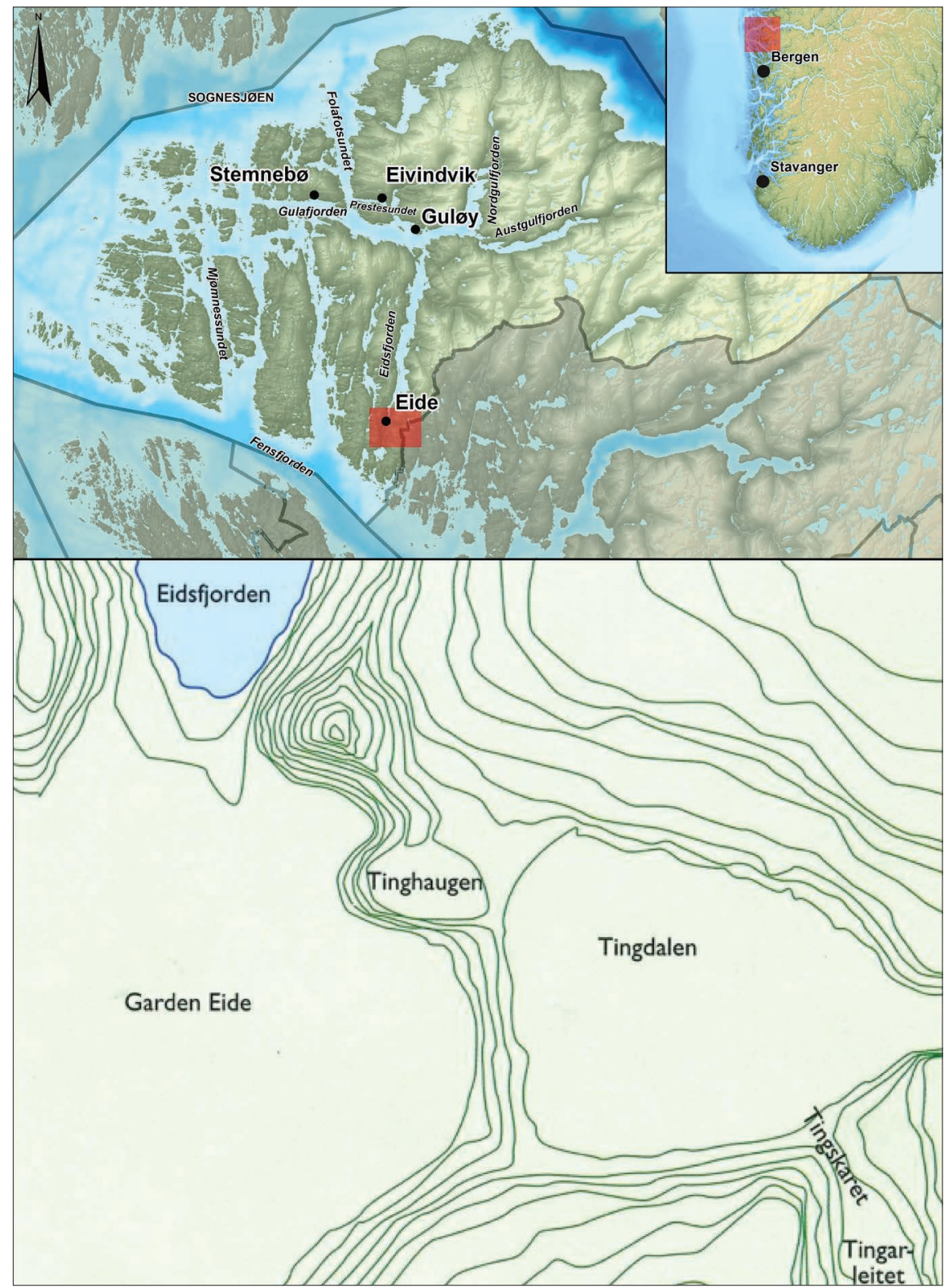

FIGURE 4.2 I Eide farm, Norway (Garden Eide on the map). The Eide thing-site lay central to the local thing district of Gulen and served as a local thing for the ship-district. It should not be confused with the main Gulathing assembly located in the outskirts of the same thing district, first at Stemnebø and later moved to Eivindvik. Work by Frode Iversen, based on Helle 200 I. Composite image and map by Tudor Skinner. Fluvial data courtesy of OpenStreetMap.org. Bathymetric data courtesy of EMODnet Bathymetry Consortium (2018): EMODnet Digital Bathymetry (DTM). 
where the River Nidelva empties into the Trondheimsfjord), held half a month before St John's Eve. From the eight provinces, all farmers with labourers had a duty to attend the Øyrathing (F I, 4; NgL I, I 22, I 28). It has been suggested that the Øyrathing was the lawthing for the eight provinces by the Trondheimsfjord before the law province was expanded to include the three coastal provinces to the west (Indrebø I935, 2I-22; Iversen 20I7d). It may be significant, however, that the Øyrathing was not a representative thing, like all the other lawthings. In the I260s the Øyrathing had two main functions: to endorse laws and to elect the king. A royal charter from I 260 unequivocally states the king to be chosen at Øyrathing in Nidaros (RN I, I974). According to Sverri's saga, only kings received by Øyrathing were legitimate (ON rett tekin) as kings of Norway (Sverri's saga, Ch. 6). On the basis of this, Jørn Sandnes (I967) suggested that the Øyrathing was established by royal decree when Nidaros was founded. This is highly plausible and the Øyrathing is most likely to be the younger thing connected to the founding of the town, and Frostathing as the prime lawthing of the law province (Iversen $2017 \mathrm{~d}$ ).

Eilif, lawman of Nidaros, was mentioned in a document of $\mathbf{2 9 7}$, and Indrebø argued that he had functions both in the town and the rural hinterland (Indrebø I935, 496-467). If this was the case, it was only an interlude, as in 1346 the urban and rural roles were again divided in Trondheim (DN V, I 86). By I422, however, the lawmen went by the title the 'Frostathing and town lawman' (DN III, 66). The Frosta peninsula was located in the middle of the Trondheimsfjord, an optimal situation at the border of Outer Trøndelag (four counties), Inner Trøndelag (four counties), and the three coastal counties to the west (Figure 4.22). The last recorded assembly at Frosta took place in I 572 (Nissen I956, 33). It has been suggested that the thing was held at the farm Logtun (Sandnes and Hagland I994) (Figure 4.22). The name Logtun means 'The site/farm of law' (Brink 2004a, 2I3), and legal documents were issued at Logtun, recorded in I 433 (DN V, 623) and I 506 (Nissen I956, 32). Logtun was the lawman's residence and part of the lawman's estate. The law-book and the thing seal were kept in the Logtun church (Nissen I956, I7; Sanmark 20I7a, 7I). It is generally assumed that the thing was held at 'Thinghaugen' at Logtun but this may be a romantic construction (Stamnes 20I7). The antiquarian Gerhard Schønning visited Frosta c. I 773-76, some 200 years after the Frostathing ceased to function. He suggested that the outdoor assembly was located at the nearby farm Rygg (Schøning I9I0 [I778], 25I). Schøning's view seems to rest on an idea that stone-circles were thing places, however, and there is one at Rygg. On the other hand, he also recorded an older place-name Ting-huva, (ON) Thinghoug, 'Thing mound', at Rygg but this is inconclusive evidence for the location of the Frostathing (Stamnes 20I7); the mound could have aquired its name as a landmark situated on the route to the thing. The wetlands called Logtunmyra ('The fen of the farm Logtun') can help pinpoint the area of the thing meetings, as its extent shows that Logtun farm was bounded by water, at least on one side. This is the highest point in the area and is surrounded by flat land, which may have served for the assembly participants (Sanmark 20I7a, 99).

Steigen lawthing for Hålogaland law district is mentioned in $\mathrm{I}_{4} \mathrm{O} 4$ (DN II, 580 ; Falkanger 2007, 20). The relationship between the lawthing at Steigen and a thing at Vågan remains disputed (Bertelsen I985, I72). Narve Bjørgo (I982, 50) argues convincingly that the Vågan thing at Brudberget was a town thing and not 

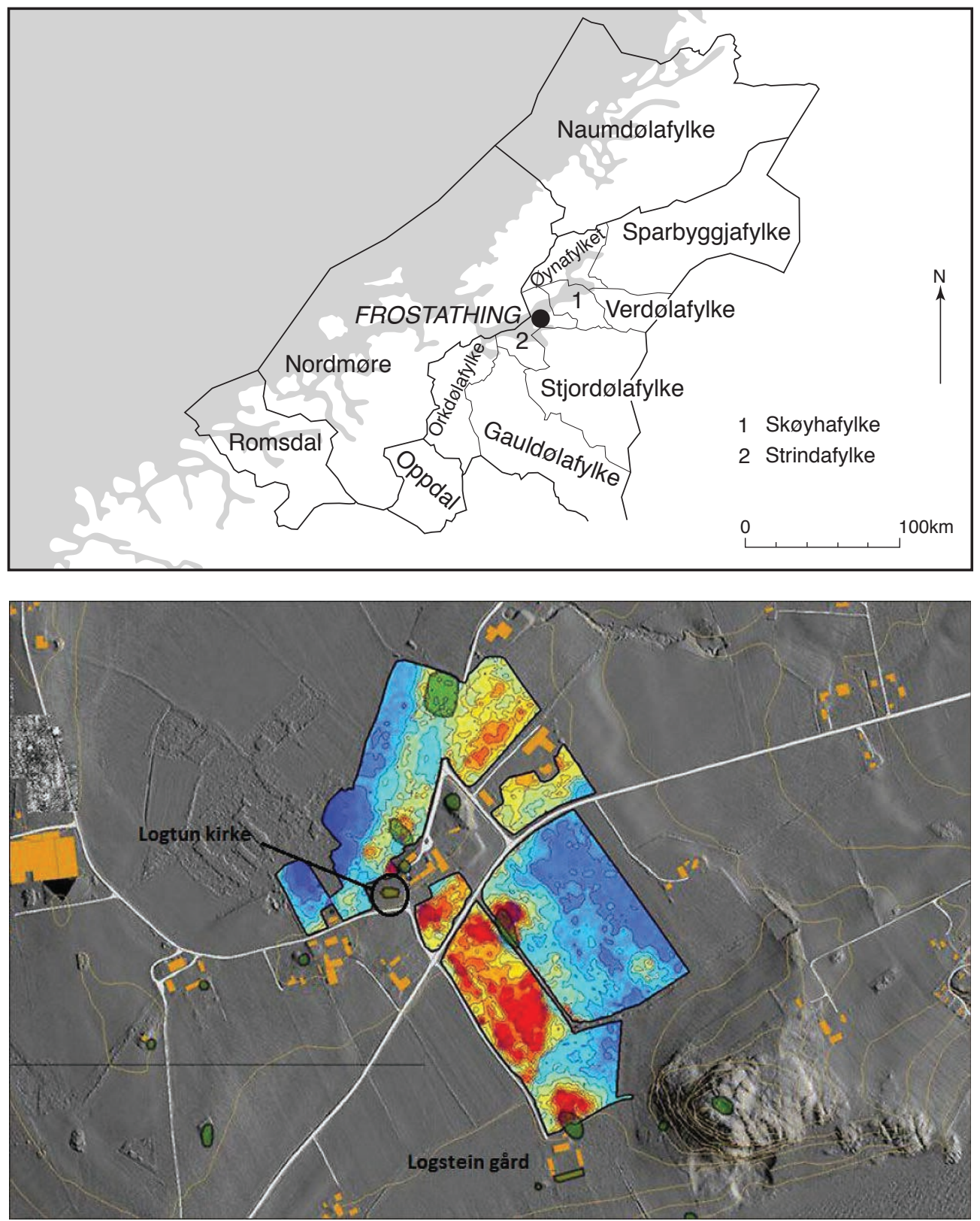

FiguRE 4.22 The Frostathing. The last recorded assembly at Frosta took place in I 572. It has been suggested that the thing was held at the farm Logtun. Geophysical survey by Arne Stamnes, NTNU shows high human activity in the areas between Logtun church and Logtun farm. The map above shows the provinces connected to the Frostathing in I 274. Map by Frode Iversen reproduced from Iversen $2017 \mathrm{~d}$. Geophysical plan reproduced with permission from Stamnes 2017. 


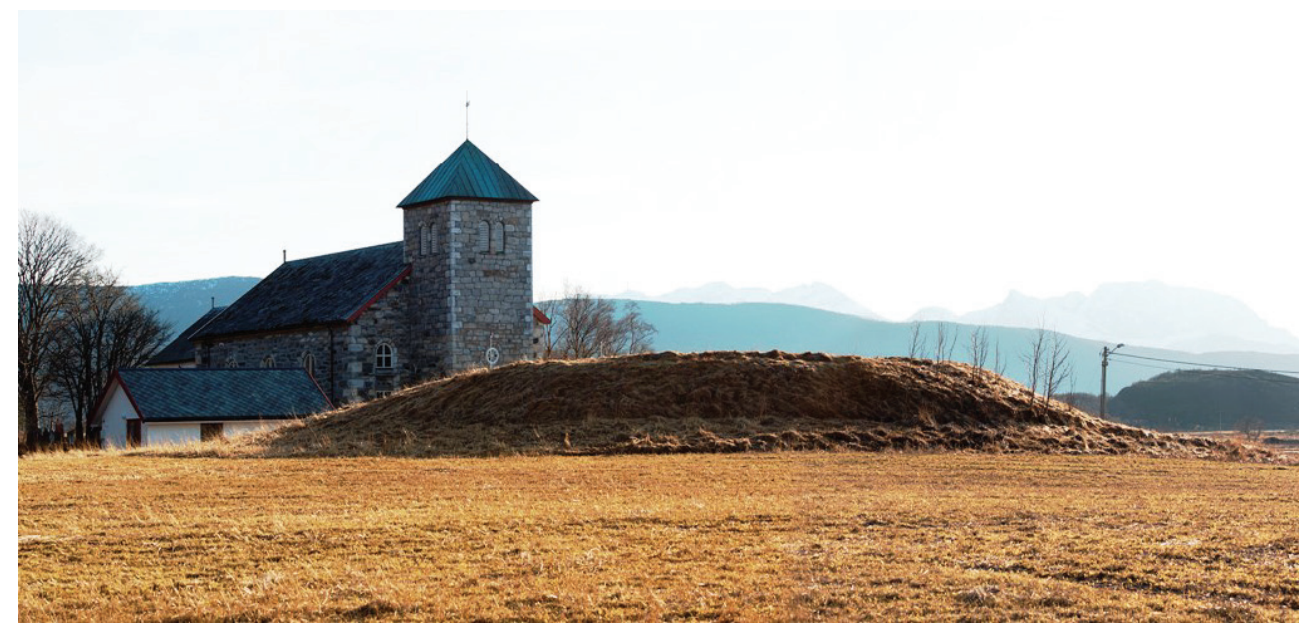

Figure 4.23 Sigar's mound. Photograph by Ernst Furhatt. CC BY-SA 3.०.

a lawthing. At Steigen the lawthing was located close to the church on the island of Engeløya central to Hålogaland. Like all Norwegian lawthings, this functioned until I797. Excavations beneath the church floor have revealed burials of named officials (MNorw lensmenn) and unidentified lawmen and their families, interred to the right of the altar (Munch I99I, 6I). In I958-59 Harald E Lund also excavated the 'farm mound' north of the church (these are middens that accumulate from settlement activity with the farmstead usually sitting on top). According to Lund, this was the medieval residence of the lawman and he further believed that the actual thing was held at the mound Sigarshaugen, 'Sigar's mound'. This is one of the three largest mounds in northern Norway, $30 \mathrm{~m}$ wide and $3 \mathrm{~m}$ high, located west of the church (Bjerck I993, IO, I 5) (Figure 4.23). In comparison, the top-level assembly for Jämtland, was located on the island of Frösön in Lake Storsjön (near Östersund), according to tradition at Sproteid. This is probably identical to present-day Draged, a characteristic isthmus and peninsula on the island. Top-level assemblies for Jämtland are recorded in the $\mathrm{I} 4$ th century when various meetings took place by the royal manor Förberg (modern Berg) (Styffe I9II, 472; e.g. SDHK 5539; Holm 2000) (Figure 4.24 ). In view of the proximity of Sproteid to Berg, this most likely means that the assembly was still held in the same area, or very close to it. The assembly was held the week after St Gregory's feast day in March, while the date of the thing in 1604 was I4 days before St John's Eve (Hallanger and Brandt I 855 , 8; Munch I 862, 374).

Finally arguments can be made for the geographic area once covered by the Eidsivathing Law. Most likely it coincided with the diocese of Hamar and much of the mountain land (Figure 4.25). The border between the dioceses of Hamar and Oslo fell between Brunkeberg (Hamar) and Kvitseid (Oslo) (DN IX, I86; DN III, 29I). In all likelihood this mirrors the border between the Eidsivathing and Borgarthing areas (Ødegaard 20I 5, 9I-95). Like the coastal land, the mountain land was divided into four patriae (Lat.) ('law provinces') in II 50-75 and two law districts in I223. 


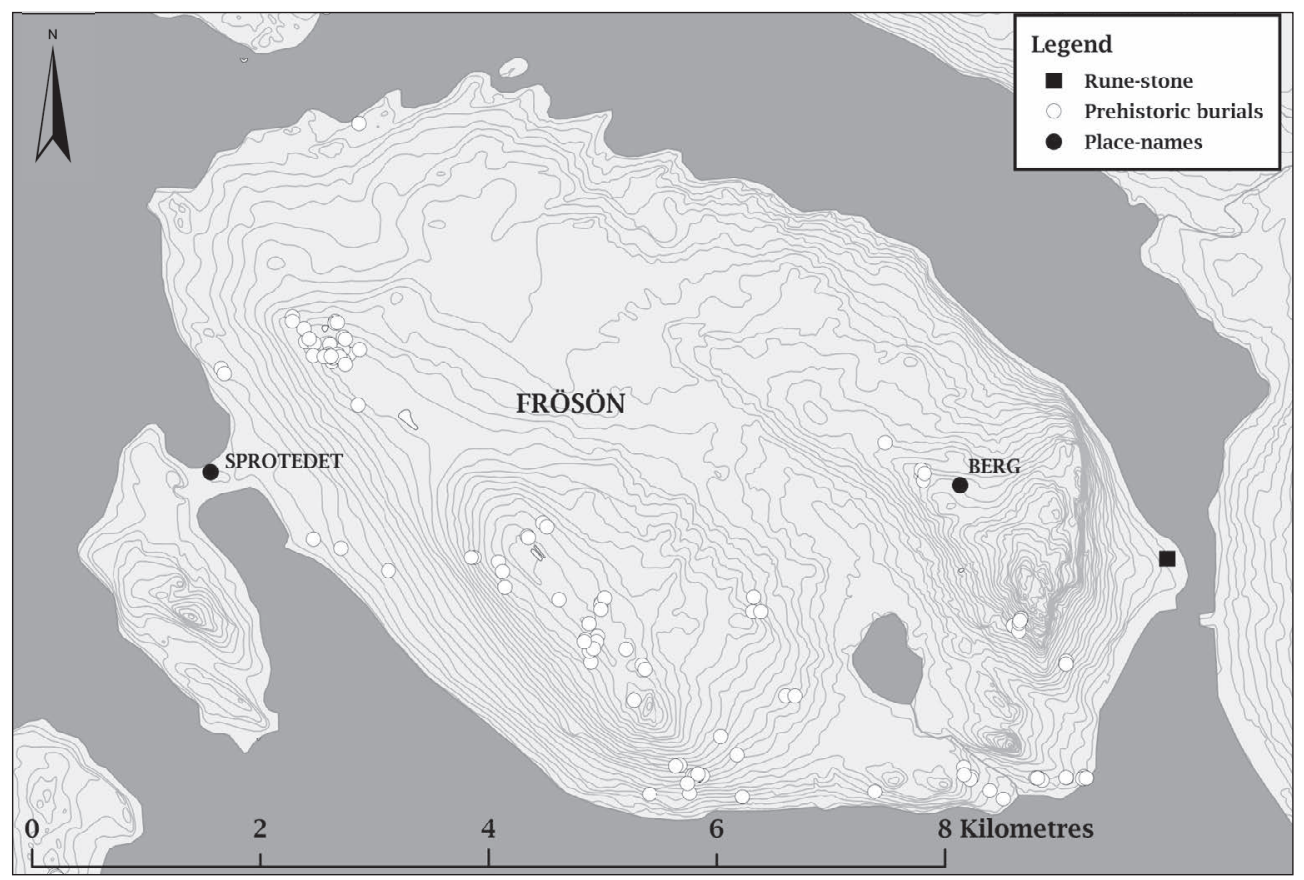

FIGURE 4.24 Frösön in Jämtland, Sweden. The top-level assembly site by Sprotedet, documented as an assembly between the I 5 th and the 17 th centuries. Förberg (Berg) was the royal manor and the location of the winter market in the I 4 th and I 5 th centuries. Map by Alexandra Sanmark and Tudor Skinner.

Two surviving I 4 th-century manuscripts of the Eidsivathing ecclesiastical regulations probably from the IIth/I 2 th centuries mention lawmen in plural, indicating an older division in several law districts (Halvorsen and Rindal 2008, 49, 90). To resolve this problem, it can be suggested that two patriae shared a lawman. According to this logic, the southern law district included (a) Upper Telemark with remote settlements in Numedal, and (b) Ringerike and Romerike and surrounding provinces, while the northern law district contained (a) Hedmark with Østerdalen and (b) Gudbrandsdalen and neighbouring provinces. The bishops of Hamar had two residences within the diocese: at Hamar to the north and at Storøya in Hole, Ringerike, to the south. This was to administer the two parts of the diocese (Hommedal I999). The lawthing for the northern law district was at Hamar (a lawman is mentioned in Hamar in I 293; RN 2, 72I) and therefore near the bishop's palace. If we assume a parallel ecclesiastical and secular organisation, a lawthing for the southern law district may be sought near Storøya.

Archaeological evidence suggests that the bishop's palace on Storøya existed in the 13 th century, but an ecclesiastical focus probably dates back to the foundation of the diocese in the mid-I2th century (Hommedal I999, I3). A written judgement (Mod Norw domsbrev) from I389 shows clearly that the bishop executed his 


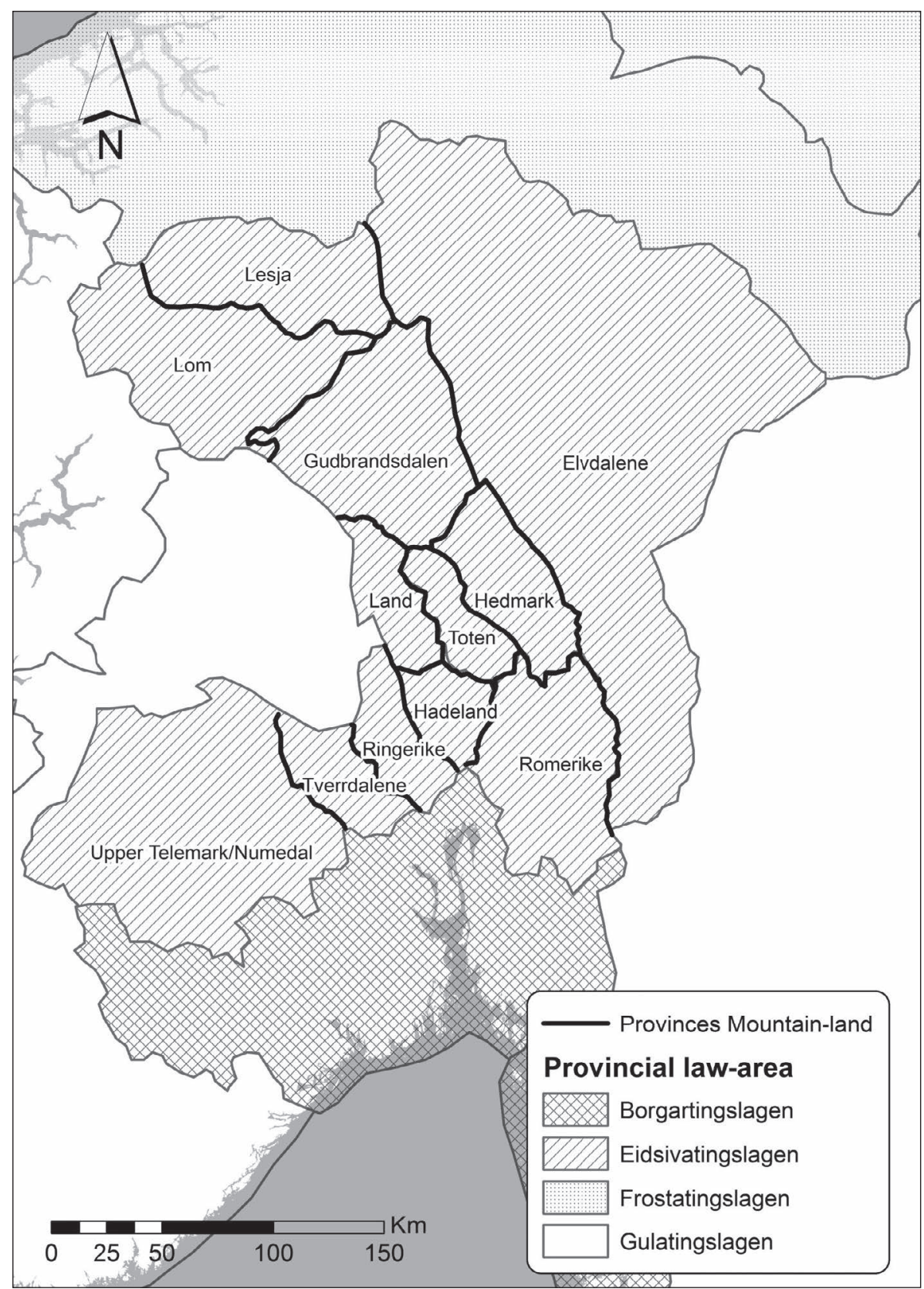

FIGURE 4.25 The Eidsivathing law province prior to c. I 250. Later, Upper Telemark was transferred to the Skien lawthing and Tverrdalene to Tønsberg lawthing. The legal administration of the remaining provinces was divided between the lawmen of Oslo and Hamar. However, the Eidsivathing kept functioning as the main lawthing for this region. Map by Frode Iversen. 
power of prosecution from Storøya (DN IV, 56I). Storøya borders the royal manor at Stein, where Halfdan the Black was reputedly buried in around AD 850 (Rolfsen and Larsen 2005, I 24). The archaeologists Perry Rolfsen and Jan Henning Larsen conclude, after a thorough review of historical and archaeological sources regarding the phenomena of 'Halfdan's burial mounds' in eastern Norway, that the great mound at Stein is the best candidate as Halfdan's burial site (Rolfsen and Larsen 2005, I 24). Halfdan the Black in later tradition is regarded as a law-maker, and Snorri Sturluson accredits him in the early $\mathrm{I} 3_{\text {th }}$ century with setting fixed fines for offences, which were proportional to the man's lineage and standing (Heimskringla, Halfdan the Black's saga, Ch. 7). If Snorri is recounting a genuine tradition, it is tempting to seek a lawthing for the southern law district in the vicinity of Stein/Storøya. This, however, remains uncertain. The northern law district in the Eidsivathing area encompassed (a) Hedmark with Østerdalen and (b) Gudbrandsdalen and the provinces. The 'people' of Gudbrandsdalen, Hedmark and Østerdalen supported the inauguration of King Christian I [Norway r. AD I450-I48I] in Oslo in I450 (DN III, 8I2). This area appears to coincide with the northern law district of 1223 , where Sakse was the lawman.

Thus in Norway, despite a wealth of medieval documentation and a greater confidence than in Denmark in establishing administrative districts and their developments over time, there are difficulties in establishing the original locations for meeting-places. When evidence is present, however, there are hints that borders, elevated locations and places with good water and land access were all relevant to locating early outdoor assemblies. Wetland areas may have been significant too, and single large mounds, perhaps burial mounds, also feature sometimes at possible thing locations. There are again suggestions that topographically elevated places were chosen, as well as isthmuses. As the next chapter sets out in more detail, there are also striking relationships between medieval thing sites and archaeologically attested places of gathering or meetings of the Iron-Age and Migration periods (see Tjølling above and Chapter 5). As we shall see, however, the spatial proximity between these archaeologically attested meeting-places and place-name evidence for the medieval thing is variable. As in Sweden and Denmark, there is also good evidence that the locations of meetings moved, often to urban centres. Evidence suggests that while toplevel provincial assemblies remained active across the Middle Ages, their functions and locations changed, as the legal system was integrated into the growing state. Emerging towns were important as legal centres. By the I 3 th and I 4 th centuries, across all three regions, a form of higher court was established, pre-empted by the royal réttarthing, a form of political and royal meeting. In Norway, churches were located at times next to assembly locations hinting at the continuity of meeting traditions at some sites, but a change in cult-focus.

Across all regions, a large number of top-level assemblies seem to have been associated with the older law provinces and typically one would most often rise to prominence over time. In a few cases the ancient nature of the top-level assemblies is indicated by archaeological finds, for instance Gamla Uppsala. In Denmark, these things also operated as the location for royal inaugurations (see below). The Danish law districts potentially reflect older legal communities, which over time were absorbed into larger, judicial communities, related to the development of bigger political units. Snorri's description of the kingdom of Svípjóð could be an example 
of this development. Further coordination of the law is evident in, for example, the amalgamation of the three folkland laws into the Law of Uppland described above which later also applied in Finland. Gradually, the organisation of the judicial system became a national concern and over time, legal connections become increasingly evident. A milestone for Norway and Sweden was the development of joint laws enabling a reorganisation of the geography of the judicial areas that were no longer tied to the administration of regional laws. In Norway such laws were issued in I 274 for the rural areas and in 1276 for the towns. In Sweden this took place in 1350 for the rural areas, while the regional 'triple structure' of Denmark was kept throughout the Middle Ages. This may explain why the regional structure of the lawthing was more rigid in Denmark than in Sweden and Norway during the Late Middle Ages.

\subsection{ROYAL INAUGURATION SITES IN SCANDINAVIA}

As outlined in Chapter I, inauguration rituals were another form of public assembly in medieval societies. In Scandinavia, they were a specific kind of meeting and there are often correlations in the locations of top-level provincial legal assemblies and places of inauguration. This could, as in Denmark, involve an almost direct relationship with the location of the medieval landsthing or, as in Sweden, the inauguration site might be linked to assembly sites by designated royal routes of travel. In this comparison of evidence for administrative structures and the operation of the thing in Sweden, Denmark and Norway, it is important, therefore, to consider the similarities and differences in how royal inauguration sites operated in relation to the thing.

Royal inauguration inevitably features in many written sources, although very few details are provided of actual rituals. Many of the inauguration sites are mentioned by name, but without any detailed description. As with thing sites, to understand the location and operation of inauguration places, information needs to be collected from laws, medieval charters and chronicles and, to some extent, sagas and skaldic poetry. The traditions surrounding royal election and inauguration seem to follow broadly the same pattern in the three Scandinavian kingdoms of Norway, Sweden and Denmark, although by far the most detailed evidence comes from Sweden. Using the early Swedish provincial laws, and glimpses from Norwegian and Danish written sources, the ceremonies practised in the Viking Age and the early Christian period seem to have started with a royal election at a primary inauguration site. After this event, the new king was expected to travel through the kingdom stopping at key assembly sites in the different provinces where the local population had the right to approve or reject him as king.

Coronations are first documented in II70 in Denmark, I208 in Sweden, and II 63 in Norway, but seem to have complemented rather than replaced older ceremonies relating to election and inauguration (Grundberg 2005; Helle I972, 49-50; Markus 2013, I23-I24; Sundqvist 200I; 2002). Coronations were church ceremonies, where the king received the blessing and approval of the Church, and strictly speaking this was not a prerequisite for becoming king. For instance, King Haakon Haakonsson was not crowned until 30 years after he had become king of Norway in I2I7 (Helle 2009). This type of event altered in character in accordance with the changes in the Nordic unions. Most kings after I3 I9 were traditionally 
crowned in their respective realms, but there were also joint coronations which emphasised the joining of the kingdoms. Examples are Magnus Eriksson who was crowned for both Norway and Sweden in Stockholm I336, and Eric of Pomerania who was crowned as joint king in Kalmar I397. Eric had already been crowned as king of Norway, probably in I392 (Dørum I995; Haug I995; Opsahl 2003; 2017).

The path to becoming a joint king during the time of the Kalmar Union was a long one (Bjørkvik I996). Christopher of Bavaria was initially elected as king of Denmark on 9 April I44O, in I44 I he was elected as king of Sweden and in I 442 he was proclaimed elected king of Norway (Hørby I979). On New Year's Day I443 he was crowned in Ribe Cathedral and proclaimed as Denmark's archirex (Lat.) or 'Arch King'. In I449/50, during the Kalmar Union, the hereditary principles were removed for Norway, which then joined Sweden and Denmark as elected monarchies (Erslev I882; Imsen I974d). The leader of the Privy Council (Mod Sw riksraid) appointed new kings, and the inauguration was given new meaning as an acclamation of the elected king and as consent for the king. What is clear from existing sources, however, is that early inaugurations were outdoor events that required an assembly of people.

\section{Sweden}

According to various sources, royal elections for the kingdom of Sweden took place at 'Mora thing' (Mod Sw Mora ting) (Jansson I985; SL K I; for an overview, see Larsson 2010, 291-292; Holmbäck and Wessén I962, 4, 23, fn 22a). The Law of Uppland does not mention Mora, but instead states that elections took place in 'Uppsala' (Holmbäck and Wessén I933, UL K I). Elections at Mora are documented from I 275 onwards in documents and by carved stones preserved at the site (Jansson I985, I77-I78, 24I; Larsson 20I0, 29I-292). Several of the provincial laws stated that the 'the Swedes' (interpreted as the people of 'Svealand proper', i.e. the three folklands of Uppland) had the right to elect new kings, although no mention of Mora is made (Holmbäck and Wessén I946, ÄVG K I). The Uppland Law is more specific and stated that it was indeed the three folkland units who should elect the new king (Holmbäck and Wessén I933, UL K I). Once the king had been accepted, the lawman should 'deem' him king, meaning that the king had to swear an oath to guard the peace and law (Holmgren I937, I9; Holmbäck and Wessén I933, UL K I). Another likely reference to Mora thing is found in the Saga of Olaf the Holy: in a section describing a thing meeting at Gamla Uppsala, it is stated that five kings had been drowned at the $(\mathrm{ON})$ Múlathing as they had been filled with 'arrogance'. This has been interpreted as a deposition ritual (Hollander I964, 32I; Larsson 20I0, 29I; Sundqvist 2002, 63I-633).

Mora thing has been identified as (Mod Sw) Mora kungsäng 'the royal meadow at Mora', located I.5 km from Gamla Uppsala. It has previously been noted that Mora was a suitable meeting-place as it was situated on the boundary between Tiundaland and Attundaland (Styffe I9I I, 33I). The location was also the best possible for thing participants from Fjärdrundaland as they could travel along Örsundaån and into the northern part of Lake Mälaren, from which major waterways (the Fyris River and Långhundraleden) led directly to Mora (Figure 4.26). Långhundraleden was the major water route through southern Uppland and, therefore, also served thing participants 


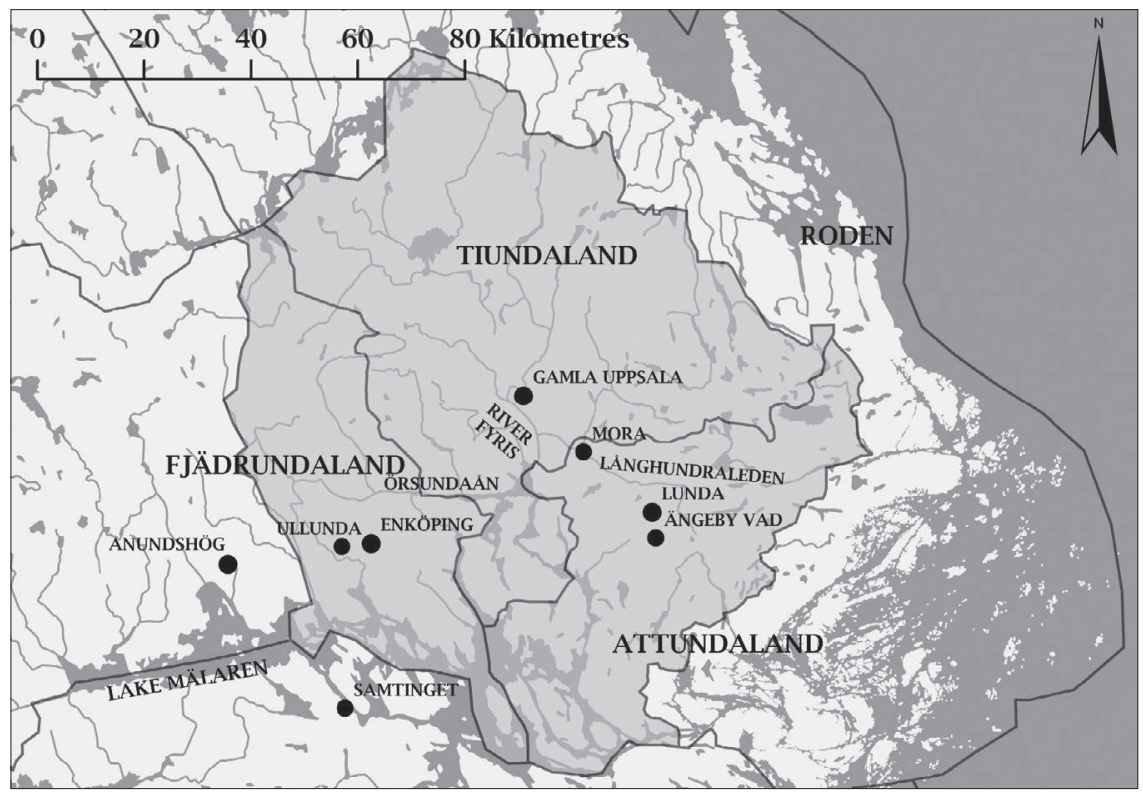

FIGURE 4.26 The location of Mora thing in relation to the three folkland units of Uppland with their respective assemblies. Mora thing was the inauguration site of the Swedish kingdom and the potential joint assembly site for all three folkland units. Map by Alexandra Sanmark and Tudor Skinner.

travelling from Tiundaland and Attundaland. It should be noted though that despite the presence of these significant water routes, the journey to Mora would have been challenging for inhabitants of all three folklands. This was probably not a significant problem as the site only seems to have been used very occasionally. Apart from royal elections, Mora is also the most likely candidate for the meeting in I 296 at which the Law of Uppland was accepted by the three folklands (see above).

Mora's location on the convergence of a number of communication routes and its accessibility are key features of assembly sites (Sanmark 2009; 20I3). Recent research and fieldwork at Mora have highlighted some additional assembly features which allow the site to be pinpointed (Larsson 20I0; 20I3) (Figure 4.27). Two cemeteries, one of which is partly excavated and dated to the I Ith century, are positioned on the edges of Mora kungsäng along with a large mound, with a spring next to it, located roughly in the middle of the 'meadow' (Larsson 2010, 295-296). A construction made of gravel, stones and wooden posts, interpreted as the remains of a road or jetty, led up from the river (Långhundraleden) and connected to an old road which passed right by the large mound (Larsson 20IO; 20I3). This construction was rather substantial, stretching at least I 45 metres. No date is known, but reconstruction of old water levels suggests a date in the Vendel/Viking periods (Larsson 20I0, 297-298; 20I3). Additional finds of importance are three rune-stones (U 486, $\mathrm{U}_{4} 87, \mathrm{U}_{4} 88$ ) (Sanmark 20I 5). 


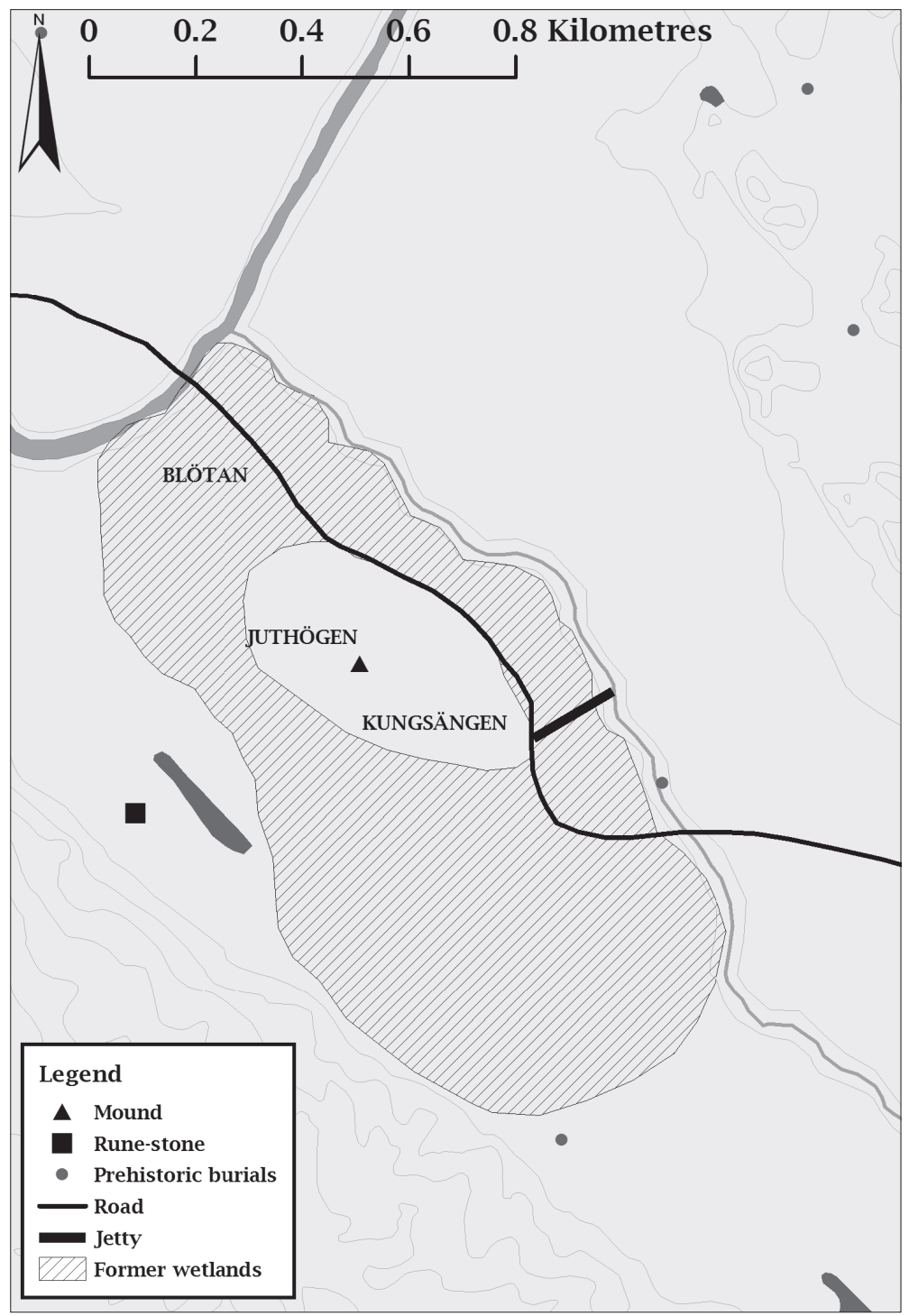

FIGURE 4.27 Mora thing: At Mora kungsäng ('royal meadow'), there was a large mound, Juthögen, with a spring. Reconstructions of old water levels have shown that around the year $\mathrm{AD} 500$ the mound and the spring were on a small island. The surrounding area would have continued to be wet for the next few hundred years, which is backed up by place-names. Mora denotes 'fenland' and Blötan means 'the wet meadow'. A large construction, interpreted as a I $45 \mathrm{~m}$-long jetty, connected the landing place on the river (Långhundraleden) to the old road, which led to the mound. The jetty was most likely constructed in the Vendel or Viking periods. The 'royal meadow' was moreover enclosed by two prehistoric cemeteries, partly excavated and with dates from the early I Ith century. Map by Alexandra Sanmark and Tudor Skinner, on the basis of fieldwork carried out by Mats G Larsson in 2010 and 2013 . 
After election at Mora, the new king would travel the ceremonial journey of the Eriksgata in order to be accepted by the population in the various districts of his kingdom (Jansson I985, I77-I79; Sundqvist 200I) (Figure 4.28). Upon entering each province, the king would be met by representatives of the local population and escorted to a suitable assembly site (or maybe several sites) at which the local lawman should again 'deem' him king (Holmbäck and Wessén 1946, ÄVG K I; Sundqvist 200I). After this ceremony the king should be taken to the boundary of the next province where another handover would take place (Holmbäck and Wessén I946, ÄVG R I; Holmgren I937, I9). The Eriksgata is first recorded in the laws of the late I 3 th century, but tradition is most likely of 'pre-Christian' date, although the actual route has presumably changed over time (Sanmark and Semple 20I0; Sundqvist 200I). The description of the Eriksgata in the Law of Uppland reads as follows:

\begin{abstract}
Now he [the king] shall ride the Eriksgata. They [the men of Uppland] shall follow him and give him hostages and swear him oaths. From Uppsala they shall follow him to Strängnäs. There the men of Södermanland shall receive him and with safe conduct and hostages follow him to Svintuna. There the men of Östergötland shall meet him with their hostages and follow him through their land to the middle of the forest Holaved. There the people of Småland shall meet him and follow him to Junabäck [Juna Stream]. There the people of Västergötland shall meet him with safe conduct and hostages and follow him to Ramundeboda. There the people of Närke shall meet him and follow him through their land to Uppbåga bridge. There the people of Västmanland shall meet him and with safe conduct and hostages and follow him to Östen's bridge. There the people of Uppland shall meet him and follow him to Uppsala (Holmbäck and Wessén I933, our translation from Mod Sw).
\end{abstract}

Apart from Mora thing, the sources do not provide any information on the sites attended by the king as part of his journey. The top-level landsthing sites, when they were in suitable locations, are the most likely candidates and the Eriksgata indeed passed all the identified/suggested landsthing sites in the provinces involved apart from the one in Småland. This may be explained by the fact that this province only seems to have been included in the Eriksgata in the $\mathrm{I} 3$ th century, and travelling all the way to Växjö would have added a substantial distance to the already long route. It therefore seems probable that the Småland meetings were held by Junabäck, in modern Jönköping. The Jönköping town privileges date from I 284 , but the town is most likely of older date (Bäck 20I4).

The reconstruction of the Eriksgata shows that a number of other assembly sites were located along this route too, and it is possible that here some kind of rituals and ceremonies relating to the newly elected kings took place also. The coincidence of route and assembly place is of course commonplace, so it should not only be put down to this being a royal route (Brink 2004a; Sanmark 2009). The final part of the inauguration took place at Mora where the king was lifted onto the stones (Holmbäck and Wessén I940, SL 47; Sundqvist 2001, 633-637). It has been argued that medieval inauguration rituals often involved kings being raised on to stones, shields or chairs. These traditions are thought to derive from pre-Christian elements (Sundqvist 200I, 8) and will be given further consideration below. 


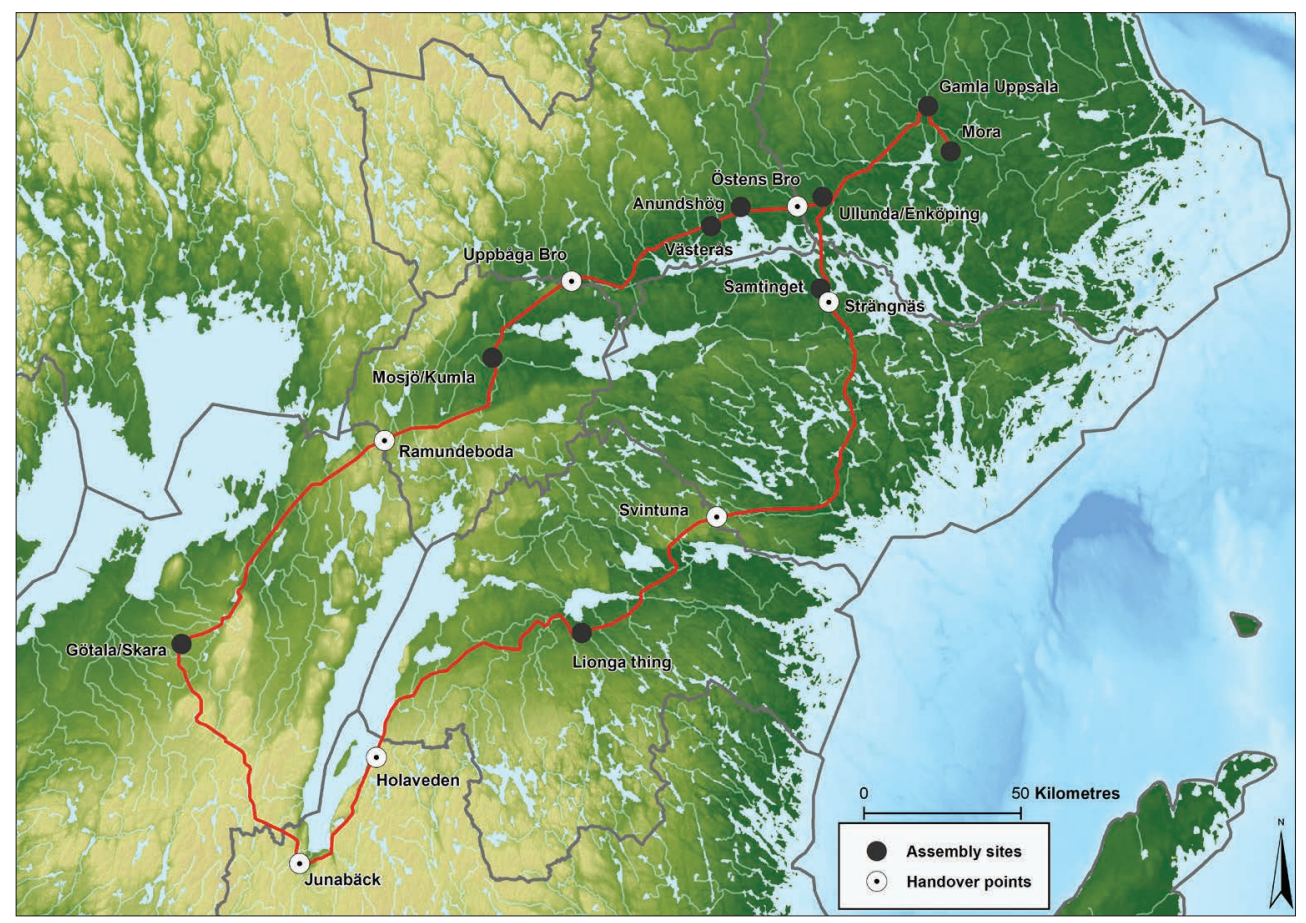

Figure 4.28 The royal route of the Eriksgata through medieval Sweden with the top-level assembly sites and handover points along the route. Reconstructed on the basis of the provincial laws, old maps and Mannerfelt (1936). Map by Alexandra Sanmark, Brian Buchanan and Tudor Skinner. Bathymetric data courtesy of the Baltic Sea Bathymetry Database by the Baltic Sea Hydrographic Commission, under a CC BY-SA 3.0 Unported Licence. Topographic detail courtesy of Lantmäteriet.

\section{Denmark}

It is generally accepted that both the election and inauguration of a king were conducted at Denmark's three most important landsthings: Viborg, Ringsted and Lund (Figure 4.29). Inaugurations are also known from Urnehoved in south Jutland and the landsthing on Fyn (probably in Odense) (Larsen I840, 26I, note 2). By the I 3 th century, Viborg was the foremost inauguration site in Denmark, but in earlier times this role seems to have fallen to Isøre in northern Zealand. Isøre and Viborg thus form a parallel to the Øyrathing in Norway and Mora in Sweden. According to Saxo Grammaticus, Isøre had origins far back in time, as the place of inauguration of the legendary King Høder in around AD 500 when royals had their seats at Lejre (Saxo v. I, I I 4, I I.IO.2, 2, 83). Saxo reported that royal elections took place at Isøre in the late IIth and the early I 2 th century, as well as a peace agreement attended by King Valdemar [r. AD II46-II82), and other visits by the king and bishops (Saxo v. 2, 339, II.10.2, 83). 
The location of the inauguration site is not known, apart from that it was roughly located by Skansehage, close to Rørvig (Koch I984, 60-6I). Identifying the exact location is challenging because the area has changed hugely over time due to shifting sand. The name Isøre, which fell out of use in the I4th century, is derived from is ('ice') and eyrr ('sandy, stony beach'), but the old name of the Isefjord bay was most likley 'Isørefjord', suggesting that it is named after Isøre, which highlights the significance of this site (Anonymous I929, xx, 74). Isøre was highly strategic as a place for royal election and inauguration for a number of reasons. Firstly, it was accessible for people from all the different parts of Denmark, Jutland, Zealand and Skåne (Figure 4.29). Secondly, Saxo stated that there was a good natural harbour (I I.IO.2; Zeeberg and Engelhardt 2000, 2, 83). Saxo also stated that there were treacherous sand banks, visible only at low tide (I I.IO.2; Zeeberg and Engelhardt 2000, 2, 83), making this area ideal for keeping fleets and people safe. Isøre moreover protected the entry to the Isefjord bay which led into the heart of Denmark where Lejre was located, and also Roskilde, a Viking-Age trading site and later the episcopal see of Zealand (Markus 2013, I23-I 24). That this area was well guarded is demonstrated by the (undated) remains of a beacon and a moated fortification and three possible mounds [Dan Lokalitet I38I95/I90899/I05566]. Supposedly this place ranked over Ringsted, Viborg and Lund. Saxo claimed Christianity in Denmark was introduced

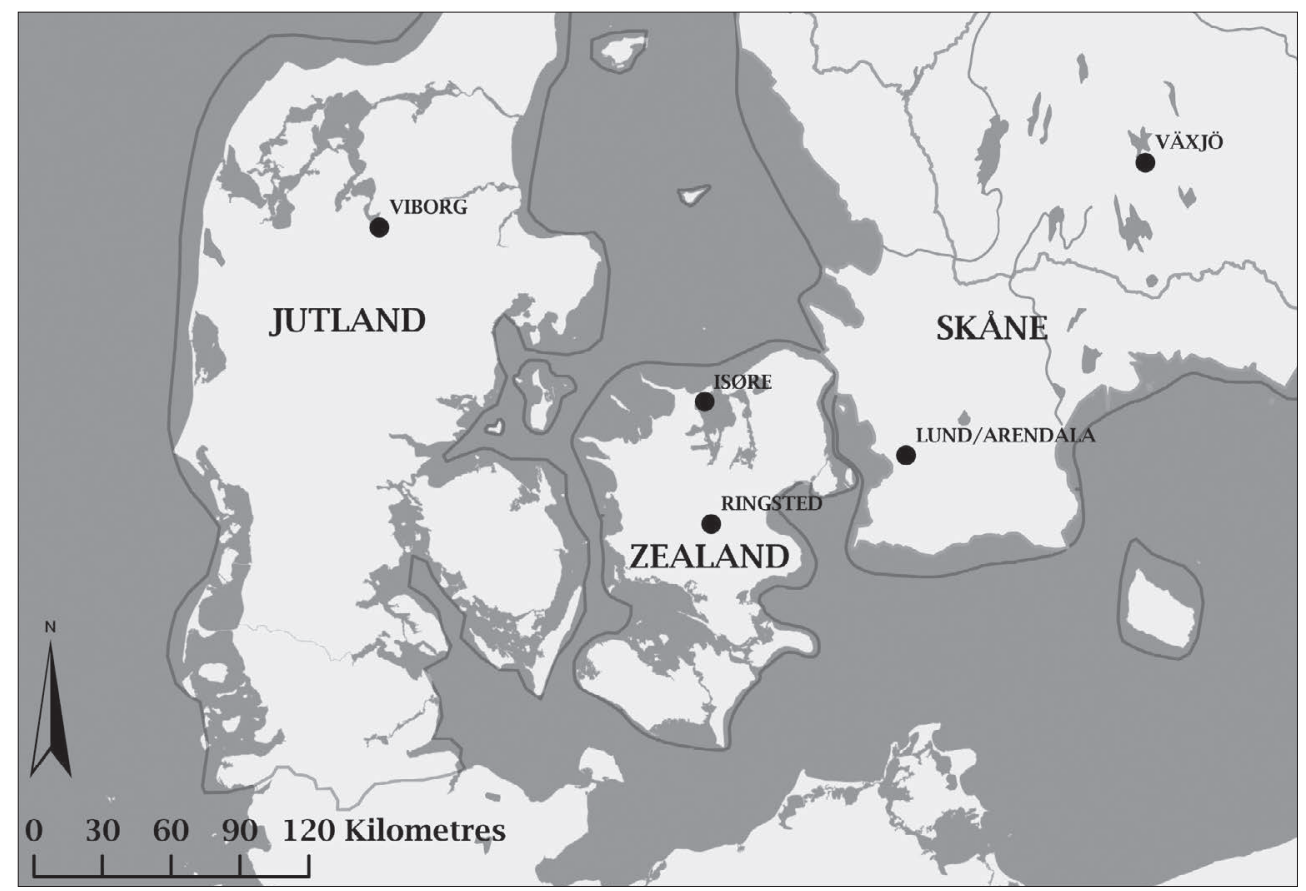

FIGURE 4.29 Denmark's landsthings, also used for inaugurations. This map also shows the location of Isøre, seemingly the oldest Danish inauguration site. Map by Alexandra Sanmark and Tudor Skinner. 
at Isøre and it has been suggested that the Isøre Harbour was where the military fleet gathered and accepted the king. Archaeological evidence shows human presence from the Bronze Age onwards.

By the I $5^{\text {th }}$ century, a tradition similar to those found in Sweden existed in Denmark. After election at Viborg's landsthing, the kings were expected to travel to the other top-level provincial things in order to be accepted as king. According to a document from I423, Lund was the second stop on this journey (Blomqvist I95 I, 268). The antiquity of this tradition is unknown, but the similarities with practices evident in Sweden and Norway imply this too may reference an older tradition. Many places for royal elections near Lund have been suggested, above all the mounds Kungshögen, 'The King's mound'; Lerbäckshög, 'Mud brook's mound'; and Sliparebacken, 'Grinder's hill' (Svensson 2015, 86). The I7th-century scholar Kilian Stobaeus in fact suggested that the inauguration site may have alternated between different mounds in the vicinity. The place-names of Lerbäckshög and Sliparebacken appear in older texts in various forms, for example for Sliparebacken: (Mod Sw) Sankt Liberius hög, and for Lerbäckshög: (Mod Sw) Libers hög, Leobards hög, Trelejonborgs hög, etc. All demonstrate a connection with mounds and the latter two imply some connection with the three leopards or lions from the Danish national coat of arms (Blomqvist I95 I, 267; Ingers I962, 74-76; Sjöborg I 8 I 5, 30). The first known inauguration of a king at Viborg took place in 1027 when Harthacnut was chosen as the King of Denmark [r. AD IO35-IO4I]. The last inauguration at Viborg took place in 1657 when the nine-year-old crown-prince became King Christian V [r. AD I646-I699]. After the introduction of absolutism and hereditary kingship in I660, the Danish kings were no longer inaugurated at the landsthings.

The Chronicon Lethrense (Lejrekrøniken) (CL) c. II70-90, mentions the inauguration of the mythical King Dan, who was allegedly lifted on to a stone called the Danærigh (qui dicitur Danærigh (Lat.) in the Chronicle), to receive his royal name (CL Ch. 2, 3). This is identified as the so-called inauguration stone at Viborg (Nielsen I964, 5). Also, at Ringsted, oral traditions survive that included reference to stones. The late-medieval thing meetings are said to have been held by St Benedict's Church by a number of recumbent stones known as the (Mod Dan) Tingstenene or 'The thing stones' (Figure 4.30). Although, these stones are not connected to royal inauguration, this still remains an interesting parallel to traditions recorded for Viborg and Mora. These strengthen the idea that medieval inauguration rituals may have involved stones or other elevated features (see below).

From I 483 , the coronation marked the elected king's acceptance of royal power, and inauguration took place at the four landsthings of Viborg, Odense, Ringsted and Lund. In I6 Io the provincial inauguration of Zealand moved to Copenhagen and by I 660 the inauguration ritual had disappeared entirely in Denmark (Jørgensen I922).

\section{Norway}

Royal inauguration was called (ON) konungstekja in Norway during the Middle Ages and was a regular event until I648. The older traditions are enshrined in sagas and skaldic poetry and have been studied in detail by the legal historian Absalon Taranger (I934). Literary sources from the 13 th century describe rituals from the 


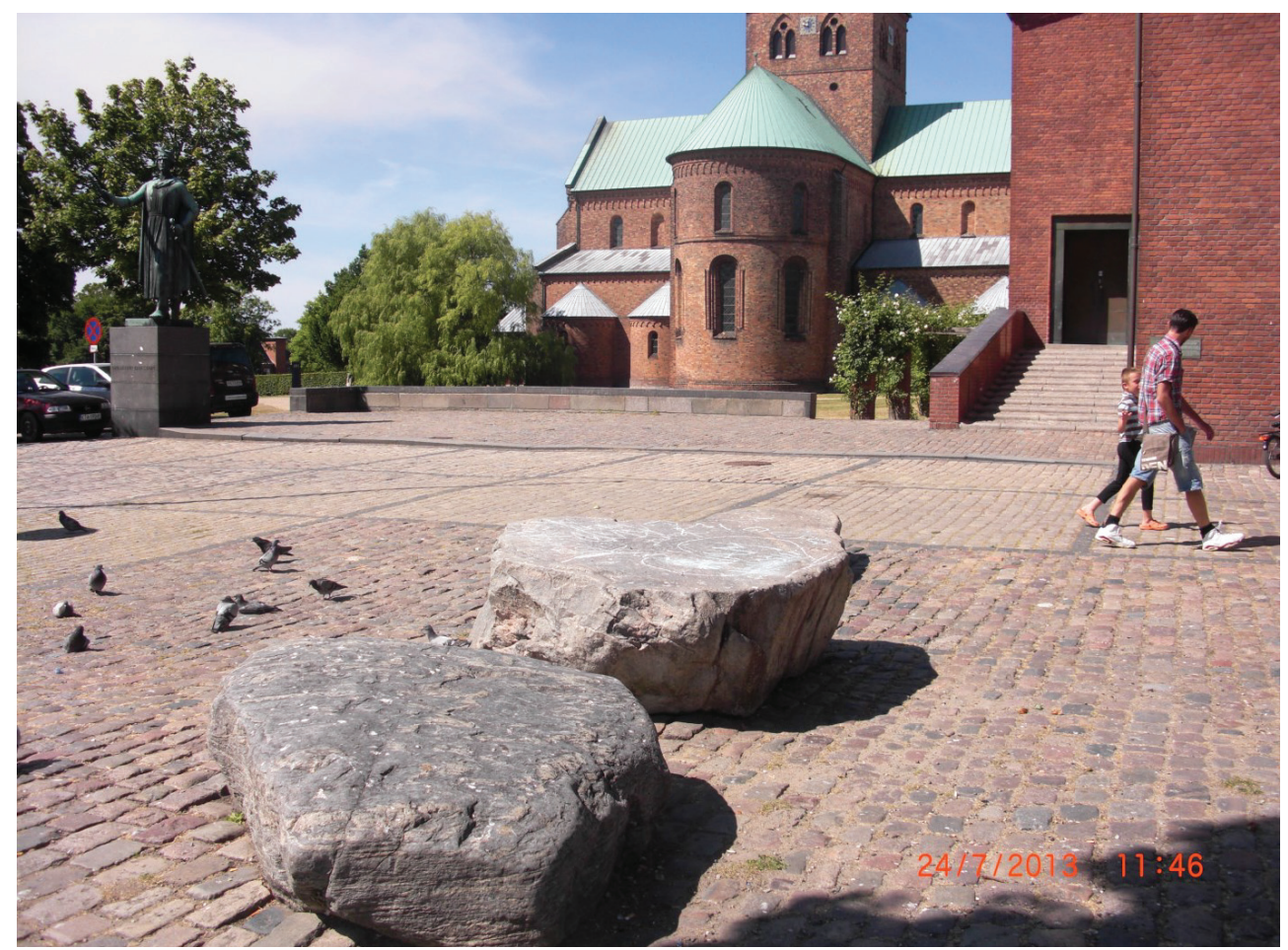

Figure 4.30 'The thing stones' (Tingstenene), located just outside St Benedict's Church in Ringsted, Denmark. Reproduced with the permission of Ringsted Tourist Information.

inauguration of Haakon the Good in 934. It seems that until the new succession law was introduced in II63/64, inauguration was enacted in a common format in Norway. According to these traditions, all sons whether illegitimate and legitimate, from the last or earlier supra-regional kings (landkonger), had the right to request a royal election. The potential king could be awarded all the land, half the land or smaller parts, depending on whether he had brothers or others to rule jointly with. A joint kingdom ruled by brothers was commonplace. The new succession laws favoured the oldest son, and tentatively promoted a move to hereditary kingdoms with sole rulers (Taranger I934, I I3).

The inauguration assembly is the royal thing most frequently mentioned in the sagas. Inaugurations before II 50 are discussed by Taranger (I934, III), who uses this saga material, especially Heimskringla, to suggest how potential kings had themselves inaugurated at various things. He states that royal names were given at the lawthings, and that earlier this authority was associated with the (ON) fylkisping (Taranger I934, II3-I24). Haakon the Good was allegedly appointed king at the thing of Opplanda and in Trøndelag (possibly at one of the courtyard-type sites discussed in the next chapter; see Iversen $2017 \mathrm{C} ; 20 \mathrm{I} 7 \mathrm{~d}$ ), and gave royal names to 


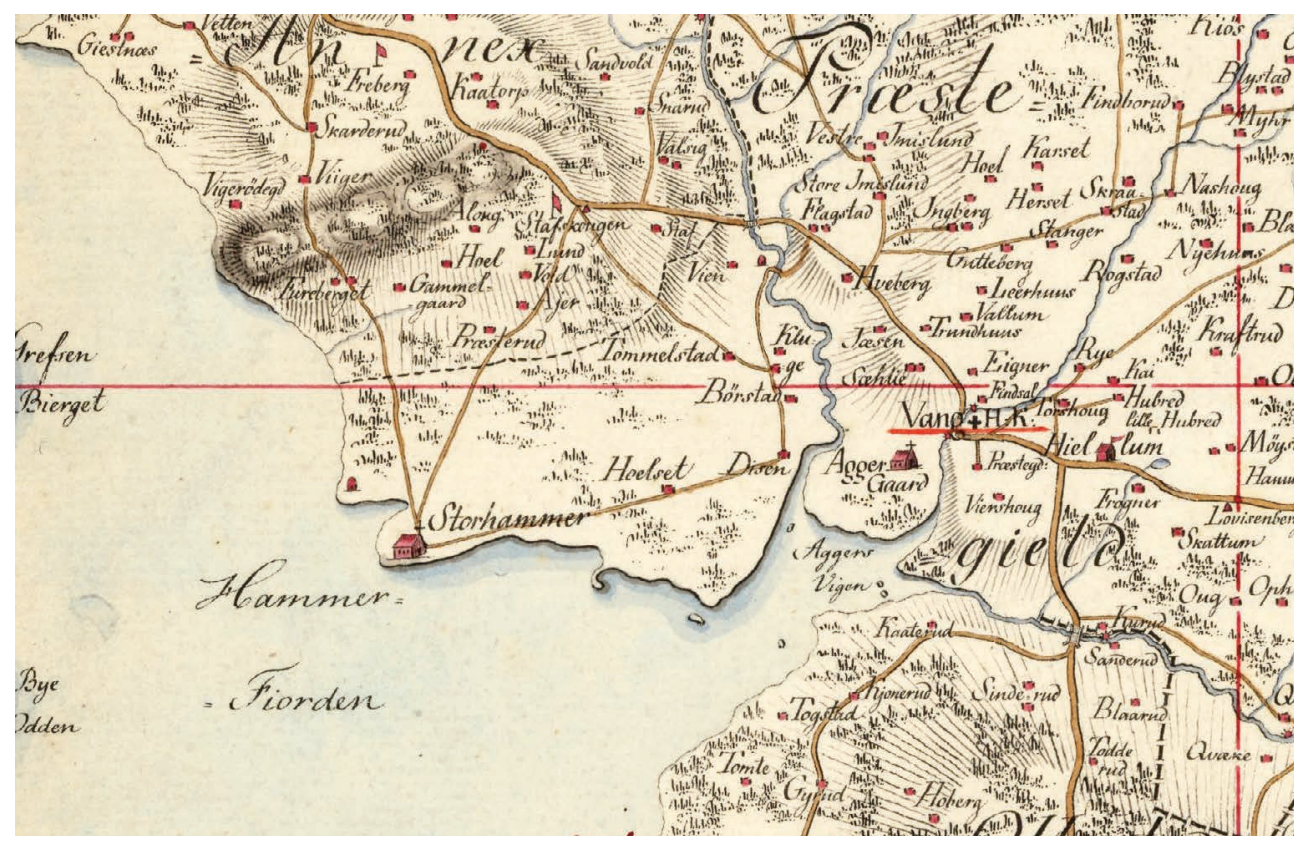

FIGURE 4.3 I In Norway, 38 inaugurations are recorded before c. I 269: I7 at Øyrathing by Trondheim, 5 at Haugathing by Tønsberg, 5 at Borgarthing by Borg, 3 in Bergen, and 3 at Opplanda and Romerike where the site of the inauguration is uncertain, but it may have taken place at Åker i Vang. This map of I 804 shows a straight road leading from the town of Hamar (marked Storhammer) towards Disen and Åker (marked Agger), Norway. It may or may not be an old processional road. When passing Disen and the river at Elvsholmen (the River-island), the largest prehistoric burial mound in the county of Hedmark is located at Midstranda (part of Åker), with a diameter of c. $50 \mathrm{~m}, 6 \mathrm{~m}$ in height with a flat top (ID 52544). CC BY-SA 3.0.

his petty kings in Viken (Taranger I934, I42). In this context, Taranger argued that a legitimate king could, in principle, transfer royal power to petty kings as he wished.

After the new succession laws of $1 \mathrm{6} 63 / 64$, further succession laws were introduced in I260 and I273 (Helle I972). The new laws of II63/64 introduced a defined hereditary succession, and asserted that it was the oldest legitimate son of the king, who had the primary right to the throne, thus putting an end to older traditions and signalling a move towards the single realm of Norway as a principle (Taranger I934, 293). Between II63/64 and I260 some 38 inaugurations took place (Helle I972, I30). Seventeen of these are recorded at the Øyrathing by Trondheim, five at Haugathing by Tønsberg (I I85, I I93, I 204, I 205, I 217), five at Borgarthing by Borg (II96, I 204, I 205, I207, I2I7), three in Bergen (II6I, I2I7, I240), and three at Opplanda and Romerike where the site of the inauguration is uncertain, but it may have taken place at Åker in Vang (I I62, I I66, I 226) (Figures 4.3 I and 4.32). 


\section{MIASEN}

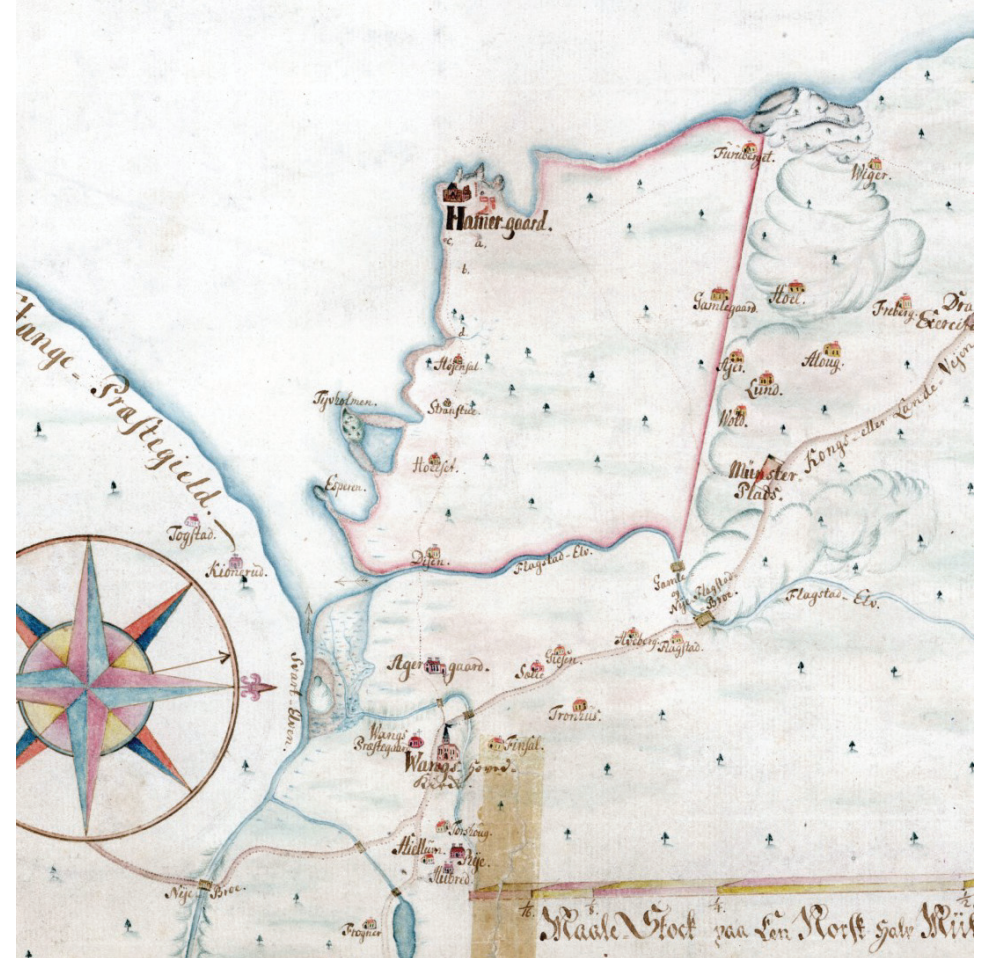

Figure 4.32 This I7I2 map shows the medieval jurisdiction of Hamar town (marked red). The Elvsholmen site sits on the border of the urban and rural jurisdiction between Hamar and Åker. CC BY-SA 3.0 .

In addition there were single inaugurations at Kaupanger in Sogn (I 2OI) and in Oslo (I226). Fillipus Simonsson was given his royal name at the Maria cemetery in Borg in I207.

Haakon Haakonsson, who stood behind the succession law of I 260 , received his royal names at three things in Ranrike in I 2I7, at a meeting in the hundred of Vettne, at Hornboruthing by Hamburgsund, in the hundred of Kville, and at Älvbakke by Kungälv/Konghelle $(\mathrm{HH}, 45,49)$. For the area of the Gulathing, Haakon received his royal name by Kristikirken in Bergen in $\operatorname{I} 2 \mathrm{I} 7(\mathrm{HH}, 45,49)$. The inauguration sites used at this time are diverse. Those situated in towns and by churches can be assumed to arrive only with urbanisation and Christianization from the I Ith century onwards. This applies to Kaupanger in Sogn, Kungälv in Bohuslän, Kristikirken (Christ Church) in Bergen and the Maria cemetery in Borg. The origins of the Øyrathing, Haugathing, and the Åkerthing (Åker in Vang) are more unclear. They were all located close to 
I Ith-century towns. Recently, it has been argued that Svein, the son of Canute the Great and Ælfgifu of Northampton, was the first to be inaugurated at Øyrathing in I029-30 (Iversen 20I7d). The latter two were, however, in a rural context, situated outside the medieval town area of Tønsberg and Hamar. In recent years, a large cooking-pit field has been identified and partly excavated at Åker, dating to the 6th8 th centuries. These types of site, explored in more depth in Chapter 5, attest to largescale and repeated gatherings of people in the open air, where cooking and eating together may have been a central part of the ritual activity. The site at Åker is not yet published, but was most likely related to some sort of repeated gathering. The Haugathing is discussed in much greater detail in the next chapter.

It is clear that the blessing of the Church was of political significance and a legitimising force throughout the Middle Ages; the first coronation in Bergen of Magnus Erlingsson in I $163 / 64$ would have been such an occasion. This coronation was a way of legitimising a child king who was not the son of a king. Taranger argued that this was an example of what he calls a 'flock kingdom', or a 'hird' or 'army kingdom'. It was a confederation of the members of the elite who backed the royal election. He pointed to similar processes at the elections of, for instance, Haakon Torefostre (1069-95) who was inaugurated at Opplandene and in Trøndelag, and was only king for a year, which meant his kingship was of limited importance (Taranger I934, 293).

The new succession rules of I I63/64 and especially I 260 seem to have reduced the influence of regional things on royal elections. Whereas earlier inauguration rituals took place at the lawthing and $(\mathrm{ON})$ fylkisping, this ended with the new law of I 260; Haakon Haakonsson stated that from I260 royal inaugurations were to take place at the Øyrathing (NgL I, 263; II, 309; RN I, 974). It was specified that bishops, abbots, lawmen and the (ON) hirð ('retinues and armed companions of the king') should meet with the I 2 wisest men from each bishopric (RN I, 974). These I 2 'public representatives' were appointed by the commanders of the hirð (ON hirðstjórer), and were paid for their journey if they had no royal estates and therefore belonged to the king's men. The same source demonstrates it was considered treason not to take part in an inauguration, and everyone should have set out for Øyrathing before one month had passed, after it was made known that the king had died.

Jørn Sandnes (I967) has argued that the Øyrathing was created by royal power as Nidaros was founded in the IIth century. The Øyrathing had two main purposes during the I 260 s: to approve new legislation and elect kings. Jørn Sandnes has pointed out that both the acceptance of law and the royal elections initially only applied to the eight provinces of Trøndelag, but that the Øyrathing became the leading inauguration site in the realm due to the political importance of Trøndelag, which was reinforced due to Olaf the Holy being buried in the Nidaros Cathedral (KLNM XXI, I I). Magnus the Good is said to have been inaugurated at Øyrathing and skaldic poetry suggests that King Svein was inaugurated here in c. I030, however, the Øyrathing is probably not much older and there are reasons to believe that inaugurations earlier than this may have taken place at the (ON) fylkisping or courtyard sites (Iversen 20I7d).

The most detailed account of a royal election is found in the succession law of I 273 (NgL II, 2I-32, comp. NgL I, 263-264 and NgL III, 44-49) and described in detail in Hirdskråen 'the law for the king's hird or army' (Chs 5-I I, NgL II, 395-399; Imsen $2000,7 \mathrm{I}-73$ ). This is a rare and important account that is worth considering 
in some detail. The royal election was on a feast day, or possibly a Sunday, and the thing was called according to old custom, i.e. through a summons. On the day that the election took place at the thing, a hird meeting was held; the hird and the future king negotiated amongst themselves the most important issues. The possible king had to renew the privileges of the members of the hird and improve them for those who had deserved it. The thing was called at dawn on the day of inauguration and the hirð presented itself in full attire (Mod Norw hoerbunad). The ceremony started in the church and the mass De spiritu sancto was sung and read for the future king, which was followed by several named prayers. After mass, the future king walked up to the altar and prayed for the mercy of God, and for the interceding of Virgin Mary and King Olaf the Holy. Upon this, the future king received the blessing of the bishop while kneeling. Crosses and other holy items were then carried in procession from the church to the thing.

At the thing, a high seat with several steps was set up, with one seat in the middle, the highest, which remained empty. The chieftains were to sit on the lower steps and the future king on the step below the highest seat. When the thing was ready, the foremost, either a learned man or layman, presented the future king with his royal name and recited a pre-ordained text (Imsen 2000, 69). After this the bishops, (Mod Norw) lendmenn, (ON) hirðstjórer and lawmen got up and lifted the king into the highest seat, and the learned men sang Te deum and the laymen Kyrie elesion. The next step of the ritual was the royal pledge where the king swore to uphold the Christian law that was introduced by Olaf the Holy, and later laws that applied to all subjects born as well as unborn. Upon that dukes and earls swore allegiance to the king, followed by the lendmenn and farmers. The day after the royal election the henchmen pledged allegiance to the king. While this is a 13 th-century account, the elevation of the king is striking and must have created a symbolic visual effect, rendering all other leading persons from the realm subordinate. It also testifies how important it was for a new king to negotiate in advance of the inauguration with the hirð and gain the support of the Church.

Around $\mathrm{I}_{3} 80$ the coronation and inauguration ritual was moved from the Øyrathing to Graderne at the nearby archbishopric cemetery in Trondheim. Graderne was the 'royal seat' (Swensen I964) and was supposedly raised over the altar of the older Mariakirken (Church of St Mary), which was demolished at the end of the I 2 th century (Swensen I964, 502).

Inaugurations took place in Norway during the time of the Kalmar Union and the following union with Denmark until I648 and delegates from different areas took part. In I 548 the king's oldest son Frederik was inaugurated in his father's place (Christian III) in Oslo. These were important events where the conditions between the elite, people and king were negotiated. After the Reformation of I 537 royal inauguration moved to Oslo/Kristiania (from I624) (Akts no st hist I, I-25, 37-I I9, II, I-306), but the tradition ceased in I648 (Imsen I974e).

\section{Inauguration in context}

Inauguration and royal elections formed the ceremonial celebration of the hereditary king in his office. A change in custom can be perceived over time that ran 
parallel to the development of smaller regional kingdoms in the Viking Age into the larger unified kingdoms of the Early to High Middle Ages, and then the joint kingdoms and Nordic unions of the Late Middle Ages. While the evidence is not comprehensive in its survival, it seems that there were fewer inauguration sites in Norway, whereas in Sweden and Denmark, the inauguration custom was more prevalent as a rite and there were more places of inauguraton and the tradition continued throughout the Middle Ages.

After I 60 , inaugurations in Norway were conducted in places closely related to the king. The kings of Norway created inauguration sites near their royal estates. One example is Haugathing, situated in between the royal estate Sem and the royal town of Tønsberg. The Øyrathing, discussed above, which became the most important place of inauguration in the whole kingdom, was also situated by the royal estate and townby Lade and Nidaros. In Denmark the inaugurations at the landsthing took place throughout the Middle Ages. It is also evident that inaugurations before mid-I2th century in Norway took place at rural thing sites, maybe at both the fylkisping and lawthing. According to the Older Law of Västergötland from the I220s, the Swedes could still appoint or reject kings (Holmbäck and Wessén 1946, 36). New kings were initially elected by the people of the three folkland units of Tiundaland, Attundaland and Fjärdrundaland. The election was then sanctioned by the lawman of Uppland. The same scenario was to be played out by the lawmen of the rest of the kingdom on the Eriksgata, where inaugurations took place on a journey through the various law provinces. The final inauguration took place at Mora thing were the future king was lifted onto 'the stones' at Mora (SL 47; Zachrisson 2010, I67). This, along with other potential pre-Christian elements of the Coronation ritual, such as the use of stones, shields and chairs, might point to the retention of early rituals (Sundqvist 200I, 628). After all had been completed, the coronation took place in Uppsala. This was clearly a later addition to the rituals of royal election and inauguration.

The Hirdskraien also describes the exaltation of the king in the Norwegian inauguration ritual. By this time, Christian elements, such as mass and singing in the Church of St Mary (Mariakirken), had already been made an integral part of the ritual and preceded the actual royal election which took place at the thing site. The Øyrathing and Frostathing form an interesting parallel to Mora thing and Gamla Uppsala in Sweden. Both Mora and Øyrathing were the primary inauguration assemblies of their respective realms. Both were situated near top-level provincial assemblies and archbishoprics: Uppsala and Nidaros. Both were also located in important agricultural areas. Kings who wished to gain power over the whole realm depended on the support of the archbishop and these important provinces in economic terms. In Denmark, Viborg was given an especially important role in the royal inauguration ritual, perhaps because Jutland was the most important province with the most hundreds. A close relationship is evident across all three kingdoms between the political importance and size of a province and the hosting of places for inauguration rituals. From I397 onwards, when the three Scandinavian kingdoms joined the Kalmar Union, royal inaugurations and coronation rituals changed.

In sum, there are hints of early traditions in the evidence for inauguration rituals and places, in the mentions of stones and mounds, and the correspondences of some sites with cemeteries and earlier prehistoric places of gathering. The elevation of 
prospective kings on stones, chairs, shields, and perhaps mounds, during the rituals also has correspondences with traditions of inauguration known from medieval Ireland and Scotland (see Chapter 2 and FitzPatrick 2004a). It is, however, very difficult to prove an early origin for these kinds of king-making rituals. It is worth noting that in Elizabeth FitzPatrick's work on inauguration sites and rituals in Ireland, there is considerable evidence for the invention of inauguration traditions in the medieval era as well as some suggestion of early pre-eminent locations for royal ritual and assembly (FitzPatrick 2004a). It is in the evidence from Sweden in particular, that the patterning of inauguration sites and thing sites implies a connection to types of itinerant ceremonies that could have evolved in relation to the need for chiefs and kings to win support for their claims to power (Sanmark 2009). Likewise, the tentative evidence for the co-location of inaugurations and thing sites in medieval Denmark and, to an extent, Norway, points to similar kinds of regulating processes for elite power.

\subsection{DISCUSSION}

This chapter has provided an overview of the thing organisation present in the three Scandinavian kingdoms from the Viking Age until the I4th century. The general idea of the thing in each realm is the same, with administrative units and associated thing sites comprising a hierarchical system of division and authority. The terminology used varies between and within kingdoms, showing the importance of local custom and tradition for legal practices (see Figure I.8). The least variation is found in Denmark, but that may be an artifice of the documentary source material. Evidence of an intermediate (regional) level of administration is sparse, found only in Norway, suggesting that top-level and local assembly sites carried the most value (evident too in the Norse North Atlantic settlements, see Chapter 6). The top-level assemblies gained their superior status on the basis that they represented the largest administrative units (the law provinces) and thus hosted larger numbers of participants and attendees than the local and regional assemblies. In Norway and Denmark, the law provinces were subdivided into law districts (ON lögsókn), which although they shared the same law, had their own top-level lawthings or landsthings. It is not known when these districts were introduced, but they were evidently in place in Norway by the $\mathrm{I} 3$ th century. These districts may well reflect older administrative units that gradually merged into larger provinces. This idea is supported by the pattern observed in Sweden, with 'The ten hundreds' of Småland and the three folklands of Uppland. It is at the local level that the largest differences in terminology are found (see Figure r.8). Despite this, these units seem to have operated in similar ways across the three kingdoms. This alone is compelling evidence for the dynamic nature of the thing. While the word itself survived for centuries and was revived (see Chapter 2), the thing system even in the Viking Age and medieval eras was subject to adjustment. It is important to stress, therefore, that the thing systems in each kingdom were far from stable. As the three Scandinavian kingdoms were unified during the course of the Middle Ages, royal reforms took place. These are most clearly seen in the royal laws issued in late $\mathrm{I} 3$ thand I4th-century Norway and Sweden, and less is therefore known about changes in Denmark at this time. The evidence shows that kings tried to simplify and streamline 
the existing systems, while also increasing their control. Over time, the numbers of meetings and levels of negotiation were reduced. Initially the purpose of thing hierarchy must have been to regulate legal disputes in neutral courts at different levels: from local feuds to provincial-level disagreements. Due to increased royal control and changes to authority on the ground, through the development of towns, control over dispute resolution was, however, increasingly tightened and restricted.

Later royal and church administrative regions developed with churches and various types of royal farms as centres. Towns had their own sets of laws and also their own thing sites. This seems to have been the case from the early Viking Age. As the trading centres and proto-towns grew and developed into 'proper' towns with bishops and royal estates and castles, an amalgamation of town and countryside can be observed. Across Scandinavia, by the I 3 th and I4th centuries, almost all rural assemblies had been abandoned in favour of new thing sites within the towns. In this way, power was centralised and the king could control both the assemblies and associated activities, such as trade. Further changes took place over time. There is some evidence for things being moved to, or being joined by, a church. Later it was frequent for both local and top-level things to move indoors, most likely because of the greater emphasis placed on written minutes. This shift can be observed in towns, for example in Odense were assemblies were held in the 'Black Friars' monastery in the $5_{5}$ th and I6th centuries. On a local level, indoor meetings are recorded above all from the I 7 th century, when most communities had their own 'thing house' or 'thing cottage', providing indoor facilities for the meetings (Imsen I974a, 59; Sanmark 2009).

Moving back in time to the earliest outdoor top-level assemblies, it is clear that these sites share some strong characteristics. They were in most cases found in striking natural locations, by key communication routes. Accessibility is, unsuprisingly, a key attribute. What is perhaps important, however, is the location of assemblies and some inauguration sites at places where a range of land and water routes converge. Some assemblies were also located at boundaries where the borders of several districts met. While placing meetings on boundaries in very accessible locations has functional benefits, such choices may also be ideologically charged. These kinds of location were common to all-a form of 'no-man's land' where no one participating group could claim any control or precedence (Pantos 2002). There are hints as well that locations can reflect connections to key resources: a fording place or bridge for example, wetlands, heath and grazing land. These aspects could be important, denoting reasons for meeting, both in terms of seasonal activities and perhaps the need to negotiate the sharing of access or maintance of collective assets (Semple and Sanmark 2013). The relevance of water to the situation of the thing is very notable across Scandinavia. Islands, isthmuses and sites bounded by marsh, wetland and watercourses are regularly encountered in these Scandinavian countries. The Frostathing in Norway, for example, was located in the area around Logtun which was elevated and next to wetlands and bounded by water at least on one side (Sanmark 20I7a, 99). There are numerous examples and it is worth considering that the importance of water as a boundary feature can be found in many written sources (Riisøy 2013, 33-34) and islands and water-enclosed sites sometimes carry sacred associations (Zachrisson 2004). Elevated topographic positions seem to have been favoured as well, and promontories. 
While some of the most striking sites are found in Sweden, many top-level assemblies had long biographies and prominent remains, as exemplified by the Frostathing and Gamla Uppsala. Mounds-perhaps older burial mounds-had an important part to play. They functioned as site markers and perhaps as platforms used during thing rituals, but they must also have offered an ancestral presence. Mounds in Scandinavia were strongly connected to land-ownership. (ON) Oðal land was land that belonged to individuals 'which could not be sold except when forced by necessity' (Iversen 2008; Zachrisson I994, 220). This kind of land-holding was central to power in Viking-Age Scandinavia. It was a way of determining legitimate inheritance, lineage and legal rights and was also relevant to claiming kingship (Sanmark 20I7a, 85). Some of the medieval regulations that survive regarding proving land-ownership mention the relevance of mounds for claiming ancestry and descent (Zachrisson I994, 220-22I; see also Iversen 2008; Sanmark 2017a, 83-86). Such ideas appear in Irish written sources as well for the early medieval and medieval eras describing rituals involving mounds linked to land claims (Charles-Edwards I976) and the regular use of mounds as loci for inauguration sites (FitzPatrick 2004a). Sitting on mounds is a theme present in both 'Celtic' and Scandinavian traditions of expressing elite power, rightful kingship and seeking inspiration (Brink 2004a; 2004b; Ellis-Davidson I964). Both FitzPatrick and Sanmark have enphasised the ritual importance of sitting, either in terms of enthroning a king, or being seated, at an assembly (see FitzPatrick 2004b, I3I-I72; Sanmark 20I7a, I09-II2). This may explain some of the connections here between assembly and stones, benches, timber platforms and defined spaces for performance. The rituals of inaguration mentioned here also include varied practices for elevating a king on a stone or throne, something explored by Olof Sundqvist in relation to broader evidence from the continent for the elevation of newly elected kings on stones, shields and chairs (2016, 492-497). It is notable too that assembly sites in Scandinavia are situated in relation to palimpsests, where more than one monument and monument type is present and the ages of these monuments are varied (Semple and Sanmark 20I3). This is also a feature of royal sites in Ireland and Scotland (Driscoll I998; Newman I998; Warner I988).

In the latter regions, there has been more interpretative emphasis on the idea of invention. Such associations are considered conscious expressions of power with the past drawn upon to set the scene of the enactment and expression of contemporary elite ambition (FitzPatrick 2004a; Semple 2013, I93-223). Alongside the presence of mounds, there are a few cases where assemblies are situated in relation to earlier cemeteries and burials. This, of course, connects well to the ideas presented above on the importance of ancestors to land claims and to signalling rightful power. It is worth noting that recent evidence points to this being a feature as well of early medieval English meeting-places, with some recent striking examples where a late Anglo-Saxon assembly site is situated in relation to complexes of early Anglo-Saxon burials (as well as burial mounds) (Brookes 20I9; Reynolds 20I8). In Ireland too there are striking associations with the (OIr) óenach or popular assembly (Gleeson 20I8). Various other types of thing architecture have also been identified, again mostly at thing sites in Sweden. At sites such as Bällsta and Anundshög in Sweden, stones were used to create settings for the thing. Five stone ship-settings were probably added to the site at Anundshög in the Vendel or Viking Age, while the square setting of 
stones at the assembly site in Bällsta, Uppland, Sweden remains undated. Linear stone monuments are found at assembly sites too, such as Aspa Löt (Figure I.4), Kjula ås and Ängebyvad, while the first written evidence for the thing comes from runestones raised at thing sites in the I Ith century (Brink 2004a; 2004b; Sanmark 20I 5; 20I7a, 76-II7; Sanmark and Semple 20I0). Two such rune-stones erected around $\mathrm{AD}$ IOIO-I 5 survive at Bällsta (SRD U 225 and U 226). These stones are standing on a terrace, most likely constructed for meetings, together with a slope forming the 'stand' for the audience. The runic inscription attests to the 'making' of the thing site as a memorial and presumably to the creation of the square setting of stones (Sanmark and Semple 2010). The excavations at Anundshög in Västmanland, Sweden, have also provided evidence of a long row of timber monumental markers or posts (Sanmark and Semple 20 I I, IO-I 2), something also attested now through excavations at Gamla Uppsala (Beronius Jörpeland et al. 20I3; Sanmark 20I7a, 63-64).

It is striking here, however, that despite these commonalities, there are also distinctive regional and even local differences in the situation of assemblies and assembly architecture. In Norway, as the next chapter will explore in more detail, relationships with burials, mounds or monumental palimpsests are less commonly attested than in Sweden. There are, however, marked associations between places with excavated evidence for late prehistoric and Migration-period gatherings and later documented thing sites. The assembly places of Denmark are also much less demonstrative in terms of using pre-existing features or being located in topographically distinctive situations. Such variances may, of course, reflect an imbalance in how law and administration have been explored in each country. The meeting-sites of Sweden do, however, stand out, in terms of well attested archaeological evidence for sites with a complex multi-period architecture, linkage to routes used for the expression of elite and royal power. In Sweden, too, there is good evidence as well for the kinds of precursor gathering activity explored in relation to case studies in Norway in Chapter 5, attested by hearths and communal cooking that predate the more monumental settings of the Viking Age.

The Scandinavian inauguration sites shared similar characteristics to the toplevel assembly sites, and it is notable that on several occasions top-level provincial assemblies and inauguration sites coincide in all three kingdoms. In Norway this is particularly evident for the earliest inauguration sites. Later, fewer sites kept the right to appoint kings, and the act became highly regulated. By I 260 only one site in Norway was regarded as the legitimate inauguration site. In Denmark, in contrast, three or four sites kept inauguration rights during the Middle Ages, maintaining the structure of the three law provinces. There was, however, a hierarchy between the sites, with Viborg ranked first. It is interesting to note that many inauguration sites were located on royal land. This is clearly seen in Denmark where all the major sites (Viborg, Lund, Ringsted, Odense) around I 230 were bona regalia (Lat.) (kungalev). Bona regalia is defined as the crown's institutional property, as opposed to the personal lands of kings - the bona patrimonalia (Lat.) (Iversen 20II). The situation was similar in Norway, where all inauguration sites had close ties to royal land or towns. In some cases, however, these sites seem to have been located also on 'neutral ground', on boundaries between the most influential areas. This was the case at Mora in Sweden, which was situated on the boundary between Tiundaland and 
Attundaland, two of the most important and most densely populated administrative units in Svealand. In other cases, inauguration sites were located on the boundaries between important royal towns and rural royal manors, for instance the Haugathing on the border between the royal town of Tønsberg and the estate of the royal manor Sem.

In Sweden the Erikgata was in place in the Late Middle Ages, involving travel and ceremony, for accepting new supra-regional kings, and evidence suggests that similar traditions may have existed in Denmark and Norway too. The core of these medieval inauguration rituals seems to originate in late prehistory, and although the Scandinavian kingdoms were Christian, old traditions were not abolished and instead new Christian ceremonies were added to existing practices. In this way, coronations became an integrated and crucial part of the itinerant rituals. Between I 397 and I 523 , the kingdoms of Scandinavia were joined together in the Kalmar Union, but despite this, each kingdom seems to have kept their own inauguration customs.

Over time, in all three countries, a greater Church influence can be discerned. This can be seen in the relocation of assemblies at times by or near churches but also in the establishment of churches near outdoor meeting-places (Ødegaard 2018a). This process of relocation is compounded by the general move to relocate things to urban areas and eventually to situate them indoors. All of this underlines that although evidence for early meeting practices is present in the Iron-Age and Migration periods, the functions and situations of meetings were fluid and subject to change over time, even during the early- to late-medieval eras. It is difficult as well to place inauguration places and rituals in this early frame. Such processes may be medieval developments in relation to the need for kings to win support and extert legitimate authority. In this context it is worth bearing in mind that the medieval and latemedieval emphases on 'correct' and 'ancient' traditions and places of assembly may itself be a form of invention, aimed, like the outdoor theatricalities of inauguration, at signalling the seeming ancient and inviolable nature of the assembly institution. Despite this, the frequent emphasis on a relationship with a large mound, burials or cemeteries is interesting as a common concern across outdoor thing sites and some inauguration locations. The presence of earlier evidence at some sites for hearths and cooking pits also suggests that in some instances meeting-locations may have been revisited and revived over time, or have continued in some form, developing from seasonal gathering places to more formalised locations for judicial and legal activity. As the next chapter on Norway will demonstrate, there are interesting relationships in some instances between medieval meeting-sites and indications of late prehistoric precursors, but the locus of activity was still fluid according to social, religious and political changes.

In conclusion, this chapter has highlighted the similarities and differences in terms of administrative units, assembly sites and inauguration sites across the three kingdoms of Norway, Sweden and Denmark. The strength of the assembly system is shown by its longevity, although it was regularly reformed according to real or perceived needs: as the geography of power and politics shifted, so did the thing sites and their architecture. 


\section{CHAPTER 5 \\ LANDSCAPES OF LAW \\ IN NORWAY}

\section{I SUMMARY}

This chapter now moves on to examine Norwegian institutions in greater detail. Case-study regions provide an opportunity for in depth exploration of archaeological and spatial characteristics and the development of administrative systems and locations over time. Here we examine some of the earliest possible evidence for thing sites, including the cooking-pit type sites referred to in Chapter 4 and so-called courtyard sites of Norway. The nature and purpose of these gathering places are assessed and the scale of interests they served is quantified. The origin and development of the law provinces in Norway are evaluated and consideration is given to how small communities may have been transformed and merged into larger societies.

\section{$5 \cdot 2$ INTRODUCTION}

The thing organisation of the Borgarthing law province in eastern Norway may offer some of the very earliest evidence for collective gatherings that could be connected to the thing. It has been suggested that Trøndelag was the first province to submit to the expansion of supra-regional power, and that eastern regions were gradually integrated into a single political entity from the IIth century onwards (Sigurðsson 2008a). The case of Hålogaland is explored next-a province where the many 'courtyard' sites provide an opportunity for examining their connections to thing formation. This chapter then considers the Gulathing law province. This has been identified in previous scholarship as a likely geographical starting point for the rise of supra-regional power in the 9 th and Ioth centuries (Helle I982; 200I; Iversen 2008; 20I I; Krag I990; I993; I995). Finally the chapter reflects on what the evidence suggests regarding the presence and development of processes of collective organisation and the impacts of royal power across AD 400-I 500.

\section{$5 \cdot 3$ THE NORWEGIAN KINGDOM: THE HISTORIC THING SYSTEM}

The royal power in Trøndelag by the turn of the Ist millennium AD was held by the so-called Earls of Lade, who in the Ioth and early I Ith centuries were engaged in achieving alliances with the kings in Denmark (Johnsen I98I). In the IIth and I 2 th centuries, Norway remained unstable as a political unit, dominated by rival elites (Helle I995; Krag I995). Long-lasting civil wars characterised this period. 
At this time the Norwegian kingdom encompassed three distinct topographic regions. According to Historia Norwegiae (c. I I 50-75; Ekrem and Mortensen 2003, 55-60) these comprised: the coastal land or Zona itaque maritime (Lat.); the middle or mountain area, the Mediterranea zona/De montains Norwegie (Lat.) in inland southern Norway; and the land of the Sámi, De Finnis (Lat.), covering the majority of arctic northern Norway. The Sámi paid a large amount of tax and tribute to the kingdom but otherwise held an independent position, to some extent comparable to the tribute-paying areas of the Faroes, Shetland, Orkney, Iceland and Greenland called the skattlands (Wrrdahl 2006).

The coastal landscape of Norway, as we have seen, was, according to Historia Norwegiae, organised in four patriae (Lat.) or law provinces. These comprised Viken to the east (Sinius orientalis Lat.) (the Borgarthing area), the Gulathing (Gulacia Lat.), Trondheim (Trondemia Lat.), and Hålogaland (Halogia Lat.) (Figure 5.ra). As Chapter 4 outlines, the main thing within a law province was named lawthing. Different provincial laws applied in the coastal land: the Borgarthing Law in the south-east, the Gulathing Law in the south-west, and the Frostathing Law in mid- and northern Norway, including Hålogaland (Figure 5.rb). The Eidsivathing Law applied to the 'mountain lands', corresponding to Hamar diocese founded in the mid-I2th century. In the I I6os, the coastal lands covered by the laws of Borgarthing, Gulathing and Frostathing comprised 30 provinces in total, while there were just $\mathrm{I} 2$ in the mountain lands where the Eidsivathing law applied (Iversen 20I7a).

The largest units in existence prior to the formation of the patria (Lat.) were termed fylkir in Old Norse, meaning 'lands' and called 'folklands' by early scholars (Taranger I 898, II) although we equate it here as meaning a unit of division akin to a 'county'. These seem to have comprised judicial units and were served by the (ON) fylkisping, the 'county-thing'. This thing served the county, but some 'halfcounty things' (ON hölfuping) existed as well. The counties were further subdivided into even smaller units with 'quarter-things' (ON fjórðungsping), third-things (ON priðjungsping) or (ON) skipreiðuping or 'things serving the ship-districts'. The 'ship-districts' termed $(\mathrm{ON})$ skipreiður in the $\mathbf{I}_{3}$ th century applied to the coastal areas of Norway. A skipreiða is generally understood as a territorial unit obliged to build and supply a war ship for the naval defence system (ON leiðangr) (Bjørkvik I970, 546) (see Chapter 4). The leiðangr is held to have been introduced in the Ioth century (e.g. Ersland 2000, 42-53), according to Snorri Sturluson's I 3 th-century account of King Haakon the Good [r. AD 934-96I] who also apparently introduced the skipreiða system (Hødnebø and Magerøy I979, 93). Some 270 skipreiður comprised territorial units originally related to the naval defence (Bjørkvik I970, 546; Hobæk 20I3, 65). Ship-districts were also judicial units, but in Hålogaland and eastern Norway in the Borgarthing province, the ship-districts were mid-level units and not local thing districts. This contrasts to the Gulathing and Frostathing provinces. The leiðangr, however, given its widespread appearance, was one of the few 'national structures' in the Norwegian kingdom prior to the I Ith century, and was allegedly organised during the reign of Haakon the Good (c. AD 920-960) (Ersland 2000).

Despite these top- and middle-level changes over time, the units functioning at the most local level of division or organisation seem to have been the most stable and to have had the deepest roots. Such units are known under various names in 
a

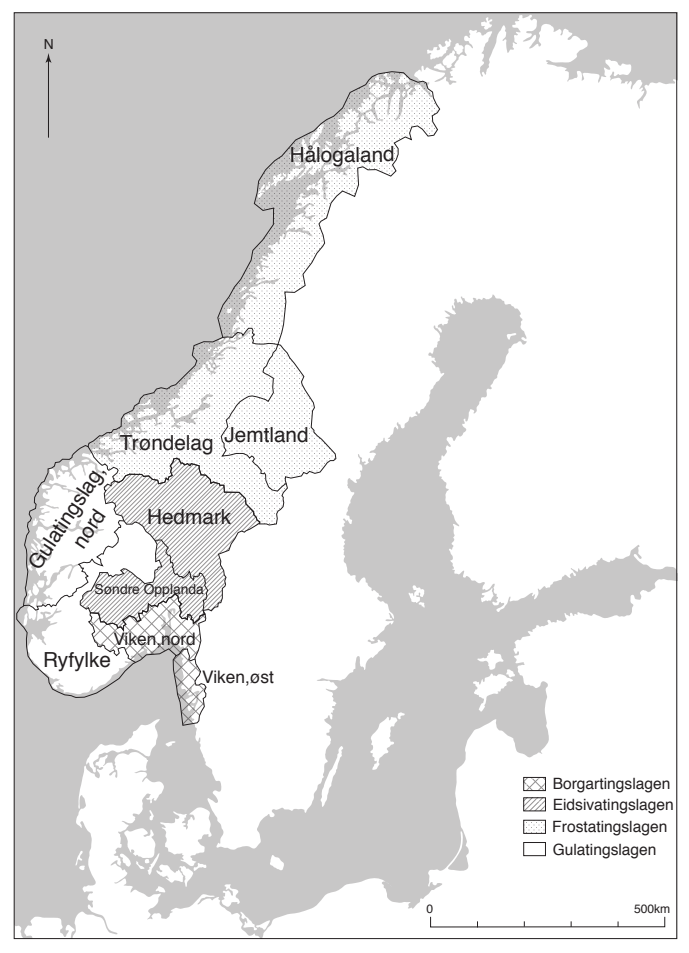

b

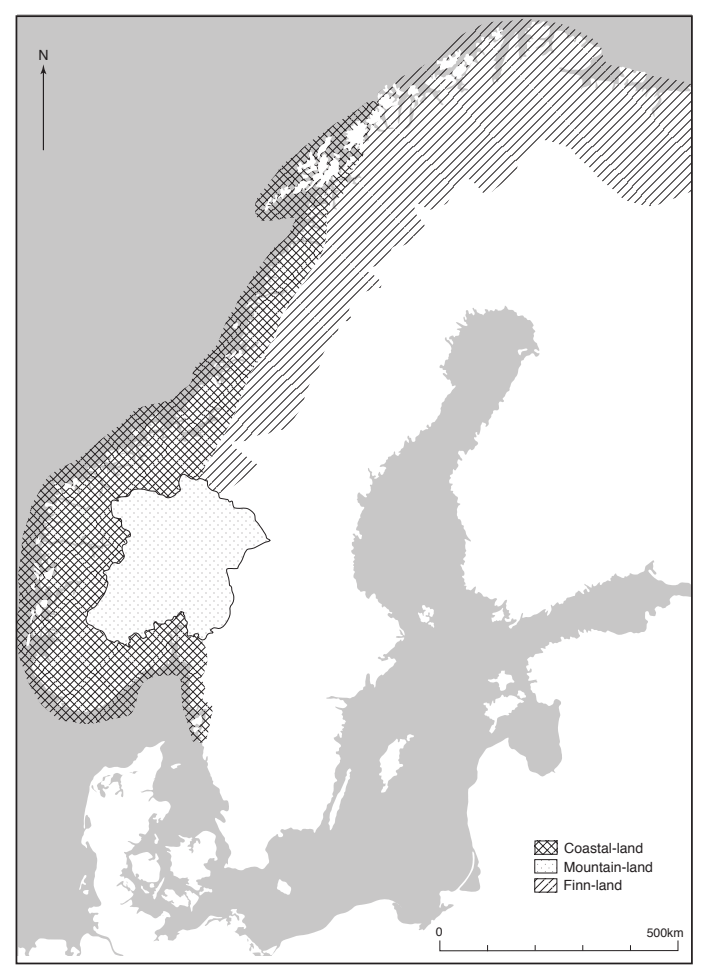

Figure 5.I a) Patria or law provinces of coastal Norway; b) the coastal and mountain lands and land of the Sámi. Main regions (I I 50-75), patria or law provinces (I I 5O-75) and law districts of Norway (I 223). The law districts are recorded in Haakon's-saga for the year I223. Maps by Frode Iversen and Yvonne Beadnell. 
different regions. The mid-I3th-century saga Fagrskinna ('Beautiful skin') uses $(\mathrm{ON})$ pinghá (ON há is from the verb heyja, meaning 'to hold' or to initiate) as a common name for a local thing district in Norway. In general though, local meetings were named $(\mathrm{ON})$ almannaping meaning 'ordinary' or 'all men' thing. The pinghá is a unit representing local communal organisation and corresponds to the English and central European hundred, also found in eastern Sweden. As explained in Chapter I, this level of organisation in this study is termed the 'local level' and was served by a 'local thing'. In total some 550 assemblies of this level were operational in Norway in the Middle Ages. These represented the basic unit of territory and were the building blocks for the half-, quarter- and third-counties and the ship-districts - the mid-level units.

The higher one moves up in the administrative framework, the more unstable the units become. The next mid-level tier of administration at least in some regions appears to have consisted of clusters of communities ranging from groups of around four or five to larger collectives of I4 or I 5 , as evidenced in Rogaland in western Norway (Iversen 20I5b) and Trøndelag (Iversen 20I7d). Representatives met regularly at a set thing. There is no common historical term for this level of unit, but it can be equated with the numeric units: the half-county, quarter, thirds, sixths and eighths and ship-districts. Mid-level things in Ryfylke in western Norway were still functioning as representational assemblies in the I620s, but were disbanded during the reign of King Christian IV [r. AD I 588-I648] (Iversen 20I 5 b).

Before larger law areas came into existence, at the top level, the county-thing served the $(\mathrm{ON})$ fylki. According to Taranger, this shire court had $\mathrm{I} 2$ members (Taranger I 898, 3I). Later, several hundred delegates attended supra-county meetings and illegitimate absence could result in fines. The most prominent men of the king attended together with the bishop and a certain number of appointed priests. A lawman led the proceedings; over time this role evolved, from an adviser to the court in the IIth and I2th centuries, to a regular royal judge by the late $\mathrm{I} 3$ th century. As the legal system was gradually integrated within a single kingdom, the lawman became the king's man (Helle 200I).

By I274, as Chapter 4 has already discussed, the highest-ranked legal assembly in Norway was termed (ON) lögping (lawthing) and this served the patria (Lat.) (L III, 2). The 'court' (ON lögrétta) comprised 36 members who were selected from a wider group of attendees, some from each county. The court-members were placed at the innermost area bounded by a $(\mathrm{ON})$ vébönd-a band enclosing an area which was perceived as sacred (ON vé) ( $\mathrm{L}$ III, 2). According to the I 274 law, 485 delegates were required to attend the Frostathing in Trøndelag and 90 are recorded similarly for the Eidsivathing. For the Gulathing law province, information exists that informs on fluctuations in the size of delegations: with a reduction in attendees from around 400 in the early IIth century, to 248 delegates in the mid-I 2 th, and I 48 delegates in 1274 (Helle 200I, 65; Iversen 2015a). Across this time-period the leiðangr, the system relating to naval defence, also changed; initially communities appointed men to crew the ships, by the early I 3 th century, this had been replaced by an indirect system based on taxation, which funded professional warriors for the king (ON hirð) (Ersland 2000). Less direct involvement in the defence system may have contributed to weakening community involvement in the top-level thing. 
These top-ranking legal assemblies were representational, drawing on a fairly large population. In the early modern period, the Borgarthing law provinces had some 220,000 inhabitants and the population would probably have been lower in the Middle Ages. In the Gulathing law province it is suggested that 400 delegates in the early IIth century represented a population of around $100,0 \circ 0$ equating to one delegate per 250-300 people (Iversen $2015 \mathrm{~d}, 9-10$ ). In sharp contrast, at a local level, meetings were not representational, all householders within the district gathered. Attendance was optional for widows (if householders) and those unable to attend (i.e. those who were ill or immobile), while those who ran their farm alone and without assistance were required to meet only at the three most important meetings: the manslaughter thing, royal thing and census thing (Eithun et al. I994, I03; G I3 I). A case would only be transferred from one level to another if the thing could not agree and there was no equivalent to the modern right to appeal (Skevik I997, I). The cases were probably brought to the most relevant court: local matters were treated locally and regional matters at a higher level.

In the Borgarthing law province, co-dependent regions were significantly altered around I250-I300, when changes were made both in the Borgarthing and Eidsivathing (Iversen 2017a; Ødegaard 2015, 96-99, I06-II2). Prior to c. I250, Grenland was under the Borgarthing and Upper Telemark under the Eidsivathing. Skien's hinterland was amalgamated under a new jurisdiction and the lawthing located within the town. This change encouraged increased interaction across the older law provinces, which was formative for the modern Telemark county (except Numedal). Significant changes occurred after $\mathrm{I} 223$ and the civil wars. Rural lawthings were relocated to the towns and the lawmen's role in town and countryside was conjoined (Seip I934, I6-24). The lawthings of Gulen and Avaldsnes in the Gulathing were absorbed by Bergen and Stavanger in the I3oos. The Borgarthing lost its overall function as a thing when new (ON) lögsókn 'law districts' were created around I 300 . Shortly after I 572 Frostathing moved to Trondheim (Nissen I956, 33).

While there were at least nine rural lawthing sites in $\mathrm{I} 223$, only Foss, Steigen and Eidsvoll remained in rural areas in I604. Konghelle or (MNorw) Konungahella, was a border town that was too impractically located to be the central lawthing for Bohuslän. Foss was more central, and perhaps remained the location of the lawthing for this reason. In scarcely urbanised Hålogaland, Steigen remained the thing site, and the town of Vågan did not have the gravity as town to attract the lawthing. As outlined in Chapter 4, Konghelle (Bohuslän) (partly), Borg, Oslo Tønsberg, Skien, Stavanger, Bergen, Trondheim and in addition Hamar in the mountain land, all took on the functions of the lawthing. These changes, on the western side of the Oslo fjord and in the southern mountain land, were the most extensive, as jurisdictions altered to meet the needs of these coastal towns.

\section{$5 \cdot 4$ THE BORGARTHING LAW PROVINCE}

This is the first examination of administrative areas and thing sites in the historic Viken region, later the Borgarthing law province, since the I950s (Ødegaard 2015). The age and origin of the oldest administrative areas and thing sites in Viken are disputed; by the end of the Viking Age there were significant regional differences 
between the law provinces in Norway, especially related to the location and names of assemblies, the extent of the administrative areas and customs and norms. Danish sovereignty of the Viken area from the 9 th $-\mathrm{I} 2 \mathrm{th} / \mathrm{I} 3$ th centuries may have created some of the administrative differences (Krag 1995, I77) and further obscured the traces of earlier arrangements.

The Borgarthing law province included four administrative levels in the Middle Ages, at the top the law province, followed by (ON) sýsla, 'work, business, to do something', later a term for an administrative district), (ON) skipreiður and (ON) fjórdungar (Figure 5.2). The law province was served by the lawthing, which in turn was divided into $(\mathrm{ON})$ sýslur each served by an $(\mathrm{ON})$ sýslumannaping $(\mathrm{L}$ I, 7). Each sýsla was composed from a number of skipreiður, which again were further divided into fjórðungar or quarters (Figure 5.2). Each skipreiða (or ship-district) was most likely served by four thing sites related to the fjoroungar, of which one also functioned as a local skipreiða-thing. As the Norwegian kingdom became more tightly organised via a central power, most of these administrative divisions appear in the sources with set boundaries, and by the High Middle Ages older terms like (ON) fylki-, half-fylkiand $(\mathrm{ON})$ herað had disappeared from the administrative terminology.

There has been indecision regarding the identification of the ON herad (hereafter hundred) as a judicial unit in the hierarchical sequence of administrative divisions, and regarding whether the hundred spread from Denmark to Viken (Bull 19г8; I920; Indrebø 1935, I59-168). In I9I I, Sven Tunberg argued that the bundred in Bohuslän, in modern Sweden, functioned as a judicial district, while the hundred units in eastern Viken were simply (ON) bygd or 'rural districts' (I9II, 79-86). Edvard Bull rejected Tunberg's argument in an analysis of diplomas that refer to the $(\mathrm{ON})$ heraðstefna identifying them as hundred thing sites. He also argued that the skipreiða (or ship-district) units replaced the older herað or hundred divisions (Bull I9I7; I9I8, 259-262). Another significant debate has centred on whether the skipreiða units also represented a Danish model (e.g. Bull I920, 50; Hertzberg I9I4, 247-249; Indrebø I935, 259), or whether they were introduced from western Norway

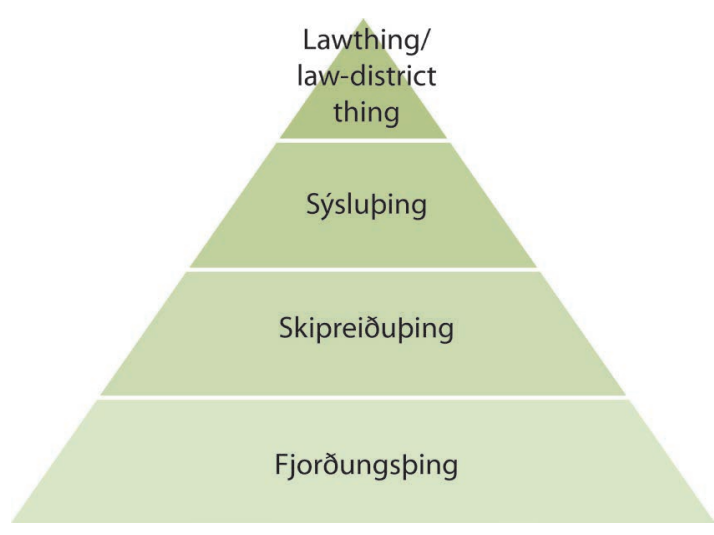

FIGURE 5.2 Model showing the tiered relationships between named types of administrative units in Norway. Diagram by Marie Ødegaard. 
by King Haakon the Good, who may in turn have been influenced by Anglo-Saxon military organisation across the North Sea (Ersland 2000, 5I; Lund I996, 45-47; Steinnes I929, 63-65). It is likely, however, that there existed some form of organised defence prior to AD 900-I000. This is supported by hillforts (normally dated to the first half or so of the Ist millennium $\mathrm{AD}$, although several of these were active in the pre-Roman Iron Age ( $500 \mathrm{BC}-\mathrm{AD} \mathrm{I}$ ) and in the Viking Age by courtyard sites (see below), by large boat houses (AD IOO-I500) (Grimm 2006; Myhre I985; I987a; Ystgaard 20I4) and beacon systems, mentioned in the Gulathing and Frostathing laws (G 3 I I, F V I).

In the first half of the 2oth century, many scholars in Norway and Sweden identified thing sites based on the evidence of diplomas and place-names (see Chapter 2). Close connections were suggested between thing sites and cult practice, guilds and activities such as horseracing and markets. Meeting-sites were generally considered to have been located centrally in the rural districts and to have remained in use from pre-Christian times up to the Reformation (Bugge I920; Schledermann I974; see also Ødegaard 2018a). Their exact location in the landscape was infrequently discussed, however, and apparent differences in function and relationships with administrative areas were also rarely studied from a broader context. As a result there was little to no consideration of why several thing sites might be recorded within the same rural district (e.g. Bugge I920, I I0; Bull I924, I43; I93 I, 64-65).

In I935, Gustav Indrebø examined the prevalence of thing sites in relation to the skipreiður and fjórðungar or quarters. He distinguished two levels of rural administration: one related to the quarter division and another served and common to the full skipreiða area. His study has been criticised because he predicated his arguments on numeric calculations and this led, in the eyes of some scholars, to an oversight in not acknowledging the potential of organic development for thing organisation in some areas (Holmsen I940-42, 360-362). Nevertheless, there are some numeric correlations evident and these may well help tease out levels of organisation and the development of administrative structures before the $\mathrm{I} 2$ th century.

\section{Administrative organisation in the Borgarthing law province}

The sources that attest to the oldest organisational structure of the law province are sparse and mainly comprise sagas and provincial laws. Both Fagrskinna (Jónsson I903, Ch. 93) and the Saga of Olaf the Holy (Heimskringla, Ch. 6I) mention the founding by King Olaf II Haraldsson [r. AD IOI 5-IO28] of a fortification and town at Borg in IоI 6 and how the king enrolled all men in the sýslur. It is assumed as a result that he also established the lawthing at Borg (Hertzberg and Brandt I874, I 44-I45). The remains of Olaf's fortification have been examined archaeologically and may date to the first half of the I Ith century (Opstad I976, I25-I40; Stylegar and Norseng 2003, 435-437). It is thus likely that the Norwegian kings began to achieve supremacy over the area from the Danes in that period (Krag I995, I77).

The ecclesiastical regulations of the Borgarthing law, elements of which may date from the first half of I Ith century (Rindal 2008, xxiii; Spørck 2009, I 57), represent an important source. This law presupposes the existence of six fylki (county) churches (i.e. main churches) situated in three counties of the law province (B 8). In practice, 
this can be used to argue for a half-fylki division (Taranger I 887; I935, 27), which corresponds to the historically attested sýslur. The sýslur were probably introduced by the king, as they were fiefs managed by the king's 'faithful' men, and may have appeared as early as the Ioth and IIth centuries (Norseng 2005, 6I-62). There is no knowledge of thing sites serving the fylkir (counties), but their existence cannot be ruled out. It is possible that the thing of the sýsla or the main lawthing replaced them.

According to the will of King Magnus the Law-Mender [r. AD I263-I280] from I 277 (DN IV, 3), the coastal Viken area was divided in 48 skipreiður. In our study, 52 possible skipreiður have been identified from medieval sources, implying that the number of divisions may have changed over time. Complete accounts of the skipreiður are not found before the I6th century, by which time the number of skipreiður had been reduced from I 6 to I 2 in Borgarsýsla (today represented by Østfold county). It is not clear why and the consequences of these changes also remain uncertain. The exterior parts of Viken were not part of the naval defence, and thus not divided in skipreiða, and their administrative system is unknown. Since the skipreiður boundaries, and thus perhaps the older herad, often coincide with the natural topography, they may be derived from older divisions between rural districts (Bull I9I 8; Jørgensen I974, 235-236). The different sizes of the skipreiða/herað units and unequal distribution of the fjórðungar suggest variations in the operation of these administrative systems between regions perhaps due to temporal or political changes (Bull I920, I42-I43; Ødegaard 20I5; Steinnes I929).

Each skipreiða is thought to have hosted four fjóroungar or quarter-thing sites, one of which served as a common meeting-place for the entire skipreiða (Indrebø I935, I36-I68). They assembled once a year to manage and control the weapons for the leiðangr fleet, thus managing the naval defence (e.g. F X, 3; G 309; L III, I 2). It was the king's representative, the $(\mathrm{ON})$ sýslumaðr, 'a royal official or 'count', who oversaw the weapons, read the royal ordinances and, later, collected taxes. This thing thus became an arena for cooperation between royal representatives and householders (Dørum 2004, 387; Imsen I990, I93-I98). The sýslumaðr is rarely mentioned in diplomas, indeed, the medieval written sources scarcely specify the functions of the different rural thing meetings. Only a few diplomas dated between the I 4 th and I 6 th centuries offer any detail, with three sites being referred to as a 'weapon thing' (ON vápnaping) sites (DN II, 804/ I454; DN VI, 45 I/I434; DN XVIII, 79/I 460; NHD 2 $\mathrm{r}$ III (2):25/I6II). By studying thing sites in relation to the administrative areas, the skipreiða-things or 'weapon things' can be differentiated from the quarter-things as such sites are located centrally in the skipreiða, have good communications and were visited more frequently by public officials like the sheriff (ON lénsmaðr) and bailiff (ON foguti) (Ødegaard 201 5, 277).

As mentioned above, the oldest secular sources for Viken indicate three fylkir (counties) existed (B 8) in the IIth-I 2 th centuries, generally assumed to be Vestfold, Vingulmork and Ranrike (Munch I852, IOO-IO2) (Figure 5.3). According to the Saga of Haakon Haakonsson ( $\mathrm{HH} \mathrm{Ch.} \mathrm{94),} \mathrm{two} \mathrm{lawmen} \mathrm{from} \mathrm{Viken} \mathrm{attended} \mathrm{a}$ large political meeting in Bergen in I 223. One came 'east from Svinesund', which corresponds to Ranrike fylki (modern day Bohuslän, Sweden), and it is evident that the second lawman's jurisdictional area, the law district (ON lögsókn), was the rest of Viken (Vestfold, Vingulmork and Grenland) (Indrebø I934-36, 492; Ødegaard 201 5 , 


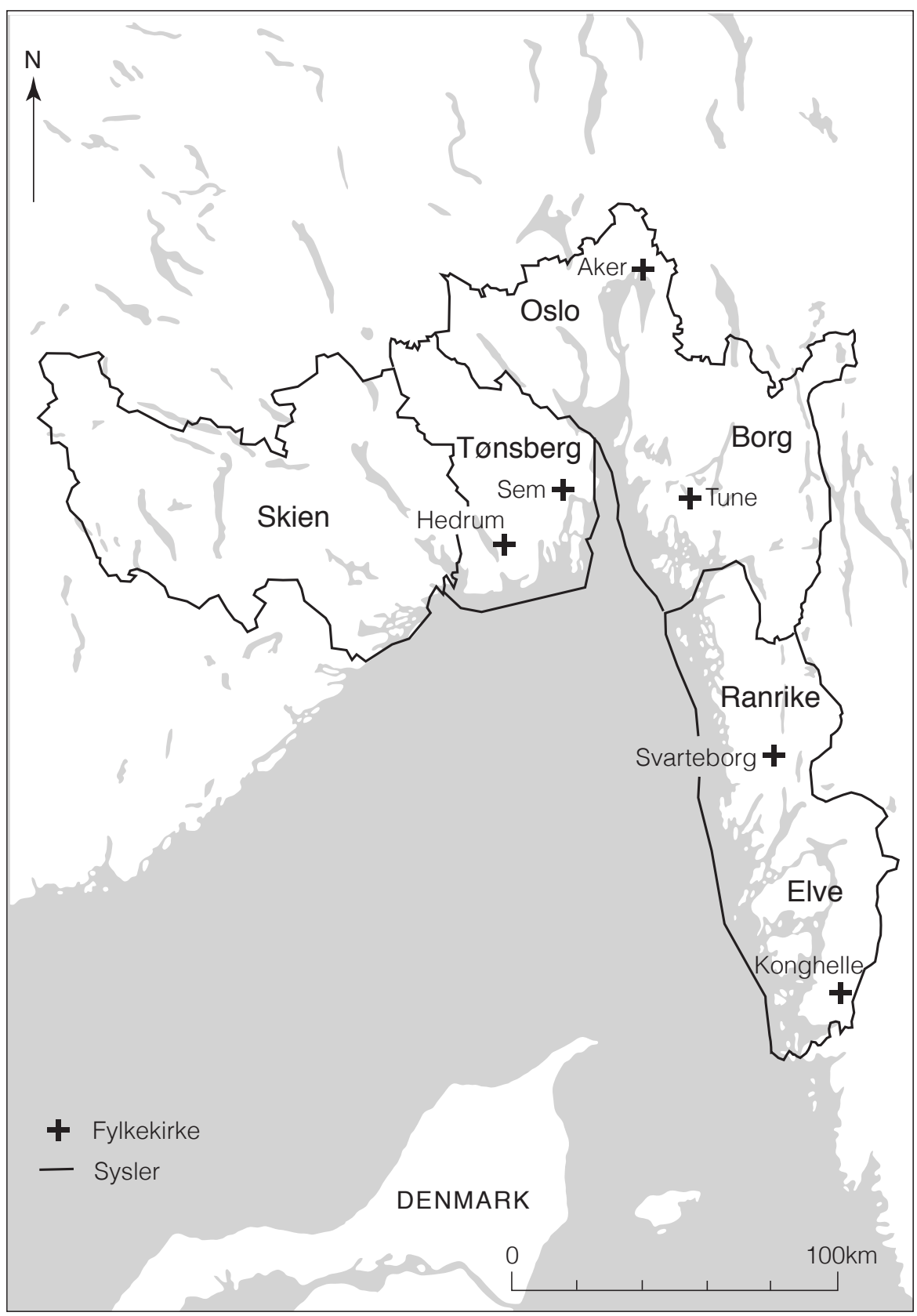

FIgURE 5.3 The sýsla districts and the county-churches of the Borgarthing. Drawn by Marie Ødegaard and Yvonne Beadnell. 
98). These divisions correspond with later law district borders and the jurisdictional oversight described in the Historia Norwegiae (Iversen 20I7a; Seip I934, I2). Thus one lawman only had jurisdiction in Ranrike; a considerably smaller region than the rest of the law district. Ranrike might also have been under Danish rule or influence earlier and for a longer period of time than the rest of Viken (Bull I920; Schreiner I927-29; Stylegar and Norseng 2003, 379-397). On these counts it seems likely that Ranrike was a later addition to the law province, and that the law province originated in the inner and central parts of Viken (Ødegaard 2015,98) (Figure 5.4).

The town of Borg (Sarpsborg, Østfold), allegedly founded in Ior6, may be the location of several thing meetings and inaugurations in the IIth century, yet Borgarthing is mentioned only once as a lawthing in I 223/I 224 (KLNM II, I 48-I 49; NgL I, 447-448). This has led to a dispute on the age of the Borgarthing lawthing in terms of how long it functioned and its origin as a common lawthing (Seip I934, 26). By the I Ioos the town might already have stagnated (Opstad I976, I47) which makes the establishment of a lawthing unlikely after this date. The construction of Borg can be viewed in connection with the description in the Saga of Olaf the Holy of the attempts to subdue Ranrike and his conflict with the Danes (Heimskringla, Saga of Olaf the Holy, Chapter 54-6I). In this context the creation of a common lawthing simultaneously, or shortly after the town and fortification were put in place, is probable. Borg is also central to the law province, yet, just a short distance from the Ranrike border, the region Olaf Haraldsson was attempting to win.

The Borgarthing as a common lawthing was thus probably an attempt at royal regulation of the law provinces of eastern Norway and had a relatively short life, functioning as common lawthing only until the mid- or second half of the $\mathrm{I}_{3}$ th century. Further reorganisation at the end of the $\mathrm{s} 3$ th century led to the inclusion of the areas bordering the north-west previously under the Eidsivathing law and the creation of Skien law district in I294 (DN II, 34) (Indrebø I934-36; Iversen 20I7a; Ødegaard 2015; Seip I934, 8-I6). From this point, the Borgarthing law province was divided in four law districts, each with a thing connected respectively to the towns or administrative centres of Skien, Tønsberg, Oslo and Konghelle (Figure 5.5).

As the secular provincial laws of the Borgarthing are lost, the supposed attendees at the lawthing meetings remain unknown. It can be assumed, however, that similarities existed with the laws of the Gulathing and the Frostathing (discussed below). The location of the lawthing and inauguration-thing sites can be identified from sagas and laws, while the things of the sýslur, skipreiður- (or ship-districts) and fjórðungar are locatable using diplomas of the $\mathrm{I} 3$ th-I 7 th centuries. The lawthing and sysselthing were probably representative things, while the inauguration, skipreiða(ship-district) and fjórðungar- (quarter) things are likely to have been althings, where all free farmers had the obligation and right to meet (F I 4; G I3 I; L III, I2; L VII 56). The lawmen held their thing meetings in towns from the I 3 th century onwards, but could also hold meetings in the rural law districts (Ødegaard 201 5, I I 2-I I 8). In I 328 , for example, documents reveal that the lawman passed a sentence at the farm of Svene in Numedal (DN VI, I 3 I), and in I 564 a sentence was pronounced in a real estate case in Tinnes in Heddal (DN XI, 7I6), both in Skien law district.

A detailed study of nine skipreiður (ship-districts) (Råde, Skaun, Onsøy, Idd, Tune, Heggen, Vemme, Åbygge and Frøyland) in Borgarsýsla (present-day Østfold 

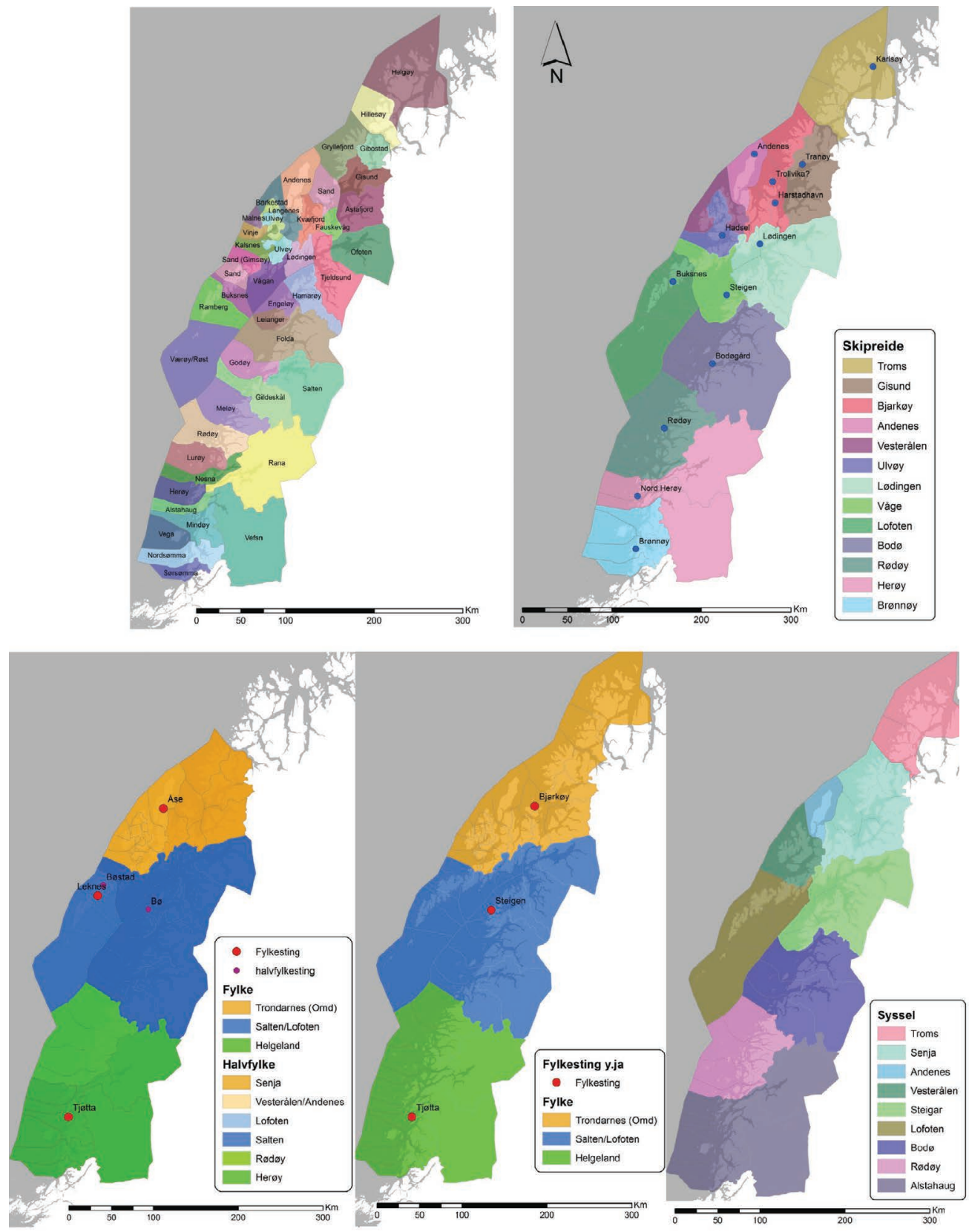

FIGURE 5.4 The law districts c. I 200, divided into four fylkir (counties), with the thing sites mentioned in the text located. Drawn by Marie Ødegaard and Yvonne Beadnell. 


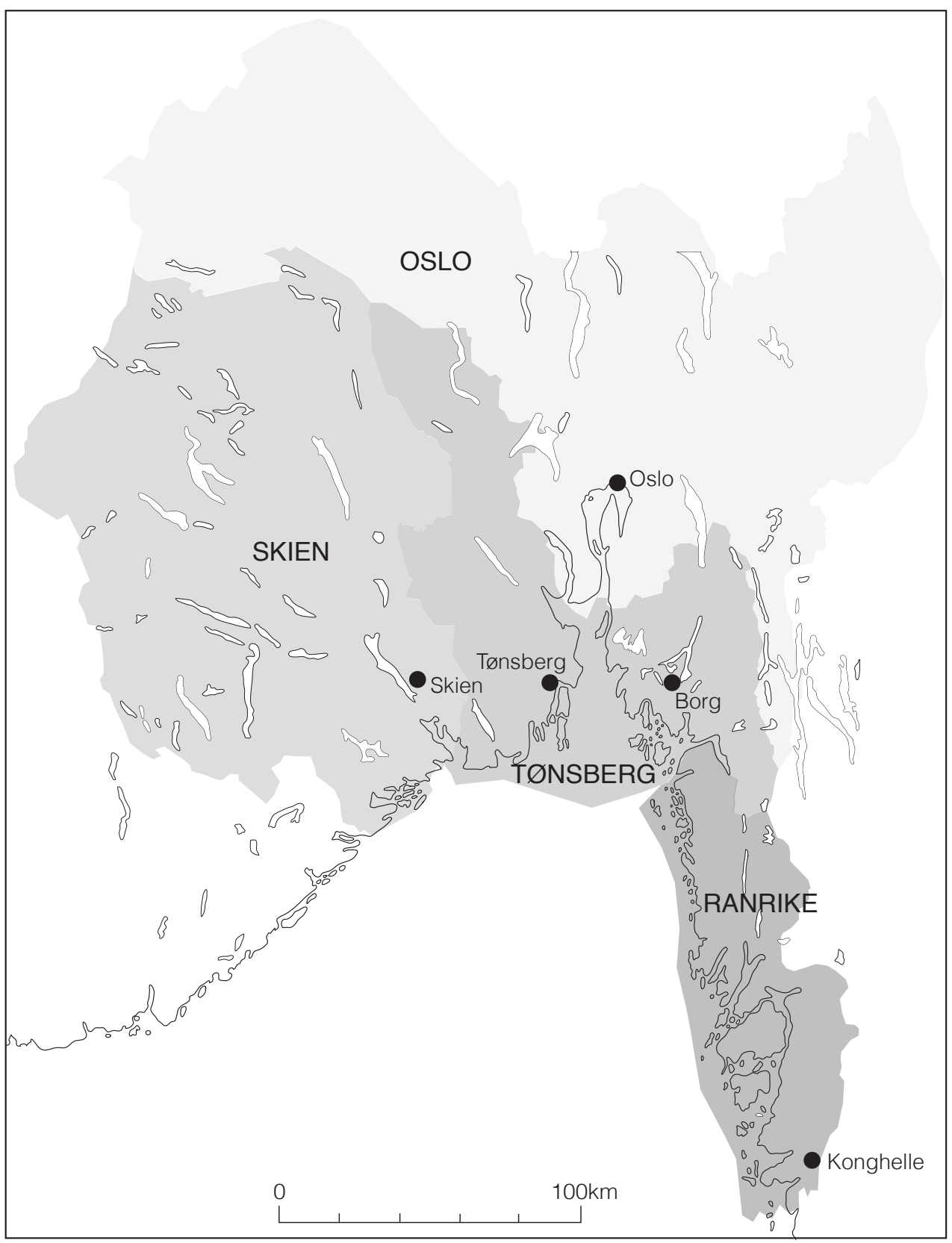

FIgURE 5.5 The Borgarthing law province, divided in four law districts each with a law district thing connected to the towns or the administrative centres of Skien, Tønsberg, Oslo and Konghelle respectively. Map by Marie Ødegaard and Yvonne Beadnell. 


\begin{tabular}{|l|l|}
\hline Public officials: & Number of visits: \\
\hline Sheriff (lénsmaðr $r$ ) & I6 \\
\hline Priest & IO \\
\hline Bailiff (foguti) & 6 \\
\hline Dean & 3 \\
\hline Bishop & I \\
\hline Lawman & I \\
\hline Aristocrat & I \\
\hline Sýslumadr & I \\
\hline Lawrightmen & 3I3 \\
\hline
\end{tabular}

FIGURE 5.6 A detailed study of nine skipreiður (Råde, Skaun, Onsøy, Idd, Tune, Heggen, Vemme, Åbygge and Frøyland) in Borgarsýsla (present-day Østfold), using diplomas dating from the end of the 13 th to the I 7 th century to provide insight into the types of officials in attendance at the meetings.

county), using diplomas dating from the end of the $\mathrm{I} 3$ th to the $\mathrm{I} 7_{\text {th }}$ centuries, provides valuable insight (Figure 5.6). At the rural thing meetings, the king's sheriff (ON lensmaðr) was the royal official that most frequently attended, followed by parish priests and then the bailiff ( $\mathrm{ON}$ fóguti). The so-called lawrightmen (ON lögréttumenn pl.) were the officials present most often and could handle cases without royal interference (Ødegaard 2015, 277-280). The lawrightmen were the communities trusted men, and were probably selected from the upper strata of the peasantry and appointed by the lawman, which took care of the local judiciary related to various village councils (ON dómr) and local thing sites (Imsen I990, 28). At the things of the skipreiður and fjórðungar, there were always at least two or three lawrightmen, but there could be as many as seven. For legal convictions, 6 or I 2 might be necessary or in rare cases 24 lawrightmen are recorded as present to pass judgement at the meetings (G 266; L IV, I 8; Imsen I990, 29-30, I97-202; Seip I934, 72-83). Apart from the public officials, the rural thing sites were probably always althings, although the diplomas do not specify this. Royal officials such as the sýslumaðr were rarely present at things, or at least are not mentioned in the diplomas. This gives the impression that local communities organised their own cases (see also Imsen I990, I00-I09; I997, 25).

To get a more complete picture one must consult sources other than diplomas, such as sagas and the royal supplements to existing laws. Many such supplements testify that the sýslumaðr prevented the local thing meetings, either by failing to arrive or by taking fines before sentences were passed (e.g. NgL III, 3-I 2, I9-30; Orning 2006, 678). The legal core was the so-called ( $\mathrm{ON})$ sáttmál where the sýslumaðr could make a compromise with the accused and issue fines so that the accused would not have to be taken to court (Holmsen I976, I76). The sýslumaðr could thus resolve and settle cases without anything being committed to written record (Seip 1942, 56 n. 2). The presence of royal officials may therefore have been more frequent than the evidence presented by the diploma material.

\section{The assembly sites: Levels and functions}

As with the evidence in Norway more broadly (see Chapter 4), little is known regarding the physical and spatial organisation of the Borgarthing law province before the IIth/I 2th centuries. While thing sites at the highest level appear in sagas 
and laws alongside inauguration sites, none have been identified archaeologically and until now the locations of these rural thing sites have been virtually unknown. The documents relating to legal action are often recorded on farms, however, and the names of the farms are specified in the diplomas, offering a means of locating meetingplaces on the ground. In addition, place-names can be used to provide a more exact location and are often preserved as minor field names or in the names of meadows. Examples include Tingvang 'Thing meadow' and Tingmyrene 'Thing marsh' in Efteløt, Kongsberg county (NG V, 378). Such names remained largely undocumented, however, until the I9th and 2oth centuries, leaving question marks over whether these attest to real thing meetings or later folk traditions.

The thing-sites of the sýslur are allegedly signalled by the locations of the fylki (county) churches (see discussion above and Figure 5.3). These lie on royal land and may have been founded by the king in the I Ith century (Brendalsmo and Molaug 20I4, I72; Sandnes I969, II8). The churches here were monumental Romanesque stone churches, probably erected in the High Middle Ages. Tune fylki-church is one of the largest in Borgarsýsla and Åker church was a basilica; a church type that is relatively rare in Norway, especially outside cities, and is considered to signal key locations in Scandinavia (Wienberg 200I, 279). The sýslumaðr was expected to summon an assembly here once a year to announce resolutions and judgements made at the lawthing (KLNM XVII, 653). The thing functions are related to judicial registration, summons, proclamations and their terms, etc. (Bull 1930, 94). This substantiates that the things of the sýslur, like their Danish counterparts (Lerdam 200I, 203), did not have judicial authority.

Few diplomas are issued at the fylki-church sites and no diplomas specify that it was a sýslur-thing. Not much is known of the sýsla-thing or the older fylkithing, indeed some have argued these assemblies never actually met in the Middle Ages (Helle 200I, 76-80; Imsen I994, 62). In the Borgarthing law province there is evidence, however, for assemblies at this level (Ødegaard 2015, I 25-I30). At three of the four fylki (or county) churches, diplomas were issued in the early modern period implying, at least at this point, that meetings of the sýslur were operating. An example from I 536 indicates that representatives from all I2 skipreiður in Borgarsýsla met at Tune fylki-church (DN XVI, 588). The reason that the things of the sýslur appear to such a small extent in the sources is probably due to their limited jurisdiction. Their absence from these sources has led to the assumption that the intermediate things disappeared and did not function as set out according to the laws. The material from the Borgarthing law province testifies, however, that the sites were maintained as important meeting-places for judicial registration and writs (Ødegaard 2015, I 28-I 29) suggesting a certain level of continuity.

After the I4th century, an increasing number of written sources especially diplomas shed light on the thing organisation at the lower levels. A number of diplomas issued across the I4th-I 7 th centuries have been studied from an estimated I 700 diplomas available pertaining to the Borgarthing law province (Ødegaard 20 I 5 ) (not including Ranrike which is now present Bohuslän in modern Sweden). The named thing sites have been classified into categories - 'correct', 'probable' and 'possible'according to how secure their identification is. Around 49 diplomas identify (MNorw) rettum stemneby/bø or 'correct thing sites'-phraseology presumably 
referring to what was considered the permanent thing site at the time in question. An example from I 525 describes a royal sheriff's visit to Sandsvær at the farm of Efteløt, the 'correct thing site' in Efteløt parish along with several lawrightmen ((MNorw) lensman i Sanswerff kunnocth gørendes ath jag war a Epther lethe rettum stemneby som liger $\mathrm{i}$ fornemde *skonn ok flere godhe men med mek) (DN II, IO79). Many diplomas locate the things by name to specific farms, but do not offer any further precise information on location and individual farms could cover large areas. Other terminology appears as well, such as $(\mathrm{ON})$ stefna or 'assembly'. In order to trace thing sites precisely, the diplomas need to be consulted along with additional corroborating written accounts. Field and place-names then need to be examined once a site has been pinned down to a specific farm or area. This project assessed some 68 sites within the Borgarthing law province as correct and probable thing sites, and 49 as possible thing sites. In several cases it is clear that meetings were held close to medieval churches,

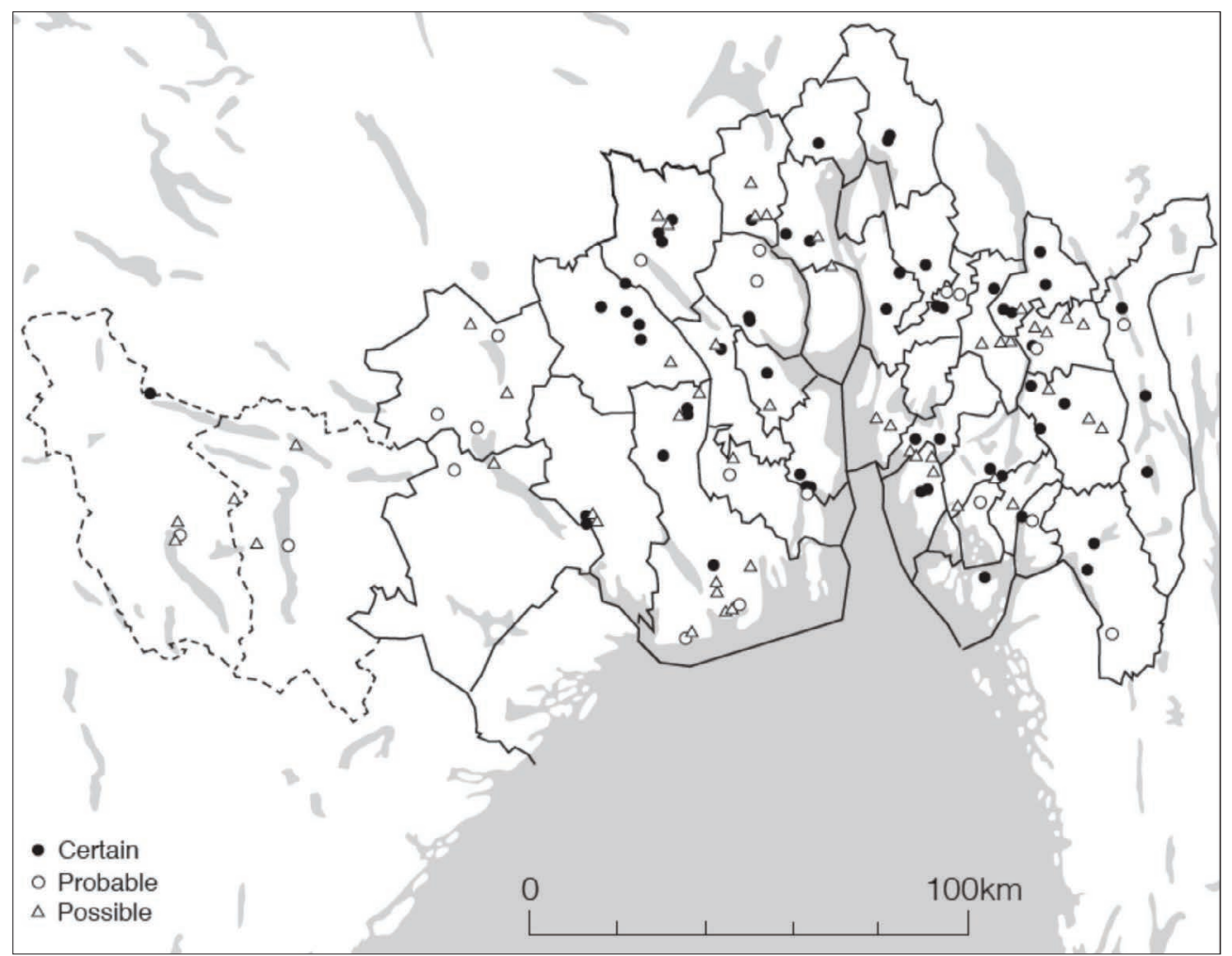

FIGURE 5.7 Thing sites in the skipreiður in Viken (without Bohuslän), Norway. The medieval administrative areas in the west are unknown, and the early modern herred divisions are marked with a dashed line. Most sites are located in key agricultural areas, often in valley bottoms and in coastal areas, near rivers and water or the sea, while just a few are located in the upper valleys of the western Borgarthing area. Map by Marie Ødegaard and Yvonne Beadnell. 
either at the churchyard or even inside, however these are often sites identified as possible (e.g. DN I, II I8/I 557; DN XXI, 290/I422, I003/I 554). Some 23 correct and probable thing locations were situated near medieval churches, in other words c. $34 \%$ of the corpus of these sites (Ødegaard 201 5, I67-I69). Connections between meeting-places and church sites are evident in medieval Sweden and Scotland (e.g. Brink 2003, 63, 67; O'Grady 2008, 369), but remain infrequent in early medieval England and the Danelaw (Baker and Brookes 20I3a, 8I-82; Skinner 20I4, 27I) (see Chapter 6). At several of the other church sites, diplomas were issued in the Late Middle Ages as well. Churches were clearly not used for all regular proceedings, but a close association is evident for a third of the identifiable sites and could imply that church sites became increasingly important as meeting-places for rural communities in the Late Middle Ages, both for weekend masses and announcements of legal nature, in the form of decrees and agreements.

A range of other geographic and topographic features are also evident. Most sites are located in key agricultural areas, often in valley bottoms and in coastal areas, near rivers and water or the sea, while just a few are located in the upper valleys of the western Borgarthing area (Figure 5.7). Three skipreiður or later municipalities do not have an identified thing site, yet some districts host up to nine possible sites. This variance might represent disparities in source representation, but real variations remain possible and such high numbers might represent different levels of meeting or changes in meeting location over time. The location of the sites, mainly in farmed areas, suggests that settlement patterns were important in the location and situation of meetings. Few are located at the boundaries of the administrative areas (Ødegaard 20I5, 263-268). Although it is difficult to inject any chronological nuance, local meeting-places in this area were, it seems, chosen in terms of a close spatial relation to populated and settled areas, processes coeval with findings from other areas such as Sweden and the Danelaw in England (see Chapter 6). In a few instances, however, archaeological evidence does provide some potential evidence for gathering places that may suggest periods of activity from late prehistory to the early medieval era.

\section{Lunde cooking-pit site}

In the Borgarthing province, there were three rural lawthings, one in each of the two law districts and a top-level lawthing (see Chapter 4). Tjølling, the medieval settlement, according to written accounts was most likely the general location of the lawthing for the area corresponding to the northern law district of the Borgarthing law province in I 223 and served the counties of Vingulsmark, Vestfold and Grenland. The medieval church at Tjølling is the largest basilica in eastern Norway as well as one of the largest Romanesque examples outside the town of Tønsberg. It may have benefitted from a higher rank and income from a larger area (Ødegaard 201 5, 308309) in a similar way to Mære church in Sparbyggjafylke in mid-Norway (DN II, I 8/I278; Sandnes I969, I I 8). In medieval times at least, people were travelling from a large area to come to Tjølling for religious activities.

While written evidence of the actual meeting location of the Tjølling lawthing is absent, the place-name derives from $(\mathrm{ON})$ pjódalyng, where the first element is interpreted as (ON) pjóð 'people' and the second element (ON) lyng 'heather' 
(NG VI, 287-289), meaning 'the heath of the peoples' (Brink 2007, 63; Zoëga 2004, 5I2). The first element pjóð has even been interpreted as meaning 'band' or even 'nation' (NG VI, 287-289; Brink 2007, 63; Fritzner I886-96, III, I024-25; Storm I90I, 227). The name Tjølling thus suggests that assemblies or meetings might have been held in the locality at an early point-perhaps in the first half of the Ist millennium (NG VI, 289; Storm I90I, 227). There are different opinions on what level of assembly the name implies (Fritzner I886-96, III, I024-25; Storm I90I, 227), but a thing meeting for southern Vestfold, a large region, was held here in I 557 (DN I, I I I 8; Skre 2007, 396), indicating an assembly of regional importance.

Lunde is about I $\mathrm{km}$ away from Tjølling and is situated in the skipreiða of Numedal and the Tønsberg sýsla in Vestfold county. The name Lunde may denote a 'holy grove' (Sandnes and Stemshaug 1976, 209). The area around Lunde has been studied in relation to the archaeological investigation of the Viking-Age town of Kaupang and the central place of (ON) Skíringssalr (e.g. Blindheim et al. I98I; I995; Skre 2007). At this location, a large cooking-pit site was discovered through geophysical prospection undertaken by the Austrian Ludwig Boltzmann Institute for Archaeological Prospection and Virtual Archaeology with The Norwegian Institute for Cultural Heritage Research and Vestfold County Council. This revealed an area comprising some 900 to Iooo hearths (Ødegaard 2015, 302). In 2012 The Assembly Project examined 30 pits at Lunde (Figure 5.8) obtaining a sequence of radiocarbon dates between $380 \mathrm{BC}$ to $\mathrm{AD} 630$, with a peak of activity between $\mathrm{AD}$ IOO and 400 (Figure 5.9) (Ødegaard 2015,302-305). The reuse of numerous pits after gaps of several hundred years could be observed, signifying that the site was repeatedly used over centuries. One cooking-pit with a diameter of $\mathrm{I} \mathrm{m}$ and a depth of $0.5 \mathrm{~m}$ has been shown, via broader comparative studies on other sites, to produce sufficient food in one episode for around 30 people (Pilø 2005, 292, no. 526) or even as many as 50 (Skre 2007,403 ). Given pits were used repeatedly and some had even bigger capacities, around I000 pits at Lunde might have served 30,000, or even perhaps 50,000 people, at any one gathering. The radiocarbon dating underlines that the pits at Lunde could not have been in use simultaneously (Ødegaard 20I 5, 305-306). Even so, the likely scale of activity is significant and at least hundreds of people might have gathered together for events involving communal cooking and eating (Ødegaard 20I9a; 20I9b).

The context of the cooking-pit site at Lunde is complicated by the discovery of another identical site some $4.5 \mathrm{~km}$ north. This is located at the farm of Bommestad and comprises around 550 cooking pits with activity spanning $\mathrm{I} 8 \mathrm{O} \mathrm{BC}-\mathrm{AD} 430$ with a peak around AD I-200 (Samdal and Bukkemoen 2008). The farm name Bommestad is recorded as Bundingsstadum in $\mathrm{I} 347$ (RB 55), reconstructed as (ON) Bundingsstaðir or Bóndpingstaðir, and could be interpreted as meaning 'the farmers or householders' thing site' (NG VI, 342), although the meaning of the prefix (ON) bóndi 'farmer/ householder' is debatable as the name is a reconstruction of an assumed Old Norse form (KLNM II, 87-95; Skrubbeltrang I990, KLNM II, 84-87; Bjørkvik I980; Iversen $2007,4-7$ ). Etymologically bóndi, if linked to (ON) bú, has several possible derivations including 'settled man with his own household' or 'someone in a position ranked over others in the community' (Fritzner I886-96, I, I67-I68). The prefix could also represent the genitive of $(\mathrm{ON})$ bonda ping 'householders' thing', which is 


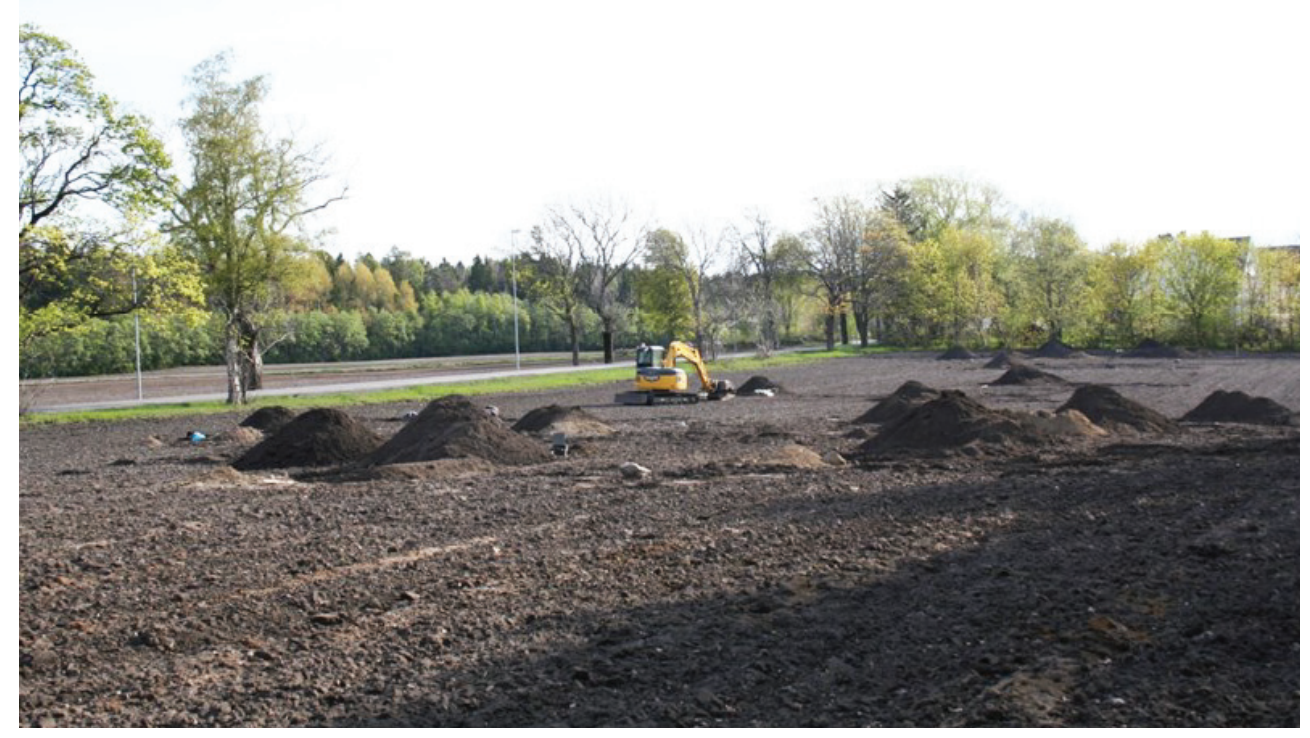

FIGURE 5.8 Lunde cooking-pit site under excavation, Norway. View looking towards the north-east. Photograph by Marie Ødegaard.

mentioned in the Borgarthing law (B I4, 5; NgL I, 37I) and can be found in Swedish sources as $(\mathrm{OS} w)$ bondething (NG VI, 342). The suffix $(\mathrm{ON})$ staðir is mostly dated to the Viking Age, but might be older (Sandnes and Stemshaug 1976, 294-295). The bonda ping mentioned in the Borgarthing law is an exceptional meeting with a three-day deadline, but may still have been a gathering that all farmers had to attend (B I 4,5$)$.

Both examples suggest that cooking-pit sites could be a form of thing precursor (Ødegaard 20I8a; 20I8b; 20I9a; 20I9b). The place-names for each site imply that they served different geographic extents: the district and the region. Cooking-pits sites seem to drop from use before the 7 th century, a change that coincided with other cultural, ecological, social and economic changes (Gräslund and Price 2012; Myhre 2002, I72; Pedersen and Widgren I998, 309). Power was increasingly centralised in the Ist millennium and as a consequence cult functions and meeting-places may have moved closer to the settlement (Henriksen 2005, 99; Herschend I997; Skre I998, 335). There is a time lapse of several hundred years before the medieval things are attested as active at Tjølling and Bommestad, which puts into question the idea that these local and regional gathering places were an early form of thing site. Nevertheless both sites attest to a local congruence between documented medieval things, place-names attesting to assemblies, and evidence for the existence of late prehistoric gathering places that were regularly used for meeting, cooking and eating. The evidence hints at the consistent role of a locality as a gathering place and, in time, the establishment in close or immediate proximity of a formalised thing meeting perhaps in the Viking Age (Ødegaard 2015; 2018a). 


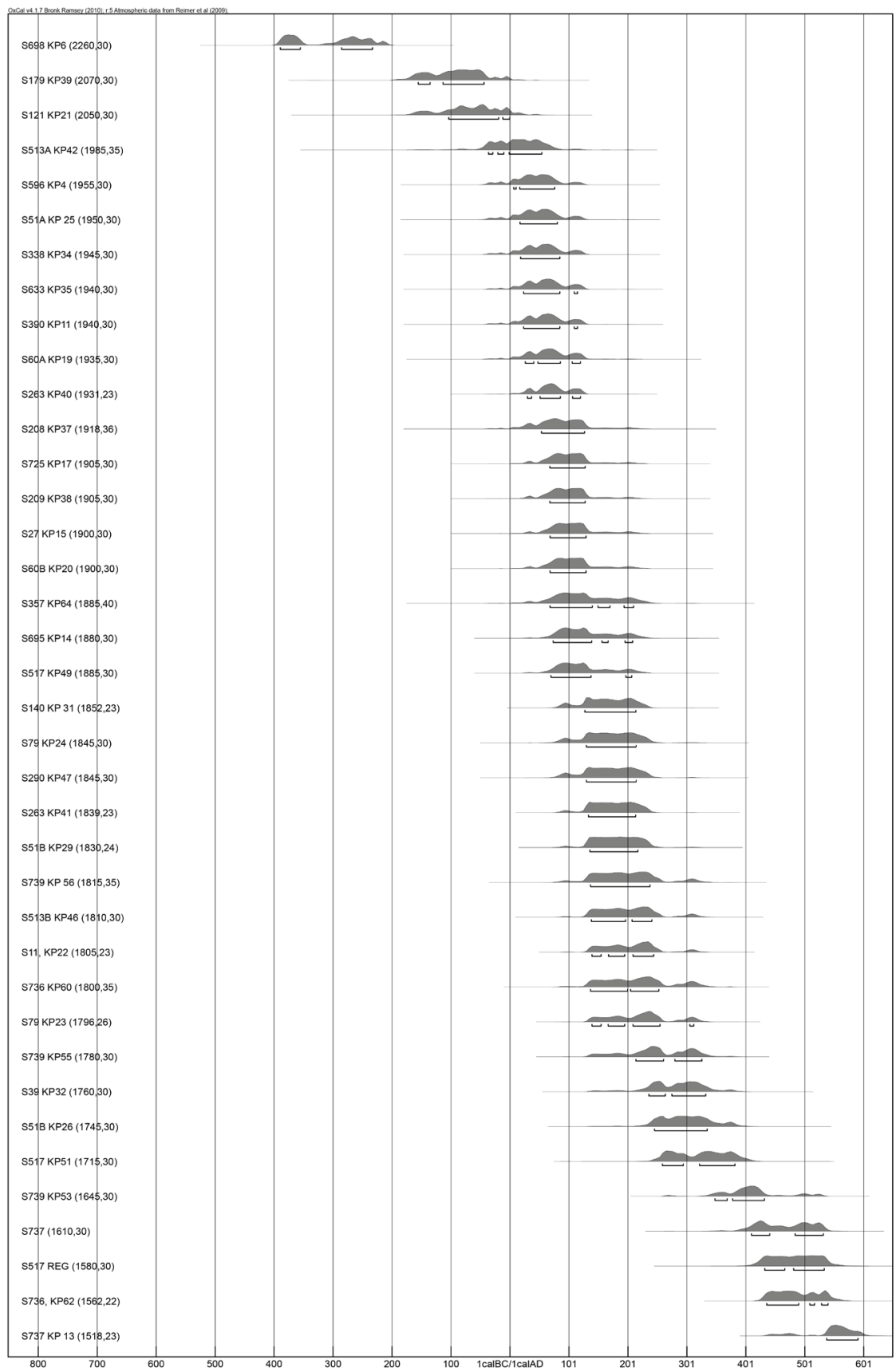

FigURE 5.9 A sequence of radiocarbon dates obtained from excavations of 30 pits at Lunde in Vestfold, Norway. This presents a date range of $380 \mathrm{BC}$ to $\mathrm{AD} 630$, with a peak of activity between AD IOO and 400 (Ødegaard 20I 5, 302-305). 


\section{The Haugathing: An inauguration site}

Haugathing (Slagen skipreiða, Tønsberg sýsla) is the most well-known royal inauguration site in the Borgarthing law province (Figure 5.4) and has already seen some discussion in Chapter 4 . Here, however, it is examined in closer detail in order to evaluate the broader landscape and temporal contexts of this inauguration site. The first known inauguration held here was of Harald Gille in I I30 (Heimskringla, Saga of Magnus the Blind and of Harald Gille, Ch. I), and the last, the crowning of King Magnus Eriksson in I3I9 [Norway r. AD I3 I9-I355] (Opsahl 2009).

The site consists of two large burial mounds, 35-40m in diameter (Gansum 2013, 47). According to the saga, Harald Fairhair's sons, Olaf and Sigrød, who allegedly died in the early 930s, were buried here (Heimskringla, Harald Fairhair's saga, Ch. 44). The name Haugar derives from (ON) haugr, 'hill or burial mounds', and indicates that the site is named after the barrows. Interestingly, several of the royal places and fylki (county) churches and thing sites in Trøndelag in mid-Norway also have (ON) haugr names, such as Sakshaug (ON Sörshaugr) and Alstadhaug (ON Ölvishaugr) (Sandnes I969, I I 8).

At Haugathing, the mounds are situated on a rocky elevation in a striking position where a number of land and water routes converge. In the Viking and medieval periods, the mounds were visible from the fjord and the inner fairway, and east and north-west towards the royal farm of Sem (Gansum and Østigård I999, 76). Their position and function as a meeting and inauguration site must be seen in the context of their connection with the royal farm and it is notable that they are located strategically just outside or on the border of the town of Tønsberg, which is likely to be from the Ioth century (Brendalsmo and Molaug 20I4, I 87). Both mounds have been partly excavated-the southern mound in I900, revealing a central cairn and a few burnt human bones (Nicolaysen I90I). The northern mound was also partly excavated in I994, and contained a large amount of charcoal. Three sets of dates were obtained, two from burnt hazel nutshells (AD 7 I 5-890 and 770-960), and one from burnt birch (AD 780-980; All to I sigma) (Gansum 20I3). In 20I2, small-scale excavations by The Assembly Project with Vestfold County Council and Vestfold Museums took place at the southern mound (Figure 5.IO), with the aims of eliciting better chronological evidence and establishing the function of the monument. Excavations revealed a charcoal layer and burned bones. The latter included a single human bone found high up in the stratigraphic sequence and varied mammal bones (Gansum 20I3, 2I). Four bones were radiocarbon dated giving a range of AD 780-970 (Beta 36I405-36I408, I Sigma) (Figure 5.I I; Ødegaard 201 5, 330). Two additional dates were taken from the charcoal layer (Beta 362247-362248), giving a range of $\mathrm{AD} 670-970$. The date frame is broad because the calibration curve of the 9 th century has a large plateau that opens up several equal statistical possibilities in one sample (Gansum 20I3, 2I). The new dates nevertheless coincide with the results from the northern mound. Together a time interval of $\mathrm{AD}$ 670-970 is suggested within which both mounds were built, but construction is most likely to be at a mid-point within the range and probably predates the time of the sons of King Harald Fairhair, around AD 950.

The Haugathing is located at what would once have been a border in the late Viking Age between the town and country straddling two different types of jurisdiction. 


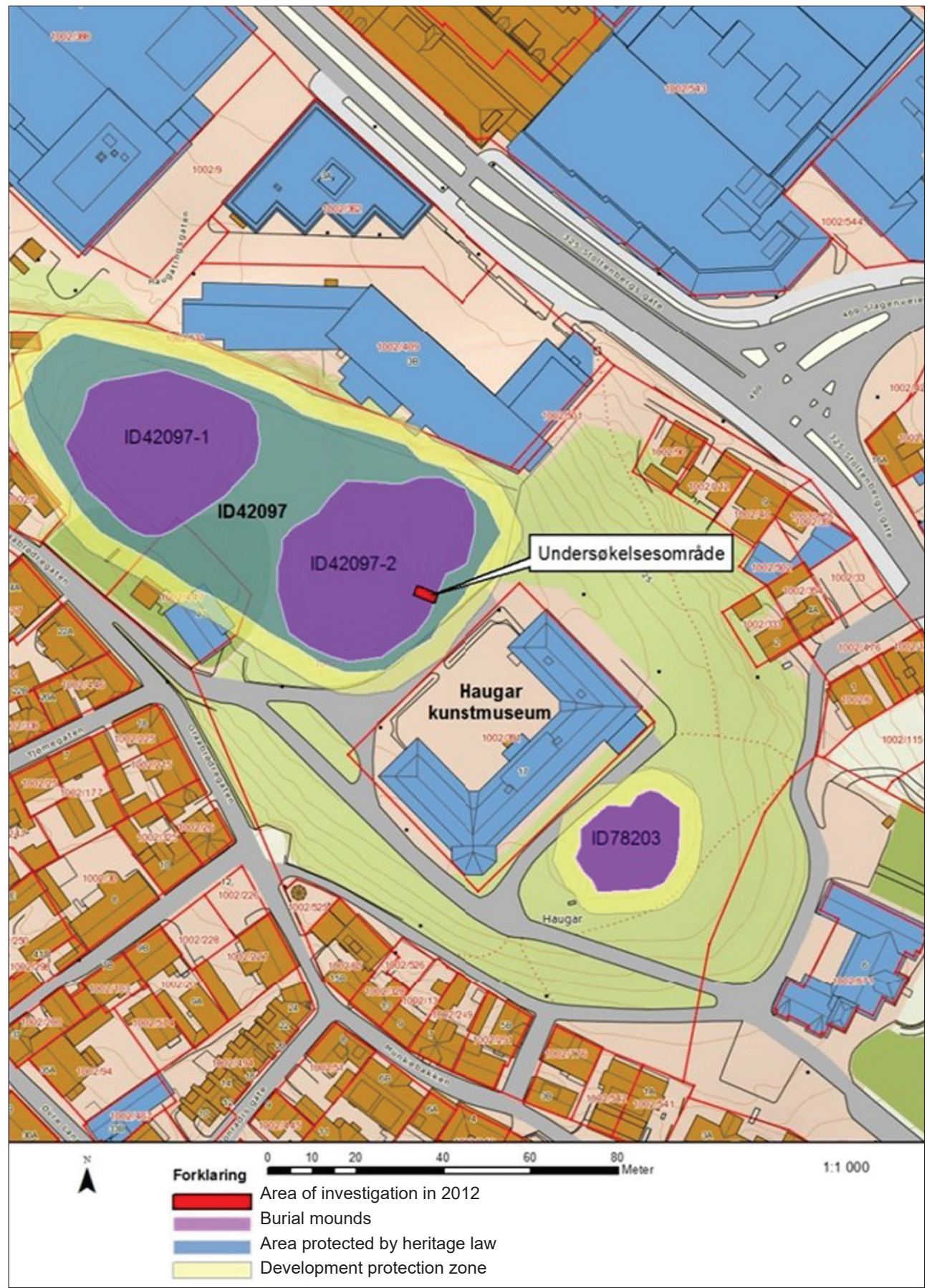

FIGURE 5.IO Location of the excavation of the southern mound at Haugathing, Norway (marked in red). Illustration by Julie Askjem/Vestfold County Council. 


\begin{tabular}{|c|c|c|c|c|c|c|c|c|}
\hline Site & Lab. Ref. & Material & BP & \pm & $68 \%$ & $95 \%$ & $\begin{array}{c}1 \text { Sigma } \\
(68 \%)\end{array}$ & $\begin{array}{c}2 \text { Sigma } \\
(95 \%)\end{array}$ \\
\hline Southern Mound & Beta-361405 & Burnt bone, medium sized animal (F502) & 1160 & 30 & $778-944$ & $773-968$ & $780-945$ & $775-970$ \\
\hline Southern Mound & Beta-361406 & Burnt bone, medium sized animal (F505) & 1190 & 30 & $778-878$ & $722-945$ & $780-880$ & $720-945$ \\
\hline Southern Mound & Beta-361408 & Burnt bone, human (F100004) & 1160 & 30 & $778-944$ & 773-968 & $780-945$ & $775-970$ \\
\hline Southern Mound & Beta-362247 & Charcoal (F509) & 1120 & 30 & $893-970$ & $778-995$ & $895-970$ & $780-995$ \\
\hline Southern Mound & Beta-362248 & Charcoal (F518) & 1300 & 30 & $669-764$ & $660-770$ & $670-765$ & $660-770$ \\
\hline Northern Mound & Tua-1016 & Charcoal, birch & 1140 & 70 & $778-979$ & $695-1021$ & $780-980$ & $695-1020$ \\
\hline
\end{tabular}

FIGURE 5.I I Dates obtained from the excavation of the southern mound at Haugathing in 20I2, and those from Gansum's excavations of the northern mound in I994. All dates calibrated in $\mathrm{OxCal} 4$, conventional radiocarbon age.

The use of the site for inauguration is thought to relate to the roth century or later and post-date the town. An undated royal amendment by Magnus VI Haakonsson the Law-Mender passed at Haugathing (NgL II, 484) offers some additional information (Bull I9I8, 26I). It introduced a regulation that allowed the local hundred things to act as the authority for any issues relating to building on deserted land. The supplement must post-date I 274 and the issue in question seems to be a rural rather than town issue. Things for the law district are also documented in the diplomas at other sites in the town, although the earliest diploma is I403 (DN I, 586). It seems that Haugathing cannot be a fylki (county) thing or lawthing (contra Johnsen I929, 32 ), but rather it seems to have functioned as an inauguration site alone, and on occasion was used to pass legislation that primarily related to the thing (Ødegaard 2OI 5, I 34) - a similar model to that suggested for the Øyrathing in the Frostating law province (Sandnes I967).

\section{Berg in Eiker: The formation of a ship-district thing}

The thing site of Berg, in Eiker skipreiða in Oslosýsla, is cited as a 'correct thing site' by diplomas which date from the I 5 th to I 7 th centuries (Figure 5.I2; see Figure 5.4 for location). One of the diplomas even specifies that a 'weapon thing' was held here in the I 5 th century (DN VI, 45I/I434). The farm is located on a hill with visibility in all directions. Berg had a medieval church situated next to the farm, which probably comprised a small stave church. The thing site was centrally located in the quarter unit as well as within the skipreiða, acting as a geographical mid-point and a central place in relation to presumed areas of population. The neighbouring farm Sem was a royal farm, at least from I240 until I 54I (Johnsen I9I4, I02). Sem was a socalled 'free-farm', a special royal, administrative farm, of which only eight are known in the country (Bjørkvik I968, 66). Four medieval quarters are known, of which all but one called Varlo take their name from a documented 'correct' or probable thing site. The farm Varlo has no other indications of being a thing site other than giving its name to the quarter. It is likely that the thing site was moved from Varlo to Berg in the I 3 th century to bring it closer to the royal farm of Sem, a move that could be linked to giving Berg weapon-thing functions thus increasing royal control over the local thing institution and judicial life in the districts (Ødegaard 20I3, 56-58). According 


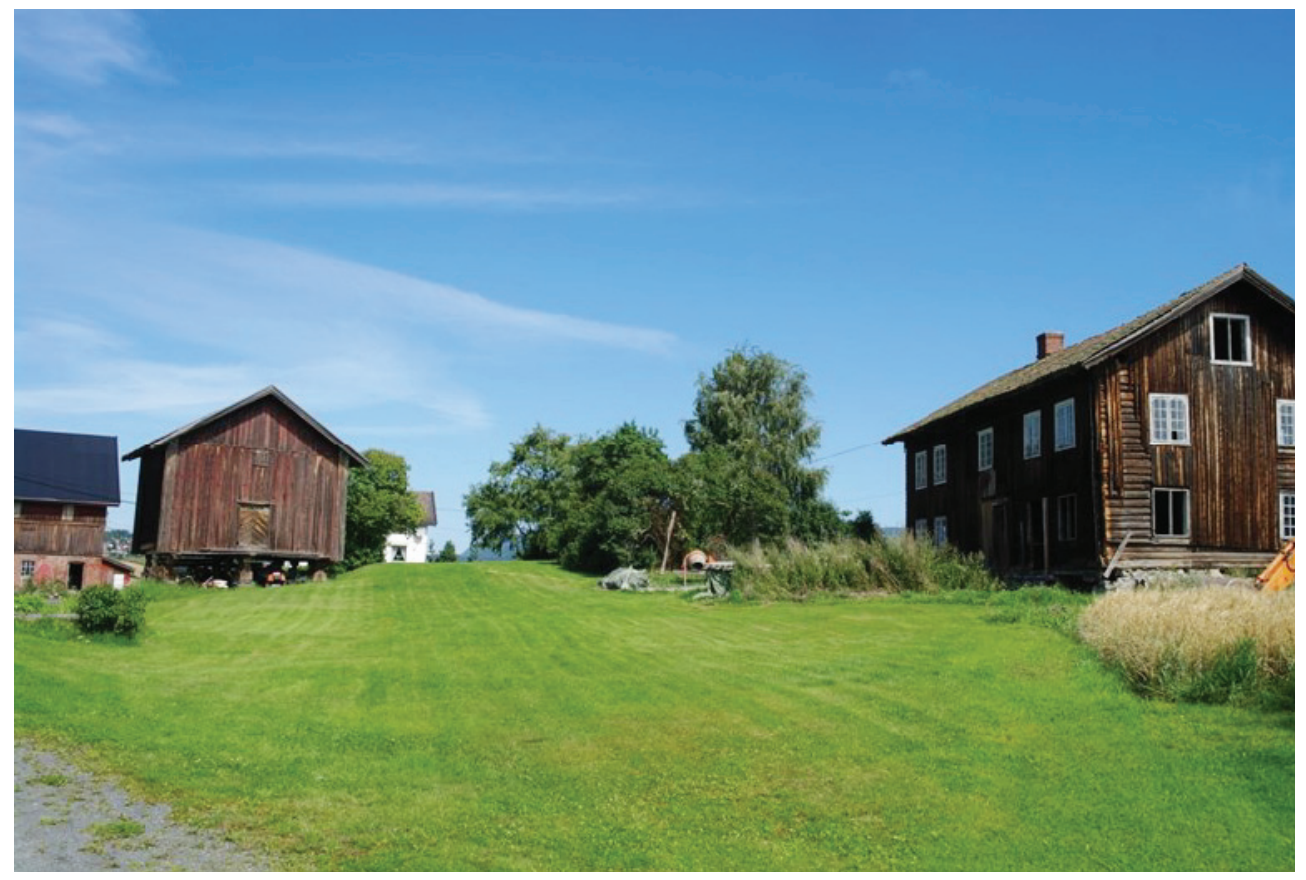

Figure 5.I2 The thing site of Berg, in Eiker skipreiða in Oslosýsla, Norway. Cited as a 'correct thing site' by diplomas dating to the I 5 th to 17 th centuries. Photograph by Marie Ødegaard.

to folk traditions, the thing meetings at Berg were held very close to the farmyard, on a small mound called 'Pilhaugen' or 'The Arrow Mound' (Moseng I 994, 90-92). In the Gulathing Law, thing meetings in cases of murders and other crimes could be summoned by so-called 'arrow summons' (ON ör), a stick made from an arrow (G I 5 I) (Andersen I974, 348; Grieg I957). Pilhaugen is most likely a natural feature and the mound was not very high and today it is partially destroyed, but it remains significant that the main skipreiða and weapon thing was linked to an elevated mound on a farm in a prominent and highly visible location (Ødegaard 20I3; 20I 5, 4I 7).

\section{The Kolberg site: A local thing site}

Kolberg in Onsøy skipreiða in Borgarsýsla (Figure 5.4) is identified as the 'correct thing site' for Onsøy in documents of the I 5 th and I 6 th centuries, and this may have been the case in earlier times too. The thing meetings were held either in the church or the churchyard at Kolberg (e.g. DN I, 929/I48 I; DN XXI, 597/I482, I084/I 559). The thing site is again located centrally in the skipreiða and also in the quarter. The church is located on a northern slope. On the hilltop, a few hundred metres from the church, is a prehistoric burial ground. The meeting was assigned to the 'Onsøy thing mound' in the 158 os and perhaps earlier (Schou I993, 234, 266). A natural meeting 


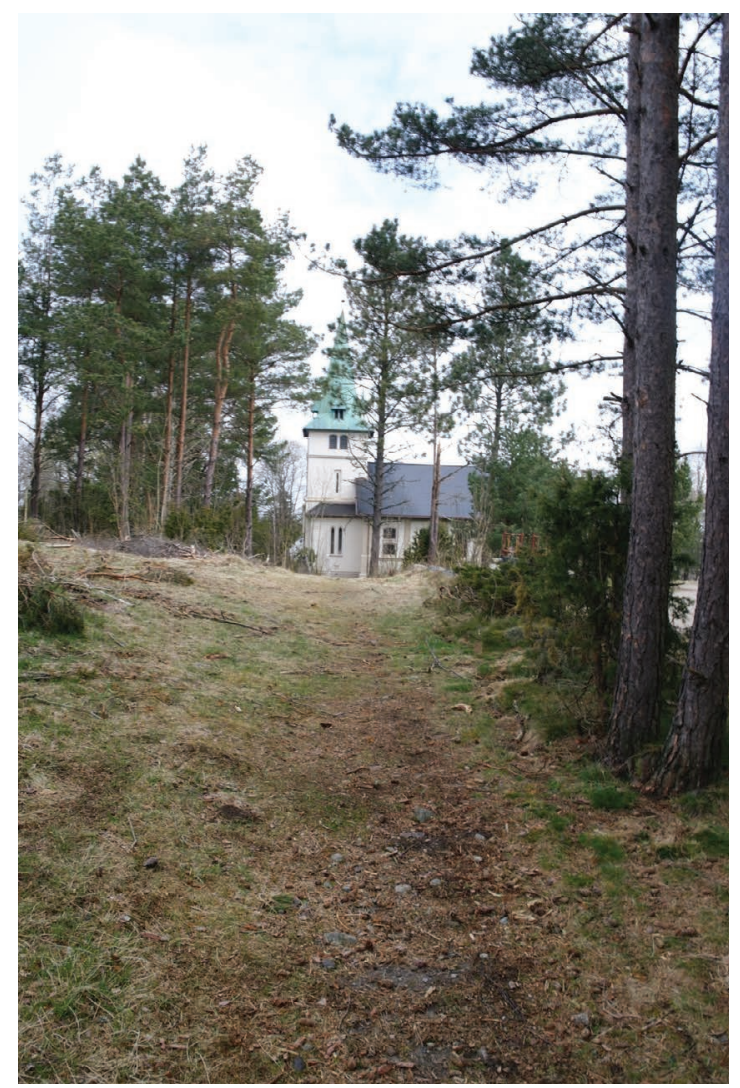

Figure 5.I3 The site at Kolberg, Norway. The photograph shows the road leading to the church, passing the grave mounds and the possible location for the thing. Photograph by Marie Ødegaard.

spot exists between the hilltop and the slope down towards the church (Figure 5.I3) and an old road crosses the hill, passing the grave mounds before reaching the church (Ødegaard 2015, 4I9). Some thing names emerged as a consequence of invented tradition in more recent times (Svensson 2007), however 'Onsøy thing mound' was documented in the I6th century, which makes it likely that the name originated even further back in time. Thing mounds are known from all over Scandinavia, Norse Scotland and the Danelaw and from England, and some are known to be prehistoric burial mounds while others are undated or appear to be non-sepulchral (Pantos and Semple 2004b; Semple and Sanmark 20I3).

\section{Summary}

The sources testify to four hierarchical administrative levels in the Borgarthing law province in the Middle Ages serving different geographic scales and holding different functions: the law province was divided into sýslur and then skipreiður and these were further divided into quarters or fjórðungar. Administrative names that went out of use around the IIth/I 2 th century provide indications of an older system. The sources suggest that the law province originated in the inner part of 
Viken, which was probably expanded in the beginning of the IIth century when Ranrike was included and the Borgarthing was established. Several changes happened in the administrative area after the mid-I3th century, when the area was divided into four law districts, all with their own thing situated in the four important towns and administrative centres: Skien, Tønsberg, Oslo and Konghelle. This led to the downgrading of the Borgarthing as a lawthing and it only continued as a thing with functions for the surrounding area. The distribution of the identified local thing sites shows that most sites were located in key agricultural areas, often in valley bottoms and coastal areas, near rivers and water/sea. The location of the sites suggests that topography and settlement patterns were important to the location of meeting-sites. A few are located at the boundaries of the administrative areas and a close connection has been established with medieval churches. Perhaps most important is the level of detail on their locational situations. Mounds - again perhaps old burial mounds - are relevant, while archaeological evidence for earlier gathering practices in the form of cooking-pit sites also exists in some cases. There is no clear-cut evidence, however, for continuous meeting pratices and places that lasted unchanged from prehistory to the medieval era. The evidence points instead to either continuing or repeat uses of these meetings locations in prehistory, in the Viking Age and in the High to Late Middle Ages. A high medieval thing meeting would have certainly been a different physical affair to the large prehistoric gatherings indicated in the Borgarthing province where people regularly met and re-established hearths for the purpose of cooking and eating together. However, each is still a crucial element in a developmental sequence of local and supra-local processes of collective action and governance that resulted in the Viking and medieval thing. There are indications from the evidence presented in Chapter 4 and above that at times the medieval thing was co-located with sites that appear to have had active prehistoric lives as gathering places. Sometimes the evidence points to a spatial proximity rather than a direct correlation between meeting-sites of different time-periods. It is also important to recognise that there is local variety in the locational settings of Viking and medieval meetings, but also in the background of late prehistoric evidence. While this provides a critique for the notion of unchanging assembly action, the evidence could also fit with a local continuity in emphasis on certain kinds of place and monument over time. There are signs that locational changes may also relate to attempts by elites to gain greater authority over meeting practices, and in this context ideas of claiming places and re-inventing traditions should not be dismissed, especially in relation to the use of mounds and outdoor locations for medieval inaugurations.

\section{$5 \cdot 5$ HÅlogaland LAW PROVINCE}

\section{The Norwegian courtyard sites (Figures 5.I4a-i)}

Rather like the cooking-pit sites in Borgarthing law province, in Hålogaland, a close association between the medieval thing and an earlier phenomenon called 'courtyard sites' can be posited. A courtyard site is a collection of houses or booths situated around an oval semi-circular open space or yard (Johansen and Søbstad I 978, 55). There are about 30 known sites in Norway (Iversen 20I 5 d) (Figure 5.I4a). 

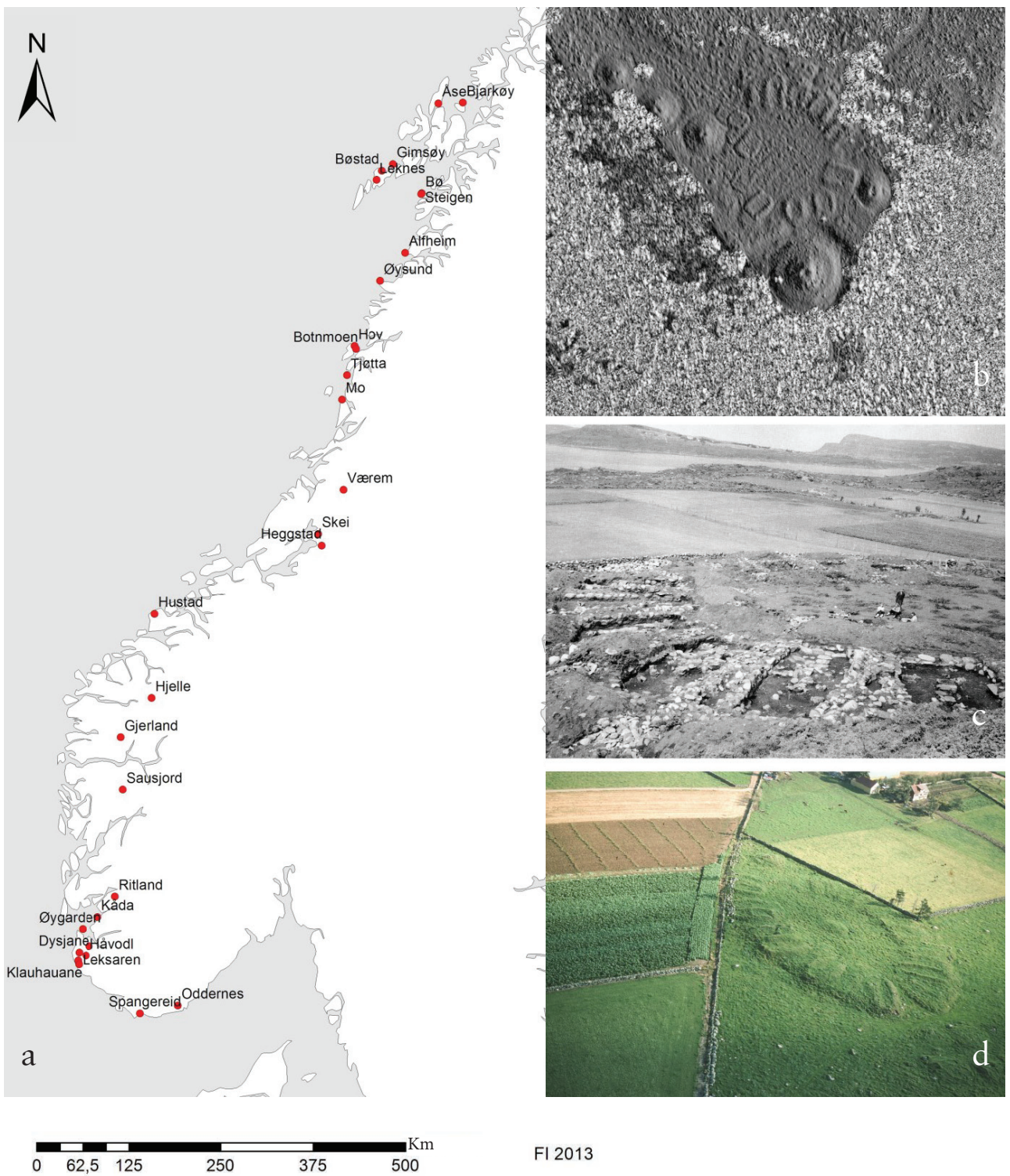

FI 2013

Figure 5.I4a-d a) Map of the courtyard sites in Norway.

b) LiDAR scan of the courtyard site at Værem. This site was still in use in the early I I th century. Image (C) Lars Forseth, Nord-Trøndelag Fylkeskommune.

c) The courtyard site of Øygarden, close to Stavanger, during the excavations by Jan Petersen, I939-40. The site was still in use in the early 8 th century.

Photograph (C) Arkeologisk Museum, Universitetet i Stavanger.

d) The courtyard site at Dysjane at Tinghaug, Jæren, AD 200-600.

Photograph () Ragne Jonsrud, Arkeologisk Museum, Universitetet i Stavanger. 

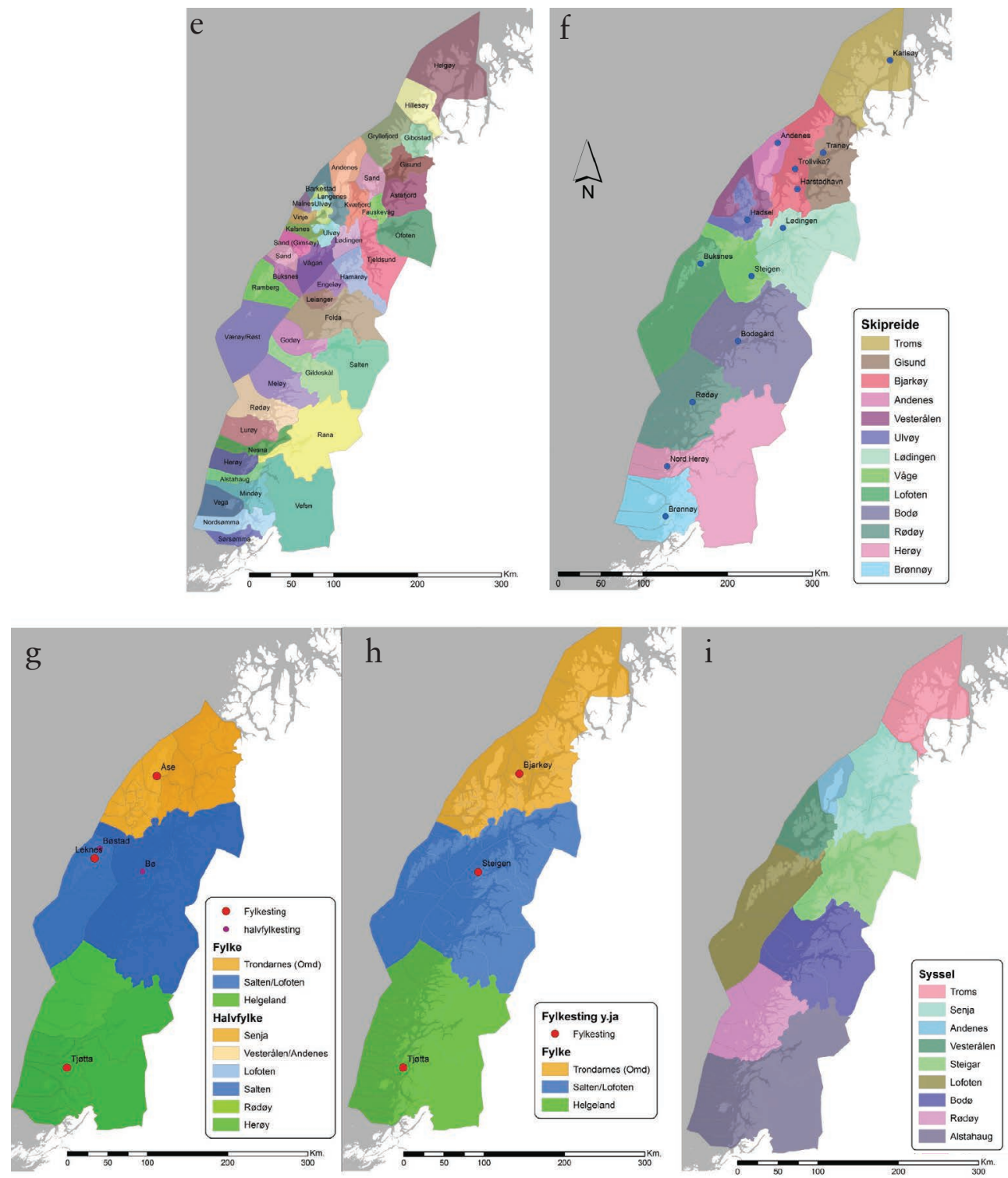

FIGURE 5.I4 $\mathrm{e}-\mathrm{i}$ e) Quarters in Hålogaland (AD I 567 ).

f) Suggested ship-districts and weapon things (AD 900-I600).

g) Courtyard sites and half-counties (half-fylkir) AD IOO-550.

h) Courtyard sites and counties (fylkir) AD 550-900.

i) Sýslur c. AD I I 50-I 250 Hålogaland. Illustration by Frode Iversen. 
These have recently been re-interpreted as thing sites that functioned at a supra-local level (A B Olsen 2005, 20I3; 20I4; M Olsen 2003; Storli 2006; 20I0; Iversen 20I4; $2015 \mathrm{a}$; 2OI $5 \mathrm{~d}$ ). Their relatively frequent distribution in only certain areas might result from temporal changes to the administrative framework or a need to serve a dispersed population. The time span during which individual sites were in use varies, but many of the sites in Norway were active for several hundred years. Some were already in use in the 2nd and 3 rd centuries (for instance, Åse in Troms, Øygarden and Leksaren, both Rogaland), while others seem to have remained active until as late as the early I I th century (Skei and Heggstad, North Trøndelag).

In broad terms, some of these 30 or so sites are characterised by an open oval area with a central mound (e.g. Dysjane in Rogaland and Bjarkøy in Troms). In other cases the houses are arranged rows and not in semi-oval structures. The sites vary in size from four to c. 20 houses. Many sites also have burial mounds and cooking pits located close by. Some have evidence for cult-foci such as stone heaps and indications of sacrificial activity, while the pits attest to collective cooking and eating as a community (Semple and Sanmark 20I3). The Skei-site in Trøndelag was located in the middle of the largest known cemetery in the vicinity (Stenvik 200I), while others were located in areas without any other apparent monuments, for example at Øygarden in Rogaland (Iversen 20I 5 b) (Figure 5.I 4c). In Norway the larger courtyard sites have a strict and regular plan. The houses were more or less of the same size and their layout was highly organised. For these reasons, the courtyard sites have been associated in previous scholarship with the development of military organisation and provision (Grimm 2010; Lund I955).

In the latter half of the I900s, a chiefdom-interpretation was dominant. Initially suggested by the archaeologist Harald Egenæs Lund, the courtyard sites of northern Norway were regarded as gathering places for minor kings and their followers (Lund I955; 1959; 1965). This hypothesis was investigated in several studies (Berglund I995; Johansen and Søbstad I978; Lillehammer I994; Løken 200I; Magnus and Myhre I986; Solberg 2002). The 2ist century has seen the revival of the thing site interpretation, followed by the discovery of two or three additional sites at Voss (Sausjord) in Hordaland and at Stryn in Sogn (Hjelle and the more uncertain site $\mathrm{Bø})$ (Olsen 2005; 20I3; 20I4). Additional support for this interpretation is provided by new analyses of the sites at Jæren and Hålogaland (Storli 2000; 2006; 2010; Olsen 2003). In the last ten years, research has strengthened this identification, notably by Inger Storli (2000; 2006; 20I0), Asle Bruen Olsen (2005; 2013; 2014) and The Assembly Project (Iversen 20I4; 20I 5a).

The end of the practice has been explained in the context of emerging supraregional royal power (Storli 2006; 20I0; Iversen 20I4; 20I 5a). It has been suggested that the king gradually gained military jurisdictions that previously had been in the hands of communal elites (Iversen 20I5C; 20I7c). The courtyard sites went out of use as military jurisdiction was transferred, voluntarily or by force, to the kingdom or larger earldoms, and local elites and chiefs and even petty kings lost influence in alliances with new supra-regional kings. Hence, the courtyard sites were abandoned when stronger royal military control was established within the kingdom. Courtyard sites are particularly relevant to the development of administration in Hålogaland. 


\section{Administrative organisation of Hålogaland law province}

In Hålogaland in 1567 the Rekneskap for dei nordlandske lena og Finnmark, published by The National Archives (Riksarkivet), presents the first systematic record of the administrative landscape (Iversen 20I5a; Jansen I943). According to this source there were 44 local thing districts in 1567 and when combined these can be used to reconstruct a total of $\mathrm{I}_{3}$ skipreiður and three main regions (Iversen 20 I $5 \mathrm{a}$ ) (see below and Figure 5.I4f). The minor jurisdictions were constituted by so-called (Mod Norw) tingsted 'thing sites' in the north and 'quarters' in the south. Additional, but dispersed, evidence supports these arrangements, located in the cadastre of Aslak Bolt c. I430 and in a I 5 th-century law manuscript (Indrebø I935, 28; Jørgensen I997, 87-99).

According to the will of King Magnus the Law-Mender there were also I3 shipdistricts in Hålogaland in I 277 , and the Gulathing Law states that seven ships were provided from the southern part and six from the north (Eithun et al. I994, I70, G 3 I 5). Most likely, the border between the north and south ran between Lofoten and Vesterålen, which is a natural border and also fits the reconstruction of the ship-district the best (Figure 5.I5). Only three such districts are named in charters, all dating to the I40Os: Loofota skipredhu (I425), Vagha skiparedhr (I472) and Raudøyar skipreide (I497) (Bull I920). A tentative reconstruction of the I3 shipdistricts can be attempted based on the premise that each ship-district should contain four quarters, as suggested by several scholars, most notably by the historian Håvard D Bratrein (I984) (Figure 5.I4f). Bratrein presented a reconstruction based on Hartvig

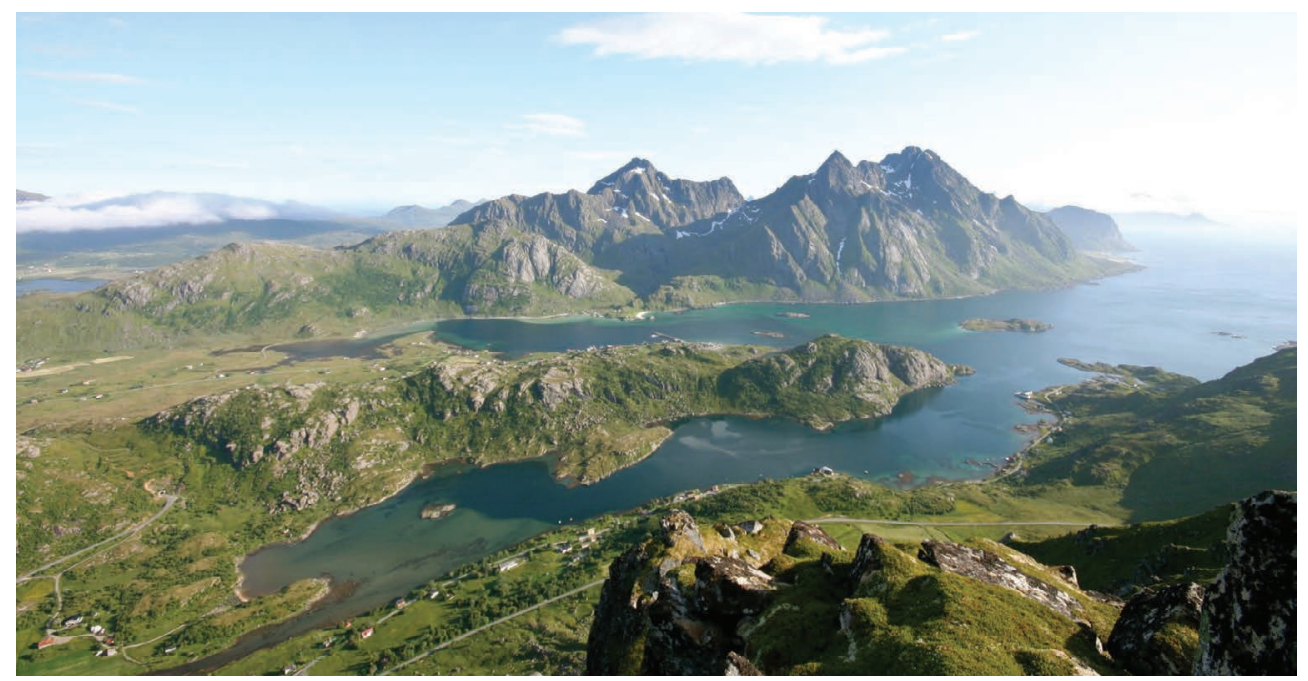

FIgURE 5.I 5 The landscape of Steinsfjorden, Vestvågøy, Lofoten, Norway. The border between the northern and the southern parts ran most likely between Lofoten and Vesterålen, which is a natural division and fits the reconstruction of ship-district the best. Photographer unknown. CC BY 2.o. 
Billes recordings from I609, which lists I 3 naval encampments and boathouses in Hålogaland (Mod Norw skjøttebaitstasjoner), arguing that these may have been the centres of the ship-districts in the Middle Ages. A slightly different arrangement can however be proposed (Iversen 20I $5 \mathrm{a}$ ).

Two larger regions can be identified that arguably equate with Old Norse fylkir: Helgeland fylki and Trondarnes fylki (Indrebø I935, 70-7I). It is uncertain whether the region lying in between represented one or two fylkir, but Vesterålen can be counted within the Trondarnes fylki, and Lofoten attributed to Salten which may or may not represent a third fylki. This potentially gives three main regions in Hålogaland: Helgeland to the south, an unnamed fylki in the middle comprising Lofoten and Salten, and Trondarsnes fylki (including Vesterålen) to the north. These fylkir were most likely subdivided in half. Two are named in surviving documents as half-counties (Herøy/Rødøy) in I430 (AB I43, I49), while the other half-counties may well have corresponded with the historically-attested regions of Salten/Lofoten and Vesterålen/Senja.

\section{The assembly sites: Levels and functions}

Again the Gulathing Law code and the will of Magnus the Law-Mender ( I 277) are the primary sources that enable a reconstruction of the administrative arrangements. Thirteen courtyard sites are known in Hålogaland and three of the larger sites were still in use in the Viking Age (AD 800-IO50): Bjarkøy, Steigen and Tjøtta. In the vicinity of several courtyard sites in Hålogland, large contemporary boathouses have been identified, potentially for warships. This may indicate the existence of a proto-leiðangr system, or the need for boathouses for delegates' ships (Grimm 2006). In the Ioth century, the leiðangr, a type of conscription system, was introduced and this relied on a main lawthing located in the middle of the region and I3 new mid-level ship-district-things that supported the miliary system.

The historically known lawthing of Hålogaland was located at Steigen in the mid-region until I797 (Falkanger 2007, 20). The first written record of the Steigen lawthing is from I404 (Lange and Unger I 852,440 ; $\mathrm{DN} 2$, no. 580), but it is assumed that this was established several hundred years prior to its appearance in written sources although this cannot be evidenced with complete certainty. Three to four courtyard sites (including Hov) are securely dated as active sites in use after c. $\mathrm{AD} 550 / 600$ and six sites have dates that place them exclusively in the period prior to $\mathrm{AD} 550 / 600$. The sites of Botnmoen and Mo are not dated and the site of Alfheim remains uncertain and is not considered further here.

First generation sites (AD 200-550/600)

Two of the earliest dated courtyard sites were located close to fylki (county) borders (Figure 5.I4g and h). This applies to Øysund (AD 200-500) which comprised only four houses (Figure 5.I4c). This site lay close to the borders of Helgeland and Salten counties. These units were both subdivided into: Rødøy half-county and Herøy half-county (Helgeland) and Salten and Lofoten in the putative northern county. Not only does the Øysund site sit on the main county/half-county divisions, the site 
has four houses, corresponding to number of the half-counties. The same pattern appears at the second early courtyard site at Gimsøy (AD 200-600) farther north. This sits on the border of 'north' and 'south' of Hålogaland, between Lofoten and Vesterålen (Figure 5.I7). There were in total six 'half-counties' in Hålogaland: four to the south and two additional half-counties to the north-Vesterålen and Senja. Again this corresponds to the six houses in evidence at Gimsøy. This correlation between structures and sub-units implies that these sites emerged as an organised means of representation - we might assume that delegations from each of the half-counties met at these sites for negotiations and dispute resolution.

These correspondences are further substantiated if the first-generation courtyard sites that lie central to the half-counties and counties are analysed. According to I6th-century administrative records (Jansen I943), there were I4 communities in the northern county (Vesterålen and Senja), up to Malangen which was the border for the Norse population prior to AD 600 (Iversen 20I5a). This border is indicated by the distribution of burial sites. Burials containing weapons datable before the late 6th century are not found north of Malangen, whereas prestigious furnished burials and graves containing weapons thought to date after AD 575 have been uncovered at Karlsøy in Troms, as far north as Nordkapp and to the east of Ekkerøy in today's area of Finnmark (Storli 2006, 79). Norse settlement most likely extended further north during the Merovingian and Viking Eras (c. AD 575-IO5O). The courtyard site at Åse (AD 200-600) is located in the middle of the region, and had I4 houses. Ase may therefore represent the county-level meeting-site for this region.

At Salten, including Lofoten, there were I 6 communities according to the I 567 record of the administrative landscape of Hålogaland (Jansen I943). Leknes is the largest site in the mid-county region of Salten and Lofotoen, and may have had I4 houses (Iversen 20I4; 20I5d). The number is somewhat uncertain because the southern part of the site was destroyed before being documented and more may have been present. At $\mathrm{B} \varnothing(\mathrm{AD} 200-550)$ in the half-county of Salten, the courtyard site comprised I 2 houses, and this half-county may have had I 2 communities if the four at Hinnøy are included. The Bøstad-site (AD 200-500) in Lofoten has only four houses, but this corresponds to the number of local communities at Vestvågøy in the western half-county (Lofoten).

Such evidence seems unlikely to be co-incidental, suggesting a period of organisation concurrent with the development of these communal sites. The evidence also implies that half-county (Bøstad/Bø) and county-things (Leknes and Åse) in Hålogland were conceived together as units of organisation. If we accept this pattern, two unidentified half-county sites may be missing in the northern county, one each for Senja and Vesterålen.

The situation for the southern county of Helgeland is somewhat more complex. Helgeland may have had $\mathrm{I} 2$ communities in the Middle Ages, or even more as the border to the south has historically been relatively fluid due to an unpractical topography and shifting affiliation. The undated sites in Helgeland (Mo and Botnmo) were quite large, but the number of houses is uncertain. The Tjøtta site (AD 200-900) may have served as an equivalent meeting-site to a county-level thing for whole of Helgeland. It had I 5-I 6 houses, which is three or four too many in a county consisting of only I 2 communities. It is possible that parts of the historic county of 
Namdalen to the south were included in the county of Helgeland, but this remains somewhat speculative. The core area of the Namdalen area consisted of I3-I5 communities, and Namdalen county had a second generation courtyard site of its own, located at Værem (AD 600-900) (Figure 5.I4b). The Værem-site had I 3 houses, corresponding well with the size of the county. Taken together, these correspondences suggest a developing system in which specific communities within counties had their own houses at the courtyard sites. The houses are on average $30-50 \mathrm{sq} \mathrm{m}$ in size which could accommodate smaller delegations.

Second generation sites (AD 550/600-900)

There are only three known sites in Hålogaland still operating after AD 550/600: at Bjarkøy (AD 200/550-900) in the northern county, at Steigen (AD 550-900) in the middle county and Tjøtta in the southern county (AD 200-900). Half-county or border-sites do not appear to have continued to function in this period which may indicate a process of centralisation and increased organisation.

Bjarkøy is surrounded by wetlands and bogs and situated approximately $\mathrm{I} \mathrm{km}$ from the historic farmsteads of Øvergård, Nergård and Austnes. It was excavated by Harald Egenæs Lund from I950 to I953. The Bjarkøy site consisted of two juxtaposed rows, each containing traces of eight house plots (Figure 5.I $8 \mathrm{a}-\mathrm{c}$ ). They were arranged around an oval courtyard with entrances facing the east and west. Thus, it had I 6 house plots, which is two more than at Åse. In I 567, there were three local thing units north of Malangen: Hillesøy, Helgøy and Skjervøy. According to the historians Håvard Dahl Bratrein (I989) and Maurits Fugelsøy (I970, 55), the Norwegian settlement in Skjervøy was not established until I 500 . Thus, there appear to have been 16 local units in the extended northern area, encompassing Ulvøy in Vesterålen in the south, to Helgøy in Troms in the north. Although the documentary evidence is far later in date than the active life-span of Bjarkøy, the number of house plots at the courtyard site corresponds to the number of late-medieval local units (Figure 5.I $8 \mathrm{a}-\mathrm{c}$ ). It is possible that Bjarkøy assumed a judicial function as a county thing site after the discontinuity of Åse and the expansion of the northern territory. When the jurisdiction was extended further north, the assembly site may have been relocated to Bjarkøy and the new thing districts and the communities of Hillesøy and Helgeøy included, each receiving their own house plot.

A similar case can be argued for Steigen (Figure 5.I6). The site Vollmoen, offers a more central position, and may well have superseded the Leknes courtyard site as an assembly location. This site had I 6 houses corresponding to the number of communities in the Salten county. The situation is much more uncertain for the Tjøtta site in the Helgeland county.

The medieval lawthing of Hålogaland, perhaps unsurprisingly given the systematic development laid out above, was established in the precise location and on the same island as the central of the three second-generation courtyard sites in Hålogaland in the Viking Age. This strongly suggests a type of centralising process, in which the most geographically central area absorbed the functions of the main lawthing of the entire province. This implies that the functions of minor countythings became centralised and that a new authority over the three main provinces in 


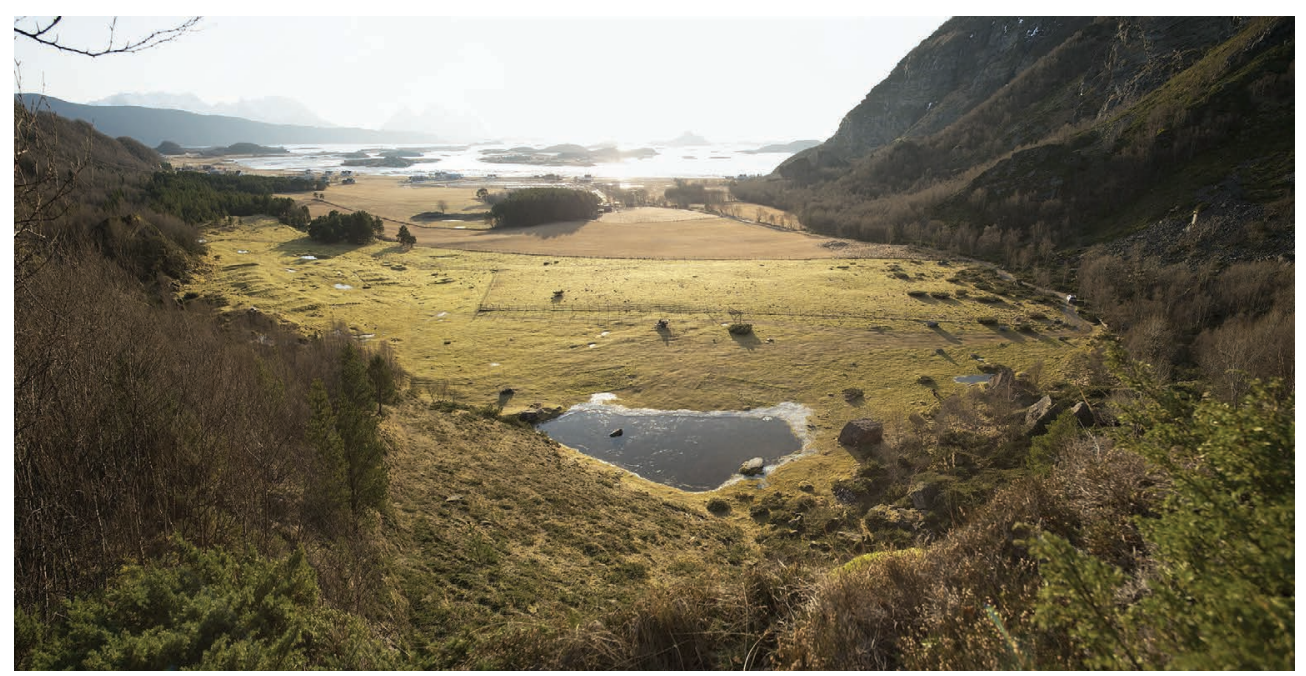

FIGURE 5.I6 The remains of the courtyard site of Vollmoen at Steigen, Norway. The site with I 5-1 6 houses was likely the county-thing for Salten and Lofoten from c. AD 550-900. Photograph Ernst Furhatt, Nordlandsmuseene.

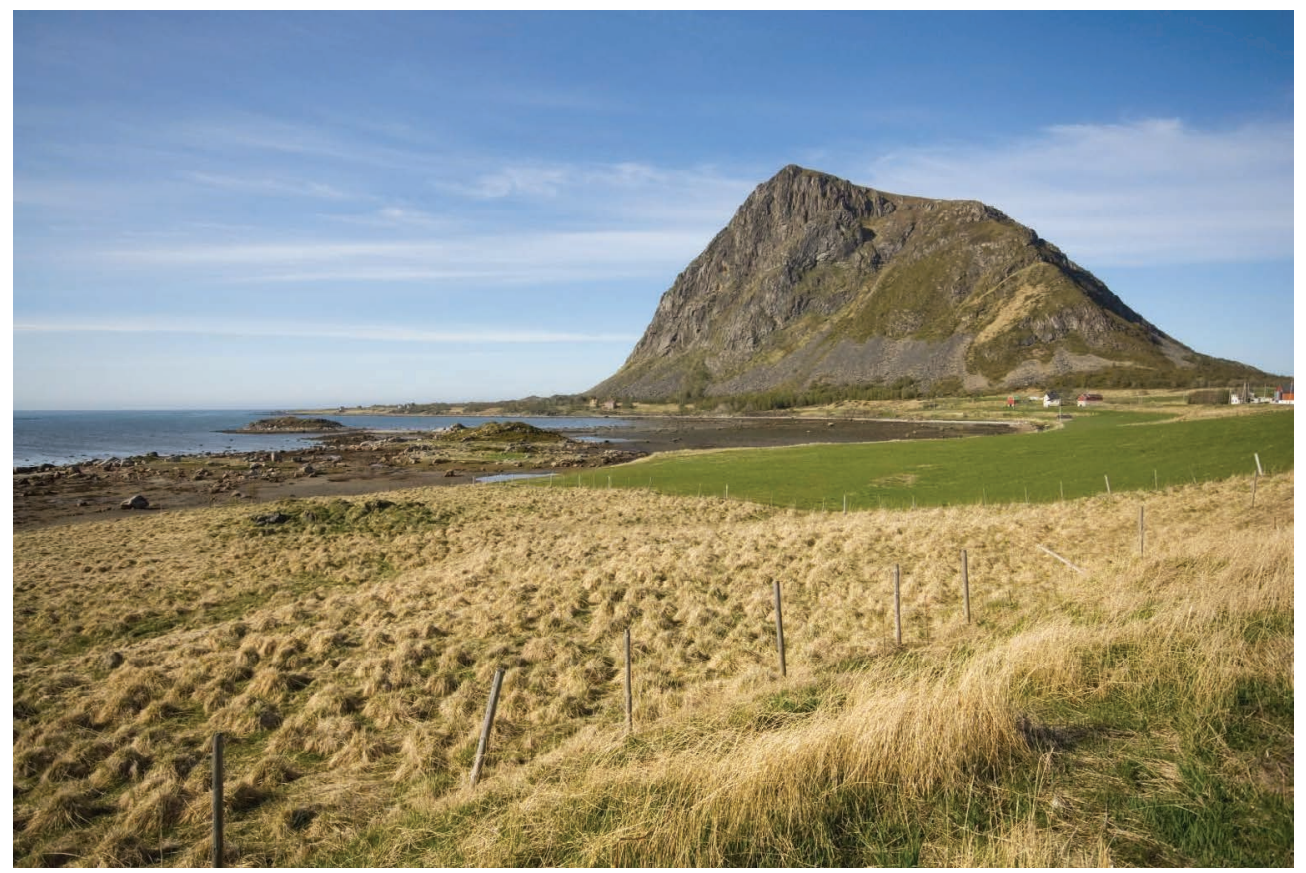

Figure 5.I7 Approximate view from the courtyard site at Gimsøy, towards the Hoven mountain. Vikspollen in the front. Photographer unknown. CC BY 2.o. 

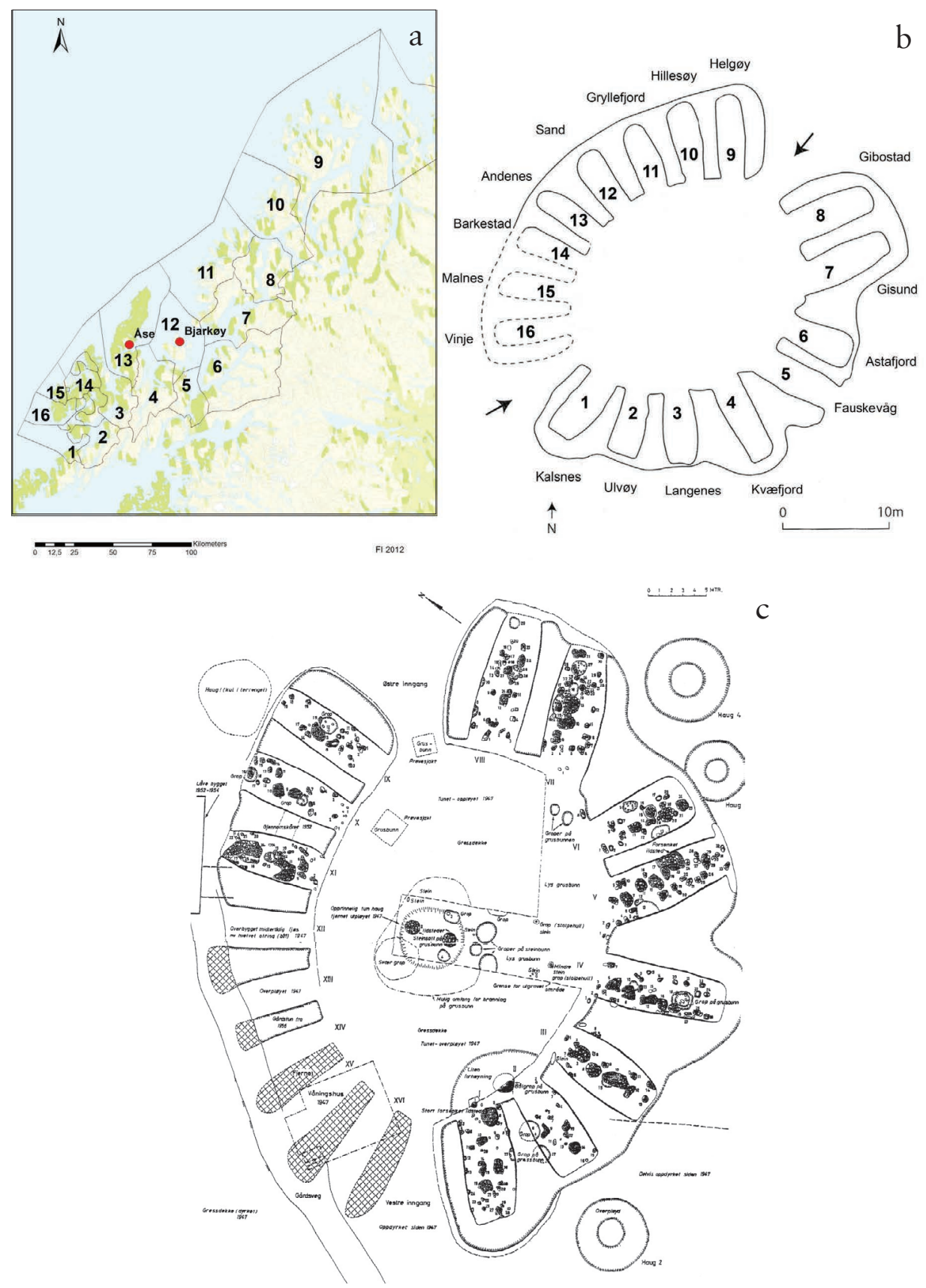

FIGURE 5.I 8 The Bjarkøy courtyard site. a) Local thing districts in northern Hålogaland AD I 567 . Image (C) Frode Iversen. b) Simplified plan of the house plots at Bjarkøy. Drawing (C) Inger Storli. c) Harald Egenæs Lund's drawing of the courtyard site at Bjarkøy, reproduced after his death by Johansen and Søbstad I978, fig. 2, I4-I 5. CC BY-NC-ND 4.O. 
Hålogaland was established. In this model, the disuse of the three major courtyard sites, if they functioned as something equivalent to county-assemblies, can be connected with the creation of a new lawthing at Steigen at Engeløya after the Ioth century, as a new system of mid-level ship-district things was established.

\section{Summary}

If courtyard sites can be accepted as the physical traces of evolving thing meeting-sites, and their changing structure, as argued here, correlates with changing local and regional administrative structures, then these sites are evidence of the developing nature of communal activity in the localites in late prehistory to the Viking Age. The military relationships emphasised by previous authors are not mutally exclusive to these ideas. Meetings that provided a context for creating consensus through gathering, cooking and perhaps cultic activities would have been the right forum to reach agreements on matters of resource-sharing, disputes and justice, and defence. The development of these sites over time, within evolving provincial organisation, again attests to assemblies as entities that were more fluid than static. The evidence in these cases points, however, to the repeated use of sites over the late prehistoric and Migration periods to the end of the Viking Age, although the form changed in some instances and some sites fell from use. The presence of cooking pits and mounds provides an interesting connection with the broader Scandinavian evidence for assembly-site attributions, suggesting activities may have centred on creating collective connections, drawing on the idea of an ancestral presence. The changing shape of this assembly system also attests to the growing influence of elites in the Viking Age, resulting in more hierarchial systems and greater elite control. The first generation judicial system, prior to $\mathrm{AD} 550 / 600$ included half-county-things, county-things, local things and some things at or on borders. This was replaced by a second generation system (AD 600-900) with only two levels: local things and county-things. There are no indications of an overreaching organisation for the whole province during this period, but it cannot be ruled out. The third generation system was introduced around AD 900 when Hålogaland became part of a supraregional Norwegian kingdom. The new system had a common lawthing for the whole region and $\mathrm{I} 3$ ship-district things located near centres controlled by royal elites, in addition to 44 local things in the subdivided ship-districts. The courtyard sites attest to an interestingly consistent approach to gathering, with a distinctive tradition of assembly architecture. While this case-study has focused on a particular province, the phenomenon is more geographically wide-ranging, but not uniform and demonstrates variability and locational change over time.

\subsection{THE GUlathing LAW PROVince}

Gulathing, as we have seen previously, was the name of the medieval law province of western Norway, the region from where the medieval Norwegian kingdom is held to have been established and expanded in the Viking Age (Krag 2008, 646-647). While the main features and development of the Gulathing law province are known from a recent and comprehensive assessment (Helle 200I), studies dealing 
with the lower administrative levels, the fylkir and fjórðungar, are few and of older date (Bull I9I8; I920, Indrebø I93 I; I935; Steinnes I933; I974). The local units of medieval administration, the skipreiður, have received more attention, most recently in an extensive study from 2000 (Ersland 2000). The focus has been mainly on their military capacities and functions, however, and the only overall study specifically dealing with the territorial aspects of the skipreiður dates to I920 (Bull I920).

The main assembly of the Gulathing law province was the Gulathing, which has received much popular and scholarly attention. The Gulathing is also one of few Norwegian assemblies where targeted archaeological investigations have been undertaken, although no decisive findings were made (Helle 200I, 52-64). In contrast, lower-ranked assembly sites of the law province have received limited attention: overviews identify only nine sites within the area of study and this number includes two locations for the Gulathing (e.g. Andersen I977, 256; Bugge I920, I3I; Helle 200I, 49-66). The other sites are only imprecisely located, none have been archaeologically investigated, and they amount to merely a small number of the assembly sites that must have been in operation within the core area of the Gulathing in the medieval period. A cautious estimate suggests a minimum of 79 sites.

\section{Administrative organisation of the Gulathing law province}

The Gulathing Law and its corresponding law province are assumed to have been established no later than the early Ioth century (Helle 200I, 23-28; Iversen $2015 \mathrm{~d}$ ). According to the Gulathing Law, known in its written form from the mid-

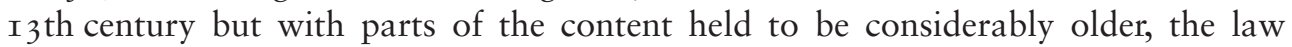
province was composed of fylkir (counties). Three fylkir constitute the original core area of the Gulathing law province (see below). The Gulathing Law also mentions units called fjórðungar 'quarters' and $(\mathrm{ON})$ áttungar 'eighths', generally held to represent subdivisions of the fylki (Helle 200I, 76-80). The fylkir are familiar from various historical sources, but the subdivided units are less well attested. Within the Gulathing, the áttungar seem to be recorded only in the law codex itself, raising doubts as to whether they represent unsuccessful/short-lived attempts at establishing a systematic structure (Helle 200I, 76-8I). The fjóroungr, however, is explicitly mentioned as a judicial district with legal assembly in the Gulathing Law (e.g. G 9, G 35, G 266), and appears to have been an important unit within the secular and ecclesiastical medieval administration. While more recent studies have argued that the introduction and organisation of the leiðangr varied between regions, there has been general agreement that skipreiður were first introduced in the Gulathing law province, probably in the Ioth century, and that the system was spread from western Norway to the entire kingdom by c. I 200 (Andersen I977, 264-265; Ersland 2000, 48-52). The skipreiður soon gained important fiscal and administrative functions in addition to the military, and in western Norway they came to function as the local level of the judicial-administrative system (Bjørkvik I970, 546; Ersland 2000, 4253; Imsen I974d). Thus the general picture of the administrative organisation of the Gulathing law province is that it encompassed, from major to local units: law province, fylki, fjórðungr, skipreiða, with assemblies at each level. The existence of the áttungr is uncertain, and the importance of the fjórðungr supposedly dwindled from 
the medieval period. It is not clear when the skipreiður started functioning as judicial units and most overviews simply state that it happened early (e.g. Imsen I974d).

Various historical records from the I 3 th and I 4 th centuries refer to Horðafylki, Sygnafylki and Firðafylki, the three fylkir that constituted the original core area of Gulathing (Helle 200I, 27), and the three areas continue to constitute main administrative units until the present. The four areas that made up the fjoroungar of Horðafylki (Nordhordland, Sunnhordland, Voss and Hardanger) also continued to function as important administrative units and are well known (Figure 5. I9), while the fjórðungar of Firðafylki and Sygnafylki seem to have gone out of administrative use and can only be reconstructed based on ecclesial records from the I 4 th century (Helle 200I, 77-78, Tryti I994, 35-38). For the area encompassed by Firðafylki, historical records attest to the two halves of the medieval fylki functioning as administrative units from the early modern period and onwards. The differing development of the fjórðungar within the core area of the Gulathing law province has until now not been explained.

This regional study of the law province has revealed that the difference is the result of a reorganisation of the administrative structure. In diplomas from the I4th and 15 th centuries the four fjórðungar of Horðafylki and the northern and southern halves of Firðafylki (Nordfjord and Sunnfjord) are explicitly termed fylkir, and for some of these areas onomastic material confirms the use of the term fylki (Hobæk in prep.). Thus there seem to have been two main phases in the medieval administrative structure for this region: one older with three fylkir subdivided into fjórðungar (Horðafylki, Firðafylki and Sygnafylki), and one later with seven fylkir. These were the original fjórðungar of Horðafylki (Nordhordland, Sunnhordland, Hardanger and Voss) and two halves of Firðafylki (Nordfjord and Sunnfjord), while Sygnafylki remained one unit (Sogn). Based on the dating of the diplomas, this reorganisation must have been completed by the end of the I 3 th century. The new fylki (county) division corresponded to the royal introduction of sýslur.

Local-level assemblies are not explicitly mentioned in the Gulathing Law, but various paragraphs show that the codex pre-supposed their existence (Helle 200I, 76-79). The local level seems to have been less regulated in the early phase, and to have had interaction with the judicial-administrative structure without being an integral part. King Magnus' law of I274, however, contains regulations for local assemblies (e.g. L I I, I 7, VII 37). This implies that from this time onwards, the royal administrative structure was broadened to encompass the local level. Thus the older phase with a law province divided into fylkir and fjórðungar was replaced with a system in which the law province was divided into fylkir and skipreiður - the hierarchy of both phases was three-tiered, but with both local- and mid-level units of the late phase significantly smaller in geographical extent than in the early phase. These changes were completed by c. I300, and fit well in the context of population growth and consolidation of the Norwegian kingdom during the I 2 th and 13 th centuries.

As for the assembly sites belonging to the medieval administrative structure, 76 possible assembly sites have been identified within the core area of the Gulathing Law province (Hobæk in prep.). Some I 27 farm- and minor place-names were identified, distributed across 84 potential sites. Seventeen were also identified from historical sources and in II cases the evidence from historical sources concurred 
with the toponymic material, giving a total of 9I, but ${ }_{5}$ sites remain, however, less convincing. This is a relatively high number of sites and potentially suggests that a significant portion are local in level. Since this level of assembly has been absent in overviews from western Norway so far, these sites are of particular interest. Three identified sites are discussed in detail here in terms of archaeology and topography.

\section{Tinghaugane in Fana: A possible (ON) fylkisping 'county-thing' site (Figure 5.I9)}

Tinghaugane is a site identified by place-name evidence alone: no documentary evidence or historical information has been found for the site. Tinghaugane means 'the thing-mounds' and is located at the farm Nedre Titlestad which was probably once a single unit with the neighbouring farm at $\varnothing v$ re Titlestad. Late prehistoric evidence is limited: none is known from Nedre Titlestad, but three burials, now lost, were recorded at Øvre Titlestad (Fett I97I), although they seem to have been related to the settlement area on the farm with little evident connection to the Tinghaugane site.

The place-name Tinghaugane indicates the presence of a thing, but judicial records from $\mathrm{I} 642$ and onwards contain no reference to assemblies or other judicial functions at Titlestad. The name Tinghaugane seems likely therefore to refer to assemblies pre-dating I642 (Larsen I980, I44-I45). Titlestad belonged to Skjold skipreiða, but its location in the south-western corner of the skipreiða is not convenient in regards to transport and communication, indeed there are better options elsewhere within Skjold skipreiða (Hobæk in prep.). Since place-names composed of ping- and other elements may date back to the Late Iron Age (see Chapter I), it is theoretically possible that Tinghaugane was the focal point of an assembly district pre-dating the ship-district organisation. However, an older area name, Steindarfjorð named after the fjord by the farm Stend (ON steindr 'stone paved'), is known and has been argued to correspond to the skipreiða (Larsen I980, I 49-I 5 I). Tinghaugane would therefore have been as inconveniently placed for the older unit as it is for the skipreiða.

When considered in the larger administrative context, however, the site location begins to make sense. It occupies a striking location within Horðafylki and is situated less than I km from the border between Nordhordland and Sunnhordland, the two western fjórðungar of the medieval Horðafylki. The two eastern fjórðungar, Voss and Hardanger, would also have good communication routes to this area (Figure 5.I9). The place is also some $1.5 \mathrm{~km}$ south-west of Fana church which can be dated to the I 2 th century. In I228, when first mentioned in written sources, Fana was a parish church, but furnished with a hospital, a holy cross and several priests. In 1303 the church and its properties were given to Apostelkirken in Bergen and only five years later it was appointed one of $\mathrm{I} 4$ royal chapels in the kingdom. In the mid-I 4 th century, Fana was also one of four high-ranked churches within the ecclesial organisation of Nordhordland (Lidén 2008, I02; see also DN I, no. 206 and DN 4, no. I 88). Several authors have noted the proximity of Fana to the river that marked the ancient border between Sunnhordland and Nordhordland (Ekroll I997, 256; Hoff et al. 2000, I; Lidén 2008, I02). It is possible that Fana held a special status in the fylki in the first phases of church organisation (Ekroll I997, 256), and more explicitly that Fana was the original fylki church of Horðafylki (Larsen I980, I62-I66; compare Gıo). 


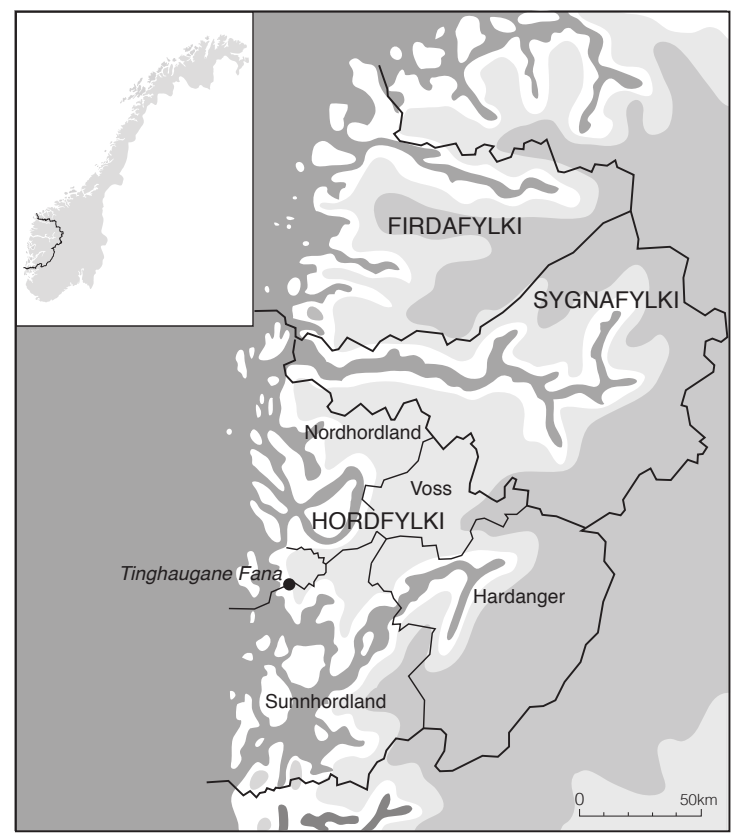

Figure 5.I9 The three original fylkir of the Gulathing law province, with the four areas of land that made up the fjórðungar of Horðafylki: Nordhordland, Sunnhordland, Voss and Hardanger.

Tinghaugane in Fana is suggested as the assembly site for Horðafylki. Illustration by Halldis Hobæk.

Tinghaugane and Fana church are thus both centrally placed within the fylki. The topography of the site seems favourable for the proceedings of an assembly, and co-location of the assembly and main church for a fylki would fit well with the administrative organisation that the older version of the Gulathing Law seems to imply. If the interpretation is correct, the date for the establishment of the thing would fall together with the creation of the fylki in the late 9th/early Ioth century and its importance would have diminished when the original Horðafylki was replaced c. I300 by its four fjórðungar.

\section{Tønjum in Lærdal: Assembly of Lærdal fjórðungr}

An assembly site at the farm Tønjum in Lærdal is recorded in a diploma from I 4 I I, which was issued at (MNorw) 'Twneime a rettom pinghstad...' (DN 2, no. 6I7). A (Mod Norw) tingstove or 'thing cottage' designated for assemblies is recorded at Tønjum in I62 I and I649 (postscripts in DN 9, no. 776). Tønjum is located in a valley with steep sides, with a north-west flowing river and a major communication route between eastern and western Norway following the valley. The route goes through the settled area of the farm or tun, with a ford/bridge close by. Toponymic material places the assembly at Tønjum within this settled area as well: Tinghaugen, 'the thing mound', is a large natural glacial deposit, with a marked outcrop in the northern part of the tun of Tønjum. On the plain just east of Tinghaugen the names Tingvoll and Tingstad, 'thing field' and 'thing site' respectively, are recorded (Figure 5.20).

A number of archaeological surveys and excavations have been undertaken in the area. Both Tønjum and the neighbouring farms have settlement traces and 


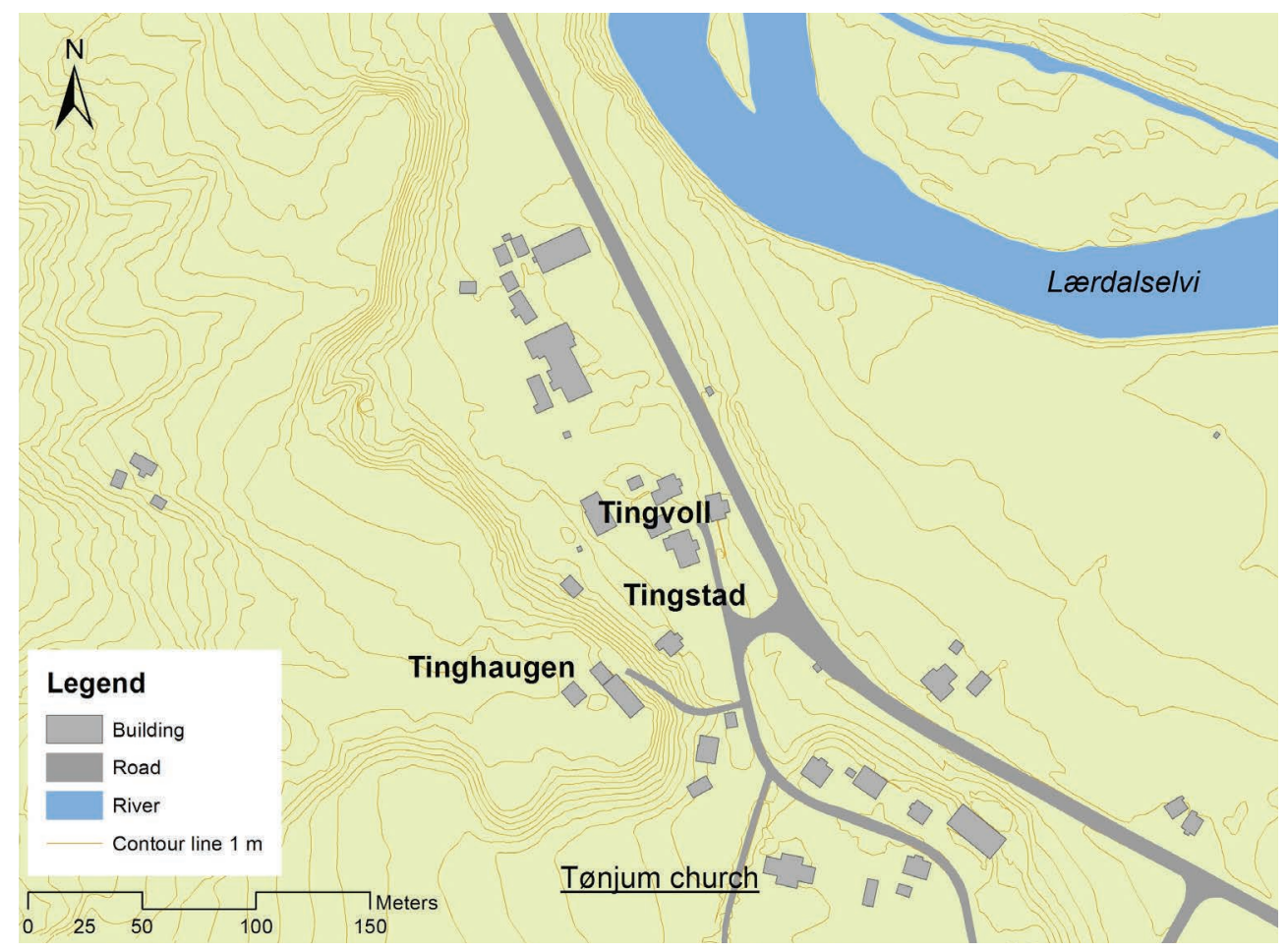

FIgURE 5.20 Toponymic evidence places the assembly at Tønjum (Sygnafylki) within the settled area: Tinghaugen, 'the thing mound', is a large natural glacial deposit, with a marked outcrop in the northern part of the tun of Tønjum.

Illustration by Halldis Hobæk.

evidence for various activities dating from the Neolithic period onwards, as well as recorded burials. Tønjum was probably a farm unit originally, together with today's farms Øvregard and Prestegarden (Espe and Hovland I994, I66). From this area a total of nine burial cairns are known, generally dated to the Bronze and Iron Ages. Two iron sickles, dated to the Iron Age, were found on the eastern side of 'the thing mound' (Fett 1952). ${ }^{\mathrm{I}}$ The site of the find has not been excavated by archaeologists, and it is not clear whether the find represents a grave or a deposit.

An assembly recorded at Tingstedt (Thing site) in Lærdal in I 54I (DN I 2, no. 600) may also relate to the place-names Tingstad and Tønjum. Lawrightmen from the six easternmost skipreiður of Sogn were present at this meeting: an indication that the assembly might have been supra-local/regional in scope. The church of Lærdal fjórðungr was located in the settled area of Tønjum (Espe and Hovland I994, I7I; Tryti I994, 34-35). As the fjórðungr or 'quarter' church, Tønjum was one of four

I Entries nos I6, I7 and I8: ID I 5780, ID 100589, ID 100729, ID 100730, I D I008 I I, ID I00589, ID I00826, ID I00827, ID I00828, ID I00833, (ID 35852, ID I0065 I, ID I00763, ID I00849, ID I0I085. 
churches in Sygnafylki visited by the bishop in $\mathrm{I}_{322}$ (DN 7, no. 98), confirming the site's importance in the medieval period. Tønjum, however, also had a central location within Lærdal skipreiða. The (Mod Norw) tingstove or 'thing cottage' recorded in the I 7 th century probably functioned at ship-district level, and the assembly site at Tønjum could have functioned at both quarter and ship-district level and with regard to communication and access it would be equally suited for both. The topography of the site seems favourable for assemblies, with the slope of the thing mound possibly functioning as a viewing place for proceedings held on the level terrain at Tingstad/ Tingvoll.

The ship-district thing at Føyno, Sunnhordland

Føyno is a small island, roughly I $\mathrm{km}$ wide. The name Føyno means 'cattle island' and may indicate its use for grazing. The oldest name for the skipreiða that Føyno belonged to is Káravik 'Kåre’s bay' (e.g. DN I2, no. I I2, I38I), in all probability referencing the location for the boat house for the ship for the leiðangr. In Kåravik, $4.5 \mathrm{~km}$ north-east of Føyno, the remains of a boat house measuring $30 \mathrm{~m}$ by $7 \mathrm{~m}$ have been recovered and dated through excavation to AD I000-II60. From the I6th century onwards this skipreiða was called Føyno, however, and this change may have taken place when the unit took on the name of its assembly site. A thing site at Føyno is recorded as the 'correct assembly site' in I4 I4 (DN I 2, no. I 55, 'Fæøy a rettre pingstodh') and has been interpreted as a local thing site (Økland and Njåstad 2005, I03-104). An assembly is also documented at Føyno in I 563 (Høyland I966, 639), but by the I 7 th century, assemblies for Føyno skipreiða appear to have been held elsewhere (Økland and Njåstad 2005, I 52 ).

Neither the diploma from I4 I 4 nor the record of I 563 indicates where on Føyno the assemblies were held, but toponymic material provides a plausible location. At the southern side of Føyno are the place names Tingvikjo and Tingholmen, the 'Thingbay' and the 'Thing-islet' (Figure 5.2I). Tingvikjo is centrally located within the skipreiða and close to main sailing routes, and would provide a relatively sheltered harbour. There are also alternative harbours in the area, particularly at the northern side of Føyno. Tingvikjo itself is a gently sloping plain which reaches a beach with rock formations on either side of the southern part, while Tingholmen is a small rocky islet.

Føyno has a rich archaeological record with six undated burial cairns, two sites with undefined activities dated to the Early Iron Age, and the remains of four house structures (Fett I967). ${ }^{2}$ One of these is located in Tingvikjo, and is square, measuring I I sq $\mathrm{m}$ externally and $4 \mathrm{sq} \mathrm{m}$ internally due to the very wide ramparts. The floor was lowered and the ramparts measure c. $1.5 \mathrm{~m}$ high internally. To the south, facing towards the sea, is an opening (Fett 1967; Økland and Njåstad 2005, I03-IO4). A sample from the structure has been dated AD 970-I020 (Kristoffersen and Warren 200I, 2II).

This structure is of particular interest due to its location, raising the question of whether the structure had any later relationship with the assembly documented in I4I4. Some $20 \mathrm{~km}$ north of Føyno is Fitjar ('fertile land'), the central farm of a

$\overline{2 \text { Entries no. 5I: ID }} 45538$, ID 55288, ID 35503 , ID 60599, ID Io8 574, ID Io8 574, ID 25598. 


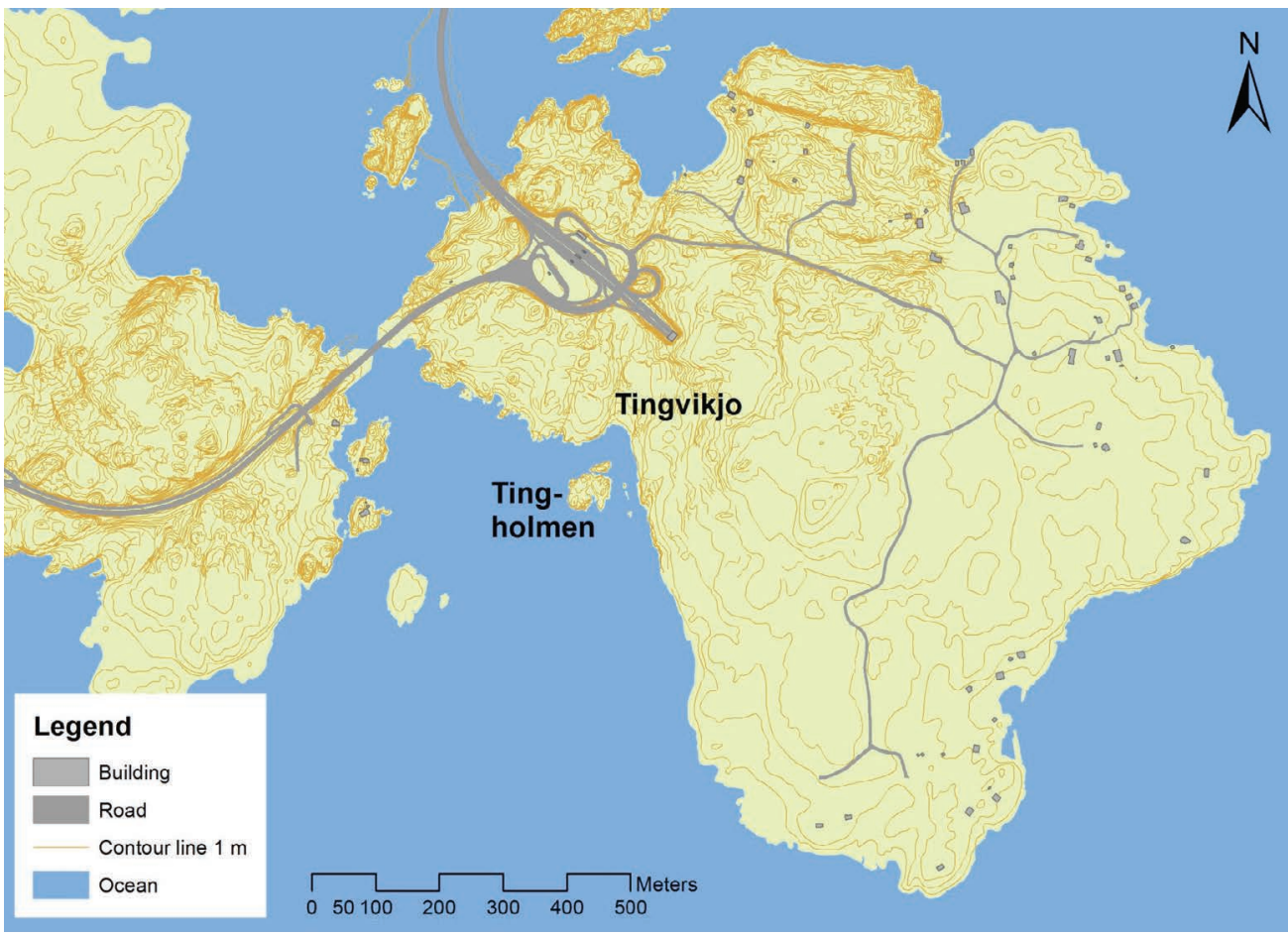

Figure 5.2I Tingvikjo with Tingholmen, Føyno, is interpreted as a local assembly site. Illustration by Halldis Hobæk.

royal manor in the Viking period. A square structure, now lost, was recorded in I 830 close to the church at Fitjar, measuring Io sq m externally with very wide ramparts and internal depth of $1.8 \mathrm{~m}$. The structure called 'Thing grave' or 'thing hollow' had an opening facing towards the sea (Kraft I830, 674). This site offers an interesting parallel to the structure in Tingvikjo, and its name implies a similar assembly association. If Tingvikjo on Føyno was used as a location for a local assembly, the site could have been active from the I I th to I 6th centuries.

\section{Summary}

This regional study of the Gulathing law province suggests that it is possible to distinguish between two main phases in the medieval administrative structure. The core area of the law province consisted of three medieval fylkir subdivided into quarters. Assemblies were held at both of these levels, as well as annual assemblies for the whole law province. Presumably there were also local assemblies, pre-supposed in the earliest version of the Gulathing Law, but the local level was less regulated, and although it was connected, the sources suggest it did not play a direct part of the royal/ecclesiastical administrative system. 
Over 70 possible assembly sites have been identified within the core area of the Gulathing law province, ranging from local to mid-level assemblies. Of the sites discussed in detail, the Tinghaugane site is suggested to have functioned as the fylkisping for Horðafylki. The assembly at Tinghaugane must be assumed to have been an important arena for negotiations between the king/royal representatives and the inhabitants of the fylki. The establishment and end of the site seem closely tied to the organisational needs of the kingdom. The site in Tingvikjo on Føyno on the other hand, was probably a local assembly. The dating of the structure in Tingvikjo to AD 970-IO20 implies that an assembly may have been functioning here well before the administrative system of the kingdom was extended to the local level. These sites illustrate the development of the administrative system in the Gulathing law province and highlight assemblies as places for interaction between rulers and the governed and as vital arenas for local communities.

While locational information on topography or associated archaeological finds is hard to establish, mounds (burial or otherwise) are again a feature at some sites. Prehistoric activity and monuments are attested, as well as evidence for burials. Communications and access are also significant for these meeting-locations. In later centuries meeting houses or buildings may have been in evidence as well.

During the $\mathrm{I} 2$ th and $\mathrm{I} 3$ th centuries important changes gradually took place and by c. I 300 there were seven fylkir within the core area of the Gulathing law province: the four quarters of Horðafylki and two halves of Firðafylki which gained status as fylkir (counties). Assemblies continued to be held at the level of the law province and at the county level. In addition, the skipreiður were by this time geographical units constituting the lowest judicial and administrative level. In other words, by the end of the $\mathrm{I} 3$ th century, the administrative system had been extended to encompass the local level.

\section{$5 \cdot 7$ CONCLUSIONS}

The study of these three law provinces, using documents and on-the-ground exploration of key sites, offers a unique insight into the development of administrative arrangements in parts of Norway. There are clear analogies to the discoveries set out in Chapter 4 which showed that communications and access were especially relevant to the location of meeting-sites. Cemeteries, mounds and other monumental forms and prehistoric evidence are common attributes. What is more pronounced in some of the Norwegian law provinces discussed here, is the evidence for late prehistoric/Migration period meeting activity in the locality or immediate vicinity of a place associated later in time with a medieval thing. This is evident at cooking-pit and courtyard sites and may offer an insight into the development of local meeting practices over time. These assemblies almost certainly changed in size, activity and organisation across prehistory to the historic era and locations may not have been used continuously. The evidence, however, does provide insight into how large communal gatherings in some regions may have acted as regulating mechanisms, enabling the forging of supra-local and even supra-regional connections and identities. Spatial correlations with known medieval thing places point to the continued use or revisitation of places for outdoor meetings as processes of administration and justice developed across the Ist millennium AD. 
The courtyard sites of Norway present equally striking testimony of assembly and perhaps judicial processes in the landscape at an early stage. In past scholarship they were seen exclusively as places for military mustering without associations with the thing institution. Courtyard sites may well have embedded various functions, however, and these may have included, as the archaeological evidence suggests, cultic functions, but they may also have operated as places of legal discussion and military jurisdiction. It is entirely possible that if these were places for regular assemblies, that decisions about the use of communal military force and maintenance of the regional defence system might have been taken here. If thing sites, these testify to the increased regulating nature and reach of elite and royal power. During the Ioth century, the command of the fleet was transferred to the king when the leiðangr was formally established. The shift from rowing ships to sail ships during the 9 th century may have changed the character and potential range of the regional defence system. Alliances and mutual defence systems for large areas became possible, and Hålogaland became more closely integrated in the expanding Norwegian kingdom. Combined with increased royal power and kingdom formation, this led to a new system of thing sites and administrative ship-districts in Hålogaland. Prior to the 7 th century, many small courtyard sites existed and then gradually became obsolete, until only three large sites were left, each of them located in their own region. During the 9 th century, the three regions merged and a new singular lawthing was established at Steigen, central to the region. Such changes may well reflect the establishment of superior jurisdiction at the expense of a number of smaller communities merged to establish larger groupings within an increasingly powerful supra-regional kingdom. The organisation of administrative areas and thing sites in the Borgarthing law province is argued here as indicative of strong royal control over the landscape. This is evident as well in the large administrative changes and moving of thing sites closer to towns and royally controlled centres, which may have influenced even the lower and local levels of administration by the I 3 th century. On the other hand, the diplomas from the $13^{\text {th/I }} 4_{\text {th }}-\mathrm{I} 7_{\text {th }}$ centuries acknowledge the continued importance of communal organisation at the local thing level.

The Gulathing province covered the areas of Sogn, Firda and Hordaland in c. AD 930 according to Egil's Saga (Helle 200I, 28) and it is possible to establish four chronological stages in the development of the Gulathing law province. It expanded in the Ioth century from a nucleated core of three counties with the addition of coastal counties. Inland areas were added in the I 2 th and I 3 th centuries. The last and geographically most extensive phase is attested in $\mathrm{I} 274$, when the law province embraced additional interior areas and valleys. These four phases illustrate the dynamic processes behind the development of a larger society from the increasing interactions between smaller communities.

While intra-site evidence is confined to the case-study areas, it does present themes common to the broader study of Scandinavian administrative system and assembly places in Chapter 4. Immense variability is demonstrated as well in the shape and form of thing locations and, potentially, in the evolutionary paths for assembly within and across localities. While the evidence points to a slow process of development for local and regional meeting practices that may have culminated in the documented medieval thing, it is also clear that the meetings and the administrative arrangements 
they served were agile and changing. The emphasis in medieval and late-medieval accounts on strict notions of the thing, in terms of location, organisation and delivery, potentially highlights a fear of local innovation. Legal action and decision-making needed to be conservatively maintained as a set of common rules if the hierarchical thing system of the medieval and late-medieval eras was to function effectively across all levels.

The communities who came together in the early centuries of the Ist millennium $\mathrm{AD}$ to cook and eat together outdoors or at courtyard sites may not have been participating in a thing of identical shape, form, name and function as the medieval rural populations of Norway in the I 3 th and I 4 th centuries, yet the evidence from these case studies does suggest compelling evidence for a strong developmental connection between late prehistoric communal organising structures and the systems of local to top-level administration and law that emerged in Viking-Age and medieval Norway. 


\section{CHAPTER 6 \\ COLONISATION AND CONTROL \\ Assembly systems in new territories}

\section{I SUMMARY}

The process of Norse colonisation and settlement was variable in different areas. The history of the Northern Isles of Scotland, the Faroe Islands and to some extent Iceland is interlinked, and these regions were subject to similar developments in their Norse settlements between the $9^{\text {th }}$ and the I 3 th centuries. The Norse colonisers in Iceland created an independent country without a king (Commonwealth Period AD 930-I262), after which Iceland became a skattland or 'tributary land' as part of the Norwegian realm. By this time, the Faroes and the Northern Isles of Scotland were also Norwegian skattlands. Norwegian power had gradually increased, but the precise moment the kingdom took control over these island groups after the first period of Norse settlement in the 9 th and Ioth centuries is unclear (Crawford 2013; Sigurðsson 2010, 62-65; Smith 20I I, I04; Wærdahl 2006, 9-10; 20I I, 69-7I). In the Danelaw the Norse settlers took over existing kingdoms, but the region was never ruled by a Scandinavian kingdom. These Norse settlers took ideas of governance, administration and law with them to new lands. Iceland and the Faroes were virtually unpopulated at the time of Norse settlement and Norse administrative systems were developed in a largely or wholly unpopulated landscape, without pre-existing divisions and monuments. Norse Scotland and England were different: these areas had been settled for thousands of years, and here the Norse interacted with existing populations, their settlements and monuments and pre-existing modes of organisation.

This chapter examines the administrative systems and some of the major assembly sites established as a result of the Norse expansion and settlement in the colonised lands west of Scandinavia. Research is focused on Iceland, the Faroes, the Northern Isles of Scotland (Orkney and Shetland) and the three Ridings of Yorkshire, located in the Danelaw in England. These areas work as useful comparisons, providing an opportunity to examine the Norse administrative systems and sites developed in previously unpopulated and populated areas.

\subsection{LAW AND ASSEMBLY IN THE NORSE SETTLEMENTS}

Very little is known about the early laws in the new Norse settlements in the North Atlantic. For Shetland, Orkney and the Faroes, laws have not survived, apart from a very short section applicable to the Faroes in the Law of Magnus the LawMender. It seems likely that the Gulathing Law (or perhaps local versions of this law) 
was used in all these island groups, as indicated for the Faroes in a letter issued by Magnus the Law-Mender in I274 (Bøe I965, I83; NgL IV, 353-354). In Iceland before Grágás, the 'Gray Goose' Laws, a collection of laws from the Commonwealth Period written down in the I3th century, came into existence (Dennis et al. I980, I) and the Gulathing Law may have been used here too. According to Íslendingabók ('Book of the Icelanders'), a Norwegian named Ulfjlót brought a law, based on the Law of the Gulathing, to Iceland in AD 930 (Grønlie 2006, 4). Parts of this law included in Landnámabók ('The Book of Settlements'; Pálsson and Edwards 20I4) have been interpreted as a Christian forgery (but see Brink 2002, I09), but given the existence of a 'few consistent similarities' (Byock I990, 58) between the Gulathing Law and Grágás, the early use and influence of the Gulathing Law remains possible.

Legal proceedings in the Danelaw are known only through law-codes promulgated further south in the kingdom of Wessex. Two in particular, the Wihtbordesstan code of Edgar (c. 963) and the Wantage code of Æthelred II (c. 997) are of special interest, as each devoted particular attention to the practice of law in the Danelaw. The Wihtbordesstan code provides the earliest known instance of the term wapentake-as (OE) waepengetace (Liebermann I898-I9I6, I, 210), while the Wantage decree demonstrates the presence of hundredal principles in wapentake proceedings and the distinctly non-hundredal 'purchase of law', literally OE lah-cop (Vinogradoff I908). The main contrast with known Scandinavian practice is in the use of the term wapentake itself. ON vápnatak is found as a term of assent in early Norwegian laws and Grágás (Dennis et al. I980, 2 I 2, fn I Iо; Helle 200 I, 72-74) but in the Danelaw it was applied to assembly sites and assembly territories themselves.

\section{Written sources for administrative and assembly arrangements}

In terms of administrative and assembly functions, Iceland during the Commonwealth Period has the richest written legacy, ranging from the detailed laws of Grágás to 'The Book of Settlements' (Landnámabók) and the sagas. These are the most detailed accounts of early administrative systems from the North Atlantic and describe the development of arrangements as early as the Ioth century. The problems with these accounts are well known; existing manuscripts date from the I 3 th century onwards and the accuracy and reliability of the descriptions have been called into question, but these sources do incorporate details of earlier administrative arrangements and activities. Despite a move to distance archaeological exploration from the sagas (Friðriksson I994; Friðriksson and Vésteinsson I992), assembly sites in Iceland are still to some degree evaluated in this context (Friðriksson et al. 2005; Whitmore 2013).

In contrast, source material for the Faroes is incredibly sparse. The medieval Foreyinga Saga mentions an assembly at Tórshavn, but with few details (Nolsøe and Jespersen 2004, 7I-73; York Powell I896) and thing sites only gain mention from the I 7 th century when the court books started appearing (Joensen I953; I969). Very few archaeological remains from the Norse period in general are known (Arge 20I4; Arge et al. 2005) and archaeology can therefore only contribute in the smallest terms. This means that for the period between the 9th/Ioth and the I 7 th centuries, the main sources are oral traditions and place-names. This is of course problematic, but it is 
important to point out that Faroese oral traditions are plentiful and considered quite reliable (Guttesen 1992, 25; Smith 2009; Thorsteinsson 2012). The situation in the Northern Isles is similar: the Orkneyinga Saga mentions a few Orkney assemblies (Pálsson and Edwards I987) but the bulk of evidence consists of references and place-names recorded in late-medieval and even later documents and oral traditions (Ballantyne and Smith I999, I994; Clouston I914). In early medieval England, legal material is almost exclusively of Anglo-Saxon provenance (Wormald I999). No record of any specific bundred or wapentake proceeding in the Northern Danelaw prior to the late I ith century has been identified. Later-medieval documents do provide detail: the cadastral survey of I086 known as Domesday Book provides the names of the hundreds and wapentakes across large parts of England and identifies the vills and manors situated within each territory. Place-names and accounts of later-medieval legal proceedings are also crucial to the reconstruction of early arrangements.

There is, therefore, an imbalance in surviving documentary accounts across the regions. Iceland stands out with a rich saga tradition, but this material is very specific to assembly practices in Icelandic society. Elsewhere documentary accounts are largely $\mathrm{I} 2$ th century or later. All regions, bar Iceland, thus share an absence of early written accounts and there are few surviving documents that describe legal arrangements and laws. Place-names, medieval and later documentary sources thus provide the core components for analysis in the chapter. In the sections that follow these sources are examined, the administrative arrangements are reconstructed, and units of administration as well as assembly sites and places are considered within their landscape context.

\subsection{ICELAND}

\section{Administrative organisation of the law province}

With the establishment of the althing around $\mathrm{AD} 930$, at the end of the settlement period (MIcel landnámsöld, c. 874-930), the country was divided into I 2 assembly districts, each with three assemblies. Two local assemblies, Kjalarnesping and Pórsnesping, are said to have existed before this time. Ari the Learned refers to 'a thing at Kjalarnes which Thorsteinn... held there together with other chieftains who joined him' (Jóhannesson I974, 35). At Pórsnes, the Norwegian Porolf Mosterbeard after setting foot on Iceland is reported to have 'held all his court sessions and he established a district assembly there with the approval of all the people in the neighbourhood' (Whitmore 2013, 69). Each assembly district consisted of three chieftaincies (ON goðorð); hence there were 36 chieftaincies in total. These chieftains had thingmen, their followers, who were obliged to attend the meetings. Each chieftain also appointed I 2 (ON) bændr (see ON bondi in Ch. 5), free farmers or householders who acted as judges (Byock 200I, I7I-I74; Dennis et al. I980, 258-259; Jóhannesson I974, 74-76; von Maurer I874, I78-I79).

Around $\mathrm{AD} 965$, a division into quarters was introduced, which changed the judicial structure of the althing: the East Quarter, the South Quarter, the West Quarter and the North Quarter. Grágás and Íslendingabók tell of three local assemblies (each with its own 'thing district') within each quarter, with the exception of the Northern 
Quarter which after 965 had four assemblies-Pingeyjarping was then added, probably as a result of population growth. After this date, there were 39 chieftains at the top of the local assemblies. The division into quarters was based on geographic boundaries such as rivers, ridges or high mountains (Byock 200I, I7I; Dennis et al. I980, 2; Jakobsson 20I2, I06; Jóhannesson I974, 49-5I, 59; Karlsson 2000, 94; Sigurðsson I989, 53, 69; Solvason 1993, I09; Vésteinsson 2006a, 316; Whitmore 20I3, 364-369, 372).

During the Ioth century Iceland was also divided into units termed (ON) hreppar (singular hreppr) each of which was shared by at least 20 farmers that had to pay tax (ON pingfararkaupsbændr, literally 'thing tax farmer'). The sources give no indication about the number of hreppar and their boundaries can only partly be recreated, and when they can be, it is evident that the later parish units cut through the hreppar boundaries (Byock 200I, I37-I38). The hreppar are unknown from other Norse areas. The ON term for region, herad, used for thing districts in Scandinavia, also appeared in Iceland however, both terms, herað and hreppar, are difficult to distinguish as herað in Iceland is not clearly defined and the terms are often used interchangeably. The hreppar were part of the local assembly structures, but it is unclear whether this was also true for the Icelandic herað (Jakobsson 20I 2, I05-I06; Jóhannesson I974, 83-89; Lárusson I961; I962; Solvason I993, I04-I06; Vésteinsson 2006b, III). Bearing in mind the role of the herad in Scandinavia, this was most likely the case. Furthermore, the relationship between the hreppar, the local assemblies and thing districts is also unclear (Jakobsson 2012, I07).

The local assemblies and their districts were abolished in I27I with the introduction of Járnsiða, a law code introduced by Magnus the Law-Mender and a new type of administrative unit called (ON) sýsla was introduced from Norway. This was connected to the royal office and in line with Norwegian practice. These new units seem largely to have followed the division of previous thing districts; they mostly replaced older units although in some cases the old units were later split into several new and smaller sýslur (Dennis et al. I980, III-II2, 24I; Jóhannesson I974, 74; Karlsson 2000, 25, 94, I 53; Lönnroth I976, I90). (OIcel) Hreppaping, assemblies of about 20 householders, now replaced the local spring assemblies (Friðriksson I994, I06; Vésteinsson et al. 2004, I73). From this time on meetings started also to be held indoors at a farm (Sigurðsson I999). A specific court building of a hreppaping was excavated at Kópavogspingstað near Reykjavík. It is mentioned from the I6th century onwards and the archaeological remains date from the I 7 th century (Sveinbjarnardóttir I986).

\section{Assembly sites: Levels and functions}

The Icelandic assembly system initially operated on three levels: at the top was the althing, followed by the quarter-things (ON fjóroungsping) and finally the local things (held in the spring and the autumn). The althing meetings were held at pingvellir in south-west Iceland. They lasted two weeks and were held at a set time each summer starting 'on the Thursday when ten weeks of summer have passed' (Dennis et al. I980, 57). All cases that had not been solved by a local assembly could be brought here. Another key component of the althing was the (ON) lögrétta, the 
meeting of the Law Council, the legislative power. It consisted of I 47 thingmen who discussed and changed existing laws or introduced new ones. Around AD 1005 the Fifth Court (ON fimtardómr) was introduced as the court of appeals for the newly created Quarter Courts (Byock 200I, I74-I77, I82-I83, 355-356; Dennis et al. I980, 246; Jóhannesson I974, 36, 40-48; Karlsson 2000, 22, 24; Lönnroth I976, I 89; Solvason 1993, 107).

Little is known about the quarter assemblies. They are mentioned only once in Grágás and do not appear to have been held regularly. The purpose was to solve the legal affairs of each of the four quarters on neutral ground for the people of different thing districts. These assemblies may have been held at specific sites, or at the sites of local assembly. It is not clear from the written records whether each quarter assembly had 36 judges, or whether there were 36 judges for all quarter assemblies in total (Byock I990, 67; 200I, I8I; Dennis et al. I980, 257; Jóhannesson I974, 52, 66; Lönnroth 1976, I90; Solvason 1993, 107). These assemblies, however, seem to have been transferred to the althing rather quickly and were then called (ON) fjórðungsdómar ('quarter courts'). It is not known whether there was a specifically designated area at Pingvellir for these courts.

At a local level, set meetings were held twice a year, resulting in the terms 'spring assemblies' (ON várping) and 'autumn assemblies' (ON leiðir). The spring assemblies were usually held between 7 and 27 May (Dennis et al. I980, 258). These meetings served the local thing districts that probably had relatively well defined boundaries (Byock 200I, I7I; Jóhannesson I974, 74; Karlsson 2000, 25). Local assemblies should be held at sites approved by the Law Council at the althing (Dennis et al. I 980, I I I-I I 2, 24 I, 258-259; Jóhannesson I974, 74). Each assembly site was in the hands of the three chieftains and they were responsible for its upkeep (Byock 200I, I7 I-I74; Dennis et al. I980, 258-259; Jóhannesson I974, 74-76; von Maurer I874, I78-I79). The law reads: 'A chieftain is to come to a spring assembly in time to roof his booth on a Saturday before the sun is shaft-high and to be ready then to go to the formal inauguration of the assembly' (Dennis et al. I980, 43).

The spring and the autumn meetings were rather different in nature. At the local spring assemblies cases of farmers and the chieftains of the district were settled (Dennis et al. I980, 24I, 258-259). The local autumn assemblies were more concerned with formalities as these meetings were held to inform those who had not been able to come to the general meeting about new laws and events (Byock 200I, I74; Jóhannesson I974, 82; von Maurer I 874, I80). These assemblies should take place at least I4 nights after the top-level assembly meeting at Pingvellir had ended (Dennis et al. I980, I I I-I I2, 24 I; Jóhannesson I974, 74).

Another form of assembly also existed, the (ON) héraðsdómar. These were held ad hoc at places, away from the established local assembly sites. In this way, they form the equivalent of the extraordinary assemblies known from Swedish laws (see Chapter 4). The héraðsdómar included commune courts (to deal with matters of broken commune rules), outfield courts, communal pasture courts (to deal with the clarification of the rights for the communal pasture), and courts for foreign traders (Dennis et al. 2000, 37I-372). In addition, there were $(\mathrm{ON})$ féránsdómr, courts of confiscation, which could be held at the home of a person about to be outlawed and if this was not known then at the home of the responsible chieftain, or even at the 
althing. A chieftain or the plaintiff could execute law by confiscating the property of a person outlawed at an assembly, or collect fines and sentences imposed by the court (féránsdómr). According to Grágás, the féránsdómr should be held 'somewhere outside the [home-field] wall where there is neither arable land nor meadow land and not beyond bowshot from the wall and on a line from the wall towards the place where the man who prosecuted him has his home' (Byock I993; Dennis et al. I980, $89,243-244)$.

\section{The archaeology and topography of the sites}

In addition to the althing site at Pingvellir, I7-20 local assembly sites have been identified by means of archaeology, written sources and place-names (Friðriksson 20II, 346, 355; Vésteinsson 2006a, 309-310, 317; Whitmore 2013): Kjalarnesping, Pverárping, Pórsnesping, Porskafjarðarping, Dýrafjarðarping, Pingeyrar, Hegranesping, Leiðarnes, Vaðlaping, Skuldapingsey, Sunnudalsping, Krakalækjarping, Múlaping, Skaftafellsping, Leiðvöllur, Pingskálar, and Árnesping (Figure 6.I). All local sites are marked by place-names that contain the element $(\mathrm{ON})$ ping (e.g. Pingeyrar)

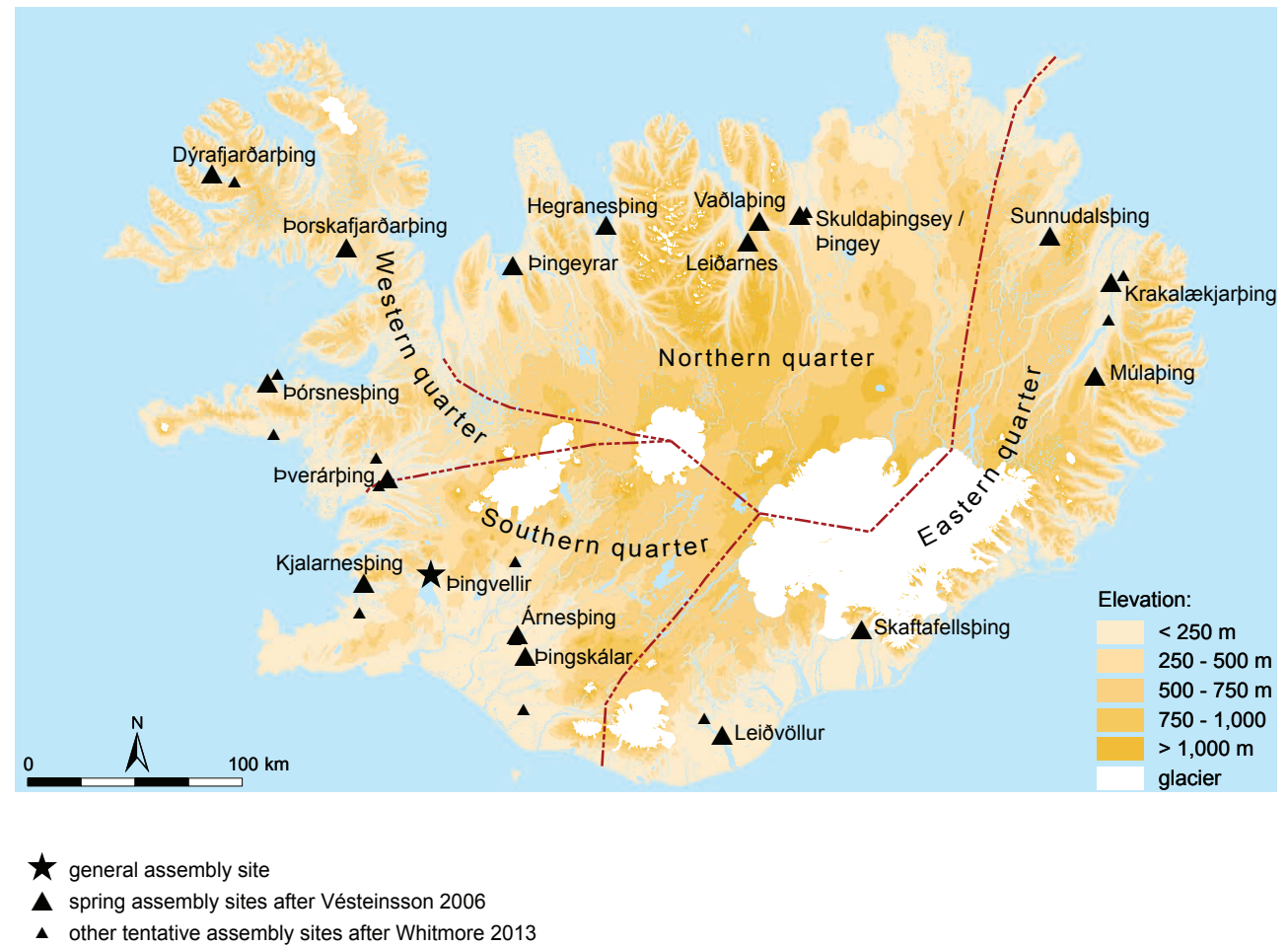

FIGURE 6.I Map of Iceland with I7 potential assembly sites (large triangles) and other potential assembly sites (small triangles) with the background of the quarter division. By Joris Coolen (site names and locations mentioned by Vésteinsson 2006a and Whitmore 2013). 
or (ON) leið as in autumn (e.g. Leiðarnes). It could be argued that those sites with the place-name element leið are likely to indicate that autumn assemblies were held here and that this implies again that the assemblies in spring and autumn were held at a separate location. Seven of these sites can be equated to the locations of specific local spring assemblies mentioned in the sagas: Pórsnes, Pingeyrar, Hegranes, Pingey, Pingmúli, Pingskálar and Árnes (Vésteinsson et al. 2004, I7 I and fn I). There are local assemblies known from sagas which have not yet been identified on the ground and also sites that do not fit the administrative landscape (Vésteinsson 20I3, I I2). The latter have been identified as thing sites due to the typical archaeological features of a meeting-place such as booths or ping place-name elements, but are not known from written sources. Hence, there are more ping place-names than there should be assembly sites, which indicates that sites were moved according to needs. It is possible that these sites shifted over time, which could explain why some quarters seem to have more than their share of sites (Sanmark 2017a, I65-166). As with assemblies in other areas, these sites and their period of use are difficult to date.

The Icelandic sites have a number of recurring traits. As shown in previous chapters, one of the main priorities when selecting sites was good accessibility. People had to be able to reach an assembly easily if coming on foot, by horse, or by boat. This is clearly seen at Pingvellir, the site of the althing, which is located approximately $40 \mathrm{~km}$ north-east of Reykjavík, at a plain at the River Öxará which runs into Lake Pingvallavatn. The site is situated in an area that has been settled since the beginning of the colonisation of Iceland. The settled areas of the Rivers Hvítá and Pjórsá, east of Pingvellir, are nearby, as is the Mosfell Valley just to the west, and the episcopal see at Skálholt to the east. While Pingvellir is easily accessible by horse and by foot, it is some distance from the sea however. The nearest sea access is at Hvalfjörour, the fjord approximately $20 \mathrm{~km}$ north of Pingvellir as the crow flies. People either travelled to Pingvellir on foot or by horse, or took a boat into Hvalfjörður or arrived at the southern coast near Eyrarbakki, to then continue their journey on foot or by horse.

Striking landscape features are also connected to the Icelandic assemblies. This is the case particularly with Pingvellir, which therefore forms a parallel to the top-level assemblies in Scandinavia (see Chapter 4 and Sanmark 20I7a, 76-II6). The site is characterised by a set of impressive landscape features, landmarks which obviously were significant factors for the selection of this site (Figure 6.2). Most prominent are the impressive lava cracks and canyons, the largest one called Almannagja where the River Öxará forms a waterfall (Öxaráfoss). At the estuary lie several islands and spits of land and the river runs into Lake Pingvallavatn, the largest lake in Iceland. It is reported in the Book of the Icelanders that Grimr Goatbeard had been sent to Norway to study the Gulathing Law, and then explored parts of Iceland to find the right place for the althing to be established as a water supply was essential for visitors to the assembly (Grønlie 2006; Jóhannesson I974, 38-39; Karlsson 2000, 20).

Úlfljótr lived in the east in Lón. And it is said that his foster-brother was Grímr geitskor, who explored the whole of Iceland on Úlfljotr's recommendation before the althing was held. And everyone in the country gave him a penny for that, and he later gave the money to the temples (Íslendingabók, Ch. 2; Grønlie 2006, 4-5). 


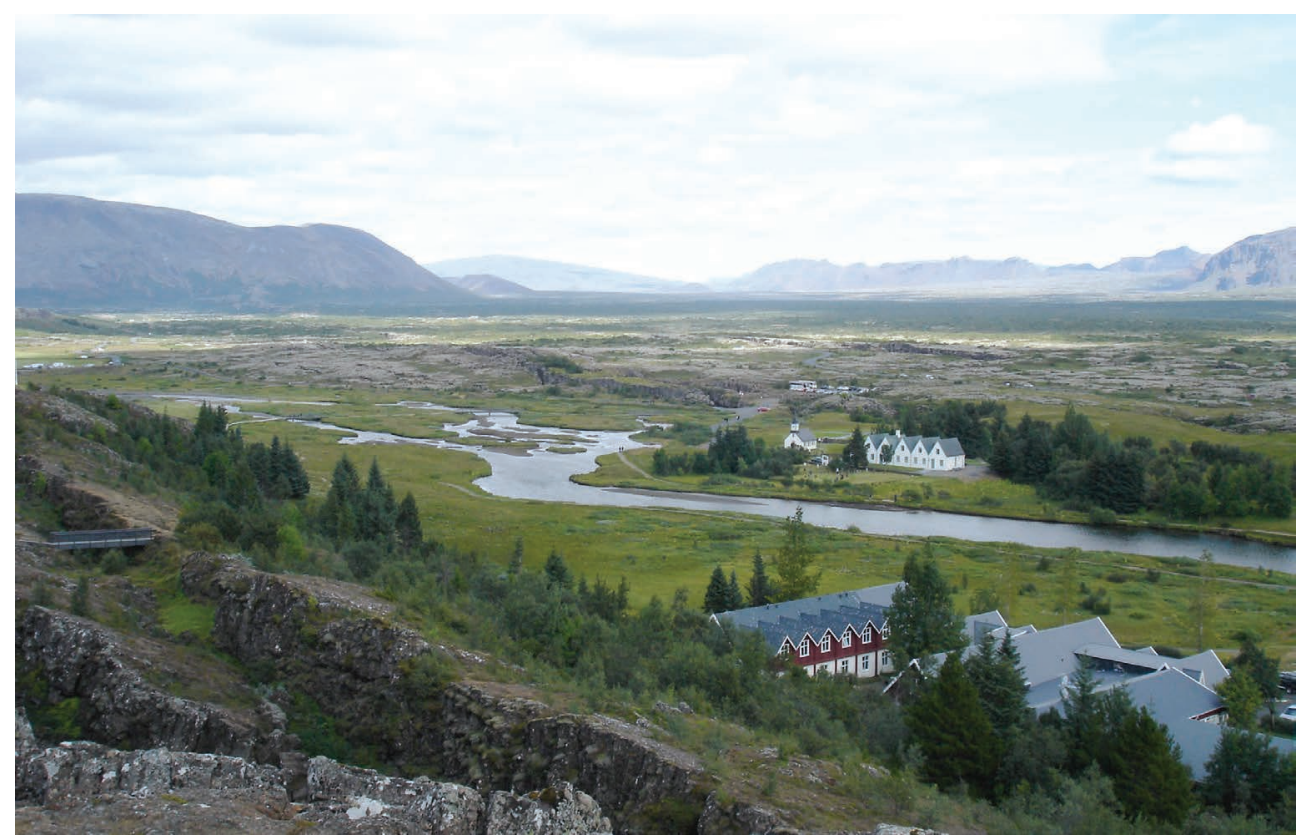

FIGURE 6.2 View over Pingvellir, Iceland. Photograph by Fredrik Sundman.

This is important as this supports the idea that sites were selected according to strict principles (Chapter 4). Popular belief has it that at the beginning of the Commonwealth Period the River Öxará followed a different course but was then diverted into Almannagjá to ensure water supply for the visitors (Jóhannesson I974, 4I), but this has not been investigated so far.

Other important landscape features, known above all from written sources are the Law Rock (ON lögberg) and thing slopes (ON pingbrekka): the Law Rock was the platform for the law speakers at Pingvellir from which proclamations were made (Dennis et al. I980, I08, 240; Whitmore 2013, I3-I4) to the audience below. This is reported in Njál's saga, and also in Grágás (Dennis et al. I980, 59; Lárusson I966; Sanmark 20IO, I 86). According to Grágás, local spring assembly places also should contain a slope (pingbrekka) from which announcements were made. This would correspond to the lögberg. Indeed, brekka place-name components are known from sites such as Pingbrekka at Pórsnesping, mentioned in Eyrbyggia saga, and Pingbrekka at Pinghóll, mentioned in Egil's saga (Whitmore 2013, I3-I4, 79, I09).

In Iceland, perhaps the most typical feature of assembly sites are the booths (ON búð, plural búðir), temporary dwellings where the assembly attendants stayed during or after the meetings. As a rule, they had turf walls, sometimes faced and bolstered with stones, and the roof consisted of a wooden frame covered with woollen cloth (ON vaðmál) (Figure 6.3). The details of this are reported in sagas and also know from archaeological excavations and even pictorial evidence (the latter from the I 8th century; Pórðarson I92 I-22) (see Figure 2.2). According to Grágás, assembly 


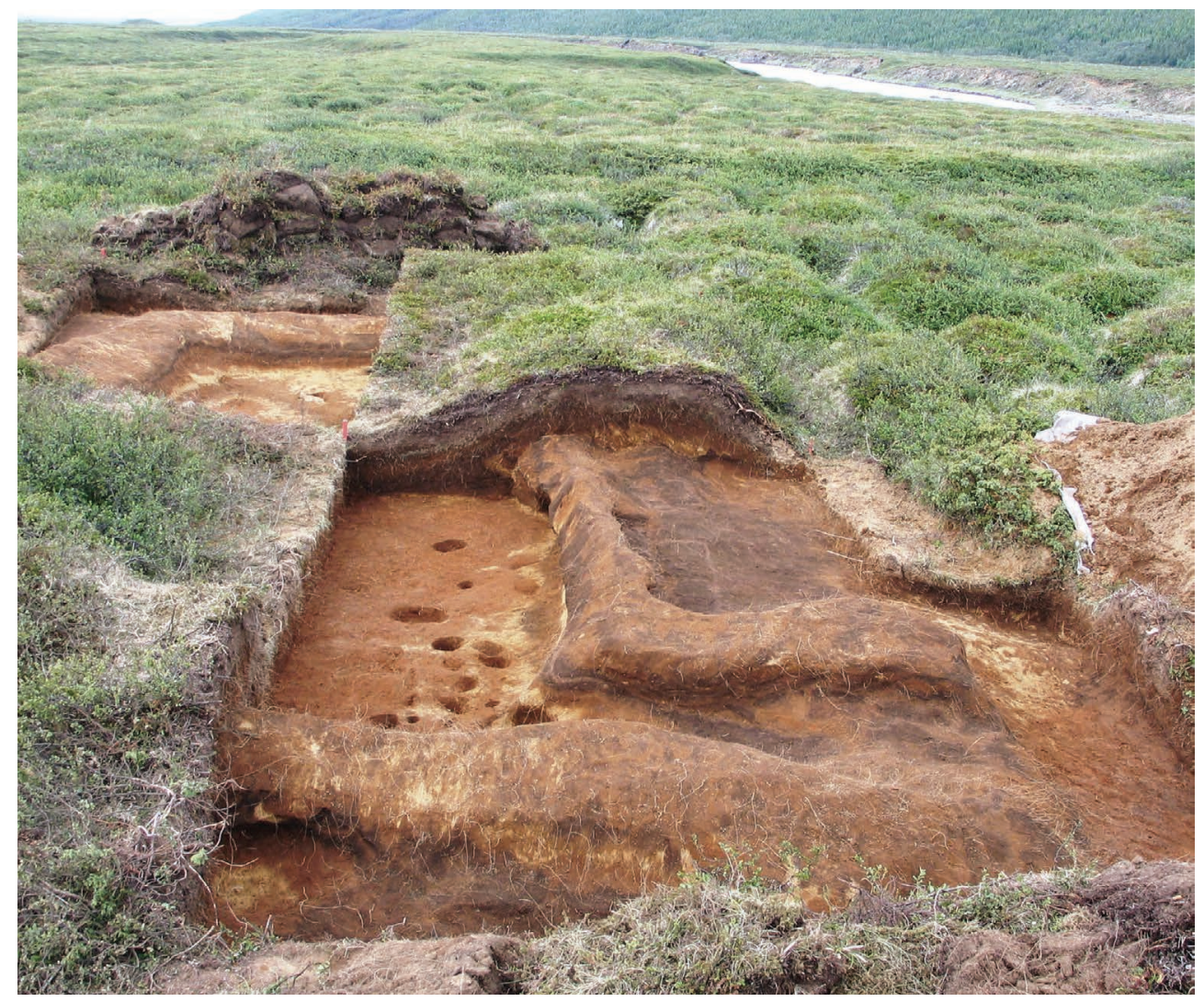

Figure 6.3 A booth at Pingey, Iceland, during excavation in 2005.

Photograph by Howell M Roberts, Fornleifastofnun Íslands.

attendants and participants had the right to build booths for themselves which they were to use during the following meetings and not build new ones (Dennis et al. I980, III-II2, 24I; Jóhannesson I974, 74). Each year, before the meetings began, the assembly attendants returned to their booths, put new roofs on top of them and took them down again after the meetings were over (Friðriksson 1994, I07; Vésteinsson 2013).

During many surveys, the number of booths per site has been counted and their outlines recorded but due to erosion, the effects of time and agricultural land use their numbers have changed over time. Trying to decipher the arrangement of the booths within the sites, Adolf Friðriksson has suggested that the grouping of the buildings represents different phases in the evolution of power consolidation before the I260s (Friðriksson 20I I, 354-357). The booths therefore can also be seen as highly symbolic structures mirroring power consolidation in Iceland (Friðriksson 20II). Building on this, Orri Vésteinsson has convincingly assigned two levels of symbolic meanings to the booths. On the one hand, booth-building can be interpreted as a symbol of the 
participation of the booth-owners in the assembly. Also, political symbolism has been seen in the size of the booths, their number and their arrangement, as this seems to have reflected the units of the administrative landscape in Iceland (Vésteinsson 2013). On the basis of the number of booths per site and the catchment area of assembly attendants at, for example, Árnes, Leiðarnes and Hegranes, Vésteinsson suggested that each booth could well represent a local community of 5-I 5 farms, the smallest political unit during the Viking Age, and that at the top of each community and booth there was a thingman (Vésteinsson 20I3, I I 8-120).

To date, booths have only been identified at Icelandic assembly sites. They may well have been part of Greenlandic assembly sites too (Sanmark 20I0) and according to written sources they also seem to have existed at the assembly site at Tinganes in the Faroe Islands (Vésteinsson 2013), but no examples have yet been found. A possible parallel to the thing booths are the house structures at Norwegian courtyard sites (discussed in Chapter 5).

At Pingvellir, various booths have been investigated from the I9th century onwards (Figure 6.4). The excavations by Sigurður Vigfússon cut through some booth structures (known as Biskupabúð) revealing parts of the turf walls, in some cases accumulated and separable into different occupation phases. He also dug a trench across the Law Rock (Vigfússon I88O-8I) where hearth remains older than the booths were found (Bell 20I0, 47; Vigfússon I880-8I). Biskupabúð was re-excavated in the early 2000 s and revealed a series of overlying booth structures proving that this complex had been used for quite some time and had also been rebuilt (Friðriksson et al. 2004). Such an accumulation of overlying booth structures has only been found at Pingvellir and not at any of the local assemblies (Vésteinsson 20I3, I I7-I I 8). This testifies that Pingvellir was a site that was in use for a very long time and booths were repaired or exchanged constantly. The duration of sites is unknown for the local assembly sites since none has been completely excavated and dating material is scarce, but written sources suggest that they fell out of use c. I27I. The archaeology of the sites at different levels therefore reflects the political administrative changes that took place in Iceland over time.

Despite the many surveys carried out, archaeological excavations have taken place at only four local assembly sites: Pingnes, Skuldapingsey, Hegranes and Pingey. In all cases the excavated areas were comparatively small. Only at Pingnes has a complete building been uncovered. Booths were partially excavated at all four sites and in all cases it was clear that these buildings were used only for a very short period of time (Whitmore 2013, 353). Hegranesping, located on a headland at the mouth of Skagafjörður near the farm Garður, is mentioned in a few sagas (Friðriksson 2004, 39; for a complete list, see Whitmore 2013, 324). The site was first investigated by Kristian Kaalund (I877-82) who described 25 booths, and subsequently also by Sigurður Vigfússon (I888-92) and Daniel Bruun (I899), who produced the first survey plan of the site showing about 80 booths (Figure 6.5). These booths were arranged in rows from north to south, following the topography of the headland. The booths in the southern part are surrounded by an enclosure and to the south-east lies a circular enclosure with a rectangular ruin in the centre. Bruun suggested that the large enclosure was added around the booths at a later date. In the early I970s the Icelandic National Museum conducted a rescue excavation of a booth, revealing 


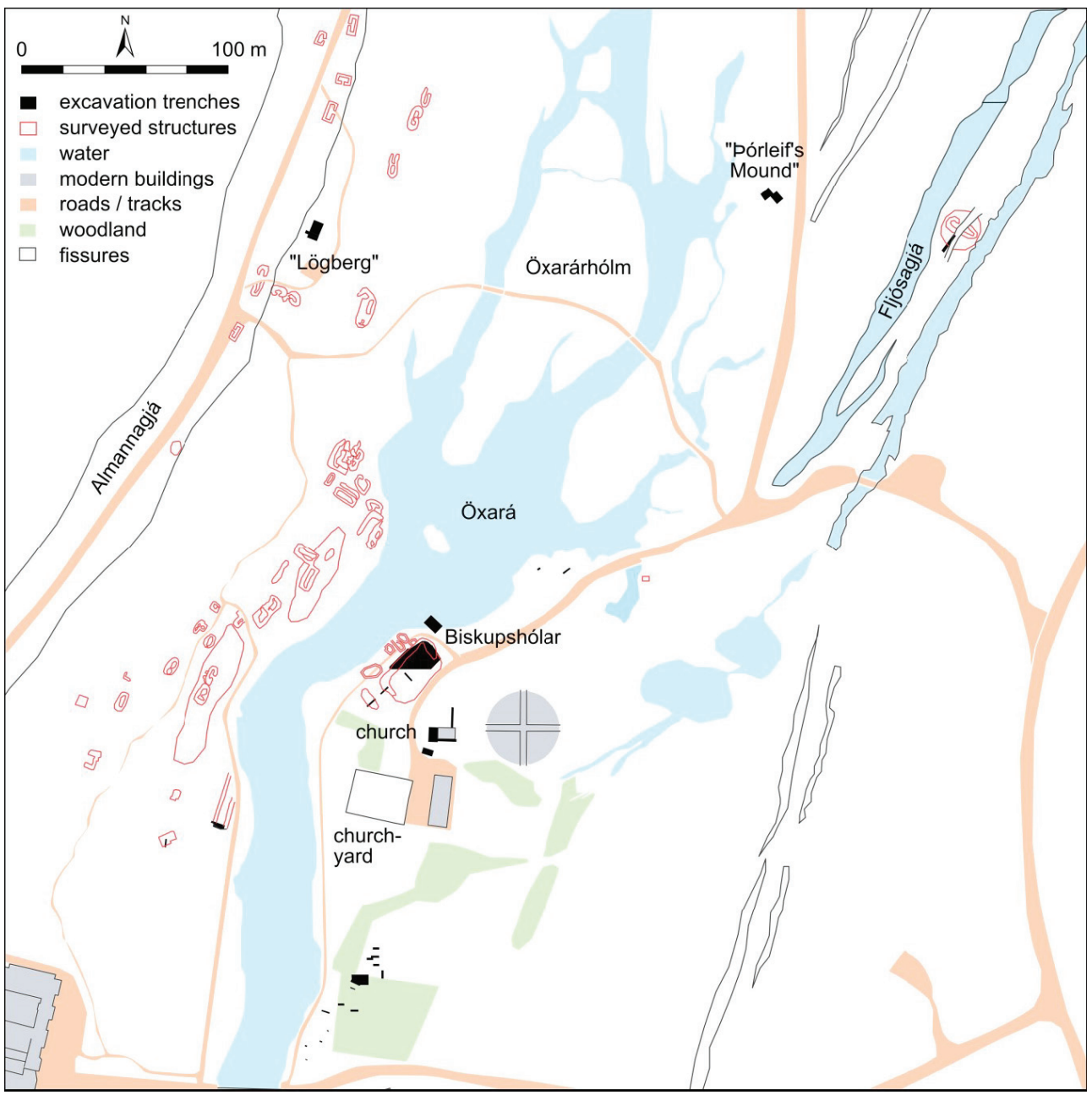

FIgURE 6.4 Map of Pingvellir, Iceland, with surveyed ruins and excavated areas. Map by Howell M Roberts and Joris Coolen. Reproduced from Mehler 201 5 , fig. 2.

the turf-and-stone wall foundations, a doorway in the southern part and a series of small post-holes belonging to the roof construction. The booth was about $\mathrm{I} 2 \mathrm{~m}$ by $4 \mathrm{~m}$ and in the interior no stamped floor could be found, indicating that the building was only used for a very short time. The few finds discovered included sheep bones, a whetstone, some iron nails and a bone pin of medieval date (Ólafsson and Snæsdóttir I975). Another booth was partially excavated in 2003 (Gestsdóttir 2004, 45-5I), the turf walls of which contained tephra from the year I I04, proving that the structure was built after this time.

In the I9th century, when many Icelandic assembly sites were investigated by antiquarians, dómhringar (ON dómr 'court, judgement', and hringur 'circle'; 


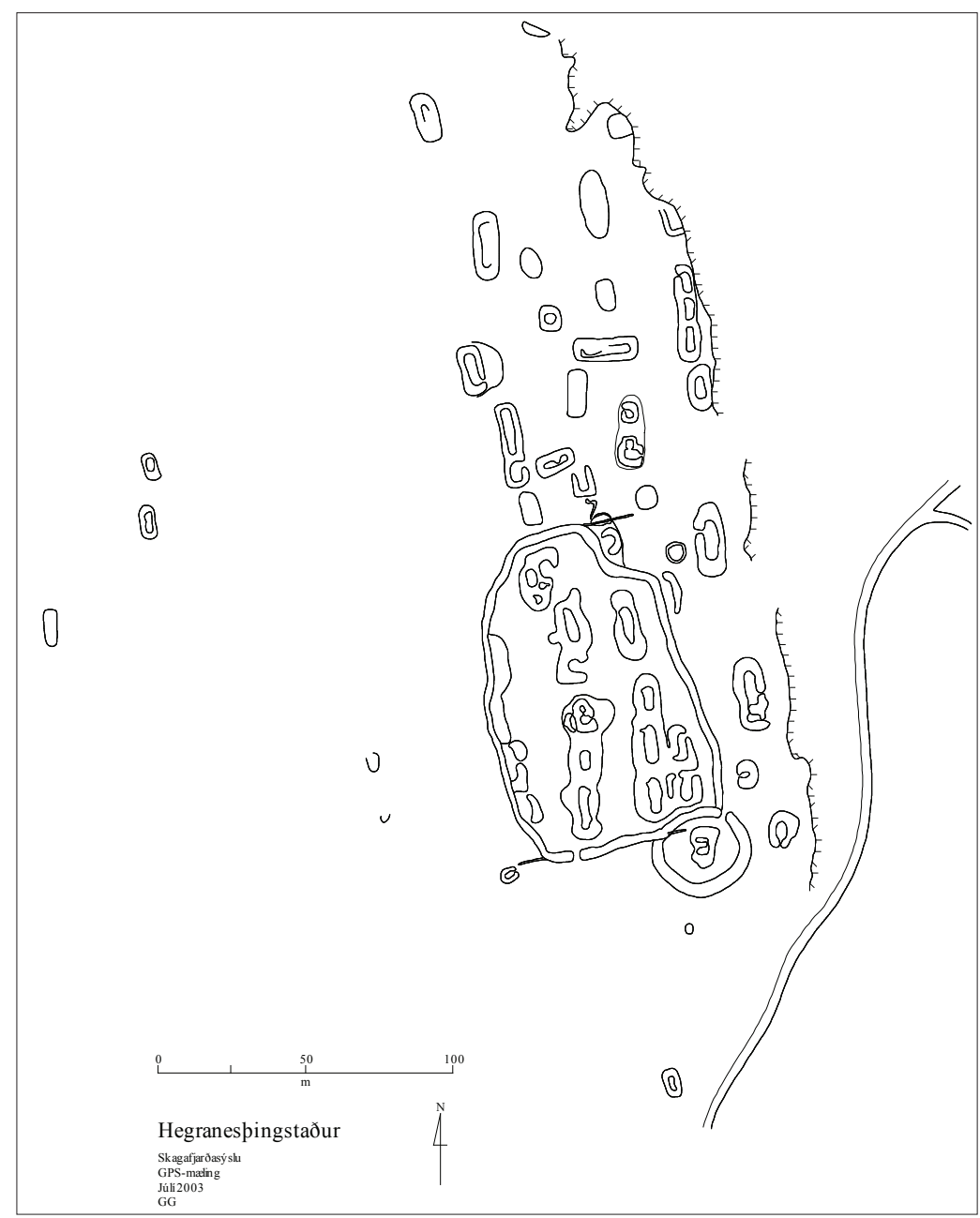

FIGURE 6.5 Ruins of the assembly site at Hegranes, Iceland. Image by Fornleifastonfun slands.

dómhringur 'court circle') were identified at almost every district assembly site. Dómhringar, or court circles, described in sagas and Grágás, were thought to be solid constructions to host the panel of judges during their discussions; according to Grágás, the law court was seated in a dómhringur: '...oc sitia í dom hring...' (Grágás I, 82 and 77; Dennis et al. I980, 87; see also Friðriksson and Vésteinsson I992, 27-3 I). Recent investigation of a number of alleged dómhringar has demonstrated, however, that these have little more in common than their round shape. A review of the written evidence has shown that the term dómhringur had two different meanings in the $\mathrm{I} 3$ th century: it could either refer to a panel of judges sitting in a circle (e.g. Víga-Glúms saga or Bandamanna saga), or it could designate a circular construction made of 
turf or stone (or both), in which pagan sacrifices took place (e.g. Eyrbyggia saga) (Friðriksson and Vésteinsson I992, 27-29).

Systematic archaeological research in the early I990s, concentrating in the west of Iceland, has shown that most of the alleged 28 dómhringar in this region had neither any common characteristic features nor were they any different from structures with agricultural character. The examples that were investigated archaeologically turned out to be an enclosure for a cemetery (at Belgsholt in Melasveit), and an enclosure for the storage of hay (at Gerði near Akranes). In neither case is there a record of a ping place-name, booths, nor written evidence suggesting an assembly site, and the idea of dómhringar at these sites was based on oral tradition (Friðriksson and Vésteinsson I 992, 27-3 I, 38-56 with figs 8, I 3 and I7). It is worth adding that court circles were previously also thought to have existed in Sweden (Mod Sw domarringar), but here most of them have turned out to be Early Iron-Age burials (Arne 1938). One more example is also known from Shetland and this is discussed in more detail below.

Friðriksson and Vésteinsson have suggested that the round enclosures previously thought to be dómhringar were set up to provide an area of grazing for the horses of the assembly attendants so that no farmland would be damaged (Friðriksson and Vésteinsson I992, 27-3 I, 38-56 with figs 8, I3 and I7). In Shetland, oral tradition recorded in the $\mathrm{I} 8$ th century has it that people who came to attend the meeting at Tingwall had to leave their horses at two different farms (Brand I883, I84; Smith 2009, 37-45), but no round structures are known for that. In Greenland possible horse pens have been identified at Brattahlið and Garðar which could have served the horses of the assembly visitors, and be part of what needed to be supplied by the chieftains (Sanmark 2010, I83, I86). It would only have been possible to keep horses inside a closed structure, however, if all the horses belonged to the same herd. Horses from different herds or farms easily start fights which people generally wanted to prevent (Joris Coolen pers. comm.). But it is possible that closed structures such as dómhringar were built to have an arena for horse fights. In Iceland, horse fights (ON hestavíg or hestaping) were part of the medieval society and they are frequently mentioned in sagas and law books. They were often part of the entertainment during assemblies and there are a couple of place-names such as Hestapingshóll ('horse-meeting-hill') or Hestapingseyrar ('horse-meeting-sands') which relate to that (Gogosz 2014; Guðmundsson I903, 33; Solheim I956, 67-68). Valtýr Guðmundsson $(1903,35)$ has already pointed out that the spectators of such fights assembled in a ring formation, but without connecting this to dómhringar. A horse fight is reported for example in Njal's saga and it seems to have taken place at an assembly site, but there is no mention that this took place inside a built structure ( $\mathrm{Ch} 58$ ). The fight is described in detail and the location is indicated in a poem that is part of this chapter and that starts with: 'At the Thing there is a throng; Past all bounds the crowding comes' (Guðmundsson I903, 4I). Similar usage could be suggested for the Greelandic circular structures too (Sanmark 20I7a, I89).

At Hegranes as well, a presumed 'court circle' was excavated. This was the circular enclosure, some $30 \mathrm{~m}$ in diameter, in the south-west part of the site. As with the excavated booth mentioned above, the enclosure also contained tephra from I I04. Inside the enclosure was a rectangular building and two possible graves, the fills of which also contained I ro4-tephra and hence it was concluded that this enclosure 
and the structure within are the remains of a medieval church and cemetery. Finds included only fragments of iron nails and an unidentifiable copper-alloy fragment. A human femur was found near the excavated booth, probably from the cemetery (Batey 2004).

In the summer of 2012, The Assembly Project conducted a resistivity survey in the area of the assembly site at Pingeyrar, Austur-Húnavatnssýsla, northern Iceland (Coolen and Mehler 20I2). Pingeyrar is the place where the Húnavatnsping was held and the sources refer to it as a local spring assembly as well as an autumn assembly. The layout of the ruins and the extension of the site within that area remains unknown and only a few structures have remained, the most prominent being an alleged dómhringur that was first recorded in 1878 (Figure 6.6).

The aim of the surveys was to clarify the nature of this feature and to possibly find other structures buried in the home-field of the farm of Pingeyrar. Three areas were surveyed, covering I.3 hectares in total. The main area is located north of the farmstead and measures I.I hectares. It covers the dómhringur and a modern graveyard. To the east, an area of $800 \mathrm{sq} \mathrm{m}$ targeted the possible remains of two booths or outhouses, which are faintly visible on the slope. Finally, an area of $\mathrm{I} 200 \mathrm{sq} \mathrm{m}$ was measured west of the new farmhouse. The area was levelled in the 2 oth century and there are no visible ruins here today. The resistivity survey produced the clearest results south of the dómhringur, where the remains of a circular enclosure, possible burials and a church building could be detected, indicating the former cemetery of

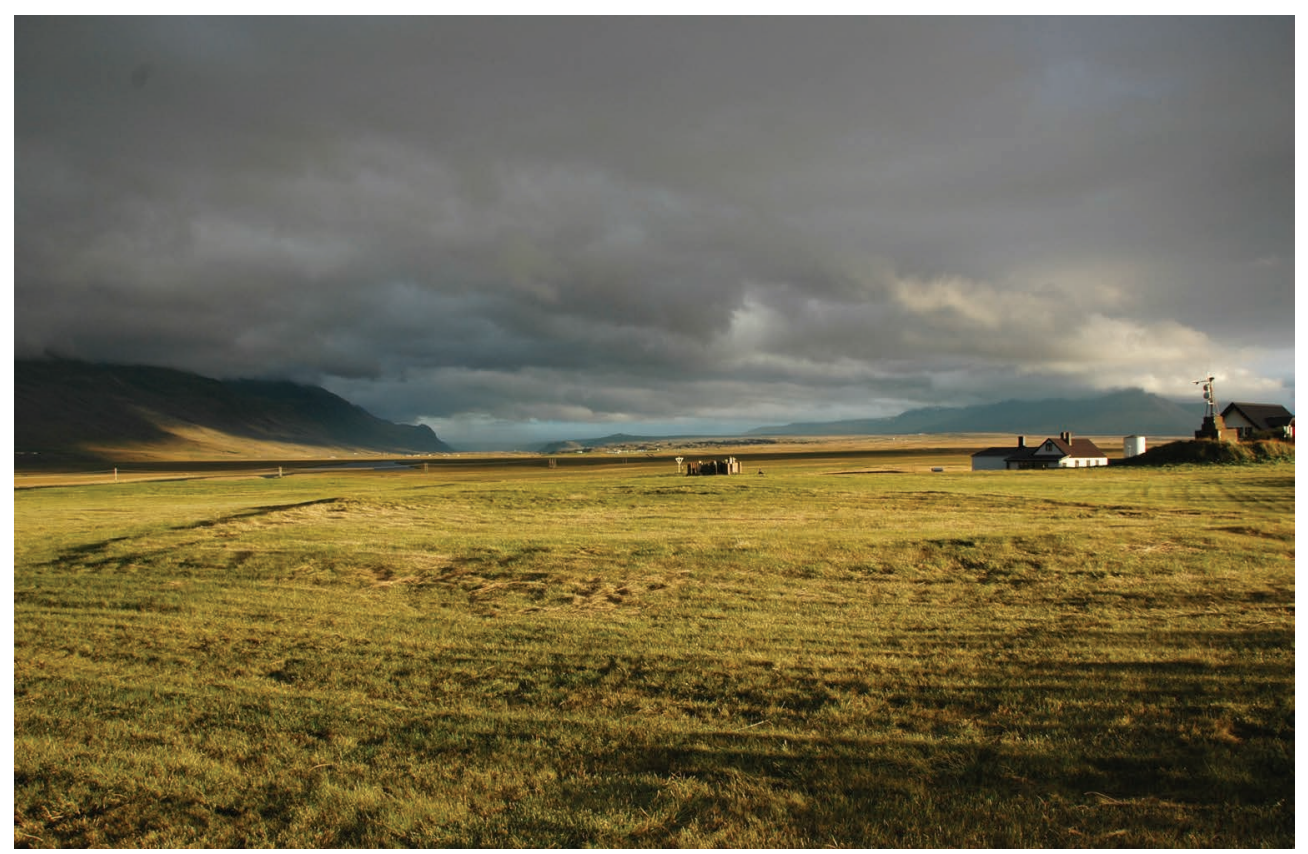

Figure 6.6 Alleged dómbringur at Pingeyrar, Iceland. Photograph by Joris Coolen (C) The Assembly Project. 
Pingeyrar. It consists of a nave with an apse in the east and has been interpreted to be the remains of a church built in I695 (Coolen and Mehler 2015, 27). A recent test trench excavated within this church building suggests that this is older than the I th century (Steinunn Kristjánsdóttir pers. comm.).

The resistivity survey and the surface model give a clear representation of the outline and structure of the dómhringur, but the interpretation of the structure's function is problematic (Figure 6.7). This is in line with the previous critical assessment and re-evaluation of other such structures in Iceland (Friðriksson and Vésteinsson I992) proving that despite some alleged characteristic features the identification of local assembly sites is not easy and the idea that Icelandic assembly sites are marked by round enclosures formerly interpreted as court circles (dómhringar) remains a challenge. As for Iceland, we are left with a group of round structures, often but not always part of identified assembly sites, which according to oral tradition are referred to as court circles. Considerable written sources exist which clearly testify to the existence and function of such structures as part of assembly practice. Some may have been used as arenas for horse fights that took place during the assemblies, some may later have been used as horse pens, after the sites fell out of use, or became enclosures for churches or churchyards such as the one at Hegranes.

What remains to be analysed is the connection between churches, monasteries and assembly sites in Iceland. Were they part of the assembly sites or erected only later when the sites fell out of use? And if they were part of the assembly sites, what was their role? It is conceivable that meetings were held also inside these churches, as
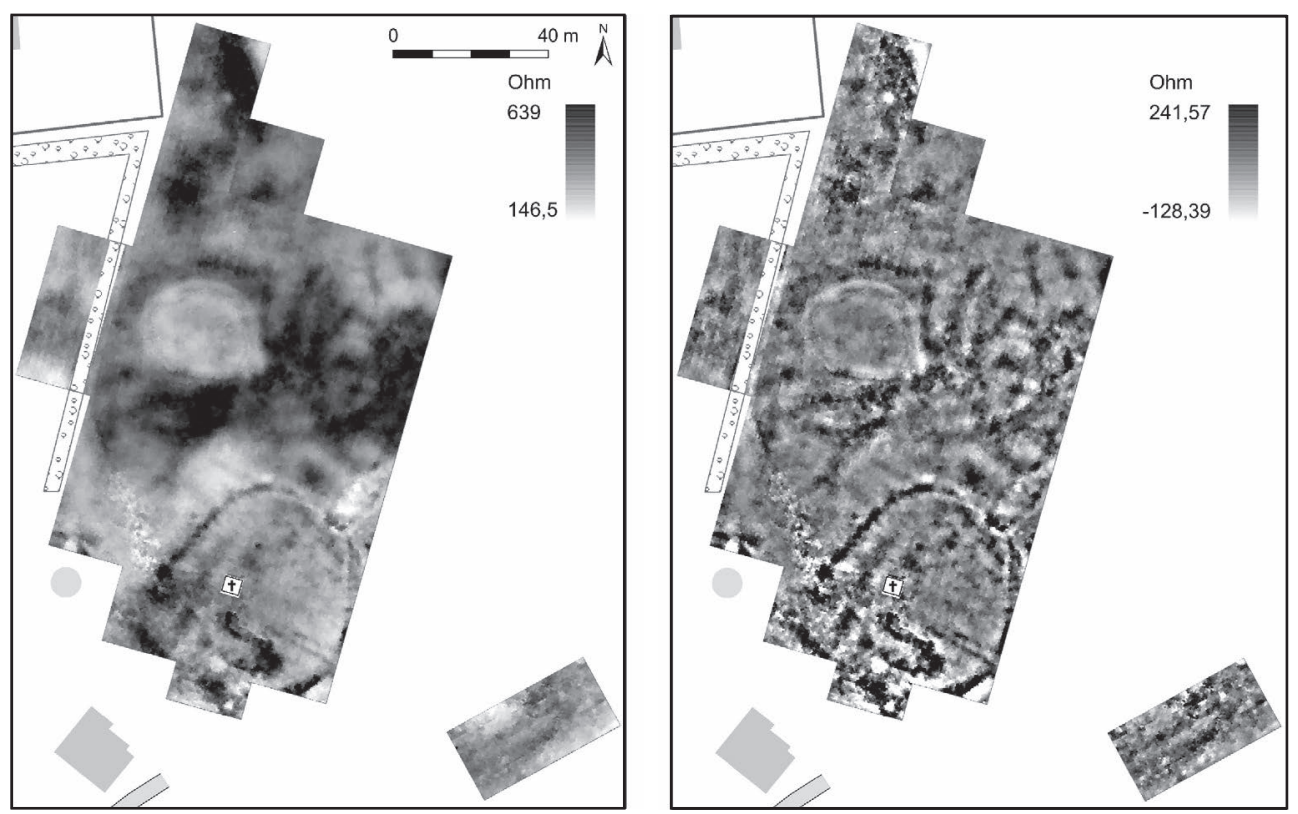

FiguRE 6.7 Resistivity survey at Pingeyrar. Reproduced from Coolen and Mehler 20I 5, fig. 5. (C) The Assembly Project. 
was the case at Tingwall in Shetland in the I 4 th century (see below), especially during bad weather, but it must be kept in mind that churches from the Commonwealth Period (AD 930-I 262) were very small and could not host many people. An average church like the one at Hofstaðir, northern Iceland, was about $20 \mathrm{sq} \mathrm{m}$ in size (Gestsdóttir 2003, 26). In the case of Pingeyrar, a church must certainly have been at the assembly site from early on. The Pingeyrar monastery was founded most likely in II33 (Karlsson 2008), at a time when the assembly site was in use according to written sources. Another example would be the monastic church and the assembly site at Helgafell and Pingvellir on Snæfellsnes which are very close, and the site at Hegranes where the church and cemetery defintiely post-date the assembly (Whitmore 20 I $_{3}, 8 \mathrm{I}$ ). On the other hand, there are local assembly sites in Iceland with churches located some distance away (e.g. Pingnes, where the church at Viðey is roughly 5 $\mathrm{km}$ away). Strong connections between churches and assembly sites have also been observed in Scandinavia, although the shift to churches seems to have been rather gradual and not all sites were associated with churches (see Chapters 4 and 5; Hobæk 2013; Ødegaard 2013; Sanmark 2009; 2017a, I43-I60). The few connections found in Iceland between churches and assemblies may reflect the abandonment of the local meeting-sites earlier than in parts of Scandinavia (Sanmark 20I7a, I73-I74).

The general assembly site at Pingvellir also had a church from early on; east of the River Öxará lies the present church. The first church is assumed to have been erected in the IIth century, but probably stood in the present cemetery and no remains are known. Excavations at the present church have revealed earlier structures, possibly from older church buildings dating back to the I 6 th century, and also booths (Hallmundsdóttir and Juel Hansen 20I2; Vésteinsson I999, 8). It is conceivable that the procession to open the assembly outlined in Grágás (Dennis et al. I980, Chs 23-24) started here, or that parts of the meetings were held inside the old church. As discussed below, the Faroese lawthing in the I 7 th century started in the nearby church and then the delegates went in a procession to the assembly site (Nolsøe and Jespersen 2004,85 ). It is interesting to note that in the case of Pingvellir, Iceland, a document from around I 200 mentions that a wall of the former church exhibited signs in the shape of $(\mathrm{ON})$ stikur and álnir ('ells'), which were standard Icelandic measurements at that time (DI I, 307; Gelsinger I98 I, 35). Calibrated measurement units are known from public buildings and churches connected to thing sites outside Iceland, for instance in Norway and the Faroes. Lawmen were in the possession of similar measurement tools controlling the proper weighing of goods in the latemedieval period (SD I, no. 237, fol. IO; Arge and Mehler 20I2; Joensen I953, 39). It is conceivable that the church at Pingvellir also played an important role for the transactions of goods or settling of fines (Mehler 201 5, 76).

Finally, the connection between water and assembly sites must be addressed. As shown in Chapter 4, this was a particularly strong Scandinavian assembly trait. It was vital to have access to freshwater, and sites were also set up near water for mythological and legal reasons, representing symbolic islands (Myrberg 2009, I07-III; Riisøy 20I3, 33-34; Sanmark 20I7a, 89-IO3). In this context it is important to point out that all Icelandic thing sites are located near water, either the sea, by a river or a lake (Vésteinsson et al. 2004, I77; Whitmore 20I3, 35 I-363). 


\subsection{FAROE ISLANDS}

Faroese assemblies have been the subject of research, for example by Hans Jacob Debes (I995, 37-65), Jens Pauli Nolsøe and Kári Jespersen (2004, 53-60; 85-89) and most recently by Arne Thorsteinsson (2012), which provides an excellent point of departure for the analysis presented here. Thorsteinsson demonstrated that in most thing districts (ON singular sýsla, plural sýslur), two assembly sites can be identified: 'early' and 'late' sites (Figure 6.8). Five of six early sites are known from oral traditions and all six late ones from the I7th-century court books (Joensen I96I; I969). These later sites are rather securely identified, as on several occasions the farms where meetings were held are named in the sources. In this chapter Thorsteinsson's work has been used in conjunction with the I7th-century court books, as well as place-names and archaeological and landscape features to try to examine the earlier sites. Most sites have also been visited and recorded by The Assembly Project and new conclusions regarding the Faroese thing sites have thus been reached. For example, a possible location for the early thing site on the island of Vágoy for which no tradition is preserved, has been suggested, above all based on the landscape characteristics observed at the known assemblies. The approach, however, provides fewer results than in other areas, as very few Norse settlements and burials are known from sagas and archaeological evidence (Arge et al. 2005, 604).

\section{Administrative organisation of the law province}

Very little can be said about the early Faroese administrative organisation during the Viking and medieval period. There was clearly a top-level althing in Tórshavn, which in the course of the late 13 th or early I 4 th century was made into a lawthing, after the Faroes had become a Norwegian skattland. From that moment on, the Faroese general assembly lost its legislative powers and was more firmly taken into the hands of the Norwegian kingdom (Joensen I953; I969; Poulsen and Zachariasen I97I; Smith 2009, 38-39; Sølvará 2002, 26, 42; Wærdahl 20II, 69-7I; Werner I994, I3 I). At least by the time of the surviving written sources, the lawthing worked in conjunction with local assemblies, as was the case in Iceland, and it may have been the case for the Northern Isles of Scotland too. The lawthing meetings were held once a year, most likely on Ólavsøka (St Olaf's Wake) on 29 July, and the local things met in the spring (Mod Faroese várting) and there are also some references to autumn meetings, thus reminding us of Icelandic practice (Debes I757[2005], 25 I; Nolsøe and Jespersen 2004, 85; Thorsteinsson 20I 2, 55). Lucas Debes in his Foroce et Foroa Reserata, published in I673, gives some details about the local things and the lawthings, which at that time functioned like the assemblies in Denmark. At the top of the Faroese lawthing was the bailiff and one representative from each of the six thing districts brought cases to the main court. Sources of the I 7 th century also state that the lawthing at Tórshavn started early in the morning on St Olaf's Wake with a mass held at the church in the harbour. Then the participants went in a procession to the assembly place at Tinganes (Nolsøe and Jespersen 2004, 85). The verdict was set by the judge who was supported by 36 løgrættumenn (representatives), six from each district, and two 'law writers' (Mod 


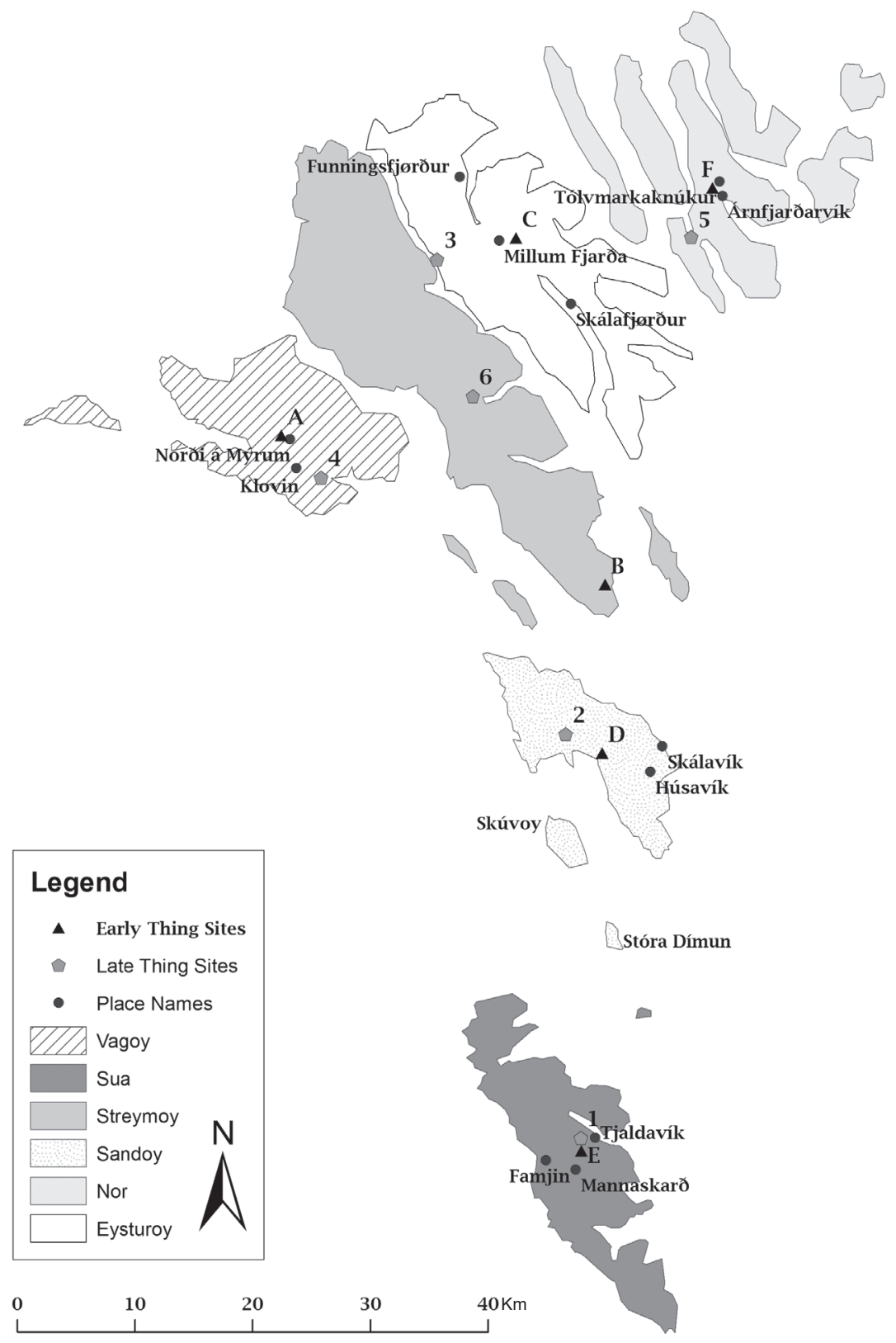

FiguRE 6.8 Early and late assembly sites in the Faroe Islands and the six administrative sýsla districts. I) Ørðavík, 2) Sandur, 3) Selatrað, 4) Miðvágur, 5) í Vági, 6) Kollafjørður. A) Suggested area of the early thing site in Eysturoy, B) Tórshavn, C) Stevnuválur, D) Millum Vatna, E) Uppi millum Stovur, F) í Køtlum. Reproduced and modified from Thorsteinsson $20 \mathrm{I} 2$ with permission. 
Faroese sorinskrivari). The latter were introduced to the Faroes in I59I (Debes I757[2005], 252-253).

\section{Assembly sites: Levels and functions}

According to I7th-century sources, the Faroes were divided into six thing districts, each with its own assembly site: Suðuroy, Sandoy, Vágoy, Streymoy, Eysturoy and Norðuroyar (Figure 6.8) (Debes I757[2005], 25I). These districts are seen to be of much older date, although no earlier written records exist (Thorsteinsson 20I2, 55 ). Some support is, however, found in a document, dating from c. AD I $350-\mathrm{I} 400$, called Skipan um tingfaratoll which can be translated as 'regulations regarding thing remuneration for thing representatives'. This document thus outlines the compensation that should be paid to the representatives who attended the lawthing. In the Norwegian sections of the Law of Magnus the Law-Mender, this type of compensation is listed according to thing districts. For the Faroes, the remuneration is calculated according to the distance to the lawthing in Tórshavn, and is on the whole done island by island, but at least three of the I 7 th-century thing districts can be traced here. Suðuroy and Norðuroyar are mentioned by name, while the Streymoy district can be inferred (NgL IV, 353-354; Arge et al. 2005, 605; Sanmark 2017a, I74-I 76). The idea of continuity in terms of thing districts makes sense in light of the evidence from the rest of the Norse world, where research has shown that assembly districts tend to be long lived, although with some adjustments in terms of boundaries (Sanmark 2009). This means that although these sources are very late, they can still be used as a starting point for the examination of the Faroese thing sites.

\section{The archaeology and topography of the sites}

In this section the early thing sites will be discussed along the same lines as the Icelandic sites, highlighting the site locations and the most striking and recurring features. Location, as ever, seems to have been a key principle in site selection. The toplevel assembly, the thing of 'the Færey people' or 'the Streamsey' thing is referred to in the Foreyinga Saga (York Powell I896, Chs 24, 25, 4I, see also Chs 5, 26-28, 30, $42,48)$ (Figure 6.9), which also stated that the assembly was 'in Streamsey, at a haven there called Thorshaven' (York Powell I896, Chs 5 and I7). In view of the Faroes as a whole, Tórshavn, in the southern part of Streymoy, is one of the most convenient places to meet. In line with Scandinavian assemblies (see Chapters 4 and 5), Tórshavn would have been easily accessible above all from the coast, easy to recognise and easy to control, and therefore highly suitable as a thing site, although the harbour was rather exposed (Símun Arge pers. comm.). The rocky spit of Tinganes contains a number of inscriptions in the form of letters and numbers (Figure 6.10). Rolf Guttesen (I998; Debes I995, 44-45; Nolsøe and Jespersen 2004, 80-85) interpreted them as the carved initials of lawmen from the post-medieval period, bearing witness of the meetings that took place here at that time, also been convincingly argued by Helgi Michelsen that these markings are instead made by early modern traders (Michelsen 2006, App. I).

The local thing sites too are found in places where communication routes meet, but unlike Tórshavn they were all located inland. In Suðuroy, the old thing site is 

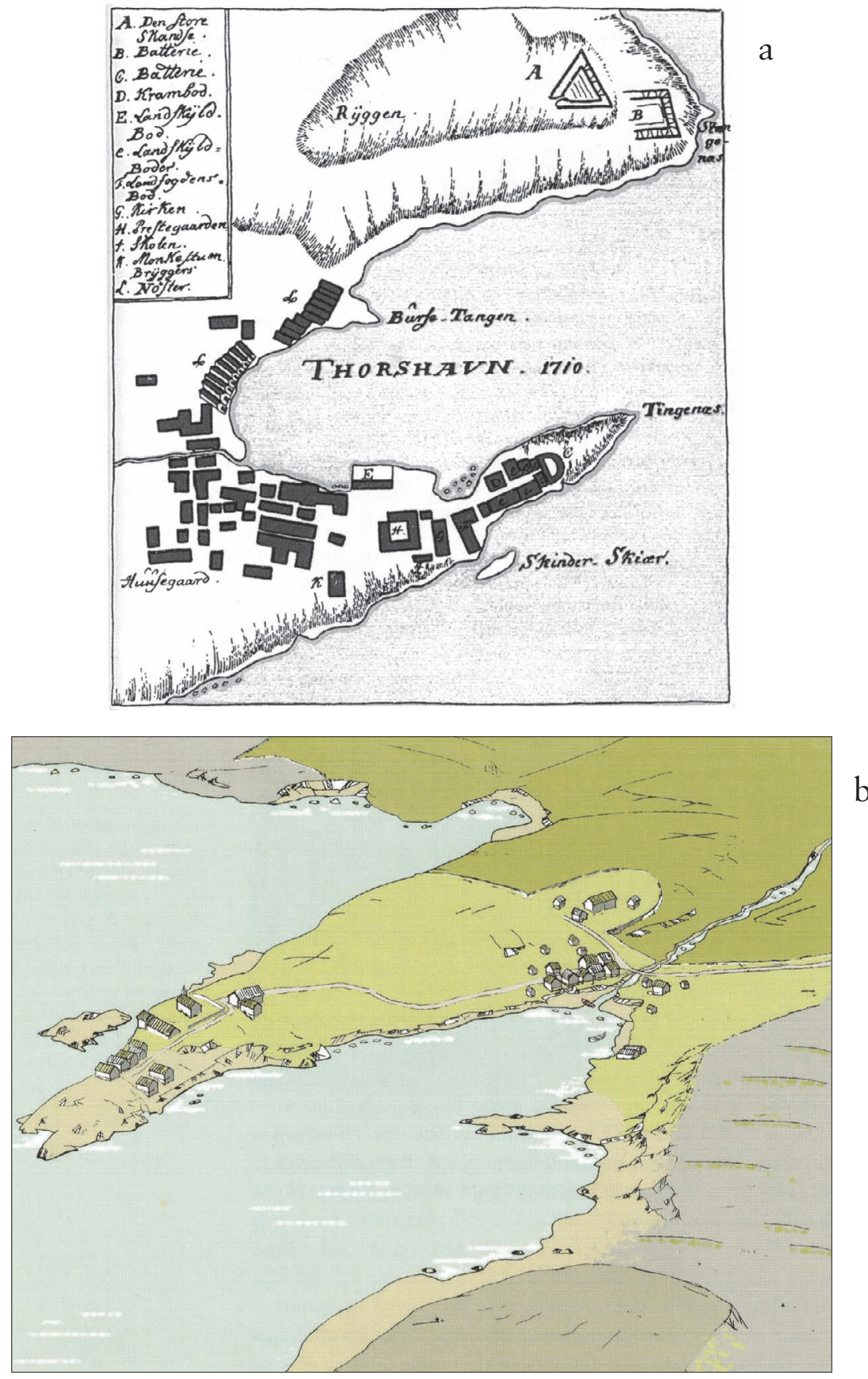

Figure 6.9 The assembly site at Tórshavn on Streymoy: a) Tórshavn in I7Io, made by

Rasmus Juel, with the location of Tinganes. Reproduced from Debes 2000, Io.

b) Reconstruction of Tórshavn around I 400 , with the Tinganes headland at the very left side. Reproduced from Nolsøe and Jespersen 2004, 230. 

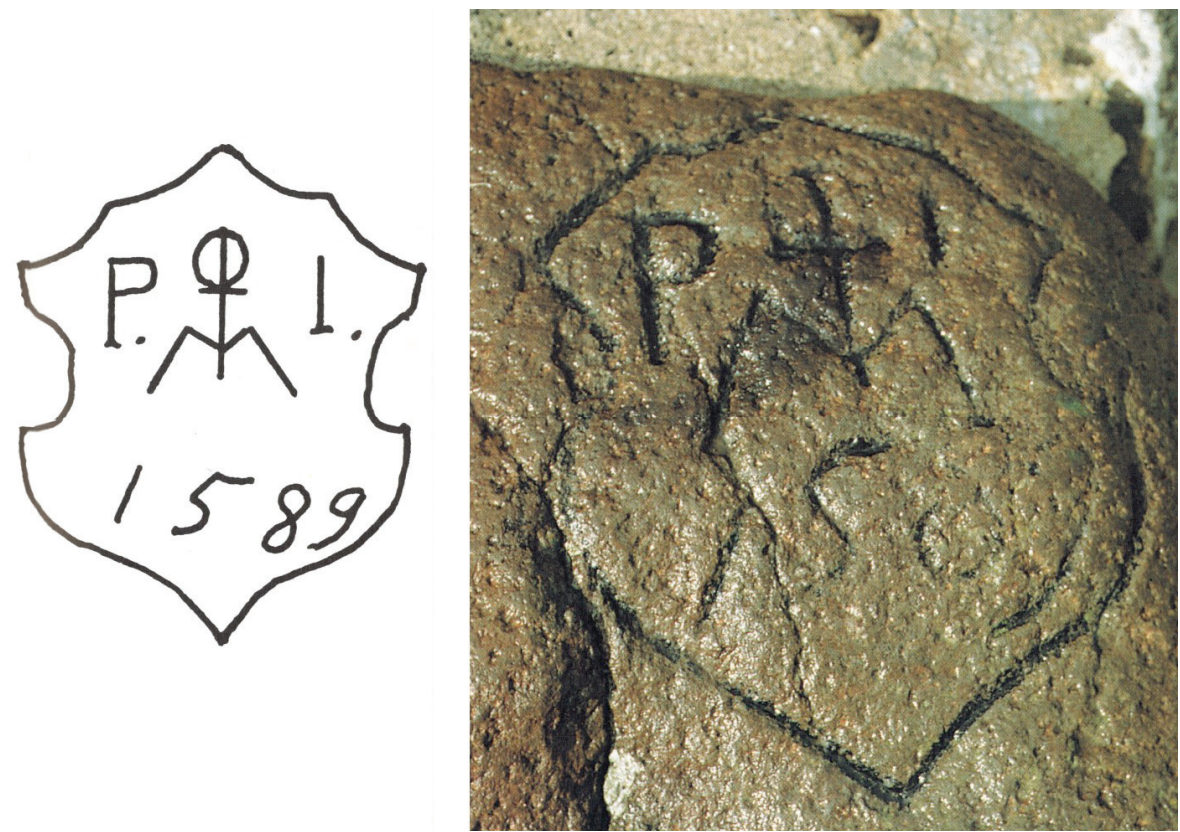

Figure 6.I0 Inscription at Tinganes, Tórshavn, showing the letters P and I and the year I 589 . The incision is is argued by some to be one of several marks left by Faroese lawmen.

Reproduced from Michelsen 2007, 6.

said to have been located at Uppi millum Stovur (Figure 6.II). The site is located in the mountains close to the island's main route and between the two natural harbours at Øravík and Famjin. In spite of appearances, this site was rather easy to access. In terms of settlements across the whole island, it is rather central, so would have been suitable in this sense (MacGregor 1987, II 2-I3I). There is one final feature, which strongly supports the idea that this was indeed the location of the Suðuroy assembly; it is situated in the Mannaskarð mountain pass, which formed the boundary between the two thing districts referred to in the Tingfaratoll document, and is a modern sýsla boundary (MacGregor I987, II2; NgL IV, 353-354). A boundary location may be a suitable feature for assemblies that served more than one district (Pantos 2004b; Sanmark 20I7a, I77-I78).

Millum Vatna, the local thing for Sandoy has a similar location (Figure 6.II). This site is equidistant overland from known early settlements on Sandoy (Thorsteinsson 2OI2, 57). The modern boundaries of three councils meet at the site, perhaps suggesting that this is an old boundary, and again, this site seems to have been used for people coming from different areas. In Eysturoy, the old thing site called Stevnuválur was centrally located, although it could not be reached by boat (Figure 6.I2). The site is situated very close to the modern road in the pass between the mountains in the middle of the island. This is likely to be an old stretch of road for people travelling across the island. Again this is the modern boundary between two councils, suggesting 
a

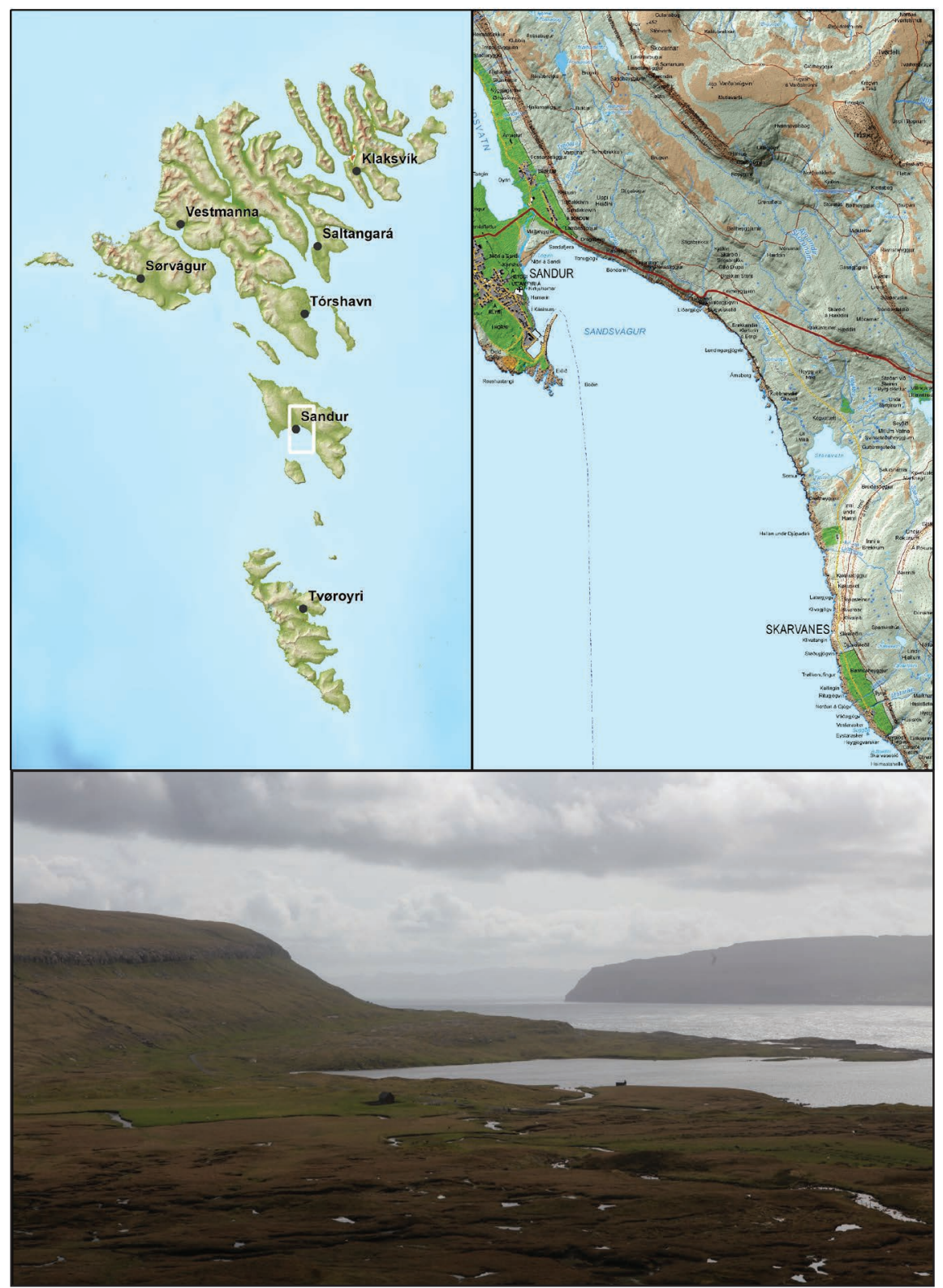

b

Figure 6.I I The assembly site at Millum Vatna on Sandoy in the Faroe Islands: a) location and b) the locality. Photograph by Fredrik Sundman. Map and Image by Tudor Skinner. Bathymetric data courtesy of Amante, C. and B.W. Eakins, 2009. ETOPO I I Arc-Minute Global Relief Model: Procedures, Data Sources and Analysis. NOAA Technical Memorandum NESDIS NGDC-24. National Geophysical Data Center, NOAA. doi:I0.7289/V5C8276M [Accessed 22.5.2019]. 
a
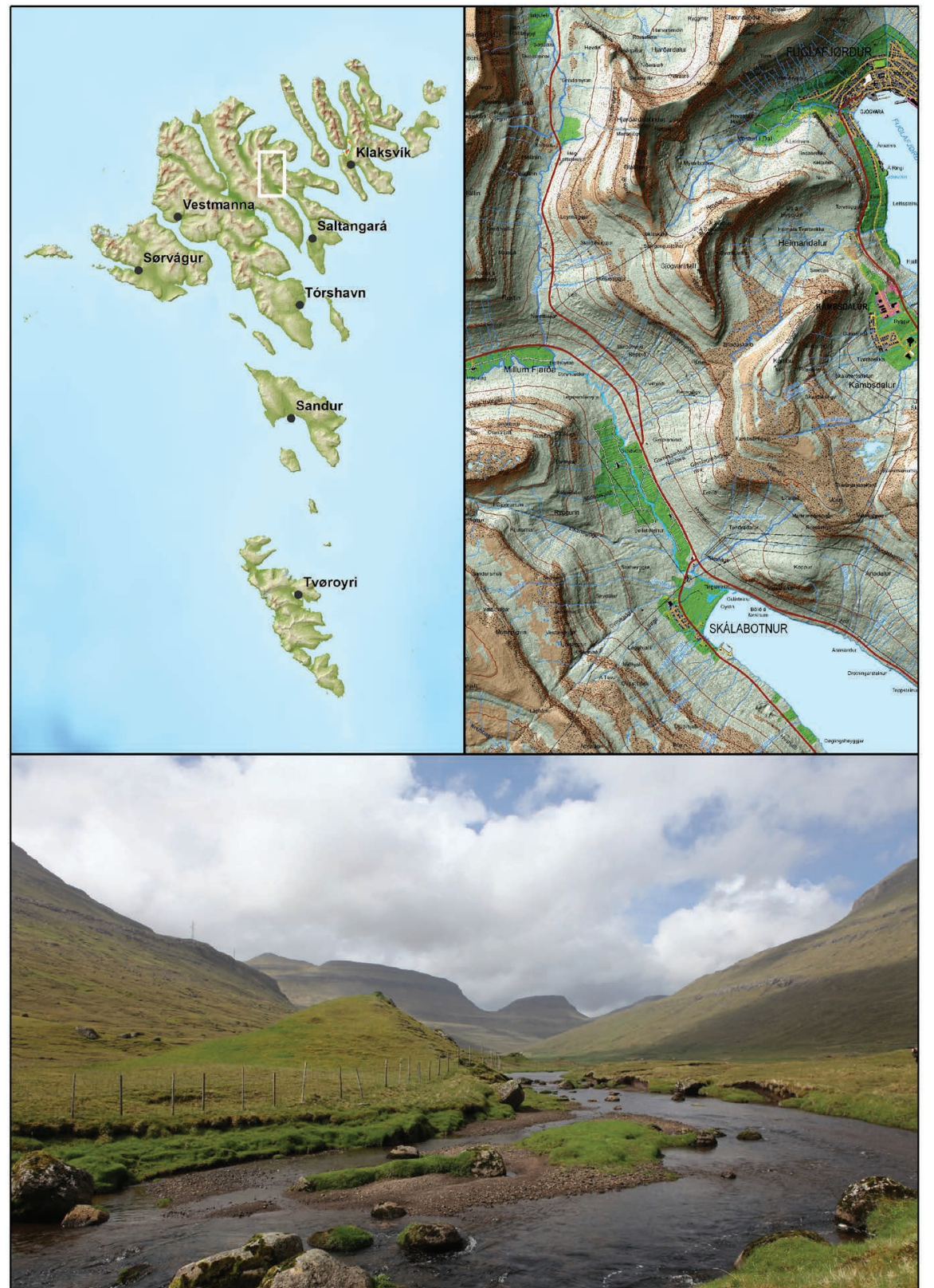

FIgURE 6.I2 The Stevnuválur assembly site on Eysturoy in the Faroe Islands: a) location and b) the locality. Photograph by Fredrik Sundman. Map and Image by Tudor Skinner. Bathymetric data courtesy of Amante, C. and B.W. Eakins, 2009. ETOPOI I Arc-Minute Global Relief Model: Procedures, Data Sources and Analysis. NOAA Technical Memorandum NESDIS NGDC-24. National Geophysical Data Center, NOAA. doi:10.7289/V 5C8276M [Accessed 22.5.2019]. 
this may be an older boundary. Í Køtlum was also highly suitable in terms of location as it was situated on Borðoy in the middle of the Norðuroyar district, at the head of the deep fjord Árnfjarðarvík (Figure 6.I3). Today there is a sandy beach and it is a very suitable place for boats to be anchored or pulled up on the shore. The site could also be reached from the north as the path linking these parts of the island went straight past the site (Thorsteinsson 20I2, 6I).

Water is a strong feature of assembly sites in the Faroes, as elsewhere in the Norse world. Apart from Tórshavn, at least three of the four identified early sites are located close to water in some form. Concerning the local sites, a particularly striking example is Millum Vatna ('between the waters') on Sandoy, where the name refers to an area between two small lakes near the present village of Sandur (Thorsteinsson 20I2, 57) (Figure 6.I I). The area is generally rather boggy, but with a dry slope overlooking the area. At the site, there are possible archaeological remains of unknown nature. At í Køtlum, Norðuroyar, Stevnuválur and Eysturoyar streams are located by the sites.

As mentioned above (see Section 6.2) there are some indications that thing booths existed also in the Faroes. According to oral tradition there were once thing booths in the area north of Tinganes in Tórshavn; this area is said to have been called Tingunibúð, derived from (ON) Pingmannabúd (Barnes 1974, 382-387). This would make sense as Tinganes itself is due to its rocky character not suitable for booths, and the booths known may have been located away from the actual meetings. From I 524 onwards documents exist testifying to meetings held indoors at Tinganes (Nolsøe and Jespersen 2004, II9-I20). Archaeological investigations in the basements of some of the most southerly buildings at Tinganes show that merchants' buildings and other dwellings were once located here. In post-medieval written sources these are referred to as e.g. (Mod Dan) købmandends lejebod ('The merchants' booth') or (Mod Dan) den gamle krambod ('The old warehouse') (Arge and Michelsen 2004, 35, 49; Thorsteinsson I986, 2, 6-7). The post-medieval warehouses were solid buildings and frequently it is reported that the lawmen had to control the goods offered for sale in these buildings (Arge and Mehler 20I2, I84-I85). The potential overlap between thing booths and traders' boothd has not yet been sufficiently addressed (see Sanmark 20 Io in regards to the Greenland booths). In the Faroes, only one other possible booth reference is known. This relates to the local site Uppi millum Stovur in Suðuroy. Assembly participants are said to have pitched their tents (perhaps on top of booth structures) at Tjaldavík ('Tent bay'), close to Øravík (Thorsteinsson 20I2, 35).

A few thing-site markers can be traced in the Faroes, although none of these features have been dated. At í Køtlum in Norðuroyar a big boulder called Tingsteinur ('The thing rock') is found, around which smaller stones have been erected. A mountain top named Tólvmarkaknúkur can be seen from the site. This may be significant, as the name translates as 'The summit of I 2 marks' and can perhaps be related to the fines of $\mathrm{I} 2$ marks commonly mentioned in Norwegian laws, e.g. the laws of the Gulathing and the Frostathing (G 200, 3 I 6; F 20, VI:20; Heinesen Lysaker 2008). Stevnuválur on Eyustoroy is marked by a natural roughly triangular mound. Further indication that it was selected according to its assembly features is seen in the place-name which translates as 'The assembly oval/hollow'. 


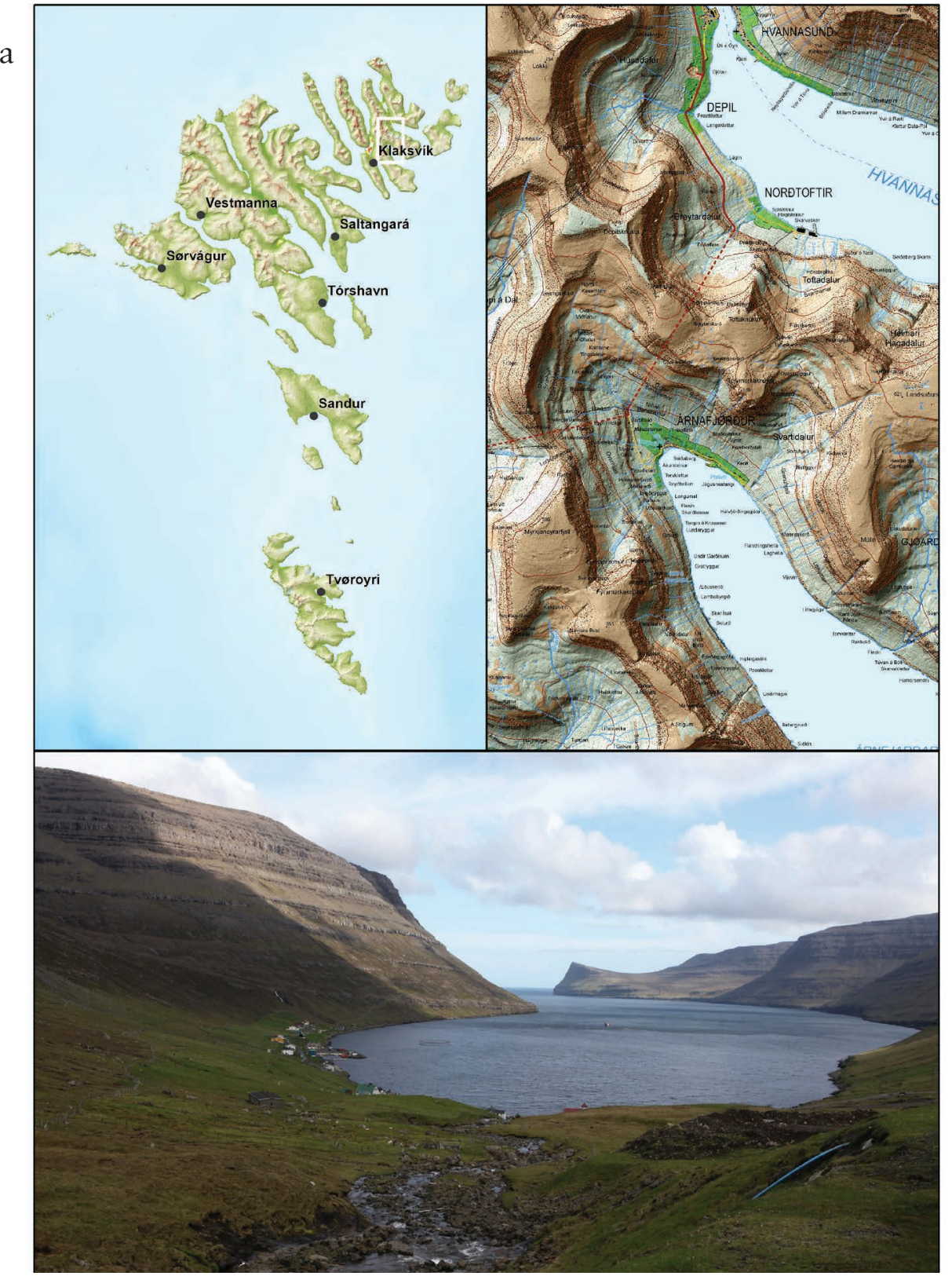

FIgURE 6.I3 The assembly site at í Køtlum in Norðuroyar in the Faroe Islands: a) location and b) the locality. Photograph by Fredrik Sundman. Map and image by Tudor Skinner. Bathymetric data courtesy of Amante, C. and B.W. Eakins, 2009. ETOPO I I Arc-Minute Global Relief Model: Procedures, Data Sources and Analysis. NOAA Technical Memorandum NESDIS NGDC-24. National Geophysical Data Center, NOAA. doi:I0.7289/V 5C8276M [Accessed 22.5.2019]. 
Thing sites and traces of Norse administrative organisation are found across Norse Scotland, but have so far been subject to very little in-depth research. The first attempts at tracing thing sites in Orkney and Shetland emerged in the rath century (Clouston I9I4; Hibbert I83 I; see Smith 2009) and more recently, several overviews of the known assembly sites have been produced (Crawford I987, 206-2 I0; Gibbon 20I2; O'Grady 2008 I95-20I; Smith 2009; Sanmark 20I3). The interdisciplinary method used by The Assembly Project has led to the identification of several new potential assembly sites in Orkney and Shetland. The most useful written sources are the Orkneyinga saga, which mentions a few thing meetings in Orkney, and latemedieval and early-modern documents referring to assembly sites and meetings (Ballantyne and Smith 1994; I999; Clouston 19I4; Pálsson and Edwards 1987; Sanmark 20I3). All potential assembly sites have been visited and recorded and, in addition, new data have been provided by the archaeological investigations at Tingwall in Shetland (Coolen and Mehler 20I4), Papa Stour (Coolen and Mehler 20IO) and Delting in Shetland carried out by The Assembly Project.

Potential Pictish influence on the Norse thing organisation in Orkney and Shetland is difficult to assess. The Picts clearly had their own administrative organisation. No details are known, but the system may have been similar to that described in Irish sources, where the (OIr) óenach was a political and judicial assembly where king enacted laws and ordinances. The sources also refer to the (OIr) airecht as an assembly of 'free men' and a 'law court', which seem to have formed part of the óenach (Gleeson 20I 5, 35; Grigg 20I 5, 46, 88-92). Some Pictish assembly sites in mainland Scotland have been suggested, such as Moncrieffe Hill in Perthshire as an assembly for the Tayside-Strathearn region, while Rhynie, Aberdeenshire, may have functioned as such for the kingdom of Fortriu in the north. By Rhynie is Tap o' Noth, an Iron-Age hillfort, as well as a high-status-potentially royal-site and several symbol stones. It was also located on a crossroads and therefore suitable for gatherings (Driscoll 2004; Grigg 20I 5, 46, 84-8; Noble et al. 20I3; O'Grady 2008; Whyte 20I4). No such evidence for Orkney and Shetland has yet been presented.

\section{Administrative organisation of Orkney and Shetland}

Thing sites in Orkney and Shetland were most likely related to herað districts and the sources also hint at divisions into quarters and eighths, although these were seemingly not related to the assemblies (Crawford and Sanmark 2016; Sanmark 20I3). The Norse units of pennylands and urislands found in both Orkney and Shetland related to taxation and no correspondence between these and the herað units has been found.

Shetland is interesting as it is the only area in Scotland where thing sites can be related to any kind of administrative district; here eight parishes are named after assemblies (Gunnes and Kjellberg 1979, nos I5I, I30, I50; Jakobsen I936, I25; Smith 2009; Sanmark 20I3; Stewart I987, 300). In view of the continuously changing administrative patterns in Scandinavia (see Chapters 4 and 5), these Shetland 'thing parishes' most likely represent a phase of reorganisation carried out by Kings Magnus 
the Law-Mender and Haakon Magnusson in the late I 3 th or I4th centuries (Smith 2009, 42-44; 20I I; Sanmark 20I3) (see Chapter I).

\section{Assembly sites: Levels and functions}

Little is known about the assembly hierarchy in the Northern Isles, but it is likely that the system developed in a similar way to the Faroes, with the top-level assembly being changed from an althing to a lawthing. In Shetland, the lawthing is referred to in documents from I 307 and I 577, when meetings were held at Law Ting Holm, Tingwall, and its existence is further supported by place-name evidence and late traditions (Ballantyne and Smith I999, 2-3, 25-28, 30- 3I, 34-35, I83-224, 239). The Orkney lawthing is recorded from 1496 onwards when meetings were held in Kirkwall (Ballantyne and Smith I999, 30 [I 5I0], 32 [I 5I6]; Clouston I9 I4, 74, no. xxxii). No althing for either Orkney or Shetland is referred to, but as they formed an integral part of the thing organisation it would be very surprising if they never existed. On the basis of other althing descriptions in the sagas, it can be argued that the reference in the Orkneyinga saga to a thing meeting that took place on 'Mainland, where the people of Orkney had their place of assembly' (Pálsson and Edwards I987, Ch. 47) was most probably the althing site. The most likely location of this assembly is the Neolithic chambered tomb Maeshowe in the middle of the Orkney Mainland as the features of this site are strongly reminiscent of top-level Scandinavian assembly sites (see below for further discussion). In Shetland, the place-names that make up the first elements in the parish names have, in analogy with Scandinavia, been used as starting points in the search for the local thing sites (Sanmark 20I3; Smith 2009, 4I; Stewart I987, 300) (Figure 6.I4). In this way, five sites have been identified: Sand in Sandsting, Aith in Aithsting, Lunna in Lunnasting, Dale in Delting, and Gardiestaing in (ON) Rauðarping. Less exact locations for the two thing sites in the parishes of Nesting, and (ON) Pvæitaping have also been suggested (Sanmark 2013). Pvæitaping and Rauðarping are two 'lost' parishes which, according to two I 4th-century documents were 'in the diocese of Orkney', which consisted of both Orkney and Shetland. One of the documents explicitly states that Pvæitaping was in Shetland, and it is therefore assumed that Rauðarping was too (Ballantyne and Smith I999, 3; Gunnes and Kjellberg I979, nos I30, I 50, I 5 I; Smith 2009, 4I-42; Sanmark 20I3). Moving south to Orkney, eight potential local thing sites have been identified, albeit to varying degrees of certainty (Figure 6.I5). These are Tingwall, Dingieshowe and Kirkwall on the Orkney Mainland, Ting on Westray, Tingly Loup on Sanday, Hoxa on South Ronaldsay, Doomy Hill on Eday, and Gruddo on Rousay (for full details, see Sanmark 2017a, I98-260).

\section{The archaeology and topography of the sites}

The lawthing site at Tingwall in Shetland and Maeshowe the proposed top-level assembly in Orkney may seem very different, but they actually share a number of important traits. They are both centrally located within their respective island groups, away from the sea, but where many natural land routes converge. Maeshowe is also just a short walk from a sea loch. No meetings are recorded at Maeshowe, but 


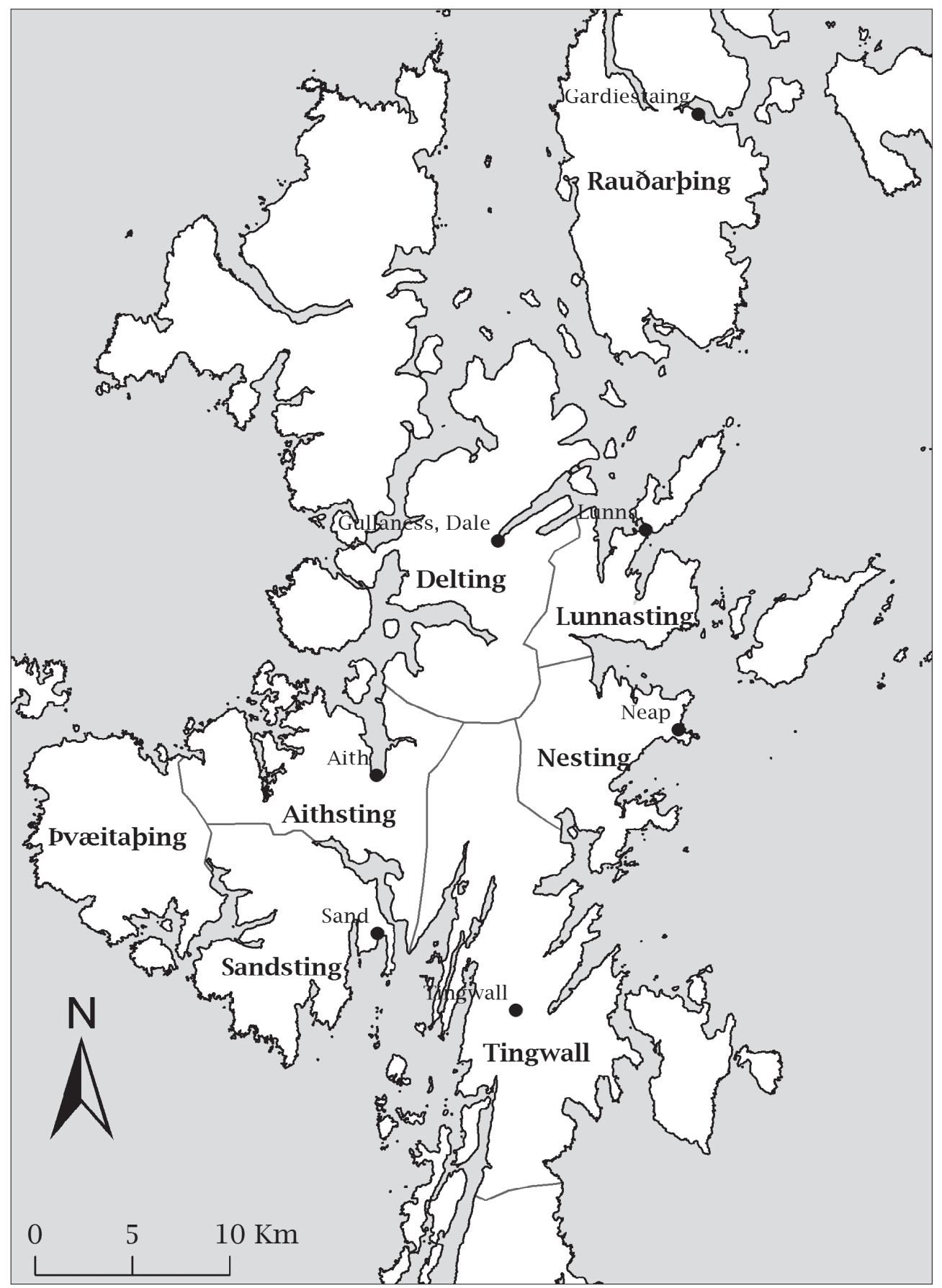

Figure 6.I4 Thing sites in Shetland, Scotland, in their respective 'thing parishes'. Reproduced with permission of the Ordnance Survey. Map by Alexandra Sanmark and Brian Buchanan. 


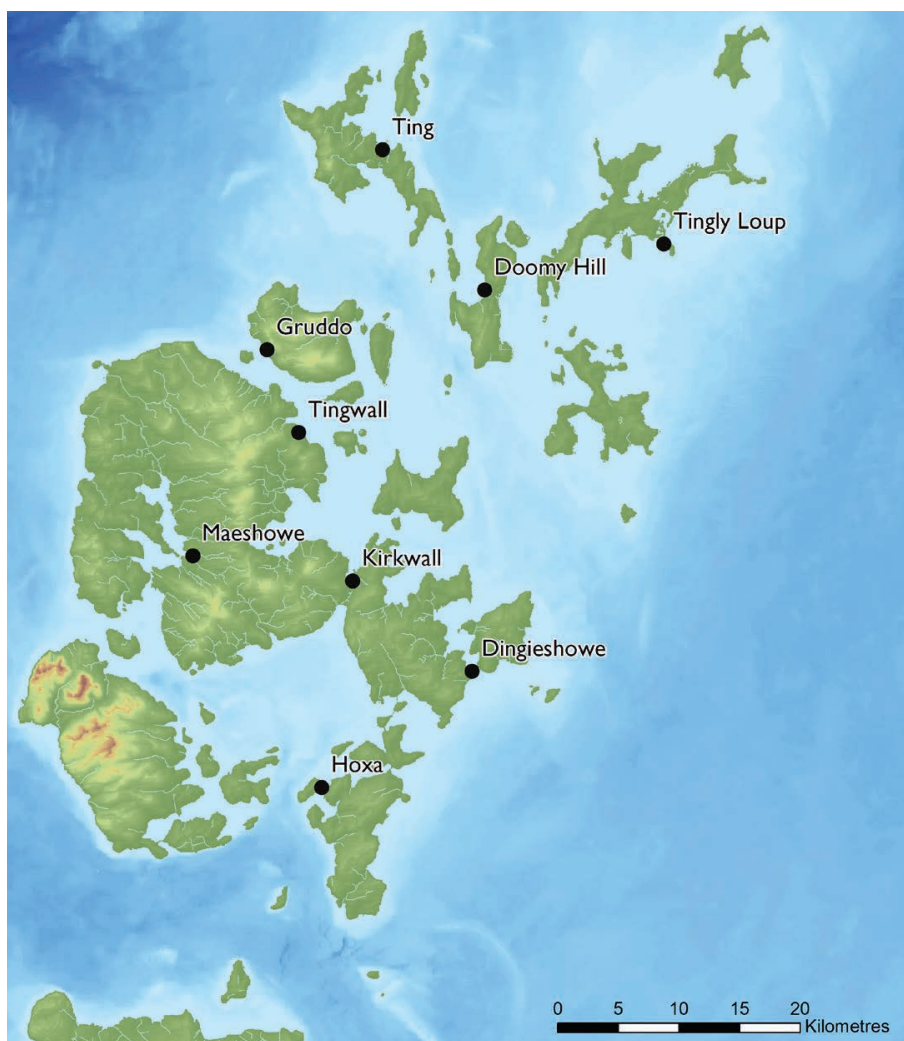

FIGURE 6.I 5 The location of thing sites in Orkney, Scotland. Reproduced with permission of the Ordnance Survey. Map by Alexandra Sanmark and Tudor Skinner.

excavations have shown that the bank surrounding the mound was rebuilt around AD $905 \pm 65$ (Renfrew I979, 36-38), demonstrating that the Norse maintained the monument, probably for use as an assembly site (Sanmark 20I7a, 22 I-223). Tingwall, recorded as an assembly site for lawthings between I 307 and I 577, was located in the middle of the Shetland Islands, some $5 \mathrm{~km}$ from landing places and trading centres at Scalloway and Laxfirth that date at least back to the late-medieval period. Tingwall is the most likely location of the Shetland althing as well (Ballantyne and Smith I999, I96). After the I 570s, the meetings were no longer held here but Lord Robert Stewart moved them to his castle in Scalloway (Smith 2009, 39). Kirkwall too, where lawthing

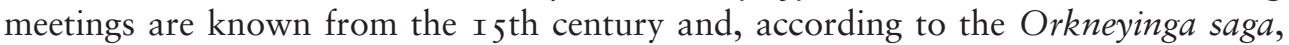
thing meetings were held in the I2th century (Sanmark 2012), was in a key location for communications.

In terms of local sites in both island groups it is striking to note that all sites are close to the sea. Isthmus and portage locations are particularly common. In Shetland this is seen at Aith in Aithsting and the assembly in Lunnasting, where both names contain (ON) eið ('isthmus' and/or 'portage'). Other Shetland sites with portage 
locations are Gardiestaing in Rauðarping and Sand in Sandsting (Sanmark 20I3). In Orkney, one thing-site name is seen to contain (ON) eið: Dingieshowe, probably derived from (ON) Pingeiðshaugr, 'The Mound of the thing portage/isthmus' (Figure 6.I6) (Berit Sandnes pers. comm.). Other potential portage assemblies are Hoxa on South Ronaldsay and Doomy Hill on Eday. Kirkwall too is located on an isthmus (Sanmark 20I2; 20I7a, 2I 2-2I3; Waugh 20IO). The remaining sites are also in locations that were easy to access, found next to the sea or at short distance from the sea (Sanmark 2017a, 202-219). Tingwall on the Orkney Mainland is one such example. This site would have been suitable for people coming by horse from the northern part of the West Mainland and by boat from, for instance, Rousay, Wyre and Egilsay (Tingwall is today used as a ferry port for these islands) and other islands to the north and north-east.

In these island groups, the portage and sea-side location of many sites links into the presence of water at sites, as seen in other geographical areas. In addition, fresh water streams are found by all sites in Shetland and many of the Orkney sites (Sanmark 2013, I03). The symbolic use of water to enclose the sites may have made them into areas of sacred space (Chapter 4 ; Sanmark 20I5). This applies in particular to Tingwall in Shetland. Here meetings were held at Law Ting Holm, an island until

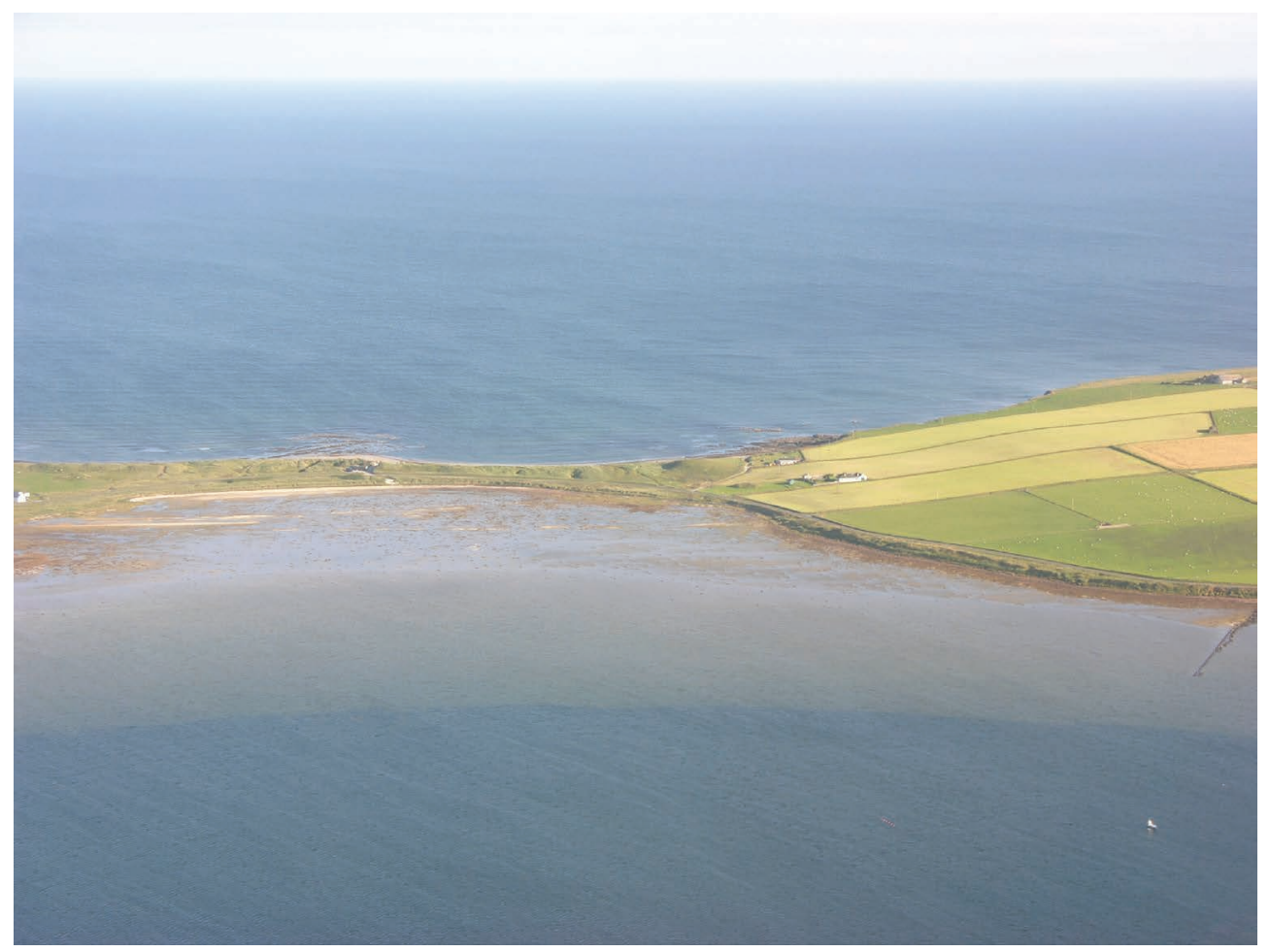

FIGURE 6.I6 Dingieshowe, thing site located on a narrow isthmus, Orkney, Scotland. Photograph (C) David Griffiths, University of Oxford. 
Tingwall Loch was drained in the I 85 os (Coolen and Mehler 20I4, 6, 22-25; Smith $2009,4 \mathrm{I})$. Today there is a causeway, $40 \mathrm{~m}$ long and almost $2 \mathrm{~m}$ wide, consisting of a double row of boulders, linking the Holm to the shore (Figure 6.I7). A causeway consisting of boulders appears on a painting by Sir Henry Dryden, dated c. I 855 . The use and function of a causeway for the thing meetings was moreover described in I7OI by John Brand: 'All the Country concerned to be there, stood at some distance from the Holm on the side of the Loch, and when any of their Causes was to be Judged or Determined, or the judge found it necessary that any person should compear before him, he was called upon by the Officer, and went in by these steping stones, who when heard, returned the same way he came' (Brand I883, I83-I84; Coolen and Mehler 20I4, 6; Smith 2009, 39-4I).

In 20 I I TAP excavated parts of the causeway and demonstrated that it is lying on top of pottery from the 183 os and therefore of rather recent date (Coolen and Mehler 2OI4, I22-I25). This chronology means that John Brand's description predates the current structure, although the reference to 'steping stones' fits the boulder construction rather well. There are several possible scenarios that would reconcile the recent dating of the existing causeway and Brand's earlier description. The first is that one or more earlier causeways have existed, of which all traces have now been

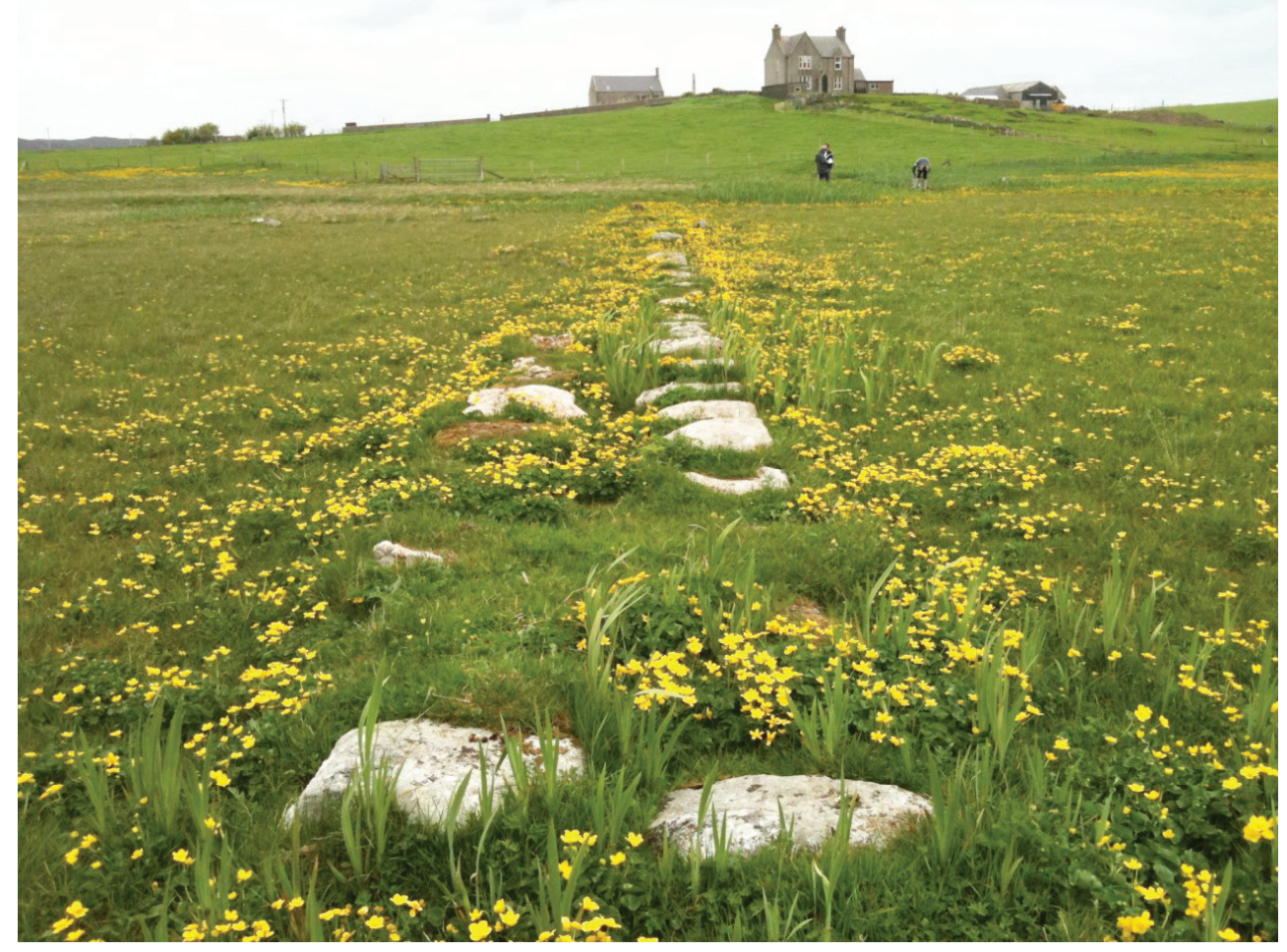

Figure 6.I7 The causeway at Tingwall, Shetland. Photograph by Natascha Mehler. (C) The Assembly Project. 
removed, at least in the excavated trench, and that the causeway was reconstructed after c. I830 (Coolen and Mehler 20I4, I24). A second possibility is that temporary causeways have existed, made of wooden planks and/or stones that were laid out for each meeting. A third possibility, at least for the earliest phase of the assembly, is that participants waded to reach the island. As pointed out in Chapter 4, thing sites in Scandinavia are frequently located by fording places, and the entering of a thing site may have involved the ritual crossing of 'holy waters', as suggested for example by the Eddic poem Grimnir's Sayings (Grimnismál; Sanmark 2009, 23 I-232; 20I 5 ; $2017 \mathrm{a}, \mathrm{IOO})$. One suggestion is therefore that such a crossing was required for those taking part in the thing meetings during the (early) Norse period.

As the site remained in use until the I570s, and belief systems and traditions changed, the appeal of this manner of accessing the island may have faded, and a causeway may have been constructed. This possibility would explain the mention of 'these steping stones' from I70I. It may, of course, also be a combination of these suggestions, and the causeway may have been rebuilt on several occasions. A possible point in time for such a (re)construction might be the I8th or I9th centuries, when interest in old assembly sites and sites of national importance was reawakened (Chapter 2; Coolen and Mehler 20I4, I24). In 2010, our project carried out a magnetometry survey covering an area of some 9.3 hectares on the northern shore of Loch Tingwall. This area could have been the place where the assembly attendants camped, but no obvious archaeological features or structures were discovered (Coolen and Mehler 2014, 7-19).

In Orkney and Shetland, monument reuse at thing sites was a rather common feature. The clearest case is Tingwall. The excavations carried out by The Assembly Project in 20I I revealed that Law Ting Holm was the site of an Iron-Age settlement where considerable iron-working took place, which may have had roots further back in time. Although no clear architectural remains were observed, the cultural layers contained a considerable amount of pottery, animal bones, slag, stone tools and even the bones of a child. Within the excavated trench two fire places were also found, either used as hearths or furnaces (Figure 6.I8). Archaeomagnetic samples produced calibrated dates that were ambiguous, datable either to the Middle Ages or to the Late Iron Age (Outram et al. 20I4). The settlement was deliberately dismantled which could have been done by its latest settlers, the Picts, or later during the Viking period when people chose the location for its natural and historical characteristics and decided to level the area to host meetings. No clear evidence of Norse activity was found, but it must be kept in mind that only a small part of the Holm was excavated. The seeming lack of Norse evidence should not necessarily be interpreted to mean that Ting Holm was not used as a thing site. The evidence linking the assembly meetings to the Holm is too strong to be discounted on the basis of negative evidence (Coolen and Mehler 2014, I22-I26). Moreover, as seen in Chapters 4 and 5, the reuse of older sites as assemblies was frequent practice in Scandinavia, and when excavated, they tend to be poor in Norse finds and features (see also Coolen and Mehler 20I I; Sanmark 2009; Sanmark and Semple 2008; 2010).

Another possible example of monument reuse is the isthmus of the Lunnasting assembly in Shetland, where there are archaeological remains from multiple periods. The most striking feature is the probable Iron-Age broch mound (Sanmark 2013, I03). 


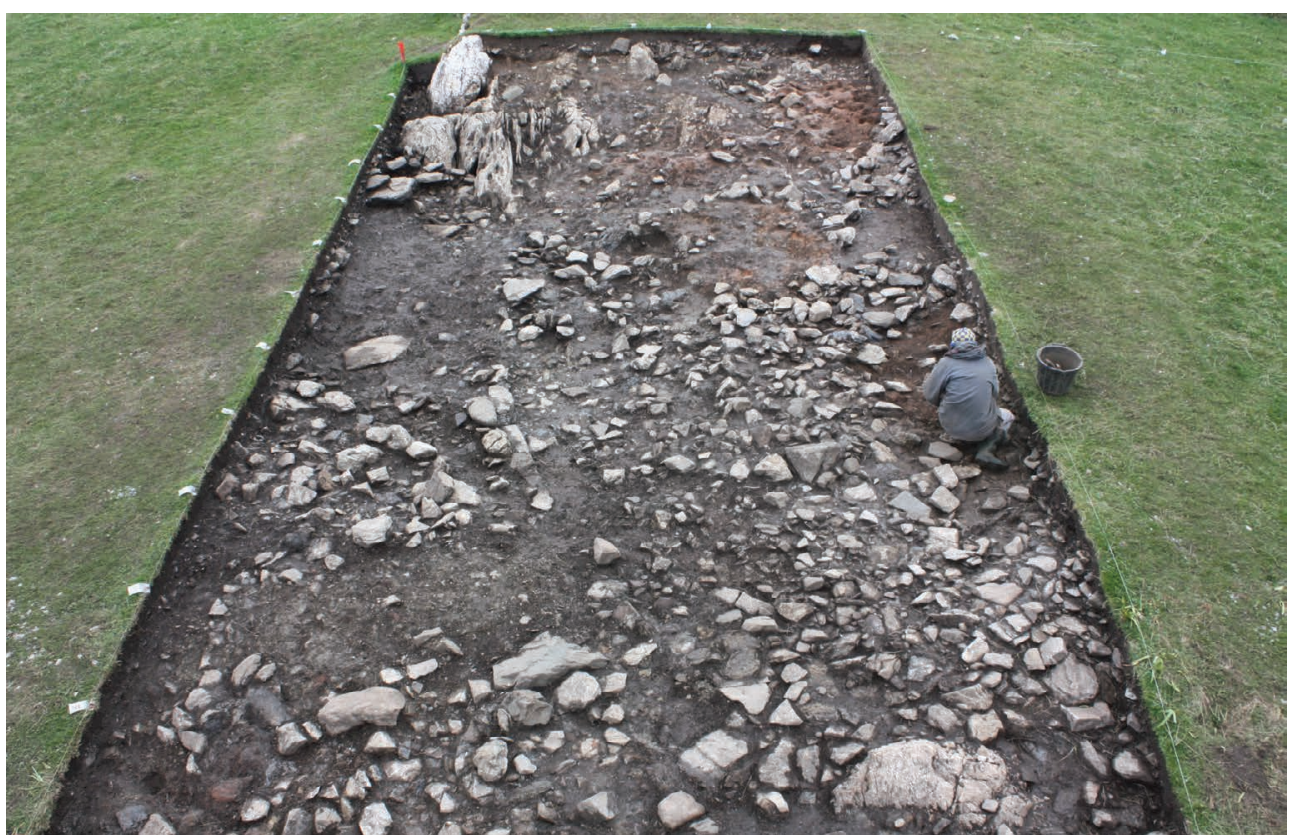

Figure 6.I 8 The Law Ting Holm, Shetland, during excavation in 20I I. Photograph by Ronny Weßling. (C) The Assembly Project.

Sites with large mounds were frequently used for assemblies in Scandinavia and also in Norse Scotland as a whole (O'Grady 2008, I95-20I; Sanmark 20I7a, 83-86; Semple and Sanmark 2013). There are several other such sites in Orkney. At Dingieshowe there is a broch mound, c. $7 \mathrm{~m}$ high (see Figure 6.I6). Tingwall too is focused around a broch mound, surrounded by flat fields that would have been suitable for the people gathered for meetings (Figure 6.19). Hoxa is another likely candidate (Sanmark 2017a, 219-227).

Maeshowe must, of course, be addressed here (Figures 6.20). The large Neolithic chambered cairn covered by a turf mound, distinct in the flat Orkney landscape, had many strong assembly characteristics and was in addition located in the centre of the Orkney Mainland. An added attraction must have been the surrounding Neolithic ritual landscape, with two henge monuments and various standing stones that would have been highly suitable for assembly and cult rituals along the lines of those envisaged at top-level Scandinavian assembly sites, such as Gamla Uppsala (Chapter 4; and Sanmark 20I7a, 6I, 83-84, 89-9I). Of course this is speculative and there are other striking monuments in Orkney that may have been used by the Norse for assembly purposes (for discussions of the relationship between Norse sites and earlier monuments, see Leonard 20II and McLeod 2015). None of these sites, however, have as many assembly indicators as Maeshowe, and they are less central to the whole of Orkney. Further evaluation of such sites may, however, result in new suggestions of Norse monument reuse, for a variety of reasons. 


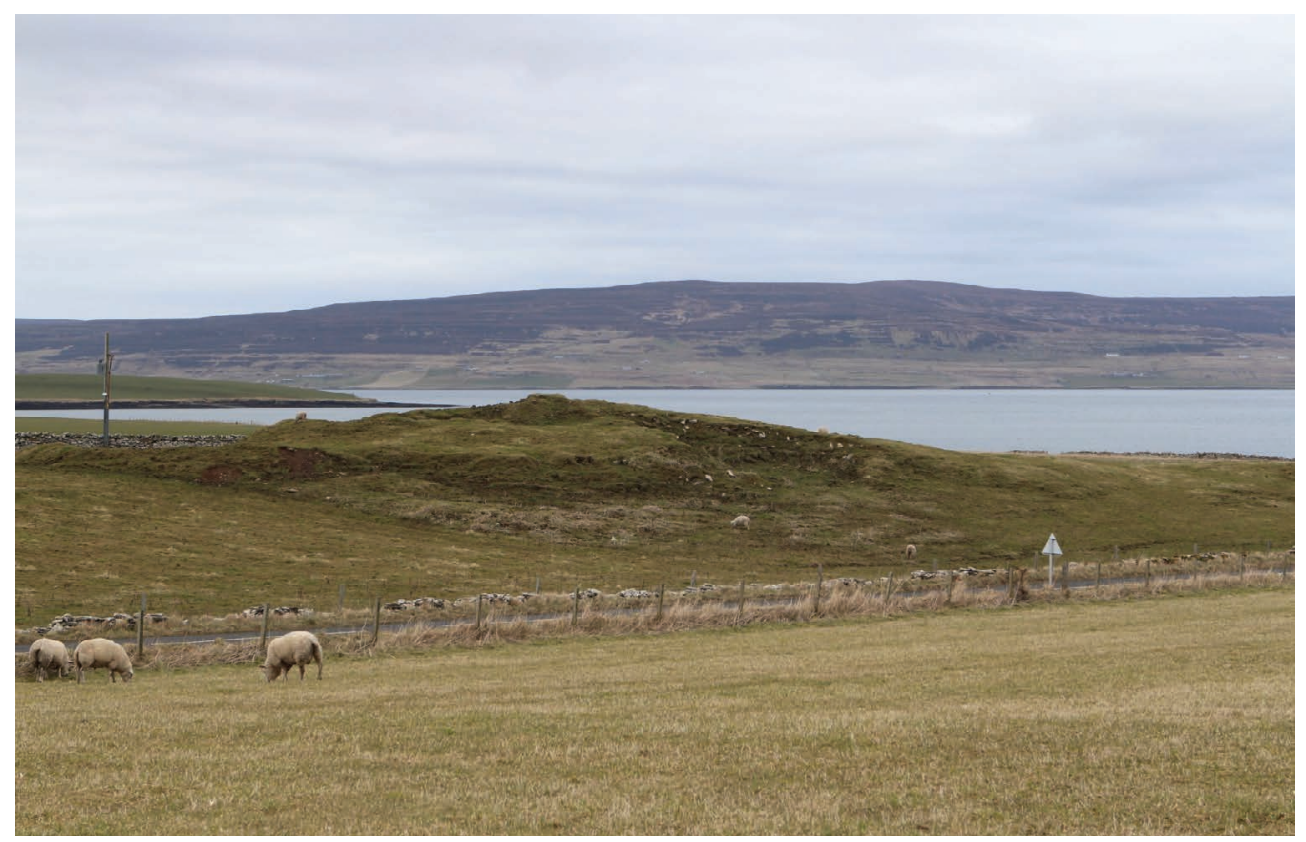

FIGURE 6.19 Tingwall in Orkney. (C) Fredrik Sundman.

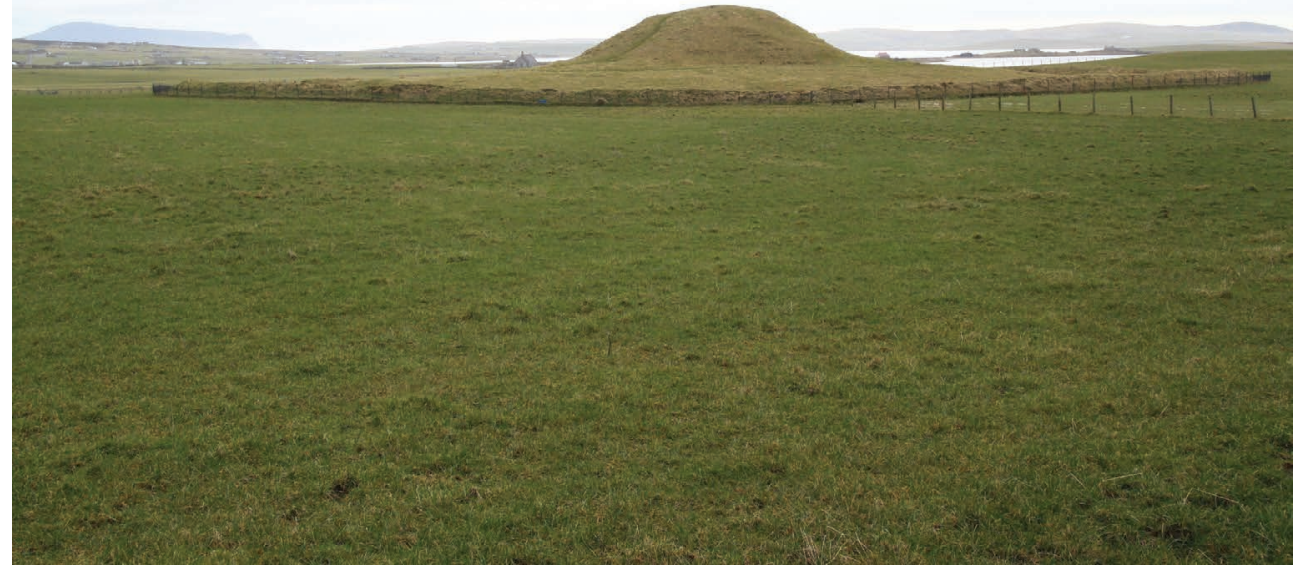

FiguRE 6.20 Maeshowe, the Neolithic chambered tomb that may have been the focus for the top-level thing, Orkney. (C) Fredrik Sundman. 
The possible use of the standing stones around Maeshowe for assembly procedures links into other references to standing stones in the Norse settlements. In Iceland in some cases such stones were named (ON) blótsteinn ('sacrifice stone'), for example like the one at Pórsnes, where cultic practices of some sort may have taken place. Eyrbyggia saga (Ch. Io) reports that 'the stain of blood can still be seen on the stone' (Friðriksson I994, I I 2; Friðriksson and Vésteinsson I992, I3, 57; Whitmore 20I3, 75-76). Such stones are known from many areas and may be interwoven in legends and myths. The $(\mathrm{ON})$ term blótsteinn may relate to the German term blauer Stein ('blue stone'), which is for example known from Cologne, where culprits were made to confess their crime before their execution (Meier I93I). Another example is the standing stone at Tingwall, Shetland, located near the Law Ting Holm. According to local tradition, it was here that Earl Henry of Orkney killed Malise Sperra, his cousin and main opponent, as well as seven of his men in the late I4th century (O’Grady 2008, 208; Crawford I987).

Another archaeological feature known from Icelandic assembly sites, although a problematic one, is also known from Shetland, and is that of a court circle (ON dómhringur) (see earlier discussions). On the island of Papa Stour, which possibly belonged to the Pvæitaping, lies Housa Voe, a protected bay and former harbour for the Biggings, a well known Norse high-status farm in Shetland (Crawford and

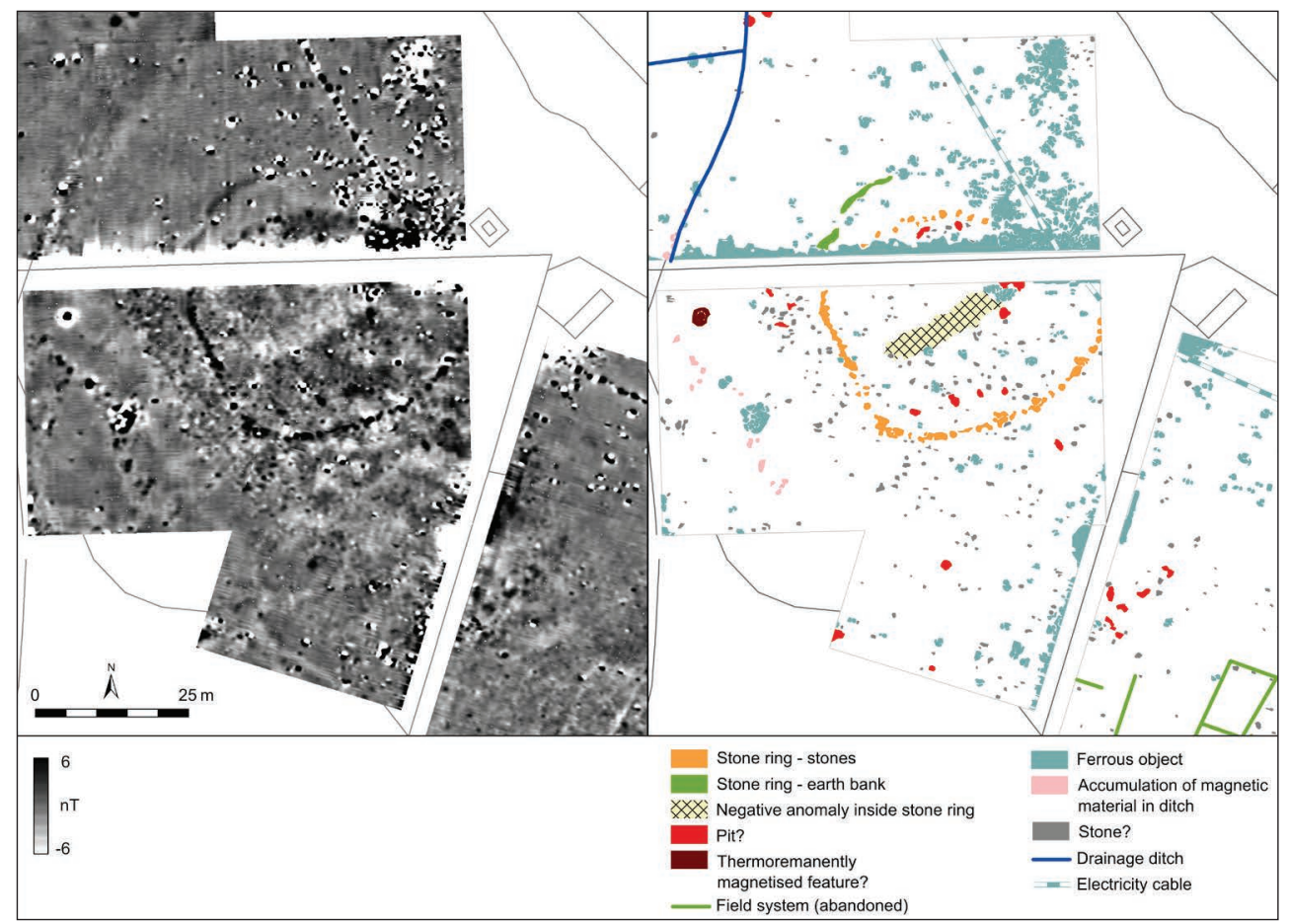

Figure 6.2I Results of the geophysical survey at Housa Voe, Papa Stour, Shetland. Reproduced from Coolen and Mehler 20I0. (C) The Assembly Project. 
Ballin Smith I999). Just above the beach lies an archaeological feature known in oral history as a 'stone ring'. There are no written documents referring to the structure and oral tradition goes back to the late I 8th century at least. In June 20I0, The Assembly Project undertook a magnetometry survey of the structure in order to clarify the monument's archaeological context (Figure 6.2I). In the data the structure appears very clearly, with a remarkable rectangular anomaly in its centre. The function of the latter is not known. The shape of the enclosure is actually not a circle but a horseshoe with an open end towards the sea. The precise location of the structure at the central axis of the voe is striking. It provides an excellent view over the voe. The survey, however, has not given any indication on the function of the structure and excavation is needed (Coolen and Mehler 2010). Hence, the Papa Stour 'stone ring' is yet another example of the challenges that so-called court circles provide.

In Orkney and Shetland, there are links between the top-level sites and churches. This is seen at Kirkwall where the lawthing was held not far from the I 2 th-century

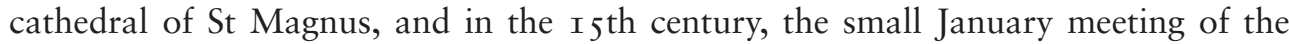
lawthing was held inside the cathedral (Gibbon 2012), although the larger meetings were most likely still held outside (Ballantyne and Smith I999, 30 [I 5 IO], 32 [I 5 I6]; Clouston I9I4, 74, no. xxxii; Sanmark 2017a, 233). In Shetland, Tingwall Church, located very near Law Ting Holm, was the seat of the Archdeacon and the most important church in Shetland (Cant I975, 2I). The first written record mentioning the Shetland top-level assembly in 1307 records that the meeting was held in the church at Pingavollr' (SD I, no. 3; Coolen and Mehler 20I4, 6). The present church was presumably built between I788 and I790, but evidence suggests the existence of an older, late I 2 th-century church. In Shetland, links are also found between churches and local assembly sites. One such example is Dale in Delting, which is located $250 \mathrm{~m}$ from a chapel. A magnetometry survey carried out at the potential thing site by our project did not identify any archaeological features (Sanmark 2013, I04). Other Shetland thing sites with chapels are Gardiestaing, Sand, Lunna, Dale, and Aith. As these buildings have not been properly dated, although some may be of medieval origin, a relationship with the thing sites cannot be verified (Sanmark 2013, I04).

\subsection{THE DANELAW}

As set out in the first chapter, the Danelaw was a region of northern and eastern England ceded to Norse settlers in the late 9th century (Hadley 2008, 375-377) (Figure 6.22). The focus of our project was on the Ridings of Yorkshire that form just part of the area so-called the Danelaw. The term Danelaw is first potentially encountered in Æthelred II's Wantage decree, promulgated at the turn of the Ist millennium AD, and can be identified more conclusively shortly thereafter in the king's Enham decrees (VI Æthelred) of Ioo8 (Hadley 2008, 375). Early research into Danelaw assembly practices focused on the sites themselves, such as Ralph Thoresby's treatment of the place-name Tingley (I7 I 5, I95). In terms of historical investigation, the lack of documentation compared to the rich source material for southern England has resulted in comparative neglect. Arguments for increased evidence of royal power and control have been made largely on the evidence from the kingdoms of Wessex and Mercia (Keynes I990; Sawyer I983; Wormald I986), but insights have been achieved 
FigURE 6.22

Approximate boundary of the Danelaw, highlighting the location of the Ridings of Yorkshire.

Map by Tudor Skinner.

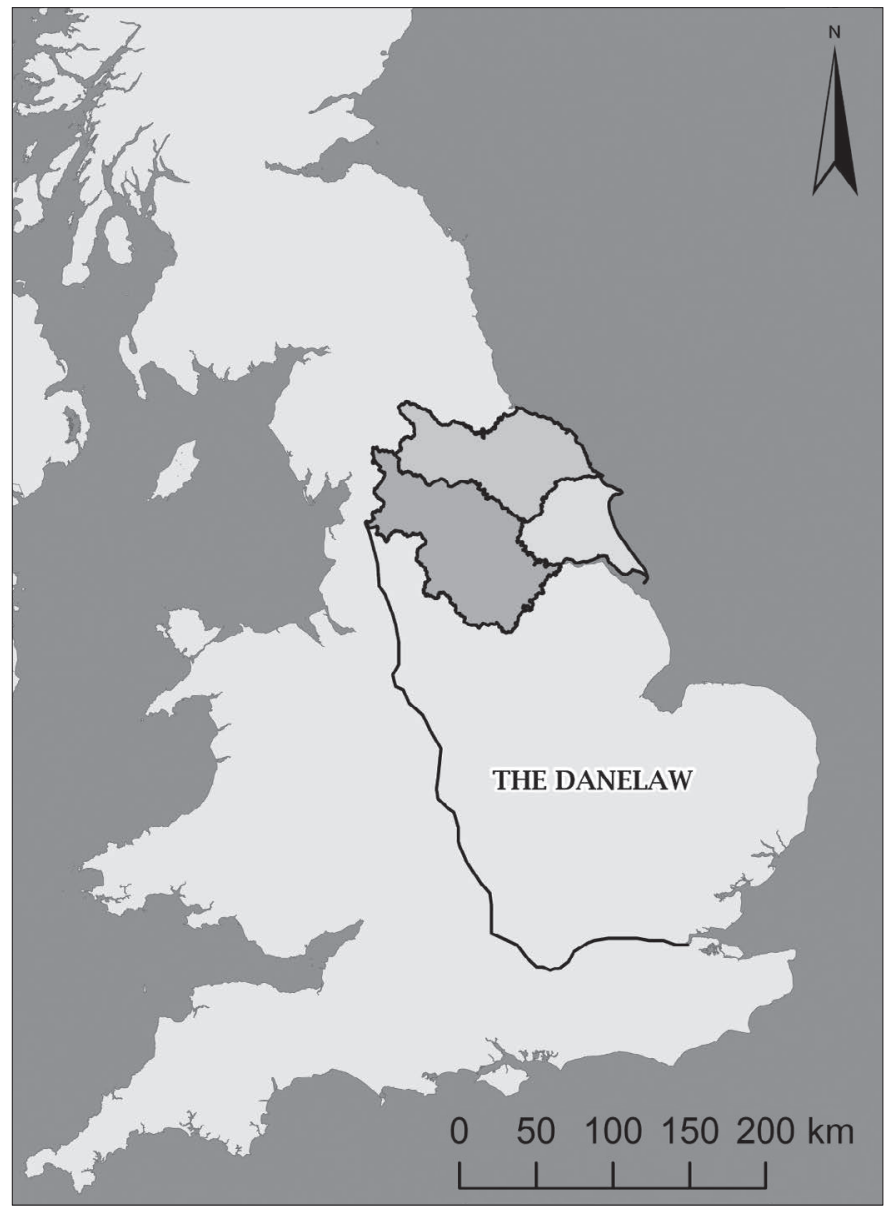

which demonstrate distinct arrangements in the Danelaw alongside evidence for potentially inherited administrative arrangements (Loyn I974, 4; Molyneaux 20I I, 83-86; Roffe 2007, I94-I95; see Turner 2000 on shared topographic traditions with the south).

\section{Administrative organisation of the law province}

The earliest suggestion of a Norse law province in Britain is found in the late 9th-century Treaty of Alfred and Guthrum, denoting a region north of the River Thames and Watling Street (Whitelock I979, 4I6-4I7). During the establishment of the Danelaw, local potentates were installed in the existing Anglo-Saxon kingdoms (ASC A 874) though soon enough a number of other polities emerged within. The Five Boroughs, organised around the fortified settlements of Derby, Leicester, Lincoln, Nottingham and Stamford, were treated as a distinct territory in the Wantage decree issued by the Anglo-Saxon King Æthelred II [r. AD 978-IOI3] 
(Liebermann I 898-I9I6, I, 228) while a Viking kingdom of Northumbria, centred on York, survived into the mid-Ioth century (ASC E 952/954). In this sense the Danelaw actually refers to a grouping of law provinces. By the end of the Ioth century the territories of the Danelaw had been incorporated within the emerging kingdom of England, though a distinct identity remained, as the Wantage decree demonstrates.

More comprehensive evidence for the administrative structure of the Danelaw comes from the returns of Domesday Book, a cadastral survey of England conducted in the late I Ith century. For much of southern England, it outlines subshire jurisdictions known as hundreds. In the northern parts of the Danelaw region however, one instead encounters the wapentake, a seemingly analogous territory (Figure 6.23). Each of these jurisdictions first appeared in Anglo-Saxon legislation of the mid-Ioth century as devices of local administration and justice (Liebermann I898-I9I6, I, 210; Wormald I999, 378). Despite this, as mentioned above, the term wapentake is of clear Old Norse origin (Anderson I934, xxi). In Domesday Book the wapentake was concentrated in the area of the Five Boroughs and Yorkshire (with the exception of its East Riding, which was reckoned instead in hundreds). Intriguingly, the term wapentake is found not as a territorial jurisdiction in medieval legal practice in Scandinavia, but instead as a term of assent and ratification at assemblies (e.g. Dennis et al. I980, 212, fn II0; Helle 200I, 72-74; Taranger I9I5, 3.I2). The

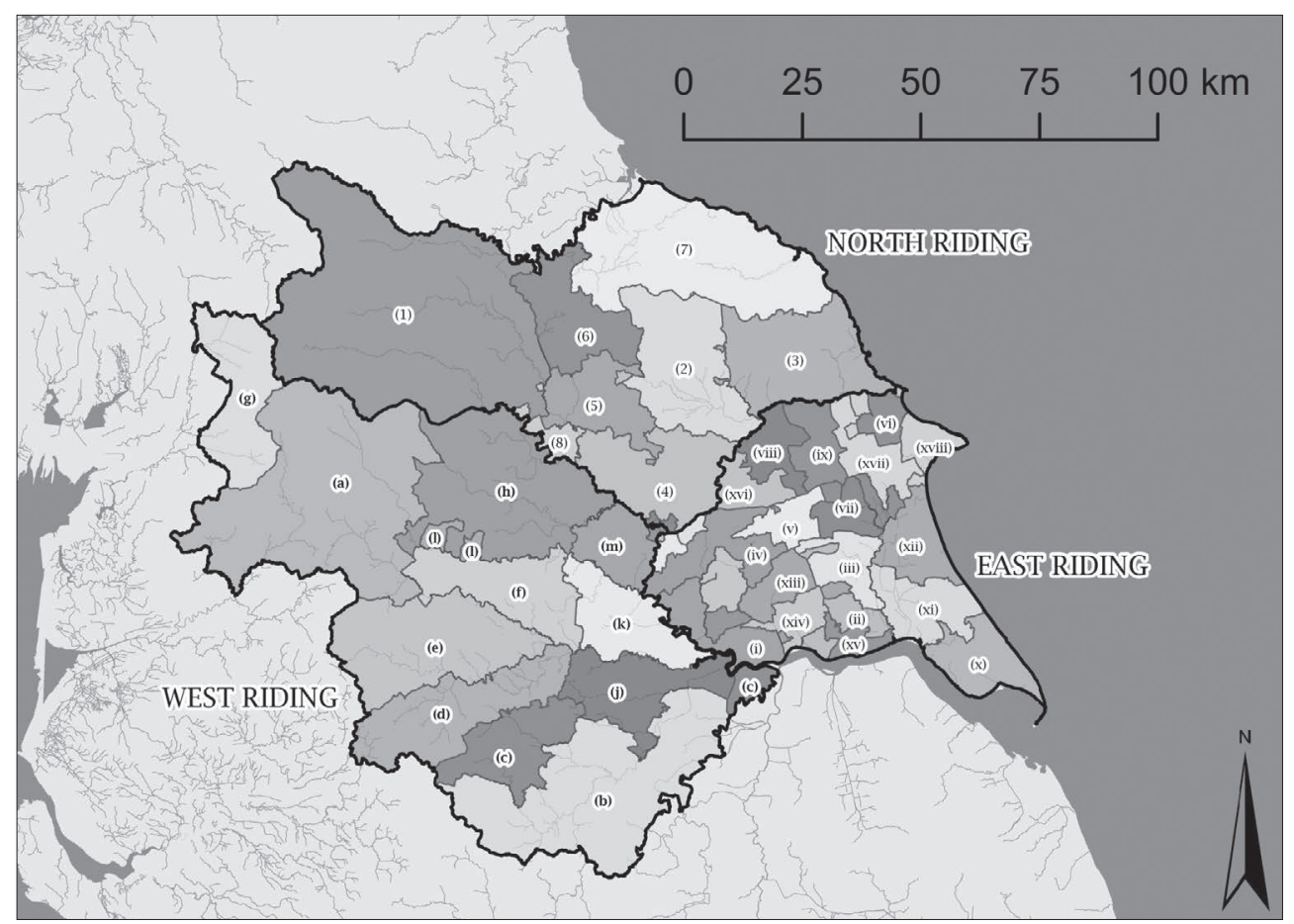

FIGURE 6.23 Wapentake and hundred territories in the Ridings of Yorkshire, c. Io86. Map by Tudor Skinner. 
overriding impression given in the Northern Danelaw is of Anglo-Saxon law practiced under Scandinavian influence, rather than a region of Scandinavian law. It is certainly evident that this influence extended down to the localities, as demonstrated by the institution of the (ON) byjar-lög ('law of the village') constituting governance at the level of the vill (a small administrative region, associated with individual settlements in Domesday Book) (Smith I96ra, I06). The Ridings of Yorkshire and Lincolnshire, which circumscribed groupings of wapentakes, demonstrate as well that Scandinavian influence was also manifest at a broader geographical scale.

\section{The assembly sites: Levels and functions}

The territorial evidence for the hundred and wapentake strongly intimates a hierarchical scheme. This is best demonstrated in the structure of Domesday Book, with the assembly territories posed as discrete subdivisions of the shire, except in Yorkshire and Lincolnshire, where the shire is instead divided by Riding and then wapentake (except in the East Riding of Yorkshire, where hundreds constituted the latter subdivision). In the case of the Northern Danelaw prior to the Norman Conquest, the shire court would presumably have convened in the county town, such as York or Lincoln, or else in an associated location. Certainly the Wantage decree demonstrates the existence of both an assembly of the Five Boroughs and separate borough assemblies at the end of the Ioth century (Liebermann I898-I9I6, I, 228). At the next level down, courts of the Ridings are more problematic, only emerging in later-I 3 th-century sources. Where identified, however, they appear to be associated with locations and landscape foci similar to those linked to the network of wapentake sites, and examples of this include Craike Hill, a remodelled mound in the East Riding of Yorkshire (Figure 6.24).

Below the level of shire (and in some cases Riding) one finds the hundred, and increasingly in the Northern Danelaw, the wapentake. While law-codes such as the Hundred Ordinance and Wihtbordesstan decree specify some of the workings of the hundred and wapentake (Wormald I999, 317, 378; Loyn I974, 4), nothing approaching a schedule of these assembly territories was attempted until the compilation of Domesday Book in the late I Ith century (Figure 6.24). In most cases the territorial nomenclature directly references the sites in question, such as Agbrigg wapentake (ON 'Aggi's bridge'; Smith I96Ib, II7) in the West Riding of Yorkshire. In other cases, however, the location cannot be confidently determined. Some names reference wider districts, such as Scarsdale wapentake, Derbyshire (ON 'Scarfr's valley'; Pantos 2002, 270), while others refer to the dominant manor of the territory, for example Oswaldbeck wapentake in Nottinghamshire (Anderson 1934, 39; Stenton I9I0, 44). The former conceals the location of the assembly site, and in relation to the latter, evidence suggests it is problematic to assume that assemblies were convened at the estate centre (see below). In these situations, later medieval court records have been used to indicate the assumed continuity of a hundred/wapentake venue in these districts, though the noted presence of multiple venues poses obvious challenges. For instance, the later medieval wapentake of Dickering, in the East Riding of Yorkshire, is recorded as meeting at both Burton Fleming and Rudston (Brown I902, 67; Lancaster I9I2, I02). Notwithstanding these issues, it is clear that when hundred 
documentation has been allied with detailed place-name analysis (e.g. Swan et al. I993), a significant proportion of these places can be identified.

Place-names attesting to assembly practices signal a second significant class of potential assembly site (Figure 6.25). The Old English elements (ge)mot and spell, joined by the Old Norse ping, can signify 'meeting', 'speech' and 'assembly' respectively and are considered to provide strong evidence for the location of earlier medieval conciliar practice (Pantos 2004a). These elements are found only rarely as part of hundred and wapentake names, for example Spelhoe hundred, Northamptonshire. Conversely, in areas where consideration has extended to the field names (e.g. Cameron I984; Smith I96Ia), they proliferate. Pantos has proposed that these sites may demonstrate the existence of locally prominent sub-hundredal assemblies (Pantos 2002, I69), while John Baker and Stuart Brookes (2013a, 78) suggest that they may also represent a palimpsest of previous conciliar arrangements, attesting in turn to the substantial reorganisation of local administration towards the end of the early medieval period.

Below the level of the wapentake in Lincolnshire, Nottinghamshire and Derbyshire, a further subdivision in the Domesday text is found, known as the twelvecarucate hundred (Hadley 2000, IOI). David Roffe (2000, 56) has argued that these were functionally analogous to the subdivisions of the bundred known as tithings from early medieval southern England. With evidence elsewhere for a synonymous

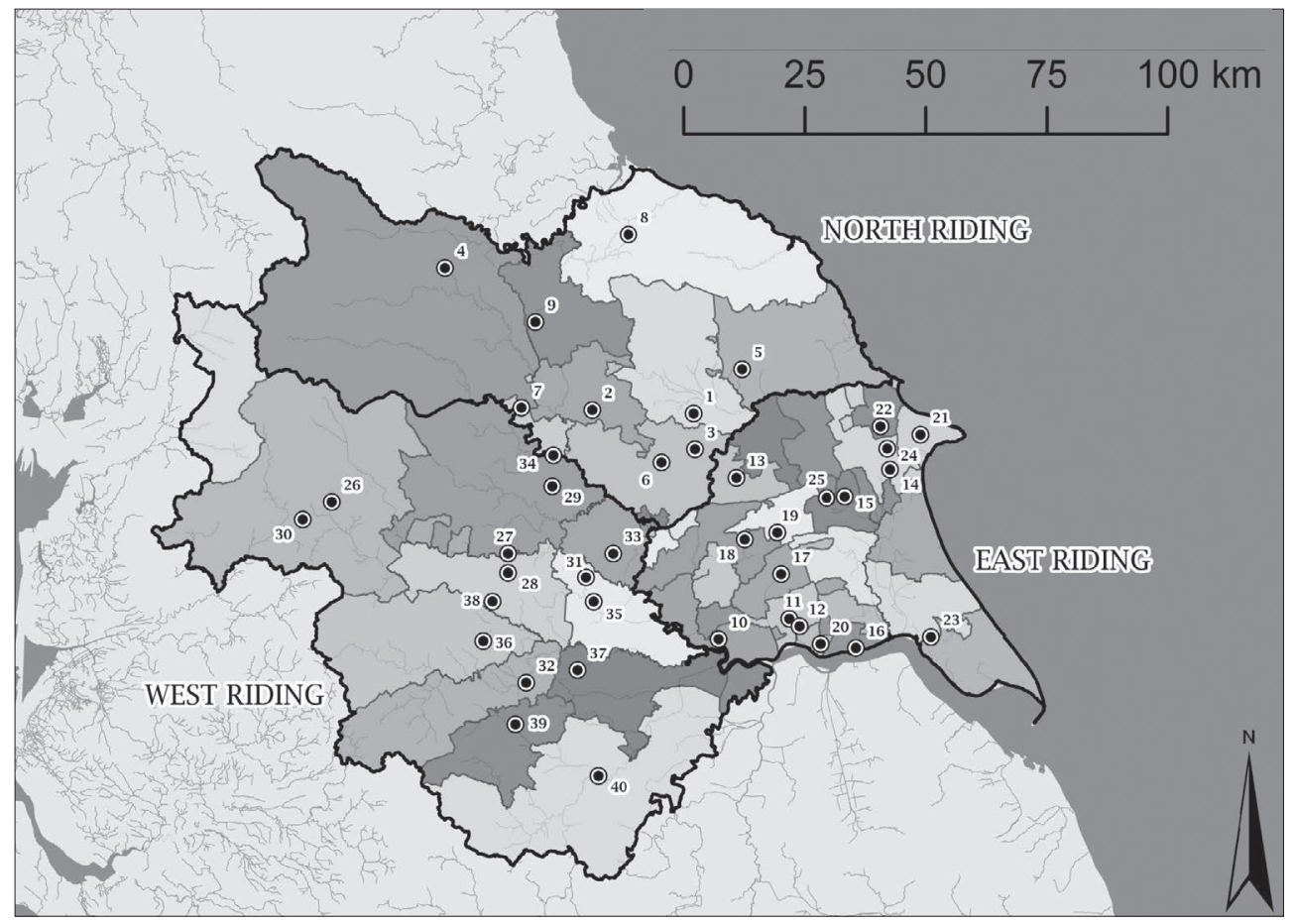

FIGURE 6.24 Documented assembly sites in the Ridings of Yorkshire. Map by Tudor Skinner. 
subdivision known as the (ON) temanetale in parts of the North Riding of Yorkshire (Page I9I4, I7) and the byjar-lög, sub-hundredal governance was evidently well developed (Skinner 20I4). Nonetheless, the uneven nature of the evidence resists attempts to extrapolate with confidence a consistent level of assembly below the bundred and wapentake.

The overall architecture and spatial arrangement of these systems is underlined in the demands in the early medieval law-codes that attempts to seek local justice be exhausted before appeals to higher jurisdictions are made. This is most clearly demonstrated in II Cnut I9, which states that a case must go through the hundred court three times before appeal can be extended to the shire court (Liebermann I898-I9I6, 320-322). There are numerous accounts of legal actions in the later medieval period shuttling between the wapentake and the crown, such as the Manslaghtre inquisitions of Kirkby Malzeard (Brown I 898, 99-IOI). In practice, elements of a conciliar hierarchy were observed, though much abused. Accounts of legal actions mandated and reported for the hundred and wapentake give, however, no clear indication of hierarchical differentiation, with misdemeanours both petty and grave found in the bundred and shire courts alike. Where a pre-hundredal conciliar structure has been identified, such as the (OE) folcgemote (e.g. II Æthelstan 2; see Liebermann I898-I9I6, I60), its functionality suits the bundred and the shire court

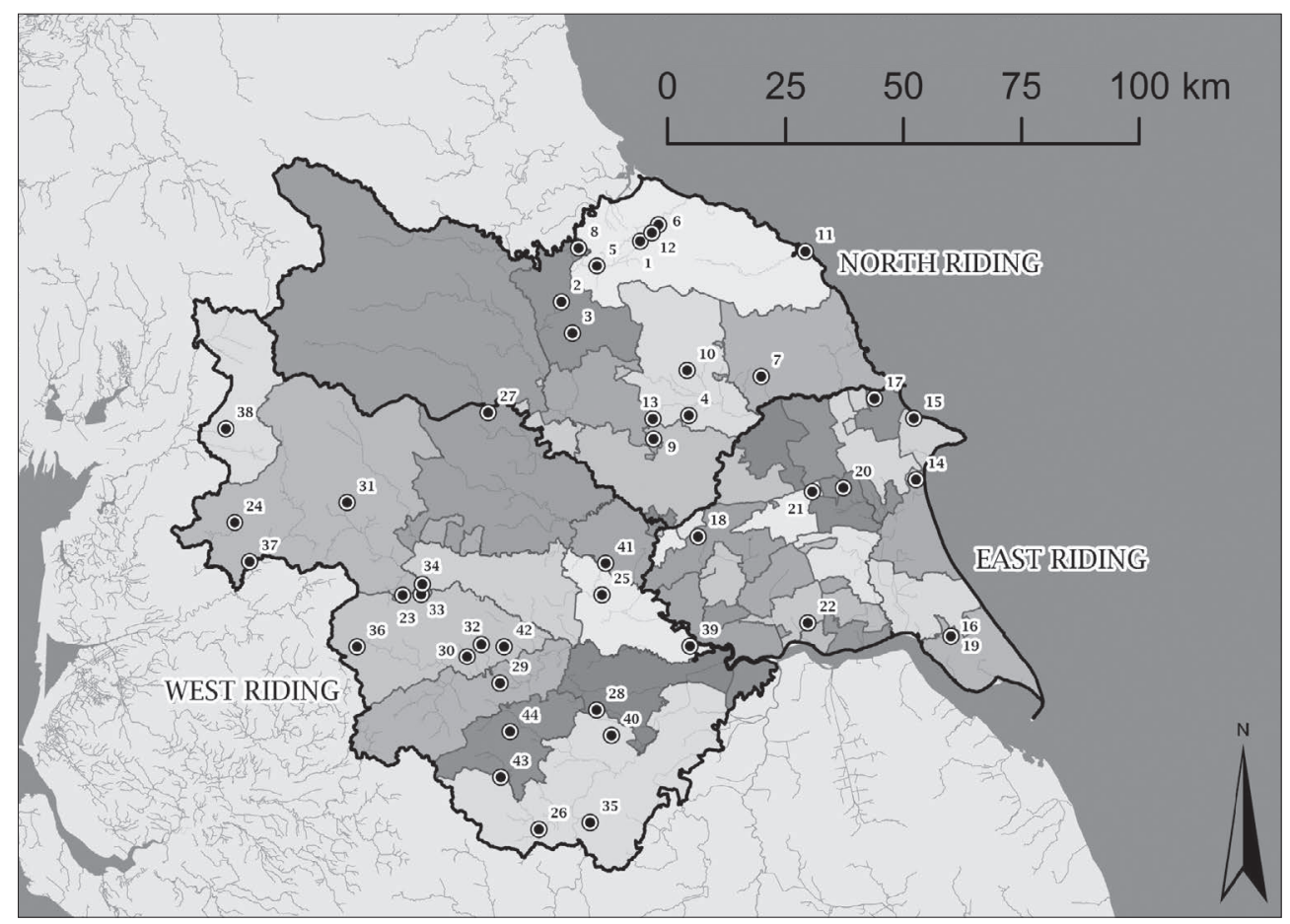

FIGURE 6.25 Place-name attested assembly sites in the Ridings of Yorkshire. Map by Tudor Skinner. 
equally well (Liebermann I898-I9I6, I60). On the other hand, the post-Conquest legal compilation the Leges Edwardi Confessoris (c. II30; O’Brien I999) presents a bundred court and shire court of distinctly blurred competencies (Pollock and Maitland I 898, 530). Indeed, Maitland considered the differences between the shire and hundred court to be largely geographical, itself an affirmation of Edward Coke's earlier position, of the bundred court as a devolved body of the shire, linked to the higher court through its officers (Coke I669, 267). It is likely that this can be at least partially explained by a hundred and wapentake system that was reactive to local custom.

\section{The archaeology and topography of sites}

The identification of assembly sites in the Danelaw proceeds from place-name identification, both for documented venues of assembly and assembly-attesting toponyms. The focus here is Yorkshire which formed just part of the area known as the Danelaw. Place-names in this county can broadly be divided into varied attestations of landscape foci, such as mounds, crosses and trees, alongside those that cite wider areas, from settlements and fields up to entire district names, e.g. Holderness in the East Riding of Yorkshire (ON 'headland of the hold'; Smith I937, I4-I5). Placenames attesting to landscape foci comprise around half of the bundred and wapentake names found in the Yorkshire Domesday, and the vast majority of assembly-attesting names identified in the same region. They are the most straightforward to identify, though recent industrial development in the region has left few surviving remains.

In terms of location, assembly sites in the Northern Danelaw do not seem to possess a strong relationship with coastal sites or river crossings. There are some conspicuous exceptions in the case of river crossings, such as Strafforth Sands and Bolesford in the West and North Ridings of Yorkshire respectively, though this does not appear to form part of a wider pattern. There are also a very small number of sites associated with springs, including Welton (OE w(i)ella tun 'springside farmstead'; Smith 1937,220 ) in the East Riding of Yorkshire and Halikeld (ON heilagr kelda 'holy well'; Anderson I934, Io) in the West Riding of Yorkshire. Halikeld is in fact the one spring/well name in the Danelaw associated with assembly that utilises Old Norse nomenclature-elsewhere the Old English elements wiella and mere are utilised (Anderson I939b, I74-I75) (Figure 6.26). It is very unlikely that these sites were newly patronised in the Anglo-Scandinavian era, but it may be that their co-option within sub-shire administration was a late move. The absence of focus on riverine locales is matched by the lack of a substantive relationship with what is known of the Roman road network (Margary I973). Yet many, such as Tingley (West Riding) and Stony Cross, Wombleton (North Riding) were located at crossroads (Skinner 20I4). The impression given is of integration not within national or regional, but rather local communication networks. There is one very frequent characteristic shared by the location of many assembly sites, regardless of variable form. The vast majority of both documented and place-name attesting assembly sites are found situated at a short remove from significant settlements and estate centres throughout Yorkshire. This phenomenon can broadly be divided into two categories: those closely positioned on estate borders and those occupying a more ambiguous location, albeit still within the ambit of the broad settlement pattern. 


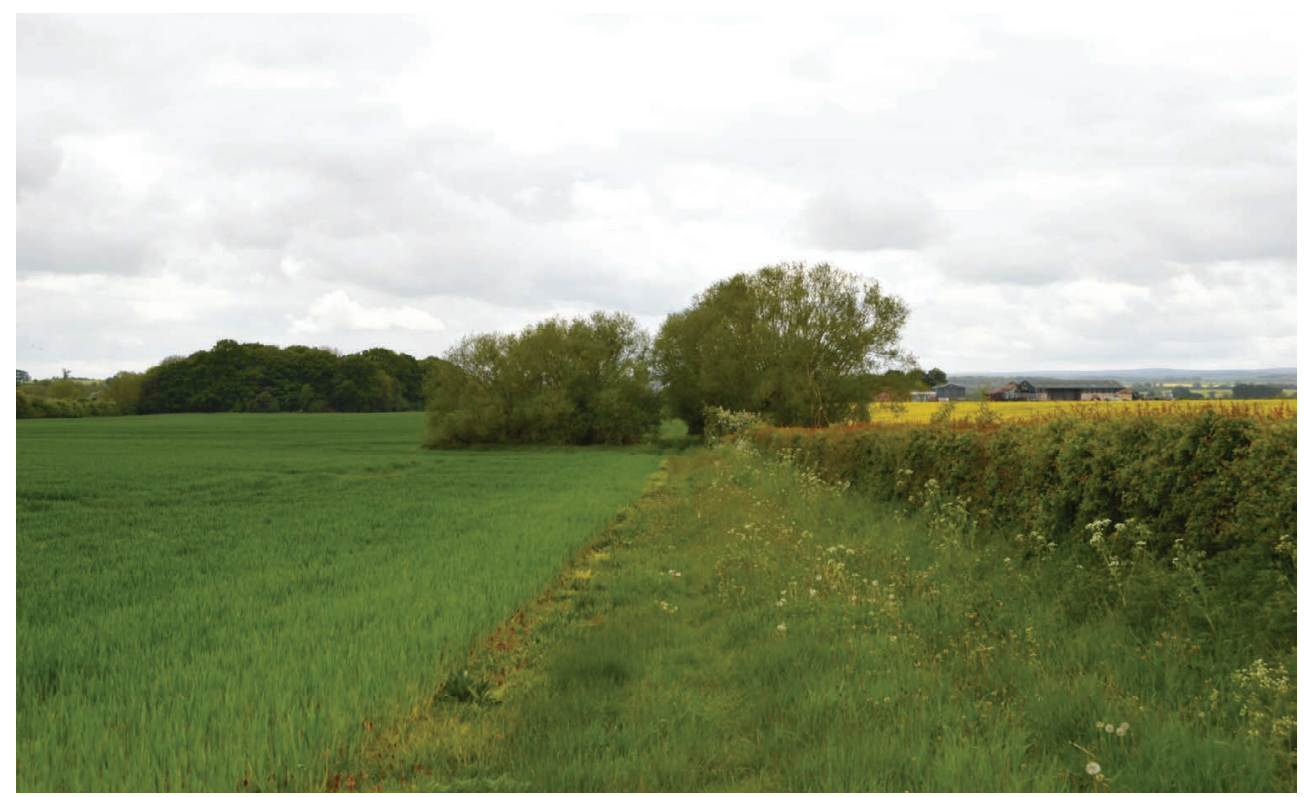

Figure 6.26 Halikeld, one of several springs with this name south of Melmerby, North Yorkshire, associated with the eponymous wapentake. Photograph by Tudor Skinner.

Barkston Ash, in the West Riding of Yorkshire, comprises a wapentake focus of little apparent note until one considers its position on the northern border of the pre-Conquest archiepiscopal estate of Sherburn-in-Elmet (Farrer I9I4, 2I-22). This interface is underlined by a detached portion of the adjacent parish of Saxton on the site of the said ash tree. Strafford Sands, another West Riding wapentake focus, occupies a very similar position at a fording point on the northern border of Conisbrough soke. Furthermore, the North Riding wapentake sites of Bolesford and Birdforth are each positioned on the border of large Domesday sokes, between Easingwold and Bulmer, and Coxwold and Topcliffe, respectively. The soke of Driffield, East Yorkshire, is largely co-extensive with the eponymous Domesday hundred (though see Hadley 2000, I05). The road known as 'Spellowgate' leads north-west of the town into the Yorkshire Wolds, almost directly to the artificial mound of Spellow Clump, overlooking the town on the wold ridge at the edge of the manorial estate. In a similar manner, the surviving mound at Spell Howe is situated on the wold ridge in Turbar bundred near the western extent of the manor of Hunmanby (Figure 6.27). As with Driffield, the manorial caput was linked to the mound by 'the road from Spelhou' recorded in the I3th century (Farrer I9I 5, 477). Meanwhile the old site of Huntow looms on the wold ridge north of the manorial centre of Bridlington within Huntow bundred. These latter two examples do not explicitly reference the estate border, but reflect instead the landscape aspect noted at Spellow Clump. The possibility that ridgeline assembly occurred more widely, at least in the East Riding, is underlined by the presence of likely early medieval mortuary deposits on the wold ridgelines above 
Acklam and Hessle respectively (Meaney I964, 29I; Mortimer I905, 83-84; Whellan I $859,209 n)$.

Beyond these more conspicuous examples, the vast majority of both documented and place-name attested assembly sites are situated within a few kilometres of significant settlements and estate centres, such as Tingley with respect to Morley (also the name of the West Riding wapentake) and Ainsty Cliff (another Domesday wapentake name of the West Riding) in relation to the city of York itself. Indeed, the only seemingly intra-mural wapentake focus, Osgoldcross, was in fact situated within an extra-mural market area of the medieval castle of Pontefact (Creighton 2002, I20; Muir I997, 228). Assembly placement, thus represents a near ubiquitous pattern, allowing for the physical and cultural topography of respective locales. Much the same situation applies to an occasional assembly site serving the city of York, at Toft Green. This site, now close to York railway station, appears in an inquisition of the early I 4 th century in relation to a dispute between an adjacent Dominican Friary and the citizens of York. The latter argued that land at Toft Green should not be encroached upon, as it was known to host 'an assembly of the people to show arms... a common market [and]... the place of duel' (Palmer I88I, 400). Notwithstanding that this at best constitutes very late intimations of assembly activity for the period under study, it remains that Toft Green, as with Osgoldcross at Pontefract, was also a formerly extra-mural venue that even in the early I 4 th century had yet to be fully

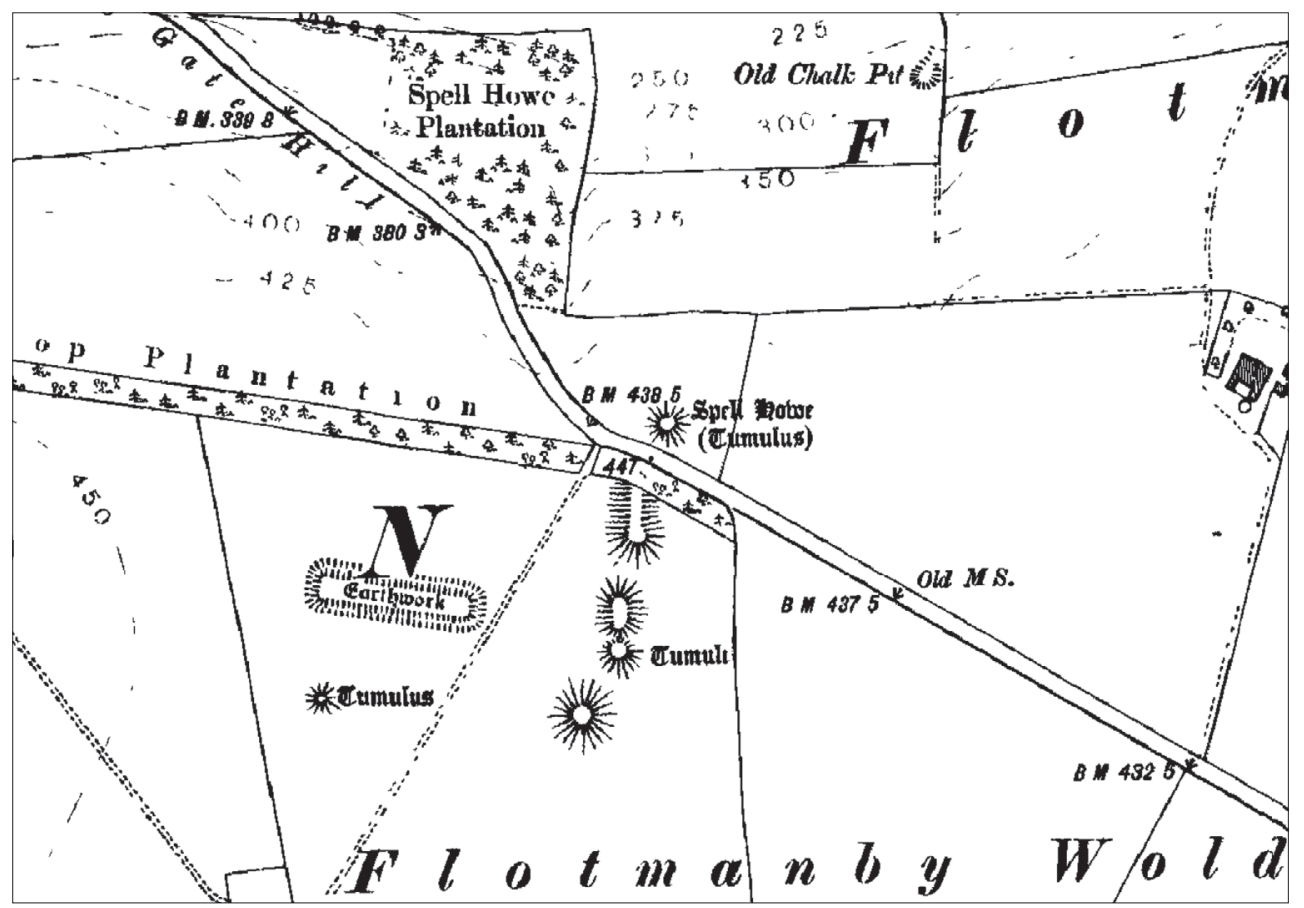

FiguRE 6.27 Spell Howe depicted on the Second Edition 6-inch Ordnance Survey (Yorkshire CX.NW, revised I909). 
incorporated within the urban fabric of York. Beyond sparse documented regal events (i.e. synods, baptisms, coups) in early medieval urban contexts, assembly practices in this part of the Danelaw appear to abide by a very strong ancillary pattern, whether by distance from a settlement/estate centre or by extra-mural separation from an urban jurisdiction.

These liminal situations may well have possessed both pragmatic and symbolic aspects. They would seem to offer space, accessibility and the potential for unmediated counsel and witness - almost theatrically so in the case of the East Riding ridgeline assemblies at Spellow Clump and Huntow. Their legitimacy may also have been underwritten by the liminal character of the venue (Pantos 2002; Semple I998; 2OI3). This is partially complemented by earlier legal proceedings. Maitland notes an estate border assembly of 849 in the Worcester area, designated to counterbalance the local lord's own interests (I 897, 275; SI 272). Further, the I 2th-century Leges Henrici Primi cites estate boundary assemblies known as divisae, designated to tackle pleas between equal, landed, private jurisdictions (Liebermann I898-I9I6, I, 565). It is very unlikely that each wapentake or hundred assembly represented a clash of local estates. While this is ostensibly plausible for Bolesford and Birdforth, noted above, it is very unlikely for Barkston Ash, where the Sherburn-in-Elmet estate enjoyed effective hegemony over the wider wapentake. Instead, each local estate interacted with wider royal jurisdiction through the system of hundreds and wapentakes.

This likely explains only some of the broader repertoire of assembly sites in the study area, but the evidence complements strong indications of estate influence on the system and layout of the wapentakes. The border assemblies at Bolesford and Birdforth are matched by twin estates that are largely co-extensive with their respective wapentakes, while the Domesday wapentake of Dic (later Pickering Lythe) is dissected by the two sokes of Pickering and Falsgrave. While it is true that no wapentake or bundred directly shadows a single estate (Hadley 2000, I05), it is highly likely that the framework of wapentakes witnessed in Domesday Book was predicated on a lattice of earlier estates.

Amid a varied category of names referring to monumental foci, mounds stand out. Pantos $(2002$, 68) demonstrated that mounds comprised the second most common hundred or wapentake name in England after manorial appellations, at around I I \%. This proportion rises to $43 \%$ when consideration turns to the corpus of assembly-attesting names. Both figures tally with the evidence from Yorkshire. Only three artificial mounds are extant however: the later medieval Riding court at Craike Hill, the assembly-attesting Spell Howe and the similarly-attesting Spellow Clump, all in the East Riding of Yorkshire. Craike Hill is one of the few excavated assembly sites in Yorkshire, surviving as a remodelled hill-spur in a dry valley of the Yorkshire Wolds. During excavations in the late I9th century, John Mortimer found a flexed inhumation inserted into the southern side of the crest of the hill-spur (I905, 235). The presence of worked iron with the burial has encouraged Sam Lucy (I998, I30) and latterly Jo Buckberry $(2004,433-434)$ to identify this as a secondary Anglo-Saxon inhumation. Craike Hill is also part of a larger monumental complex of Bronze Age and Iron-Age barrows to the west of Driffield (Stoertz I997, 32). The now-destroyed mound at Tingley was the focus of more recent investigation in 2010 , subject to a metal-detector survey prior to development. This site had earlier been described by 
Ralph Thoresby as among the 'monuments of the Danish times' (I7I 5, I95). The survey identified a cluster of 8 th-9th century pins in the immediate area of the lost mound (PAS, $7 \mathrm{D}_{4} \mathrm{BF}_{2} ; 7 \mathrm{D}_{3} \mathrm{I}_{62} ; 7 \mathrm{D}_{91} \mathrm{I}_{4}$; these and hereafter represent the unique reference numbers issued by the Portable Antiquities Scheme) alongside a 5 th/6thcentury brooch fragment (PAS, $\left.7 \mathrm{CF}_{1} \mathrm{~A}_{2}\right)$. Assembly mounds are too frequent to be dismissed merely as expedient landscape markers. Instead, the strong mortuary associations linked to barrows in general, and to assembly mounds in particular, has led several to argue that the ancestral and/or supernal qualities linked to these sites were being appropriated, in order to legitimate contemporaneous power relations (FitzPatrick 2004b; Semple 2013, 234-225). The evidence from the mounds at Craike Hill and Tingley represents phases of activity in the early medieval period divided by long periods of time. In a landscape of ancient earthworks, these places it seems were well remembered.

In the Danelaw there appears to be no clear relationship between assembly sites and churches. Where the two are, rarely, in close proximity, as in St Giles, Pontefract, and the Osgoldcross assembly site, the church is demonstrably later in date. Standing crosses, however, comprise the second most frequent monument focus in both documented and place-name attested assemblies after mounds in the Ridings of Yorkshire. This is exemplified by the wapentake of Osgoldcross and the assemblyattesting Spelcros. Unlike mounds, this proportion does not reflect a national trend. The Old Norse element kross is largely restricted to the Danelaw-in hundredal contexts around half of the instances of this element are located in Yorkshire alone (Anderson I939b, I9I; Pantos 2002, 67). No crosses survive, although an early I9thcentury account does describe the Osgoldcross, then in Pontefract market-place (Fox I 827, 355). Indeed, only one relict fragment exists in the wider Danelaw, that of the Elloe Stone in Lincolnshire (Everson and Stocker I999, I62-I64). In Yorkshire, however, another surviving orthostat did function as a wapentake focus. This is the Rudston monolith, situated in the churchyard of the eponymous East Riding village and dating to the late Neolithic or early Bronze Age (Barclay and Bayliss I999; Dymond I966; Manby I988) (Figure 6.28). A court of Dickering wapentake (as opposed to the preceding East Riding hundreds) was first recorded at Rudston in I 297 (Brown I902, 67) with a later proceedings in I449 specifying the venue as 'le Stane' (Maxwell-Lyte I909, 306). Interestingly, despite numerous watching briefs and evaluations in the village, no early medieval material has been identified in the surrounds of the monolith or within the footprint of the present village (e.g. Bradley 200I; Rawson 2005; 2007), whereas evidence of an early medieval cremation cemetery does exist, juxtaposed with a Romano-British settlement directly south of present-day Rudston (e.g. PAS, YORYM-CDD8A4, YORYM-Ci6ı64, YORYM-I48Co7). This cemetery is in turn co-extensive with more ephemeral Ioth-century activity, including a silver plate fragment and a coin of Æthelred II of England, suggestive of a bullion deposit (PAS, YORYM-6B $78 \mathrm{D}_{4}$, YORYM-4BA 333 ). It appears to attest to at least one period of early medieval activity on the site of a cemetery that had lapsed many centuries before. This juxtaposition of early Anglo-Saxon cremation material and Anglo-Scandinavian bullion is witnessed again immediately south of North Cave, a likely bundred assembly (PAS, SWYOR-500E27, SWYOR-485B34; SWYOR4A8Ar6, SWYOR-Eı6C 5 5). The parallels with Tingley and Craike Hill are striking. 


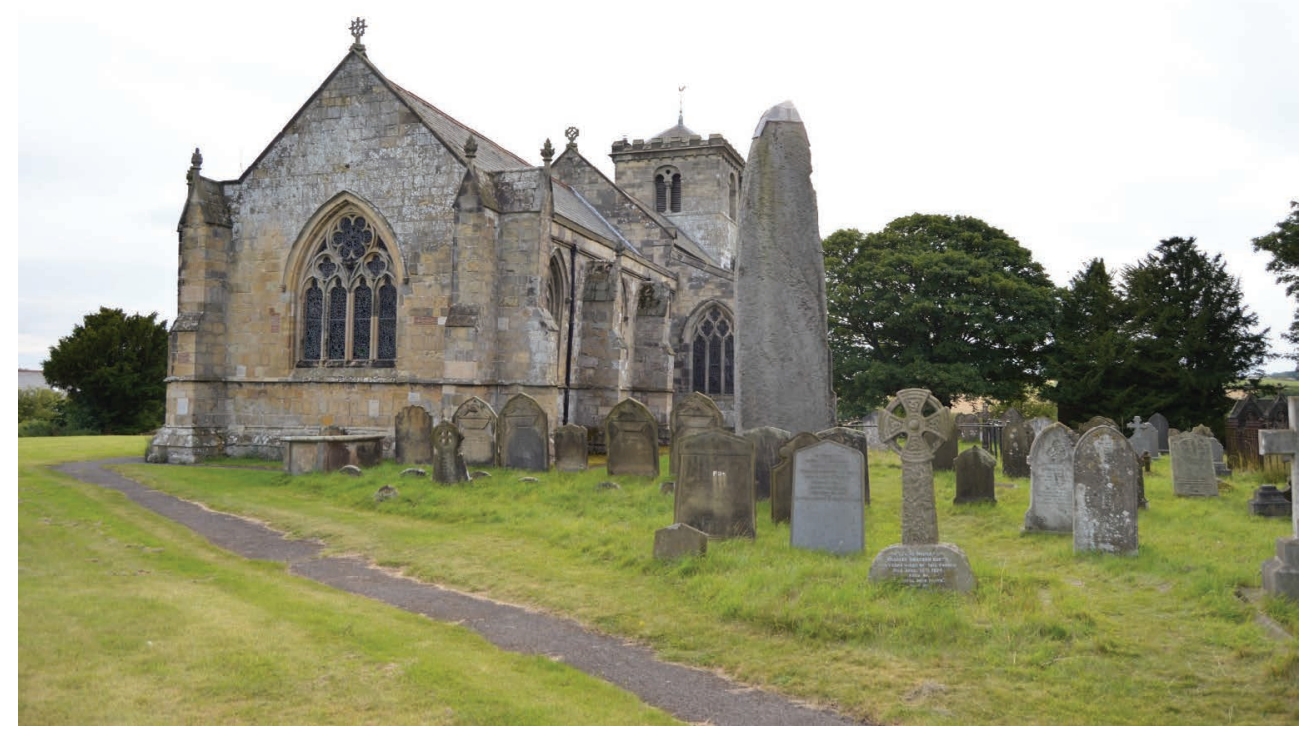

FIGURE 6.28 The Rudston Monolith, within the churchyard of All Saints, Rudston, East Riding of Yorkshire. Photograph by Sarah Semple.

Several documented hundred and wapentake names in Yorkshire refer to trees, including Skyrack (OE 'shire/shining oak'; Smith I96Ic, 88) and Gerlestre (ON/OE 'Earl's/Jarl's tree'; Smith I928, 79). No examples survive today, although the Skyrack Oak in Headingley is thought to have survived into the I 9 th century. Both Anderson (I934, I 58-I 59) and later Hooke (2010, I72) have stressed the role of trees as archaic boundary markers. More recently, Sarah Semple has highlighted the presence of trees as spiritually significant in Anglo-Saxon England, as seen in various late ordinances that attempted to forbid sanctuary and other activities in relation to trees, wells and stones (Semple 20I3, 66-69). This line of argument has been developed significantly in the work of Michael Bintley (2OI 5). The preponderance of assembly crosses in the Danelaw could reflect processes of claiming as well as sanctification.

This is by no means a comprehensive assessment of landscape foci. Other names refer to valleys, ravines, hill-clefts and dykes. One frequently encounters multiple foci, noting the enclosures proximate to the sites of Spellow Hill, Spellow Clump and Spell Howe, or the cross at Spelcros, situated at a six-way road junction directly north of Wombleton. The primary observation is not that assembly venues favoured certain sites, but that they are chiefly characterised by variety. When one also considers how few are linked into the Roman road network (Margary I973), as opposed to ubiquitous integration with more local communications, it becomes clear that these sites were established and maintained within a context of local concerns. That is not, however, to suggest that the evidence necessarily favours the old model of folk institutions (e.g. Kemble I849; Stubbs I874). It is just as plausible that 
local institutions were embraced into the mechanisms of higher order governance, a hypothesis favoured by their high-profile presence within Domesday Book, and in the telling phrase from the I2th-century Dialogus de Scaccario, discussed in Chapter 2, ruricole melius hoc norunt (Lat.) 'the country people know this better' (FitzNeal et al. 1902, 108). This favours a model of locally organised governance co-opted within regional and jurisdictional power structures, one that complements Jolliffe's proposal of the Ioth-century hundred as one of sparse definition, unlikely to clash with local legal practice and well suited for imposition in regions beyond Wessex (Jolliffe I937, I2I).

\subsection{DISCUSSION}

The broad geographic approach of The Assembly Project has made it possible to compare the assembly systems known in Scandinavia, to those identified in Iceland, Faroe Islands, Northern Isles, and in the the northern Danelaw in Yorkshire. The region is vast, but all places were settled by the Norse and hence share a common political history and elements of cultural history. Several striking similarities, but also noticeable differences, can be observed. Politically, the situation in Iceland is at least on the surface rather different from that of the other skattlands as Iceland was a more independent state until the I260s, while the Faroe Islands and the Northern Isles of Scotland were gradually drawn into the Norwegian kingdom from the time of settlement (Byock I990, 58; Dennis et al. I980, I). It is, however, important to remember that until the mid-I2th century Norwegian kings did not involve themselves very much in the Atlantic islands (Thomson 2008, II3-II4). In Iceland, the althing made law and answered for Iceland in exchanges with other countries, and therefore its foundation was in effect the creation of the Icelandic state (Dennis et al. I980, 2; Grønlie 2006, Ch. 3). The evidence from the Danelaw presents numerous contrasts, not least due to the strong influence of pre-existing Anglian administrative arrangements. That said, much of the contemporary documentary record derives from more southerly Anglo-Saxon sources. Despite this there are some similarities in the assembly organisation across the North Atlantic area.

\section{Assembly site features}

Some strong traits can be observed across the areas examined. In terms of location local assembly sites tend to follow a general pattern, dependent on surrounding topography. In Orkney and Shetland local thing sites are often close to the sea, on isthmuses or at the bases of fjords. The one site that breaks this pattern is Tingwall in Shetland, the top-level assembly in an inland location. It seems that in this case a situation central to the whole island group, rather than access via boat, was considered more important. It is interesting to note that this resembles the situation in Iceland where the top-level assembly is situated inland, but the opposite was the case in the Faroes, where all the local assembly sites were located inland and only the althing at Tinganes was on the coast.

In the Faroes, candidates for the early thing sites exist for five out of the six thing districts. All these sites were located away from known settlements, and all apart from 
Tórshavn were inland. In Suðuroy and Norðoyar the older thing sites are located far up in the mountains, with Eysturoy high on a cliff, but still close to the coast, while at Sandoy the site is found in a lowland area (Thorsteinsson 20I2, 64). The prime motivator regarding location seems to have been that the thing sites should be central for the district as a whole. This drive seems to have been stronger than in other areas of the North Atlantic, where assembly sites were frequently located in places that were easy to reach by sea. In order to reach the Faroese assembly sites, people would have had to travel by horse and on foot. This is supported by the fact that they were all situated close to important routes between the villages (Thorsteinsson 20I 2, 64). In Iceland, no clear pattern can be observed. Some local assembly sites are very near the sea (e.g. Pórsnesping, Pingeyrar), while others are located inland (e.g. Árnesping, Skaftafellsping). Correlations between these sites with both areas of settlement and routeways can, however, be observed (Sanmark 2017a, I66-168).

Two patterns are apparent in the location of the wapentake, hundred and placename attested assemblies of the Danelaw. Numerous sites are found at crossroads, river crossings and other communication nodes, yet the correlation with what is known of the Roman road network and the more direct routeways between identified early medieval settlements and estate centres is surprisingly weak. Instead, they appear to be integrated within the local communication networks. The second important observation is that almost all assembly sites are located at a short distance, generally between $500 \mathrm{~m}$ and $3 \mathrm{~km}$, from settlements and manors that were in existence by at least the later IIth century. When assembly-attesting road names such as the Spellowgate in Driffield link these settlements with these sites, the impression given is of a recurring link, of the assembly site as a common ancillary node to these centres.

Finally, it is interesting to note that water is a strong feature in most of the areas studied here, as in the homelands, suggesting that water was a prerequisite for the assembly (Riisøy 20I3; Sanmark 20I3; Sanmark 2017a 202-I9, 89-103). This pattern does not appear to be evident in the Danelaw, with a higher proportion of assemblies with springs and wells in fact noted in the English evidence, perhaps indicative of the extent to which existing conciliar arrangements were co-opted in the Danelaw law provinces.

Several striking similarities but also clear differences can be observed across the settlement areas. It is, for instance, noticeable that in the Faroes and Iceland, thing sites rarely seem to be focused around particular features or monuments. A major difference is of course the lack of earlier monuments in Iceland and the Faroes as there simply were no monuments to reuse and adopt. In both Faroes and Iceland, although Viking-Age burials exist, the thing sites do not seem to use these as site markers either. In Scotland the Norse were keen on using existing mounds as assemblies, often Iron-Age broch mounds or settlements, as illustrated here via the examples of Orkney and Shetland. At the time of the Viking settlement, these broch remains would most likely have been turf-covered mounds (O'Grady 2008, I99), and would in this sense have been very similar to assembly mounds known from the Scandinavian homelands. Mounds signified royal power and land ownership and were for this reason particularly suitable for assemblies for the Norse settlers in Scotland, in a way that perhaps would not have been needed in the unpopulated islands of the Faroes and Iceland (Sanmark 20I7a, 83-86). In Scandinavia, there are 
many examples of thing sites established on sites with a very long biography, such as Kjula ås in Södermanland and Anundshög in Västmanland, both of which were used for burial from the Iron Age. Other examples are Bommestad and Tjølling in Norway, where the cooking-pit fields may illustrate the longevity of these gathering places and locales (see Chapter 5; Ødegaard 201 5; 2017, 3, 83, 97; Sanmark and Semple 2008; 20IO; Semple and Sanmark 20I3). The evidence from the Danelaw assembly sites likewise demonstrates a predilection towards monumental mounds, supporting Aliki Pantos' earlier observation on the topography of hundredal sites in central and southern England (2002). This reinforces the sense that these were deemed suitable by Norse settlers, yet at the same time brings into question the extent to which the mound can be treated as a diagnostic attribute of Scandinavian conciliar influence, especially when one considers similar patterns in Ireland and Scotland (Driscoll I998; FitzPatrick 2004b; Skinner and Semple 2016).

As illustrated by Chapters 4 and 5, roughly from the I4th century onwards, many thing sites in Scandinavia were moved to churches, away from mounds and other prehistoric features. The thing sites with mounds in the Northern Isles can therefore be seen to represent the oldest thing sites. In comparison with the rest of Norse Scotland and also Scandinavia it can be argued that these sites must have been created and used between the 9th and I Ith centuries, in line with the keen interest in monument reuse by the Norse during this time.

A connection between local sites and churches is also seen in Shetland (and also Greenland; Sanmark 2010), and to some extent in Iceland, but this link is not found in Orkney and the Faroes. This is interesting as it breaks the pattern seen in the other areas (see Chapters 4 and 5). In England the situation is different again as the church was firmly established here before the arrival of the Norse. In the Danelaw there seems to be no significant connection between church and assembly sites. It is difficult, however, to compare this with Scandinavian patterns, given the early nature of the evidence from the Danelaw (c. Ioth and I Ith centuries). What is unusual is the proportion of assembly sites associated by place-name or by physical remains with standing crosses. This is particularly pronounced in comparison to southern England and appears to represent a quality quite specific to assemblies of the Danelaw region. What remains to be analysed is the character of the connection between churches and assemblies of the lower levels in the newly colonised areas.

As in Scandinavia (see Chapter 4 ) a rather strong connection between top-level assembly sites and bishops can be seen in the Northern Isles and the Faroes. The first episcopal seat of the Faroes was located in Kirkjubøur at the southern tip of the island of Streymoy, only a few kilometres away from Tinganes at Tórshavn, but if the coastal path was taken, the distance was some $12 \mathrm{~km}$. This was the episcopal residence until the modern period when a new cathedral was built in Tórshavn, a few hundred metres north of Tinganes (Guttesen I992, 25). In Orkney, the lawthing was held in Kirkwall, not far from St Magnus Cathedral and in Shetland Tingwall was the seat of the Archdeacon, the most important church in the island group. The situation in Iceland was similar. Pingvellir is located near the episcopal see at Skálholt, roughly $30 \mathrm{~km}$ as the crow flies, and the two bishops of Iceland were members of the Law Council at Pingvellir since the Commonwealth Period (Porsteinsson I987, 32). An impressive witness to this is the late I Ith-century bronze crozier found at Pingvellir 
in I957, interpreted as a bishop's crozier (Porsteinsson I987, 53). The oldest church building here goes back to around the year ıooo, and after the establishment of the episcopal see at Skálholt in I056, the church at Pingvellir was also used for meetings of the Skálholt clergy (Porsteinsson I987, 54).

\section{New insights}

Some interesting patterns emerge for the Faroese thing sites. The thing districts can be traced back to c. I350-I400, and they may well go further back in time. This becomes even more likely, considering that they comprised whole islands, given the most likely changes will have been the amalgamation of the smaller islands into existing districts. It is not known when the thing districts were first created, but compared to the other areas of Norse settlement a date in the early settlement period can be suggested. In all districts, a shift seems to have taken place prior to the I 7 th century and in all cases but one, meetings seem to have been moved not necessarily to the closest settlement, but rather to the most significant village in the district (see Figure 6.9). The developments in the Faroes are therefore similar to Sweden, where thing meetings were moved away from the old sites to the nearest settlement of importance (see Chapter 4; Sanmark 2009). It is not known when the old sites were abandoned and new ones were created in the villages, as no earlier records exist. Comparisons with other areas suggest it is unlikely to have taken place on a regular basis before the early I 6 th century. By the time of the I 7 th century, records state that meetings were held indoors and it is possible that the move inside buildings took place at the same time as the move to the villages.

The pattern presented for the Faroes seems very neat, with two thing sites from different time-periods in each district. This impression is also given by the location of assembly sites on administrative boundaries. It is, however, important to point out that the pattern presented here is a simplified one, as there are other place-names, such as Tinghellan and Dómheyggjar (containing ON dóm verdict), which are not documented as thing sites (Thorsteinsson 20I2, 56). These names may indicate old assembly sites, sites for one-off meetings, or they could simply be later constructions. Research from other areas has demonstrated that there is great variation in assembly sites and the situation was most likely the same in the Faroes. We should not, therefore, expect to be able to fit all sites into the identified thing districts, but realise that it is possible that smaller islands had their own assembly sites at various points in time.

In Iceland, the evidence also suggests a changing pattern in terms of local sites. Both the written sources and the archaeological remains indicate that the administrative system was reformed in line with the demands of the time. In the early period, there seems to have been a multitude of administrative districts, the roles of which are not entirely clear. The most intriguing is perhaps the traces of a herað organisation, at times seemingly interchangeable with the hreppr. If the herað organisation had followed the pattern observed in Scandinavia, then these units should have formed the local thing districts. This does not, however, seem to have been the case, and instead the name of the local units has not been preserved.

In Orkney and Shetland, traces of a herað organisation are found in place-names in both island groups, such as the Herra place-names in Shetland (De Herra in Yell, 
Fetlar and Lunnasting; the Harray in Tingwall), and Harray in Orkney (Crawford I987, 84; 20I3, I 5 I-I 52; Marwick I952, I30-I3 I; Stewart I987, I30). This must be an older system than the parish organisation introduced in the $\mathrm{I} 2$ th and $\mathrm{I} 3$ th centuries in Orkney (Gibbon 2007). The Shetland 'thing parishes' were most likely formed during a phase of reorganisation, carried out by Magnus the Law-Mender and Haakon Magnusson in the late $\mathrm{I} 3$ th or the early I4th centuries (Smith 2009, $42-44 ; 201 \mathrm{I})$. This makes sense in view of the evidence from the Faroes, where a revised system is also suggested. In Shetland and Orkney thing sites are all rather centrally located within the respective districts, which suggests they were chosen to fit in with this system. The reorganisation in Shetland is further supported by the link between local thing sites and churches/chapels, as research from Scandinavia suggests that over the course of the Middle Ages, local thing sites were increasingly moved to the vicinity of parish churches (Sanmark 2009). At this point in time, the existing sites that were in suitable locations were kept, and those that were not were replaced by newly created sites. It is possible that this was the case in Orkney too, but at present there is no evidence to support this. In view of these reorganisations, it is also worth pointing out that both Iceland and Faroes were reorganised into sýslur. The sýslur are first mentioned in the $\mathrm{I} 260$ s but they did not function as administrative units until after the Reformation (Porsteinsson I972). The sýsla districts may have been introduced also to the Faroes in the I 3 th century and it is therefore possible that changes in the administrative systems were made around the same time by Norwegian kings across the North Atlantic.

The assembly sites identified in the Danelaw are almost all first documented in the late-IIth century in Domesday Book. The existence of the bundred and the wapentake in the region can be identified in law-codes from the mid-Ioth century. It is highly unlikely that this marks the commencement of conciliar activity, but rather its formalisation. The limited excavation evidence does suggest that mound/barrow sites like Tingley (West Riding of Yorkshire) and Craike Hill (East Riding of Yorkshire) were the focus of early medieval secondary activity prior to the Ioth century (see Skinner and Semple 20I6). More compelling is the ancillary location of so many of assembly sites, be they mounds, crosses or springs, in relation to estate centres. Some centres, such as Driffield, are documented as early as the beginning of the 8th century (ASC D 705), and this carries with it the implication that late conciliar arrangements were based around an earlier network of estates, a situation that explains much of the contrast between the evidence of the Danelaw and other areas of Norse colonisation (Skinner 20I4). The relatively early cessation of the Danelaw as an autonomous political entity may also account for a number of the differences observed with the other study areas in Scandinavia and beyond. 


\section{CHAPTER 7 \\ ASSEMBLY AND TRADE IN \\ ICELAND AND BEYOND}

\section{I SUMMARY}

In Scandinavia and the islands in the North Atlantic, assemblies were not merely arenas for the exercise of political decision-making and jurisdiction-as we have seen. Meetings also provided a forum for religious practices and social interactions. Mercantile activities featured at some sites such as economic transactions including exchange, trade, negotiations and even craftworking and manufacture. This is similar to the ways in which popular assemblies in Ireland, equivalent to the thing, may have operated (Gleeson 20I5; 20I8). We know a great deal about the markets that took place during the assemblies at Gamla Uppsala, Sweden (Granlund I958; Staf I935, 225), but was this also the practice in other areas of the North Atlantic? In this chapter, Iceland is presented as a case-study. The written sources and archaeological data available for analysis are in general better in Iceland than in relation to the other North Atlantic islands and Scandinavia. The model that emerges from this analysis is, however, contextualised with results from Scandinavia, the Faroe Islands, Shetland and Orkney.

\subsection{REgUlation AND ASSEMBLy IN THE COMMONWEALTH PERIOD}

In the newly colonised areas in the North Atlantic, foreign merchants were vital in terms of bringing many goods which could not be otherwise obtained. Hence, unregulated commerce was hardly practical and also undesirable, especially when actors from different economic systems, that is, traders from emporia or early urbanised settlements of Scandinavia, Britain or the continent, met with clients on the North Atlantic islands. During the Viking and medieval periods Icelandic society did not operate on the basis of coins. Trade was conducted almost exclusively by barter, and people either paid in-kind or established credit. Everyday items such as food, clothing and tools were mostly exchanged for other commodities like fish, butter or cloth. Barter is often defined as a transaction in which notions of equal value are initially absent but are established over the course of the barter process (Feinman and Garraty 20I0, I7I; Humphrey and Hugh-Jones I992, 4-8). Still, despite the existence of a commodity money system, silver-either in the form of coins or as hack silver-was the main currency in Iceland until the I 2 th century, against which the values of other items were calculated (Gelsinger I98 I, 34; Gullbekk 20I I, I 86). Such an agreement of values was part of the Icelandic assembly procedure. In Iceland and probably also the Faroe Islands, regulation included the agreement on values of 
goods, the fixing of prices and the control of weights and scales. The latter is only reported from the later medieval period (e.g. Arge and Mehler 201 2, I 84-1 85 ; Mehler $2015,75-76)$, but we can assume that these were earlier practices. In Iceland, during the Viking Age and the early medieval period, documents describe how trade was controlled and regulated first of all by the chieftains (ON goðar). As the leaders of the thing they were able to bring about agreements on equivalents of goods and controlled payments by setting up the prices for the trade between Icelanders and foreigners. Once a foreign ship arrived, the chieftain who lived nearest to the landing place where the ship anchored went there to put maximum prices on the goods, a process referred to as kaupsetning in Old Norse (von Maurer I874, I96; Porláksson I978, I I3). This kaupsetning was done through $(\mathrm{ON})$ forráðsmen, three elected inspectors per district, who were probably appointed by chieftains on behalf of the thing institution. After the arrival of a ship, they went to the harbour to price the goods. Violations led to hearings either in the home of the prosecutor or at the local assembly site, also termed the local spring assembly site. Grágás reports that:

\footnotetext{
They are to have set standard values within half a month from the time ships reach land, but if men buy before standard values are set or buy at dearer rates, then the case lies with the men who are to have charge of trading. The one who prosecutes is to summon in that suit at his home in the half-month after he has learnt of the deal and prosecute it at a district court [i.e. local assembly site] (Grágás, Ch. 167; Dennis et al. 2000, 92-93; our addition).
}

The kaupsetning probably also created 'market peace' (ON kaupgrið), a common practice during the Viking period and Middle Ages throughout northern Europe to protect both clients and traders. In Scandinavia, a white shield was held up or put onto the ship's mast, to clearly signal their peaceful intentions. Once accepted by all parties, grið was reached, denoting an agreed peaceful relationship. In Iceland this practice was known too. In the Saga of Grettir the Strong (Ch. 72) we read of a grið oath to secure Grettir's unharmed leave from the assembly (Müller-Boysen I990, 88-89). Market peace is probably related to the concept of 'thing peace' (known as ON friðr or griðr) (see Chapter 4; Sanmark 20I 5), known, for example, from Gamla Uppsala, where the Law of Uppland refers to the $(\mathrm{ON})$ disapings friper-the peace that lasted for the duration of the markets and the assemblies (Collin and Schlyter I 834, 274-275, 309; Holmbäck and Wessén I933, 205-206). German written sources telling of market peace (Mod Germ Marktfriede) have survived from the $3_{3}$ th century onwards (DRW 9, col. 260). Here, market peace was often symbolised by a large cross erected at the site of the fair (Ellmers I990, I03-I05, I07). The tradition of erecting market crosses is also documented in Scotland in the early modern period, for example seen in Kirkwall in Orkney, where the market cross ('merkit cross') was placed outside the court house ('tollbooth') (Mair I988, 29-68; Sanmark 20I7a, 249).

Each chieftain had several thingmen, representatives, who were sometimes also local traders (Byock 200I, II 8-I22; Ebel I998, 26I). It is reasonable to assume that such thingmen were amongst those local traders mentioned in written sources who acquired goods from the foreign merchants and then sold them on to Icelanders who were not able to come to the trading sites to do business with the foreigners directly (Ebel I977, 4; Gardiner and Mehler 2007, 399 and tab. I). Chieftains also had 
the power to block ships from trading, cared for the lodging of foreign traders and often invited them to stay on their farms. According to Sturlunga saga, for example, the chieftain Pórðr Sturluson had a merchant staying with him in I 226 (Jakobsson 2007, I 45). They also protected foreign traders against assaults, as exemplified in Ljósvetninga saga where a Norwegian trader had been given rotten goods in exchange for his imported wares. Chieftain Guðmundr, who had lodged the merchant over winter, compensated for his loss but then brought the case and the deceitful farmer, a thingman of chieftain Pórir, before the althing at Pingvellir (Ebel I985, II4). Grágás regulates that in the case of the death of a merchant, chieftains administered the inheritance until an heir was found (Ebel I998, 262). Above all, the control of foreign trade was a major source of the chieftain's wealth (von Maurer I874, 39, 200, 433; Miller I986, 38; Porláksson I978, I I2). Sverrir Jakobsson has suggested on the basis of written accounts handed down in sagas that Icelandic chieftains could also demonstrate their status to some degree by turning up at assemblies in the company of Norwegian merchants with shields. These merchants, whom the chieftains often hosted at home, were usually in the possession of weapons and when accompanying a chieftain to an assembly, one can see how these overseas guests could easily become symbols of status and power for the chieftain (Jakobsson 2007, I46).

The prices for goods were set up both by the Law Council at Pingvellir, in accordance with General Assembly regulation' (Grágás II, $\mathbb{2 4 6}$; Dennis et al. 2000), and during the local spring assemblies (Byock 200I, I7I-I74; Bruun I987, I74; Dennis et al. 2000, 396). Grágás contains the oldest surviving price lists of goods and the value of items, the first of which is dated to c. I I 50 (Ch. 246 and Addendum 430; Dennis et al. 2000, 207-2 I0, $357 \mathrm{fn} \mathrm{I4).} \mathrm{One} \mathrm{new} \mathrm{iron} \mathrm{cauldron} \mathrm{of} \mathrm{about} \mathrm{I} 6 \mathrm{~kg}$, for example, was defined as worth $60(\mathrm{ON})$ lögaurar, six sheep skins were worth I (ON) lögeyrir. A lögeyrir was a legitimate instrument of payment. It was not a coin but the weight of an ounce which corresponded to the value of 6 ells of $(\mathrm{ON})$ vaðmál (vadmal is a coarse and dense woollen fabric), but that value varied slightly over time (Ebel I985, i 16; Naumann I987, tab. I and 377).

The Icelandic local spring assemblies consisted of two parts: they started with the $(\mathrm{ON})$ sóknarping, the courts of prosecution, followed by the $(\mathrm{ON})$ skuldaping, where courts of payment took place, creditors and debtors met, and people put values on goods traded within the district. Hence, in theory, the prices of goods could vary between districts (Byock 200I, I7I; Gelsinger I98 I, 39; Hastrup I98 5, 224; von Maurer I 874, I79-I80; Stefánsson I984, 46I-462), but the reality of this remains unknown.

The pricing of goods was obviously taken to protect the Icelandic clients from any fraud by foreign traders. This was especially important given the absence of coinage or currency and the reliance on the accepted value of goods involved in exchange. The system also ensured that foreign traders could conduct their businesses in Iceland without too much difficulty. In Grágás an important entry reveals parity in the way Icelanders and foreigners were treated: 'Laws are the same for our countrymen as for foreigners' (Grágás II, Add. \43I; Dennis et al. 2000, 359). This implies that foreign merchants conducting business in Iceland were subject to Icelandic law. That merchants needed to follow local law seems to have been the case also in Scandinavia, although here the specific 'trading laws' (ON bjarkeyjarréttr) were applied (Hagland 20I4, 57; Wessén I956). The parity principle did not change, even after the death of 
a foreign merchant. A dispute settled at the assembly is reported in Ljósvetninga saga (Ch. I) which tells of a Norwegian trader named Sigurður who had been cheated by Sölmundur, an Icelandic farmer of dubious character. Sölmundur had bought goods which he promised to pay later, but when the merchant came to collect his debts he was told that all goods had been rotten and Sölmundur would not pay his debts. The Norwegian merchant was killed by Soxolf, one of Sölmundur's men. The case was later settled at the assembly. Soxolf was exiled for the rest of his life and Sölmundur was outlawed for three years (Andersson and Miller I989, I23-I25).

While actions on land fell under Icelandic jurisdiction, cases that arose during sea journeys were settled on board the ships. Ships that arrived from Norway, for example, had to use the trading laws (ON bjarkeyjarréttr) from their home towns. According to these laws sailors and merchants were able to set up a ship thing (or mót) while on board, where all decisions were legally binding. Fines that resulted from the verdicts were split: between parties, in this case the skipper and sailors. Icelandic records such as The Book of Settlements or the Saga of the Sword Brothers (Fóstbroeðra saga) report that such a meeting on board of a ship was held at the mast (ON við siglu) and marked by putting up a red shield as a sign. A thing meeting could also be held in the harbour, or even at the end of the landing bridge of the boat $(\mathrm{ON}$ við bryggjusporðr) (Falk I9I2, 5; Müller-Boysen I990, I4I-I43). The Book of the Icelanders reports of a case where Norwegians had chopped off the hand of a man named Skæring at Gásir, an important trading place in northern Iceland (Miller I990, Io). The case was taken up at the very place and although no details are handed down we can imagine that this was an ad hoc meeting in the harbour. Meetings in harbours or on ships correspond to laws handed down in the section on the laws of the sea traders (ON farmannalög) in the bjarkeyjarréttr (Chs 42 and I73), the section that regulates urban life and overseas trade (Müller-Boysen I990, I I7-I 2I; Strauch 20I I, I66-I76).

Trade in Iceland was thus largely controlled by the chieftains and the foreign merchants were in a rather disadvantaged position, having to accept the value system and prices of the Icelanders (Gelsinger I98I, 38). This concentration of power in the hands of the chieftains, empowered by the thing institution, decreased noticeably during the 13 th century, as will be discussed in the next section.

\subsection{REgUlation OF TRADE IN ICELAND IN THE LATER MIDDLE AGES}

During the High Middle Ages the operation of foreign trade in Iceland changed considerably. The power of the Icelandic assembly system, used by the chieftains to regulate trade, was substantially reduced after 1220 , when chieftains started to lose their monopoly to ascertain the prices of goods to the merchants. It has been argued that this change was brought about by the foreign merchants who had been unhappy with the system and gradually were able to expand their power and influence (Durrenberger et al. I986-89; Karlsson 2000, 5I; Porláksson I978, II3; I992, 24I-243; Wieske 20II, 84-85). Especially after Iceland had become part of the Norwegian realm in $\mathbf{2} 262$ it was drawn further into the Northern European markets and trade could no longer operate on Icelandic terms only. In order to keep the realm under control, legislation was necessary that was valid for all parts of 
Norway, including Iceland. In the I260s/I 270 S King Magnus the Law-Mender [r. AD I263-I280] brought about legal reforms which had consequences also for Iceland, where two royal laws were introduced, Jarnsiða (I 27I) and Jónsbók (I28I), the first being based on the provincial laws of the Gulathing and the Frostathing and which abolished the chieftain system. The latter, Jónsbók, was based on the Norwegian bylaws but contained a section named (ON) Farmanna læg which was specially written for Iceland (Frankot 20I 2, IO; Meissner I950, 458-48I). The adoption of these two laws implied the introduction of the Norwegian administrative and legal system in Iceland (see Chapter 6; Sigurðsson 2010, 64).

In Scandinavia, many rural lawthings were relocated into the growing towns during the $\mathrm{I} 3^{\text {th }}$ and $\mathrm{I} 4^{\text {th }}$ centuries and trade with foreign merchants was now to a large extent channelled through the towns, enabling the king to keep trade under better control (see Chapters 4 and 5; Iversen 20I7a). The new laws of King Magnus the Law-Mender of I 274 and I 276 provided identical regulations for the entire kingdom and the towns of Bergen, Oslo, Trondheim and Tønsberg, respectively. The latter law, which probably also applied to all Norwegian towns with (ON) takmark or 'own jurisdiction', was a revision of the older mutually different bjarkeyjarréttr (Strauch 20II, I66-I76).

The increase in legal power can also be regarded as a consequence of the socalled commercial revolution of the Middle Ages (Lopez 1976; de Roover 1942), a term describing the period of increasing trade with bulk commodities and the change from the use of periodically used trading sites to permanent markets which reached Scandinavia during the $\mathrm{I} 3$ th century. The characteristics and dynamics are not yet fully understood, but in Norway, this 'revolution' resulted in the emergence of a distinct merchant class and a trade system that was to a large extent self-determined (Wieske 20II, 44-53, I36). As mentioned above (see Chapter 4), Norwegian towns were directly controlled by the king and his new town law of I 276 (Iversen 20I7a). In Iceland, by contrast, a merchant class in the sense of a group of people making a living only by trade or being organised in guilds, never existed and there were no towns either. Trade was mostly in the hands of chieftains who were already dominant (Gelsinger I98I, 3I-32). When the power of the foreign merchants increased, however, they were able to take over the pricing policy and the prices of goods were now negotiated between the foreigners and the bailiffs of the Danish-Norwegian Crown. Mercantile disputes were settled between the traders and the Danish authorities (Baasch I889, 62) and at the end of the Middle Ages foreign traders were directed at certain ports through a licencing arrangement set up by the Danish king (e.g. Mehler and Gardiner $2013,2-3)$. By the end of the medieval period, the system in which commerce in Iceland was previously embedded had changed from being mostly authoritarian and in the hands of the Icelandic chieftains, to a trade arrangement based on the negotiating skills between the foreign parties of the traders and the Danish administration.

\subsection{TRADE AND MARKETS AT THE ICELANDIC LOCAL SPRING ASSEMBLIES}

During the Commonwealth Period and later, foreign trade in Iceland took place at established coastal trading sites such as Gásir in northern Iceland, which were regularly visited during the summer seasons, roughly between late April and late 
August. Jónsbók regulates that no trading ship was allowed to leave Iceland after the Nativity of Mary, which is 8 September (Falk I9I2, 20). Markets, however, could be set up wherever a ship landed, or form part of the local spring assembly (Gelsinger I98I, 32; Jóhannesson I974, 8I) when the meeting was located near a harbour or landing place, either at the coast or at estuaries (Figure 7.I).

Grágás explicitly states that the participants in the local spring assemblies 'may have with them their clothes, tents, and food; a man may have 40 pounds of trade goods in addition if he wishes.' (Grágás I, Ch. Io; Dennis et al. I980, 43). Indeed, we read in the Sturlunga saga, referring to the Pórsnes thing on Snæfellsnes near Helgafell, that flour was frequently for sale during the assembly: (ON) ef korn gxti at kaupa, tvau mjöl-sáld á Pórsnesspingi, 'if grain was for sale, then two halves of a ship's pound of ground grain at the Pórsnes assembly' (Porgils saga ok Hafliða, Ch. Io; Ebel I985, I I 5). The Icelandic term sáld denotes the weight of half of a ship's pound, and flour is a commodity that during the Viking and medieval periods was almost exclusively imported (Gísladóttir I999, I24; Mehler 20I I, I74, I76). According to The Book of

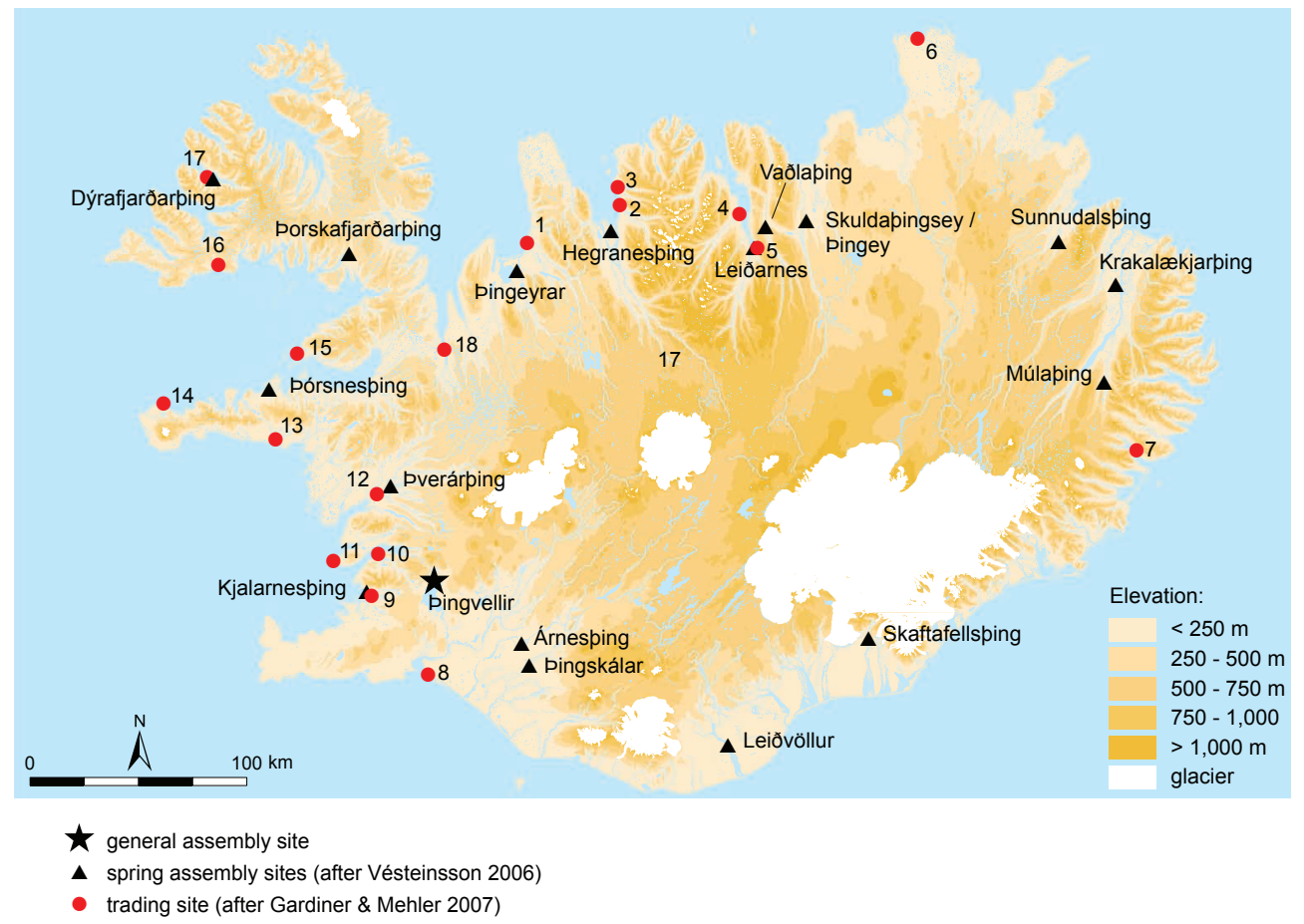

FIGURE 7.I Map of Iceland with local spring assembly sites and trading sites of the Viking Period and Middle Ages. I Blönduós, 2 Kolkuós, 3 Hofsós, 4 Gásir, 5 Kaupangur, 6 Melrakkaslétta, 7 Gautavík, 8 Eyrarbakki, 9 Perneyjarsund, ıo Búðasandur / Máriuhöfn, I I Akranes, I2 Hvítárvellir, I3 Búðarhamar, I4 Rif, I 5 Dagverðarnes, I6 Vaðall, I7 Önundarfjörður, I 8 Hrútafjörður. Map by Joris Coolen, Mark Gardiner and Natascha Mehler, after Vésteinsson 2006a, fig. 2 and Gardiner and Mehler 2007, figs 4, 5, 6 and 9. 
the Settlements, Pórsnesping was established by Thorolf Moster-Beard. According to Eyrbyggia saga, Thorolf was a Norwegian who on his way to settle in Iceland threw the sacred high-seat pillars over board in order to find the best place to settle. In the place where the pillars landed he established a thing site where he also built a 'cult building' (ON hof) (Whitmore 20I3, 68-69). Eyrbyggja saga later reports that the assembly place was relocated and renamed (ON) Pingvellir, to become the quarter assembly for the Western Quarter in the 960s (Whitmore 20I3, 7I). Several booths were recorded at Pingvellir in the late I9th century (Kaalund I877-82; Vigfússon I 880-8I), but all physical evidence of the assembly has now been destroyed by modern building activities.

The local spring assemblies took place in early May (see Chapter 6), which corresponds roughly to the opening of the shipping season and the arrival of foreign ships. The two parts of these assemblies, the $(\mathrm{ON})$ sóknarping and the skuldaping, courts of prosecution and payments are interesting in this context. As pointed out above, chieftains decided on prices for foreign goods and once that was done their inspectors could go to the ships, announce the pricing and start the trading season. A harbour or landing place near an assembly site would have been convenient, not only for the assembly participants, but also to better control trade through the chieftain and his allies. When foreign trading ships arrived, the foreign traders either slept on board or set up their tents near the harbour and the ship (Falk I9 I 2, I I-I 2). The area where goods were exchanged was thus not the assembly site itself, but near to it, and close to, or at the harbour.

Indeed, such arrangements are frequently mentioned in sagas but it is difficult to trace this in the archaeological record. The problem is that the functions of the sites, as arenas for assemblies or places for trade and exchange, need to be securely identified which is difficult. The site of Pingeyri in the West Fjords, for example, is mentioned in the Saga of Gísli the Outlaw, in a description that identifies that trade with Norwegian merchants was conducted some $2 \mathrm{~km}$ nearby at the landing place of Sandaós, where the River Sandaá runs into Dýrafjörður (Whitmore 2013, 44-45) (Figure 7.2). Another example is the site of Vaðlaping which was located close to Kaupangur at the mouth of the River Eyjafjarðará near Akureyri. The site is only identified through a series of place-names and no archaeological remains are known. Vaðlaping was one of the spring assemblies in the Northern Quarter in use during the first centuries of the settlement of Iceland. It is mentioned in Ljósvetninga saga (Ch. 3) and Víga-Glums saga in which Glúm starts a brawl at the assembly (Ch. 24). The site of the Vaðlaping is suggested to be identical with today's place-name Búðalág, 'the hollow of booths' (Figure 7.3). Old place-names include a stream named Pingmannalækur ('Stream of the thingmen') that comes down the hill known by the place-name Pingmannahnjúkur ('Mountain of the thingmen') and Pingmannavegur ('Path of the thingmen') is also near. In I 896 the Danish antiquarian Daniel Bruun recorded and partially excavated structures which he interpreted as booth ruins belonging to the Vaðlaping (Bruun I987, I80-I 8 I; Kaalund I877-82, I25-I 28). A survey by our project revealed, however, that these structures are the remains of a farm instead. The ruins recorded and excavated by Daniel Bruun are typical for an Icelandic farm building and no traces of characteristic assembly structures such as booths were found. 


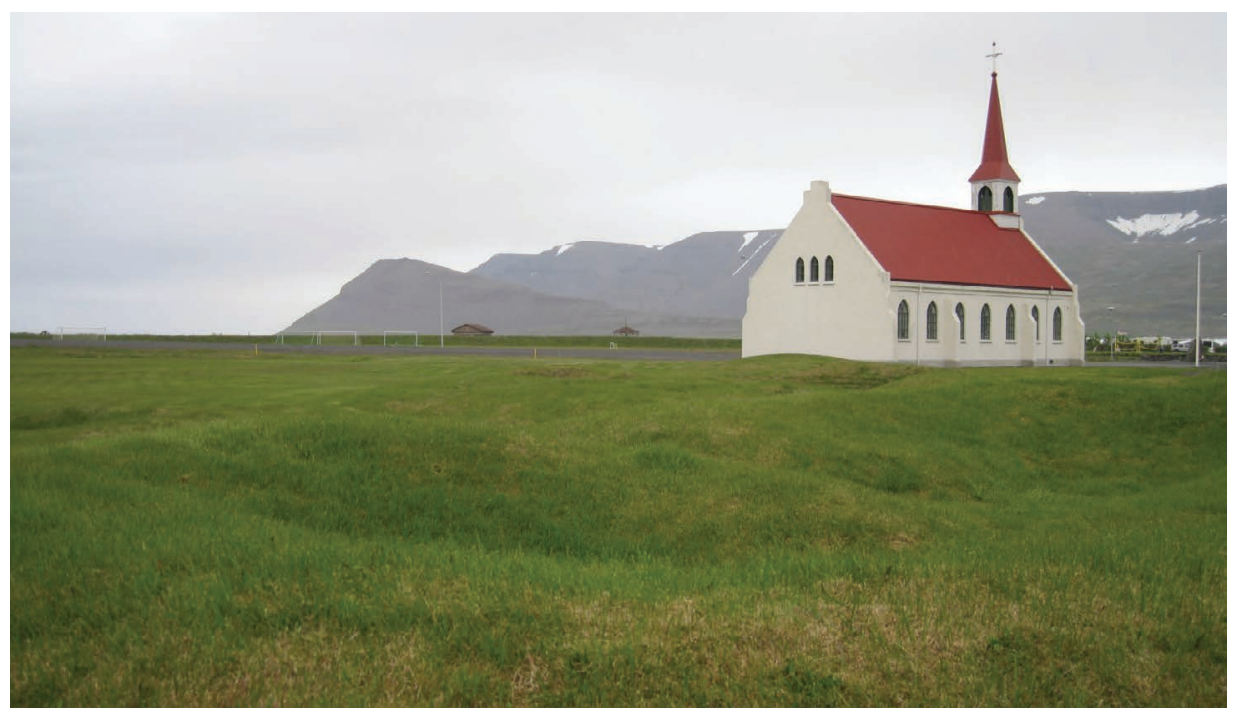

FIGURE 7.2 Booth remains at Pingeyri in the West Fjords, Iceland. Photograph by Natascha Mehler. (C) The Assembly Project.

Some distance from the farm, a c. I $8 \mathrm{~m}$ long row of stones along the mouth of the River Eyjafjarðará is known, which could be the remains of a jetty, but the structure is neither excavated nor dated (Figure 7.4). If it is of medieval or Viking date, this structure could be the remains of Kaupangur. This name derives from $(\mathrm{ON})$ kaupangr meaning 'trading place' which is the place-name of some trading places in Scandinavia (Fritzner I 886-96). In Iceland, there is only this single kaupangr placename and the place is mentioned in a number of written sources, for example in Ljósvetninga saga, when Ísólfur attends a meeting in Kaupangur (Ch. 23). The Old Norse wording samkoma ('coming together') does not specify that this was a political assembly, but the text indicates that some sort of dispute was settled at this meeting which took place at the end of the winter:

(ON) Síðan fór Ísolfur heim og leið veturinn. Og einmánuð öndverðan var samkoma að Hálsi í Fnjóskadal. En nú var hún í Kaupangi undir eins og kom Eyjólfur pví seint pangað og var par lokið öllum samkomumálum er hann kom.

Ísolf went home and the winter passed. Early in the last month of winter there was an assembly at Háls in Fnjoskadal, but at the same time there was an assembly held at Kaupang and for that reason Eyjolf came late and all the business was concluded when he arrived (Vollmer 20I I, 330; own translation).

Kaupangur and Vaðlaping would be one example for the close integration and spatial arrangement of assembly and trade. Another example is Kolkuós in Skagafjörður, a trading site connected to the bishopric of Hólar, which has been 


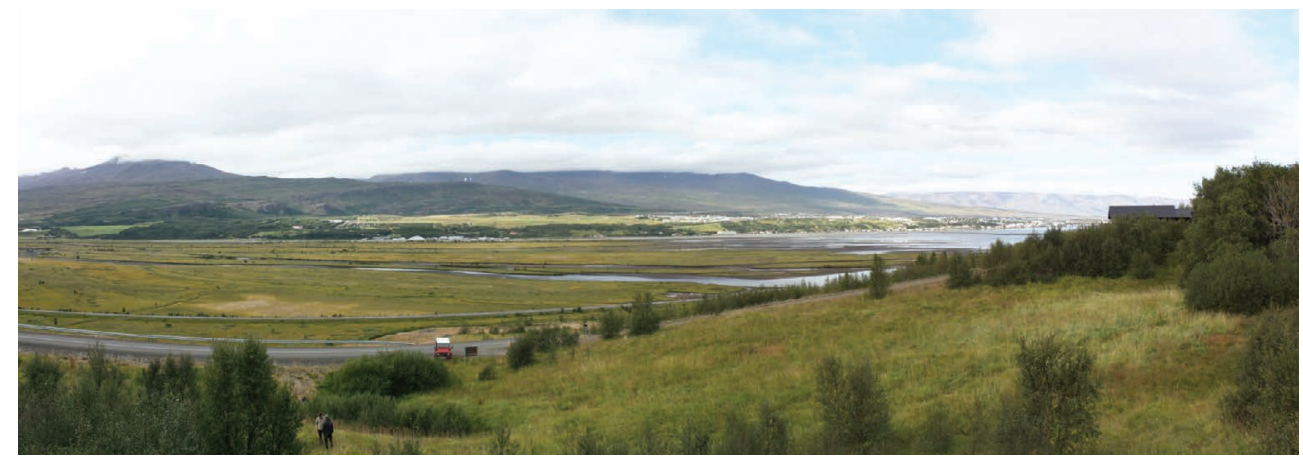

FIGURE 7.3 View of the area where Vaðlaping was once located, at the mouth of the River Eyjafjarðará, Iceland. Photograph by Ronny Weßling. (C) The Assembly Project.

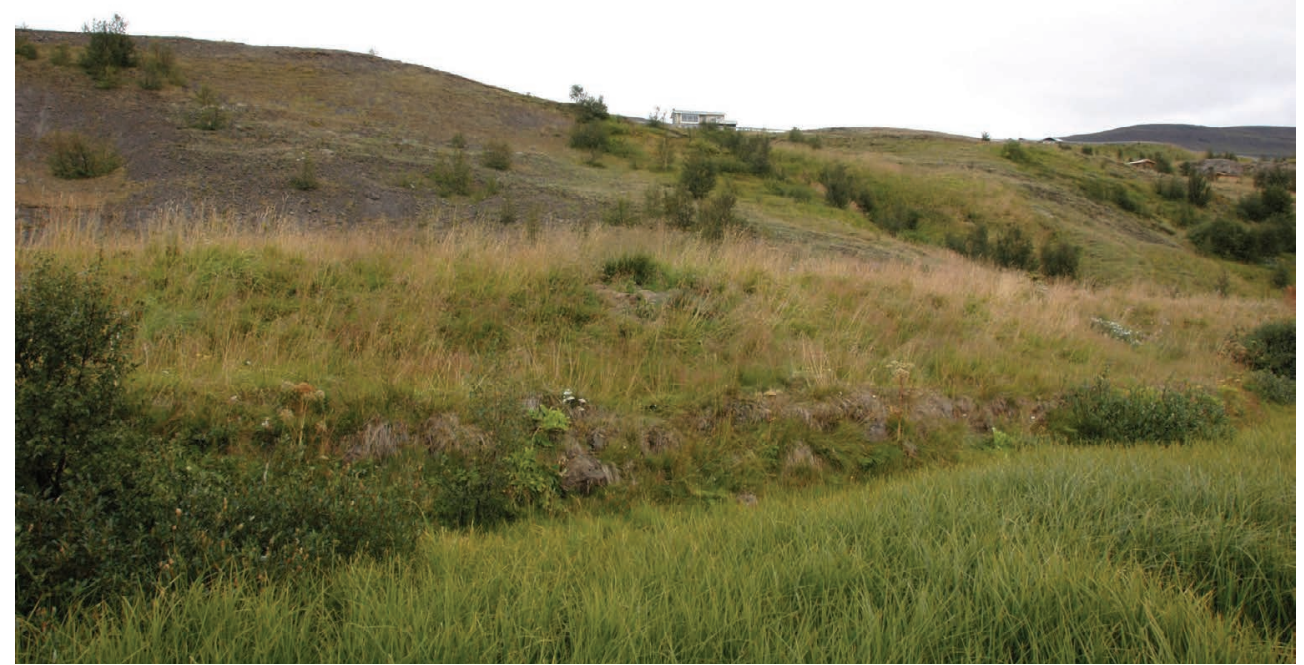

Figure 7.4 The possible remains of a jetty at Eyjafjarðará, Iceland. Photograph by Ronny Weßling. () The Assembly Project.

excavated (although not fully published) in the last few years and which offers additional corroboration (e.g. Carter 20I 5, I 85-I 86; Traustadóttir et al. 20I I). The site dates back to the Ioth century. The local spring assembly site at Hegranes is c. Io km away (Carter 20I5, 268; Whitmore 20I3, 334-335). A scenario whereby the $(\mathrm{ON})$ kaupsetning or pricing of goods, taking place at Kolkuós, might correspond with a local spring assembly at Hegranes is easy to visualise (see Whitmore 20I3, $334-335$ ). Concentrating the conduct of trade and jurisdiction would have benefitted from the joint imposition of peace during both kinds of meeting. 
Combining assembly meetings with foreign trade provided several practicalities. External trade operated through harbours and landing places and attending a meeting nearby would have allowed the participants, many of which had travelled some distance, to also carry out business as part of their trip. Foreign trade would have been easier to control since chieftains and their representatives were nearby. Goods would not have to be transported inland by the merchants but instead the clients could take care of the logistics themselves. This system could only work, however, if ships arrived near the time of the assembly meetings which could be problematic. Written sources frequently report how difficult it was to land a ship intentionally at a specific landing place and instead they were often pulled in ashore at a place suitable for landing and not necessarily near a settlement. Bandamanna saga (Ch. I), for example, describes how Oddur Ófeigsson, a very experienced sailor, never sailed his ship further west than Hrútafjörður or further north than Eyjafjörður, as he was only able to securely land his boat within this c. I20 km area. Another example is found in Kormáks saga (Ch. I 5) where it is reported that Pórarinn the Strong was a lucky seafarer because he always made the harbour he aimed at, a skill that obviously was seen as a great and rare quality. In such a system we can imagine that meetings were called specifically for when a ship arrived, as was the case at Gásir mentioned above, since assemblies were not only held at set dates but also when needed.

\subsection{TRADE AT THE ICELANDIC GENERAL ASSEMBLy OF PINGVELliR}

The general assemblies at Pingvellir were important political and social gatherings (Jóhannesson I974, 35-47; Karlsson 2000, 20-27). The influential historian Björn Porsteinsson asserted in the I950s that Pingvellir was the greatest trading place in Iceland, where merchants and craftsmen brought their goods and foreigners came to carry out their business (Porsteinsson I953, I05), an idea that lives on in scholarly writing to this day. The idea that Pingvellir was a substantial trading place, however, ultimately stems from saga passages and law texts that refer to trade conducted at local assemblies and not at the top-level assembly. This information appears to have been extrapolated to include the assumption that trade was also a prime activity at Pingvellir (e.g. Ebel I977, 7; I985, I I 5; Miller I986, 20). It seems an obvious assumption that food, tools, clothes, and other goods would have been traded during the large meetings at Pingvellir, where people gathered together for an extended period of time, with many of the attendees having travelled long distances. Recent analysis of relevant written and archaeological evidence, carried out as part of The Assembly Project, has queried whether trade was conducted during the general assembly, demonstrating that evidence is actually very weak and ambiguous: the general assembly did not involve foreign merchants and barely exceeded necessary levels of provisioning (Mehler 2015).

Pingvellir is easily accessible by horse and by foot but is some distance from the sea. The nearest sea access is at Hvalfjörður, a fjord approximately $20 \mathrm{~km}$ directly north-west of Pingvellir, which is the location of Maríuhöfn (also known as Búðasandur), a seasonal trading site in Hvalfjörður (the fjord of whales) (Figure 7.5). The site is frequently mentioned in written sources such as the Icelandic Annals between I339 and I4I3, mostly in connection with the bishop's see at Skálholt 


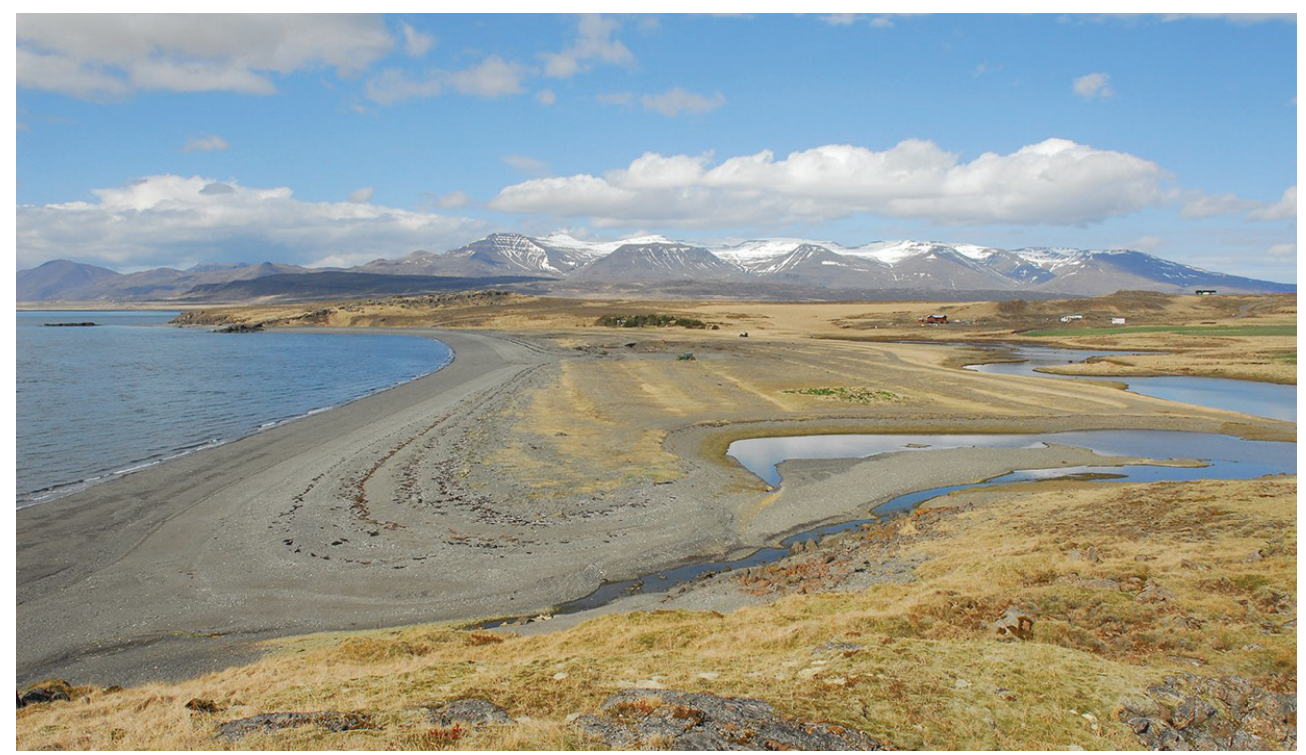

Figure 7.5 View over Maríuhöfn (also known as Búðasandur), a seasonal trading site near Pingvellir, Iceland. Photograph by Natascha Mehler. (C) The Assembly Project.

or the general assembly at Pingvellir. According to the Gottskálks Annals, (ON) Biskupsbússan kom í Hvalfjörður móti Pingi, 'the bishop's ship arrived in Hvalfjörður near the time of the assembly' (Porkelsson 2004, 78). A cluster of booths has survived on the sandy beach and small trenches were excavated in I982 and I985 (Gardiner and Mehler 2007, 4I3-4I 5; Porkelsson 2004, esp. 56) (Figure 7.6). Other important harbours near Pingvellir used during and after the Commonwealth Period include Eyrarbakki (c. $40 \mathrm{~km}$ distance), Leiruvogur (c. $30 \mathrm{~km}$ distance) and even Hvítárvellir (c. $45 \mathrm{~km}$ distance) (Byock et al. 2005; Gardiner and Mehler 2007, figs 5 and 9). Quite a number of participants who came to the meetings at Pingvellir must have arrived by boat via one of these coastal trading sites (Nordal I990, I00) and then continued their journey on foot or horseback. Here, at the harbours, Icelanders would have had the opportunity to do business with foreign merchants and incoming goods could be exchanged for Icelandic goods without further transport to Pingvellir (Mehler 20I 5 ). As argued above, it was at such sites where direct trade between Icelanders and foreign merchants happened, while inland trade was largely in the hands of Icelanders (Ebel I977; Gardiner and Mehler 2007, 399 with tab. I).

\subsection{THE ICELANDIC MODEL IN CONTEXT}

During the 9th to IIth centuries foreign trade was channelled through coastal trading sites across most parts of northern Europe and Scandinavia, before urbanisation set in. The coastal market sites or emporia of northern Europe were characterised by common features: they were located on navigable coasts or on major 


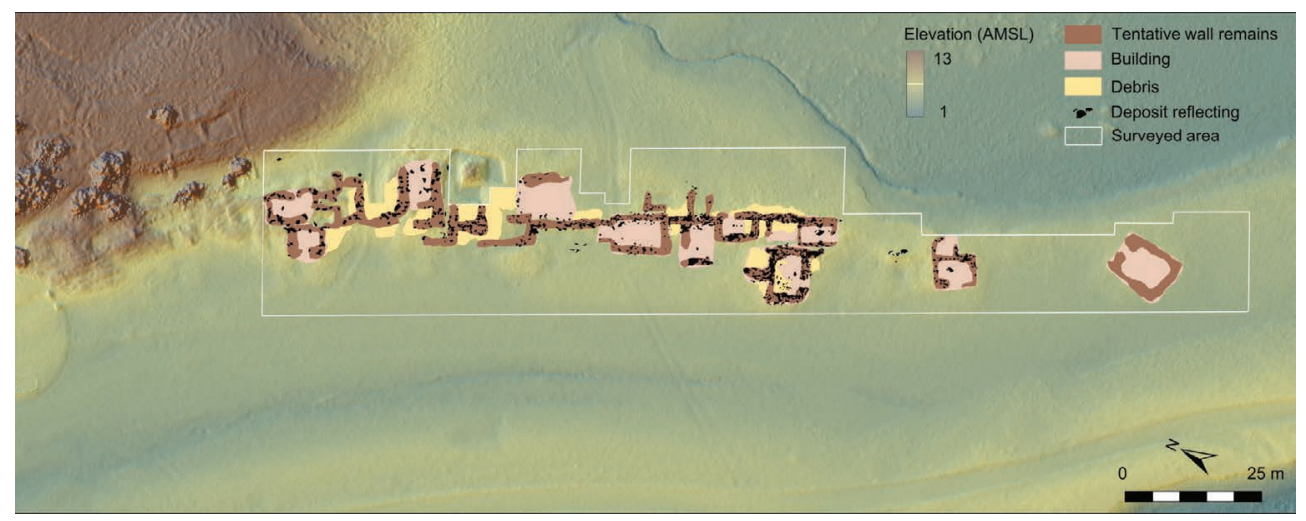

FiguRE 7.6 Plan and digital terrain model of the trading site Maríuhöfn (or Búðasandur) in Hvalfjörður, Iceland, after a geophysical survey carried out in 2015. Image by Ronny Weßling, Joris Coolen, Natascha Mehler (C) HaNoA project.

inland river routes, at or near existing settlements. Many were established on large open spaces and had no permanent structures (Ellmers I990), although at some, archaeological investigation has revealed evidence for more intensive planning and regulation of activities over time (see for example the Royal Opera House excavations by Malcolm et al. 2003; and discussion of the southern English trading emporia of lundenwic by Cowie et al. 20I2). But how the Icelandic model of regulating external trade relates to practices established elsewhere, for example in Norway, remains to be analysed. In the case of Norway it is worth pointing out that there are many similarities to the Icelandic model, as there is no evidence of foreign trade conducted at top-level assemblies such as the one at Frosta-instead local assembly sites do seem to have functioned as trading sites. An example would be the site of Veøy or 'holy island', an island in Møre og Romsdal county (Figure 7.7). A decree from King Olaf Haakonsson [Norway r. AD I380-I387], issued in $\mathrm{I}_{3} 84$, regulated trade in northern Norway and it ordered the people from Romsdalen to bring their trading goods to Veøy (NgL III, 222-224). Veøy's function as an assembly site is, however, only handed down through oral tradition, according to which the meetings were held near the present-day church (Solli 2008, I I6). Another example would be the close proximity $(4 \mathrm{~km})$ of the Viking-Age trading site of Kaupang in eastern Norway with the assembly place of Tjølling, discussed in Chapters 4 and 5. All in all, there are few examples of trade at local assemblies in Norway (Ødegaard 2018a).

In contrast, when we look at Sweden, the top-level assembly at Gamla Uppsala was also the arena for a large market, the so-called (OSw) disping (Granlund I958; Staf I935, 225) (see Chapters 4 and 5). The Saga of Olaf the Holy, written by Snorri Sturluson (I I79-I24I) in approximately I230, tells in Chapter 77 of a large market:

At that place and time was also to be the assembly of all Swedes, and there was also a market and a fair which lasted a week. Now when Christianity was introduced, the general assembly and the market was still being held there (Ebel I987, 28I). 


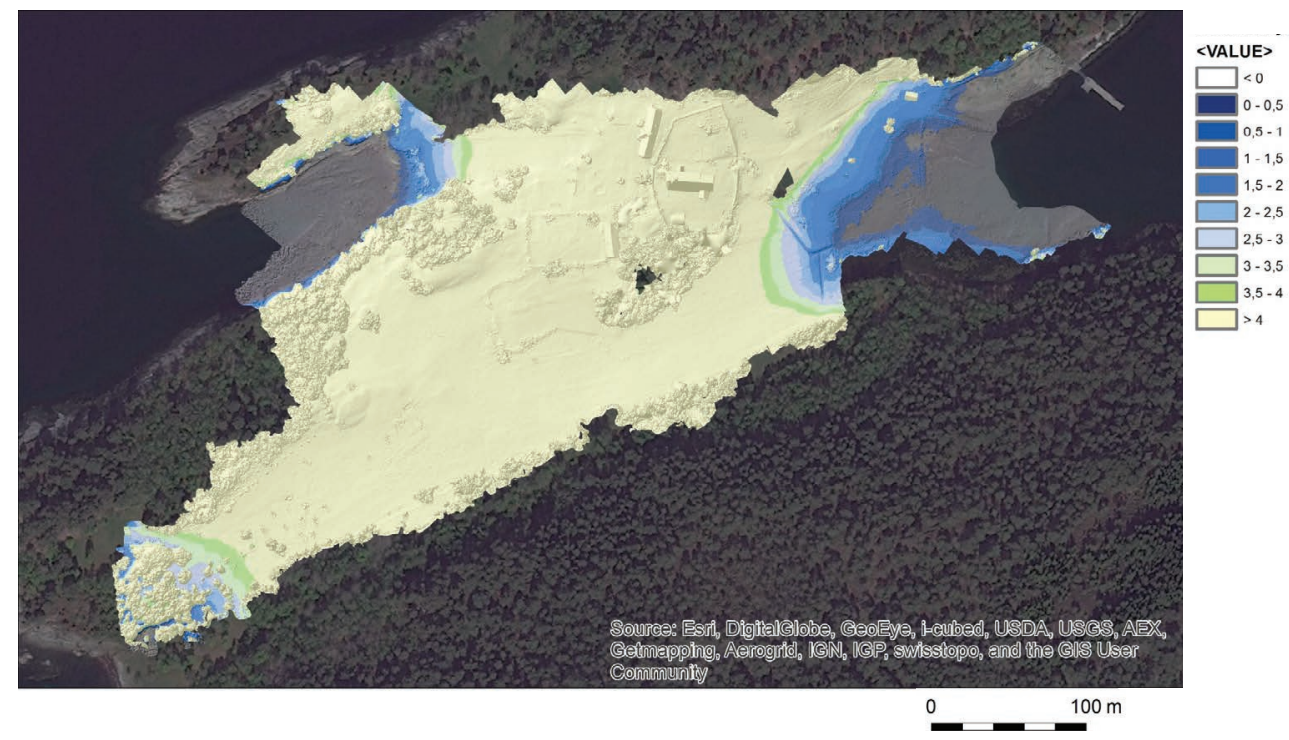

FIGURE 7.7 Digital terrain model of the ruins of Veøy, Møre and Romsdal county, Norway. Image by Ronny Weßling, Joris Coolen, Natascha Mehler (c) HaNOA project.

The Law of Uppland too refers to the markets and the assemblies held at Gamla Uppsala (Collin and Schlyter I 834, 274-275, 309; Holmbäck and Wessén I933, 205206). Recent excavations conducted at Gamla Uppsala have confirmed this picture. Weights, hack silver, balances and debris from metal production have been discovered (Ljungkvist 2009, 26-28, Ljungkvist et al. 20I I, 579). Indeed, in Sweden, there is no evidence of trade conducted at the local assembly sites, but instead only at the top-level sites such as Frösön, in Jämtland, Enköping, and Folklandstingstad, both in Uppland, which were situated at key locations in terms of communication. On the island of Gotland we find a Viking-Age trading place at the top-level assembly in Roma, adjacent to Kräklinge tingsängen, 'meadow of the Kräklinge thing' (Myrberg 2009, I05). Lund, the top-level assembly for Skåne, was held very close to Tre högars marknad, 'the market of the three mounds' (Sanmark 20I7a, I49; Svensson $2015,83)$.

How trade was regulated on the other North Atlantic islands remains unknown. The written sources do not inform us and only few Norse trading sites in the sense of established sites are known from the Faroe Islands, Shetland, and Orkney. In the Faroes, for example, the only known site used for foreign trade was located at the Tinganes peninsula at Tórshavn. This was also the meeting-place of the lawthing (Thorsteinsson I986, 4; see Chapter 6). Hence, foreign trade and jurisdiction took place only a few metres apart (Arge and Mehler 20I 2). All the local Faroese assembly sites are located inland and Tórshavn would have been the only one easily accessible by boat (see Chapter 6). Similarly, Kirkwall in Orkney was the place for both trade and the Orkney lawthing. According to the Orkneyinga saga, the Kirkwall thing in 
Orkney existed by the I 2 th century, about the time when Kirkwall was starting to develop into a central place with trade as a major element (Sanmark 20I 2; 20I7a, 230). In Shetland, the top-level assembly place located at Tingwall was not used for trade, as far as written and archaeological evidence retrieved so far can tell (Coolen and Mehler 2014; Smith 2009), but the site was close to two trading sites (Figure 7.8). About $4 \mathrm{~km}$ linear distance to the north-east lies Laxfirth, which Ola Sinclair, Chamberlain of Shetland, described in I 563 as one of the eight main trading sites of the islands having been in use for quite some time (SD I, no. I40). Another one he lists is Scalloway, about $5 \mathrm{~km}$ south-west of Tingwall (SD I, no. I 40). Both trading sites provide harbour access to Tingwall on either side of Shetland Mainland (see Chapter 6). The location of the assembly sites, either inland or at the coast and hence their access to the sea, were the key factors for whether trade was conducted at or near the local or top-level assemblies. At Tórshavn and Kirkwall, the lawthings met at, or close to, the harbours, while Tingwall in Shetland was located in the interior and hence trade was conducted at the nearest harbour.

\section{$7 \cdot 7$ DISCUSSION}

It is clear that trade, exchange and assembly could be co-extant in the past in northern Europe, with the popular assemblies of Ireland presenting an interesting model where decision-making and gathering were combined with games and fairs (Gleeson 20I5; 20I8). More broadly, many examples of temporary assemblies and

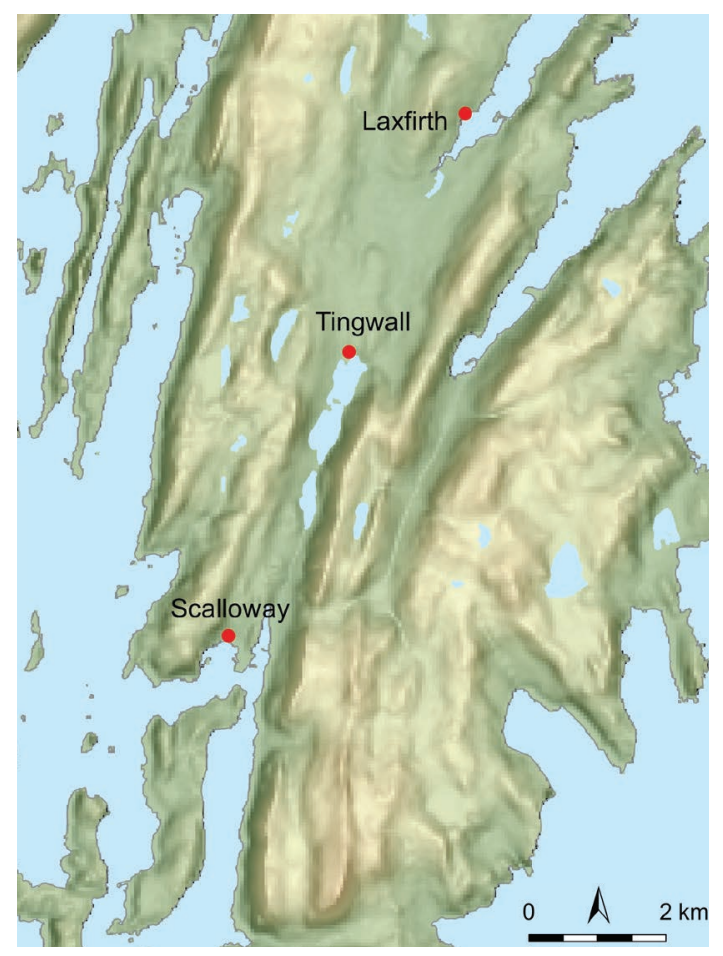

FIGURE 7.8 Tingwall, Shetland, and neighbouring trading sites of Laxfirth and Scalloway. Map by Joris Coolen. (C) The Assembly Project. 
gatherings seem to have provided the opportunity for production, trade and exchange (e.g. Nebbia et al. 2018; Swenson 2018). The archaeology of trade and market-places is a common research area, but most studies focus on the structural or artefactual evidence, means of transportation or infrastructure and the process of the exchange of goods, whereas the investigation of the involved social mechanisms has always been a shortcoming (Feinman and Garraty 2010, I69). Such mechanisms are essential in order to understand how trade, both foreign and internal, operated in practice, how societies regulated the international exchange of goods, and how much economic activities are embedded into social institutions and relations (Polanyi I957, 33-34).

This chapter has demonstrated, most notably, that the assembly institution in Iceland played a crucial regulatory role for foreign trade in the North Atlantic. A model of the regulation of foreign trade through the assembly system emerges which can be summarised as follows. During the Commonwealth Period, foreign trade was regulated first of all through a system of price fixing, concentrated in the hands of the chieftains who acted on behalf of the assembly system. The fixing of prices was done both at the althing and the local spring assemblies, but it is not clear whether prices changed annually or only when required, or whether the prices fixed at Pingvellir were binding for the whole country. The regulation and conduction of trade was primarily part of the spring assembly procedures but the level of regularity remains unknown. In addition, markets could be set up near established spring assembly sites, at the nearest possible natural harbour or landing place. Pingvellir was the arena for political and social gatherings but foreign trade did not take place here. Hence, in Iceland, where no royal power was present, the assembly institution was in fact the only tool to govern systematically the supply through foreign tradesmen and to protect the Icelandic clients from fraud. Although the regulations were most tangible at local assembly sites, it did affect the whole country through chieftains networks and regulations issued at the top-level assembly. Thus, rather than a serendipitous relationship whereby assemblies provided an ideal context for trade and exchange, the relationsip between assembly and trade was far more structured. Trading seems to have been conciously channelled and managed through the assembly processes and sites in Iceland. Indeed it may be the case that this Icelandic model seems to be rooted in a Norwegian model, where trade was channelled through coastal sites such as Kaupang or Vågan which paired trade and assembly. A Norwegian origin for this system would not be surprising as the early Icelandic laws were also seemingly based on Norwegian laws (see Chapter 6.2) and a large proportion of first settlers came from Norway. We have to bear in mind, however, that the change in this system that is evident after the Commonwealth Period has to do with the fact that Iceland never had any urban centres whereas in Norway relatively large towns emerged during the Middle Ages and these towns gradually took over the trade and also the rural assemblies (see Chapters 4 and 5; Iversen 20I7a; Sanmark 20I7a, I 57-60; Ødegaard 20I8a). This new system allowed the Norwegian kings to control the trading more closely and it is in this late-medieval period that the Icelandic and Norwegian systems start drifting apart. The combination of trade and assembly in Norway at or near one site, seems to stop with the relocation of rural sites into the towns and the concentration of royal power therein, and rural assemblies too were relocated at times into towns. This fits with the broader Scandinavian model set out in Chapters 4 and 5 whereby, over time, 
meetings were relocated to urban sites and greater royal reach and regulation is event over the meeting hierarchies. More investigation is needed in the case of Norway, however, to establish what happened to markets held near rural assembly sites during the later Middle Ages as towns grew (but see Ødegaard 20I8a), and to what extent exactly the emerging Norwegian model provides an administrative framework for Iceland.

What also remains to be studied in more detail is the role of the chieftains in the process of trade regulation within the Icelandic system. On the one hand, chieftains were regarded as powerful men serving common interests, they were regarded as public institutions who were responsible for keeping the order upright (e.g. Byock 200I, 67; Karlsson 1972; Lárusson I960). With this background in mind we could imagine that they put the welfare of the Icelanders above their own interests and regulated trade with the main aim to protect the Icelanders from fraud through foreign traders as much as they could. On the other hand, many chieftains had initially left Norway to settle in Iceland in their struggle for independence and freedom. In the Age of Settlement many chieftains competed for power and powerful families surely did not want to give that up. In the I Ith and I 2 th centuries, the 39 chieftaincies of Iceland were controlled by only five families, a clear sign that power remained in the hands of a few (e.g. Sigurðsson I995). Under these circumstances it seems plausible that some chieftains were primarily or solely driven by self-interest, to strengthen their own power within their own districts by protecting foreign merchants and to increase their own wealth by lodging the merchants on their farms. In newly colonised lands such as Iceland this would surely have been tempting.

It is furthermore clear that foreign trade was conducted at sites which were easy to access from the sea and by land, and which were embedded in good communication routes. In general, if local or top-level assembly sites were situated at or near coasts, they could have been used also for trade conducted at or near the assembly sites or near the assembly sites. In Iceland and Norway we see this happen at local assembly sites, in the latter case until towns start to absorb markets and assemblies. In the Faroes, Orkney and Sweden such a pattern seems to be valid only for the top-level sites because here these are either located by the sea (in the case of the Faroes and Orkney) or by good water and land routes. For Shetland, more work needs to be done as at present there is no firm written or archaeological basis for Viking-Age or earlymedieval trading sites and it is hence not possible to analyse the relationship between trading and assembly sites during this period. This underpins once more that although integrated in many ways, the societies of the North Atlantic islands and Scandinavia in the Viking and late-medieval periods were also individual societies with their distinctive and own characteristics (Smith I990, 25). This applied as well to the regulation of trade which was surely done with the needs of these societies in mind and driven by independent and shared practicalities. Practicalities set aside, in Iceland the efforts to protect the Icelandic clients versus the interests of foreign traders helped to consolidate the growing collective identity of the young Icelandic society. 


\section{CHAPTER 8 \\ THINGS IN THE NORTH}

\section{I SUMMARY}

The powerful role of early research traditions and their influence on our own methods and interpretations provides a starting point for this chapter. Here we draw together, discuss and set into context the findings from our project. This chapter assesses some of the early evidence for organised gatherings in Scandinavia, before reviewing specific attributes of the thing, with emphasis on the kinds of practices that took place, who attended, and evidence for activities and rituals created for assembly activity. We then review the placement of the thing and the use of natural and antecedent features as assembly foci. We explore what this reveals about the longterm development of the collective processes that enabled medieval communities to manage disputes and relations. We also review evidence for the influence of elites, kings and the church and the changes brought about by the development of urban centres. Here we focus on our study regions, but also draw more broadly on evidence from Britain and Ireland and elsewhere, to demonstrate broader trajectories of change in (early) medieval northern Europe.

\subsection{THE SHADOW OF THE PAST}

The prehistoric and pre-Christian past in northern Europe lacks a written record, while the material record for the Ist to Ioth centuries $\mathrm{AD}$ can be sporadic and inconsistent. Yet in these centuries, the basic framework for medieval Europe emerged, as networks of small-scale polities transformed into larger political units. For these reasons, perhaps, the Ist millennium has frequently provided a window for the political and scholarly imagination (see Chapter 2). It is a time in which many historians and archaeologists have tried to find evidence for the emergence of 'national' consciousness and identity, especially during the Romantic nationalism of the I9th century (Oergel I998). The study of assembly is no exception to these trends. The first attestations in Roman written accounts of councils or meetings in the outdoors have been used time again to underwrite ideas of an early, pure and free-spirited mode of democratic consensus in Northern European regions (Oergel I998, 76). What is interesting is that specialists in European late prehistoric archaeology have relied on these same written sources in arguments for a heterarchical structure for the Late Iron-Age societies that lived in the shadow of imperial control (FernándezGötz 20I2; 20I4a; 20I4b; 20I7; Thurston 200I; 20IO). The concilia described in these accounts, whether relevant to a frontier province like Gaul or the Iron Age communities of Germania Inferior, were described by Roman authors as a practice 
common to these wide-ranging and different Iron-Age populations. In the same way, in the study of medieval history and archaeology, there has been a strong tendency to see the meetings described by Roman writers as a closely related form of organisation to the documented assemblies present in different regions of northern Europe, in the centuries before and after the turn of the Ist millennium AD. The notion of a panGermanic idea of governance that endured from late prehistory to medieval times has persisted in the study of a timeframe during which complex and hierarchical societal organisation emerged in the form of early medieval polities and kingdoms.

What hope then do we have as modern scholars of avoiding similar pitfalls? First, historiography has been vital to our programme of work. Legal history, place-name studies and research on regional administrative arrangements have cast long shadows in modern scholarship. Any modern research relies on the lists and catalogues of unitary arrangements and meeting-places created by scholars like Wildte and Arngart, and the translation and publication and commentary on early laws by Hertzberg and Brant or Taranger. Uncritical use of such publications could lead to a replication of methodological error. As Chapter 3 sets out, we have used onthe-ground and remote survey, as well as work with primary sources, to reduce our reliance on these secondary syntheses. Historiographical research has also highlighted how prone this research area is to manipulation in political and nationalist discourses. This has set the critical tone for our work - recognising that investment in research on early governance has a tendency to arise in times of political disjuncture, has helped us evaluate the context for our own project. Our transnational framework, we believe, directly counters the insular nationalist research trends of the past. We have also drawn on Ireland, Scotland and England to broaden our comparative frame and encompass some regions considered in the past to present evidence of 'Celtic' rather than 'Germanic' notions of kingship, justice and assembly. We recognise, however, that we still risk promoting a European narrative of early democratic tradition, just as scholars once pursued a common prehistoric Germanic origin for law and meeting customs. The chapters in this book are, nevertheless, rich in evidence for diversity in how modes of consensus emerged and developed and how they operated in different landscapes. A single common, ancient origin for meeting traditions is hard to promote in the face of this variance. It is also important to remember that within such a broad geographic study area we have regions that were once within imperial control, some that bordered the Empire and some that maintained independence from Roman power from prehistory to the early historic era. We have even studied the establishment of assembly systems in unpopulated regions. These differences alone should exert an influence on the early medieval record. The populations of northern Europe in the first half of the Ist millennium $\mathrm{AD}$ were also faced with some dramatic changes and events including imperial influence, war, climatic catastrophes and pandemics. It is possible that common collective structures might develop in response to these kinds of impacts. Imperial proximity could also provide a possible catalyst for greater levels of local and regional organisation centred on military needs. We need to recognise, as well, that the movement of people between southern Scandinavia, Frisia and Francia and eastern and southern England in the 5 th century $\mathrm{AD}$ (Schiffels et al. 20I6), may well have resulted in the introduction of new ideas, or influenced existing notions, of law and consensus. Finally, we know the thing was closely connected to the Viking 
diaspora (c. AD 800-I050) and was unquestionably exported from the homeland regions of Scandinavia to territories colonised by the Norse (Sanmark 20I7a). The development of administrative systems and assembly practices must, therefore, be accepted and investigated as a multi-layered process of development and influence.

In this complex scene, our evidence is instructive in revealing that fairly large and organised assemblies/gatherings appear as ground-up developments in Norway and Sweden in the Late Iron-Age/Migration eras (see Chapters 4 and 5). In Ireland, as well, some forms of assembly place, notably the royal sites, are thought to develop their seminal status within the Late Iron Age (Gleeson 2018; Newman I998). The evidence for these early structures is varied and regionally distinctive, however, and we do not have these early local-level meeting conventions in all regions studied here. Nevertheless, there are commonalities in the shape and levels of early medieval assembly organisation and their linkage to land division and management. There are similarities too in the type of activities that participants engaged in, but the physical settings and site architecture of assembly sites remain very distinctive.

As Chapters 2 and 3 reveal, past methods have recognisable weaknesses. One of the most common problems is the tendency for both legal research and assembly studies to 'work back' from the medieval documents, using retrogressive approaches to unpick earlier practice (see discussion in Lambert 20I7, 9). Linked to this is the risk of conflating different written sources from different places and times, in an effort to conjure up a common vision of early legal tradition (Wormald I999, I2). A further inadequacy has been the reliance by some on just single genres of evidence. For example, while place-names can help us locate political and administrative activity in the landscape, they are hard to date, they move around the landscape over time, and are prone to being re-coined or invented in early modern and modern times (Brink 1999; 2002; Pantos 2004a). To combat the inherent weaknesses of each type of evidence, these sources need be used in conjunction: triangulation between cartographic, historical and material evidence strengthens the veracity of the combined data sources (see Baker and Brookes 20I5).

Reviewing past scholarship has enabled us to realise a better approach. An interdisciplinary methodology, drawing on multiple sources of evidence and a range of medieval to early modern sources, offers the best chance of an unbiased account of the changing political and administrative structures in early medieval societies (see Chapter 3). While the historiographical research highlights the risks in conflating evidence drawn from differing time-periods, the retrogressive approaches of historical and landscape historical research are employed here to rigorously understand the changing landscape and locations over time. We are of course 'looking back in time', but our combination of methods has allowed us to do this with as much care and caution as possible.

In some of our most contentious but intriguing case-studies, striking connections can be made between excavated courtyard structures that date to the mid-Ist millennium $\mathrm{AD}$ and the documented local unitary arrangements of $\mathrm{I} 6$ th century, e.g. Salten, Hålogaland (see Chapter 5). Such correspondences hint at early structures and enduring arrangements in some regions of northern Europe, and yet as our detailed work shows, even the courtyard sites vary in temporal terms and longevity, again underlining that places, arrangements and systems were prone to change. Our aim is 
to present a longitudinal view that allows us to see how local organisational structures changed over time and how assembly processes and places varied across all the regions under discussion. This has helped us understand assemblies and the administrative arrangements they were part of as dynamic and agent entities (see Chapter 6; and Skinner and Semple 20I6). They were powerful enough to influence the arrival of new authority and local organisation (see discussion of Yorkshire and the Danelaw in Chapter 6), but the act of creating meeting-places and assembling at them could also be used to 'overwrite' past activity (see Chapter 6; and Coolen and Mehler 20I4). As Eric Hobsbawm has so ably demonstrated, traditions can be invented. A sense of permanence can be created precisely to create gravitas or add power to an act or event. It is clear that at a local level, occasionally assembly practices appear to have lasted centuries, but also that the processes and organisational structure could change, especially when elites, chiefs and kings were able to secure influential control.

In the remainder of this chapter, we assess the evidence for meeting conventions and structures in the Scandinavian homelands and their potential relationships to the medieval thing; we then gather our findings to explore how the thing operated, the activities associated with meetings, and who attended. We concentrate on the thing as attested in the Scandinavian homelands and in the regions colonised by the Norse and we draw together evidence from different sources and times in order to more fully illustrate the ways in which this form of governance operated at local and regional levels. We then consider the landscape locations of thing meetings and the ways in which sites were enhanced and developed physically as meeting-locations. In this section, we draw far more widely on comparative evidence from other regions, to show the striking similarities in meeting location evident in the British, Irish and North Atlantic regions colonised by the Norse.

\subsection{BASIC STRUCTURES AND BEGINNINGS?}

In Scandinavia, the system of administrative units served by assemblies, in simple terms, comprised large law provinces divided in to smaller local hundreds. The closegrained assessment of unitary arrangements in parts of Norway and Sweden seen in Chapters 4 and 5, demonstrates that this basic structure of local and top-level divisions was a common system. At the basic level, the primary unit was thus also a hundred or its cognate. The thing as a form of political and judicial assembly served both the local and top-level divisions and in some regions, there are hints of an intermediary mid-level of organisation as well. The linguistic term thing, as Chapter I argues, is thought to be much older than the documents that name the thing in Scandinavia in the High and Late Middle Ages (Bjorvand and Lindeman 2007, 940).

In the evidence presented in this volume, in relation to parts of Norway, there are hints in the documentary sources, the terminologies for units and meetings, and in the divisions on the ground, of some quite early organisational and meeting structures. In parts of eastern Norway, in Viken, for example, the (ON) pinghá thinghold denoted the local 'thing district'. These small units remained intact for centuries, acting as the building blocks for later and larger divisions. While these arrangements are not in evidence everywhere, this does indicate how small units of territory might describe a basic unit of collective division, used to denote legal and even military responsibilities. 
$(\mathrm{ON})$ pinghá are, with some provisos, cognate to the (ON) herað, Mod Dan herred and the hundred. In western Scandinavia, the earliest named large divisions were (ON) fylki, meaning 'folklands' or 'coming together' (see Chapter 5). These were superseded and absorbed into law provinces (patria Lat.) and the skipreiður in Norway by the I 3 th century, although they maintained an active local function. Fylki are attested in documentary sources from I IOO onwards, but they have been argued to reflect preChristian organisational divisions (Munch I849, I3). The naming of such units also emphasises a relationship between the people of a territory and a sense of jurisdiction over activities within that 'land'. (ON) land, 'land' operated broadly, it seems, as a term for a geographically defined legal entity.

It is the on-the-ground archaeological remains, however, that reveal some surprising early evidence for assembly activity. One of the most striking connections made by fieldwork during this project is the co-location of the 'cooking-pit sites' that feature in eastern Norway and later place-name attested or documented thing sites. This is fully rehearsed in Chapters 4 and 5 where the examples of Tjølling in Vestfold, Norway, and another nearby example at Bommestad are discussed. The place-name Bommestad means 'the farmers or householders' thing site' (see Chapter 5). At this site, a complex of some 485 cooking-pits and 64 hearths has been located (Bukkemoen and Samdal 2008; Ødegaard 201 5; 2019a). These large cooking-pit sites in Norway are located close to monuments of different kinds and the scale of the gatherings themselves could be described as monumental. The earliest these sites appear in use is c. AD IOo. Both of the examples discussed in this volume appear to have dropped from use by c. AD 400. In general, these features have been recognised and described since the I 9 th century in Norway and in broad terms can date between c. $500 \mathrm{BC}$ and AD 500 (Gustavsen et al. 20I7, 25). In the case of Lunde, near Tjølling in Vestfold, the defined distribution of activity implies some kind of delineation. There are also a number of undated burial mounds (Gustavsen et al. 20I7, 28), and this juxtaposition remains interesting in light of broader trends in assembly placement discussed below. These cooking-pit sites are plausibly argued as socio-political gathering sites (Gustavsen et al. 20I7, 28-29; Ødegaard 20I5; Semple and Sanmark 20I3), where groups periodically came to gather, cook and eat perhaps while settling disputes or forging connections and alliances (Skre 2007, 399). The association between the cooking-pit site at Bommestad and a place-name which may refer to a farmers or householders thing, is echoed at Lunde where the parish name Tjølling in its medieval form means the 'people's ling/heather' implying a form of communal location and perhaps a meeting-place (see Chapter 5; Gustavsen et al. 2017, 29). While absolute continuity between these kinds of feasting site and the medieval thing are hard to assert with complete confidence, such convergences do suggest that sites established in the Iron Age at specific locales held strong connections with the idea of group meetings and a sense of collective identity. The association of gatherings with certain locations may have survived in local and regional memory and practice for centuries, shaping the administrative geography of a locality in the Viking Age and High Middle Ages. By returning to the same site, and even perhaps the same hearth, given these were reopened and repeatedly used, memories of shared experiences in the past could be relived and strengthen the social cohesion between communities and families in the present (Gustavsen et al. 20I7; ; Ødegaard 201 5; Semple and Sanmark 2013). While 
the examples presented in Chapter 5 are confined to Norway, evidence for hearths and cooking-pit sites is known from northern Germany, Denmark, Sweden and northwest Poland. While the same immediate connections with medieval thing organisation are less easy to argue for, the evidence could point to broader and deeper traditions in these regions in the first half of the Ist millennium AD. Further fieldwork is necessary to test this.

The second piece of compelling evidence for early socio-political gatherings is found in the courtyard sites of Norway. Again, the evidence is set out at length in Chapters 4 and 5, and requires only a summary here. Rather like the cooking-pit sites, a close association between the medieval thing and the earlier phenomenon of 'courtyard sites' in Norway is posited. Courtyard sites are striking in their form that comprises a collection of houses or booths situated around an oval semi-circular open space (Johansen and Søbstad I978, 55 ). The time span during which individual sites were in use varies, but many of the sites in Norway were active for several hundred years. Some were already in use in the 2 nd and 3 rd centuries (for instance, Áse in Troms, Øygarden, Leksaren, both Rogaland), while others seem to have remained active until as late as the early I Ith century (Skei and Heggstad, North Trøndelag). These sites, like some cooking-pit sites, are associated with cemeteries and burial mounds, although others so not seem to have these associations (see Chapter 5). The sites have been argued to have socio-political and military purposes and some appear to demonstrate evidence of cultic activity associated with stone heaps or mounds (Grimm 2010; Iversen 20I 5b; Lund I95 5; Semple and Sanmark 2013). The work of this project has connected the form and layout of some courtyard sites with the form and divisions present in the fylki or county in which the site is located (see Chapter 5 ). In most cases courtyard sites are active around the middle of the Ist millennium $\mathrm{AD}$, but some second generation sites remained active in the Viking Age.

The distinctive nature of these two types of site, and their existence in different regions of Norway, provides evidence for how local and regional socio-political mechanisms for decision-making might develop side-by-side and take very different forms. Neither of these meeting-site types can be equated directly with the medieval thing but they do look, in terms of date, form, and function, to be kinds of precursors. These sites hint at the development of meeting mechanisms by Iron Age populations in the centuries $\mathrm{BC}$ and $\mathrm{AD}$, but their establishment and use is more frequent in the first half and middle of the Ist millennium AD. The presence in Sweden of cooking pits and hearths at monumental meeting-locations, that took on a role as early medieval and medieval assembly sites, supports associations between gathering and cooking in the Iron Age as a possible precursor to more formalised systems and sites of gathering in the Viking Age (see Sanmark 20I7a, I34-I37). The architecture of these Norwegiantype sites, whether in terms of the booth-buildings placed side-by-side at courtyard sites, or the excavation and repeat visits to large hearths within the cooking-pit complexes, also seems symptomatic of collective and collaborative action.

This evidence does not attest to a common origin for the thing or assembly as a mechanism, but it does reinforce arguments presented in relation to other regions, such as Gaul or Britain, for the emergence of more regulated mechanisms for consensus and decision-making in the Late Iron Age (see Chapters I and 2). The association between these kinds of late prehistoric meeting-place and later thing place-name 
evidence also suggests that these locations continued to exert an agency and may have been retained in memory as the right places for local supra-local outdoor meetings. A less investigated facet is that these types of site also demonstrate associations with cemeteries and burial mounds and in some instances appear to mark places with important communal resources. These geographic aspects bear strong relations to the general attributes of early medieval assemblies attested in Scandinavia, Britain and Ireland and in the regions colonised by the Norse (see below).

\subsection{THINGS IN OPERATION}

Early medieval and medieval thing meetings were highly complex gatherings and this is reflected in the way these meetings operated. The gatherings that occurred were not only of a political and judicial nature, many other forms of activity also took place at the thing sites and at cognate forms of assembly.

\section{Meeting times}

Thing meetings were held at set times of the year and were called in relation to specific events, such as killings. In the time before the written sources we cannot establish the timings of meetings with certainty, but it seems that the toplevel assemblies were held once a year, most likely coincident with large seasonal and calendric events. The Icelandic althing was held at midsummer. Grágás stated that 'all chieftains are to come to the Assembly before the sun leaves Pingvöllr on the Thursday when ten weeks of summer have passed', i.e. roughly between I8 and 24 June (Grágás Ch. 23; Dennis et al. I980, 57; Jóhannesson I974, 45). With Christianity, the assemblies often became tied to Christian feast days, as seen for example in Norway (Seip I934, 25-29). Meetings on the local level were held more frequently and presumably called when the need arose.

The Icelandic sources provide the clearest insight into how the different assemblies were distributed across the year. Here three types of set meetings were held annually, and the same may have been the case in the Faroes and possibly Orkney (Debes I757, 25 I; Nolsøe and Jespersen 2004, 85; Thorsteinsson 2012). The three types of meetings were all held in the months which were the best for travelling: the local spring assemblies in Iceland were held over four to seven days in May (Benediktsson I974; Grágás Ch. 56; Dennis et al. I980, 258), and then followed the althing in June. As Kirsten Hastrup has pointed out, the top-level assembly was the centre for time-reckoning, not only because it took place at midsummer, but also since the lawspeaker announced specific dates of the calendar for the coming year at the assembly (Hastrup I985, 26-28). Finally, the autumn assemblies were meant to take place, at the latest, I4 nights after the top-level assembly at Pingvellir had ended, that is between July and the end of August. The autumn assembly lasted only one or two days (Grágás Ch. 6I; Dennis et al. I980, I I I-I I2, 24 I; Jóhannesson I974, 74; Lárusson I956), and the purpose was to inform the people who had not attended the meeting at Pingvellir about new laws and verdicts passed.

To use a specific example: a person who had attended the local assembly at Hegranes in the Northern Quarter (see Figure 6.2) and who then had to travel to 
the assembly at Pingvellir would have had to cover a distance of roughly $200 \mathrm{~km}$. A person on horseback could cover around 25 to $40 \mathrm{~km}$ per day, and depending on the quality of the paths, weather conditions and the availability of additional horses and sufficient fodder, this journey would have taken roughly between five and seven days. If the Hegranes assembly ended on 27 May and the althing started around midsummer, the thing participant could work on the farm for about two or three weeks before commencing the journey south to Pingvellir. To attend both the local spring assembly and the althing, an attendant from the Northern Quarter would thus have been away from the farm for four to five weeks. At the period around midsummer, travel conditions would have been good with the warmer summer temperatures and the extra daylight. During summer, cattle and sheep were grazing and livestock farmers carried out work at their farms, maintaining buildings, gathering natural food and driftwood (Byock 200I, 47-48). With some men and women away for a few or several weeks each summer, this work had to be carried out by the men and women who remained at home, of which some were likely servants or slaves.

The thingmen were compensated for their absence from the farms for attending the assembly at Pingvellir. In Iceland, this payment went under the name of Pingfararkaup, a certain amount that had to be paid by every free farmer of a certain wealth and was then used to compensate those who attended at Pingvellir. Since coins were not in use, this was a value of victuals or other goods called (ON) lögaurar (singular lögeyrir), which was not a fixed sum but depended on the distance from the farm to Pingvellir (Benediktsson I976a; Lárusson I966). This practice of travel compensation is known from the Faroes (pingfarartollr), Norway and possibly Orkney too (pingfarareyrir) (Benediktsson I976b; Hødnebø I976). A day's journey to the althing was called pingmannaleið (shortened for ON pingmanna and dagleið). The term stands for a day that was spent for this, and not for an exact distance (Benediktsson I976b). The guiding principle of the compensation scheme was simple, the longer the distance the higher the compensation. According to the one Faroese section in Norwegian law, the island group was divided into no less than 2 I tariff zones (NgL IV, 666). Representatives living closest to the assembly site, from Kollafjørður, Ragtangi and Nólsoy, received five ells of woollen cloth (ON vaðmál), while those furthest away, from the southern part of Suðuroy received as much as 20 ells of cloth (Taranger I9 I 5,8). Similar calculations can be attempted for Norway (Gullbekk and Iversen 20I7).

\section{Activities at the thing}

The previous chapters have outlined and discussed the major political, social and economic activities that took place at the assemblies, both in the Scandinavian homelands and in the areas of Norse colonisation in the North Atlantic islands and the Danelaw. It has become clear that assembly sites were not only political and judicial arenas, but also places where a variety of complex activities of a cultic, social, economic and political nature took place. These seemingly separate activities were interlinked and played important roles in the wider scheme of the assembly meetings. 


\section{Creating and opening the assembly}

Assembly sites were chosen for characteristic landscape features that the selected sites provided. In the processes of site selection, site design and the opening of the specific assemblies on set dates, nothing was left to chance. The 'architecture' of some sites of assembly clearly points to collective concerns and memory creation. The Icelandic law stated that after the arrival at the assembly site at Pingvellir assembly participants should 'go to the same booth as the chieftain to whose assembly group they belong and each shall bring an awning to reach across the booth. Each of them shall then receive but not pay assembly attendance dues' (Grágás Ch. 23; Dennis et al. I980, 57). The building or repairing of a booth was a symbol for the participation of the booth-owners in the assembly. Each year, before the meetings began, the assembly attendants returned to their booth, put new roofs on top of them and took them down again after the meetings were over (Vésteinsson 2013).

The Icelandic sources also contain the most detailed information on the rituals relating to the opening of the assembly, the most detailed source being the assembly procedure section of Grágás (Ch. 20-Ch. 85; Dennis et al. 1980, 53-138). We are told that the annual meeting at the althing started with an inaugural ceremony and procession led by the allsherjargooi, the supreme chieftain (who could trace his ancestors back to Ingolf Arnarson, supposedly the first settler of Iceland). The supreme chieftain during this act demarcated a sanctuary area called pinghelgi where the assembly was to be held (Byock 200I, I76; Jóhannesson I974, 45-47). Most likely, as part of the opening process, a sanctuary enclosure for the judges to take seat was demarcated via the so-called vébönd. It is, however, most likely that the enclosure was taken down again after the meeting had ended, and erected again for the next meeting in a symbolic act.

\section{Drinking and eating rituals}

There is an increasing body of evidence of ritual feasting and drinking at the thing. This is clearly suggested in the written sources, such as Hymir's Poem (Hymiskviða) (Løkka 20I3, 23) and the late-medieval Gotlandic source Guta Saga, which states that people from the same thing district came together for cultic gatherings where food was prepared in cooking-pits (Narmo I996, 92-93; Peel I999, 5). Icelandic sagas also tell of beer brewers who were present at the althing. In the satirical work Ölkofra páttr (Ch. I) we are told of Pórhallur, who makes a living by selling beer during the althing (Esser 20I I, 37 I). Similarly, Orms páttr Stórólfssonar (Ch. 4) refers to some sort of a brewery (ON heituhús) at Pingvellir.

Eating and drinking at gatherings is suggested by archaeological evidence from across Scandinavia (Ødegaard 20I5, 30I-3I8; Sanmark 20I7a, I34-7; Semple and Sanmark 2013). One of the most striking connections between assemblies and cooking and eating is explored above: the 'cooking-pit sites' found in eastern Norway. While actual continuity between these kinds of feasting site and the medieval thing are difficult to prove with certainty, such convergences underline how cooking and eating together and feasting may have emerged as a common mechanism in late prehistory for creating local connections and alliances. It is worth considering this in 
the context the evidence for feasting at different forms of assembly locale in Ireland. The local (OIr) túath kin-group-level assembly sites are argued by Patrick Gleeson to be defined by burial enclosures with evidence for a broader range of communal activity evidenced by rubbish pits, animal remains, and food waste, while feasting is attested too at the higher order (OIr) óenach (Gleeson 20I5). It is also interesting to note that by the late Anglo-Saxon period in England laws do attest to merrymaking and feasting at assemblies as well as drinking (see Pantos 2002, 89). Archaeological evidence is also present in the form of rubbish pits and remains at the site of Saltwood in Kent attesting to regular gatherings and eating at the cemetery site after its use for burial had ceased (Reynolds 2018).

\section{Games and competitions}

The association of games with assemblies is evident in Britain and Ireland where associations with horseracing, wrestling and even pig coursing are suggested (respectively Pantos 2004b, I66; Aitchison 1994, 6I-66; FitzPatrick 20I5). Games and competitions are suggested by a variety of sources as well as activities that took place at things in Scandinavia and in the Norse settlements in the North Atlantic, for example as wrestling competitions (ON glíma) and storytelling (Gardeła 20I2, 240; Jochens I995, I05). Other activities, such as horseracing and horse fights, may well have taken place in connection with assembly meetings too. In this volume, it has been suggested that the circular structures previously interpreted to be $(\mathrm{ON})$ dómhringar found at some assemblies in Iceland and Greenland could been arenas for horse fights (see Chapter 6.2). Horse competitions are suggested by various placenames, above all in Norway and Orkney (Ødegaard 20I8a; Semple and Sanmark 20I3). Leikvin, Romsdal, a Norwegian Iron-Age cooking-pit site, which also seems to have been used for communal gatherings and possibly thing meetings, contains the $(\mathrm{ON})$ element leik, which is associated with cultic games and events (Loftsgarden et al. 2017; Solberg 2002, 228). Nearby Holskeid contains (ON) skeið that may signify a track used for horseracing, with suggested connections to the fertility cult (Narmo 1996, 96-97). A similar pattern is found close to the thing site at Tingwall, Orkney, where the place-names Lyking (leikvin) and Skiddy (skeið) appear within less than a $2 \mathrm{~km}$ radius of the assembly site (Marwick I952, I23). A few place-names near Norwegian courtyard sites suggest that similar activities took place (Leknes (Lofoten), Leikenga (Tjøtta), Leikvang (Skjelbrei); Grimm 2010, 43, 53), but in the Borgarting area of Norway, there is little or no evidence for associations between horseracing/ fights and thing sites (Ødegaard 2018a).

There are similarities here with the local and supra-local assemblies of Britain and Ireland. Aliki Pantos has identified connections between assemblies in AngloSaxon England and place-names suggestive of 'play' perhaps involving sports, wrestling or horseracing such as Gainfield hundred in Berkshire which is thought to derive from OE gama feld 'open land of games' (Pantos 2002, 89). In medieval Ireland and Scotland, strong connections between horseracing and assemblies have also been noted (Driscoll 2004, 83; FitzPatrick 201 5, 54) with games and horseracing argued as essential elements of the (OIr) óenaig in Ireland (Gleeson 201 5,35 ). 


\section{Duels/judicial killing/sacrifice}

Duels took place at things, though most probably in a demarcated area separate to the legal proceedings. The Book of the Icelanders states that the two men Thord and Tungu-Odd fought at the local assembly at Pingnes, and then again at the main assembly at Pingvellir. Both were the main individuals in a lawsuit for manslaughter and since that could not be settled at the local thing it was transferred to the althing (Byock 200I, I77). This could well have been an (ON) hólmgang, a formal duelling to decide a law case, but presumably, this also provided some entertainment. As the term hólmgang makes clear, the duel took place at a hólm, 'a small island', within an enclosed and demarcated area. At Pingvellir, this took place at Öxaráholm, an island in Öxará, the 'axe river' that runs into Lake Pingvallavatn (see Figure 6.4). When the duel had ended, a bull was purportedly sacrificed and killed by the victor; the former a practice reported to have been officially forbidden around 1005 , with the introduction of the Fifth Court (see Chapter 6.2), but that seems to have continued illegally throughout the Middle Ages. As late as I 527, the two Catholic bishops fought a duel on the island in Öxará River (Byock 200I, I83; Ciklamini I963; Guðmundsson I924, 56-57; Hastrup I985, 2I4-2 I 5; Sieg I966). A number of such duels are reported in Kormáks saga, for example one that took place at the local assembly at Húnavatn (Ch. 2I, trans. Collingwood and Stefánsson I902, I I7-II9). The procedure of these duels was quite elaborate and Egil's saga (Ch. 64) reports that the fights took place within a demarcated area marked by a circle of stones (ON lagðir steinar útan um). This bears striking parallels to the enigmatic structures called dómhringar, 'court circles', which according to written evidence had two different meanings, either be a panel of judges sitting in a circle (e.g. Víga-Glúms saga or Bandamanna saga), or it could designate a circular construction made of turf or stone (or both), in which pagan sacrifices took place (e.g. Eyrbyggja saga) (Friðriksson and Vésteinsson I992, esp. 27-29). It is possible that a variety of activities took place within the circular structures mentioned in association with assemblies, and given that duels were fought on assembly islands it is tempting to imagine Law Ting Holm at Tingwall, Shetland, as a place for such duels.

Human sacrifices may also have been carried out at assemblies, at least until Christianity was introduced, although these may also have taken the form of judicial executions (Sanmark 20I7a, II2). One of the most drastic recorded incidents took place at Pingvellir during the meeting when Christianity was introduced. At this assembly, eight men, two from each quarter, were reportedly sacrificed in order to prevent the introduction of Christianity (Aðalsteinsson I999; Gunnell 2009, I06). At the assembly site of Pórsnes on the Snæfellsnes peninsula, a blótsteinn ('sacrifice stone') is refered to in Eyrbyggia saga (see Chapter 6.4). No archaeological material testifying to sacrifices at assembly sites have yet been found, but the recent archaeological discoveries of the cemetery at Ingiríðarstaðir are worth mentioning here. For the first time, remains of sacrified humans and animals were identified which testifies to this practice in Iceland (Roberts 2015). Ritual offerings of animals and humans are also reported from assembly sites at Uppsala and Gotland (Riisøy 20I3; Sanmark 2015) and scholars have pointed out that although some of these events described in written sources of the Ioth and I Ith centuries and later may be Christian propaganda, elements in these accounts may be true and reflect real practices. 
Evidence for animal sacrifice is also forthcoming from excavations. In Norway, at the courtyard site of Klauhaugane, Jæren, a mound $(7 \mathrm{~m}$ in diameter) was located in the middle of the courtyard, and investigated by several archaeologists (Grimm 2010, I3). Pottery was found in the south-east, and a horse's tooth and a lot of animal bone higher up in the mound. Beneath the mound, Oddmund Møllerop unexpectedly found a rectangular wooden construction of $5 \mathrm{sq} \mathrm{m}$, consisting of well preserved standing timber planks. A sample was radiocarbon dated to the Iron Age/Migration period (AD 353-58I) (Iversen 20I7c, 727). While Møllerop interpreted the feature as remains of a building (Møllerop I97I, I 59; Grimm 20I0, I73; Grimm and Pesch 2010, I5), we would not rule out its possible function as a base for benches. The cultural deposits in the mound may very well stem from offerings and ritual meals taking place at the centre of the courtyard site. Animal sacrifices were also regular components of assemblies in pre-Christian Iceland (Aðalsteinsson I999), such as the killing of bulls (ON blótnaut, 'sacrificial bull') mentioned above (Davidson I988, 53; Gunnell 2009, I08). It seems that the offering of male animals was of particular significance (Lucas and McGovern 2008, 24).

Associations between judicial execution and English assembly sites are a longheld preconception, but there is little evidence for executions or killings at bundred assemblies. There are a few instances, however, where an assembly of much greater size and importance may have born witness to executions. The most notable is Wandlebury hillfort in Cambridgeshire, UK, which is recorded as the location for meetings in the Ioth century and a number of excavated burials are thought to be execution victims (Pantos 2002, 93; Semple 2013, 20I). There are, however, plenty of 'gallows' place-names that have been associated with assembly sites, but these are hard to verify and seem on the whole to represent medieval and later names, and perhaps execution activities, associated with long abandoned assemblylocations (see Pantos 2002, 90-94). In a detailed study of Mangrove Knob, Northamptonshire, Pantos has revealed a close visual relationship between the communal meeting-place and places of execution and killing on the boundaries of the hundredal unit (2002, I 52-I 58 ). In Scotland, similar associations exist in local tradition, with some documented examples of execution at some open-air judicial sites, but again the evidence is largely medieval and post-medieval in date (O'Grady 2008, 360-362).

\section{Who attended the thing meetings?}

Apart from I7th-century thing books, the written sources do not provide any detailed information on who attended and participated in the assemblies. The information supplied by the thing books of Ryfylke, Norway, prior to 1623 offers valuable information to the modi operandi of the representational thing in Norway. The thing books list all representatives by name (Iversen $20{ }_{5} \mathrm{c}$ ). The regular quarterthings, (ON) fjórðungsping, were often held in March. The principle of geographic representation is striking. Delegations of an equal size, consisting of three or six men from each local community attended, in addition to a royal official from each district. In later centuries, in Ryfylke in Rogaland, some I I 7 delegates are recorded in attendance at a county-level thing (Iversen $2015 \mathrm{c}$ ). 
The earlier sagas tend only to include statements referring to 'people' who gathered for the meetings, as for example the Orkneyinga saga and 'the assembly site of the people of Orkney' (Guðmundsson 1965, I05; Pálsson and Edwards I978, 9I; Rafn I 832; Sanmark 20I4). The laws provide the most detailed information on who was allowed to participate, but there is no evidence to show to what extent and whether these regulations were followed. The laws make it clear that the main participants in the assemblies were the landowners, the majority of whom were most likely men, but not exclusively (Sanmark 20I4).

According to the Norwegian laws of the Frosta and the Gulathing, the thingmen were required (or encouraged, depending on the type of meeting) to attend local and regional assemblies. A thingman was defined as a free household leader with tenants (ON bóndi) over I 5 years of age with at least one worker. For the representative top-level things, selected thingmen from each law province attended ( $G$ 35, I3 I and 266; F I; L I I; Bøe I965, I78; Hagland and Sandnes I994, xv-xvii; Helle 200I, 76-8I). The regulations for who could become a representative at the lawthing seem to have been the same as for the thingmen (G I3 I; L I I). These representatives had the right to vote at the meetings, while at local and regional meeting verdicts were settled by the thingmen from the area (Sanmark 2006; Helle 200I, 72). In Iceland, the thingmen were freemen, older than I 2 years, with a settled home and able to pay $(\mathrm{ON})$ pingfararkaup ('thing dues'). These people were expected to attend their local spring assemblies and the annual top-level althing, together with the chieftains (Grágás Ch. 20 and Ch. 22; Dennis et al. I980, 53, 56; Foote and Wilson I980, 57-59, 86). There was also a language requirement; 'foreigners' were expected to have been resident in Iceland for at least three years, or be able to speak the Norse language (Grágás Chs 20 and 23; Dennis et al. I980, 53, 58). This shows that in all areas the people with the most direct access to the assembly were landholders who owned more than a small part of land, although tenants, and freed slaves were also able to participate. The Norwegian and Icelandic regulations are very similar in these respects (Sanmark 20I7a, 45-50)

Both Norwegian and Icelandic laws stipulated that there were three groups of men who were not entitled to participate in the thing meetings. The early Norwegian laws stated that 'slaves' and the 'dishonoured' (such as outlaws) (F I; G I3 I) were excluded from the thing meetings. In Iceland this group of people could take part in the assemblies as long as they paid the thing dues (Foote and Wilson I980, 86). Here, however, 'foreigners' who had been in the country less than three years and those who had not paid the thing dues were also excluded (Grágás Ch. 20; Dennis et al. I980, 53). In addition, men who were 'not able bodied' - the old, sick and disabled along with 'lone workers' - were not required to attend the assembly (F I; G I3 I; Grágás Ch. 87; Dennis et al. I980, I 5I). All these groups, apart from the slaves, included freemen. The proportion of the population that these participants constituted is not known, but it does mean that generalised declarations that the assemblies were meetings for 'the men' are less representative of the situation, at least as described in the laws (Sanmark 20I4). The Icelandic sagas also suggest that status played a very important role at the thing, since people of high status often got preferential treatment (Bagge 200I). Indeed, the Icelandic concept of thing dues most likely meant that there must have been constant fluctuations in terms of who qualified for full rights at the 
thing (Foote and Wilson I980, 87). In Norway, until the middle of the I 3 th century, local householders seem to have been rather influential at the things, with authority increasing according to wealth (Bagge 200I; Helle 200I, I 55 ).

Some women clearly had the right to attend assemblies and many others may have participated on the margins (Sanmark 20I4; 20I7a, Ch. 2; Mundal I994; 200I; Venås I 989). In the earliest Norwegian laws, five groups of women had the right to participate actively in the thing meetings: widows, 'ring women' (singular baugrýgr, unmarried women without close male relatives, who could therefore inherit 'both odal [land holdings] and movables [goods]' (G 275; Larson I935, 4II [our insertions]; Mundal 200I, 249-250), women who were in disputes with other women, 'women who maintain a household' (this classification may have included not only widows, but also women whose husbands were unwell or away from home), and female witnesses (F VI:4, F VII 8; G 275; Clover I993, 369-370; Mundal 200I, 242, 249250; Sanmark 20I4). In most cases, but not all, these women were not required to attend/participate in the thing meetings, and could choose to be represented by a male relation (F I; G I3 I; Mundal 200I, 242).

In later legislation from Iceland, the participation of women was more restricted and widows were not allowed to act as principals in murder cases, and female chieftains were probably not allowed to participate in the thing. It is also unclear whether Icelandic women were allowed to be witnesses at the thing (Grágás Ch. 94 and Ch. 95; Dennis et al. I980, I56, I58; Mundal I994, 600-601). There were, however, exceptions even at this late juncture: women whose husbands were away, 'ring women', widows or unmarried women over the age of 20 could be in charge of their own lawsuits in cases of assault or minor wounds (Bagerius 2009, 54; Clover I993, 369-370; Grágás Ch. 95 and Ch. I I3; Dennis et al. I980, I 58, I 8I).

In medieval Norway and Iceland, women therefore had legal rights to participate in the assemblies, although in varying degrees (Mundal I994; 200I). For women, access to the assembly was largely dependent on marital status and was therefore likely to change during their lifetime (although this would have been the case for many men too, in the event of illness and old age). However, since the laws did allow for women to participate in thing meetings at all levels, where they must have been able to vote along with the eligible men, terms such as 'thingman' and 'representative' could in practice refer to women as well as men. This is fully in line with earlier research demonstrating that terms such as maðr and friáls maðr denoted 'human', rather than '(free) man' (Helle 200I, I45; Mundal I994, 600-60I; Sanmark 20I4).

\subsection{THINGS IN THE LANDSCAPE}

\section{Natural features and topographic attributes}

Assembly sites largely operated outdoors as meetings involving a number of participants that may have lasted several days. The meeting-locations identified in our research are characterised by a set of landscape features. Some were necessary in supporting access to meetings or the hosting of large numbers of people, others appear to have carried a more symbolic or ideological meaning. In the regions studied here, assemblies were often located in relation to distinct topographic features and 
this is something reflected more broadly in our understanding of meeting-places in Britain and Ireland as well. Perhaps the most iconic natural landmark chosen for the thing is Pingvellir, Iceland, a parallel for the top-level assemblies in Scandinavia. Not only is this the location of the largest lake in Iceland, but the site is distinguished by its setting in a natural and dramatic volcanic fault (see Chapter 6). Similar dramatic situations were selected in the Faroe Islands, situated in the mountains along important mountain passes, for example Uppi millum Stovur on Suðuroy (see Figure 6.II). In the Ridings of Yorkshire, once part of the Danelaw, locations of assembly are argued to reflect pre-Ioth century arrangements, and here too evidence attests to the frequent use of dramatic situations, for example along the East Riding ridgeline in Yorkshire (Chapter 6). This seems to reflect broader trends in early medieval England for the use of hills and spurs of land or 'hanging promontories' (Baker and Brookes 2013b). In Ireland meeting-sites, including inauguration sites, were often situated in elevated locations on hills or rocky outcrops (see examples in Gleeson 2018, I08-г09), while judicial assembly sites in Scotland were often located on hills (O'Grady 20I4). There is a tradition across Ireland and Scotland as well for inauguration locations to be especially dramatic. Some of the Scottish 'royal' sites such as Scone and Dunadd take advantage of a prominent natural rise, for example, the 'Moot Hill' at Scone stands on a natural terrace giving unobstructed views that encompassed most of the early kingdoms of Fortriu and Gowrie (see discussion by Driscoll 2004, 8I-87; I998; O’Grady 2008). In Ireland, a site like Rathcroghan in Connaught exemplifies the choice of very prominent locations for promulgating law, for popular assembly and probably for inauguration as well for the kings of Connacht (FitzPatrick 2004b, 8I-82).

Elevated places make good landmarks and are easily locatable, but elevated places for meetings of all kinds may have created a distinction between special activity on the summit and the secular gathering. In the medieval Scandinavian sources, elevated places (including mounds and stones) were relevant to seeking inspiration and wisdom (Davidson I988, I3-I5, I9-20; Sanmark 2010). Hills and mounds were important in Norse cult practices involving the dead and kings, and there are suggestions that one might communicate with the dead at elevated locations and mounds to seek esoteric knowledge (Sanmark 20I0; 20I7a, 86). These references are of course hard to disentangle from the preference for meeting at old burial mounds and contemporary mounds, but they do endorse the idea that high and dramatic places were special in many regions, and that such locations held more than a practical significance.

In terms of inauguration rituals, there may well have been an element of prestige as well in the choice of particularly elevated locations (Sundqvist 2016, 492-497). 'Sitting on a mound' (ON sitja á haugi) was strongly connected to the claiming of kingship and royal rule (Sundqvist 20I6, 493-494). Inaugural and coronation rituals across Europe involved modes of elevating kings on shields and chairs. Highly visible and elevated locations are especially relevant to royal power in Ireland and Scotland. In the context of Elizabeth FitzPatrick and Oliver O'Grady's arguments for the use of ceremonial venues for medieval royal investitures and legislative gatherings, it is also important to note that such prestige locations retained a significance in medieval kingship rituals, and were appropriated in forms of ceremonial investiture to add a 
legitimacy to the medieval/late-medieval proceedings (FitzPatrick 2004b; O'Grady 20I8).

Water too is a striking feature of Scandinavian and North Atlantic assemblies. Water was highly relevant in terms of access and fresh water would have been necessary for people and animals, but it seems to have held an ideological significance. In the Eddic poems, Nanna Løkka has argued that water and rivers are often cited as barriers or division separating the secular and sacred (2010; 2013). Rivers divide the mythological landscape and sometimes deities such as Thor are forced to cross water to access sacred places including the thing (Løkka 20IO, I4I-I45; but most importantly Løkka 20I3; Sanmark 2009). Water as an assembly boundary is evident in written accounts, and wading through water on foot or horseback constituted a ritual crossing into the sacred area of the assembly: where the 'thing peace' applied (Sanmark 2015; 2017a, 86-IO2). It is interesting, therefore, that as late as the I6th century, Olaus Magnus referred to the strict traditions of legal meeting outdoors sometimes on islands (see Chapter 2). Quite a number of thing sites, both in the Scandinavian homelands and in areas of Norse settlement, are often found on islands and isthmuses (ON) eið, also translated as 'portage', see Waugh 2010). Examples of islands include Selaön (Södermanland, Sweden), Tingwall (Shetland) and Eileann Thinngartsaigh (Hebrides), and examples of isthmuses include Sproteid (Sweden), Tingvoll by Tiltereidet (Møre and Romsdal, Norway), Sandsting (Shetland) and Dingieshowe (Orkney), Eidsivathing, Eidsvoll (Norway), Sandsting (Shetland) and Dingieshowe (Orkney) (Sanmark 20I3; 20I7a, 56-57). At Law Ting Holm in Shetland, the Norse settlers adopted an island with the remains of an extensive Iron-Age settlement of the broch period as the location for the lawthing (Coolen and Mehler 20I4). Another famous choice of an island for a major ceremonial gathering is the use of the eyot of Kingston-on-Thames in England as an early coronation site (Barrow 200I). The use of tidal rivers and estuaries for other Anglo-Saxon coronation rituals underscores the idea that water was, in some instances, considered to divide the secular and sacred worlds (Barrow 200I).

Crossing places such as fords and bridges are also common locations for assemblies (Brink 2004a; Meaney 1997; Pantos 2002; Sanmark 2009). These, of course, were perhaps symbolic in terms of their liminality, but these locations were also important resources of mutual communal importance (e.g. Baker and Brookes 20I5, I2-I3; Meaney I997, 234-239; Sanmark 20IO, I80-I8I; Sanmark and Semple 20I0). Bridges, fords and portages facilitated the movement of goods, people and food. It is possible that the use of such locations reflects a communal concern and culpability for the maintenance and preservation of thoroughfares and crossing places. Such responsibilities lay with the land-owner and communities in late AngloSaxon England (Abels I988, 53-57; Brooks I97I; Higham I992, I47-I48; Pantos 2002, I44-I45), while in Scandinavia runic inscriptions demonstrate that bridges were frequently constructed by local families (Brink 2000; Gräslund 200I, 78-79).

Alongside rocks, hills and water, other natural, but less enduring foci, are attested in written and place-name evidence. Several documented hundred and wapentake names in Yorkshire refer to trees, including Skyrack (OE 'shire/shining oak'; Smith I96Ic, 88) and Gerlestre (ON/OE 'Earl's/Jarl's tree'; Smith I92 8, 79). No examples survive today, but both Anderson (I934, I 58-I 59) and Hooke (2010, I72) 
have stressed the role of trees as boundary markers. Trees are recognised in England as potent elements in pre-Christian beliefs, signalled by various late ordinances that attempted to forbid sanctuary and other activities in relation to trees, wells and stones (Bintley 2015). Of course, in some of our study regions, we are dealing with treeless landscapes (see Chapter 6). Other natural resources may also have driven the placement of assemblies, such as wood pasture or grazing.

In sum, hills and elevated places and locations next to, or bounded by, water, including crossing places, were just some of the natural and seminal places chosen for assembly. These choices were likely motivated by a combination of practical and ideological ideas. There were clearly precise choices made about assembly locations in terms of access and prominence, but the reasons were complex and natural landmarks were only one driving factor. It is worth remembering how the Scandinavian sources frequently carried a strict sense of the 'correct' place where meetings should be held, reinforcing the idea that a level of precision was necessary in deciding upon a meeting-place. The evidence presented here reinforces the notion that some early medieval meetings were conservatively managed over time in terms of locus and that this might pertain to a need to maintain control of particular locations, such as nodes in communication networks or landing places. This might explain the hints of deeper trajectories of local practice over the longue durée, linked to communal and shared needs. There are suggestions as well that elite assembly rituals, especially inauguration, frequently demanded prestige outdoor locations with notable landmarks, high visibility and prominence, and in some instances watercourses were also used to dramatize claims to kingship (Barrow 200I). Such examples support the idea of elite 'invention' and the situating of power in landscape terms, in order to promote the legitimate authority of a claimant (FitzPatrick 2004b; Sanmark 20I 5 ; Semple 20I3).

\section{Accessibility}

Accessibility is one of the most important assembly features, after all the aim was to ensure that all those who should attend could reach a meeting. The symbolic and mythological reasons for the location of assembly sites near water has already been emphasised (Chapter 6.2 and above), but water was also important for travel. Assembly sites in the archipelagos of Faroes, Shetland and Orkney, where sea travel was crucial, are all located close to the seaboard. In the Northern Isles of Scotland, this is further emphasised by the use of isthmuses as portages, used to pull boats from one side to the other (Sanmark 2013) (see Chapter 6). Islands have been reviewed above, but together these types of position may have been ideologically suitable for decisionmaking activities (Pantos 2002), but were also eminently accessible (Sanmark 2009; 20I3; 20I7a). The site of Mora in Sweden emphasises the importance of accessibility. It lies at the convergence of a number of communication routes (Sanmark 2009; 2013) and a construction made of gravel, stones and wooden posts is interpreted as the remains of a Vendel/Viking period road or jetty, leading up from the river (Långhundraleden) and connecting to an old road which accessed the site (Larsson 2010; 2013; 2017, 93-94). It is worth remembering, however, that to travel to Mora for many would have entailed a long and challenging journey. Harbours seem to be a regular occurrence at locatable assembly sites, present in examples from Norway and 
Sweden, and inevitably important to the assembly locations in the Northern Isles of Scotland and in Iceland (see Chapters 4, 6 and 7).

In contrast, in Yorkshire in the Danelaw, the pattern of assembly locations shows little if any correlation with traversable watercourses, running counter to the prominence of navigable water, harbours or fording places in the character of thing sites in Scandinavia and other Norse colonised locations (Riisøy 20 I 3; Sanmark 20I3). A high proportion of assemblies associated with springs, wells, watercourses, bridges and fords can be found in southern England making the absence of such associations in Yorkshire within the Danelaw all the more distinctive (Chapter 6; Skinner 20I4). While there are many shared attributes in the situation of assemblies, the topography and resource base of each region clearly exerted an independent influence. While the Norse brought legal administrative arrangements to Yorkshire, their concepts of assembly placement were not, it seems, rolled out across the plains and Wolds. Indeed, this difference in the assembly topography of sites in the Danelaw may well reflect the extent to which pre-existing conciliar arrangements were co-opted under Norse law. In Yorkshire, instead, striking topographic factors in assembly placement include associations with natural ridges and high ground and trees. The pattern of meetingplaces can also be argued to link to early estate boundaries reinforcing the idea that existing arrangements, at least in Yorkshire, were adapted within the administrative set-up of the Danelaw (Skinner 2014; Skinner and Semple 2016; and see Chapter 6).

Iceland and the Faroes are of course unique in our study area, as places without pre-existing populations that were colonised by the Norse. Sea access was vital in Iceland, but once colonised, communities also needed to meet and cross the inland zone. A network of bridle paths existed which connected settlements, and the assembly places (Byock 200I, 46; Sanmark 20I7a, I66-I67). Specific placenames have survived that underline the significance of travel to the assembly site and perhaps acting as visual signposts. In northern Iceland, by the Vaðlaping site, a stream named Pingmannalækur ('Stream of the thingmen') runs down the hill named Pingmannahnjúkur ('Mountain of the thingmen') to the plain where the local assemblies were once held and close by is Pingmannavegur, the 'path of the thingmen' (see Chapter 7.4). These connections show the significance of accessibility for the communities settled in Iceland and the important place of the thing in their lives.

While watercourses might be used in some high level inaugural rituals (see above), in the Northern Isles of Scotland and in Iceland it is worth remembering that watercourses, harbours and portages were also crucial resources for survival. Access and claims to these would have been a source of contention, especially in relation perhaps to the movement of goods and trade and travel in general. Again, therefore, although relating to a later phase of thing development and operation, assembly locations demonstrate an interesting correlation with vital resources that may have needed careful management in terms of collective needs.

\section{Antecedent features}

The association between early medieval assemblies and burial mounds or barrows is frequently remarked upon, but until now, the ubiquitous nature of this preference has not been recognised. Mounds-often old burial mounds-were a feature of 
popular assemblies and royal sites in Ireland, featured at assembly locations in early medieval Scotland, and were a common choice in England as well for the hundred or shire meeting. As the chapters in this volume demonstrate, meeting-mounds were also present at assembly places in Sweden, in Norway and in Denmark. In colonised regions such as Shetland and Orkney, old mounds were also brought in to use in this later phase of thing development, commonly broch remains, which by the Viking Age formed large mound-like features (see Chapter 6; Sanmark 20I7a, 219). As one might expect, the only regions under study where mounds did not feature as locations of assembly, are Iceland and the Faroes-places almost virtually uninhabited until their colonisation by the Norse. In Norway and Denmark, as Chapter 5 identifies, old mounds occasionally provided a focus for meetings - for inauguration rituals and for the thing. Some Norwegian courtyard sites are also located in direct proximity to large mounds and cemeteries, for example at Trøndelag, Skei and Heggstad (Iversen 20I7d). The use of mounds in Norway and Denmark is, however, less frequently attested than in Britain and Sweden, but in Denmark excavation demonstrates that, in at least some cases, associated mounds of prehistoric date can be identified in conjunction (see Chapter 4).

Alongside mounds, other forms of 'old' monument were also used as meetinglocations (see Chapters 4-6) and sometimes in Sweden, Ireland, Scotland and England, palimpsests of monuments formed a backdrop for a later assembly. Forteviot and Scone in Scotland have been explored in depth elsewhere and demonstrated as royal sites and places of inauguration located amid a density of monuments of varying dates (Driscoll I988; I998; 2004). While barrows or mounds predominate in the corpus assessed in this volume, old settlements such as Iron-Age brochs were also used in Orkney and Shetland as thing sites. The excavations at Tingwall suggest that an island settlement of some kind, characterised by hearth material, was levelled to clear a space for the Norse thing (see Chapter 6).

It is also important to note that cemeteries and burial grounds, some with burial mounds and additional monument types, but some without, also feature in assembly placement. Examples can be found in Sweden, in Norway and in Denmark, although associations are more common again in the former. There is good, but not ubiquitous, evidence from England for associations with early Anglo-Saxon cemeteries, some with burial mounds (Brookes 20I9; Semple 2004; 20I3; Williams 2004). The case of Saltwood in Kent, now much cited, demonstrates evidence for gatherings at an early medieval and pre-Christian cemetery complex with multi-focal areas of burial situated in relation to older prehistoric mounds and a routeway. Excavated evidence revealed pits and features that suggest the place was revisited for gatherings in the $\mathrm{mid} / \mathrm{late}$ Anglo-Saxon period (Reynolds 20I8, I28; Riddler and Trecarthen 2006, 67-68). By the mid-IIth century the location was named Heane, the name also carried by the hundred unit in which it was situated, strongly suggesting that the site remained the assembly location for the bundred (Reynolds 2018, I27-I28). In Ireland, it is also now recognised that the cognate to the hundred court, the (OIr) óenach, a popular assembly, was also frequently sited in relation to early medieval burials and cemeteries, and these meetings involved gathering and feasting practices that seem to go beyond the normal needs of a familial unit (Gleeson 20I8). Gleeson argues for distinctions in the evidence that imply inclusive and exclusive gathering sites, with 
some hosting small numbers of burials and a monumental focus often located near boundaries and others with a more central location, operating as potentially more large-scale and communal meeting sites (Gleeson 20I8, II4). The more complex sites also provide evidence for production and crop processing. While such sites sometimes had monumental features and were likely conspicuous, Gleeson argues for a shift in emphasis to a more monumental architecture in the 8 th century. This change introduced the period in which assemblies became central in the formation of provinces and to the proclamation of law and the time when these assembly landscapes became the focus of literature and place-name lore (Charles-Edwards 2000, 556; Gleeson 20I8, II6). It is interesting that these authors, although using very different datasets that some would argue draw on 'Celtic' versus 'Germanic' regions, have come to similar conclusions, arguing that the use of cemetery locations, some with mounds and monuments, represents evidence of the processes of social aggregation beyond the level of individual households and communities (Gleeson 20I8, II4-II7; Reynolds 20I8, I3I). Each argues that these places were central to the emergence of notions of supra-local identity, power, kingship and kingdoms.

Unpicking what seems to be a common tradition of locating assemblies and inaugurations at antecedent monuments and burial grounds is, therefore, a challenge. It is clear that the age of the monuments and cemeteries used as meetinglocations varied greatly. At some sites burial mounds of differing dates, along with associated flat-grave cemeteries, provided an extensive and multi-focal complex for the performance of assemblies (e.g. Gleeson 2018, I I4-II5; Sanmark and Semple 20II). In Sweden, the cemeteries and burial mounds used as meeting-locations might be Migration or Viking period in date (see Chapter 5) and sometimes there are associated monuments such as ship-settings and standing stones and multiple smaller barrows (Semple and Sanmark 20I3). In England, both prehistoric barrows and early medieval pre-Christian barrows and cemeteries were utilised later as hundred and shire meeting-places (Brookes 20I9; Reynolds 201 8; Semple 2013), but so were older hillforts and prehistoric enclosures and linear ditches (Pantos 2002; Semple 20I3). In Ireland, as discussed above, both cemeteries and burial mounds were used to situate popular assemblies and royal sites (Gleeson 20I 5; 20I 8), while mounds continued to be used in royal inauguration rituals right through the High and Late Middle Ages (FitzPatrick 2004b; 20I 5). In Wales, the term (OW) gorsedd meant both 'court' and 'burial mound', suggestive perhaps of early associations between gatherings and cemeteries or old burial mounds (Charles-Edwards 2004).

Thus at some point in the development of local and top-level administrative arrangements, burial mounds seem to have taken on a marked significance in terms of locating meetings and inauguration rituals, but they were not used everywhere. Linked to this, burials and cemeteries, both prehistoric and early medieval, feature as locational drivers for outdoor meeting practices. The funerary reuse of old monuments, burial mounds in particular, is a feature of many early medieval pre-Christian and Conversion period societies. It is a practice evident as well in prehistory, but there is a marked tendency for early medieval communities to situate themselves and their dead, by means of the strategic use of older monuments and barrows (Semple 2003; 2008; 20I3; Williams I997; 2004; 2006). Such acts have argued to represent a need to draw on the ancestral (Williams I997), to signal the land claims of early commu- 
nities (Lucy I992; I998), and to be a stage in the forging of a new elite, aristocratic identity as polities and larger kingdoms emerged (Semple 2013). The use of burial mounds or mounds for assembly, in archaeological terms, is certainly evident after the $7_{\text {th }}$ century and in Sweden, such features are particularly notable in relation to the thing sites of the Viking Age (Sanmark 20I7a, 56-80). In Ireland similar traditions are evident in relation to the royal sites and the more prosaic locations for regional assemblies (FitzPatrick 2004a; 2004b; Gleeson 2015) with increased monumentality present from the 8th century at popular assembly locations (Gleeson 2018).

It is important to consider these trends for situating assemblies at cemeteries and mounds in the context of the connection of mounds with land-ownership. Arguments for the adoption and use of prehistoric mounds for burial as a means of claiming and legitimising claims to land are widely accepted (see above), but additional, interesting evidence is present in written sources that suggests burial mounds were important as long-term markers of land ownership. This is notable in Scandinavia in particular. Here (ON) óðal was land that belonged to an individual or family (Iversen 2008; Zachrisson I994, 220). This kind of land-holding was central to power in Viking-Age Scandinavia. It was a way of determining legitimate inheritance, lineage and legal rights and was relevant to claiming kingship (Sanmark 20I7a, 85). Some of the medieval regulations that survive regarding proving land-ownership mention the relevance of mounds for claiming ancestry and descent (Sanmark 2017a, 83-86; Zachrisson I994, 220-22 I). Óðal land is considered a key structuring concept for Old Norse society, as it defined free individuals and their rights, including their right to vote and appear at the assembly (Sanmark 20I7a, 85). In Norway, medieval regulations on land-holding required a person to prove ownership by listing the generations back 'to the mound and to pagan times' (NgL III: I2 I, Zachrisson I994, 22 I). It is suggested by Torun Zachrisson that the Viking-Age tradition of secondary burial where dead relatives were interred in or above the graves of earlier ancestors was to confirm the possession of land and the person's status (Zachrisson I994). Very similar ideas appear in Irish written sources as well. Early Irish law tracts suggest that hereditary rights to kinland could be delimited by marking the boundaries with grave mound or collection of grave mounds (Charles-Edwards I976; O'Brien and Bhreathnach 20II) and legitimate claims could be demonstrated by ploughing the mound/s demonstrating ancestral acceptance (Charles-Edwards I976). Adrián Maldonado in his discussion of burial rites in early medieval Scotland argues that cemeteries were places of power and that the reuse of older burial places was a strategy of 'embodying' ancestors. He suggests the early medieval cemetery as a place that, perhaps before open-air courts in Scotland, harnessed the dead to acts of gathering, decision-making and oath taking (Maldonado 20I3, 8). In recent studies of early court sites in Scotland, close connections with previous and existing cemeteries are also suggested as well as the reuse of ancient monuments including burial mounds (O'Grady 2008; 20I4).

At the heart of all of these practices is a common set of principles: that landholding relied on signalling an ancestral connection and that explicit physical acts of connection were necessary in exerting and maintaining those claims. Such acts often involved burials and cemeteries, burial mounds and older monuments. In the recent work of Kate Mees on the reuse of antecedent monuments in south-western Britain for early medieval burial, Mees argues first for secondary burial rites using prehistoric 
monuments to be as relevant to British practices as to early medieval English traditions. Secondly she makes a convincing link between acts of reuse and the routeways relevant to accessing upland grazing and shared resources (Mees 20I9), thus suggesting that burial and monument reuse were essential signals of communal, as well as individual, rights and claims to resource and land. There are strong suggestions, therefore, that gathering at cemeteries, ancient/contemporary burial mounds and older monumental features or complexes, was a practice of broader significance to many populations in early medieval northern Europe and that it embraced the notion of burial places and older monuments as useful markers and symbols of hereditary rights and collective ownership. Cooking and eating is discussed above, but it is worth noting that in the Irish and Scandinavian evidence there are suggestions that activities at these sites, monuments and cemeteries, involved cooking and eating together, reinforcing perhaps the collective act and nature of assembling together at a location of perceived ancestral importance.

There is a second strand of practice present, however, in the evidence of situating assemblies at monumentalised places. This involves the appropriation of the past and the monumental development of sites in relation to the growth of elite power. A marked change is evident around the second half of the Ist millennium AD that seems to demonstrate an increased elite investment in the past and in monumentalising places (Sanmark 20I 5; 20I7a, 82-I I 5; Semple 20I3). The emergence of greater elite control over landscape and people may have prompted these processes of appropriation. By the second half of the Ist millennium, evidence suggests that older monuments were used, alongside new forms of monumentality, to situate political and legal conventions. At sites like Anundshög (Sweden), the addition of new standing stones and a rune-stone, as well as a row of large timber posts, are just some of the new architectural traditions added to the site from the Late Iron Age to medieval periods. These kinds of monumentality would have served to create a ceremonial architecture for the thing (Sanmark 20I5). Sanmark has connected such moves to the greater regulation of systems of meeting and governance. Such sites are connected to the royal route of Eriksgata and these processes seem to chart the creation of a royal itinerary that involved the king or chief travelling to meet and be accepted by the people of the assembly. Some of these sites, like Anundshög, had long been active places, but through ritualised royal travel, they were harnessed to a new elite purpose-the ancient burial grounds and mounds, now serving to legitimate the decision-making in relation to a new chief or king and also provide communal identities (Sanmark 2009; 20I5; 20I7a). Such processes appear to have involved the recreation of assembly places with the addition of a greater array of monuments, rendering these sites more relevant to top-level and elite signalling. Gleeson (2018) has argued for similar processes in 8th-century Ireland. In early medieval England, an increased elite interest in the past is suggested in the 7 th century, signalled in overt demonstrations of power through rich burials that reused, or appropriated, older burial mounds and in the situation of 7 th-century royal palaces within seminal landscapes of large older monuments (Semple 2013, I3-62, I93-223). These changes were broader than England and can be linked to a need on the part of elites to establish narratives of ancestry and claims (see arguments in Semple 2013, 48-62). In late Anglo-Saxon England outdoor top-level meetings persisted and royal inauguration too sometimes 
made use of outdoor theatre and natural features, while the written record reveals how ancient remains and monuments continued to exert an agency as legendary and powerful places and remained significant to claiming power and denoting local landholding (Semple 2013). While ancient monuments were still chosen for meetings, their potency as an aid to creating a legitimate arena for decision-making and power may also have led to new appropriations and practices involving burial mounds and other ancient monuments. FitzPatrick's work on Ireland demonstrates that such choices were an active early medieval strategy (FitzPatrick 2004b; 2015), but that such practices were both continued and revisited by the dynastic families of Ireland as late as the Nine Years War (see Chapter 2).

It is also important to consider, in this context, how traditions might be invented (Hobsbawm I990). There is evidence that points to the purposeful creation of some mounds to suit the needs of a meeting (Sanmark and Semple 2008; 2010). Adkins and Petchey (1984) argued this many years ago for England although some of their evidence no longer holds true. A similar process is suggested at Aspa Löt in Sweden, where a non-sepulchral mound was constructed perhaps at the same time that a row of stones and rune-stones attesting to the thing were raised in the I ith century (Sanmark and Semple 2008; 20I0). While it is possible that a mound had simply become an essential element in the architecture necessary for a meeting-place, establishing and monumentalising an assembly or thing, may also have been a way of securing power within local systems of governance. It is interesting that in Yorkshire, a pre-Iothcentury pattern can be discerned in which the use of mounds closely situated to estate boundaries seems to have prevailed (see Skinner and Semple 2016 and Chapter 6). It is uncertain if these were prehistoric, Roman or early medieval pre-Christian burial mounds, but what is striking is that the organisation of districts seems to have been closely linked to choosing a prominent marker by the limits of an estate centre at which collective business might be conducted (Sanmark 20I7a, II7-I42; Skinner 20I4; Skinner and Semple 20I6). It is worth considering whether such patterns draw on a more significant time-depth, reflecting the division of land-holdings around real or perceived ancestral claims, or if later, centrally-planned processes of division produced this kind of systematic pattern (for arguments for a Ioth-century hundred geography in England, see Molyneaux 20I5, I4I-I 55). In Yorkshire this pattern appears to be pre-Danelaw possibly involving a regularisation of land-holding and assembly in the 8th century, a process by which old mounds and monuments may have been drawn in as new locational markers for local meeting-sites (Skinner 20I4; Skinner and Semple 20I6). More overt appropriation and invention is evident in the Northern Isles of Scotland. A striking adoption is that of Maeshowe on the Orkney Mainland (whether as an assembly or for other purposes; see Chapter 6). This choice, alongside the use of other seminal locations and monuments, such as that evidenced at Law Ting Holm, describes the new Norse authority in the islands-physical symbols of new claims on the land.

Ancient places and particularly burial mounds thus proffered powerful sites at which to create enduring senses of memory, place and identity that linked people to their immediate landscape. Monuments were relevant to expressions of legitimate ownership, both collective and individual. Assembly played a mediating role, helping to harness the ancestral power of ancient sites to local agendas and later to elite 
concerns. What is evident, is that over time the physical remains of the past as well as assembly practices were brought more fully within elite and royal ambits.

\section{Mediating resources}

Assembly sites often combine a range of assets: they are visible, accessible, located at important seasonal resource zones and are marked by many ancient monuments or cemeteries pointing to long-term activity and/or long-held local or regional importance as a centre. The term 'resource' is used here in its broadest sense. Many of the topographic associations outlined above such as water, harbours and crossing places and necessary features such as rich lowland pasture or upland grazing, would have been vital to human activity in the localities. Other less obvious resources might include spiritually resonant places, locations with ancestral associations or sites considered symbolic of ancient ties to land (Semple and Sanmark 20 I3; and above). It is noticeable that at some of the most seminal and famous assembly sites, for example at Yeavering in England, were in locations with multiple numinous qualities (Semple et al. 2017; Thomas 2018). Here, gatherings and royal performance were situated on an elevation, at a confluence of routes, by a fording place, in the shadow of a hillfort, on a plateau marked by prehistoric remains etc. The use of this palace site for large seasonal assemblies in the 7 th century may have been just one stage formalising longheld practices of seasonal gathering (Semple et al. 20I7).

Assembly was certainly a 'liminal' affair (see Pantos 2004b for discussion; and Sanmark 2017a, 3, 93), but sometimes this 'liminality' may belie that assemblies were situated in relation to prominent resources. Water, food and shelter, wood, grazing, and wetlands were all crucial to human survival and less obvious resources might include the ancestors, the supernatural, herbs and medicinal plants, fishing grounds, spiritually resonant places, or sites of legend and memory (Semple and Sanmark 20I3, 528). Marginal zones at the edge of cultivated and settled landscapes were significant to populations for the provision of common woodland, grazing and wild foods (Svensson and Gardiner 2009). In addition, these resource areas were shared between communities and in some cases were used for millennia, while heath and common land, particularly shared grazing and upland resources, were central to communal use over lengthy periods. In previous sections, Oosthuizen's arguments for the importance of common resources to the shape of emerging social and political structures in early Anglo-Saxon England have been reviewed. There are connections in our datasets that link meeting-sites with the management of shared resources on a seasonal basis. In England, evidence for early meeting-places suggests associations with wood pasture and the (OE) feld 'open grazing land'. Battle locations for this early time-period are often named in relation to the feld as well, underscoring perhaps a role as both liminal and communal land (Hooke 20I0; Semple 20I3). While intangible in archaeological terms, we should not underestimate the importance of the seasonal cycles of activity and mobility relevant to the rural communities of the Late Iron Age and early medieval eras. In a discussion of long-term ritual practices along the River Witham in Lincolnshire, England, the seasonal fishing rights on the river are argued to be central to a longue durée of ritual interaction and practice around the causeways providing crossing places along the water-course (Everson and Stocker 20I I). 
Many thing locations and their early precursors may similarly have served as meeting-sites at key resource zones. The Norwegian courtyard sites are recognised to lie at the boundary between cultivated agricultural land and the outlands (see for example, Saupstad, Lofoten and Hov on Løkta; Storli 200I) and in wetland landscapes - for example, Bjarkøy on Bjarkøya and Bøstad in Lofoten (Johansen and Søbstad I978; Storli 200I). Such zones are recognised as important economic areas that could provide a surplus and thus a basis for power (Øye 2009). Associations with (ON) lyng 'heather' can be found such as Tjølling, Norway (see Chapters 4 and 5), Lionga thing outside Linköping and Ljunga in Vifolka härad, the latter two in Östergötland, Sweden. The place-name Ljunga is also found near assembly sites in Södermanland, Sweden, in several instances (Sanmark 2009, 233). Such associations might intimate the location of meeting-sites in proximity to shared open land. Practical considerations are relevant as well, as it would have been wise, in some seasons, to avoid the main areas of cultivation. Some of the Viking-Age great hall complexes in Scandinavia such as Lejre, Denmark, are acknowledged to lie in hunting grounds, as are some Anglo-Saxon palaces used for royal councils and meetings in the roth and I Ith centuries, e.g. Cheddar, Somerset (see Rollason 2012 for summary). Hunting grounds are also argued to be important as places of assembly in Irish tradition too (FitzPatrick 20I2; 20I5). Therefore, while liminality may have been important, accessibility was perhaps just as significant. Most of all shared accessibility to key resources and managing access and responsibility for those resources, may well have been driving factors in the establishment of collective mechanisms for mediating feud, conflict and ownership. As noted above, the relationship of assemblies to all kinds to water, and particularly to harbours and portages in the Northern Isles may also demonstrate a need to control places of key importance or to manage shared access.

More detailed interrogation of the location of assembly places in relation to topographic and geographical placement is needed. We can assume that land and shore access, grazing and woodland management and common land were just some of the facets of daily life that required negotiation between communities and to which groups might have laid claim. The sharing of resources, particularly in the challenging times of the first half of the Ist millennium $\mathrm{AD}$, may have created a need for action and activities that reinforced a sense of group ownership and collective identity and that also facilitated interactions between households.

\subsection{CONTEMPORARY THING STRUCTURES AND FEATURES}

The imposition of new monuments at thing sites deserves further interrogation. These kinds of structural addition fall into two categories which are not mutually exclusive. On the one hand, some features added to sites had a functional purpose such as housing for those attending a meeting, on the other we have features that relate instead to activities and signalling, that had a more ideological or ceremonial purpose. Temporary furnishings are hinted at by place-names and written accounts. Wooden benches, for example, are mentioned in place-names and in late-medieval Scandinavian laws. Tents were also a mainstay for anyone attending an outdoor meeting. 


\section{Fencing the thing}

Standing posts and fences are a feature of assembly sites and things. Written sources clearly allude to the fencing or enclosure of sites and in some of the earliest sources, it is clear that the creation of this enclosure at the thing was a holy act, creating a sacred space for a meeting. The $(\mathrm{ON})$ vébönd $(\mathrm{ON}$ vé $=$ holy) is thought to have comprised a sanctuary enclosure created by wooden poles connected by a band. This structure according to Egil's saga, existed at the Gulathing in Norway where it is reported that the poles were made of hazel wood (Friðriksson and Vésteinsson I992, 3I). A similar structure, although without any specific mention of wood types, is also mentioned in the Frostathing Law, circumfencing the Law Court (ON lögrétta), and is mentioned again in the laws of Magnus the Law-Mender. In Germanic and Norse mythology, hazel was the tree of god Pór, and thought to be a source of wisdom; the use of hazel poles for enclosing courts/law areas is attested in Frankish Law (Lex Ribuaria 67:5) (Niewegłowski I 988, I 57-I 58). Hazel poles would have been rather small in diameter, and as a number of sources indicate, it was intended as a temporary enclosure, to be removed after a meeting had ended. The rite of fencing the assembly is discussed in more detail below, but it is worth noting that this kind of enclosure for assemblies seems to have been in use in the Faroe Islands and in Iceland too. The Hundabrævið tells of the Faroe lawthing to have taken place within a vébönd (Brink 2002, 90), and the Icelandic Jónsbók (I28I) mentions it too. In I329, it is reported that lawman Snorri Narfason set up vébönd at the althing in Iceland, and this seems to have been also done in the following centuries (Friðriksson and Vésteinsson I992, 3I-32). The use of hazel in Viking and medieval Iceland is highly unlikely as there have never been hazel trees there, nor were any hazel remains found during archaeological investigations of Viking and medieval sites (Bell 2010, 43). Interestingly, the reference to a vébönd from the Icelandic Egil's saga does explicitly refer to hazel, as those from Norway do. Icelanders probably used birch instead, although the import of hazel for this purpose is conceivable, given its highly symbolic meaning and importance. In Shetland, for example, hazel has been known at least since the Neolithic period (Edwards and Whittington I998) and would have been easily available for use.

A few possible vébönd-like constructions have been identified archaeologically, although we do not know if these features were referred to in these terms. Thing-site enclosures are known at Anundshög and Gamla Uppsala (Sanmark 201 5; 20I7a, Ch. 4; Semple and Sanmark 2013). Another site, which seems to have had a religious purpose and may not have been an assembly location, is at Ullevi near Linköping in Östergötland, Sweden. The place-name refers to the god Ull and the word vé. The site dates to c. $400 \mathrm{BC}-\mathrm{AD} 400$ and comprised a large rectangular fenced area which enclosed a number of cooking pits and a path. The rectangular enclosure consisting of a series of small post-holes is interpreted as the remains of a vébönd (Andrén 2005, I IO-I I 2). A similar construction, although consisting of larger posts, has been excavated at the Vendel-Period cult site at Lilla Ullevi in Uppland, Sweden (Bäck et al. 2008; see also Ødegaard 2018b). It is also worth noting that Tynwald Hill on the Isle of Man was still being fenced off annually for the assembly as late as the I 4 th century (Clucas r925a; 1925b). 
By coming together to camp, to fence and clear a site, or to repair a booth, individuals became part of a regular communal activity, bonding the group in readiness for the purpose of assembly. Such processes were therefore long-lived, widespread, and not confined to pre-Christian activity. New evidence has emerged in recent years for large monumental fenced enclosures at Jelling in Denmark, Gamla Uppsala and Anundshög in Sweden (see Chapters 4 and 6). There are interesting hints here that these features echo the need to enclose the area of an assembly in the manner of the wooden fencing of the vébönd, but these rows of posts seem to represent a somewhat more monumental investment. These are discussed further below in relation to activities at the thing.

\section{Standing stones, stone settings and rune-stones}

Alongside the raising of fences and standing posts, standing stones, stone settings and rune-stones were added to some thing sites, notably those in Sweden (Brink 2004a; 2004b; Semple and Sanmark 2013; Sanmark and Semple 2010). Such monuments underscore individual interest in thing-site maintenance. Rune-stone inscriptions attest to individuals 'raising' stones and 'creating' things. These do not invalidate the idea of a collective responsibility for thing sites, but instead point perhaps to an increasing need to monumentalise and maintain a site.

Brink identified the setting up of standing stones as an element of thing architecture (2004a; 2004b). At sites such as Bällsta and Anundshög in Sweden, stones were used to create settings (Sanmark 20I5). Five stone ship-settings were probably added to the site at Anundshög in the Viking Age (Sanmark 20I7a, I3I), while the square setting of stones at Bällsta remains undated. Linear stone monuments are found at assembly sites too, such as Aspa Löt and Kjula ås (see Figure 4.9) in Södermanland and Ängebyvad in Uppland (Sanmark 20I7a, 97), while some of the first written evidence for the thing comes from rune-stones raised at thing sites in the I Ith century (see Chapter 4). Two rune-stones erected around AD IOIO-IOI 5 survive at the assembly site in Bällsta, Uppland, Sweden (SRD, U 225 and U 226). The runestones are standing on a terrace, most likely constructed for meetings together with a slope forming the 'stand' for the audience. The runic inscription attests to the 'making' of the thing site as a memorial and presumably to the creation of the square setting of stones as well (Sanmark 20I7a, I, 78; Sanmark and Semple 2010).

\section{Thing structures}

Booths (ON singular búð, plural búðir) in Iceland were turf-built, sometimes reinforced with stone, following traditional building techniques (see Chapters 6 and 7). An I 8th-century sketch (see Chapter 2), seems to show these as 'tented' structures, reflecting a roofing technique that used a cloth-covered timber frame (Pórðarson I92 I-22) (see Figures 2.3 and 6.3). Indeed according to Grágás, assembly attendants and participants had the right to build booths (Dennis et al. I980, III-II2, 24I; Jóhannesson 1974,74 ) and a chieftain was required to come to the assembly in a timely manner to allow time for the roofing of his structure (Dennis et al. I980, 43; see too Chapter 6). 
While the laws speak of individual responsibility; as a group, those attending the thing were responsible for the maintenance and collective arrangements on the site (Friðriksson I994, I07; Vésteinsson 2013). In this way, the booths themselves as monuments can signal something of the political dynamic of the thing community: the grouping of the buildings could represent different phases in the evolution of power, their phases signalling the consolidation of power over time (Friðriksson 20II, 354-357). By building booths, the owners also signalled their participation in the collective assembly (Vésteinsson 20I3). Similar processes may have been at work in Norway at an earlier period.

Courtyard sites represent collections of houses situated around an oval semi-circular open space or yard (Iversen 20I5a; 20I7b; 20I7d; Johansen and Søbstad I978, 55; Storli 2006, 2010; and see Chapter 5). The number of houses at these sites often corresponds to the number of local assembly units within historically documented areas. This suggests that each local community had its own booth at the site (Chapter 5; Iversen 2015a), just as the system seems to have functioned in Iceland with possible correspondence between number of booths and parishes (Vésteinsson 2013).

Each year, before the meetings began in Iceland, the assembly attendants returned to their booth, put new roofs on top of them and took the structures down again after the meetings were over (Friðriksson 1994, I07; Mehler 201 2; Vésteinsson $2013)$. Besides their functional purpose as dwellings to camp near the assembly sites, booths can be seen as highly symbolic structures that mirror power consolidation in Iceland (Friðriksson 20II). Orri Vésteinsson has convincingly assigned two levels of symbolic meanings for the booths at Icelandic assembly sites. On the one hand, booth-building is symbolic of the participation of the community in the assembly. Above that, a political symbolism is added by the size of the booths, their number and their arrangement, as this seems to have reflected the units of the administrative landscape in Iceland (Vésteinsson 20I3). To date, booths have only been identified at Icelandic assembly sites. They may well have been part of Greenlandic assembly sites too (Sanmark 20IO) and according to written sources they also seem to have existed at the assembly site at Tinganes in the Faroe Islands (Vésteinsson 2013) but no examples have yet been found there. Tents are mentioned in the sagas (Olav Tryggvason saga, Ch. 47), are possibly referred to in the place-name Tjaldavík ('Tent bay') in the Faroes (Thorsteinsson 201 2, 35), and may feature in a diploma attested at the Eidsivathing in Norway (DN II, 304/I349) (see Ødegaard 201 5, 346).

It is also necessary to discuss some of the more tenuous, yet commonly mentioned thing monuments. The descriptions in early sources of fencing or encircling a thing site (e.g. see the Gulathing Law, Ch. 9I, where a thing site is detailed as being Pingring or round in shape; Brink 2002, 90), has led to many mis-identifications of thing locations. In the I9th century, when many Icelandic assembly sites were investigated by antiquarians, dómhríngar (ON dómr, ‘doom'; singular dómhríngur) were identified at almost every district assembly. Dómhringar, or court circles, described in medieval literature, were thought to be solid constructions to host the panel of judges during their discussions, and according to Grágás, the law court was seated in a dómhríngur (Friðriksson and Vésteinsson I992, 27-28). Critical research focused on a number of alleged dómhríngar in Iceland has shown however that these structures were identified 
as assembly sites merely as a result of their round shape. Many excavated examples have turned out to be enclosures built for other purposes (see Chapter 6). Friðriksson and Vésteinsson (1992) have suggested these round enclosures were simply set up to provide an area of grazing for the horses of the assembly attendants so that no farmland would be damaged (Friðriksson and Vésteinsson I992, 27-3 I, 38-56 with figs $8, \mathrm{I}_{3}$ and $\mathrm{I} 7$ ).

What is striking is that the evidence offers hints of both individual and collective responsibility in the evidence for contemporary investment at sites and their maintenance. While the evidence here is drawn from a broad variety of thing sites from different regions and times, the range of collective endeavours provides an interesting insight into local-level organisation and responsibility, for example for clearance and fencing. In Iceland, the strict rules on arrival and establishing the booth at assemblies must have made for a vibrant collective event as families arrived and set up their individual booth (see Chapters 6 and 7). In Viking-Age Sweden, however, thing sites were being 'made' and dedicated by individuals, indicating the ways in which families might be expected to contribute to collective organisation, but also suggesting an ability for individuals to exert or claim more power over the thing. It is within the more complex settings that greater investment by elites can be discerned. The erection of standing stones, rune-stones and the large settings of timber posts for fences or to create standing rows of posts, for example at Jelling in Denmark or Gamla Uppsala in Sweden, suggest architectural fashions that may have been aimed at delineating space and directing movement to and on these sites (Sanmark 20I5; Semple and Sanmark 20I3). An interesting parallel can be found in the appearance of royal palace complexes in England in the 7 th century. These seem to have been only temporarily occupied sites, but were monumental in scale in terms of their timber halls and architectural settings (Thomas 20I8). There is a level of organisation at these sites that hints at the control and direction of people and at Yeavering in Northumberland, in addition to the hall complex, a large timber open-air theatre implies the need for structures linked to managing largescale meetings. These palace sites in England are thought to have been royal sites serving an itinerant king and retinue and to have been places where tribute was exacted and authority displayed. As discussed previously, these are often situated in relation to older prehistoric monuments that would have enhanced the impact of their situation in the landscape. The focus on these prehistoric associations, however, has sometimes overshadowed consideration of the use of the monumental nature of the halls, the bounded space and enclosures and standing timber posts or markers on these sites. The structured layout and orientation and alignment of buildings and their doorways suggests these complexes may even have served as settings for elaborate ritual performances. Likewise, in Ireland, there are suggestions that over time, the large popular assembly sites acquired greater complexity and became more monumental in nature acquiring new enclosures, structures for coursing animals, and in some instances pre-existing monuments were recut and newly delineated (FitzPatrick 201 5, 63; Gleeson 201 5, 45; 2018). Patrick Gleeson suggests that these changes relate to the development of major supra-regional kingdoms in Ireland from the 8 th century onwards $(2015,46-47)$. 


\subsection{THINGS IN CONTEXT}

In the sections above, and in previous chapters, significant advances have been made in understanding the development and operation of assembly systems and meeting-places in Scandinavia and in the regions colonised by the Norse. Similarities and differences are identified in relation to the landscape locations, architecture and activities of the thing and its cognates. We now explore the broader trends in the evidence, first in relation to assembly beginnings and then in terms of elite and royal control of sites and consensus mechanisms.

\section{Beginnings?}

Assemblies and gatherings in various forms are part of all societies, pre-literate and literate. As Chapter I argued, temporary gatherings are known from early prehistory to the present. These can serve many different purposes: commerce and trade, political and judicial decision-making, military, and cultic or religious functions. They can also provide a forum for multiple activities, for example, production, trade and cultic activity. Within complex societal development, assemblies can play a crucial role in driving alliances or determining cultural or political differences (Swenson 20I8). They can be used to reaffirm and delineate established norms and rules (Ugwuanyi and Schofield 2018), but can also provide opportunities for a short time to adopt a different kind of group identity (Semple 20I8). An assembly can also achieve significant power through the collective presence of a large group-crowds can be volatile and dangerous. It is hard, for example, to win over a large crowd to an idea or concept. Rules and rituals can, however, create cohesion and a sense of common purpose and identity. Erving Goffman argued that human behaviour should be understood as an evolving social process of people relating to each other (I959). His work promoted the idea of dramaturgy: that social behaviour can be understood as a performance with actors and spectators and that the stage and setting, appearance and manner of performance were all central to the communication, negotiation and development of social values (Goffman I959; I967; I974). In this context, the temporary assembly as a locus of performance is an unrivalled opportunity to bring about changes in social order. For a time participants can leave behind norms and participate instead in a new form of collective identity (Semple 201 8). Large gatherings and events are a powerful means of creating a common collective sense of belonging (Gardner 2018), but can also encourage difference (White 2013; and papers in Korom 20I3). The mechanics of a performance can be controlled to bring about a particular result (Clarke and Mangham 2004). In this way, the temporary gathering or assembly is a forum ripe for dramatizing rank and authority in order to gain more power over individuals and groups (Geertz I980).

In T J Chevral's (T L Thurston's) exploration of power and conflict in the southern Scandinavian Iron Age, the assemblies mentioned by Tacitus and other writers are argued as regulating mechanisms on the power of aspirant elites and kings (Thurston 200I, 45-48). In the Late Iron Age in Gaul and Britain, public gatherings and assemblies are attested in late classical sources, but also in the archaeological evidence and material culture that survives (Fernández-Götz 20I2; Moore 20I2; 
Poux 20I2, I77-I9I). The emergence and development of polyfocal monumentalised complexes in south-western Britain, as symptomatic of an emerging need to stage and regulate power and authority, is a particularly interesting insight into the part seasonal assemblies may have played in the Late Iron Age (Moore 2012). The large gatherings at oppida in Gaul, that perhaps involved decision-making on power, justice and military matters, point to a need for modes of meeting and consensus driven by greater social complexity (Fernández-Götz 20I2; 20I4a; 20I4b). Chevral (Thurston) has questioned the very purpose of hillforts and oppida, pointing to their varied functions and the rarity of elite associations, suggesting that they could be reconceived as communal sructures (Thurston 20I0, 222). This is within a much broader argument that demands a reconceptualisation of power in the Iron Age, emphasising a heterarchical system of mutually dependent and regulating activities in which the assembly played a part (Thurston 2010, 193-254). Chevral (Thurston) points to the way in which the Iron Age can be characterised by both its 'unity and diversity... where broadly shared elements contrast with regional distinctiveness':

\footnotetext{
...few have looked at Iron Age Europe in a multiscalar, nested manner, in which polities lie in within territories, territories are nested within sub-regions, within regions, and macroregions, that together constitute a continent wide scale of phenomena, all differentiated by local histories but connected through their shared history of interaction or common origins and their organization into local and regional alliances, trading relationships, and belief systems (Thurston 2010, 237).
}

This is a particularly striking and relevant paradigm in which to consider the evidence presented here for the assembly systems and practices of northern Europe, where broad common elements are present, but are balanced by signs of regional difference. Rather than seeking to situate evidence within ethnic frameworks, and argue for broad pan-'Celtic' or pan-'Germanic' traditions of power, Chevral (Thurston) suggests that we should understand the commonalities of Iron-Age power as a form of shared practice (Thurston 2010, 237).

As discussed above, our project has established interesting evidence for the inception of forms of local/supra-local assembly practices in the Iron Age in Norway, but connecting this to the Viking-Age and medieval thing remains challenging. Likewise, the concept of a single early pan-Germanic idea of meetings geared to socio-political and judicial functions is hard to accept given the sheer diversity in the forms and types of meeting-sites across Scandinavia. Yet there are some remarkable similarities in the basic structures of administrative organisation and locational attributes and these are not confined to the Scandinavian homelands, but are evident in Britain and Ireland as well. This is particularly significant because these shared characteristics straddle regions long considered culturally separate and representative of 'Celtic' versus 'Germanic' traditions. These common features, in terms of unitary arrangements, naming and topographic/archaeological associations, are assessed below.

In Scandinavia, the system of administrative units served by assemblies, in simple terms, comprised large law provinces divided into and smaller local hundreds. The close-grained assessment of unitary arrangements in parts of Norway and Sweden, 
seen in Chapters 4 and 5, demonstrates that this basic structure of local and top-level divisions was a common system. At the basic level, the primary unit was a hundred or its cognate. As we have seen, in parts of eastern Norway, in Viken, the $(\mathrm{ON})$ pinghá, the local 'thing districts', were small units that remained intact for centuries, acting as the building blocks for later and larger divisions. While these arrangements are not in evidence everywhere, this does indicate how small units of territory might describe a basic unit of collective division, used to denote legal and even military responsibilities. The $(\mathrm{ON})$ pinghá are, with some provisos, cognate to the $(\mathrm{ON})$ herad, the MDan herred and the hundred. At the heart then of the thing institution in Scandinavia is a common principle of division and, as Chapter I sets out, broader commonalities exist in terms of how land and territory was divided in Britain and Ireland and how assemblies operated in terms of these units of division. In England the hundred meeting served a unit composed of roughly a hundred hides, the hide being 'the land farmed by, and supporting, a peasant family' (Faith I999). The mallus in Francia was also an assembly that served the centena or 'hundred' (Barnwell 2004, 242). Even in Wales and Ireland the land-holding units, the cantred/trícha céts, appear to have been defined in relation to a hundred unit. In western Scandinavia, (ON) fylki, in this volume translated as 'county', seem to have represented 'folklands' (see Chapter 5 and above) and are argued to reflect a form of pre-Christian organisation. The naming of these units emphasises a relationship between the people of a territory and a sense of jurisdiction and ownership of the activities within that 'land'. Indeed (ON) land, 'land', seems to have been a widespread Scandinavian term for a geographically defined legal entity. It is important to recognise that these basic and sometimes early units of division in Scandinavia, Britain and Ireland, pinghá, herað, centena, cantred, cét, fylki etc, are all based on multiples of a primary building block. That primary basic structure is, to paraphrase Rosamond Faith on the meaning of the OE hide, likely a unit of land supporting a single household or farm. Chevral (Thurston) argues for the single independent household as the main building block or unit of production in Late Iron-Age society (Thurston 20I0, 238). This is based on Sastre's model of agrarian society in which households manipulated social structures and practices to benefit themselves (Sastre 2002). This demonstrates the ways in which unitary divisions and assemblies may have emerged and developed, and connects the local level of assembly, the thing or hundred, with a basic organising principle and unit used to divide land and people. Terms like fylki and folkland in Sweden hint at a process of 'coming together' to discuss and manage that collective resource.

The linguistic term thing, as Chapter I argues, is thought to be much older than the documents that name the thing in Scandinavia in the High Middle Ages (Bjorvand and Lindeman 2007, 940). The widespread use of the term ping in Old Norse, Old English and other Germanic languages, implies it was an active common concept across a number of regions during the Ist millennium AD. Its link to the basic unit of territory in Viken is interesting, suggesting its early connection to the organising principles for rural agrarian communities. Ping, however, is not common to all regions and is not the only term used for an assembly. In Anglo-Saxon England, the use if OE ping 'to hold a meeting' is rare beyond the earliest written laws (Pantos 2004a, I83). Instead, OE mæthel 'assembly' and gemot 'council/moot' are the terms that feature in place-names and the latter is a far more frequent (Pantos 2004a; 2004b). In southern 
Germany, the Old High German term for an assembly site of the early medieval period was mahal (related to the OE mæthel) and from the Ioth century onwards, the term ding is known. In Ireland, the OIr terms for assembly were varied, including óenach, airecht, cét, dál and rígdál, to name just a few, with terms often referring to an assembly of a specific type or function (Gleeson 20I 5, 34). Thus despite a basic commonality in the make-up and components of administrative divisions, there are still major variations in the terminologies for the consensual mechanisms used to manage the basic units of local organisation. This signals the varied ways in which assemblies operated at different levels for specific purposes and regional distinctions on naming and functions.

Discussion here is restricted to the regions of Scandinavia, Britain and Ireland, and occasionally Francia, but it is worth underlining that we know that assemblies existed more broadly in post-Roman Spain and in Frisia and Saxony. In Spain, despite the complications of surviving Roman traditions of local governance and the introduction in some areas of Visigothic concepts of power and organisation, and later Arab and Berber systems of social organisation, written sources attest to a variety of mechanisms (Glick 2005, I44-I83; Kulikowski 2005; Stocking 2000). Collective management existed at a local level for essential resources such as irrigation channels and mills where the collective group took responsibility for the resource and resolving feud (Glick 2005, I44-I 83). Much larger forms of popular and public assembly also took place, which were highly managed and theatrical and served the purposes of elites and the church (Stocking 2000, I66-I69). This demonstrates that here, as well, assembly operated at the local and top levels serving as mediating mechanisms for collective management and as a moderator on elite action. In Saxony, documentary accounts relating to the 9 th and Ioth centuries indicate that assemblies took place serving a number of levels of authority and may have been related to large cultic hall complexes, but the locations and physical sites of these meetings remain untested (Ehlers 20I6).

Bringing all of this evidence together, of course, conflates the practices and regimes of different places in different time-periods. Why should such systems be related or share affinities? Processes of governance changed over time; something strongly exemplified in Chapters 4, 5 and 6, demonstrating that the thing structures and systems of Scandinavia changed and evolved even if concerns persisted over regularity and correct procedure. The Frankish mallus, the Old English witan, the English shire and hundred were also evolving structures, and were not static in time or place (Barnwell 2004; Sanmark 2017a, 35 ).

The similarity of some principles, however, such as a common set of ideas of division, a basic household unit, common locational aspects and similar kinds of activity, remain compelling, hinting perhaps at the kind of common rural ideology suggested by Chevral (Thurston) (see above). Susan Oosthuizen has recently made convincing arguments for the rights of common property, that is the co-ownership of resources like pasture, wetlands, woodlands fishing waters etc., as a highly significant and shaping factor in the administrative and assembly systems evident in Anglo-Saxon England (Oosthuizen 20I6). Common property rights are usually legal rights, they also need to be flexible and changing and are based on equity and operate through oral traditions of custom and practice providing a flexible pragmatic system of sharing 
and management over the longue durée (Oosthuizen 20I6, 20). In England, numerous authors have argued that regional identity may well have hinged on collective rights and practices with common resources forming the 'raw material of early political development' (see Faith I997, I47; but also Oosthuizen 2016, 23). Such rights were not merely evident in England, however, they existed in early medieval Wales and in Ireland common land was held by the (OIr) túath or kin-group (Davies I982, 63). In sum, Oosthuizen argues for the long duration of land-holding and land-dividing principles rooted in prehistoric forms of collective organisation, based upon the need for rural communities to share and negotiate common resources and thus manage feud, conflict and the breakdown of sharing mechanisms. Most significantly, such processes need not have any particular ethnic or cultural constraint. Oosthuizen makes the point that these kinds of common property rights offer a stable structure for collective governance which, particularly in the form of assemblies, could be easily harnessed to political expression (Oosthuizen 20I6, I7). In a similar vein to Chevral (Thurston), Oosthuizen's model posits that 'collective governance, with its emphasis on horizontal decision-making, was a complement, not a threat, to the growing power base of the kingdom builders' (Oosthuizen 2016, I7) - in other words, such systems were essential in regulating rural life in the localities, but were equally apposite to the emergent power structures of the elite.

Tacitus, in discussing assembly practices in the northern regions in Ist century AD, differentiated assemblies serving the pagus (Lat.), or the smallest of the administrative districts of a province, and annual collective assemblies or cult gatherings that served a regional level of division (Iversen 20I3; Sanmark 20I7a, 32-33). While we must be extremely circumspect of this one source, at the very least the text implies a range of types of assembly may have existed in his regions of study, with differing purposes, different levels of regularity and that operated at different sizes and scales (Iversen 2013). From region to region, the evidence presented in Chapters 4, 5, 6 and 7 points to locally and regionally distinctive arrangements for assemblies that responded to the geographic nature of territories and their resources and the needs of the populations inhabiting them.

Resources and territory seem to have been managed at both a local and regional level, with assemblies of varying size and regularity serving these two tiers of cooperation. Such arrangements are reflected in the basic organisation of the medieval thing across Scandinavia and in the regions beyond. Many of these meetingplaces, whether local or top-level are connected to what can be termed resource areas. These, as the sections above argue, can include uplands and open lands for common use for grazing, portages and crossing places, bridging and fording points, heather/heath, wetlands and hunting grounds. Crucially these connections are not confined to the thing sites of Scandinavia, or their potential precursor sites; these kinds of relationship can be argued for the local and supra-local assembly sites in many regions. Connections to hunting grounds are argued for Ireland and England (FitzPatrick 20I2; Gleeson 20 I 8, I I I; Rollason 20I 2), while in Anglo-Saxon England connections with bridges and fording places, with the feld and upland areas, with tracks and drove routes, are all attested (Pantos 2002). Baker and Brookes (2013 b) have argued for particular associations in England between hundred assemblies and 'hanging promontories' connected with maintaining visual dominance and fields of 
view in the landscape. These hanging promontory situations might also reflect the essential need for maintaining routes of movement from lowland to upland and access to common grazing areas for rural communities. Connections with key natural resource areas and routes are some of the basic influences on the situation of meetingplaces in all regions studied here. Returning to the proposals of Chevral (Thurston) and Oosthuizen, if the two basic principles that shaped Iron-Age life were the single household/farm and common land and resources, then these locational trends for assembly locations seem to echo a common need for meeting practices rooted in these modes of existence for rural communities.

The second significant commonality is the association of meeting-places with cemeteries, with mounds or burial mounds, or with both. This has been discussed at length already and this connection exists right across Scandinavia, Britain and Ireland. This theme is picked up again below in relation to elite modes of governance, kingship and assembly, but the evidence presented here demonstrates that these kinds of relationships are as relevant to local and early forms of assembly, as they are to later elite action and top-level assembly. These connections do not occur at every site, but they do demonstrate that sometimes people chose to gather, cook and eat together, within the presence of the dead. What is compelling is that in recent years similar trends have been established in Ireland and England (Gleeson 201 8; Reynolds 2018; Brookes 2019). The evidence takes two forms: on the one hand, old, prehistoric burial mounds are adopted and used for assembly locations, and on the other, evidence demonstrates associations with early medieval burials and cemeteries. Again, these similarities cannot be argued to be exported or shared, but they feed the idea of a common grammar for rural communities in which claiming land and resources as individuals or households required visible linkage to ancestral sites. The reuse of old monuments for burial, especially barrows, is a tradition evident in many parts of early medieval Europe, and is connected to land claims and the use of old burial sites to signal legitimate claims in the present. Such traditions occur across Britain and Ireland (Maldonado 2013; Petts I998; Williams I997). Burying the dead in this way and holding assemblies at these kinds of location, as well as at early medieval cemeteries, has little to do with ethnicity. Instead, these practices may well relate to long-term rural management strategies used in many regions to signal perceived claims to land and resource.

Burying the dead at older monuments and meeting at old burial monuments and cemeteries are also strategies that may have enabled groups to compete and claim land and resources in times of significant pressure. Meeting at these kinds of place implies the dead remained agent in processes of decision-making, place-making and making connections with the land and signalling ownership (Semple 2018,3-4). As the Irish sources intimate the dead could also reject claims to land (Charles-Edwards I976). To maintain, claim or renew rights to resource and land may thus have required physical acts of burial, but also gathering regularly with the dead, embracing them within the group, and including them within a genealogical/hereditary narrative around claims and ownership (see Reynolds 2018, fig. 8).

Feasting at the grave and cemetery is evident in a number of societies and cultures as a mode of family gathering and communication (e.g. Valk 2006). Moreover, the use of cemeteries, old and recent, as seasonal places of gathering is a strategy used by 
some nomadic/travelling populations to anchor the group to the landscape through ancestral connections (e.g. González-Ruibal and de Torres 2018, 24-25). We might, therefore, see such trends in the regions under study in this volume as indicative of actions intended to maintain or claim ancestral linkages in the disrupted times of the Late Iron Age and Migration eras. Such acts would have been relevant to local, kin-based units of organisation, but also to broader expressions of group identity. Gatherings revolving around the need to seasonally move livestock, or to plant or harvest crops, can bring people together in large groups to share activities. Such ordinary practices can themselves be ritualised, because the success of the population depends on these activities being carried out in propitious circumstances. What differentiates the assembly traditions in the Ist millennium $\mathrm{AD}$ from practices that must have taken place right across prehistory is a greater sense of regularity in how people and land were divided and how these divisions and groups managed their own interactions and their interactions with others.

A final striking commonality is the evidence for cooking and eating together, whether attested archaeologically or by documentary accounts. Any assembly, by necessity, involved travel and a temporary stay in a designated location. Bringing and preparing food would have been essential to such operations. Cooking together, however, and eating together in groups, is a useful cohesive mechanism for bonding. Likewise the common mentions of games of different kinds, whether horseracing, pig-coursing or wrestling, and intimations of hunting, points to the use of temporary meetings as locations for team-building activities which surely served, like eating together, to reinforce group connections and synergies. The regularity and repetition of the meetings themselves would have reinforced the power of an assembly, tying decision-making firmly to memory and giving participants a sense of collective responsibility over the curation of such rituals and rules (Sanmark 20I7a, I I7-I 42). The right to attend and speak, and together voice consent or protest, must also have created a sense of common participation.

By the mid to late Ist millennium AD, the processes of assembly became far more regulated and ordered in Scandinavia and in other regions. This section has pointed to broad connections between the assembly mechanisms present in Scandinavia, Britain and Ireland and suggested that early modes of consensus were not constrained in term of region, or political/ethnic divisions. Norse thing organisation, however, while neither new, nor unique, was connected to a tradition of customary law and assembly that seems similar and connected to Germanic law, although parallel developments in legal operation and structure are of course possible (Sanmark 2017a, 243-245). The basic principles of local organisation, division and assembly, however, may have emerged in late prehistory as broader symptoms of heterarchical development in northern societies. The Late Iron Age and Migration period brought movements of people that may have spread ideas, but also introduced pressures and stresses that may have injected a greater need for formalised mechanisms of regulation and management at a group level that enhanced identity and cohesion. Within this scene, Roman and Germanic legal traditions were important to local and supra-local levels of organisation, but meeting systems and practices remained physically influenced by the geographical qualities of places, the resources and lifestyles of communities, and the role of coalescence and collaboration as a means of survival. In the ist millennium AD, 
however, these differing modes of assembly activity eventually found a common form in Scandinavia as the concept of the thing.

\subsection{KINGS, THINGS AND THE CHURCH}

By the second half of the Ist millennium $\mathrm{AD}$ there are broad suggestions from both documentary and archaeological sources of evidence for greater elite involvement in the enactment of power and assembly. A greater ritualisation of assembly has been recognised, alongside changes in the form and monumental nature of sites (Sanmark 2017a, 82-1 I6; Semple and Sanmark 2013). These changes are linked to the establishment of new elite forms of residence, royal itineraries and movement to secure and maintain power, as well as claims to legitimate ancestry signalled through monumentality and assembly theatre. The arrival of Christianity also had substantive effects on assembly practices, and ultimately seems to have played a part in ending traditional meeting practices at important outdoor locations in some regions.

As kingdoms grew in size, elites needed better administrative mechanisms for keeping the peace. Royal itineraries are evident in several regions under discussion, as are royal councils. The popular and public assembly and thing seem, however, to have retained a significant, if not vital place, in this new elite theatre. The itinerant kings of Iron-Age and medieval Scandinavia travelled between their royal estates, located at key places within their kingdoms. The royal villas of northern Europe had a spectrum of legal, economic, religious and cultural functions. These of course varied depending on the royal villa, its ranking, and other factors such as size and location. Control of routeways over land, sea and rivers were extremely important to the king. Most of the royal villas had legal and military central functions within their territories.

The administrative and military functions of the royal vills were probably rather similar to such functions at any aristocratic centres. In the areas where the king did not have direct control, he had to renounce parts of the revenue from fines and taxes to allies, who in principle should deliver military benefits and secure the area for the king. It would naturally be in the king's interest to directly control as large an area as possible. Strong royal power rested upon direct geographic control. One way to do this may have been to relocate the higher ranked thing sites closer to royal centres, or establish royal centres by the thing and in doing so secure greater elite control over the legal system.

The large assemblies of the Carolingian empire were frequently held at royal palaces. The source collection Regesta Imperii contains the written evidence from the Carolingians to Maximilian I (I459-I 5I9). Of the I46 assemblies held at royal palaces that are mentioned in the Regesta Imperii during the Carolingian period (743-903), I05 were held at 22 of the 50 identified palaces in the Carolingia (Iversen 2009, I08). Most assemblies were held at Aachen (2I assemblies), Worms (I6), Regensburg (9), Frankfurt (7), Ingelheim (5) and Nijmegen (5). Similar patterns occur in England. Large assemblies are recorded at 60 of the I 50 documented preconquest royal vills (Sawyer I983). Tamworth in the kingdom of Mercia stands out in hosting $\mathrm{I} 2$ assemblies between $\mathrm{AD}$ 675-857, and Amesbury, Bath, Cirencester and Southampton each hosted four assemblies between AD 796-IO20. 
A similar picture should be expected in Scandinavia, but the sources here are far more limited. To some degree this process is evidenced in Norway, however, where the courtyard sites were associated with local elite power. These sites were gradually abandoned over long periods of time and new highly ranked things were established at royal centres such as Avaldsnes and Hesby in Rogaland (Iversen 20 I $5 \mathrm{c}$ ). In the late Viking Age, others, such as the Øyrathing by Nidaros (Trondheim) were established near new towns (Chapter 4 ). Sometimes royal manors seem to have been established in close vicinity to important thing sites. It is rarely possible to determine if the assembly or the royal estate is the oldest. What is clear is that by the Late Middle Ages, across Scandinavia there are many examples where royal estates and top-level assemblies coincided, or were located in close vicinity of each other. Examples of such sites include Odense and Lund in medieval Denmark, Linköping and Uppsala in Sweden and Øyrathing, Haugathing and Åker in Norway (Chapter 4).

An interesting case-study is represented by the (Mod Norw) huseby/ (Mod Sw) busaby farms which are not co-extant with assemblies but were linked to the unit of the bundred (Lindkvist 20I6). Some I 40 are known from the Scandinavian countries, Schleswig and the Orkney Islands (Steinnes I955; I959; Brink 2000a; 2000b; Crawford 2006; Stylegar and Westerdahl 2004; Crawford and Sanmark 2016). Since Henrik Schück's (I9I4) classic work on the Uppsala öd husaby farms, they have been central to the academic discussion on early royal power, particularly in Sweden and Norway (Iversen 20II; 20I6). In a recent study, Iversen (20I6) has pointed out that the husaby estates of western Sweden-where they are less in number-better correspond to the late-medieval unit known as (Mod Norw) fogderier. This is also the case for large parts of Norway. While in Denmark they correspond with the early medieval bishoprics. The fylkir (counties) were primarily connected to the collection of taxes and fees, a situation that suggests finance was important for the huseby estates too. While it is clear the huseby estates do not correspond with assembly sites systematically and spatially, there is evidence that these farms became important collection and storage points for the levy taxes. This function is seen in the buseby name, which translates as 'the estate with the large houses'. It has been suggested that the role of these farms was linked to the assembly by a need for approval from the decision-making body and that the dues were considered as part of 'the royal rights' (Iversen 2016).

As discussed in Chapters 4 and 6, kings were often mobile in how they managed their growing territories. This practice is attested best by the royal route of Eriksgata described in Swedish provincial laws, but some traces of similar traditions can be seen in sources from both Norway and Denmark, as well as the Frankish kingdom from the Merovingian period onwards (Sundqvist 200I). No such traditions are known from the Norse settlements as, of course, Iceland had no king and the Norwegian king was not present in Norse Scotland. The Eriksgata in Sweden is roughly described in the legal texts and an approximation of the route has been reconstructed. It can be shown that it passes the top-level assembly sites in the provinces. The same pattern is found for late-medieval Denmark. In Sweden, the Eriksgata also passed various local assembly sites (Sanmark 2009; Sanmark and Semple 20IO; Sanmark 20I7a, I04-6). This was an opportunity for the local elite to meet the newly elected king and make alliances with him. 


\section{Inauguration}

Kings in Scandinavia, as in many other places, were dependent on the approval of the population in their kingdom. This was the case from the very start, with their election and inauguration, at Mora in Sweden, the Øyrathing in Norway and Viborg in Denmark. Written sources show that newly elected kings should be elevated for example on stones or high seats. Ruling from an elevated position seems to be related to the Old Norse tradition of claiming kingship and ruling from a mound (Chapter 4 ). The use of mounds is connected to inauguration sites and rituals documented in early medieval Christian Ireland as well. The elevation of a newly elected king is a feature in various parts of early medieval Europe. In view of this, it seems that some shared practices existed in royal inauguration rituals across north-western Europe, regardless of religion.

\section{Things, the church and urban development}

The thing and the thing districts were related to basic social issues such as security and legal protection, and the thing sites were places where people from rural areas gathered. As shown in Chapters 4 and 5, the top-level assembly sites were moved into the new and expanding towns in the 13 th and 14 th centuries. From the I 2 th and I3th centuries, parishes became very important in Scandinavia in social terms. In some areas they were created on existing structures and in other areas they developed through the church-builders' socio-geographical contacts and the density of private churches. Assemblies and thing meeting were, by this point, often connected to churches, and this may signal changes in meeting patterns. On the other hand, there is evidence that churches were built close to old thing sites. It is hard to determine in many cases whether the church or the meeting-site is the oldest feature (Sanmark 20I7a, I43-I44, 232-233).

Many cities in Europe became self-ruling constitutional entities when 'urban power' increased in the I 3 th and I 4 th centuries. In I 52 I, 84 of some 4 , 000 towns in the Holy Roman Empire were 'free imperial cities' (urbs imperialis libera Lat.). These powerful towns were represented in the Imperial Diet (Mod German Reichstag), had a high degree of autonomy and rights, and were subordinate only to the emperor (Hartmann 2005). The northernmost freetowns expanded their trade towards Scandinavia from the I2th century, where initially fish and later timber tempted foreign traders. Compared to Europe, the degree of urbanisation in Scandinavia was low, especially in Norway (Holt 2009). In II 35 the English chronicler Ordericus Vitalis knew of only six towns in the Norwegian kingdom: Konghelle, Borg, Oslo, Tønsberg, Bergen and Nidaros (Vitalis I 852). By the end of the Middle Ages there were only 16 towns in Norway while more than Ioo in Denmark and 40-50 in Sweden (Jensen I990; Helle 2006). Therefore the number of urban jurisdictions with municipality rights was rather low in Scandinavia compared to the European continent and Britain and Ireland.

The level of royal power, and hence the kings' potential impact on the communal thing system, varied greatly from the core areas of the Frankish realm to the peripheries of Scandinavia and beyond. With immunity, in the Frankish realm 
from the 500s, manorial judicial authority followed; such rights gradually became territorialised, and new territories were created, where the lower court was linked with manorial rights and the higher court was linked with the feudal lord or king. In most parts of Scandinavia, the judicial developments took another direction; here communal power was stronger.

It seems clear that new, large law provinces were created in Scandinavia in the Ioth-I 2 th centuries. Subordinate areas were integrated into larger law provinces and were represented at top-level assemblies such as the Gulathing and Borgarthing in the $\mathrm{I} 3^{\text {th }}$ century. Processes of territorialisation were a result of interplay between emerging royal power and the thing, both playing an important role in the consolidation of proto-states. New resources in the inlands of Norway and Sweden were exploited and drawn into the Viking-Age economy. An interesting example of changes benefiting increased elite or aristocratic control over land and people are the (Mod Norw) birk of Norway. These were legal entities separate from the bundreds and rural law and represented a monastery or a noble estate that has been granted lower legal jurisdiction over their land and the people dwelling on it. In Norway, birk were first introduced I67I and I673/84 when Larvik and Jarlsberg in Vestfold were founded. Apart from in Vestfold, these units never achieved further significance in Norway. In Denmark, however, the situation was different and this type of legal designation was used more broadly. Typically, the courts were located at the manor house or the monastery (Lerdam 2004), thus bringing decision-making within the control of the local lord.

Around the 9th and Ioth centuries, more rigorous systems of administration and justice begin to show more clearly in the material and landscape record. Our work has identified that the processes of kingdom formation and territorialisation began to have a distinct effect on the shape and divisions of administrative units and on the form and functions of the assembly. It is in this era that royal dynasties gained ground. Kings needed more permanent structures in order to consolidate their power in newly acquired or disputed regions. In some regions, supra-regional kings are argued to have depended on existing powerful dynasties and the church. Fringe areas were defined as fiefs and earldoms, and became important as places of exploitation. In such areas, supra-regional kings needed the acceptance of the thing institution to get access to resources and wealth. The local communities are likely to have been driving forces in such territorialising processes, benefitting from the king's authority and power to sanction the law. The assembly is thus argued as a powerful agent, facilitating royal access, but at the same time regulating the reach of royal power.

\section{Royal involvement and power}

Within the systems of assembly that developed around the North Sea, space, place and monuments seem to have frequently featured in the creation of 'theatres' of discourse, structuring power and hierarchical displays (Sanmark 2015). Although these changes did not happen all in one period, complex monumentalised places of assembly seem to appear alongside the presence of elite power, especially the arrival of kings who aspired to claims over larger territories. Within the regions studied in this volume, there is clear evidence for increased elite and royal involvement in 
assembly, but also a more intense monumetalisation of power at assembly sites in the Early and High Middles Ages. As elite families and kings aspired to dynastic rule and extended their control over larger territories, new symbolic repertoires were developed involving regalia, palaces, monumental burial rituals and public performance (Roach 2013; Semple 20I3). Patrick Gleeson has argued in Ireland that important changes

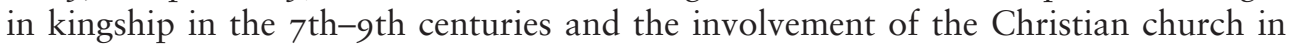
polity-building processes led to changes in the nature of local identity signalled in the distancing of burial and assembly as well as the creation of new assembly monuments (Gleeson 201 5, 47). These changes are connected to the development of supra-regional kingdoms (Gleeson 20I 5, 46). In England in the 7th century, the relatively short-lived palace complexes such as Lyminge in Kent or Yeavering in Northumberland denote a major physical change in how kingship or rulership were being enacted. We can connect these sites to itinerant power, to the need to exact tribute, but also to the need to perform power and justice as part of the ruling mechanisms for larger territories. These sites are situated in landscapes heavily invested with ancestral meaning and are framed by older monuments, and although short-lived, signal an aspiration on the part of elite families to establish long-term ancestral claims to territory and land (Semple 20I3). We know, through the site at Yeavering and documentary accounts of other palace locations, that these were places of gathering and assembly (Semple 20I3). Later in time, both shire-level meetings and the royal council or (OE) witan were also held in locations that sometimes held similar associations with older monuments and were situated within 'resonant' or 'meaningful' landscapes (Brookes 20II; Lavelle 2005; Semple 2013). Similar processes are evident in Sweden in the Vendel and Viking periods, with evidence for elite ritual itineraries and a formalisation of thing sites connected to these routes of movement (Sanmark 2009; 20I 5; this volume Chapter 4). Complex burial rites, coinage and concepts of dynastic lineage as well as regalia and laws, are all evident in Anglo-Saxon England from the 7 th century onwards and they have been suggested by many to signal the emergence of more complex power structures and kingdom formation (e.g. Carver I992; Reynolds I999; 201 8; Scull I993; I999; 200I). We can perhaps situate our evidence for more formal assembly arrangements including itineraries, palaces, and fixed places for meetings in the shadow of past monument complexes, as attributes attesting to complex changes involving new hierarchies and larger political territories. In this way, assembly can be identified as a crucial building block. First, in the negotiation and consolidation of local identities and claims; later, in the choreography of elite performance and power. It is notable, as well, that inauguration rituals demonstrate a level of theatrical complexity in situation and practice that is similar to types of royal performance in Ireland and Scotland in the Early and High Middle Ages (see Chapter 4).

As royal powers began to expand territories and kingdoms, the thing was exported to new lands. In Norway, a system of dynastic core areas controlled through property has been suggested (Iversen 20II; see also Iversen 2007; 2008). In the semi-periphery, specific farms would provide for the needs of travelling kings. Fringe areas were defined as fiefs and earldoms, and became increasingly important. A system developed by which the fringe was exploited to support the core. The thing was a dynamic entity, facilitating interactions and regulating exploitation of the fringe by the core. The same can be argued for the establishment of thing systems in 
new lands by the Norse-similar principles and notions of law and gathering were exported and facilitated cohesion and overlordship, but how these were emplanted varies considerably in terms of the terrain and the existing lifeways and assembly structures of the local inhabitants. In the early medieval societies around the North Sea and the North Atlantic, powerful chiefs competed over resources, land, goods, access to coastal routes and trading rights. The assembly in these instances may well have been altered or created anew to draw the support of the participants. Freshly created systems of assembly are suggested in Sweden to have been inspired by the needs of chiefs or kings to circumnavigate their realms and subjects to gain access to those in power (Sanmark 2009). The place of assembly may therefore represent something powerful about a collective sense of identity, place and being, but it is also likely to have presented an opportunity for those in authority, to 'create' a sense of power and past. The evidence presented for the Northern Isles and Iceland encapsulates this sense of using assembly to create power by drawing on old sites to establish new processes of governance. In Orkney and Shetland, the use of existing brochs and other monument forms, such as settlement mounds, as assembly locations demonstrates the ways in which new systems at the periphery might be established in response to existing landscape narratives, overwriting local places of importance and local claims to land. Within Yorkshire, in the Danelaw, the evidence suggests the wholesale adaption of existing structures and meeting-places (Skinner and Semple 20I6; Chapter 6). The physical past in these instances was appropriated and absorbed within a new legal/administrative landscape.

These kinds of elite strategy are evident in Ireland and in Scotland in the High and Late Middle Ages where mounds, stones, thrones and other physical features were appropriated for the performance of lordly power in terms of assembly and inauguration. The past was mined for elements that might help create greater legitimacy for kings and dynastic groups (FitzPatrick 2004a). This process of appropriation and invention, however, remained vibrant and relevant throughout the medieval to modern eras in many places. Important loci of assembly, inauguration and royal power, were often revisited in documentary and physical terms creating long-term connections with the late prehistoric and early medieval past (see Chapter 2). These 'invented traditions' comprise a set of practices of ritual and symbolic nature, constructed in order to legitimise certain norms and imply continuity with a particular time in the past (Hobsbawm I983, I). As Richard Bradley argues, the use of the antecedent landscape to situate, and legitimate power is a tool common to many early medieval populations (Bradley I987; I993). What our research here has shown is that such processes operated at both a local and elite level, but over time elite and royal involvement took hold and assembly and landscape became fundamental to how authority was enacted. The connection of these activities to the first documented large kingdoms, kings and dynasties, has meant that the idea of assembly and places of assembly and inauguration, as well as the rituals associated with them, maintained a profound hold on medieval ideas of local power and kingship. Even after the thing and other forms of assembly and inauguration sites had ceased to function, they remained potent concepts in early modern and modern national discourse and the sites could acquire new resonance as places of gathering in the post-medieval era. 


\subsection{SUMMARY}

Assemblies and gatherings held on a regular basis were institutions in evidence in a variety of shapes and forms in different parts of northern Europe in the Ist millennium AD. Studying the administrative systems they were connected to, and the details of the processes of assembly and decision-making, are hampered by the limited written evidence that survives for most of the era. What this chapter has shown, however, is that the topography and archaeology of assembly places offers a rich vein of information for local and regional variations in practice. In our documentary accounts and later sources, we also learn in far more detail about the people who attended and the activities that took place. Together, despite issues of chronology, we can build a picture of how these meetings operated and where they were located and how both can inform the social processes of the communities inhabiting parts of northern Europe in the Ist millennium AD. Striking connections are made here between assemblies and the management of common resources, locations of ancestral importance and land claims, revealing the kinds of community-building activities that may have been necessary for Late Iron Age and early medieval populations. In this way, we have been able to characterise assembly in its early forms. On the one hand, there is marked diversity in how local sites were situated, but at the same time, there are some common characteristics that we have linked to the essential needs of rural populations.

We have shown the creativity of early medieval populations in terms of meetings and systems. At local and supra-local levels, households and populations used physical acts, drawing on terrain and antecedent monuments, to 'write in' individual and communal claims. They monumentalised places, enhanced them, and guarded them with tradition and ritual, enabling, we can assume, the retention of knowledge and memory about ownership and connections to place. A common organising principle emerged over time in Scandinavia, however, which is illustrated by the highly regulated late-medieval thing. This institution, like its cognates, appears to have developed and wrapped in the local level precursor meetings and systems. Over the Ist millennium $\mathrm{AD}$, assembly and gathering practices seem to have become important for elite engagement and control, and local systems of governance were eventually changed and streamlined. In these changes, we can see the development of more hierarchical structures in these societies, but it is interesting to note that meetings and assemblies were important building blocks for this era of growing social complexity. Over time, these places and mechanisms for negotiation and dispute settlement became locales where authority and power could be consolidated and territorial-control extended. 


\section{CHAPTER 9 \\ CONCLUDING THOUGHTS}

In this volume, we have shown that assembly places and practices are fundamental to our understanding of how medieval society in northern Europe was transformed from a network of small-scale, local power structures to a competing system of large kingdoms with royally driven administration. The thing and assemblies in general, were institutions that emerged in a variety of shapes and forms in different parts of northern Europe and provided an arena for negotiation and dispute settlement. Over time they became places where authority and power could be consolidated and territorial control extended.

Assemblies varied in size and purpose. There is striking evidence presented here for early and collective origins. Assembly traditions relating to dispute settlement are almost certainly ancient and took many forms. Such practices would have been subject to significant development over time. The unique perspective offered by this study of the thing, is that at the point at which early medieval regulatory and legal practices emerge in the place-name and written records, there is some sense of overlap or connectedness with earlier communal practices evident in the archaeological record. There are strong arguments for seeing the processes of territorial consolidation evident in many regions in the ist millennium as a stimulus for the introduction of greater regulatory procedures for dealing with territorial concerns. What is intriguing, and comes to the fore in this study because we have encompassed regions that lay within and outside of the Roman Empire, is that these processes of collective organisation were present in parts of Iron-Age Europe in the late Ist millennium AD and present in the archaeological record of the Ist millennium BC. In this sense, the assembly was not a single and common institution, with its roots in the ancient Germanicspeaking world, but a shared concept necessary to human existence. Similar processes of collective management existed for rural communities across many regions and popular assemblies served many purposes.

One of the main outcomes, therefore, from our work is that there is no single model for assembly. The thing has many northern European cognates and at the root of all are some basic principles and ideas that demonstrate little ethnic association. Instead, there are indications that mechanisms for meeting and decision-making emerged in several regions in the Ist millennium $\mathrm{AD}$, some perhaps even before, and these greatly varied in their forms and functions, but were underpinned by some necessities of rural life: first, the need to maintain claims to land and, second, the necessity of managing shared assets and maintaining access to common resources. While the earliest evidence is sporadic, there are strong indications that meetings took the form of outdoor events geared to creating collective cohesion. The likelihood 
that these involved cooking and eating, games and competitions and can be tied to seasonal cycles of activity and the management of resources such as hunting grounds or upland grazing, also points to much broader and early developmental processes for these kinds of activity. These needs continued to underpin how local-level assemblies operated in the early medieval era. The linkage between assemblies and bridges, roads, uplands and other nodal places underlines the important role of assembly as a place for local collective negotiation and regulation. The common connections to cemeteries and burial mounds, or mounds, is another striking attribute that hints at the long-term relevance of perceived ancestral places to northern European practices of claiming land and accessing resource. These connections fit well with the greater intensity of burying the dead in relation to older monuments and boundaries within the early to mid-Ist millennium $\mathrm{AD}$ and the links between land-holding, burial mounds and claims of ancestry.

This multi-vocal evidence, however, is not at odds with the emergence of the more regulated thing institution and other cognates in early medieval societies. While the mechanisms of consensus are clearly not exported 'out' from any single Iron-Age society, by the mid-Ist millennium AD the terminologies at least for assemblies point to common ideas and names for local and supra-local gatherings. The establishment of the thing as a widespread term for assembly, despite differences in the terminologies for the unitary arrangements served by the thing in Scandinavia, suggests a common sense of purpose for the thing as a legal and assembly institution. The evidence suggests ground-up processes for the development of gathering places and assemblies in different regions, yet it is also clear that the Scandviavian thing emerged as a common organising terminology and principle for local to supra-local governance in the Ist millennium AD. The concilia recorded by Roman authors in contemporary Iron-Age societies were varied in terms of their geographic locations and functions, and while the thing or its precursors were probably referenced by these accounts, it is likely that other administrative mechanisms with different ground-up trajectories were also embraced in these descriptions.

The broader package of evidence across Britain, Ireland and Gaul suggests congruent processes of development for local consensual mechanisms with intimations in some areas, like Gaul, that the proximity of imperial authority may have played a part in stimulating heterarchical forms of governance. The dynamic events that affected parts of Scandinavia in the early first millennium AD, which include the collapse of the northern frontiers, migrations and climatic catastrophes, may well have resulted in the adoption and adaption of diverse local gathering conventions within a more regulatory set of mechanisms for political and judicial assemblies. An important unifying trend is the common association of the thing and other assembly types with legal institutions. Despite the consistency of documentary accounts on the nature and operation of the thing, as we argue in Chapters 4 and 5 , the general idea of organisation in terms of administrative units and associated thing sites is similar, but the terminology used varies both between, and within, political units and kingdoms. This underlines perhaps the significant ground-up influence of local custom and practice on the development of the common thing (Figure I.8). Another indication of ground-up processes of development is hinted at in the varied, yet combined, functions of assemblies and particularly the thing. Associations with military organisation 
are often suggested and have been raised specifically in relation to some of the Norwegian-type sites. Military agency and mustering are not, however, mutually exclusive from decision-making, resource management or legal decision-making. The strong intimation from the evidence presented here is that assemblies were multifunctional and combined a range of activities that were important to a collective group, and that the act of assembling regularly and performing the same activities, curated these ideas and practices in the community for the long-term. In this volume we have placed a great deal of emphasis on land-holding and resource management as stimulants, but the evidence intimates that assemblies were also team-building affairs, where games and feasting encouraged group cohesion and perhaps also led to the forging of new, larger group identities. Legal decisions and feud resolution were also central to reinforcing group dynamics and regulation. We need to remember that the people themselves were a resource and thus the use of assembly structures as a means of mobilising people for group activities is another likely outcome, something that would have appealed to elite desires for greater authority over the populace. Acts of human sacrifice, suggested at some major assemblies, provide an interesting insight into the power of an assembly over individuals and how acting for the purpose and benefit of the collective might be overriding (see Chapter 8). Similarly, assembly as a mechanism for enlisting military obligation from families is not mutually exclusive to any of the other purposes and activities proposed here and was certainly a facet of the large assemblies described by Roman writers (see Chapter I). In sum, the development of types of assembly in many regions in the Ist millennium AD and their multi-faceted operation and diverse forms strongly imply modes of ground-up development, but there are some interesting commonalities in unitary arrangements, locational aspects and functions. Within our regions, as more complex hierarchical power structures emerged, more consistent systems were developed, that drew in existing practices. In Scandinavia, at what appears to be quite an early point in time, a common idea of an assembly with legal functions - the thing - was in operation which served systems and units of varying kinds of complexity and age and that carried the same conceptual function and terminology.

In time, the thing was exported to new areas by the Norse, to Iceland, Greenland, Scotland and the Faroe Islands, the Danelaw, Ireland and to the Isle of Man. Again, however, its establishment in these different places was a process of response and engagement with existing populations and structures, or, in the case of Iceland, Greenland and the Faroes, the organic establishment of familiar structures in an unpopulated landscape. In the evidence discussed in Chapter 6, the level of diversity of approach is most evident in how the Norse rolled out and embedded new systems. In some instances, in regions like Yorkshire, they adopted existing systems. In parts of the Northern Isles of Scotland, they appear to have adopted and adapted existing monuments, modifying and even erasing them, although we do not know if these monuments and places held assembly functions in the pre-Norse era (see Chapter 6). In Iceland, assembly developed according to the unique needs of that community in terms of location and associations with harbours and trade (Chapter 7 ).

Thing organisation was thus far from stable although some rural unitary systems appear to have had long lives. By the second half of the Ist millennium and in the early centuries of the 2 nd millennium, a more powerful form of elite theatre emerged. 
Meetings - both royal and legal-facilitated dialogue and debate between different tiers of authority, while others gave voice to those individuals permitted to attend (of course this was still selective and not everyone was able to take part). Some meetings were held regularly and others less frequently, but all remained intrinsic to peacekeeping, and the regulation and maintenance of the laws. It is in this period that we see far more elaborate monumentality at some sites and in some regions, with chiefs and kings investing more in public performance and spectacle. Assembly was now used in the performance of elite power, as an element of existing practice and tradition that could be drawn upon to legitimate and underpin new authority. Assemblies that had once been arenas for local negotiation emerged as more formalised places where rulership could be enacted and the law enforced. There are numerous examples where meeting-sites were embellished with new forms of monument or were situated to consciously embrace existing and older monuments, adding legitimation to political action.

The movement of elites and kings around their territories seems to have stimulated new architectural forms connected with public performance and the ancient past. The export of the thing to new areas also resulted in some interesting practices. In the Northern Isles and other inhabited areas colonised by the Norse, existing monuments were appropriated and reused and crucially they seem to have been physically modified at times. In Iceland, not previously inhabited, natural features were used, including slopes and slightly elevated locations and a new architectural form was established: the booth or temporary structure that could protect attendees while staying at the site. These structures became more than functional, revisited year after year and maintained by families, creating strong familial and even ancestral connections to the traditions of attending the assembly.

In Norway, in the $\mathrm{I}_{3}$ th and $\mathrm{I} 4_{\text {th }}$ centuries, assemblies continued to be a regulatory mechanism for elite power, but major changes evident here and elsewhere in Scandinavia, resulted in the adjustment of assembly systems to encompass urban centres, the establishment of churches and regulation by kings. The biggest impact in Scandinavian terms on thing organisation was increased royal control and reform. As the three Scandinavian kingdoms were unified during the course of the Middle Ages, royal reforms took place. These are most clearly seen in the royal laws issued in late I $3^{\text {th- }}$ and I4th-century Norway and Sweden, but less is known about changes in Denmark at this time. The evidence shows that kings tried to simplify and streamline the existing systems, while also increasing their control. Over time, the numbers of meetings and levels of negotiation in thing systems were reduced. Initially the purpose of thing hierarchy must have been to regulate legal disputes in neutral courts at different levels: from local feuds to provincial-level disagreements. Due to increased royal control and changes to authority on the ground through the development of towns, control over dispute resolution was, however, tightened and restricted.

Chris Gosden has described archaeology as 'a perilous, but necessary search for the things that bind and divide human groups locally and globally' (I994, I66). The search for the origins, development and cessation of the thing institution in northern Europe is precisely this kind of endeavour. As the previous chapters have revealed, historical and archaeological evidence can be challenging and imprecise, and the bringing together of medieval written accounts with archaeological evidence requires 
careful handling. Ultimately, however, the story of the thing is one that centres on exploring a broader story regarding the human need for collective discussion and mediation, for mechanisms that help to bind people together and resolve disputes. By seeking to get to the heart of how such mechanisms operated in the early northern literate societies, we may learn something of the intrinsic drivers behind group mechanisms for consensus, for justice and self-regulation, which remain as important now for human populations as they must have been in the past.

The historical record has long been given primacy and combined with insular traditions of research and an emphasis on legal history, the study of assembly has often taken the path of a search for an ancient origin or a pan-Germanic idea of regulation, consensus and law. A transnational approach, combined with detailed historiography, was designed to combat these long-held problems and facilitate the first broad investigation of the thing in a long-term context. Our interdisciplinary methods, which have used a combination of source materials, excavation and survey, have tested assumptions and associations and enabled us to make more substantive arguments for the development of assembly mechanisms in northern Europe and the development of the thing. We have used documentary sources, but they have not been given primacy. Instead, we have explored and tested our evidence by comparing and contrasting archaeological findings, new fieldwork results, evidence compiled using cartographic and retrogressive techniques, landscape and topographic survey and place-name studies. In doing so we have set out a method for successfully exploring what was once considered an intangible and archaeologically challenging area of study. This method has relevance and can be exported well beyond northern Europe and thus offers a model for how to harness landscape evidence to more fully understanding the local organising and collective principles at work in pre- and protohistoric populations.

Our intention has also been to integrate British, Irish, and Scandinavian notions of assembly systems and practices and test out what we know of their independent trajectories and developments across the Ist and early 2nd millennium AD. In doing so we have been able to fundamentally critique notions of assembly as both insular in nature and relevant only to ethnic or national paradigms and have cast doubt on the concept of a single 'Germanic' Late Iron-Age tradition of open-air conciliar meetings. Instead, we have characterised the thing and its cognates as diverse and changing, with clear evidence for regional differences in location, form and function. These have been argued to support the idea of the ground-up development of consensual mechanisms in different parts of Europe, that initially operated according to local needs, pressures and resources. It is suggested here that operating within rural landscapes required negotiation and cooperation between families, households and groups. This in turn became a driver for the development of more formal mechanisms for dispute settlement and administrative activities.

While there is multi-vocality and diversity in the evidence, we have also, for the first time, come close to characterising this institution in terms of its development, form and operation. We have been able to argue for its early collective character, its association with key resources in the landscape and its linkage to the kinds of management practices needed when households and groups are required to share assets, from routes and bridges to upland grazing. Associations with graves, cemeteries 
and early monuments offer tantalising suggestions of the operation of meetings in relation to perceived ancestral locations and the dead. As elite power developed, so assembly sites changed, acquiring more monumental forms, burials, standing posts and other elaborate features, and these changes appear to be linked to an increased use of public performance by the aspirant elites, chieftains and and kings in early medieval Europe and investment in 'place-making' and a view to inventing tradition to add legitimacy to power. These sites and monumental/architectural repertoires were subsequently repeatedly mined for use in medieval top-level assembly traditions, including inauguration performances. Top-level assemblies were more volatile and prone to change, but the basic local-level structures proved enduring, often surviving well in to the medieval era.

The emergence of the thing, and the assembly more broadly, and its associated systems can no longer be conceived as a simple top-down process and neither can it be characterised as a purely early medieval or Germanic phenomenon. The roots of early medieval assemblies are deep and diverse. What is important is that common regulating mechanisms emerged within and across different regions and in the Ist millennium $\mathrm{AD}$ these may have provided the foundations for an increasingly complex processes by which polities and kingdoms developed. The thing as well as its cognates seem to have been powerful territorialising agencies in their own right. By providing a means of meeting and negotiating new alliances and identities could be formed. It may also have provided populations with crucial mechanisms for cooperation, that could sustain communities in challenging times. In these ways the assembly or thing may have encouraged a sense of common identity and through the kinds of meetingplaces chosen reinforced this by means of visual ancestral connections with cemeteries or older monuments. Such structures may have provided the building blocks for the kinds of political identities that emerge in some of our earliest early medieval references to particular groups and peoples.

What is also evident is that assemblies were key mechanisms through which elites could negotiate greater power. In some regions, elites and the thing were dependent on each other. The thing facilitated authority, but also regulated it. The ways in which administrative frameworks were migrated and imposed in new areas has revealed new evidence for the diverse ways in which this happened and how lordly authority in these areas used existing administrative structures, monuments and places to situate their authority. Overall, the entire trajectory for the emergence and development of assembly systems and places underlines how in non-literate societies, meetings, performances, outdoor places and monuments were all crucial tools in creating and memorialising narratives of identity, ownership, collective and elite power. The complex palimpsests used for assembly across northern Europe are physical attestations of the stories and legends employed by communities and elites to establish and claim lineage, genealogy and ownership.

Early medieval society presents archaeologists and historians with great opportunities, but also frustrations. From the Ist to the I2th centuries AD, northern Europe was subject to radical change. The collapse of Roman authority in some areas gave way to new kingdoms and modes of rule, and climatic events created dramatic disorder. Writing was introduced, kingdoms and provinces developed, and a new single religion was slowly established at the expense of old ties and beliefs. 
As regional groups coalesced or were brought together by leaders, through war or alliance, common identities emerged and were consciously promoted. Objects, clothing, language, architecture and the landscape itself, were all of material use in distinguishing a sense of being, personhood and place (Insoll 2007, I). As any early medievalist will acknowledge, the historical and archaeological source material for the Ist millennium in northern Europe is sparse. This scarcity of information makes the Ist millennium a dangerous world in which historians and archaeologists risk 'imagining' the past. Yet, while the stakes are high, the era provides the chance to interrogate some of the primary mechanisms of emergent political power. Our project has drawn on an holistic combination of evidence to look in some detail at how assemblies operated in this era: who might have attended and where people met. It has enabled us to take a temporal perspective evaluating how these systems of governance emerged and why they ended. We now have some understanding of how local to regional collective meetings may have developed into the better documented medieval legal institutions exemplified by the Scandinavian thing. At the same time our work on the evolution of the thing and its concomitants provides a richer narrative on the human past, revealing how assembly was linked to landscape and the sense of identity created in populations by the division of the land into households, farms and territories. It is perhaps no surprise these early regulatory systems were wedded to landscape, given that a sense of place is accepted as intrinsic to a sense of belonging (Basso I996). The indications, that local assembly practices may have hinged on sites connected with land ownership, collective resources and identity, reveal the potency perhaps of the basic mechanisms for rural survival. Why such collective mechanisms for resolution emerged or proliferated and became more formalised across the Ist millennium AD may lie in the significant upheavals experienced by parts of northern Europe in this timeframe. The collapse of economic networks, the erosion of kinbased systems, religious change, raiding, colonisation etc, may have promoted the strong reliance by communities on mechanisms for coalition and consensus in their locality (see DeMarrais 2016; Pluckhahn 20I3, I 89). Ideas of tradition, memory and the preservation and strict maintenance of long-term local arrangements may also have assisted in reinforcing local senses of connection to place, although such practices could also be invented to legitimise norms and structures (Hobsbawm I983, I).

Landscape and monumentality are mediums though which ritual and symbolic performance can be 'read' (see Brück 2005 for summary). In the non-literate societies of early medieval northern Europe physical performance was key to establishing connections and ownership, enacting law and asserting power (Clanchy I979; Roach 2013). The landscapes and material culture associated with assemblies provide a discursive terrain that offers insights into this world of performance and the competing needs of locality, identity, legitimacy and power. Within the medieval localities of northern Europe, for the first time, we have shared the experience of local populations, interrogating their reliance on landscape, their connections to place, the importance of the dead and older monuments, and their need to establish and maintain control over their land and resources. We can also see in these assemblages of monuments and features, place-names, texts and inscriptions, something of the powerful competition for resource experienced by early medieval communities that required effective processes for negotiation, and discern something of the 
regulatory and legal needs of communities, such as their concerns about theft, feud and survival and anxieties regarding access, travel, and seasonal resources. We can also sense something of the precariousness of people's lives and the vulnerability of these populations. Assemblies are argued here as the basic mechanisms of consensus that, given the right climate and situation, may have facilitated and driven groundup processes of political development in post-Roman and Late Iron-Age Europe, but it is the participants themselves who used the forum of the assembly to secure and win increased authority and status. Negotiating power and the processes of kingship in early medieval Europe were ultimately bound up with the development of these meeting systems, but even after the power of assembly as a regulating instrument had waned, the public and ritual theatre of the assembly remained crucial for signalling legitimate and rightful authority.

The potency of the assembly as a concept has subsequently endured, and has been revisited repeatedly in national discourses. Even the physical sites themselves have been brought back into use or have been recreated. This alone says something about the conceptual power of these early outdoor meetings in European national consciousness in the longue durée. Only by breaking down this national insularity has the true potentiality of assembly as a polity and kingdom-building mechanism been revealed, along with its unique ability to motivate the coalescences of people and power that gave rise to the first provinces and kingdoms in northern Europe. 


\section{GLOSSARY}

Please note that as set out in Chapter I, where a specific modern Norwegian, Danish or Swedish or indeed Icelandic term is used in the text, the term is given in italics. In instances where it is necessary to distinguish the modern language in use, abbreviations pre-empt the word in parentheses. These are explained in the list of abbreviations given at the beginning of the book. In many cases the original Old Norse, Old Norwegian, Old German or Old Icelandic is used. These terms are included in bold and not in italics and relevant abbreviations pre-empt the word in parentheses to indicate the language. Some terms also appear for the first time in medieval documents and these medieval words are given in the book in bold and not in italics but are again pre-empted by abbreviations in parentheses to indicate the language. All abbreviations are explained in the list given at the beginning of the book. If a translation is offered for either a modern or ancient term, this follows in ordinary script in quote marks, e.g. (Mod Dan) herredsting (ODan herritzting, 'a local thing'). Latin terms are also rendered in bold and not in italics and are followed by (Lat.). All specialist terms used in the volume are included and explained in this glossary.

Alpingi (OIcel) (Mod Engl/ Mod Germ althing): A thing in Scandinavia where all members of a defined group were obliged or encouraged to meet, depending on the type of meeting. In a local context this applied to all free men and some free women. In a regional context where assemblies were often representational, the 'all' probably referred to all the representatives. In Iceland, on the other hand, althing was the name of the general assembly at the top of the hierarchy. This was never changed, although Iceland became part of Norway where lawthing was the default term for the top-level assembly.

Áttungr (ON): Translates as 'one eighth'. This administrative unit is known from all the Scandinavian countries, although their form and function varied strongly between regions. Within the Gulathing law province the attungar represented subdivisions of the (ON) fylki (see fylki).

Bjarkeyjarréttr (ON): Translates as the 'law of Björkö' (Sweden); law of the I2th century onwards, but of earlier origin, specific to trading sites and proto-towns across Scandinavia.

Birketing (Mod Dan): A district court active in post-medieval times.

Blótsteinn $(\mathrm{ON})$ : Refers to a 'sacrifice stone' in Iceland; from $(\mathrm{ON})$ blót 'sacrifice' and steinn 'stone'. 
Bona regalia (Lat.): Land belonging to the kingdom.

Disaping (ON): The top-level assembly for the Kingdom of Sweden, held at Gamla Uppsala.

Dómhringur $(\mathrm{ON})$ [plural dómhríngar]: $(\mathrm{ON})$ dómr means 'court, judgement' and $(\mathrm{ON})$ hringur means 'circle', thus 'court circle'; structural feature described in sagas to host the panel of judges sitting in a circle. It can also mean a circular construction where pagan sacrifices took place; mostly known from Iceland.

Dómr (ON): Court, judgement. In Norway this meant village council and not an actual thing meeting.

Eriksgata (Mod Sw): A Swedish royal ceremonial route through different provinces of the kingdom that newly elected kings had to travel in order to be accepted by the whole population. Recorded in the $\mathrm{I} 3$ th century, but of older origin.

Féránsdómr $(\mathrm{ON})$ : In Iceland this refers to a court of confiscation, held at the home of the responsible chieftain, or at the althing.

Fimtardómr (ON): The Fifth Court of Iceland, the court of appeals for the Quarter Courts, introduced around AD I005.

Fjórðungr (ON): Translates as ‘one fourth’ (Mod Sw fjärding, Mod Norw fjerding). This administrative unit is known in all the Scandinavian countries, although their form and function varied strongly between regions. Within the Gulathing law province, which is discussed in this volume, the fjoroungar represented subdivisions of the fylki (see fylki).

Fjórðungsping (ON): Quarter assembly in Iceland, to solve the legal affairs of each of the four quarters on neutral ground for the people of different thing districts; quarter assemblies were not held often but were transferred to take place as part of the althing at Pingvellir where this was then called fjórðungsdómar ('quarter court').

Folkland (Mod Sw): Administrative unit in parts of Sweden gradually phased out over the course of the Late Middle Ages.

Fylki (ON) [plural fylkir]: Large administrative divisions in Norway, usually translated as 'county'.

Goðorð (ON): Icelandic chieftaincy.

Grágás (ON): Also known as the 'Gray Goose Laws'; the earliest written law from Iceland. The oldest surviving parts were written down in the I260s, but many regulations seem to be of older date. Italicised to denote its status as a primary written source.

Herað (ON) (Mod Sw härad; Mod Dan herred; Mod Norw herred): The smallest local administrative unit, known from all the Scandinavian countries, although never uniformly enforced. Other types of locally or regionally specific small unit also existed (see skipreiða and hundari). 
Heraðsdómar (ON): In Iceland, these included commune courts, outfield courts, communal pasture courts and courts for foreign traders; heraðsdómar were held on an ad hoc basis.

Heraðsping $(\mathrm{ON})$ : A local thing for the population of the herað.

Herred (Mod Dan and Mod Norw): The local administrative units of Denmark and Norway, translated as hundred.

Herredag (Mod Norw) (but occurred as well in Denmark and Sweden): An annual meeting between the king and the national council, with judicial powers. Attested in the late-medieval/ post-medieval eras in all three countries.

Hirð (ON): King’s closest allies.

Hirðstjór (ON): The leader or commander of the hirð.

Hofdingiafundr (MNorw): A royal meeting in Norway, a gathering of the most prominent people/chieftans in the Kingdom. A term similar to the English Witan.

Hreppaping (ON): Local assembly in Iceland, for about 20 householders. The hreppaping replaced the local spring assemblies (see várping).

Hreppr (ON) [plural hreppar]: Local administrative unit in Iceland, containing at least 20 farms.

Hundari $(\mathrm{ON})$ : The local administrative unit in the Svealand region of Sweden, gradually replaced by härad, translated as hundred.

Hundred (OE, ME, Mod Eng): The smallest administrative unit in Anglo-Saxon England. The equivalent of the Scandinavian herað. Not uniformly enforced, as other types of unit existed too (see wapentake).

Härad (Mod Sw): The local administrative unit in the Götaland region of Sweden, derived from $(\mathrm{ON})$ herað. From the I 4 th century, härad became more and more common and was eventually adopted across Sweden, translated as hundred.

Jarnsiða $(\mathrm{ON})$ : Law introduced in Iceland by Magnus the Law-Mender as the successor of Grágás.

Konungstekja (MNorw): A royal inauguration in Norway.

Landsthing (Mod Sw and Mod Dan landsting) (OSw landzping and ODan landzting): The assembly at the top of hierarchy in each law province, equivalent to the Norwegian lawthing (see below). As with the term thing and lawthing, in this volume we use the generic term landsthing throughout the main text when referring to top-level assemblies in Sweden and Denmark.

Law province: An area that had its own law. In the I3th/I 4 th centuries there were I6 such provinces across Scandinavia, and at least five in the Norse settlements in the west.

Lawthing (ON lögping): The top-level thing(s) (there could be several) within a law province. A lawthing was a representative assembly where royal law was introduced and enforced. 
Leiðangr (ON): The naval defence system of Scandinavia.

Leiðir (ON): Old Norse for local autumn assemblies in Iceland.

Lendmaðr (ON): Baron.

Lögberg $(\mathrm{ON})$ : 'Law Rock', an elevation or platform for the law speaker to make announcements and proclamations to the audience below.

Lögmaðr (ON) (Lawman)/(ON) Lögsögumaðr (lawspeaker): The person whose responsibility it was to memorise and recite the laws at the assembly and give (ON) órskuror, in other words, explain the stance of the law regarding matters brought to the thing. From the late $\mathrm{I} 3$ th century, the lawman became an approved judge, who could deliver verdicts.

Lögrétta $(\mathrm{ON})$ : The meeting of the Law Council, the legislative power, in Iceland during the althing.

Lögréttumaðr (ON): Translates as lawrightman; a delegate to a mid- or top-level or thing.

Lögsókn (ON) (Mod Dan/Mod Norw Lagsogn): A law district (literal translation law parish). A subdivision of a law province (see this term), found in Norway and Denmark. Each lögsókn had its own lawman (see lögmaðr). For instance, in Norway in 1223 there were three such subdivisions in the Frostathing Law province and two in the other law provinces.

Moot (Mod Engl): From (OE) (ge)mot means 'meeting, speech, assembly'.

Overlagting (Mod Norw): The term for a supreme court in Norway in the I6th century.

Provincial law: A law that applied in each of the law provinces of Denmark, Norway and Sweden. In the I3th/I 4th centuries there were I 6 such laws across Scandinavia.

Réttarthing (MDan): Meetings in Denmark and Norway where the king had judicial power which later developed into a kind of High Court. In use until c. I660.

Ræfsta ping (OSw): (Mod Sw räfsteting): Royal assemblies in Sweden instigated from the I 4 th century, held in correlation with markets.

Riding (Mod Engl): Secular (?) administrative unit in Yorkshire and Lincolnshire, England, see Priðjungr.

Samping (OSw): 'Common thing' market and top-level assembly for the province of Södermanland in Sweden. Held in the town of Strängnäs.

Shire (Mod Engl): Generalised designation of territorial jurisdiction first noted in the

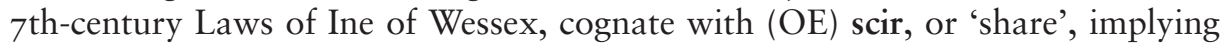
sub-division. A link has been proposed with contemporaneously documented regiones (Loyn 1984). The term was first used for the large shires of Wessex in England in the mid-8th century and by the early I Ith century was closely associated with the county divisions of England. 
Skattland (ON): Tributary lands that were subordinate to the Norwegian king (e.g. Iceland, the Northern Isles of Scotland and the Faroe Islands); the term is first recorded in the Law of Magnus the Law-Mender in I 274.

Skipreiða (ON): 'Ship-district', administrative unit connected to the levy fleet (leiðangr) in Norway in the Ioth and I Ith centuries. The skipreiður were also judicial units with their own assemblies (see herað).

Stefna $(\mathrm{ON})$ : Assembly.

Sýsla (ON) (pl sýslur): Administrative district connected to royal office, found in Norway, Denmark (Jutland), Iceland and the Faroe Islands. In Iceland these districts were only introduced in the I 3 th century when Iceland became part of the kingdom of Norway, when they may also have been introduced into the Faroes.

Sýslumaðr (ON): The royal official of the sýslur (see sýsla), representative of the king.

Tithing (Mod Engl): A subdivision of the Anglo-Saxon hundred consisting of ten members designated to vouch surety for one another. An equivalent term, Temanetale, is encountered in the wapentakes of Richmondshire, UK.

Vápnaping $(\mathrm{ON})$ : A thing meeting that 'all free men of major age' should attend and produce for inspection the arms which they were lawfully bound to have.

Várping $(\mathrm{ON})$ : The $\mathrm{I} 3$ Icelandic assemblies that served the local thing districts and represented the tier below the althing at Pingvellir. Also called spring assemblies. Term also used in Faroes and perhaps in Orkney. Usually held between 7 and 27 May.

Wapentake (Mod Engl): Administrative district found in the Danelaw. A division of the riding and/or shire. The rough equivalent of an Anglo-Saxon hundred. Term derived from $(\mathrm{ON})$ vápnatak.

Pingfararkaupsbændr (ON): In Iceland, a farmer that has to pay tax.

Pinghá $(\mathrm{ON})$ : A local unit in Norway representing local communal organisation; corresponds to an English hundred.

Pingmaðr (ON): Land-owners/'freemen' aged over I 2 or I 5 , depending on geographical area, who had the right to attend the thing meetings.

Priðjungr (ON): 'One third', administrative unit. In eastern Norway (Romerike and Hedmark), known only as an ecclesiastical unit. Also found in Yorkshire, England (see Riding above). 


\section{BIBLIOGRAPHY}

\section{Written Sources}

Bede. Historia Ecclesiae Gentis Anglorum (trans. Sherley-Price I968)

Caesar. Bello Gallica (trans. Hammond I996)

Collected Papers of Frederic Maitland, III, Laws of the Anglo-Saxons (ed. Fisher I9I I)

Deutsches Rechtswörterbuch, I9I2 http://www.deutsches-rechtswoerterbuch.de/ueber.htm [accessed April 20I7]

Diplomatarium Danicum (Det danske sprog- og litteraturselskab, ed. I938, Reitzel, Copenhagen)

Diplomatarium Islandicum. Íslenzkt fornbréfasafn volumes I-I6 (I857-I972), Íslenzka bókmentafélag, Reykjavik

Diplomatarium Norvegicum: Oldbreve til kundskab om Norges indre og ydre forhold, sprog, slægter, sæder, lovgivning og rettergang i middelalderen I 849-present, P T Mallings forlagshandel, Christiania/ Oslo

Grágás (trans. Dennis et al. I980; trans. Dennis et al. 2000)

Heimskringla, Snorri Sturlasson (Hollander I964)

Historia Norwegiae c. I I 50-75 (ed. Ekrem and Mortensen 2003, 55-60)

History of the Archbishops of Hamburg-Bremen (ed. and trans. Tschan 2002)

Knytlingasaga (trans. Jónsson I900)

Orms páttr Stórólfssonar (Wahl et al. 20I I)

Njál's saga (trans. Bayerschmidt and Hollander I998)

Regesta Norvegica I-I I (I989-20I6)

Saga of Olaf the Holy (Hollander I964)

Saxo (Zeeberg and Engelhardt 2000)

Saxon, Gesta Danorum (ed. and trans. Friis-Jensen and Fisher 201 5)

Shetland Documents (Ballantyne and Smith I994; I999)

Sverri's saga (Indrebø I920)

Tacitus. Germania (trans. Rives I999)

Tingbókin. Faroese thing books (Joensen I953; Joensen I969)

Vita Lebuini antiqua (Hofmeister I976[1926-34])

Vitce sanctorum Danorum (Gertz I908-I2)

\section{References}

Aarsleff, H, I983 The Study of Language in England, I780-I860, University of Minnesota Press

Abels, R, I988 Lordship and Military Obligation in Anglo-Saxon England, University of California Press, Berkeley

Adkins, R and Petchey, M, I984 'Secklow hundred mound and other meeting place mounds in England', Archaeological Journal I4 I, 243-25 I

Aðalsteinsson, J H, 1999 Under the cloak: A pagan ritual turning point in the conversion of Iceland, University of Iceland Press, Reykjavik

Aðils, J Jónsson, I903 Íslenzkt pjóðerni: Alpýðufyrirlestrar, Icelandic Nationality Public Lectures, Reykjavík

Ahlberg, O, I946a 'Tingsplatser i Södermanland och Närke före tillkomsten av I734 års lagar', Rig 29, $96-\mathrm{I} 25$ 
Ahlberg, O, I946b 'Tingsplatser i det medeltida Södermanland', Sörmlandsbygden I 5, 4I-52

Aitchison, N B, I994 Armagh and the Royal Centres in Early Medieval Ireland: Monuments, Cosmology, and the Past, Boydell and Brewer, Woodbridge

Aitchison, N B, 2000 Scotland's Stone of Destiny: Myth, History, Nationhood, Stroud, Sutton

Albrectsen, E, 1984 Aelnoths krønike: oversat og kommenteret af Erling Albrectsen; efterskrift af Preben Meulengracht Sørensen, Odense Universitetsforlag, Odense

Alcock, L, I988 'The activities of potentates in Celtic Britain, AD 500-800: A positivist approach', in S Driscoll and M R Nieke (eds), Power and Politics in Early Medieval Britain and Ireland, Edinburgh University Press, Edinburgh, 22-46

Andersen, N H, 2004 'Sarup: Causewayed enclosures placed in a Neolithic ritual landscape on Funen, Denmark', Journal of Nordic Archaeological Science I4, I I-I 7

Andersen, P S, 1974 'Ting: Norge', Kuturbistorisk Leksikon for Nordisk Medeltid I 8, Malmo, 346-359

Andersen, P S, 1977 Samlingen av Norge og kristningen av landet. 800-I 130. Handbok i Norges Historie bind 2, Universitetsforlaget, Oslo

Andersen, P, 20Io Studier i dansk proceshistorie: tiden indtil Danske Lov I683 (Bibliotek for ret og kultur bd. 2), Djøf: Jurist- og Økonomforbundet, Copenhagen

Andersen, P, 20I I Legal Procedure and Practice in Medieval Denmark, Brill, Leiden

Anderson, J, I886 Scotland in Pagan Times: the Bronze and Stone Ages, D Douglas, Edinburgh

Anderson, O S, 1934 The English Hundred Names, vol. I, Lunds Universitets Arsskrift, Lund

Anderson, O S, I939a The English Hundred Names: The South-Western Counties, vol. 2, Lunds Universitets Arsskrift, Lund

Anderson, O S, 1939b The English Hundred Names: The South-Eastern Counties, vol. 3, Lunds Universitets Arsskrift, Lund

Andersson, I and Granlund, J, I956-78 Kulturhistorisk Leksikon for Nordisk Middelalder, vols I-22, Rosenkilde og Bagger, Copenhagen, Allhem, Malmö

Andersson, T M and Miller, W I, I989 Law and Literature in Medieval Iceland. Ljósvetninga saga and Valla-Ljóts saga, Stanford University Press, Stanford

Andersson, T, 2010 'Fanns det en medeltida Ölandslag?', Saga och Sed 2010, 17-20

Andersson, W, 1932 Kyrkor i medelsta Härad. Konsthistoriskt inventarium. Sveriges kyrkor, Blekinge vol. I.2, Svenska Bokhandelscentralen A-B, Stockholm

Andrews, J H, I986 'Mapping the past in the past: The cartographer as antiquarian in pre-Ordnance Survey Ireland', in C Thomas (ed.), Rural Landscapes and Communities: Essays Presented to Desmond McCourt, Irish Academic Press, Dublin, 3 I-63

Andrén, A, I998 'En centralort utan textbelägg? Uppåkra som ett historiskt-arkeologiskt problem', in L Larsson and B Hårdh (eds), Centrala platser, centrala frågor: Sambällsstrukturen under järnåldern. En vänbok till Berta Stjernquist, Almqvist and Wiksell International, Stockholm, Sweden, I37-I 46

Andrén, A, 2005 'Behind heathendom: Archaeological studies of Old Norse Religion', Scottish Archaeological Journal 27:2, 105-138

Anglert, M and Thomasson, J, 2003 Landskapsarkeologi och tidig medeltid, Acta Archaeologica Lundesia, Lund

Anonymous, 1929 Danmarks stednavne. $\mathrm{N} r$ 2, Frederiksborg amts stednavne, Stednavneudvalget, Københavns Universitet, Copenhagen

Anund J and Beronius Jörpeland, L (eds), 2003 Landningsplats forntiden. Riksantikvarieämbetet arkeologiska undersökningar. Skrifter $n r$ 49, Riksantikvarieämbetet, Stockholm

Arge, S V and Mehler, N, 20I2 'Adventures far from home: Hanseatic trade with the Faroe Islands', in H Harnow, D Cranstone, P Belford and L Høst Madsen (eds), Across the North Sea: Later Historical Archaeology in Denmark and Britain, Studies in History and Social Sciences 444, University Press of Southern Denmark, Odense, I75-I 87

Arge, S V, 2014 'Viking Faroes: Settlement, paleoeconomy, and chronology', Journal of the North Atlantic, Special Volume 7, I-I7

Arge, S V and Michelsen, H, 2004 'Fornfrøðiligar rannsóknir í gomlu havnini', in J P A Nolsøe and K Jespersen (eds), Havnar Søga I, Nørhaven, Tórshavn, 23-52

Arge, S V, Sveinbjarnardóttir, G, Edwards, K J and Buckland, P C, 2005 'Viking and medieval settlement in the Faroes: People, place and environment', Human Ecology 33:5, 597-620

Arne, T J, I938 'Domarringarna äro gravar', Fornvännen 33, I65-I77 
Arnold, B and Blair Gibson, D, 1995 Celtic Chiefdom, Celtic State: The Evolution of Complex Social Systems in Prehistoric Europe, Cambridge University Press, Cambridge

Aschehoug, T, I866 Statsforfatningen i Norge og Danmark indtil I8I4 [Constitution of Denmark and Norway until I 8 I 4 ], Felberg og Landmark, Christiania/Copenhagen

Atkin, $\mathrm{M}, 1978$ 'Viking race-courses? The distribution of skeid place-name elements in Northern England', Journal of the English Place-Name Society I0, 26-39

Austin, D, I990 'The proper study of Medieval Archaeology', in D Austin and L Alcock (eds), From the Baltic to the Black Sea: Studies in Medieval Archaeology, Unwin, London, 9-35

Axboe, M, 200I 'Året 536', Skalk 4, 28-32

Baasch, E, I 889 Die Islandfahrt der Deutschen, namentlich der Hamburger, vom I5. bis I7. Jahrhundert, Forschungen zur hamburgischen Handelsgeschichte I, Heroldsche Buchhandlung, Hamburg

Bagerius, H, 2009 Mandom och mödom: Sexualitet, homosocialitet och aristokratisk identitet på det senmedeltida Island, unpublished $\mathrm{PhD}$ thesis, Göteborgs universitet, http://hdl.handle.net/2077/20277 [accessed November 20I3]

Bagge, S, 1989 'Det politiske menneske og det førstatlige samfunn', Norsk Historisk Tidsskrift 68, 227-245

Bagge, S, 200I 'Law and justice in the Middle Ages: A case study', in L Bisgaard, C Selch Jensen, K Villads Jensen and J Lind (eds), Medieval Spirituality in Scandinavia and Europe, Odense University Press, Odense, $73-85$

Baker, J, 20 I I 'Warriors and watchmen: Place-names and Anglo-Saxon civil defence', Medieval Archaeology $55,258-267$

Baker, J and Brookes, S, 20rza 'Governance at the Anglo-Scandinavian interface: Hundredal organization in the southern Danelaw', Journal of the North Atlantic, Special Volume 5, 76-95

Baker, J and Brookes, S, 20I3 b 'Monumentalising the political landscape: A special class of Anglo-Saxon assembly site', Antiquaries Journal 93, I47-162

Baker, J and Brookes, S, 20г $3 \mathrm{c}$ 'Outside the gate: Sub-urban legal practices in early medieval England', World Archaeology 45:5, 747-76I

Baker, J and Brookes, S, 20I5 'Identifying outdoor assembly sites in early medieval England', Journal of Field Archaeology 40, 3-2I

Ballantyne, J H and Smith, B (eds), I994 Shetland Documents I580-I6 I I, Shetland Islands Council and Shetland Times, Lerwick

Ballantyne, J H and Smith, B (eds), I999 Shetland Documents I I95-I579, Shetland Islands Council and Shetland Times, Lerwick

Barceló, J A and Pallarés, M, I996 'From visual seduction to spatial analysis: A critique of GIS in archaeology', Archeologia e Calcolatori 7, 327-335

Barclay, A and Bayliss, A, 1999 'Cursus monuments and the radiocarbon problem', in A Barclay and J Harding (eds), Pathways and Ceremonies: The Cursus Monuments of Britain and Ireland, Oxbow Books, Oxford, I I -29

Barnes, M, I974 'Tingsted. Vesterhavsøyene for øvrig', Kulturhistorisk leksikon for nordisk middelalder I $8,382-387$

Barnwell, P S, 2003 'Political assemblies: Introduction', in P S Barnwell and M Mostert (eds), Political Assemblies in the Earlier Middle Ages, Brepols, Turnhout, I-IO

Barnwell, P S, 2004 'The early Frankish mallus: Its nature, participants and practices', in A Pantos and S Semple (eds), Assembly Places and Practices in Medieval Europe, Four Courts Press, Dublin, 233-246

Barnwell, P S and Mostert, M, 2003 (eds), Political Assemblies in the Earlier Middle Ages, Brepols, Turnhout

Barrett, J H, 2004 'Beyond war or peace: The study of culture contact in Viking-Age Scotland', in J Hines, A Lane and M Redknap (eds), Land, Sea and Home: Proceedings of a Conference on Viking-Period Settlement, The Society for Medieval Archaeology Monograph 20, Leeds, 207-2I 8

Barrow, G, I973 The Kingdom of the Scots: Government, Church and Society from the Eleventh to the Fourteenth Century, Edinburgh University Press, Edinburgh

Barrow, J, 200 I 'Chester's earliest regatta? Edgar's Dee-rowing revisited', Early Medieval Europe Iо, 8 I-93 Barry, G H J, I 805 A History of the Orkney Islands, W Peace, Kirkwall

Basso, K, I996 Widsom Sits in Places: Landscape and language among the Western Apache, University of New Mexico, Albuquerque 
Bately, J, 2009 'Wulfstan's voyage and his description of Estland. The text and the language of the text', in A Englert and A Trakadas (eds), Wulfstan's Voyage: The Baltic Sea Region in the Early Viking Age as Seen from Shipboard, Maritime culture of the North 2, The Viking Ship Museum, Roskilde, I4-28

Batey, C, 2004 'Finds from Hegranesping 2003', in A Friðriksson (ed.), Pinghald að fornu, Fornleifarannsóknir 2003, unpublished reports of the Institute of Archaeology, Iceland, no. FS233O2I42, Reykjavik, 52-53

Bayerschmidt, C F and Hollander, L M, I998 Njál's Saga, Wordsworth, Herfordshire

Bell, A, 2010 Pingvellir: Archaeology of the Althing, unpublished MA dissertation, University of Iceland

Benediktsson, J, I974 'Tingsted, Island', in J Danstrup (ed.), Kulturhistorisk Leksikon for nordisk middelalder, vol. 18 , Rosenkilde og Bagger, Copenhagen, $38 \mathrm{I}-382$

Benediktsson, J, I976a 'Pingfararkaup', in A Karker (ed.), Kulturhistorisk Leksikon for nordisk middelalder, vol. 20, Rosenkilde og Bagger, Copenhagen, 380

Benediktsson, J, 1976b 'Pingmannaleið', in A Karker (ed.), Kulturhistorisk Leksikon for nordisk middelalder, vol. 20, Rosenkilde og Bagger, Copenhagen, $38 \mathrm{I}$

Berglund, B, I995 Tjøtta-riket: en arkeologisk undersøkelse av maktforhold og sentrumsdannelser på Helgelandskysten fra Kr. f. til I700 e. Kr. UNIT, Vitenskapsmuseet, Fakultet for arkeologi og kulturhistorie, Arkeologisk avdeling, Trondheim

Beronius Jörpeland, L and Bäck, M, 2003 'Skallerbohlet beläget widh häradz skilnaden-Lunda socken och bebyggelsearkeologi i en häradsallmänning', in J Anund and L Beronius Jörpeland (eds), Landningsplats forntiden. Riksantikvarieämbetet arkeologiska undersökningar. Skrifter nr 49, Riksantikvarieämbetet, Stockholm, I77-2I4

Beronius Jörpeland, L, Göthberg, H, Seiler, A and Wikborg, J, 20I3 'Monumentala stolprader i Gamla Uppsala', Fornvännen 108, 278-28I

Bertelsen, R, 1985 Lofoten og Vesterålens historie, fra den eldste tiden til ca. $1500 \mathrm{e}$. Kr. Kommunene i Lofoten, Vesterålen

Bhreathnach, E, 20II 'Transforming kingship and cult: The provincial capitals in early medieval Ireland', in R Schot, C Newman and E Bhreathnach (eds), The Landscape of Kingship and Cult: Text and Archaeology, Four Courts Press, Dublin

Bintley, M, 20I 5 Trees in the Religions of Early Medieval England, Boydell Press, Woodbridge

Bjerck, H B, I993 I jernalderhøvdingens innerste rike. Fotefar mot nord, Nordland fylkeskommune, Bodø

Bjorvand, $\mathrm{H}$ and Lindeman, F O (eds), 2007 Våre arveord: Etymologisk ordbok, Novus, Oslo

Bjørgo, N, I982 'Vågastemna i mellomalderen', in S Imsen and G Sandvik (eds), Hamarspor. Eitfestskrift til Lars Hamre I9 1 2-23. Januar-1982, Universitetsforlaget, Oslo, 4-60

Bjørkvik, H, I 968 'Det norske krongodset i reformasjonshundreåret', unpublished manuscript, Trondheim

Bjørkvik, H, I970 'Skipreide', in F Hødnebø (ed.), Kulturhistorisk leksikon for nordisk middelalder fra vikingtid til reformasjonstid I5, Gyldendal Norsk Forlag, Oslo, 546-55I

Bjørkvik, H, I980 ‘Bonde', Kulturhistorisk Leksikon for Nordisk Middelalder II, 89-95

Bjørkvik, H, I996 Folketap og sammenbrudd I350-I 520, bd. 4 i Aschehoug Norgeshistorie, Oslo

Blindheim, C, Heyerdahl-Larsen, B and Tollnes, R L (eds), I98 I Kaupang funnene, bind I, Norske Oldfunn XI, Universitetets Oldsaksamling, Universitetet i Oslo, Oslo

Blindheim, C, Heyerdahl-Larsen, B and Tollnes, R L (eds), I995 Kaupang-funnene, bind 2: Gravplassene $i$ Bikjholbergene/Lamøya. Undersøkelsene 1950-1957, Del A Gravskikk. Norske Oldfunn XVI, Universitetets Oldsaksamling, Universitetet i Oslo, Oslo

Blinkhorn, E and Little, A, $20 \mathrm{I} 8$ 'Being ritual in Mesolithic Britain and Ireland: Identifying ritual behaviour within an ephemeral material record', Journal of World Prehistory 3I, 403-420

Blomqvist, R, I95 I Lunds historia. I, Medeltiden, LiberLäromedel/Gleerup, Lund

Bohman, S, I997 Historia, museer och nationalism, Stockholm, Carlssons

Booth, P, Champion, T, Foreman, S, Garwood, P, Glass, H, Munby, J and Reynolds, A J, 20 I On Track: the Archaeology of High Speed I Section I in Kent, Wessex Archaeology, Oxford

Brackmann, R, $20 \mathrm{I} 2$ The Elizabethan Invention of Anglo-Saxon England, Laurence Nowell, William Lambarde and the study of Old English, D S Brewer, Cambridge

Bradley, J, 200I Archaeological Watching Brief: Land West of the Old School, Rudston, Humber Field Archaeology, Kingston-upon-Hull

Bradley, R, I987 'Time regained: The creation of continuity', Journal of the British Archaeological Association I40, I-I7 
Bradley, R, I993 Altering the Earth: The I992 Rhind Lectures, The Society of Antiquaries of Scotland Monograph 8, Edinburgh

Bradley, R, 2007 The Prehistory of Britain and Ireland, Cambridge University Press, Cambridge

Brand, J, I883 A Brief Description of Orkney, Zetland, Pightland-Firth, and Caithness, William Brown, Edinburgh

Bratrein, H D, I984 'Skjøttebåter og leidangsskip i Nord-Norge', Acta Borelia. A Norwegian Journal of Circumpolar Societies I, 27-37

Bratrein, H D, 1989 Fra steinalder til àr I700. Karlsøy og Helgøy bygdebok: folkeliv, noringsliv, samfunnsliv I, Karlsøy kommune, Hansnes

Brendalsmo, J and Molaug, P B, 20I4 'To norske byer i middelalderen: Oslo og Tønsberg før ca. I300', Collegium Medievale 27, I36-202

Brink, S, I996 'Forsaringen: Nordens äldsta lagbud', in E Roesdahl and P Meulengracht Sørensen (eds), Beretning fra femtende tvoerfaglige vikingesymposium, Højbjerg Hikuin, Århus, 27-55

Brink, S, I999 'Social order in the early Scandinavian landscape', in C Fabech and J Ringtved (eds), Settlement and Landscape: Proceedings of a conference in Àrhus, Denmark, May 4-7 I998, Jutland Archaeological Society, Moesgård, 424-439

Brink, S, 2000a 'Nordens husabyar: unga eller gamla?', in M Olausson (ed.), En bok om husabyar, Uppsala, 65-73

Brink, S, 200ob 'Forntida vägar', Bebyggelsehistorisk tidskrift 39, 23-64

Brink, S, 200I 'Mythologizing landscape, place and space of cult and myth', in M Stausberg (ed.), Kontinuitäten und Brüche in der Religionsgeschichte. Festschrift für Anders Hultgard zu seinem 65. Geburtstag am 23.I2.2002, Walter de Gruyter, New York, I-3 I

Brink, S, 2002 'Law and legal customs in Viking Age Scandinavia', in J Jesch (ed.), Scandinavians from the Vendel Period to the Tenth Century, Studies in Historical Archaeoethnology, Boydell Press, Woodbridge, 87-I 27

Brink, S, 2003 'Den förkristna muntliga traditionen i Norden: till frågan om det kollektiva minnet', in L Elmevik (ed.), Saga och sed. Kungl. Gustav Adolfs Akademiens årsbok, Annales Academiae Regiae Gustavi Adolphi, Uppsala, 7 I-8 I

Brink, S, 2004a 'Legal assembly sites in early Scandinavia', in A Pantos and S Semple (eds), Assembly Places and Practices in Medieval Europe, Four Courts Press, Dublin, 205-2 I6

Brink, S, 2004b 'Mytologiska rum och eskatologiska föreställningar i det vikingatida Norden', in A Andrén, K Jennbert and C Raudvere (eds), Ordning mot kaos: studier av nordisk förkristen kosmologi, Nordic Academic Press, Lund, 29I-3 I 6

Brink, S, 2007 'Skiringssal, Kaupang, Tjølling: The toponymic evidence', in D Skre (ed.), Kaupang in Skiringssal, Kaupang Excavation Project Publication Series, Oslo/Århus, 53-64

Brink, S, 2008 'Law and society: Polities and legal customs in Viking Scandinavia', in S Brink and N Price (eds), The Viking World, Routledge, London, 23-3 I

Brink, S, 20 I I 'Oral fragments in the earliest Old Swedish laws?', in M Mostert and P S Barnwell (eds), Medieval Legal Process: Physical, Spoken and Written Performance in The Middle Ages, Brepols, Turnhout, I47-I 56

Brink, S, 20I3 'Myth and ritual in the pre-Christian Scandinavian landscape', in S W Nordeide and S Brink (eds), Sacred Sites and Holy Places: Exploring the Sacralization of Landscape through Time and Space, Brepols, Turnhout, 33-52

Brink, S, 20I4 'The Hälsinge Law between south and west, king and Church, and local customs', in S Brink and L Collinson (eds), New approaches to early law in Scandinavia, Brepols, Turnhout, 37-56

Brink, S and Collinson, L (eds), 20I4 New approaches to early law in Scandinavia, Brepols, Turnhout

Brookes, S, 20I I 'The lathes of Kent: A review of the evidence', in S J Brookes, S Harrington and A Reynolds (eds), Studies in Early Anglo-Saxon Art and Archaeology: Papers in Honour of Martin G Welch, Archaeopress, Oxford, I 56-I70

Brookes, S, 2019 'Folk cemeteries, assembly and territorial geography in early Anglo-Saxon England', in A Reynolds, J Caroll and B Yorke (eds), Power and Place in Later Roman and Early Medieval Europe: Interdisciplinary Perspectives on Governance and Civil Organization, Proceedings of the British Academy, Oxford University Press, Oxford, I05-I 24

Brookes, S and Reynolds, A, 201 I 'The origins of political order and the Anglo-Saxon State', Archaeology International I $3,84-93$ 
Brooks, N P, I97I 'The development of military obligations in eighth- and ninth-century England', in P Clemoes and K Hughes (eds), England Before the Conquest, Cambridge University Press, Cambridge, 69-84

Brown, W, I898 Yorkshire Inquisitions of the Reigns of Henry III and Edward I. Volume 2, Yorkshire Archaeological Society, Leeds

Brown, W, 1902 Yorkshire Inquisitions of the Reigns of Henry III and Edward I. Volume 3, Yorkshire Archaeological Society, Leeds

Brun, P, 1995 'From chiefdom to state organisation in Celtic Europe', in B Arnold and D Blair Gibson (eds), Celtic Chiefdom, Celtic State: The Evolution of Complex Social Systems in Prehistoric Europe, Cambridge University Press, Cambridge, I3-25

Brunner, H, I908 'The sources of English law', in Association of American Law Schools (eds), Selected Essays in Anglo-American Legal History I-III, II, 7-52

Bruun, D, I899 Arkceologiske Undersøgelser paa Island foretagne i Sommeren I898, Det nordiske Forlag, Copenhagen

Bruun, D, I987 Fortidsminder og nutidshjem paa Island, Gyldendal, Copenhagen (2nd edn)

Brück, J, 2005 'Experiencing the past? The development of phenomenological archaeology in British Prehistory', Archaeological Dialogues I 2:I, 45-72

Buckberry, J L, 2004 A Social and Anthropological Analysis of Conversion Period and Later Anglo-Saxon Cemeteries in Lincolnshire and Yorkshire, unpublished PhD thesis, University of Sheffield

Bugge, A, 1904 Vikingerne: Billeder Fra Vore Forfaedres Liv, Gyldendalske Boghandel, Copenhagen

Bugge, A, 1920 'Tingsteder, gilder og andre gamle mittpunkter i de norske bygder', Historisk Tidsskrift 5:4, $7-152$ and $195-252$

Bukkemoen, G B and Samdal, M, 2008 'Bommestad 2: kokegropfelt og dyrkningsspor fra jernalder', in L E Gjerpe (ed.), Hus, boplass- og dyrkningsspor. EI 8-prosjektet Vestfold. Bind 3. Varia 73, Kulturhistorisk Museum, Fornminneseksjonen, Universitetet i Oslo, Oslo, 247-264

Bull, E, I917 'Skipstomter og naustetomter fra vikingetid eller middelalder', Foreningen til Norske Fortidsmindesmoerkers Bevaring. Aarsberetning I917, I7-23

Bull, E, I9I 8 'Studier over Norges administrative inddeling i middelalderen', Historisk Tidsskrift 5, 257282

Bull, E, I920 Leding. Militcer- og finansforfatning I Norge $i$ celdre tid, Steenske forlag, Cristiania/ Copenhagen

Bull, E, I92 I 'Politiske inndelinger på Oplandene i gammel tid', Bygd og bonde, 49-7I

Bull, E, I924 'Stevne', Historisk Tidsskrift 5:6, 30-I45

Bull, E, I930 'Fylke', Scandia 3, 78-I05

Bull, E, I93 I Fra omkring I000 til I280. Det Norske folks liv og historie giennem tidene, vol. 2, Aschehoug, Oslo

Bure, J, I599 Runakenslones lerespan

Byock, J L, I990 Medieval Iceland: Society, Sagas and Power, University of California Press, Berkeley (revised edn)

Byock, J L, 1993 'Goði', in P Pulsiano and K Wolf (eds), Medieval Scandinavia: An Encyclopedia, Garland Publishing, New York/London, 230-23I

Byock, J L, 200I Viking Age Iceland, Penguin, London

Byock, J, Walker, P, Erlandson, J, Holck, P, Zori, D, Guðmundsson, M and Tveskov, M, 2005 'A Viking Age valley in Iceland: The Mosfell Archaeological Project', Medieval Archaeology 49, I96-220

Byrne, F J, 1973 Irish Kings and High-Kings, Four Courts Press, Dublin

Bäck, M, 20I4 'Nyköping och den tidiga urbaniseringen i östra Skandinavien', Situne Dei, 6-2I

Bäck, M, Hållans Stenholm, A-M and Ljung, J-Å, 2008 Lilla Ullevi: Historien om det fridlysta rummet. Vendeltida helgedom, medeltida by och I6oo-talsgård, Uppland, Bro socken, Klöv och Lilla Ullevi I:5, Jursta 3:3, RÄ̈ 145: arkeologisk undersökning, Hägersten: UV Mitt, Avdelningen för arkeologiska undersökningar, Riksantikvarieämbetet

Bøe, A, I 965 'Lagting. Noreg og Faerøyane', Kulturhistorisk leksikon for nordisk middelalder I0, I78-1 84

Bøe, A, I966 'Magnus Lagabøtes landslov', in J Granlund (ed.), Kulturhistoriskt lexikon för nordisk medeltid från vikingatid till reformationstid $\mathrm{I} \mathrm{I}, 23 \mathrm{I}-237$

Callissendorff, K, I966 'Folklandstingstad och en gammal färdled', Fornvännen 6I, 244-249 
Cam, H M, I932 'Manerium cum Hundredo: The hundred and the hundredal manor', English Historical Review 47, 353-376

Camden, W, I707 [ I 586] Britannia, London

Cameron, K, 1984 The Place-names of Lincolnshire part I, English Place-Name Society 58, Nottingham

Cant, R G, 1975 The Medieval Churches and Chapels of Shetland, Shetland Archaeological and Historical Society, Lerwick

Carroll, J, 20I 2 'Changing places, changing functions?', in R Jones and S Semple (eds), Sense of Place in Anglo-Saxon England, Shaun Tyas, Donnington, I68-179

Carter, T, 2015 Iceland's Networked Society: Revealing How the Global Affairs of the Viking Age created new forms of social complexity, Brill, Leiden

Carver, M O H, I992 The Age of Sutton Hoo, Boydell Press, Woodbridge

Charles-Edwards, T, I976 'Boundaries in early Irish law', in P Sawyer (ed.), Medieval Settlement: Continuity and Change, Arnold, London

Charles-Edwards, T, 2000 Early Christian Ireland, Cambridge University Press, Cambridge

Charles-Edwards, T, 2004 'Gorsedd dadl, and llys: Assemblies and courts in medieval Wales', in A Pantos and S Semple (eds), Assembly Places and Practices in Medieval Europe, Four Courts Press, Dublin, 95-108

Charpentier Ljungqvist, F, 20I4 Kungamakten och lagen: en jämförelse mellan Danmark, Norge och Sverige under högmedeltiden, Historiska institutionen, Stockholms universitet, Stockholm

Christensen, A, 1988 Middelalderbyen Odense, J Centrum, Viby

Claassen, C, 20 I I 'Rock shelters as women's retreats: Understanding Newt Kash', American Antiquity 76 , 628-64I

Clanchy, M T, 1979 From Memory to Written record: England 1066-I307, Arnold, London

Clarke, T and Mangham, I, 2004 'From dramaturgy to theatre as technology: The case of corporate theatre', Journal of Management Studies 4I:I, 37-59

Clouston, J S, I9I4 Records of the Earldom of Orkney I 299-I6 I4, Scottish History Society, Edinburgh

Clover, C J, 1993 'Regardless of sex: Men, women, and power in early northern Europe', Speculum 68:2, $363-387$

Clucas, G F, I925a 'Tynwald Hill in ancient days', Proceedings of the Isle of Man Natural History and Antiquarian Society 2, I60-I63

Clucas, G F, 1925b Tynwald, Douglas, privately printed

Coke, E, I669 The Third Part of the Institutes of the Laws of England: Concerning High Treason and other pleas of the Crown and Criminal causes, A Crook, London

Collin, H S and Schlyter, C J, I 834 Corpus iuris sueo-gotorum antiqui, P A Norstedt and Sons, Stockholm

Collingwood, W G and Stefánsson, J (trans.), 1902 The Life and Death of Cormac the Skald, W Holmes, Ulverston

Comeau, R, 20I4 'Bayvil in Cemais: An early medieval assembly site in South-West Wales?', Medieval Archaeology 58, 270-284

Content, $\mathrm{S}$ and Williams, H, 2010 'Creating the pagan English: From the Tudors to the present day', in M O H Carver, A Sanmark and S Semple (eds), Signals of Belief in Early England, Anglo-Saxon Paganism Revisited, Oxbow Books, Oxford, I $8 \mathrm{I}-200$

Coolen, J, 2016 'Gallows, cairns, and things: A study of tentative gallows sites in Shetland', Journal of the North Atlantic, Special Volume 8, 93-I I 4

Coolen, J and Mehler, N, 2010 Geophysical Survey at Housa Voe, Papa Stour, Shetland 2010, The Assembly Project, unpublished Field Report 2

Coolen, J and Mehler, N, 20I I Archaeological Excavations at the Law Ting Holm, Tingwall, Shetland 20I I, The Assembly Project, unpublished Field Report 4

Coolen, J and Mehler, N 20I2 Geophysical and Topographical Surveys at Pingeyrar, Iceland 2012, The Assembly Project, unpublished Field Report 6

Coolen, J and Mehler, N, 20I4 Excavations and Surveys at the Law Ting Holm, Tingwall, Shetland: An Iron Age Settlement and Medieval Assembly Site, British Archaeological Reports British Series 592, Archaeopress, Oxford

Coolen, J and Mehler, N, 20I5 'Surveying the assembly site and churches of Pingeyrar', Archaeologia Islandica I I, I I-32 
Costello, E, 201 8 'Temporary freedoms? Ethnoarchaeology of female herders at seasonal sites in northern Europe', World Archaeology 50:I, I 65-I 84

Cotter, P, 2005 'Functions of the cantred in medieval Ireland', Peritia I9, 308-232

Cowie, R and Blackmore, L, with Davis, A, Kiely, J and Reilly, K, 2012 Lundenwic: Excavations in Middle Saxon London, 1987-2000, Museum of London Monograph 63, London

Crawford, B, I987 Scandinavian Scotland, Leicester University Press, Leicester

Crawford, B, 2006 'Kongemakt og jarlemakt, stedsnavn som bevis?', Viking 2006, I95-2 I 4

Crawford, B, 20I3 The Northern Earldoms: Orkney and Caithness from AD 870 to I 470 , John Donald, Edinburgh

Crawford, B and Ballin Smith, B, 1999 The Biggings, Papa Stour, Shetland: The History and Excavation of a Royal Norwegian Farm, The Society of Antiquaries of Scotland Monograph Series I 5, Edinburgh

Crawford, B and Sanmark, A, 20I6 'The Orkney Huseby farms: The onomastic, historical and archaeological context', in L E Christensen, T Lemm and A Pedersen (eds), Husebyer: Status quo, open questions and perspectives, Studies in Archaeology and History 20:3, Jelling Series, National Museum, Copenhagen, 9I-IO5

Creighton, $\mathrm{O}$ H, 2002 Castles and Landscapes: Power, Community and Fortification in Medieval England, Equinox, London

Darvill, T, 2004 'Tynwald Hill and the "things" of power', in A Pantos and S Semple (eds), Assembly Places and Practices in Medieval Europe, Four Courts Press, Dublin, 21 7-233

Davies, W, I982 Wales in the Early Middle Ages, Leicester University Press, Leicester

Debes, H J, I995 Føroya søga 2: Skattland og len, Føroya Skúlabókagrunnur, Tórshavn

Debes, H J, 2000 Føroya søga 3: Frá kongligum einahandli til embætisveldi, Føroya Skúlabókagrunnur, Tórshavn

Debes, L J, I673 Foroce et Foroa Reserata, Copenhagen

Debes, L J, I757 Natürliche und Politische Historie der Inseln Färöe, Schriftenreihe des Deutsch-Färöischen Freundeskreises 9, Deutsch-Färöischer Freundeskreis, Mühlheim a.d. Ruhr (2005 edn reprint by N B Vogt)

DeMarrais, E, 2016 'Making pacts and co-operative acts: The archaeology of coalition and consensus', World Archaeolgy 48: I, I-I3

Dennis, A, Foote, P, and Perkins, R (trans.), I980 Laws of early Iceland: Grágás. The Codex Regius of Grágás with material from other manuscripts, vol. I, University of Manitoba Press, Winnipeg

Dennis, A, Foote, P, and Perkins, R (eds), 2000 Laws of early Iceland: Grágás. The Codex Regius of Grágás with material from other manuscripts, vol. 2, University of Manitoba Press, Winnipeg

Díaz-Andreu, M, I995 'Archaeology and nationalism in Spain', in P Kohl and C Fawcett (eds), Nationalism, Politics and the Practice of Archaeology, Cambridge, Cambridge University Press, 39-56

Díaz-Andreu, M, 2007 A World History of Nineteenth-Century Archaeology: Nationalism, Colonialism and the Past, Oxford University Press, Oxford

Driscoll, S T, I988 'The relationship between history and archaeology: Artefacts, documents and power', in S T Driscoll and M R Nieke (eds), Power and Politics in Early Medieval Britain and Ireland, Edinburgh University Press, Edinburgh, I62-I 87

Driscoll, S, I 998 'Picts and prehistory: Cultural resource management in early medieval Scotland', World Archaeology 30:I, I 42-I 58

Driscoll, S, 2002 Alba. The Gaelic Kingdom of Scotland AD 800-I I 24, Birlinn Ltd with Historic Scotland, Edinburgh

Driscoll, S, 2003 'Govan: An early medieval royal centre on the Clyde', in R Welander, D Breeze and T O Clancy (eds), The Stone of Destiny: Artefact and Icon, The Society of Antiquaries of Scotland Monograph 22, 77-83

Driscoll, S, 2004 'The archaeological context of assembly in early medieval Scotland: Scone and its comparanda', in A Pantos and S Semple (eds), Assembly Places and Practices in Medieval Europe, Four Courts Press, Dublin, 73-94

Duffy, S, I997 'Ireland's Hastings', in C Harper-Bill, L Abrams, M Chibnall, S D Church and J Counihan (eds), Proceedings of the Battle Conference in Dublin I997, Anglo-Norman studies 20, Boydell, Woodbridge

Duffy, S, 2005 'A reconsideration of the site of Dublin's Viking thing-mót', in T Condit and C Corlett (eds), Above and Beyond, Essays in Memory of Leo Swan, Wordwell, Dublin, 35 I-360 
Durrenberger, P, Durrenberger, D, and Eysteinsson, Á, I986-89 'Economic representation and narrative structure in Hænsa-Póris saga', Saga Book of the Viking Society 22, I43-I65

Dymond, D, I966 'Ritual monuments at Rudston, E Yorkshire, England', Proceedings of the Prehistoric Society 32, 86-95

Dørum, K, I995 'Ble Erik av Pommern kronet i Norge før Kalmarmøtet?', Historisk Tidskrift 74, hf. 4, $469-472$

Dørum, K, 2004 Romerike og riksintegreringen. Integreringen av Romerike og det norske rikskongedømmet i perioden ca. I000-I350, Acta Humaniora, University of Oslo, Oslo

Ebel, E, I977 'Kaufmann und Handel auf Island zur Sagazeit', Hansische Geschichtsblätter 95, I-26

Ebel, E, I 985 'Der regionale Handel am Beispiel Islands zur Sagazeit', in K Düwel, H, Jankuhn, H, Siems and D Tiempe (eds), Untersuchungen zu Handel und Verkehr der vor- und frühgeschichtlichen Zeit in Mittel- und Nordeuropa, vol. I, Methodische Grundlaggen und Darstellungen zum Handel in vorgeschichtlicher Zeit und in der Antike, Vandenhoek and Rupprecht, Göttingen, I09-I 26

Ebel, E, I987 'Der Fernhandel von der Wikingerzeit bis in das I2. Jahrhundert in Nordeuropa nach altnordischen Quellen', in K Düwel, H, Jankuhn, H, Siems and D Tiempe (eds), Untersuchungen zu Handel und Verkehr der vor- und frühgeschichtlichen

Ebel, E, 1998 'Gode, Godentum', Reallexikon der Germanischen Altertumskunde, vol. I2, Walter de Gruyter, Berlin, 260-263

Edwards, K J and Whittington, G, I998 'Landscape and environment in prehistoric West Mainland, Shetland', Landcape History 20:I, 5-I7

Edwards, N, 1990 The Archaeology of Early Medieval Ireland, B T Batsford Ltd, London

Edwards, N, 2009 'Rethinking the Pillar of Eliseg', The Antiquaries Journal 89, I43-177

Ehlers, C, 2016 'Between Marklo and Merseburg: Assemblies and their sites in Saxony from the beginning of Christianization to the time of the Ottonian kings', Journal of the North Atlantic, Special Volume 8, I 34 -I 40

Eithun, B, Rindal, M and Ulset, T, 1994 Den eldre Gulatingsloven, Riksarkivet, Oslo

Ekrem, I and Mortensen, L B (eds), 2003 Historia Norwegie, Museum Tusculanum Press, Copenhagen

Ekroll, Ø, 1997 Med kleber og kalk: Norsk steinbygging i mellomalderen, Det Norske Samlaget, Oslo

Ekwall, E, I960 A Dictionary of English Place-Names, Oxford

Ellis-Davidson, H, 1964 Gods and Myths of Northern Europe, Penguin Books Ltd, London

Ellis-Davidson, H, I988 Myths and Symbols in Pagan Europe: Early Scandinavian and Celtic Religions, Syracuse University Press, New York

Ellmers, D, I990 'Die Verlagerung des Fernhandels vom öffentlichen Ufermarkt in die privaten Kaufhäuser der Kaufleute', Lübecker Schriften zur Archäologie und Kulturgeschichte 20, IOI-IO8

Emmelin, A, I944 'Om tingsställen i Uppland och Västmanland före tillkomsten av 1734 års lag’, Rig 27, 89 -I I I

Ersland, G A, I999 'I. Inn i unionen', in G A Ersland and H Sandvik (eds), Norsk historie I300-1625, Det Norske Samlaget, Oslo, I6-I 38

Ersland, G A, 2000 'Kongshird og leidangsbonde', in G A Ersland and T H Holm (ed.), Norsk Forsvarshistorie, bind I. Krigsmakt og kongemakt 900-I 8I4, Eide forlag, Bergen, I3-I 54

Erslev, K, I 882 Dronning Margrethe og Kalmarunionens Grundlaggelse, Jacob Erslev, Copenhagen

Espe, A and Hovland, K, I994 Lcerdal Bygdebok. Band III. Heim og cett. Tønjum og Hauge sokn, Lærdal kommune, Lærdal

Esser, T, 20I I Die Erzählung von Pórhall Biermütze, in K Blödl, A Vollmer and Z Zernack (eds), Isländersagas 3, Fischer Verlag, Frankfurt am Main, 37 I-38 I

Everson, P and Stocker, D, 1999 Corpus of Anglo-Saxon Stone Sculpture Volume V: Lincolnshire, Oxford University Press, Oxford

Everson, P and Stocker D, 20I I Custodians of Continuity? The Premonstratensian Abbey at Barlings and the Landscape of Ritual, Lincolnshire Archaeological and Heritage Report Series I I, Lincoln Heritage Trust, Lincoln

Facos, M, I998 Nationalism and the Nordic Imagination, Swedish Art of the I89os, University of California Press, Berkeley

Faith, R, 1997 The English Peasantry and the Growth of Lordship, Leicester University Press, London and New York 
Faith, R, 1999 'Hide', in M Lapidge, J Blair, S Keynes and D Scragg (eds), The Blackwell Encyclopedia of Anglo-Saxon England, Oxford, Blackwell, 238-239

Falk, A, I9I 2 'Altnordisches Seewesen', Wörter und Sachen. Kulturhistorische Zeitschrift für Sprach- und Sachforschung 4, I-I I 8

Falkanger, A T, 2007 Lagmann og lagting i Hålogaland giennom Iooo år, Universitetsforlaget, Oslo

Farrer, W, I9I4 Early Yorkshire Charters, Volume I, Ballantyne, Hanson and Co, Edinburgh

Farrer, W, I9I 5 Early Yorkshire Charters, Volume 2, Ballantyne, Hanson and Co, Edinburgh

von Feilitzen, O, I96I, The Published Writings of Eilert Ekwall: A Bibliography, Gleerup, Lund

Feinman, G M, and Garraty, C P, 2010 'Preindustrial markets and marketing: Archaeological perspectives', Annual Review of Anthropology 39, I67-I9I

Fellows-Jensen, G, I993 'Tingwall, Dingwall and Thingwall', in Twenty-eight papers presented to Hans Bekker-Nielsen on the occasion of his 6oth birthday, Odense University Press, Odense, 53-67

Fenger, O, 1999 'Med lov skal land bygges', Middelalderens Danmark, 52-63

Fenger, O, 200 I Lov og ret $i$ Europas historie, Aarhus Universitetsforlag, Aarhus

Fenwick J, Gerarghy, R, Waddell, J and Barton, K, 2006 'The innermost secrets of Rathcróghan Mound', Archaeology Ireland 20, 26-29

Fernández-Götz, M, 2012 'Die Rolle der Heiligtümer bei der Konstruktion kollektiver Identitäten: das Beispiel der treverischen Oppida', Archäologisches Korrespondenzblatt 42:4, 509-524

Fernández-Götz, M, 20I4a 'Reassessing the Oppida: The role of power and religion', Oxford Journal of Archaeology 33:4, 379-394

Fernández-Götz, M, 20I4b Identity and Power: The Transformation of Iron Age Societies in Northeast Gaul, Amsterdam Archaeological Studies 2I, Amsterdam

Fernández-Götz, M, 2017 'Urbanization in Iron Age Europe: Trajectories, patterns and social dynamics', Journal of Archaeological Research 2017, I-46

Fett, P, I952 Førhistoriske minne i Sogn. Lardal prestegjeld, Historisk Museum, University of Bergen, Bergen

Fett, P, I967 Førhistoriske minne i Sunnhordland. Stord prestegjeld, Historisk Museum, University of Bergen, Bergen

Fett, P, I97I Førhistoriske minne i Midhordland. Fana prestegield: herunder Birkeland og Storetveit prestegjeld, Historisk Museum, University of Bergen, Bergen

Fiorato, V, 2009 'Greenham common: The conservation and management of a Cold War archetype', in J Schofield and W Cocroft (eds), A Fearsome Heritage: Diverse Legacies of the Cold War, Left Coast Press, Walnut Creek, I29-I 54

Fischer-Lichte, E, 2005 Theatre, Sacrifice, Ritual: Exploring Forms of Political Theatre, Routledge, London

Fisher, H A L (ed.), I9 I I The Collected Papers of Frederic William Maitland, vol. 3, Cambridge University Press, Cambridge

Fisher, P, Higgins, H (trans.), Foote, P (ed.), I999 Olaus Magnus. Historia de Gentibus Septentrionalibus, Rome, I 555, Hakluyt Society, London

FitzNeal, R, Hughes, A, Crump, C G and Johnson, C, I902 De Necessariis Observantiis Scaccarii Dialogus, Clarendon Press, Oxford

FitzPatrick, E, 2004a 'Royal inauguration mounds in medieval Ireland: Antique landscape and tradition', in A Pantos and S Semple (eds), Assembly Places and Practices in Medieval Europe, Four Courts Press, Dublin, 44-72

FitzPatrick, E, 2004b Royal Inanguration in Gaelic Ireland c. II00-I600: A Cultural Landscape Study, Boydell Press, Woodbridge

FitzPatrick, E, 20I2 'Formaoil na Fiann: Hunting preserves and assembly places in Gaelic Ireland', Proceedings of the Harvard Celtic Colloquium 32, 95-I I 8

FitzPatrick, E, 20I5 'Assembly places and elite collective identities in medieval Ireland', Journal of the North Atlantic, Special Volume 8, 52-68

Foote, P, 1987 'Reflections on Landabrigðispáttr and Rekapáttr in Grágás', in K Hastrup and P Meulengracht Sørensen (eds), Tradition og historieskriving: Kilderne til Nordens aldste historie, Aarhus University Press, Aarhus, 53-64

Foote, P and Wilson, D M, I980 The Viking Achievement, Great Civilizations Series, Sidgwick and Jackson, London

Fox, G, I 827 The History of Pontefract, in Yorkshire, John Fox, Pontefract 
Frankot, E, 20I2 'Of laws of ships and shipmen': Medieval Maritime Law and its Practice in Urban Northern Europe, Edinburgh University Press, Edinburgh

Friðriksson, A, I994 Sagas and Popular Antiquarianism in Icelandic Archaeology, Avebury, Aldershot

Friðriksson, A (ed.), 2004 Pinghald að fornu: Fornleifarannsóknir 2003, unpublished reports of the Institute of Archaeology, Iceland, no. FS233-02I42, Reykjavik

Friðriksson, A, 20I I 'Pingstaðir', in B Lárusdóttir (ed.), Mannvist: Sýnisbók íslenskra fornleifa, Opna, Reykjavik, $344-358$

Friðriksson, A, Roberts, H M, Guðmundsson, G, 2004 Pingstaðarannsóknir 2004, unpublished report, Fornleifastofnun Íslands, unpublished reports of the Institute of Archaeology, Iceland, no. FS275O2I43, Reykjavik

Friðriksson, A, Roberts, H M, Guðmundsson, G, Gísladóttir, G A, Sigurgeirsson, M Á, and Damiata, B 2005 Pingvellir og pinghald að fornu. Framvinduskýrsla 2005, unpublished report of the Institute of Archaeology, Iceland, unpublished reports of the Institute of Archaeology, Iceland, no. FS307-02 I43, Reykjavik

Friðriksson, A and Vésteinsson, O, 1992 'Dómhringa saga. Grein um fornleifaskýringar', Saga 30, 7-79

Friis-Jensen, K and Fisher, P (eds and trans.), 2015 Saxo, Gesta Danorum: The History of the Danes (vols I-2), Clarendon Press, Oxford

Fritzner, J, I886-96, Ordbog over det gamle norske sprog (3 vols), Feilberg and Landmark, Cristiania/ Copenhagen

Fugelsøy, M, I970 Skjervøy: Et prestegjeld og et herred i Nord-Troms I, Skjervøy kommune, Skjervøy

Fukuyama, F, 20I I The Origins of Political Order, Profile, London

Gansum, T, 20I3 Hangar and Hangating: Archaeology of Mounds on an Assembly Site, Haugar Vestfold Kunstmuseum, Tønsberg

Gansum, T and Østigård, T, 1999 'En haug med ritualer: Haugar og rikssamlingene', Vestfoldminne I998/1999, 74-99

Gardeła, L, 2OI 2 'What the Vikings did for fun? Sports and pastimes in medieval Northern Europe', World Archaeology 44:2, 234-427

Gardiner, M, 20I2 'Oral tradition, landscape and the social life of place-names', in R Jones and S Semple (eds), Sense of Place in Anglo-Saxon England, Shaun Tyas, Donington, I6-30

Gardiner, M and Mehler, N, 2007 'English and Hanseatic trading and fishing sites in medieval Iceland. Report on initial fieldwork', Germania 85, 385-427

Gardiner, M and Rippon, S, 2007 'Introduction: The medieval landscapes of Britain', in M Gardiner and S Rippon (eds), Medieval Landscapes, Windgather Press, Oxford, I-8

Gardner, J, 2018 'Beneath the rubble, the Crystal Palace! The surprising persistence of a temporary mega event', World Archaeology 50.I, I 85-I99

Geertz, C, I980 Negara: The Theatre State in Nineteenth-Century Bali, Princeton University Press, Princeton

Gelling, M, 1978 Signposts to the Past, Dent, London

Gelsinger, B E, I98 I Icelandic Enterprise: Commerce and Economy in the Middle Ages, University of South Carolina Press, Columbia

Gerrard, C M, 2003 Medieval Archaeology: Understanding Traditions and Contemporary Approaches, Routledge, London

Gertz, M C (ed.), I908-I 2 Ælnoth Vite Sanctorum Danorum, Danske Helgeners Levned, Copenhagen

Gertz, M C (ed.), I9I7-I 8 Scriptores Minores Historice Danicce, vol. I, Copenhagen

Gestsdóttir, H, 2003 'The Chapel', in G Lucas (ed.), Hofstaðir 2002. Framvinduskýrslur/Interim Report, unpublished reports of the Institute of Archaeology, Iceland, no. FS I93-9Io I Io, Reykjavik, 26-29

Gestsdóttir, H, 2004 Hofstaðir 2003. Framvinduskýrsla/Interim Report, unpublished reports of the Institute of Archaeology, Iceland, no. FS230-9I0 I I , Reykjavik

Gibbon, S J, 2007 'Medieval parish formation in Orkney', in B Ballin Smith, S Taylor and G Williams (eds), West over Sea: Studies in Scandinavian Sea-Borne Expansion and Settlement Before I300, Brill, Koninklijke, $235-250$

Gibbon, S J, 2012 'Orkney's things', in O Owen (ed.), Things in the Viking World, THING project, The Shetland Amenity Trust, Lerwick, 80-93

Gísladóttir, H, 1999 Íslensk matarhefð, Mál og mennig, Reykjavik 
Gjerpe, L E, 2008 EI8-prosjektet Vestfold. 3: Hus, boplass- og dyrkningsspor, Kulturhistorisk Museum, Fornminneseksjonen, Oslo

Gleeson, P, 2012 'Constructing kingship in early medieval Ireland: Power, place and ideology', Medieval Archaeology 56, I-3 I

Gleeson, P, 20I 5 'Kingdoms, communities and Óenaig: Irish assembly practices in a northwest European context', Journal of the North Atlantic, Special Volume 8, 33-5 I

Gleeson, P, 20I 7a 'Converting kingship in early Ireland: Re-defining practices, ideologies and identities', in M Ní Mhaonáigh, R Flechner and N Edwards (eds), Transforming Landscapes of Belief in the Early Medieval Insular World and Beyond: Converting the Isles, vol. 2, Brepols, Turnhout, 287-3 I 8

Gleeson, P, 20I 7 b 'Gathering the nations: Towards an archaeology of assembly for early medieval Ireland', in F Beglane (ed), Gatherings: Past and Present, Archaeopress, Oxford

Gleeson, P, 20 I 8 'Gathering communities: Locality, governance and rulership in early medieval Ireland', World Archaeology 50:I, I00-I 20

Glick, T F, 2005 Islamic and Christian Spain in the Early Middle Ages, Brill, Leiden (2nd edn)

Goffman, E, I959 The Presentation of Self in Everyday Life, Doubleday, New York

Goffman, E, I967 Interaction Ritual: Essays on Face-to-face Behaviour, Garden City, New York

Goffman, E 1974 Frame Analysis: An Essay on the Organization of Experience, Harvard University Press, Cambridge, MA

Gogosz, R, 20I4 'Horse fights: The brutal entertainment of the Icelanders in the Middle Ages', Sredniowiecze Polski i Powszechne 5:9, I7-32

Gomme, G L, I880 Primitive Folk-Moots, Sampson Law, Marston, Searle and Rivington, London

González-Ruibal, A and de Torres, J, 2018 'The fair and sanctuary: Gathering places in a nomadic landscape (Somaliland, I000-I $850 \mathrm{AD}$ )', World Archaeology 50:I, 23-40

Gosden, C, I994 Social Being and Time, Blackwell, Oxford

Granlund, J (ed.), I956-78 Kulturhistoriskt lexikon för nordisk medeltid. Frän vikingatid till reformationstid, Allhem, Malmö

Granlund, J, I958 'Disting', in J Granlund (ed.), Kulturhistoriskt Lexikon För Nordisk Medeltid. Frän Vikingatid till Reformationstid, Allhem, Malmö, I I 2-I I 5

Grieg, S, I957 'Budstikke', Kulturhistorisk Leksikon for Nordisk Middelalder II, 338-340

Grigg, J, 2015 The Philosopher King and the Pictish Nation, Four Courts Press, Dublin

Grimm, J L C, I828 Die Deutsche Rechtsaltertümer, Dieterich, Göttingen

Grimm, O, 2006 Großbootshaus, Zentrum und Herrschaft: Zentralplatzforschung in der nordeuropäischen Archäologie (I.-I 5. Jahrhundert), Ergänzungsbände zum Reallexikon der germanischen Altertumskunde 5, Walter de Gruyter, Berlin

Grimm, O, 2010 Roman Period Court-yards in South-Western Norway: A Social Organisation in an International Perspective, AmS-skrifter 22, Arkeologisk museum, Universitetet i Stavanger, Stavanger

Grimm, O and Pesch, A, 2010 'Kulthus på Jæren?', Frá haug ok heiðni 2, I3-I 8

Grimm, O and Stylegar, F-A, 2004 'Court sites in southwest Norway: Reflection of a Roman period political organisation?’, Norwegian Archaeological Review 37, I I I-I 34

Grundberg, L, 2006 Medeltid i centrum: Europeisering, historieskrivning och kulturarvsbruk $i$ norrländska kulturmiliöer, unpublished $\mathrm{PhD}$ thesis, University of Umeå

Grundberg, M, 2005 Ceremoniernas makt: maktöverföring och genus $i$ Vasatidens kungliga ceremonier, Nordic Academic Press, Lund

Gräslund, A-S, 200I Ideologi och mentalitet. Om religionsskiftet $i$ Skandinavien frän en arkeologisk horisont, Uppsala universitet, Uppsala

Gräslund, B, 2007 'Fimbulvinter, Ragnarök och Klimatkrisen 536-537 e.Kr.', Saga och sed. Kungl. Gustav Adolfs Akademiens årsbok, Annales Academiae Regiae Gustavi Adolphi, 93-I 23

Gräslund, B and Price, N, 20I2 'Twilight of the gods? "The dust veil event" of AD 536 in critical perspective', Antiquity 86, 428-443

Grønlie, S (trans.), 2006 Íslendingabók, Kristni saga: The Book of the Icelanders, The Story of the Conversion, Viking Society for Northern Research, Short Run Press, Exeter

Guðmundsson, F (ed.), I965 Orkneyinga Saga. Legenda de Sancto Magno. Magnúss saga skemmri. Magnúss saga lengri. Helga páttr ok Úlfs, Íslenzk Fornrit 34, Hið íslenzka fornritafélag, Reykjavik

Guðmundsson, V, I903 'Hestaping fornmanna', Eimreiðin 9, 33-45

Guðmundsson, V, 1924 Island i Fristadstiden, G E Gad, Copenhagen 
Gullbekk, S, 20II 'Money and its use in the Saga Society: Silver, coins and commodity money', in S Sigmundsson (ed.), Viking Settlements and Viking Society. Papers from the Proceedings of the Sixteenth Viking Congress, Reykjavik and Reykholt, I6-23 August 2009, University of Iceland Press, Reykjavik, I76-I89

Gullbekk, S and Iversen, F 2017 'The price of justice and administration of coinage', in T Zanette and K L Glørstad (eds), Viking-Age Transformations: Trade, Craft and Resources in Western Scandinavia, Routledge, London

Gundersen, D and Hødnebø, F (trans.), I979 Håkon Håkonssonssaga, Norges kongesagaer 4, Gyldendal Norsk Forlag, Oslo. ID: nummer i Askeladden, Riksantikvarens kulturminnedatabase, http:// askeladden.ra.no/

Gunnell, T, 2009 'Ansgar's conversion of Iceland', Scripta Islandica 60, I05-I I9

Gunnes, E and Kjellberg, H (eds), I979 Regesta Norvegica IV, Kjeldeskriftfondet, Oslo

Gurevich, A J, I98 5 Categories of Medieval Culture, Routledge and Kegan Paul, London

Gustavsen, L, Cannell, R J S, Nau, E, Tonning, C, Trinks, I, Kristiansen, M, Gabler, M, Paasche, K, Gansum, T, Hinterleither, A, Poscettis, V and Neubauer, W, 2017 'Archaeological prospection of a specialised cooking-pit site at Lunde in Vestfold, Norway', Archaeological Prospection 25, I7-3 I, DOI: IO.I0002/arp.I 589

Gutenbrunner, S, I936 Die germanischen Götter-namen der antiken Inschriften, M Niemeyer, Halle

Guttesen, R, I992 'New geographical and historical Information from Lucas Janz Waghenær's FaroeChart', Geografisk Tidsskrift 92, 22-28

Guttesen, R, I998 'Búmerkini hjá Jón Heinasyni og Mikkjali í Lamba á Tinganesi’, Frøði I, I8-22

Hadley, D M, 2000 The Northern Danelaw: Its Social Structure, c. 800-I Ioo, Leicester University Press, London

Hadley, D M, 2008 'The creation of the Danelaw', in S Brink and N Price (eds), The Viking World, Routledge, London, 375-378

Hagland, J R, 20I4 'Town law versus country law: On the Kristindómsbálkr (church law) of Ni.aróss Bjarkeyjarréttr and Frostu.ingslög', in S Brink and L Collinson (eds), New Approaches to Early Law in Scandinavia, Brepols, Turnhout, 57-66

Hagland, J R and Sandnes, J (eds), I994 Frostatingslova, Det norske samlaget, Oslo

Hagland, J R and Sandnes, J, I997 Bjarkøyretten: Nidaros eldste bylov, Norrøne bokverk, Samlaget, Oslo

Hálfdanarson, G, 2000 'Pingvellir: An Icelandic "Lieu de Memoire", History and Memory I 2:I, 5-29

Hallanger, F and Brandt, F (eds), I 855 Kong Christian den Fjerdes norske Lovbog af I604, Feilberg and Landmark, Christiania

Hallmundsdóttir, M and Juel Hansen, S C, 20 I 2 Fornleifarannsókn á Pingvöllum. Vegna framkvæemda við Pingvallakirkju 2009, Fornleifadeild Náttúrustofa Vestfjarða, NV nr. 03-I2, Eyrarbakki

Halvorsen, E F and Rindal, M (eds and trans.), 2008 De eldste østlandske kristenrettene. Tekst etter håndskriftene, med oversettelser, Norrøne tekster 7, Riksarkivet, Oslo

Hamerow, H and Brennan, N, 2015 'An Anglo-Saxon great hall complex at Sutton Courtenay/Drayton, Oxfordshire: A royal centre of early Wessex?', Archaeological Journal I 72:2, 325-350

Hamerow, H, Hayden, C and Hey, G, 2007 'Anglo-Saxon and earlier settlement near Drayton Road, Sutton Courtenay, Berkshire', Archaeological Journal I64, I09-106

Hammond, C (trans.), I996 The Gallic War, by Julius Caesar, Oxford University Press, Oxford

Handley, S, 2004 'Spelman, Sir Henry (I 563/4-I64I)', Oxford Dictionary of National Biography, Oxford University Press, https://doi.org/Io.1093/ref:odnb/26I04

Hansen, W, I969 Inde i landet, William Dam's Boghandel, Rønne

Hartmann, P C, 2005 Das Heilige Römische Reich deutscher Nation in der Neuzeit I486-I806, Reclam, Stuttgart

Haselgrove, C, I995 'Late Iron Age society in Britain and north-east Europe: Structural transformation or superficial change?', in B Arnold and D Blair Gibson (eds), Celtic Chiefdom, Celtic State: The Evolution of Social Systems in Prehistoric Europe, Cambridge University Press, Cambridge, 8 I-87

Hastings, A, 1997 The Construction of Nationhood. Ethnicity, Religion and Nationalism, Cambridge University Press, Cambridge

Hastrup, K, I98 5 Culture and History in Medieval Iceland: An Anthropological Analysis of Structure and Change, Clarendon Press, Oxford

Haug, E, I995 'Erik av Pommerns norske kroning', Historisk Tidsskrift 74, hf. I, 492-508 
Hedeager, L, I992 Danmarks jernalder. Mellem stamme og stat, Aarhus Universitetsforlag, Aarhus

Hedeager, L, 20I I Iron Age Myth and Materiality: An Archaeology of Scandinavia AD 400-I000, Routledge, London

Heinesen Lysaker, L, 2008 Stedsnavn i Fjaler og Leirvík. En beskrivelse og sammenligning av to stedsnavnmaterialer fra Fjaler $i$ Norge og Leirvík på Forøyene, unpublished MA dissertation, University of Oslo

Helgerson, R, I992 Forms of Nationhood: The Elizabethan Writing of England, University of Chicago Press, Chicago, London

Helle, K, I972 Konge og gode menn i norsk riksstyring ca. II 50-I3I9, Universitetsforlag, Bergen and Oslo

Helle, K, I982 Kongssete og kjøpstad: fra opphavet til I536. Bergen bys historie I, Universitetsforlag, Bergen

Helle, K, I995 Under kirke og kongemakt I I30-I350, Aschehougs Norgeshistorie 3, Aschehoug, Oslo

Helle, K, 200 I Gulatinget og Gulatingslova, Leikanger, Skald

Helle, K, 2006 Norsk byhistorie: urbanisering gjennom I300 år, Pax, Oslo

Helle, K, 2009 'Håkon 4 Håkonsson' in Norsk biografisk leksikon, https://nbl.snl.no/ $\mathrm{H} \% \mathrm{C}_{3} \% \mathrm{~A}_{5}$ kon_4_H\% $3 \%$ A 5 konsson [accessed April 20I7]

Hellquist, E, I980 Svensk etymologisk ordbok, Liber Läromedel/Gleerup, Lund (3rd edn)

Henriksen, M B, 2005 'Danske kogegruber og kogegrubefelter fra yngre bronzealder og ældre jernalder', in L Gustafson, T Heibreen and J Martens (eds), De gåtefulle kokegroper: artikkelsamling: Kokegropseminaret 3I. november 200I, Kulturhistorisk Museum, Universitetet i Oslo, Oslo, 77-IO2

Hermansen, V and Nørlund, P (eds), I936 Danmarks kirker 5, Sorø amt, Nationalmuseet, Copenhagen

Herschend, F, I997 Livet $i$ hallen. Tre fallstudier i den yngre järnålderns aristokrati, Occasional Papers in Archaeology I4, Uppsala Universitet, Uppsala

Herschend, F, I998 The Idea of the Good in Late Iron Age Societies, Uppsala University Press, Uppsala

Herschend, F, 2009 The Early Iron Age in South Scandinavia: Social Order in Settlement and Landscape, Occasional Papers in Archaeology 46, Uppsala Universitet, Uppsala

Hertzberg, E, I9I4 'Ledingsmandskabets størrelse i Norges middelalder', Historisk Tidsskrift 5:2, 24 I-276

Hertzberg, E and Brandt, F P, I 874 Grundtrckkene $i$ den celdste norske process, Aschehoug/A W Brøgger, Cristiania/Copenhagen

Hibbert, S, I 822 A Description of the Shetland Islands, Comprising an Account of Their Geology, Scenery, Antiquities, And Superstitions, A Constable and Co, Edinburgh

Hibbert, S, I83 I 'Memoir on the tings of Orkney and Shetland', Archaeologia Scotica, 3, IO3-2 Io

Higham, N J, I992 Rome, Britain and the Anglo-Saxons, Seaby, London

Hill, C, I958 Puritanism and Revolution: Studies in the Interpretation of the English revolution of the I 7 th century, London

Hillström, M, 2010 'Contested boundaries: Nation, people and cultural history museums in Sweden and Norway I 862-I909', Culture Unbound 2, 583-607

Hingley, R, 2008 The Recovery of Roman Britain I586 to I906: A Colony So Fertile, Oxford University Press, Oxford

Hjärne, E, I952 'Svethiudh', Namn och Bygd 40, 91-I 82

Hobsbawm, E J, I983 'Introduction: Inventing traditions', in E Hobsbawm and T Tanger (eds), The Invention of Tradition, Cambridge University Press, Cambridge, I-I4

Hobsbawm, E J, I990 Nations and Nationalism since I780: Programme, Myth, Reality, Cambridge University Press, Cambridge

Hobæk, H, 20I3 'Tracing medieval administrative systems: Hardanger, Western Norway', Journal of the North Atlantic, Special Volume 5, 64-75

Hobæk, H, in prep. The Thing in Western Norway, unpublished PhD thesis, University of Oslo

Hoff, A, I997 Lov og landskab: Landskabslovenes bidrag til forståelsen af landbrugs- og landskabudviklingen i Danmark ca. 900-I250, Aarhus Universitetsforlag, Aarhus

Hoff, A-M, Lidén, H-E and Storsletten, O, 2000 Hordaland. Norges kirker Bind I, Norsk Institutt for Kulturminneforskning/Gyldendal, Oslo

Hoffmann, E, I976 Königserhebung und Thronfolgeordnung in Dänemark bis zum Ausgang des Mittelalters, Beiträge zur Geschichte und Quellenkunde des Mittelalters, Band 5, Berlin/New York

Hofmeister, A, I976 [I926-34] 'Vita Lebuini antiqua', in MGH Scriptores 3o/2, Hahn, Hannover 
Hollander, L M (ed.), I964 Snorri Sturlasson, Heimskringla. History of the Kings of Norway, University of Texas Press, Austin

Hollander, L M, I999 The Poetic Edda, University of Texas Press, Austin (2nd edn)

Holm, O, 2000 'Vad var Jamtamot?', Oknytt 21:I-2, 64-96

Holmbäck, Å and Wessén, E (eds), I933 Östgötalagen och Upplandslagen, Svenska landskapslagar. Tolkade och förklarade för nutidens svenskar, Hugo Gebers förlag, Stockholm

Holmbäck, Å and Wessén, E (eds), I936 Dalalagen och Västmannalagen, Svenska landskapslagar. Tolkade och förklarade för nutidens svenskar, Hugo Gebers förlag, Stockholm

Holmbäck, Å and Wessén, E (eds), I940 Södermannalagen och Hälsingelagen, Svenska landskapslagar, Tolkade och förklarade för nutidens svenskar, Hugo Gebers förlag, Stockholm

Holmbäck, Å and Wessén, E (eds), I943 Svenska landskapslagar Ser 4, Skånelagen och Gutalagen, Geber, Stockholm

Holmbäck, Å and Wessén, E (eds), I946 Svenska Landskapslagar. Tolkade och förklarade för nutidens svenskar, femte serien: Äldre Västgötalagen, Yngre Västgötalagen, Smålandslagens kyrkobalk och Bjärkörätten, Almqvist and Wiksell, Stockholm

Holmbäck, А̊ and Wessén, E (eds), I962 Magnus Erikssons landslag. Skrifter utgivna av Institutet för rättshistorisk forskning, grundat av Gustav och Carin Olin. Serien I, Rättshistoriskt bibliotek 6, Nord, Bokh, Stockholm

Holmbäck, ̊̊ and Wessén, E (eds), I979 Svenska landskapslagar: tolkade och förklarade för nutidens svenskar. Series 5, Äldre Västgötalagen, Yngre Västgötalagen, Smålandslagens kyrkobalk och Bjärköarätten, Geber, Stockholm

Holmgren, G, I937 'Taga och vräka konung', Fornvännen 32, I9-26

Holmsen, A, I940-42 'Nyere undersøkelser i eldre norsk samfundshistorie', Historisk tidsskrift 32, 342366

Holmsen, A, I976 Nye studier i gammel historie, Universitetsforlaget, Oslo

Holmsen, A and Simensen, J (eds), I967 Norske historikere I utvalg: Rikssamling og kristendom, Universitetsforlaget, Oslo

Holmsen, A and Simensen, J (eds), I970 Sverreættens kongedømme, Universitetsforlaget, Oslo

Holst, M K, Jessen, M J, Andersen, S W and Pedersen, A, 20I 3 'The late Viking-Age royal constructions at Jelling, central Jutland, Denmark', Praehistorische Zeitschrift 87:2, 474-505

Holt, R, 2009 'Medieval Norways's urbanization in a European perspective', in J Brendalsmo, F-E Eliassen and T Gansum (eds), Den Urbane underskog: strandsteder, utvekslingssteder og småbyer $i$ vikingtid, middelalder og tidlig nytid, Novus, Oslo, 23 I-246

Hommedal, A T, I999 'Hamarbiskopens gard på Storøya i Tyrifjorden. På sporet av et monumentalanlegg', in R Pedersen (ed.), Historien om historien, Hedmarksmuseet og Domkirkeodden, Hamar, 7-22

Hooke, D, 2010 Trees in Anglo-Saxon England: Literature, Lore and Landscape, Boydell and Brewer, Woodbridge

Hope-Taylor, B, I977 Yeavering: An Anglo-British Centre of Early Northumbria, Her Majesty's Stationery Office, London

Huitfeldt-Kaas, H J (ed.), I879 Biskop Eysteins Jordebok (Den røde Bog), Fortegnelse over det geistlige gods $i$ Oslo Bispedømme omkring Aar I400, Gundersens bogtrykkeri, Christiania

Huitfeldt-Kaas, H J (ed.), I887-I906 Norske Regnskaber og Jordebøger fra det I6. de Aarhundrede, vols I-4, Det Norske historiske kildeskriftfond, Christiania

Humphrey, C, and Hugh-Jones, S, I992 'Introduction: Barter, exchange and value', in C Humphrey and S Hugh-Jones (eds), Barter, Exchange and Value: An Anthropological Approach, Cambridge University Press, Cambridge, I-2I

Hutchinson, J, 1987 The Dynamics of Cultural Nationalism: The Gaelic Revival and the Creation of the Irish Nation State, Unwin Hyman Ltd, London

Hutton, R, I993 Pagan Religions of the British Isles, their Nature and Legacy, Palgrave Macmillan, Basingstoke

Hybel, N and Poulsen, B, 2007 The Danish Resources c. I0oo-I 550: Growth and Recession, Brill, Leiden/ Boston

Hødnebø, F, I976 'Pingfarareyrir', in A Karker (ed.), Kulturbistorisk Leksikon for nordisk middelalder, vol. 20, Rosenkilde og Bagger, Copenhagen, 380 
Hødnebø, F and Magerøy, H (eds), I979 Norges kongesagaer I-2. Heimskringla, utgave Kongesagaer/ Snorre Sturluson, Gyldendal, Oslo

Hørby, K, I979 Danmarks historie, Tiden I340-I648, bd. 2, første halvbind, Gyldendal, Copenhagen

Høyland, O, I966 Stord bygdebok 2. Gards og cettesoga, Stord herad, Stord

Imsen, S, I974a 'Bygdeting III', in R Fladby, S Imsen and H Winge (eds), Norsk historisk leksikon. Noringliv, rettsvesen, administrasjon, mynt, mål og vekt, militcre forhold, byggeskikk m.m. I5ooI850, J W Cappelens Forlag, Oslo, 58-59

Imsen, S, I974b 'Herredag', in R Fladby, S Imsen and H Winge (eds), Norsk historisk leksikon. Noringliv, rettsvesen, administrasjon, mynt, mål og vekt, militcere forhold, byggeskikk m.m. I500-I850, J W Cappelens Forlag, Oslo, I28-I29

Imsen, S, I974c 'Overlagting', in R Fladby, S Imsen and H Winge (eds), Norsk historisk leksikon. Noringliv, rettsvesen, administrasjon, mynt, mål og vekt, militcere forhold, byggeskikk m.m. I500-I850, J W Cappelens Forlag, Oslo, 247-248

Imsen, S, I974d 'Skipreide', in R Fladby, S Imsen and H Winge (eds), Norsk historisk leksikon. Noeringliv, rettsvesen, administrasjon, mynt, mål og vekt, militcere forhold, byggeskikk m.m. I500-I850, J W Cappelens Forlag, Oslo, 298

Imsen, S, I974e 'Kongehylling', in R Fladby, S Imsen and H Winge (eds), Norsk historisk leksikon. Noringliv, rettsvesen, administrasjon, mynt, mål og vekt, militcere forhold, byggeskikk m.m. I50oI 850 , J W Cappelens Forlag, Oslo, I 65

Imsen, S, I990 Norsk bondekommunalisme fra Magnus Lagabøte til Kristian Kvart. Del I. Middelalderen, Tapir Forlag, Trondheim.

Imsen, S, I994 Norsk bondekommunalisme fra Magnus Lagabøte til Kristian Kvart, Del 2 Lydriketiden nr. 7 i Skriftserie fra Historisk Institutt, Universitetet i Trondheim, Trondheim

Imsen, S, I997 'Det gamle tinget: og det nye', in D Michalsen and K Sprauten (eds), Rett og historie. Festskrift til Gudmund Sandvik, University of Oslo, Oslo, I3-35

Imsen, S, 2000 Hirdskråen. Hirdloven til Norges konge og hans håndgangne menn - etter AM 322 fol, Riksarkivet, Oslo

Imsen, S (ed.), 20I4 Rex Insularum: The King of Norway and his 'Skattlands' as a Political System c. I $260-$ c. I450, Fagbokforlaget, Bergen

Imsen, S, 2015 Land og folk i den norrøne verda ca. 900 til I450, Det Norske Samlaget, Oslo

Indrebø, G, I920 Sverris saga etter Cod. AM $3274^{\circ}$, Den Norske Historiske Kildeskriftkommission, Kristiania/Copenhagen

Indrebø, G, I93 I Fylke og fylkesnamn. Bergens Museums Årbok I93 I, vol. I, Grieg, Bergen

Indrebø, G, I934-36 'Spreidde merknader um dei norske logmannsembætti i mellomalderen', Historisk Tidsskrift 30, 489-526

Indrebø, G, I935 Fjordung: granskingar i eldre norsk organisasjons-soge. Bergens museums Årbok I935, vol. $I$, Grieg, Bergen

Ingers, I, I962 Ortnamn i Lund. I, Stadsområdet före inkorporeringarna, Gleerup, Lund

Insoll, T, 2007 The Archaeology of Identities: A Reader, Routledge, London

Ireland, S, 2009 Roman Britain: A Sourcebook, Routledge, London

Iversen, F, 2007 'Könige an der Küste und Bauern im Binnenland - Regionale Unterschiede in Westnorwegen in der jüngeren Eisenzeit (800-I050 n. Chr.)', in T Iversen, J R Myking and G Thoma (eds), Bauern zwischen Herrschaft und Genossenschaft (Peasant Relations to Lords and Government: Scandinavia and the Alpine Region I0oo-I750), Tapir Academic Press, Trondheim, I49-166

Iversen, F, 2008 Eiendom, makt og statsdannelse: Kongsgårder og gods $i$ Hordaland $i$ yngre jernalder og middelalder. Universitetet i Bergen Arkeologiske Skrifter, vol. 6, University of Bergen, Bergen

Iversen, F, 2009 'Royal villas in northern Europe', in J Antonio Quirós Castillo (ed.), The Archaeology of Early Medieval Villages in Europe, Universidad del País Vasco, Leioa

Iversen, F, 20I I 'The Beauty of Bona Regalia and the Growth of Supra-regional Powers in Scandinavia', in S Sigmundsson (ed.), Viking Settlements and Viking Society: Papers from the Proceedings of the Sixteenth Viking Congress, Reykjavik and Reykholt, I6-23 August 2009, University of Iceland Press, Reykjavik, 225-244

Iversen, F, 20I 2 'The land of milk and honey? Rescue archaeology in Norway', Post-Classical Archaeology 2, 299-3 I 8 
Iversen, F, 20I3 'Concilium and Pagus: Revisiting the Early Germanic Thing system of northern Europe', Journal of the North Atlantic, Special Volume 5, 5-17

Iversen, F, 20I4 'Om aritmetikk og rettferdighet. Tinget i randen av Europa i jernalderen', in S H Gullbekk (ed.), Ja, vi elsker frihet. En antologi, Dreyer, Oslo, 246-256

Iversen, F, 20 5 a 'Hålogland blir en rettskrets', Heimen, IOI-I 20

Iversen, F, 20I5b 'Tinglag og tunanlegg. Øygarden i Rogaland', in A Pedersen and S M Sindbaek (eds), Et feelles hav: Skagerrak og Kattegat i vikingetiden. Nordlige Verdener, Nationalmuseet, Copenhagen, $2 \mathrm{IO}-23 \mathrm{I}$

Iversen, F, $2015 \mathrm{c}$ 'Houses of Commons, Houses of Lords? The thing on the threshold of statehood in Rogaland, Western Norway', in I Baug, J Larsen and S S Myland (eds), The Merovingian and Viking Ages. I: Northern Europe in the Middle Ages; artefacts, landscapes and society. Essays in Honor of Ingvild Øye on her 7oth Birthday, Universitetet I Bergen Arkeologiske Skrifter, Universitetet i Bergen, Bergen, $175-192$

Iversen, F, $20 \mathrm{I} 5 \mathrm{~d}$ 'Community and society: The thing at the edge of Europe', Journal of the North Atlantic, Special Volume 8, I-I7

Iversen, F, 2016 'Huseby and the Scandinavian taxation model', in L E Christensen, T Lemm and A Pedersen (eds), Husebyer: Status Quo, Open Questions and Perspectives, University Press of Southern Denmark, Odense, I $2 \mathrm{I}-\mathrm{I} 4 \mathrm{O}$

Iversen, F, 20I7a 'The urban hinterland: Interaction and law-areas in Viking and medieval Norway', in Z T Glørstad and K Loftsgarden (eds), Viking-Age Transformations, Trade, Craft and Resources in Western Scandinavia, Routledge, London, $250-276$

Iversen, F, 2017 'Courtyard sites and their cultic context', in C Bis-Worch and C Theune (eds), Religion, Cults and Rituals in the Medieval Rural Enviroment, Sidestone Press, Leiden, 25-37

Iversen, F, 20I7c 'Emerging kingship in the 8th century? New datings of three courtyard sites in Rogaland', in D Skre (ed.), Avaldsnes: A Sea-Kings' Manor in First-Millennium Western Scandinavia, Walter de Gruyter, Berlin, $72 \mathrm{I}-746$

Iversen, F, 20I7d 'Tinget i Trøndelag i yngre jernalder og middelalder', in O Risbøl (ed.), Frostatinget $i$ et bistorisk lys, NTNU Vitenskapsmuseet, Trondheim, 7I-IO8

Jakobsen, J G G, 2008 Prcedikebrødrenes samfundsrolle $i$ middelalderens Danmark, unpublished PhD thesis, Institut for Historie, Kultur og Samfundsbeskrivelse, Syddansk Universitet, Odense

Jakobsen, J, 1907 Diplomatarium Faeroense: Føroyskt fodnbraevasavn. I. Miðalaldarbrøv upp til trúbótarskeiðið, H N Jacobsen, Tórshavn

Jakobsen, J, 1936 The Place-Names of Shetland, David Nutt, London

Jakobsson, S, 2007 'Strangers in Icelandic Society I I00-I 400', Viking and Medieval Scandinavia 3, I4 II 57

Jakobsson, S, $20 \mathrm{I} 2$ 'The territorialization of power in the Icelandic Commonwealth', in S Bagge, M H Gelting, F Hervik, T Lindkvist and B Poulsen (eds), Statsutvikling i Skandinavia i middelalderen, Dreyers, Oslo, IOI-I I 8

Jansen, J (ed.), I943 'Rekneskap for dei nordlandske lena og Finnmark 1566-I567', in Norske Lensrekneskapsbøker I 548-I 567, vol. 5, Riksarkivet, Oslo, I37-266

Jansson, O S, I970 'Samting', in J Granlund (ed.), Kulturhistoriskt lexikon för nordisk medeltid. Från vikingatid till reformationstid I 5 , Allhem, Malmö, $25-27$

Jansson, S B F (ed.), I98 5 Erikskrönikan, Tiden, Stockholm

Jensen, J E, I990 'Danske middelalderbyer. Middelalderlig byplanlægning i Danmark', Fortid og nutid 4, $233^{-248}$

Jochens, J, I995 Women in Old Norse Society, Cornell University Press, Cornell

Joensen, E (ed.), I953 Tingbókin I615-54, Einars, Tórshavn

Joensen, E (ed.), I96I Tingbókin I666-77, Einars, Tórshavn

Joensen, E, I969 Vártings- og løgtingsbók I667-I690, Einars forlag, Tórshavn

Johansen, O S and Søbstad, T, I978 'De nordnorske tunanleggene fra jernalderen', Viking 4I, 9-56

Johnsen, A O, I98I Håkon jarl Eriksson (998-I030). Nytt kildemateriale og nye synspunkter. Avhandlinger,

Det norske videnskaps-akademi 2:17, Universitetsforlaget, Oslo

Johnsen, N, I9I 4 Eker: Traek av en storbygds saga, Konunal Foranstaltning, Cristiania/Copenhagen

Johnsen, O A, I929 Tønsbergs historie, vol. I, Gyldendal Norsk Forlag, Oslo 
Jolliffe, J E A, I937 The Constitutional History of Medieval England from the English Settlement to I485, Adam and Charles Black, London

Jones, R and Semple, S, $20 \mathbf{I}_{2}$ 'Making sense of place in Anglo-Saxon England', in R Jones and S Semple (eds), Sense of Place in Anglo-Saxon England, Shaun Tyas, Donington

Jóhannesson, J, I974 A History of the Old Icelandic Commonwealth: Íslendinga Saga, University of Manitoba Press, Winnipeg

Jónsson, B, I 894 'Rannsóknir í ofanverðu Árnespingi I 893', Árbók hins íslenzka fornleifafélags, I-I 5

Jónsson, F (trans.), I886-88 Egils saga Skallagrimssonar, Skrifter (Samfund til Udgivelse af Gammel Nordisk Litteratur) I7, S L Møller, Copenhagen

Jónsson, F, I900 Knytlingasaga: dens kilder og historiske verd, A F Høst, Copenhagen

Jónsson, F, I903 Fagrskinna: Nóregs Kononga tal, Møller, Copenhagen

Jónsson, F, I9I 2 Den norsk-islandske skjaldedigtning: B I rettet tekst, Gyldendal, Copenhagen

Jørgensen, J G (ed.), I997 Aslak Bolts jordebok, Riksarkivet, Oslo

Jørgensen, L, 2003 'Manor and market at Lake Tissø in the sixth to eleventh centuries: The Danish "productive sites"', in T Pestell and K Ulmschneider (eds), Markets in Early Medieval Europe: Trading and 'Productive' Sites, 650-850, Windgather Press, Macclesfield, I75-207

Jørgensen, P J, I9I9 'Fjerding', in C Blangstrup (ed.), Salmonsen konversationsleksikon vol. 8, J H Schultz A/S. Copenhagen, I 87

Jørgensen, P J, I92 ra 'Herred', in C Blangstrup (ed.), Salmonsen konversationsleksikon vol. I I, J H Schultz A/S, Copenhagen, 345-347

Jørgensen, P J, I92 Ib 'Herredting', in C Blangstrup (ed.), Salmonsen konversationsleksikon vol. I I, J H Schultz A/S, Copenhagen, 349-350

Jørgensen, P J, I922 'Hyld(n)ing', in J Brøndum-Nielsen and P Raunkjaer (eds), Salmonsen konversationsleksikon vol. 22, J H Schultz A/S, Copenhagen, 48

Jørgensen, P J, I923 'Kongens Retterting', in J Brøndum-Nielsen and P Raunkjaer (eds), Salmonsen konversationsleksikon vol. 24, J H Schultz A/S, Copenhagen, 406-407

Jørgensen, P J, I974 Dansk retshistorie: retskildernes og forfatningsrettens historie indtil sidste halvdel af det I7. Aarhundred, G E C Gad, Copenhagen

Kaalund, K, I877-82 Bidrag til en historisk-topografisk beskrivelse af Island, Kommissionen for det Arnamagnæanske Legat, Copenhagen

Kaliff, A, I995 Arkeologi $i$ Östergötland. Scener ur ett landskaps förhistoria, Uppsala University, Uppsala

Karlsson, G, 1972 'Goðar og bændur', Saga ıо, 5-57

Karlsson, G, 2000 Iceland's I 000 Years: History of a Marginal Society, Mál og menning, Reykjavik

Karlsson, G, 2008 'Stofnár Pingeyrarklausturs', Saga I 6: I, I 59-I 67

Kemble, J M, I 849 The Saxons in England: A History of the English Commonwealth Till the Period of the Norman Conquest I-II, Longman, London

Keynes, S, I990 'Royal government and the written word in late Anglo-Saxon England', in R McKitterick (ed.), The Uses of Literacy in Early Mediaeval Europe, Cambridge University Press, Cambridge, 226257

Keyser, R (ed.), I 846 Norges gamle love indtil ${ }_{3} 87$ I, Chr. Grøndahl, Christiania

Keyser, R and Munch, P A (eds), I 848 Norges gamle love indtil 1387, Bbd 2, Lovgivningen under Kong Magnus Haakonssöns regjeringstid fra I 263 til I 280 , tilligemed et supplement till bd I, Chr. Grøndahl, Christiania

Keyser, R and Munch, P A (eds), I 849 Norges gamle love indtil 1387, bd 3, Lovgiuningen efter Kong Magnus Haakonssons död I 280 indtil I387, Chr. Grøndahl, Christiania

Klindt-Jensen, O, I975 A History of Scandinavian Archaeology, Thames and Hudson, London

Koch, H (ed.), I984 Politikens Danmarkshistorie. Bd 3, Kongemagt og kirke, Io6o-I24I, Politiken, Copenhagen

Kofoed, K M, I928 Bornholmske sagn og sagaer: samlet og genfortalt, J H Schulz, Copenhagen

Kohl, P L and Fawcett, C, I995 Nationalism, Politics and the Practice of Archaeology, Cambridge University Press, Cambridge

Korom, F J, 20I3 The Anthropology of Performance: A Reader, Wiley-Blackwell, New Jersey

Kraft, J, I830 Topographisk-Statistisk Beskrivelse over Kongeriget Norge 4. Det Vestenfjeldske Norge, J Craft, Christiania

Krag, C, I990 'Vestfold som utgangspunkt for den norske rikssamlingen', Collegium Medievale 3, I79-I95 
Krag, C, I993 'Hvem var Harald Hårfagre?’, in M S Vea (ed.), Rikssamlingen og Harald Hårfagre: historisk seminar på Karmøy Io. og I I. juni I993, Karmøy kommune, Kopervik, 32-40

Krag, C, 1995 Vikingtid og rikssamling: 800-1 I30, Aschehougs Norgeshistorie 2, Aschehoug, Oslo

Krag, C, 2008 'The creation of Norway', in S Brink and N Price (eds), The Viking World, Routledge, London, 645-65I

Kristensson, G, 1997 'In memoriam Professor Olof Arngart', English Studies 78:4, 385-385

Kristoffersen, K, and Warren, E, 200I Kulturminner $i$ Trekant-traséen: de arkeologiske undersøkelsene $i$ forbindelse med utbygging av Trekantsambandet i kommunene Bømlo, Sveio og Stord i Sunnhordland. Arkeologiske avhandlinger og rapporter fra Universitetet $i$ Bergen 6, Arkeologisk Institutt, Universitetet i Bergen, Bergen

Kulikowski, M, 2005 'Cities and government in late antique Hispania: Recent advances and future research', in K Bowes and M Kulikowski (eds), Hispania in Late Antiquity, Brill, Leiden, 3 I-76

Lambarde, W, I 592 Archaionomia, sive de priscis Anglorum legibus libri, London

Lambert, T, 2017 Law and Order in Anglo-Saxon England, Oxford University Press, Oxbow Books, Oxford

Lancaster, W T, I9I 2 Abstracts of the Charters and Other Documents Contained in the Chartulary of the Priory of Bridlington, J Whitehead and Sons, Leeds

Lane, A and Campbell, E, 2000 Excavations at Dunadd: An Early Dalriadic Capital, Oxbow Books, Oxford

Lange, C C A and Unger C R (eds), I 852 Diplomatarium Norvegicum. Oldbreve til Kundskab om Norges indre og ydre Forhold, Sprog, Slcegter, Sceder, Lovgivning og Rettergang i Middelalderen, vol. 2:2, P T Mallings Forlagshandel, Christiania

Larsen, I E, I840 'Om Rigsdage og provindsialforsamlinger, samt Rigsraadet i Danmark, fra det I3 de Aarhundrede indtil Statsforandringen I660', Dansk historisk tidsskrift I, 24I-333

Larsen, J, I980 Fana Bygdebok I. Fra de eldste tider til I665, Fana Bygdeboknemnd, Bergen

Larson, L M, 1935 The Earliest Norwegian Laws: Being the Gulathing Law and the Frostathing Law, Columbia University Press, New York

Larsson, L, 2007 'The Iron Age ritual building at Uppåkra, Sweden', Antiquity 8I, I I-25

Larsson, M G, 1998 'Runic inscriptions as a source for the history of settlement', in K Düwel and S Nowak (eds), Runenin-schriften als Quellen interdisziplinärer For-schung, Abhandlungen des vierten internationalen Sympsiums über Runen und Runeninschriftenin Göttingen vom 4.-9. August 1995, Ergän-zungsbände zum Reallexikon der germa-nischen Altertumskunde I 5, deGruyter, Berlin, 639-646

Larsson, M G, 2010 'Mora sten och Mora ting', Fornvännen I0 5:4, 29I-303

Larsson, M G, 20I3 'Geofysik på Mora äng', Fornvännen I08:I, 58-59

Lárusson, M M, I96I 'Herred', in J Granlund (ed.), Kulturhistoriskt lexikon för nordisk medeltid från vikingatid till reformationstid 6, 494-495

Lárusson, M M, I962 'Hreppr', in J Granlund (ed.), Kulturhistoriskt lexikon för nordisk medeltid från vikingatid till reformationstid $7, \mathrm{I}^{-22}$

Lárusson, M M, I966 'Lögberg', in J Granlund (ed.), Kulturhistoriskt lexikon för nordisk medeltid från vikingatid till reformationstid I I, I 35

Lárusson, Ó, 1956 'Alpingi', in J Danstrup (ed.), Kulturbistorisk leksikon for nordisk middelalder fra vikingtid til reformationstid I, I $23-\mathrm{I} 26$

Lárusson, Ó, I960 'Goði og Goðorð’, in J Granlund (ed.), Kulturhistoriskt lexikon för nordisk medeltid från vikingatid till reformationstid 5 , Rosenkilde og Bagger, Copenhagen, 363-366

Lavelle, R, 2005 'Why Grateley? Reflections on Anglo-Saxon kingship in a Hampshire landscape', Proceedings of the Hampshire Field Club and Archaeology Society 60, I 54-I69

Lebech, M, I935 'Jutlands gamle Retskredse', Historie/Jyske Samlinger 5:2, I 5 I-344

Leciejewicz, L and Valor, M, 2007 'Peoples and environments', in J Graham-Campbell and M Valor (eds), The Archaeology of Medieval Europe I: Eighth to Twelfth Centuries AD, Aarhus University Press, 4675

Leonard, A, 20I I 'Vikings in the Prehistoric Landscape: Studies on Mainland Orkney', Landscapes, I 2:I, $4^{2-68}$

Lerdam, H, 200I Kongen og tinget: det senmiddelalderlige retsvesen I340-I448, Museum Tusculanums Forlag, Copenhagen 
Lerdam, H, 2004 Birk, lov og ret: Birkerettens historie i Danmark indtil I600, Museum Tusculanum Press, Copenhagen

Lidén, H-E, 2008 Kirkene i Hordaland giennom tidene, Eide Forlag, Bergen

Liebermann, F, I 898-I9 6 Die Gesetze der Angelsachsen, I-III, Max Niemeyer, Halle

Liebermann, F, I9I3 The National Assembly in the Anglo-Saxon Period, Max Niemeyer, Halle

Liedgren, J, I959 'Folklandsting', in J Granlund (ed.), Kulturhistoriskt lexikon för nordisk medeltid frän vikingatid till reformationstid $4,47 \mathrm{I}-472$

Liedgren, J, I965 'Magnus Erikssons landslag', in J Granlund (ed.), Kulturhistoriskt lexikon för nordisk medeltid frän vikingatid till reformationstid I I, 222-226

Liedgren, J, I98 I 'Landskabslove Sverige', in I Andersson and J Granlund (eds), Kulturhistoriskt lexikon för nordisk medeltid frän vikingatid till reformationstid Io, 23 I-233

Lillehammer, A, I994 Fra jeger til bonde: inntil 800 e.Kr. Aschehougs Norgeshistorie, vol. I, Aschehoug, Oslo

Lindkvist, T, 20I4 'The land, men, and law of Västergötland', in S Brink and L Collinson (eds), New Approaches to Early Law in Scandinavia, Brepols, Turnhout, 89-99

Lindkvist, T, 2016 'Husabyar, administration and taxation in medieval Sweden', in L E Christensen, T Lemm and A Pedersen (eds), Husebyer: Status Quo, Open Questions and Perspectives, University Press of Southern Denmark, Odense, I4 I-I49

Lindqvist, S, I 927 'Vägvårdar och vildmarksborgar i det forntida Södermanland', Svenska turistföreningens arsskrift, 34-50

Lindroth, H, I9I 5 'Gutnal ping och Gutnalia', Från Filologiska föreningen i Lund: Språkliga Uppsatser 4, Gleerup, Lund, 66-73

Lindström, V, I974 Karlstads domkyrka. Vägledning, Ystads centraltryckeri, Ystad

Ljungkvist, J, 2009 Kartering med metalldetektor och bebyggelsestudiei norra Gamla Uppsala. Gamla Uppsala: framväxten av ett mystisk centrum. Rapport 2, Institutionen för Arkeologi och Antik Historia, Uppsala Universitet, Uppsala

Ljungkvist, J, Frölund, P, Göthberg, H, and Löwenborg, D, 20 I I 'Gamla Uppsala: Structural development of a centre in Middle Sweden', Archäologisches Korrespondenzblatt 4I, 57 I-585

Ljungqvist, J, with Sundqvist, O and Vikstrand, P, 20I3 Gamla Uppsala i ny belysning, Uppsala, Swedish Science Press, 33-68

Loftsgarden, K, Ramstad, M and Stylegar F-A, 20I7 'The skeid and other assemblies in the Norwegian "Mountain Land", in T Zanette and K L Glørstad (eds), Viking-Age Transformations, Trade, Craft and Resources in Western Scandinavia, Routledge, London

Loive, N, 2017 'Nikilis-runorna i Hardeberga', Svenska jyrkan, Sôdra Sandby Församling, https:// sv.wikipedia.org/wiki/Runinskriften_i_Hardeberga [accessed January 20I7]

London, J, 2000 Theatre Under the Nazis, Manchester University Press

Lopez, R S, 1976 The Commercial Revolution of the Middle Ages, 950-I350, Cambridge University Press, Cambridge

Lorenzen, V, I934 'Kirkebygninger og deres udstyr', Nordisk kultur 23, 94-I 88

Loyn, H R, I974 'The hundred in England in the tenth and early eleventh centuries', in H Hearder and H R Loyn (eds), British Government and Administration, University of Wales Press, Cardiff, I-I 5

Loyn, H R, I984 The Governance of Anglo-Saxon England 500-I087, Edward Arnold, London

Löwenborg, D, 20I 2 'An Iron Age shock doctrine: Did the AD 536-7 event trigger large-scale social changes in the Malaren valley area?', Journal of Archaeology and Ancient History 4, 3-29

Lucas, G and McGovern, T, 2008 'Bloody slaughter: Ritual decapitation and display at Viking age Hofstaðir Iceland', Journal of European Archaeology Io:I, 7-30

Lucy, S, I992 'The significance of mortuary ritual in the political manipulation of landscape', Archaeological Review from Cambridge II:I, 93-I05

Lucy, S, I998 The Early Anglo-Saxon Cemeteries of East Yorkshire: An Analysis and Reinterpretation, British Archaeological Reports British Series 272, Oxford

Lund, H E, I955 'Håløygske høvdingeseter fra jernalderen', Stavanger Museums Årbok, IOI-IO7

Lund, H E, I959 'Håløygske høvdingeseter og tunanlegg fra eldre og yngre jernalder', Håløygminne ıо, 244-249

Lund, H E, I965 'Håløygske høvdingegårder og tunanlegg av Steigen-typen fra eldre og yngre jernalder. "Valhall med de mange dører"', Norsk Tidsskrift for sprogvitenskap 20, 287-325 
Lund, N, 1996 Lið, leding og landevern. Hor og samfund $i$ Danmark $i$ celdre middelalder, Vikingeskibshallen, Roskilde

Lutz, A, 2000 'The study of the Anglo-Saxon Chronicle in the seventeenth century and the establishment of Old English Studies in the universities', in T Graham (ed.), The recovery of Old English: Anglo-Saxon Studies in the Sixteenth and Seventeenth Centuries, Kalamazoo, Medieval Institute Publications

Lynn, C, 2003 Navan Fort: Archaeology and Myth, Wardrell, Bray

Lönnroth, L, I976 Njáls Saga: A Critical Introduction, University of California Press, Berkeley and Los Angeles

Lönnroth, L, 2008 'The Icelandic Sagas', in S Brink and N Price (eds), The Viking World, Routledge, London, 304-322

Løken, T, 200 ' 'Jæren eller Karmøy: hvor var makta i Rogaland i eldre jernalder? Var Avaldsnes et maktsenter omkring 200 e. Kr.?', Frá Haug ok heiðni 2, I3-I4

Løkka, N, 20Io Steder og landskap i norrøn mytologi. En analyse av topografi og kosmologi i gudediktene av den Eldre Edda, University of Oslo, Oslo

Løkka, N, 20I3 'Ping goða: The mythological assembly site', Journal of the North Atlantic, Special Volume 5, I $8-27$

Løvschal, M and Fontijn, D, 2018 'Directionality and axiality in the Bronze Age: Cross-regional landscape perspectives on "fire pit lines" and other pitted connections', World Archaeology, 5 I, I 40-I 56

Macalister, R A S and Lloyd, R, I929 'Report on the excavations at Uisneach', Proceedings of the Royal Irish Academy 38, 69-I 26

MacCotter, P, 2008 Medieval Ireland: Territorial, Political and Economic Divisions, Four Courts Press, Dublin

MacDougall, H, 1982 Racial Myth in English History. Trojans, Teutons and Anglo-Saxons, Harvest House, Montreal

MacGregor, L, 1987 The Norse Settlement of Shetland and Faroe, c. 800-c. 1500: A Comparative Study, unpublished PhD thesis, University of St Andrews

Magnus, B and Myhre, B, I986 Forhistorien: fra jegergruppe til høvdingsamfunn. Norges historie I, J W Cappelen, Oslo

Magnus, O, I 555 Historia de Gentibus Septentrionalibus, Rome

Mair, C, I988 Mercat Cross and Tolbooth: Understanding Scotland's Old Burghs, John Donald, Edinburgh

Maitland, F W, I889 [1965] 'Materials for the history of English law', in Fisher (ed.), The Collected Papers of Frederic William Maitland, vol. 3, Cambridge University Press, Cambridge, I-60

Maitland, F W, I897 Domesday Book and Beyond: Three Essays in the Early History of England, Cambridge University Press, Cambridge

Malcolm, G, Bowsher, D and Cowie, R, 2003 Middle Saxon London: Excavations at the Royal Opera House I 989-99, Museum of London Monograph I 5 , London

Maldonado, A, 20I3 'Burial in early medieval Scotland: New questions', Medieval Archaeology 57, I-34

Malinowski, B, I926 Crime and Custom in Savage Society, Rowman and Littlefield, Totowa

Manby, T G, I988 'The Neolithic period in eastern Yorkshire', in T G Manby (ed.), Archaeology in Eastern Yorkshire: Essays in Honour of T C M Brewster, John R Collis, Sheffield, 35-88

Mannerfelt, M, I936 Svenska vägar och stigar, Studentföreningen Verdandis småskrifter nr 379, A Bonnier, Stockholm

Margary, I D, 1973 Roman Roads in Britain, Baker, London

Markus, K, 2013 'Baptism and the King's Coronation: Visual rhetoric of the Valdemar Dynasty on some Scanian and Danish baptismal fonts', in K Kodres and A Mänd (eds), Images and Objects in Ritual Practices in Medieval and Early Modern Northern and Central Europe, Cambridge Scholars, Newcastle upon Tyne, I 22-I 42

Marwick, H, I952 Orkney Farm-Names, W R Mackintosh, Kirkwall

Mattingly, H (trans.), I970 Tacitus. The Agricola and the Germania, trans. revs. by S A Handford, Harmondsworth, Pengiun Books

von Maurer, K, I874 Island von seiner ersten Entdeckung bis zum Untergange des Freistaats, Christian Kaiser, Munich

von Maurer, K, I907 Vorlesungen über altnordische Rechtsgeschichte, Leipzig

Maxwell-Lyte, H C, 1909 Calendar of the Patent Rolls Preserved in the Public Record Office. Henry VI Volume 5 I446-I452, Her Majesty's Stationery Office, London 
McAteer, M, 2015 'Celtic and Irish revival', British and Irish Literature, Oxford Bibliographies Online, DOI: I0.1093/OBO/9780199846719-0025

McCormick, B H, Defanti, T A and Brown, M D, I987 'Visualization in scientific computing', SIGGRAPH Computer Graphics Newsletter 2I:6, I 5-2I

McLeod, S, 2015 'Legitimation through association? Scandinavian accompanied burials and pre-historic monuments in Orkney', Journal of the North Atlantic 28, I-I 5

Meaney, A, I964 A Gazetteer of Early Anglo-Saxon Burial Sites, Allen and Unwin, London

Meaney, A, I995 'Pagan English sanctuaries, place-names and meeting-places', Anglo-Saxon Studies in Archaeology and History 8, 29-42

Meaney, A, 1997 'Hundred meeting-places in the Cambridgeshire region', in A Rumble and A Mills (eds), Names, Places and People: an Onomastic Miscellany for John Mcneal Dodgson, Watkins, Stamford, I95-240

Mees, K, 2019 Burial, Landscape and Identity in Early Medieval Wessex, Anglo-Saxon Studies 35 , Boydell and Brewer, Woodbridge

Mehler, N, 20I I 'From self-sufficiency to external supply and famine. Foodstuffs, their preparation and storage in Iceland', Ruralia 8, I73-I 86

Mehler, N, 20I2 'Thing-, Markt- und Kaufmannsbuden im westlichen Nordeuropa - Wurzeln und Gemeinsamkeiten eines Gebäudetyps', Mitteilungen der Deutschen Gesellschaft für Archäologie des Mittelalters und der Neuzeit 24, 7 I-83

Mehler, N, 20I5 'Pingvellir: A place of assembly and a market?', Journal of the North Atlantic, Special Volume 8, 69-8I

Mehler, N, and Gardiner, M, 20I3 'On the verge of colonialism: English and Hanseatic trade in the North Atlantic Islands', in P Pope and S Lewis-Simpson (eds), Exploring Atlantic Transitions: Archaeologies of Permanence and Transience in New Found Lands, The Society of Post-Medieval Archaeology Monograph 8, Woodbridge, I-I 5

Meier, J, I93 I 'Der blaue Stein zu Köln', Zeitschrift für Volkskunde 2, 29-40

Meissner, R, I950 Stadtrecht des Königs Magnus Hakonarson für Bergen, Verlag Herman Böhlaus Nachfolger, Weimar

Meulengracht Sørensen, P, I99 I 'Om eddadigtenes alder', in G Steinsland, U Drobin, J Pentikäinen and P Meulengracht Sørensen (eds), Nordisk hedendom. Et symposium, Odense Universitesforlag, Odense, 2I 7-227

Michelsen, H D, 2006 Tórshavns bebyggelsestopografi frem til I673. En arkcologisk vurdering set $i$ lyset af de historiske kilder, unpublished MA dissertation, University of Aarhus

Michelsen, H D, 2007 'Hálendskt grafitti á Tinganesi', Frøð $i$ I, 4-9

Miller, G L, Bebber, M R, Rutkoski, A, Haythorn, R, Boulanger, M T, Buchanan, B, Bush, J, Lovejoy, C O and Eren, M I, 2018 'Hunter-gatherer gatherings: Stone-tool microwear from the Welling Site (33-Co-2), Ohio, USA, supports Clovis use of outcrop-related base camps during the Pleistocene Peopling of the Americas', World Archaeology, 5 I, 47-75

Miller, W I, I986 'Gift, sale, payment, raid: Case studies in the negotiation and classification of exchange in medieval Iceland', Speculum 6I:I, I 8-50

Miller, W I, I990 Bloodtaking and Peacemaking: Feud, Law, and Society in Saga Iceland, University of Chicago Press, Chicago

Mitlid, A, 2004 'Bygdeborgene: var de lokale tiltak eller deler av en overordnet plan? En analyse av borgenes funksjon i det tidlige jernaldersamfunnet med vekt på deres forsvarsrelaterte oppgaver', Viking 67, 83-100

Molyneaux, G, 20II 'Why were some tenth-century English Kings presented as rulers of Britain?', Transactions of the Royal Historical Society 6th Series 2I, 59-9I

Molyneaux, G, 2015 The Formation of the English Kingdom in the Tenth Century, Oxford University Press, Oxford

Montesquieu, Charles de Secondat, baron de, I75I [1977] The Spirit of Laws, University of California Press Berkeley

Moore, T, 2012 'Beyond the oppida: Polyfocal complexes and late Iron Age societies in Southern Britain', Oxford Journal of Archaeology 3 I:4, 39I-4I7 
Moore, T, Braun, A, Creighton, J, Cripps, L, Haupt, P, Klenner, I, Nouvel, P, Ponroy, C and Schönfelder, M, 2013 'Oppida, agglomerations, and suburbia: The Bibracte environs and new perspectives on late Iron Age urbanism in Central-Eastern France', European Journal of Archaeology I 6:3, 49I-5I7

Morgan, P, I983 'From death to a view: The hunt for the Welsh past in the Romantic period', in E Hobsbawm and T Ranger (eds), The Invention of Tradition, Cambridge, University Press, 43-100

Mortimer, J R, I905 Forty Years' Researches in British and Saxon Burial Mounds of East Yorkshire: Including Romano-British Discoveries, and a Description of the Ancient Entrenchments of a Section of the Yorkshire Wolds, A Brown and Sons, London

Moseng, O G, 1994 Eikers historie 2: Sigden og Sagbladet, Øvre og Nedre Eiker kommuner, Hokksund

Mosse, G L, I964 The Crisis of German Ideology: Intellectual Origins of the Third Reich, Schocken Books, New York

Muir, R, I997 The Yorkshire Countryside: A Landscape History, Keele University Press, Edinburgh

Munch, G S, I99I Steigen kirke: arkeologiske undersøkelser under gulvet, Universitetet i Tromsø, Institutt for mueumsvirksomhet, Tromsø

Munch, P A, I849 Historisk-geografisk Beskrivelse over Kongeriget Norge (Noregsveldi) i Middelalderen, Wilhelm Grans Forlag, Christiania

Munch, P A, I852 Det norske Folks Historie, I:I, Tønsbergs forlag, Christiania

Munch, P A, I862 Det norske folks historie, II: I, Tønsbergs Forlag, Christiania

Mundal, E, 1994 'Kvinner som vitne i norske og islandske lover i mellomalderen', in G Sigurðsson, G Kvaran and S Steingrímsson (eds), Sagnaping: Helgað Jónasi Kristjánsyni Sjötugum ro. Apríl, Hið íslenska bókmenntafélag, Reykjavik, 593-602

Mundal, E, 200I 'The double impact of Christianization for women in Old Norse culture', in K E Børresen, $S$ Cabibbo and E Specht (eds), Gender and Religion/Genre et Religion, Rome, Carocci, 237-253

Murray, A C, 1986 'The position of the graphio in the constitutional history of Merovingian Gaul', Speculum $6,787-805$

Murray, A C, I 988 'From Roman to Frankish Gaul: 'centenarii' and 'centenae' in the administration of the Frankish Kingdom', Traditio 44, 59-100

Murrieta-Flores, P and Williams, H, 2017 'Placing the Pillar of Eliseg: Movement, visibility and memory in the early medieval landscape', Medieval Archaeology 6I:I, 69-I03

Musgrove, D, 1997 'The medieval exploitation and reclamation of the inland peat moors of the Somerset Levels', Archaeology in the Severn Estuary 8, 89-97

Müller-Boysen, C, 1990 Kaufmannsschutz und Handelsrecht im frühmittelalterlichen Nordeuropa, Wacholtz, Neumünster

Myhre, B, I985 'Boathouses as indicators of political organization', Norwegian Archaeological Review I $8: \mathrm{I}-2,36-58$

Myhre, B, I987a 'Naust, skip og leidang', in I Øye (ed.), Kystliv. Onsdagskvelder på Bryggens Museum, Bryggens Museum, Bergen, 28-47

Myhre, B, I987b 'Chieftains' graves and chiefdom territories in South Norway in the Migration Period'. Studien zur Sachsenforschung 6, I69-1 87. Niedersachsische Landesmuseum Hannover, Hildesheim

Myhre, B, 2002 'Landbruk, landskap og samfunn 400 f.Kr.-800 e.Kr.', in B Myhre and I Øye (eds), Norges landbrukshistorie I. 400 f.Kr.-I350 e.Kr, Jorda blir levevei, Det norske samlaget, Oslo, I 2-2 I 4

Myrberg, N, 2008 'Room for all? Spaces and places for thing assemblies: The case of the All-thing on Gotland, Sweden', Viking and Medieval Scandinavia 4, I33-I 58

Myrberg, N, 2009 'An Island in the middle of an Island: On cult, laws and authority in Viking Age Gotland', in E Regner, C von Heijne, L Kityler Åhfeldt and A Kjellström (eds), From Ephesus to Dalecarlia: Reflections on Body, Space and Time in Medieval and Early Modern Europe, Stockholm Studies in Archaeology 48, Stockholm, IOI-I I 8

Myrvoll, K J, 20I4 Kronologi i skaldekvade: distribusjon av metriske og språklege drag $i$ høve til tradisjonell datering og attribuering, Institutt for lingvistiske og nordiske studium, Universitetet i Oslo, Oslo

Møllerop, O, 1957 'Gård og gårdssamfunn I elder jernalder', Stavanger museums årbok, 4I-74

Møllerop, O, I97I 'De ringformede tunanlegg i Rogaland', Frá haug ok heiðni 3, I 5 I-I 66

Narmo, L E, 1996 ‘Kokekamratene på Leikvin Kult og kokegroper’, Viking 59, 79-I00 
Naumann, H-P, I987 'Warenpreise und Wertverhältnisse im alten Norden', in K Düwel, H Jankuhn, H Siems and D Timpe (eds), Untersuchungen Zu Handel Und Verkehr Der Vor- Und Frühgeschichtlichen Zeit in Mittel- Und Nordeuropa, Abhandlungen Der Akademie Der Wissenschaften in Göttingen, Philologisch-Historische Klasse, Vandenhoeck and Ruprecht, Göttingen, 374-390

Naylor, J, 2004 'Access to international trade in middle Saxon England: A case of urban over-emphasis?', in M Pasquinnucci and T Weski (eds), Close Encounters: Sea and Riverborne Trade, Ports and Hinterlands, Ship Construction and Navigation in Antiquity, the Middle Ages and in Modern Times, British Archaeological Reports International Series I 283, I39-I 46

Nebbia, M, Gaydarska, B, Millard, A and Chapman, J, 2018 'The making of Chalcolithic assembly places: Trypillia megasites as materialised consensus among equal strangers', World Archaeology 50:I, 4I-6I.

Newman, C, I997 Tara: an Archaeological Survey, Discovery Programme Monographs 2, Dublin

Newman, C, I998 'Reflections on the making of a "royal site" in early Ireland', World Archaeology 30:I, I27-I 4 I

Newman, C, 2007 'Procession and symbolism at Tara: Analysis of Tech Midchuarta (the Banqueting Hall) in the context of the sacral campus', Oxford Journal of Archaeology 26.4(4), 4 I 5-38.

Nicolaysen, N, I 862-66 Norske fornlevninger. En oplysende fortegnelse over Norges fortidslevninger celdre end reformationen og henførte til hver sit sted, Foreningen til Norske fortidsminnesmerkes bevaring, Cristiania/Copenhagen

Nicolaysen, N, I90I 'Antikvariske meddelelser', in Aarsberetning for Foreningen til norske fortidsmindesmoerkers bevaring 1900 , Cristiania/Copenhagen, 76-80

Nieke, M R and Duncan, H B, I988 'Dalriada: The establishment and maintenance of an Early Historic kingdom in northern Britain', in S T Driscoll and M R Nieke (eds), Power and Politics in Early Medieval Britain and Ireland, Edinburgh University Press, Edinburgh, 6-2 I

Nielsen, H, I964 'Konge', in J Granlund (ed.), Kulturhistoriskt lexikon för nordisk medeltid frän vikingatid till reformationstid 9, Gyldendal norsk forlag, Oslo, 4-9

Nielsen, O, I867 Bidrag til Oplysning om Sysselinddelingen i Danmark. Afhandling skreven for den filosofiske Doktorgrad, G S Wibes Bogtrykkeri, Copenhagen

Nielsen, P O, Nielsen, F O and Adamsen, C (eds), 20 I4 Solstensøen: På sporet af Bornholms bondestenalder, Bornholm Museum, Rønne

Niewegłowski, A I988 'Die religiöse Rolle der Haselnuss und der Hasel in der Urgeschichte und im Frühmittelalter', Archaeologia Polona 27, I47-I 83

Nilsson, B, I998 Sveriges kyrkohistoria, I, Missionstid och tidig medeltid, Verbum, Stockholm

Nissen, G B, I956 Frostating lagmannsembete og lagmenn inntil 1797: en historisk oversikt, Nidaros and Tøndelagens boktrykkeri, Trondheim

Niven, B, 2000 'The birth of Nazi drama? Thing plays', in J London (ed.), Theatre Under the Nazis, Manchester University Press, Manchester

Noble, G, Gondek, M, Campbell, E and Cook, M, $20{ }_{3}$ 'Between prehistory and history: The archaeological detection of social change among the Picts', Antiquity 87 (338), I I36-50.

Nolsøe, J P and Jespersen, K, 2004 Havnar søga I, Bókadeild Føroya Lærarafelags, Tórshavn

Nordal, S, I990 Icelandic culture, Cornell University, Ithaca

Nordbladh, J, 2002 'How to organise oneself within prehistory: Per Thamm and his relation to antiquity at the end of the I8th century', Antiquity 76, I4 I-I 50

Nordén, N, I938 'Tingsfjäl and bäsing', Fornvännen 33, 283-300

Norr, S and Sanmark, A, 2008 'Tingsplatser, makt och landskap', in M Olausson (ed.), Hem till Jarlabanke: jord, makt och evigt liv i östra Mälardalen under järnålder och medeltid, Historiska media, Lund, $379-396$

Norseng, P, 2005 'Borgarsysle', in P Norseng and S G Eliassen (eds), Østfolds historie, Østfold Fylkeskommune, Sarpsborg, I 2-334

Nyberg, T, 2008 'Adam av Bremen och Florenslistan', Scandia 57, I 53-I89

Nygren, C E, I934 Karlstads stads historia. D. I, Omfattande tiden I584-I7I9, på uppdrag av stadsfullmäktige, C E Nygren, Karlstad

Nørgaard, H, 2004 'fynhistorie.dk', http://fynhistorie.dis-danmark.dk/node/888 [accessed December 20I 5]

O'Brien, B R, I999 God's Peace and King's Peace: The Laws of Edward the Confessor, University of Pennsylvania Press, Philadelphia 
O'Brien, E and Bhreathnach, E, 20I I 'Irish boundary ferta, their physical manifestation and historical context', in F Edmonds and P Russell (eds), Tome: Studies in Medieval Celtic History and Law in Honour of Thomas Charles-Edwards, Studies in Celtic History 3 I, Boydell Press, Woodbridge, 55-64

Ó Corráin, D, 2010 'The Church and secular society', in L'Irlanda e gli Irlandesi nell'alto medioevo, Spoleto, Italy: Presso la sede della Fondazione, 26I-322

Ó Floinn, R, I 998 'The archaeology of the Early Viking Age in Ireland', in H Clarke, M Ní Mhaonaigh and R Ó Floinn (eds), Ireland and Scandinavia in the Early Viking Age, Four Courts Press, Dublin, I 3 I-65

O'Grady, O, 2008 The Setting and Practice of Open-air Judicial Assemblies in Medieval Scotland: A Multidisciplinary Study, unpublished PhD thesis, Department of Archaeology, University of Glasgow

O'Grady, O, 20I4 'Judicial assembly sites in Scotland: Archaeological and place-name evidence of the Scottish Court Hill', Medieval Archaeology 58, I04-I35

O'Grady, O, 2018 'Accumulating Kingship: The archaeology of elite assembly in medieval Scotland', World Archaeology 50:I, I37-I49

O’Neill, H, I977 'Salmonsbury, Boughton-on-the-Water: Some aspects of archaeology in Boughton Vale', Transactions of the Bristol and Gloucestershire Archaeology Society 95, I I-23

Oergel, M, I998 'The redeeming Teuton: Nineteenth-century notions of the Germanic in England and Germany', in G Cubitt (ed.), Imagining Nations, Manchester University Press, Manchester, 75-9 I

Ólafsson, G, and Snæsdóttir, M, I975 'Rúst í Hegranesi', Árbók hins íslenzka fornleifafélags, 69-78

Olausson, M, 2008 'När aristokratin flyttade upp på höjderna. Om folkvandringstidens befästa gårdar och andra borgar. Nya perspektiv på borgar och befästningar', Bebyggelsehistoriskt tidskrift 56, 24-40

Olausson, M, 2009 'At peace with walls: Fortifications and their significance AD 400-I I00', in H Olausson and M Olausson (eds), The Martial Society: Aspects of Warriors, Fortifications and Social Change in Scandinavia. Theses and papers in archaeology I, 35-70

Olausson, M et al., 2000 En bok om husbyar, Skrifter / Riksantikvarieämbetet, Avdelningen för arkeologiska undersökningar 33, Stockholm

Olsen, A B, 2005 'Et vikingtids tunanlegg på Hjelle i Stryn. En konservativ institusjon i et konservativt samfunn', in K A Bergsvik and A Engevik (eds), Fra funn til samfunn. Jernaldersstudier tilegnet Bergljot Solberg på 7o-årsdagen, Arkeologisk institutt, Universitetet i Bergen, 3 I9-354

Olsen, A B, 20I3 'Undersøkelse av et eldre jernalders tunanlegg på Sausjord, Voss, Hordaland - et nytt bidrag til kunnskapen om jernaldersamfunnets sosiale og politiske organisasjon', Viking 76, 87-I I 2

Olsen, A B, 2014 'Courtyard sites in western Norway: Central assembly places and judicial institutions in the late Iron Age', in M H Eriksen, U Pedersen, R Rundberget and I Axelsen (eds), Viking Worlds: Things, Spaces and Movement, Oxbow, Oxford, 43-55

Olsen, M, 2003 Den sosio-politiske organiseringen av Jceren i eldre jernalder. Et tolkningsforsøk med utgangspunkt $i$ skriftlige kilder og tunanleggene, unpublished master's thesis, Department of Archaeology and Social Anthropology, University of Tromsø

Oosthuizen, S, 2016 'Recognising and moving on from a failed paradigm: The case of agricultural landscapes in Anglo-Saxon England AD 400-800', Journal of Archaeological Research 24:2, I79-227

Opsahl, E, 2003 'Del I. 900-I 537', in E Opsahl and S Sogner (eds), Norsk innvandringshistorie I. I kongenes tid 900-I 8 I4, Pax forlag, Oslo

Opsahl, E, 2009 'Magnus 7 Eriksson', Norsk biografisk leksikon, https://nbl.snl.no/Magnus_7_Eriksson [accessed March 2015]

Opsahl, E, 20I7 'Margrete: "Norges pengefattige og magtløse dronning”?’, in A S Arnórsdóttir, B Poulsen, J B Netterstrøm and K H Andersen (eds), Dronningemagi i middelalderen. Festskrift til Anders Bøgh, Aarhus universitatetsforlag, Aarhus, 277-304

Opstad, L, I976 'Olav Haraldsons by Ior6-I 567', in E Johnsen, L Opstad and M Dehli (eds), Sarpsborg før I 839, Sarpsborg Kommune, Sarpsborg, I I 7-296

Orning, H J, 2006 'Kongemaktens lokale maktgrunnlag i middelalderen. Svar til Knut Dørum', Historisk tidsskrift $85,675-684$

Outram, Z, Harris, S E and Batt, C M, 20I4 'Archaeomagnetic dating', in J Coolen and N Mehler, Excavations and surveys at the Law Ting Holm, Tingwall, Shetland: An Iron Age settlement and medieval assembly site, British Archaeological Reports British Series 592, Oxford, 57-65

Pagán, V E, 20I 2 A Companion to Tacitus, Wiley-Blackwell, Chichester/Malden

Page, W, I9I4 The Victoria History of the County of York: The North Riding, vol. I, Constable, London 
Palmer, C F R г88I 'The Friar Preachers, or Black Friars of York', Yorkshire Archaeological Journal 6, 396-4I9

Pamp, B, I998 Från Gödelöv till Östen Undéns gata: En uppslagsbok över ortnamn i Lund under tvåtusen år. Fören, Gamla Lund, Lund

Pantos, A, 2002 Assembly Places in the Anglo-Saxon Period: Aspects of Form and Location, unpublished DPhil thesis, University of Oxford

Pantos, A, 2004a “"In medle oððe an pinge”: The Old English vocabulary of assembly', in A Pantos and S Semple (eds), Assembly Places and Practices in Early Medieval Europe, Four Courts Press, Dublin, I 8 I-2OI

Pantos, A, 2004b 'The location and form of Anglo-Saxon assembly places: Some 'moot points", in A Pantos and S Semple (eds), Assembly Places and Practices in Early Medieval Europe, Four Courts Press, Dublin, I 55-I 80

Pantos, A and Semple, S (eds), 2004a Assembly Places and Practices in Medieval Europe, Four Courts Press, Dublin

Pantos, A and Semple, S 2004b 'Introduction', in A Pantos and S Semple (eds), Assembly Places and Practices in Early Medieval Europe, Four Courts Press, Dublin, I I-23

Paus, H, I745 Gamle kongelige Forordninger og Privilegier, Udgivne for Kongeriget Norge, Copenhagen

Pálsson, H and Edwards, P (ed.), I978 Orkneyinga Saga: The History of the Earls of Orkney, Hogarth, London

Pálsson, H and Edwards, P, I987 Seven Viking Romances, Penguin, Harmondsworth

Pálsson, H and Edwards, P, 2014 The Book of Settlements: Landnámabók, University of Manitoba Press, Winnipeg

Pedersen, A, 2006 'The Jelling Monuments - Ancient royal memorial and modern world heritage site', in M Stoklund, L M Nielsen, B Holmberg and G Fellows-Jensen (eds), Runes and their Secrets. Studies in Runology, Museum Tusculanum Press, Denmark, 283-3 I4

Pedersen, E A and Widgren, M, I998 'Del 2. Järnålder. 500 f.Kr.-Iooo e.Kr.', in S Welinder, E A Pedersen and M Widgren (eds), Jordbrukets första femtusen år, Det Svenska jordbrukets historia I, Almqvist and Eiksell Tryckeri, Uppsala, 237-459

Peel, C, I999 Guta saga: The History of the Gotlanders, Viking Society for Northern Research, London

Peel, C (ed.), 2009 Guta lag: The Law of the Gotlanders, Viking Society for Northern Research, London

Petrie, G, I 839 'On the History and Antiquities of Tara Hill', Transactions of the Royal Irish Academy I 8 , $25-232$

Pestell, T, 20I I 'Markets, emporia, wics and "productive" sites: Pre-Viking trade centres in Anglo-Saxon England', in H Hamerow, D A Hinton and S Crawford (eds), The Oxford Handbook of Anglo-Saxon Archaeology, Oxford University Press, Oxford, 556-579

Petersen, A, I994 'The archaeology of the Syrian and Iraqi Hajj Routes', World Archaeology 26, 47-56

Petersen, H, I883 Herredsberejsning, Nationalmuseets arkiv, Copenhagen

Petersen, J, I936 Gamle Gårdsanlegg i Rogoland 2, Institutt for sammenlignende kulturforskning B3I, Aschehoug, Oslo

Petersen, J, I938 Innberetning om undersøkelser av Leksaren av Reiesstad i Rogaland 8/6-23/6 og I2/723.7 I938, Top. Ark. AmS, Stavanger

Petts, D, I998 'Burial and gender in late and sub-Roman Britain', in C Forcey, J Hawthorne and R Witcher (eds), TRAC 97: Proceedings of the Seventh Annual Theoretical Roman Archaeology Conference, University of Nottingham, April I997, Oxbow Books, Oxford, I I 2-I 24

Pietikäinen, P, 2000 “"The Volk” and its unconcious, Jung, Hauer, and the German revolution', Journal of Contemporary History 35, 523-539

Pilø, L, 2005 Bosted-urgård-enkeltgård. En analyse av premissene $i$ den norske bosetningshistoriske forskningstradisjonen, Oslo Arkeologisk Serie 3, Universitetet i Oslo, Oslo

Pluckhahn, T, 20I3 'Cooperation and competition among late woodland households at Kolomoki, Georgia', in D M Carballo (ed.), Cooperation and Collective Action: Archaeological Perspectives, University of Colorado Press, Boulder, I75-I96

Polanyi, K, I957 The Great Transformation, Beacon Press, Boston

Polikov, L (trans. E Howard), I974 The Aryan Myth: A History of Racist and Nationalist Ideas in Europe, Basic Books, New York 
Pollock, F and Maitland, F W, I898 The History of English Law Before the Time of Edward I, Cambridge University Press, Cambridge

Poulsen, J H W and Zachariasen, U (eds), I97 I Seyðabrcevið. Rcettarbót Hákunar hertuga Magnussonar fyri Føroyar, Føroya fróðskaparfelag, Tórshavn

Poux, M, 20I 2 Corent: Voyage au cour d'une ville gauloise, Paris (2nd edn)

Rafn, C C (trans.), I832 Foreyínga saga eller Foröboernes historie $i$ den islandske grundtekst med forøisk og dansk overscettelse, J H Schultz, Copenhagen

Rahtz, P A, I979 The Saxon and Medieval Palaces at Cheddar: Excavations I960-I962, British Archaeological Reports British Series 65, Oxford

Randsborg, K, I994 'Ole Worm. An essay on the modernization of antiquity', Acta Archaeologia 65, I35I 69

Randsborg, K, 2008 “'Kings” Jelling. Gorm and Thyra's palace, Harald's monument and grave, Svend's cathedral', Acta Archaeologia 79, I-23

Rawson, D, 2005 Archaeological Observation Investigation and Recording at I and 2 Council Bungalow, Eastgate, Rudston, Humber Field Archaeology, Kingston-upon-Hull

Rawson, D P, 2007 Archaeological Observation, Investigation and Recording at All Saints Parish Church, Rudston, Humber Field Archaeology, Kingston-upon-Hull

Ray, K and Thomas, J, 2018 Neolithic Britain: The Transformation of Social Worlds, Oxford University Press, Oxford

Redknap, M, 2000 Vikings in Wales: An Archaeological Quest, National Museums and Galleries of Wales, Cardiff

Renfrew, C, I979 Investigations in Orkney, The Society of Antiquaries of London, London

Renwick, W L (ed.), I970 A View of the Present State of Ireland by Edmund Spenser, Clarendon Press, Oxford

Reynolds, A, I999 Later Anglo-Saxon England: Life and Landscape, Tempus, Stroud

Reynolds, A, 2009 Anglo-Saxon Deviant Burial Customs, Oxford University Press, Oxford

Reynolds, A, 20I 8 'Lineage, genealogy and landscape: A high resolution archaeological model for the emergence of supra-regional society from early medieval England', World Archaeology 50:I, I 2 I-I 36

Reynolds, A, Carroll, J and Yorke, B (eds), 2019 Power and Place in Later Roman and Early Medieval Europe: Interdisciplinary Perspectives on Governance and Civil Organization. Proceedings of the British Academy, Oxford University Press, Oxford.

Riddler, I and Trecarthen, M, 2006 The prehistoric, Roman and Anglo-Saxon Funerary Landscape at Saltwood Tunnel, Kent, http://archaeologydataservice.ac.uk/catalogue//adsdata/arch-2473-I/ dissemination/pdf/A_SLT_integrated_Site_Report/SLT_ISR_text.pdf

Riisøy, A I, 20I3 'Sacred legal places in Eddic poetry - reflected in real life?', Journal of the North Atlantic, Special Volume 5, 28-4I

Rindal, M, 2008 'Innleiing', in E F Halvorsen and M Rindal (eds), De eldste østlandske kristenrettene. Tekst etter håndskriftene, med oversettelser, Norrøne Tekster nr. 7, Riksarkivet, Oslo

Rippon, S, 2004 Historic Landscape Analysis: Deciphering the Countryside, Council for British Archaeology, York

Rives, J B (trans.), I999 Tacitus: Germania, Oxford University Press, Oxford

Roach, L, 20I3 Kingship and Consent in Anglo-Saxon England, 87I-978: Assemblies and the State in the Early Middle Ages, Cambridge University Press, Cambridge

Roberts, H M, 20I5 Ingiriðarstaðir 20I5: An interim statement, Fornleifastofnun Íslands, unpublished report no. FS 588-08 I69, Reykjavik

Roffe, D R, I98 I 'The Lincolnshire Hundred', Landscape History 3, 27-36

Roffe, D R, 2000 Domesday: The Inquest and the Book, Oxford University Press

Roffe, D R, 2007 Decoding Domesday, Boydell Press, Woodbridge

Rolfsen, P and Larsen, J H, 2005 'Er det flere Halvdanshauger?', Viking 68, IOI-I 30

Rollason, D, 2012 'Forests, parks, palaces and the power of place in early medieval kingship', Early Medieval Europe 20:4, 428-449

de Roover, R, I942 'The commercial revolution of the thirteenth century', Bulletin of the Business Historical Society 95, 34-39

Rosén, J, I965 'Landsting', in J Granlund (ed), Kulturhistoriskt lexikon för nordisk medeltid från vikingatid till reformationstid, vol. I0, 293-296 
Ruthström, B, 2003 Land och fee: strukturellt-rättsfilologiska studier i fornnordiskt lagspråk över beteckningar för egendom i allmänhet med underkategorier, Institutionen för rättshistorisk forskning, Serien I, Stockholm

Ryan, M J, 20I I 'Place-names, language and the Anglo-Saxon landscape: An introduction', in N Higham and M J Ryan (eds), Place-Names, Language and the Anglo-Saxon Language, Boydell Press, Woodbridge, I-22

Rygh, O (ed.), I833-99 Norske Gaardnavne oplysninger samlede til brug ved matrikelens revision I-XIX, I833-99, Udgivne med tilføiede Forklaringer af Oluf Rygh, Fabritius, Cristiania/Copenhagen

Røgeberg, K, 2003-8 Norge i I743: innberetninger som svar på 43 spørsmål fra Danske Kanselli, I-5, Oslo

Rønneseth, O, 1959 'Alvekult og solkult i gamal tid', Syn og segn I959/I, I2-2I, I959/2, 66-74

Samdal, M and Björkan Bukkemoen, G, 2008 'Bommestad 2: kokegropfelt og dyrkningsspor fra jernalder', in L E Gjerpe (ed.), EI8-prosjektet Vestfold, 3: Hus, boplass- og dyrkningsspor, Kulturhistorisk Museum, Fornminneseksjonen, Oslo, 247-264

Sandnes, J, I967 'Trøndelags eldsste politiske historie', Historisk Tidsskrift 46, I-I9

Sandnes, J, I969 'Fylkeskirkene i Trøndelag i middelalderen. En del notater og detaljmateriale', Årbok for Trøndelag 3 , I I 6-I 36

Sandnes, J and Hagland, J R (eds), I994 Frostatingsloven, Norrøne Bokverk, Samlaget/Frosta Historielag, Oslo

Sandnes, J and Stemshaug, O, I976 Norsk stadnamnleksikon, Det norske samlaget, Oslo

Sanmark, A, 2004 Power and Conversion: A Comparative Study of Christianization in Scandinavia, Uppsala University Press, Uppsala

Sanmark, A, 2006 'The communal nature of the judicial system in early medieval Norway', Collegium Medievale I9, 3I-64

Sanmark, A, 2009 'Administrative organisation and state formation: A case study of assembly sites in Södemanland, Sweden', Medieval Archaeology 53, 205-24I

Sanmark, A, 2010 'The case of the Greenlandic assembly sites', Journal of the North Atlantic 2, I78-192

Sanmark, A, 20I2 'Kirkwall: From Norse thing site to council seat', The Orcadian, 5 April $20 \mathrm{I} 2$

Sanmark, A, 20I3 'Patterns of assembly: Norse Thing sites in Shetland', Journal of the North Atlantic, Special Volume 5, 96-I Io

Sanmark, A, 20I4 'Women at the Thing', in N Coleman and N L Løkka (eds), Nordic Women in the Viking Age, Scandinavian Academic Press, Oslo, 85-100

Sanmark, A, 2015 'At the assembly: A study of ritual space', in L Hermansson and H J Orning (eds), Power of Practice: Rituals and Politics in Northern Europe c. 650-I350, Brepols, Turnhout, 79-I I 2

Sanmark, A, 20I7a Viking Law and Order: Places and Rituals of Assembly in the Medieval North, Edinburgh University Press, Edinburgh

Sanmark, A $2017 \mathrm{~b}$ 'An exploration of thing sites in the Islands on the Scottish West Coast', in C Cooijmans (ed.) Traversing the Inner Seas, The Scottish Society for Northern Studies, Edinburgh

Sanmark, A and Semple, S, 2008 'Places of assembly: New discoveries in Sweden and England' Fornvännen I03, 245-259

Sanmark, A and Semple, S, 20I0 'The topography of outdoor assembly sites in Europe with reference to recent field results from Sweden', in H Lewis and S Semple (eds), Perspectives in Landscape Archaeology, British Archaeological Reports International Series 2103, I07-I I9

Sanmark, A and Semple, S, 20I I Tingsplatsen som arkeologiskt problem. Etapp 3: Anundshög, The Assembly Project, unpublished Field Report 3

Sastre, I, 2002 'Forms of social inequality in the Castro Culture of north-west Iberia', European Journal of Archaeology 5, 213-248

Sawyer, P H, I968 Anglo-Saxon Charters: An Annotated List and Bibliography, Offices of the Royal Historical Society, London

Sawyer, P H, 1983 'The royal tūn in pre-Conquest England', in P Wormald, D Bullough and R Collins (eds), Ideal and Reality in Frankish and Anglo-Saxon Society: Studies Presented to J M Wallace-Hadrill, Blackwell, Oxford, 273-299

Sawyer, P H, I998 Anglo-Saxon Lincolnshire, History of Lincolnshire Committee, Lincoln 
Schiffels, S, Haak, W, Paajanen, P, Llamas, B, Popescu, E, Loe, L, Clarke, R, Lyons, A, Mortimer, R, Sayers D, Tyler-Smith, C, Cooper, A and Durbin, R, 2016 'Iron Age and Anglo-Saxon genomes from East England reveal British migration history', Nature Communications 7: I0408, I-9, DOI: I0.1038/ ncommsio408|www.nature.com/naturecommunications [accessed March 20I9]

Schledermann, H, I974 'Tingsted', in I Andersson and J Granlund (eds), Kulturbistoriskt lexikon för nordisk medeltid från vikingatid till reformationstid XVIII, Allhem, Malmö, 373-376

Schnapp, A, 1993 The Discovery of the Past: The Origins of Archaeology, British Museum Press, London

Schnell, I and Ståhle, C I (eds), I938 Rannsakningar om antikviteter i Södermanland I667-I686, Sörmländska handlingar No. 5, Södermanlands hembygdsförbund, Nyköping

Schofield, A J, 2000 'Never mind the relevance? Popular culture for archaeologists', in P M Graves-Brown (ed.), Matter, Materiality and Modern Culture, Routledge, London, I 3 I-I 54

Schot, R, Bhreathnach, E and Newman, C (eds), 20II The Landscape of Kingship and Cult: Text and Archaeology, Four Courts Press, Dublin

Schou, T, I993 Onsøys historie. Tiden inntil àr I 537, Bind II, Middelalderen, Onsøy commune

Schulze, H K, 2004 Stammesverband, Gefolgschaft, Lehnswesen, Grundherrschaft. Grundstrukturen der Verfassung im Mittelalter. Third edition, vol. I, W. Kohlhammer, Stuttgart

Schuyler, R L, I946 'The Antiquaries and Sir Henry Spelman: An essay in historiography', Proceedings of the American Philosophical Society 90(2), 91-103

Schück, A, 1926 Studier rörande det svenska stadsväsendets uppkomst och äldsta utveckling, Appelberg, Uppsala

Schück, H, I9 I4 'Uppsala öd', Uppsala universitetes årsskrift. Program 2, Uppsala, 3-36

Schøning G, I9I0 Reise som giennem en deel af Norge i de aar I773, I774, I775 paa Hans Majestaet Kongens bekostning er giort og beskreven: $I$, Selskabet, Trondheim

Schreiner, J, I 927-29 'Viken og Norges samling', Historisk tidsskrift 28, 356-87

Scull, C, I993 'Archaeology, early Anglo-Saxon society and the origins of Anglo-Saxon kingdoms', AngloSaxon Studies in Archaeology and History 6, 65-82

Scull, C, 1999 'Social archaeology and Anglo-Saxon kingdom origins', Anglo-Saxon Studies in Archaeology and History IO, $17-24$

Scull, C, $200 \mathrm{I}$ 'Local and regional identities and processes of state formatoin in fifth- to seventh-century England: Some archaeological problems', in B Arrhenius (ed), Kingdoms and Regionality: Transactions from the 49th Sachsensymposion 1998 in Uppsala, Stockholm University Archaeological Research Laboratory, Stockholm, I 2 I-I 25

Scull, C, Minter, F and Plouviez, J, 2016 'Social and economic complexity in early medieval England: Acentral place complex of the East Anglian kingdom at Rendlesham, Suffolk', Antiquity 90 (354), I 594-I6I 2

Seip, J A, I934 Lagmann og lagting $i$ senmiddelalderen og det I6de arhundrede. Skrifter utgitt av det norske videnskapsakademi i Oslo. II Historisk-filosofisk Klasse, J Dybwad, Oslo

Seip, J A, I942 Sattargjerden $i$ Tunsberg og kirkens jurisdiksjon, Det norske videnskaps-akademi, Oslo

Selberg, K, 2010 Eldre norske rettskilder: En oversikt. Det juridiske fakultetsbiblioteks skriftserie, Universitetet i Oslo, Oslo

Semple, S, I998 'A fear of the past: The place of the prehistoric burial mound in the ideology of middle and later Anglo-Saxon England', World Archaeology 30, I09-I 26

Semple, S, 2003 'Burials and political boundaries in the Avebury region, North Wiltshire', Anglo-Saxon Studies in Archaeology and History I2, 72-9I

Semple, S, 2004 'Locations of assembly in early Anglo-Saxon England', in A Pantos and S Semple (eds), Assembly Places and Practices in Early Medieval Europe, Four Courts Press, Dublin, I3 $35^{-1} 54$

Semple, S, 2008 'Polities and Princes AD 400-800: New perspectives on the funerary landscape of the South Saxon Kingdom', Oxford Journal of Archaeology 27:4, 407-429

Semple, S, 2013 Perceptions of the Prehistoric in Anglo-Saxon England: Religion, Ritual and Rulership in the Landscape, Oxford University Press, Oxford

Semple, S, 2018 'Editorial', World Archaeology 50:I, I-6

Semple, S, Buchanan, B, Harrington, S, Oliver, D and Petts, D, 2017 'Power at the Edge: Yeavering, Northumberland, England', in S Semple, C Orsini and S Mui (eds), Life on the Edge: Social, Political and Religious Frontiers in Early Medieval Europe, Neue Studien zur Sachsenforschung Band 6, Braunschweigisches Landesmuseum, 9I-I I 2 
Semple, S and Sanmark, A, 20I3 'Assembly in North West Europe: Collective concerns for early societies?', European Journal of Archaeology I6, 5 I 8-542

Sherley-Price, L, I968 Bede: A History of the English Church and People, Penguin Books, Harmondsworth (2nd edn)

Shetelig, H, I944 Norske museers historie, J W Cappelen, Madison, Wisconsin

Sigurðsson, J V, I989 Frá Goðorðum til Ríkja. Próun goðavalds á I2. og I3. öld, Bókautgáfa Menningarsjóðs, Reykjavik

Sigurðsson, J V, I995 'The Icelandic aristocracy after the fall of the free state', Scandinavian Journal of History 20, I 53-I 66

Sigurðsson, J V, 1999 Chieftains and Power in the Icelandic Commonwealth, University Press of Southern Denmark, Odense

Sigurðsson, J V, 2008a Det norrøne samfunnet, vikingen, kongen, erkebiskopen og bonden, Pax, Oslo

Sigurðsson, J V, 2008b 'Iceland', in S Brink and N Price (eds), The Viking World, Routledge, London, $57 \mathrm{I}-578$

Sigurðsson, J V, 2010 'The Norse community', in S Imsen (ed.), The Norwegian Domination of the Norse World c. I IOO-c. I400, Norgesveldet Occasional Papers I, Tapir Academic Press, Trondheim, 59-75

Sigurðsson, J V, Pedersen, F and Berge, A, 2008 'Making and using the law in the North, c. 900-I350', in G Lottes, E Medijainen and J V Sigurðsson (eds), Making, Using and Resisting the Law in European History, Pisa University Press, Pisa, 37-64

Silberman, N A, I982 Digging for God and Country, Knopf, New York

Simms, K, I987 From Kings to Warlords: The Changing Political Structure of Gaelic Ireland in the Later Middle Ages, Boydell Press, Woodbridge

Sjöborg, N H, I8 I 5 Försök till en nomenklatur för nordiska fornlemningar, Carl Delén, Stockholm

Sjöholm, E, I988 Sveriges medeltidslagar. Europeisk rättstradition i politisk omvandling, A-B Nordiska Bokhandeln, Stockholm

Sjöholm, E, I990 'Sweden's medieval laws: European legal tradition, political change', Scandinavian Journal of History I $5,65-87$

Skevik, O, I997 Folk og fylker $i$ fjerne tider: Inntrøndelags historie før I600, Nord-Trøndelag fylkeskommune, Steinkjer

Skinner, A T, $20 \mathrm{I}_{4}$ Impact and Change: Assembly Practices in the Northern Danelaw, unpublished PhD thesis, Department of Archaeology, Durham University

Skinner, A T and Semple S J, 2016 'Assembly mounds in the Danelaw: Place-name and archaeological evidence in the historic landscape', Journal of the North Atlantic, Special Volume 8, I I 5-I 33

Skovgaard-Petersen, K, 2002 Historiography at the Court of Christian IV (I588-I648): Studies in the Latin histories of Denmark by Johannes Pontanus and Johannes Meursius, Museum Tusculanium Press, Copenhagen

Skre, D, 1998 Herredømmet, bosetning og besittelse på Romerike 200-I350 e. Kr. Acta Humaniora 32 , Universitetet i Oslo, Universitetsforlaget, Oslo

Skre, D, 2007 'The Skiringssal thing site pjoðalyng', in D Skre (ed.), Kaupang in Skiringssal, Kaupang Excavation Project Publication Series, Oslo/Aarhus, 385-406

Skre, D, 2008 'The development of urbanism in Scandinavia', in S Brink and N Price (eds), The Viking World, Routledge, London, 83-93

Skre, D (ed.), 2017 Avaldsnes: A Sea-Kings' Manor in First-Millennium Western Scandinavia, Walter de Gruyter, Berlin

Skrubbeltrang, F, I980 'Bonde', Kulturhistorisk Leksikon for Nordisk Middelalder II, 84-90

Smith, A H, I928 The Place-Names of the North Riding of Yorkshire, Cambridge University Press, Cambridge

Smith, A H, I937 The Place-Names of the East Riding of Yorkshire, Cambridge University Press, Cambridge

Smith, A H, г96ra The Place-Names of the West Riding of Yorkshire. Part One: Lower and Upper Strafforth and Staincross Wapentakes, Cambridge University Press, Cambridge

Smith, A H, I96Ib The Place-Names of the West Riding of Yorkshire. Part Two: Osgoldcross and Agbrigg Wapentakes, Cambridge University Press, Cambridge

Smith, A H, I96rc The Place-Names of the West Riding of Yorkshire. Part Four: Barkston Ash, Skyrack and Ainsty Wapentakes, Cambridge University Press, Cambridge 
Smith, A H, I964-65 Place-Names of Gloucestershire I-IV, Cambridge University Press, London Smith, A H, I967 The Place-Names of Westmorland, Cambridge University Press, Cambridge

Smith, B, I990 'Shetland, Scandinavia, Scotland, I300-I700', in G G Simpson (ed.), Scotland and Scandinavia, I300-1800, John Donald, Edinburgh, 25-37

Smith, B, 2009 'On the nature of tings: Shetland's law courts from the Middle Ages until I6I I', New Shetlander 250, 37-45

Smith, B, 20 I I 'Hákon Magnusson's root-and-branch reform of public institutions in Shetland, c. I300', in S Imsen (ed.), Taxes, Tributes and Tributary Lands in the Making of the Scandinavian Realm in the Middle Ages, Tapir Akademisk Forlag, Trondheim, I03-I I 2

Smith, K P and Reynolds, A, 20I4 'Introduction: The archaeology of legal culture', World Archaeology 45, 687-698

Smith, L T (ed.), I906-10 The Itinerary of John Leland in or about the years of I535-43, parts I-IX, George Bell and Sons, London

Solberg, B, 2002 'Courtyard sites north of the polar circle: Reflections of power in the Late Roman and Migration Period', in B Hårdh and L Larsson (eds), Central Places in the Migration and Merovingian Periods. Papers from the 52nd Sachsensymposium, Almquist and Wiksell, Stockholm, 219-229

Solheim, S, I956 Horse-Fight and Horse-Race in Norse Tradition, Aschehoug, Oslo

Solli, B, 2008 'Kjøpstedet på Veøya i Romsdal', in H Andersson, G Hansen and I Øye (eds), De første 200 årene: nytt blikk på 27 skandinaviske middelalderbyer, UBAS 5, Universitetet i Bergen, Bergen, IO9-I 24

Solvason, B, I993 'Institutional evolution in the Icelandic Commonwealth', Constitutional Political Economy 4:I, 97-I 25

Speed, J, I6II The History of Great Britaine under the Conquests of ye Romans, Saxons, Danes and Normans...with ye successions, lives, acts and issues of the English monarchs from Julius Caesar, to King James, William Hall and John Beale, London

Spelman, H, I664 Glossarium Archaiologicum: Continens Latino-Barbara, Peregrina, Obsoleta, \& Novatae Significationis Vocabula, Aliciam Warren, London

Spenser, E, I 5 52-99 A View of the Present State of Ireland, Partridge at the Scholartis Press [I934] Paul Watkins, Stamford

Spittal, J and Field, J (eds), I990 A Reader's Guide to the Place-Names of the United Kingdom, Stamford

Spørck, B D, 2009 Nyere norske kristenretter (ca. I260-I273), Thorleif Dahl kulturbibliotek, Oslo

Staf, N, I93 I Marknad och möte: studier rörande politiska underhandlingar med folkmenigheter $i$ Sverige och Finland intill Gustav II Adolfs tid, Börtzell, Stockholm

Staf, N, I935 Marknad och möte: studier rörande politiska underhandlingar med folkmenigheter $i$ Sverige och Finland intill Gustav II Adolfs tid, unpublished PhD thesis, University of Stockholm

Stahlschmidt P, Swaffield, S, Primdahl, J and Nellemann, V, 2017 Landscape Analysis: Investigating the Potentials of Space and Place, Routledge, London

Stamnes, A A, 2017 'På sporet av tingmennene: arkeologiske og antikvariske indikasjoner I tinglandskapet på Frosta', in O Risbøl (ed.), Frostatinget i et historisk lys, Gunneria 8 I, I 5 I-I 97

Stefánsson, M, I984 'Ding, Island', in H Beck, D Geuenich and H Steuer (eds), Reallexikon der Germanischen Altertumskunde I5, Walter de Gruyter, Berlin, 46I-464

Stein-Wilkeshuis, M, I998 'Scandinavian law in a tenth-century Rus'- Greek commercial treaty', in J M Hill and M Swan (eds), The Community, the Family and the Saint: Patterns of Power in Early Medieval Europe, Turnhout, Brepols, 3 I I-322

Steinnes, A, I929 'Kor gamal er den norske leiðangrsskipnaden?', Syn og Segn 35, 49-65

Steinnes, A, I933 Gamal skatteskipnad i Noreg II (re-published by Kildebokforlaget I982), Oslo

Steinnes, A, I95 5 Husebyar. Den norske historiske forening, Skrifter 32, DNHF, Oslo

Steinnes, A, I959 'The Huseby System in Orkney', Scottish Historical Review 38, 36-46

Steinnes, A, I974 Styrings- og rettsskipnad i Sørvest-Noreg i mellomalderen. Historisk-topografisk oversyn, Det Norske Samlaget, Oslo

Stenton, F M, I9 Iо 'Types of manorial structure in the Northern Danelaw', in P Vinogradoff (ed.), Oxford Studies in Social and Legal History ii, Clarendon Press, Oxford, 3-96

Stenton, F M, I97 I Anglo-Saxon England, Clarendon Press, Oxford (3rd edn)

Stenvik, L F, 200I Skei: et maktsenter fram fra skyggen, Vitenskapsmuseet, Norges teknisknaturvitenskapelige universitet, Trondheim 
Steuer, H and Hoeper, M, 2008 'Völkerwanderungszeitliche Höhenstationen am Scwartzwaldrand. Eine Zusammenfassung der Gemeinsamkeiten und Unterschiede', in H. Steuer and V. Bierbrauer (eds), Höhensiedlungen zwischen Antike und Mittelalter von den Ardennen bis zur Adria, Ergänzungsbände zum Reallexikon der germanischen Altertumskunde 58, 213-260

Stewart, J, I987 Shetland Place-Names, Shetland Library and Museum, Lerwick

Stocking, R L, 2000 Bishops, Councils and Consensus in the Visigothic Kingdom 589-633, The University of Michigan Press, Michigan

Stoertz, C, I997 Ancient Landscapes of the Yorkshire Wolds: Aerial Photographic Transcription and Analysis, RCHME, Swindon

Storli, I, 2000 " "Barbarians" of the north: Reflections on the establishment of courtyard sites in North Norway', Norwegian Archaeological Review 33:2, 8I-IO3

Storli, I, 200I 'Tunanleggens rolle i nordnorsk järnålder', Viking 66, 87-I I I

Storli, I, 2006 Hålogaland for rikssamlingen. Politiske prosesser i perioden 200-90o e. Kr, Instituttet for sammenlignende kulturforskning, Oslo

Storli, I, 2010 'Court-yards of Arctic Norway: Remains of thing sites and representations of political consolidation processes in the northern Germanic world during the Ist millennium AD?', Norwegian Archaeological Review 43:2, I 28-I 44

Storm, G (ed.), I 885 Norges gamle love Indtil I387. Bd. 4, Supplementer til de tre foregaaende bind samt haandskriftbeskrivelse med facsimiler, Chr. Grøndahl, Christiania

Storm, G, I90 I 'Skiringssal og Sandefjord', Historisk tidsskrift 4, 2I 4-237

Strauch, D, 2004 'Schonen', in J Hoops, H Beck and H Jahnkuhn (eds), Reallexikon der germanischen Altertumskunde 27, De Gruyter, Berlin/New York, 259-262

Strauch, D, 20I I Mittelalterliches Nordisches Recht bis I500, Reallexikon der Germanischen Altertumskunde, Ergänzungsband 73, Walter de Gruyter, Berlin

Stubbs, W, I 874 The Constitutional History of England in its Origin and Development, vol. I, Clarendon Press, Oxford

Stummann Hansen, S, 2005 'Islands Pompeji', Den Follesskandinaviske Arkcologiske Ekspedition til Pjórsárdalur $i$ I939, Studies in Archaeology and History I I, Copenhagen, 47-52

Styffe, C G, I 867 Skandinavien under unionstiden: Ett bidrag till den historiska geografien, P A Norstedt and söner, Stockholm

Styffe, C G, I9I I Skandinavien under unionstiden: med särskildt afseende på Sverige och dess förvaltning aren I3 I9 till I52I: ett bidrag till den historiska geografien, Norstedt, Stockholm

Stylegar, F-A, and Norseng, P G, 2003 'Mot historisk tid. Del 2', in E A Pedersen, F-A Stylegar and P G Norseng (eds), Øst for Folden. Østfolds historie, Østfolds fylkeskommune, Sarpsborg, 278-5 I 2

Stylegar, F-A and Westerdahl, C, 2004 'Husebyene i Norden', Viking 2004, IOI-I 38

Sundquist, N, I953 Uppsala stads historia. I, Östra Aros: stadens uppkomst och dess utveckling intill àr I 300 , Kommittén för utgivandet av Uppsala stads historia, Uppsala

Sundqvist, O, 200I 'Features of pre-Christian inauguration rituals in the medieval Swedish laws', in M Stausberg (ed.), Kontinuitäten und Brüche in der Religionsgeschichte. Festschrift für Anders Hultgard zu seinem 65. Geburtstag am 23. I2. 200I, de Gruyter, Berlin/New York, 620-650

Sundqvist, O, 2002 Freyr's Offspring: Rulers and Religion in Ancient Svea Society, Uppsala Universitet, Uppsala

Sundqvist, O, 2016 An Arena for Higher Powers: Ceremonial Buildings and Religious Strategies for Rulership in Late Iron Age Scandinavia, Brill, Leiden

Sveinbjarnardóttir, G, I986 Rannsókn á Kópavogspingstað, Prentstofa G Benediktssonar, Kópavogspingstað Svensson, E and Gardiner, M, 2009 'Introduction: Marginality in the pre-industrial European countryside', in J Klapste and P Sommer (eds), Medieval Rural Settlement in Marginal Landscapes, Ruralia 7, 2I-25

Svensson, O, 2007 'Skånska ortnamn i anslutning till rättsutövning', in A A Eggert, B Holmberg and B Jørgensen (eds), Nordiske navnes centralitet og regionalitet, Rapport fra NORNAs 35, symposium på Bornholm 4.-7. maj 20067, Norna-Rapporter 82, Norna-förlaget, Uppsala, I9I-2 I9

Svensson, O, 20I 5 'Place names, landscape, and assembly sites in Skåne, Sweden', Journal of the North Atlantic, Special Volume 8, 82-92

Swan, V G, Jones, B E A and Grady, D, I993 'Bolesford, North Riding of Yorkshire: A lost wapentake centre and its landscape', Landscape History I 5, I $3-28$

Swanton, M J, 2000 Anglo-Saxon Chronicle, Phoenix, London 
Sweet, R, 2004 Antiquaries: The Discovery of the Past in Eighteenth Century Britain, Hambledon, London Swensen, W, I964 'Kongens stol, Hyldingsstolen', in J Granlund (ed.), Kulturhistoriskt lexikon för nordisk medeltid frän vikingatid till reformationstid 9, Gyldendal norsk forlag, Oslo

Swenson, E R, 2018 'Assembling the Moche: The power of temporary gatherings on the North Coast of Peru', World Archaeology 50: I, 62-85

Sølvará, H A, 2002 Løgtingið I 50 - Hátiðarrit I: Løgtingið og høvundarnir, Tórshavn, Faroe Islands

Talbot, C H, I954 The Anglo-Saxon Missionaries in Germany: Being the Lives of SS Willibrord, Boniface, Sturm, Leoba and Lebuin, together with the Hodoeporicon of St Willibald and a Selection from the Correspondence of St Boniface, Sheed and Ward, London

Tamm, D, 2003 Kongens Retterting I 537-I660 I-II, Jurist- og Økonomforbundets Forlag, Copenhagen

Taranger, A, I887 'Om Betydningen av Herads og Herads-Kirkja i de ældre Kristenretter', Historisk Tidsskrift 2:6, 337-40I

Taranger, A, I 898 Udsigt over den norske rets historie: forelcesninger I. Kart- and Litograferingskontoret, Forlagt af Cammermeyers Boghandel, Cristiania/Copenhagen

Taranger, A, I9 I 5 Magnus Lagabøters Landslov, Cammermeyers Boghandel, Cristiania/Copenhagen

Taranger, A, I934 'Om kongevalg i Norge i sagatiden', Historisk Tidsskrift 30, I I0-I66, 273-3 I I

Taranger, A, I935 Utsikt over den norske retts historie. I: Innledning-Rettskildenes historie, Oslo

Thomas, G, 2018 'Mead-halls of the Oiscingas: A new Kentish perspective on the Anglo-Saxon great hall complex phenomenon', Medieval Archaeology 62:2, 262-303

Thomas, J J and Cook, K A (eds), 2005 Illuminating the Path: The Research and Development Agenda for Visual Analytics, IEEE Computer Society, Los Alamos

Thomle, E A, Groth, P, Scheel, F, Orholt, E W, Seip, J A and Kvamen, I (eds), I966-72 Norske HerredagsDombøger, Første til Fjerde Røkke (1893-I959), Oddvar Grønli. Norsk historisk kjeldeskrift-institutt, Styret for Kjeldeskriftfondet, Christiania

Thomson, W P L, 2008 The New History of Orkney, Birlinn, Edinburgh

Thoresby, R, I7I 5 Ducatus Leodiensis: or, the Topography of the Ancient and Populous Town of Leedes, Edward Nutt, London

Thorsteinsson, A, I986 Tinganes-Tórshavn: En kort historisk orientering. A brief historical guide, Føroya Landsstýri, Tórshavn

Thorsteinsson, A, 20I2 'Thing sites in the Faroes', in O Owen (ed.), Things in the Viking World, THING project, The Shetland Amenity Trust, Lerwick, 52-67

Thurston, T L, 200I Landscapes of Power, Landscapes of Conflict: State Formatoin in the South Scandinavian Iron Age, Kluwer Academic/Plenum Publishing, New York

Thurston, T L, 2010 'Bitter arrows and generous gifts: What was a king in the European Iron Age?', in T D Price and G M Feinman (eds), Pathways to Power: New Perspectives on the Emergence of Social Inequality, Springer, New York, I93-254

Traustadóttir, R, Guðmundsdóttir, L, Einebrant Svensson, J, and Carter, T, 20 I Kolkuós i Skagafjirði. Framvinduskýrsla: Excavation report 20 I I, unpublished report

Tryti, A E, I994 'Bergen som sentrum i bispedømmet', in I Øye (ed.), By og land $i$ middelalderen. Onsdagskvelder i Bryggens Museum 9, Bryggens Museum, Bergen, 23-43

Tschan, F J (ed. and trans.), 2002 Adam of Bremen. History of the Archbishops of Hamburg-Bremen, Columbia University Press, New York

Tunberg, S, I9 I I Studier rörande Skandinaviens äldsta politiska indelning, Appelberg, Uppsala

Turén, S, I939 'Om rätt tingsplats enligt Västmannalagen', Västmanlands fornminnesförenings årsskrift $27,5-16$

Turner, S, 2000 'Aspects of the development of public assembly in the Danelaw', Assemblage 5, http:// www.assemblage.group.shef.ac.uk/5/turner.html [accessed April 20I2]

Tvauri, A, 20I4 'The impact of the climate catastrophe of 536-537 AD in Estonia and neighbouring areas', Estonian Journal of Archaeology I 8(I), 30-56

Ugwuanyi, J K and Schofield, J, 20I 8 'Permanence, temporality and the rhythms of life: Exploring significance of the village arena in Igbo culture', World Archaeology 50:1, 7-22

Ulmschneider, K U, 2000 'Settlement, economy and the "productive" site: Middle Anglo-Saxon Lincolnshire AD 650-780', Medieval Archaeology 44, 53-79 
Ulmschneider, K and Pestell, T, 2003 'Introduction: Early medieval markets and "productive" sites', in T Pestell and K Ulmschneider (eds), Markets in Early Medieval Europe: Trading and "Productive" Sites, 650-850, Windgather Press, Macklesfield, I-IO

Unger, C R and Drolsum, A C (eds), I 869 Codex Frisianus: En samling af norske konge-sagaer (Contains Snorri Sturluson's Heimskringla, with the exception of Ólafs saga Helga, and Hákonar saga Gamla Hákonarsonar by Sturla Pórðarson), Norske historiske kildeskriftfonds skrifter, 9, Hákonar saga Gamla Hákonarsonar, P T Malling, Christiania

Valk, H, 2006 'Rites and their meaning in the traditional Seto world-view', in A Andrén, K Jennbert, C Raudvere (eds), Old Norse Religion in Long-Term Perspectives: Origins, Changes and Interactions, Nordic Academic Press, Lund, I4I-I46

Vareka, P and Symonds, J, 20I I 'The archaeology of tramping: The field research of the "Duck Valley" campsite near Jezerce', in S Michajlová (ed.), Volný as: Utopie na hranicích všed nosti (Spare Time: Utopias on the Verge of Commonness), National Gallery, Czech Republic, Prague, 69-80

Vauchez, A and Lapidge, M, 2000 Encyclopedia of the Middle Ages I, Fitzroy Dearborn, London

Venås, K, 1989 'Kvinne og mann i Gulatingslova. Etter ein idé av Lis Jacobsen', in B Eithun, E Fjell Halvorsen, M Rindal, and E Simensen (eds), Festskrift til Finn Hødnebø 29. Desember 1989, Oslo, Novus, 258-303

Vésteinsson, O, I999 Fornleifarannsókn við Pingvallakirkju. Fornleifastofnun Íslands excavation report, unpublished reports of the Institute of Archaeology, Iceland, no. FS I04-98 I 22, Reykjavik

Vésteinsson, O, 2006a 'Central areas in Iceland', in J Arneborg and B Grønnow (eds), Dynamics of Northern Societies. Proceedings of the SILA/NABO Conference on Arctic and North Atlantic Archaeology, Copenhangen, May Ioth-I4th, 2004, Aarhus University Press, Copenhagen, 307-323

Vésteinsson, O, 2006b 'Communities of dispersed settlements: Social organization at the ground level in tenth- to thirteenth-century Iceland', in W Davies, G Halsall and A Reynolds (eds), People and Space in the Middle Ages, 300-1300, Brepols, Turnhout, 87-1 I 3

Vésteinsson, O, 20I3 'What is in a booth? Material symbolism at Icelandic Assembly Sites', Journal of the North Atlantic, Special Volume 5, I I I-I 24

Vésteinsson, O, Einarsson, Á and Sigurgeirsson, M Á, 2004 'A new assembly site in Skuldapingsey, NE Iceland', in G Guðmundsson (ed.), Current Issues in Nordic Archaeology: Proceedings of the 2 Ist Conference of Nordic Archaeologists 6-9 September 200I. Akureyri Iceland, Society of Icelandic Archaeologists, Reykjavik, I7I-I79

Vigfússon, G and Unger, C R (eds), I860-68 Flateyjarbok: En samling af Norske Konge-sagaer, 3 vols, P T Mallings forlagsboghandel, Christiania [Oslo]

Vigfússon, S, I 880-8I 'Alpingisstaðr hinn forni', Árbók hins íslenzka fornleifafélags I 880-8I, 8-3 I

Vigfússon, S, I 888-92 'Rannsóknarferð um Húnavatns og Skagafjarðar sýslur I 886', Árbók hins íslenzka fornleifafélags I $888-92,76-\mathrm{I} 23$

Vikstrand, P, 200I Gudarnas platser: förkristna sakrala ortnamn i Mälarlandskapen (=Studier till en svensk ortnamnsatlas I7), Kungl. Gustav Adolfs akademien för svensk folkkultur, Uppsala

Vinogradoff, P, I908 English Society in the Eleventh Century: Essays on Engish Mediaeval History, Clarendon Press, Oxford

Vitalis, Orderici I 852 Historice ecclesiastica libri tredecim, vol. 4, (ed. and trans.), A le Prevost, Renouard, Paris

Vogt, H, 2005 Slagtens funktion $i$ nordisk højmiddelalder: kanonisk retsideologi og fredsskabende lovgivning, unpublished $\mathrm{PhD}$ thesis, Museum Tusculanum, University of Copenhagen

Vogt, H, 2009 'Secundum consuetudinem et leges patrie: The concept of law and custom in thirteenth century Denmark', in P Andersen and M Münster-Swendsen (eds), Custom: The Development and Use of a Legal Concept in the Middle Ages, DJØF Publishing, Copenhagen, 67-79

Vogt, $\mathrm{H}$ and Esmark, K, 2013 'Introduction to part two: Local disputes: Property, justice, and social transaction', in K Esmark, L Hermanson, H J Orning and H Vogt (eds), Disputing Strategies in Medieval Scandinavia, Brill, Leiden, I43-I 60

Vollmer, A (trans.), 20 I I 'Die Saga von den Leuten am Ljósavatn. Ljósvetninga saga', in K Böldl, A Vollmer and J Zernack (eds), Isländersagas vol. 4, Fischer, Frankfurt am Main, 26I-363

Waddell, J, 2005 Foundation Myths: the Beginnings of Irish Archaeology, Wordwell, Bray 
Wahl, B, Schier, K, Esser, T, Giger, K.-L, Wetzig, M Kruse (trans.), 20I I Die Erzählung von Ort Stórólfsson. Orms Páttr Stórólfssonar', in K Böldl, A Vollmer and J Zernack (eds), Isländersagas vol. I, Fischer Verlag, Frankfurt am Main, 386-405

Wailes, B, I982 'The Irish 'royal sites' in history and archaeology', Cambridge Medieval Celtic Studies 3 , I-29

Waitz, G, I 884 Vita Anskarii auctore Rimberto, Rerum Germanicarum, Monumentis Germaniae Historicis, Hannover

Waitz, G, I 886 Urkunden zur deutschen Verfassungsgeschichte im IO, I I, und I2. Jahrhundert (2nd edn I886), I, Weidmann, Berlin

Warner, R, I988 'The archaeology of early historic Irish Kingship', in S T Driscoll and M R Nieke (eds), Power and Politics in Early Medieval Britain and Ireland, Edinburgh University Press, Edinburgh, 47-68

Warner, R, 2004 'Notes on the inception and early development of the royal mound in Ireland', in A Pantos and S Semple (eds), Assembly Places and Practices in Medieval Europe, Four Courts Press, Dublin, 27-43

Watts, V E, Insley, J and Gelling, M, 2004 The Cambridge Dictionary of English Place-Names, Cambridge University Press, Cambridge

Waugh, D, 2010 'On eið-names in Orkney and other North Atlantic islands', in J Sheehan and Ó Corráin (eds), The Viking Age: Ireland and the West. Papers from the Proceedings of the Fifteenth Viking Congress, Cork, I8-27 August 2005, Four Courts Press, Dublin, 545-554

Weeks, L, Cable, C M, Franke, K A, Karacic, S, Newton, C, Roberts, J, Stepanov, I, McRae, I K, Moore, M W, David-Cuny, H, Al Aali, Y Y, Boraik, M and Zein H M, 2018 'Saruq al-Hadid: A persistent temporary place in late prehistoric Arabia', World Archaeology, 5 I, I 57-I 82

Wenskus, R, I984 'Ding', in H E A Beck (ed.), Reallexikon der germanischen Altertumskunde. Zweite, völlig neu bearbeitete und stark erweiterte Auflage unter Mitwirkung zahlreicher Fachgelehrter, Walter de Gruyter, Berlin and New York, 443-446

Werner, O, I994 'Färöer', in Reallexikon der Germanischen Altertumskunde, vol. 8, De Gruyter, Berlin, I I9-I 35

Wessén, E, I92 I 'Linköping och lionga ping', Namn och bygd 9, 27-44

Wessén, E, I956 'Björköarätt', in J Granlund (ed.), Kulturhistoriskt lexikon för nordisk medeltid från vikingatid till reformationstid $\mathrm{I}, 655-658$

Wærdahl, R B, 2006 Norges konges rike og hans skattland: kongemakt og statsutvikling $i$ den norrøne verden $i$ middelalderen [The Realm and Tributeland of the Norwegian King. Royal Power and State Formation in the Norse Medieval World], Doktoravhandlinger ved Norges teknisk-naturvitenskapelige universitet

Wærdahl, R B, 20 I I The Incorporation and Integration of the King's Tributary Lands into the Norwegian Realm c. II95-I397, Brill, Leiden

Whellan, T, I 859 History and Topography of the City of York and the North Riding of Yorkshire, vol. 2, John Green, Beverley

White, C, 2009 The Materiality of Individuality: Archaeological Studies of Individual Lives, Springer, New York

White, C, 20I3 'The Burning Man festival and the archaeology of ephemeral and temporary gatherings', in P Graves-Brown, R Harrison and A Piccini (eds), The Oxford Handbook of the Archaeology of the Contemporary World, Oxford University Press, Oxford, 595-609

Whitelock, D, I979 English Historical Documents c. 500-I042, Eyre Methuen, London

Whitmore, A, 20I3 A Landscape Study of Medieval Icelandic Assembly Places, unpublished PhD thesis, University of Cambridge

Whyte, A C, 20I4 'Gruline, Mull, and other Inner Hebridean things', The Journal of Scottish Name Studies 8 , I $5-52$

Wickham, C, 2005 Framing the Middle Ages: Europe and the Mediterranean 400-800, Oxford University Press, Oxford

Wienberg, J, I993 Den Gotiske Labyrint: Middelalderen og Kirkerne i Danmark, Lund Studies in Medieval Archaeology I I, Lund 
Wienberg, J, 200I 'Churches and centrality: Basilicas and hall-churches in medieval Scandinavia and Livonia', in M Auns (ed.), Lübeck style? Novgorod style? Baltic Rim central places as arenas for cultural encounters and urbanisation IIOO-I400 AD, Gotland University College, Centre for Baltic studies, Riga, 269-303

Wieske, N, 20I I Kommerzielle Revolution in Norwegen und Island? Intraregionaler Handel im Spiegel altwestnordischer Quellen, Münchner Nordistische Studien, vol. 6, Herbert Utz Verlag, Munich

Wildte, F, I926 'Tingsplatserna i Sverige under förhistorisk tid och medeltid', Fornvännen 2I, 2 I I-230

Wildte, F, I93 I 'Västergötlands medeltida tingsställen', RIG - kulturhistorisk tidsskrift I4:3-4, I74-I 84

Wilkinson, T, 2003 Archaeological Landscapes of the Near East, Arizona Press, Tucson

Williams, H M R, I997 'Ancient landscapes and the dead: The reuse of prehistoric and Roman monuments as early Anglo-Saxon burial sites', Medieval Archaeology 4 I, I-32

Williams, H M R, 2004 'Assembling the dead', in A Pantos and S Semple (eds), Assembly Places and Practices in Medieval Europe, Four Courts Press, Dublin, I09-I 34

Williams, H, M R, 2006 Death and Memory in Early Medieval Britain, Cambridge University Press, Cambridge

Winge, H (ed.), I 988 Lover og forordningar I 536-I605. Norsk lovstoff $i$ sammendrag, Norsk lokalhistorisk institutt, Oslo

Worm, O, I643 Danicorum monumentorum libri sex: e spissis antiquitatum tenenbris et in Dania ac Norvegia extantibus ruderibus, Hafniae

Wormald, P, I986 'Charters, law and the settlement of disputes in Anglo-Saxon England', in W Davies and P Fouracre (eds), The Settlement of Disputes in Early Medieval Europe, Cambridge University Press, Cambridge, I 49-I 68

Wormald, P, I999 The Making of English Law: King Alfred to the Twelfth Century, vol. I: Legislation and its Limits, Blackwell, Oxford

Worsaae, J J A, I 852 An Account of the Danes and Norwegians in England, Scotland and Ireland, John Murray, London

York Powell, F, I896 The Tale of Thrond of Gate, commonly called the Faereyinga Saga, David Nutt, London

Ystgaard, I, 20I4 Krigens praksis. Organisert voldsbruk og materiell kultur $i$ Midt-Norge ca. Ioo-90o e.Kr, unpublished $\mathrm{PhD}$ thesis, Norges teknisk-naturvitenskapelige universitet, Trondheim

Zachrisson, T, I994 'The Odal and its manifestation in the landscape', Current Swedish Archaeology 2, 219-238

Zachrisson, T, 2004 'Det heliga på Helgö och dess kosmiska referenser', in A Andrén, K Jennbert and C Raudvere (eds), Världsbild och kosmologi. Vägar till Midgård 4, Nordic Academic Press, Lund, 243287

Zachrisson, T, 2010 'Kungsämnen i Söderby och kungens Sigtuna. Om den materiella kulturen i och kring Söderby i Danmarks socken', in R Edberg and A Wikström (eds), Situne dei Årsskrift för Sigtunaforskning, Sigtuna Museum, Sigtuna, I63-I74

Zahrtmann, M K, I925 'Bornholms Landsting', Bornholmske Samlinger I: I6, I60-I68

Zahrtmann, M K, I934 Borringholmerens Historiebog I, Colbergs Boghandels Forlag, Rønne

Zeeberg, P (ed.), 2005 Gesta Danorum. Danmarkshistorien, Latinsk tekst udgivet af Karsten Friis-Jensen, bd. I-2, Gad forlag, Copenhagen

Zeeberg, P and Engelhardt, M L, 2000 Saxos Danmarkshistorie I-2, Dansk tekst, Det Danske Sprog- og Litteraturselskab and Gads forlag, Copenhagen

Zimmerman, L J, 2013 'Homelessness', in P Graves-Brown, R Harrison and A Piccini (eds), The Oxford Handbook of the Archaeology of the Contemporary World, Oxford University Press, Oxford, 336-350

Zimmerman, L J and Welch, J, 20I I 'Displaced and barely visible: Archaeology and the material culture of homelessness', Historical Archaeology 45, 67-85

Zoëga, G T A, 2004 A Concise Dictionary of Old Icelandic, University of Toronto Press, Toronto

Porkelsson, M, 2004 I Hvalfirði. Miðaldahöfn og hlutverk hennar, unpublished MA dissertation, Háskoli Íslands, Reykjavik

Porláksson, H, I978 'Comments on ports of trade in early medieval Europe', Norwegian Archaeological Review I I:2, I I 2-I I 4

Porláksson, H, I992 'Social ideals and the concept of profit in I3th-century Iceland', in G Pálsson (ed.), From Saga to Society: Comparative Approaches to Early Iceland, Enfield Lock, Hisarlik 
Porsteinsson, B, I953 Íslenska Pjóðveldið, Heimskringla, Reykjavik

Porsteinsson, B, I972 Syssel Kulturhistorisk Leksikon for Nordisk Middelalder I7, Copenhagen, 648-649

Porsteinsson, B, I987 Thingvellir: Iceland's National Shrine, Örn og Örlygur, Reykjavik

Pórðarson, M, I92I-22 'Fornleifar á Pingvellir', Árbók hins islenzka fornleifafélags I92I-22, Reykjavik, I-IO7

Östergren, M, 2004 'Det gotländska alltinget och cistercienserklostret i Roma', Gotländskt Arkiv 76, 4958

Ødegaard, M, 2013 'State formation, administrative areas, and thing sites in the Borgarthing Law Province, Southeast Norway', Journal of the North Atlantic, Special Volume 5, 42-63

Ødegaard, M, 2015 Tingsted og territorium: organisering av rettslandskapet $i$ Viken $i$ jernalder og middelalder, unpublished PhD thesis, Universitetet i Bergen Institutt for arkeologi, historie, kultur- og religionsvitenskap, Bergen

Ødegaard, M, 2017 Kokegropfelt Lunde, I033/I, Larvik, Vestfold, Rapport Arkeologisk Utgravning, Kulturhistorisk Museum Universitetet i Oslo, Oslo

Ødegaard, M, 20г8a 'Thing sites, cult, churches, games and markets in Viking and medieval southeast Norway (AD c. 800-I600)', World Archaeology 50:I, I 50-I64

Ødegaard, M, 20I $8 \mathrm{~b}$ 'Tinginstitusjonens alder i Skandinavia belyst ved arkeologi og stedsnavnsgransking samsvar eller ikke?', Viking 8I, 89-II6

Ødegaard, M, 2019a 'Cooking-pit sites as assembly sites. Lunde in Vestfold, South-East Norway: A regional assembly site in the Early Iron Age?', in A Reynolds, J Carroll and B Yorke (eds), Power and Place in Later Roman and Early Medieval Europe: Interdisciplinary Perspectives on Governance and Civil Organization, Proceedings of the British Academy, Oxford University Press, Oxford, I05-I 24

Ødegaard, M, 20I9b 'Assembling in times of transitions: The case of cooking-pit sites', in N Brady and C Theune (eds), Settlement Change Across Medieval Europe; Old Paradigms and New Vistas, Ruralia I $2,20 \mathrm{I}-2 \mathrm{IO}$

Økland, B, and Njåstad, M, 2005 Stord frå steinalder til oljealder. Den eldste tida fram til I720, Stord kommune, Stord

Øye, I, 2009 'On the margins of the medieval farm: Norwegian cases', in J Klapste and P Sommer (eds), Medieval Rural Settlement in Marginal Landscapes, Ruralia 7, 99-I07 


\section{INDEX}

Page numbers in italics are figures.

Page numbers with 'g' are glossary terms.

Aberdare (Wales) 32

accessibility to sites $5 \mathrm{I}, 65,93, \mathrm{II} 8, \mathrm{I} 22, \mathrm{I} 3 \mathrm{I}$,

I77, 264-5

Faroe Islands 198

Iceland I 86

activities at assemblies I92, 255, 292

Adam of Bremen 25, 26

Aðils, Jón Jónsson 34

administrative districts

terminology 20, 2 I

see also Danelaw; Denmark; Faroe Islands;

Iceland; Norway; Orkney Islands; Shetland

Islands; Sweden

Ælnoth (abbot of St Knuds Abbey) IO2

Æthelberht of Kent, King Io

Aethelred II I 8I, 2I 5, 2 I 6, 225

Age of Settlement 247

Alcock, Leslie 30

altar, Mars Thinscus 8, 9

ancestors, importance of I32, I69, 225, 267-7I, $283,284,288,290,295$

Andersen, Per Sveaas 44, 77

Anderson, Joseph 263

Anderson, Olof see Arngart, Olof

antiquarian studies I I

Britain and Ireland $28-3 \mathrm{I}$

Scandinavia $24-7,25,27,60$

Anundshög (Sweden) I 8, 46-7, 55, 66, 84, 85-6,

I32, I34, 269, 273, 274

Arngart, Olof 39-40

arrow summons I 57

Aspa Löt (Sweden) I 2, I 8, 46-7, I34, 270, 274

Assembly Project I 8, I 8, 227

Faroe Islands 196

Haugathing I 54

Law Ting Holm 2 I I, 2 I 2

Lunde I 5 I

Orkney and Shetland 205, 2IO, 2IO, 2I4, 2 I 4

Pingeyrar 193

Pingvellir 24 I, 242

Árnes (Iceland) 35, I 86, I 89

Åker (Norway) I 25, I 25, I 26-7, 285

Ängebyvad (Sweden) 80, 90, I 29

Barrow, Geoffrey 30

Barry, George 35 barter 232

'before land and lawman' 8 I

benches 60, 76, I32, 259, 272

Berg (Norway) I45, I 56-7, I 57

birk, Norway 287

bishoprics 94, I27, 285

bjarkeyjarréttr 74, 234-5, 236, 2999

Bjarkøy (Norway) I62, I64, I66, I68

Bjørgo, Narve I Io

Blekinge (modern Sweden) 98, 99

Bommestad (Norway) I 5 I-2, 252

'Book of the Icelanders' (Íslendingabók) I 8 I, I 82-3, I 86, 235, 258

'Book of Settlements, The' (Landnámabók) I I, 235,238

booths 256, 274-6

Faroe Islands 203

Iceland 28, 47, 48, I87-90, I88, 238, 239, 242,276

Norway 253

Borg (Norway) I43, I44

Borgarthing (Norway) I05, I25, I35, I39-4I, I 40

administrative organisation $\mathrm{I} 4 \mathrm{I}-7, \mathrm{I} 43, \mathrm{I} 45-7$, I $58-9$, I 78

Berg (Eiker) I 45, I 56-7, I 57

Kolberg site 145 , I $57-8$, I5 8

levels and functions I47-50, I49

locations and topography 159

Lunde cooking-pit site I 50-2, I 52-3

Bornholm (Denmark) 96, 98, I00

boundaries I6, 49, 68, I3 I, I83, 265, 267, 276, 292

Danelaw 224

and execution 259

Faroe Islands 200, 203

mapping $62,63,64,73,80$

markers 9I, 226, 264, 268

and neutral ground $133-4$

water as 263

Brand, John 2 Io

Bratrein, Håvard D I $63-4$

bridges 263

Brink, Stefan 46, 274

Britain

antiquarian studies $28-3$ I

games and competitions 257

location and topography 262

property ownership $28 \mathrm{I}$

research/excavation $47-8$ 
see also Danelaw; Scotland

Brooks, Stuart 2 I9

Brunn, Daniel 34, I 89, 238

Brunner, Heinrich, Deutsche Rechtsgeschichte $35^{-6}$

Bugge, Alexander 40

Bull, Edvard 44, I 40

Bure, Johan, Runakenslones lerespan 26

burials/cemeteries I 29, I32, I 34, 253-4, 265-8, 295-6

and communal activity 257, 269, 282-3, 292

Danelaw 224, 225

Denmark 99-I00, I03

and land ownership 268-9

Norway I 26, I 28, I 57, I 58, I65, 252

Shetland and Orkney 206, 2 I I-I 2

Sweden I I 8, I I 9

Búðasandur (Iceland) see Maríuhöfn (Iceland)

Caesar, Julius see Julius Caesar

Camden, William, Britannia 29, 3 I

Carolingian empire 284

catalogues, and place-names 39-4I

causeways 5, 2IO-II, 2IO, 27I

cemeteries see burials/cemeteries

central places $30,45,47,53-4,245$

chairs, and inauguration I29, I3O, I32

characteristics of sites $65^{-8}, 68, \mathrm{I}_{3} \mathrm{I}-2$

Cheddar (Somerset) 49, 50

Chevral, T J (T L Thurston) 6, 54, 95, 277-8, 279

chieftains/chieftaincies I 82, 296

at an inauguration 128

Denmark 95

female 26I

Iceland I 82-3, I $84-5,254,256,260,274$ and trade $233-4,235^{-6}, 238,24 \mathrm{I}, 246-7$

Norway 44, I03, I05

in Tacitus 7

chorography 25-6

Christian V I 23

Christian VIII 34

Christianity see Church; churches

Christopher of Bavaria I 8

Chronicon Lethrense I 23

Church 252, 284, 286, 296

and inauguration I 16, I 27, I 29, I 34

churches I3 I, 286

Danelaw 225

Denmark 99, IOO, IOI, IOI, IO3

Faroe Islands I95, I96, 229

Iceland I94-5, 229-30

Norway I06, I08, II 2, I I 5, I4 I, I43, I48, I $49-50$, I 56 , I 59

Tinghaugane $172-3$

Tønjum I 74-5

Orkney and Shetland 2I 5, 229

Sweden 86, 94

climate see environmental impacts

Clovis Io

Codex Frisianus I06, I08
Coke, Edward 22I

collective governance $28 \mathrm{I}, 295$

Collingwood, William Gershom, Alping (Althing)

in Session (painting) 4I, 42

colonisation I I, I 80-2, 265, 294, 296 see also Danelaw; Faroe Islands; Orkney Islands; Shetland Islands commercial revolution 236

Commonwealth Period 34, 35, I95, 232-5

compensation for attendance 198,255

competitions at assemblies 40, 72, 257, 292

confiscation, courts of I $84-5$

concilia $6,53,95,248,292$

cooking-pit sites I 27, I 34, I 50-2, I 52-3, 252 , 253, 257, 269

coronations see inauguration

cottages, thing 77, IOI, I3 I, I73, I75

court circles $34,257,258$

Iceland 35, I9I-3, I94, 275-6

Shetland I92, 2I4-I 5,2 I 4

court mounds 48

court records 59, 64, 96, I00, 2 I 8

courtyard sites $77, \mathrm{I} 27, \mathrm{I} 35$, I4I, I77-8, 250 , 253, 257, 259, 266, 272, 275, 285

Hålogaland I 59-69, I60-I, I67-8, I 78, 250

Leksaren 45, I62, 253

Craike Hill (East Riding of Yorkshire) 2 I 8, 224, $225,23 \mathrm{I}$

crosses

market 233

and market peace 233

standing 225,230

Dalarna (Sweden) 79, 82-3, 93

Dan, King 123

Danelaw I 8, I 8 I, 2I 5-I6, 2 I6, 227, 228

accessibility of sites 265

administrative organisation I I, 2I6-I 8, 2 I 7

archaeology and topography $22 \mathrm{I}-7,222-3$, $226,228,23 \mathrm{I}$

documentary sources 182

levels and functions of sites 2I8-2I, 2 I9-20

Debes, Lucas, Foroce et Foroa Reserata 196

defence 77, I36, I38, I4 I, I69, I78

hillforts 7I, I4I, 267

delegates see participants of assemblies

Delting (Shetland Islands) I 8, 205, 206, 2 I 5

Denmark I, 2, 3, I 8, 2 I-2, 95-6

administrative organisation $73,75,76-7,95-6$, 97,287

election and inauguration of kings I I 6, I2I-3, I 22, I 29, I 33

location/archaeology/topography 97-I03, 97-8, IOI, 266

nationalism 34

royal inauguration 99, I I 5, I I 6, I 2 I-3, I 22

Dialogus de Scaccario 28, 227

Dingieshowe (Orkney) 206, 209, 209, 2I 2, 263

diplomas 40, 59, I4I, I42, I47-50, I47, I 56, I 57, I 7 I I I 73, I 75, I 78,275

dispute settlement IO, 290, 29I, 293, 294-5 
England 2, 223

Iceland 235

Scandinavia 75, I06, I3 I, I65, 236, 239

in Tacitus 7

documentary sources 5, 8-9, I4, 58-62, 6I, 69, I 8I-2, 248-5 I, 290, 294-5

Domesday Book I82, 217, 227

Dryden, Sir Henry 2 IO

duels 258

dues 260,285

Eadric 8, IO

Eddic poetry 59, 77, 263

Grimnir's Sayings 2 I I

Edgar I 8 I

Egil Skallagrimsson, Lausavísur I I

Eide farm (Norway) I08, I09

Eidsivathing Law I 2

Eidsivathing (Norway) IO3, I I 2, I I4, I I 5, I 39

Ekwall, Eilert, Dictionary of English Place-Names 39

elections (kings) 8, 2 I, 37, I 27

Denmark 95

Norway I IO, I 29

Sweden I 20

elevation $262-3,264$

and inauguration I 23, I 28, I 29-30, I 32, I 54, 286

location of sites $5,26,262,264,27 \mathrm{I}$

Denmark 102-3

Iceland $I 85,237,294$

Ireland 262

Norway I I 5, I3 I, I 54, I 57

see also mounds

elites 290, 294, 296

see also chieftains; kings

Elloe Stone (Lincolnshire) 225

enclosure of the thing 273-4

England I, 2-3, 2, 284

administration development 49, 280

antiquarian research 28-9

documentary sources 182

feasting 257

games and competitions 25

hanging promontories $28 \mathrm{I}-2$

judicial execution 259

locations 263, 266, 267, 269-70, 278

nationalism $35-7$

palace sites 276

place-names I 4

research/excavation $49-50,50$

resources 27I

see also Danelaw

Enham decrees 2 I 5

entertainment 258

environmental impacts IO, 7 I-2

Eric of Pomerania I I 7

Erik Klipping, King 102

Erik, St 89

Eriksgata 47, 89, I 20, I2I, I 29, I34, 269, 285 , 3009

executions $49,2 \mathrm{I} 4,258,258-9$ extraordinary assemblies $78, \mathrm{I} 84$

Eysturoy (Faroe Islands) I97, I98, 200, 202, 203,228

fairs 5

farms, royal I3 I, I 57, 285

Faroe Islands I3, I8, 2I, 2I-2, I96, 227, 230

accessibility of sites 265

administrative organisation I96-8, I97

booths 275

churches I95

documentary sources $\mathrm{I} 8 \mathrm{I}-2$

and fencing 273

levels and functions I98

location/archaeology/topography I97, I98203, I99-202, 204, 227-8, 262

trade $232-3,244,247$

feasting $256-7,269,282-3$

cooking-pit sites I 27, I 34, I 50-2, I 52-3, 252, 253

fencing $273-4,276$

Fifth Court I 84, 258

fights

duels 258

horse I92, 257

Fillipus Simonsson I 26

FitzPatrick, Elizabeth 52, 56, I30, I32, 262, 270

Five Boroughs 2I6, 2I7, 2I 8

flour 237

footprints, carved $30,3 \mathrm{I}, 47,52$

fords I $4,49,64,263$

Danelaw 222, 265, 27I

Norway 173

Sweden $84,89,90-I$

foreign traders $232-3,234-5,238,246,247$

Forsa Rune Ring 26, 27

Francia 4, IO, 20, 279, 280, 285, 286-7

freemen 2, 36, 260

Friðriksson, Adolf 34, I88, I92, 276

Frostathing Law 58, 73, I08, 273

Frostathing (Norway) 73, I08, IIO, III, I3I, I 32

Fyn (Denmark) 98, IO2

Føyno (Norway) I75-6, I76, I77

Gaelic Revival 37-8

games/competitions 257

Gamla Uppsala (Sweden) 25, 89, 95, II 5, I32, I34

fencing 273,274

markets 244

recent research/excavation 47,90

Gásir (Iceland) 48

Geographic Information System (GIS) 64-5, 6970

Germanic, law 295

Germanic systems and law 4, Iо, 29, 33, 36-7, $49,54,95,249,278,283,295$

Roman comment on 7,9

and the term ping $8,38,279$

Germany, National Socialism 4I-3 
Gille, Harald I 54

glossary 299-303

Gomme, Laurence Primitive Folk-Moots or Open Air Assemblies in Britain 36

Gotland (Sweden) 8I, 91, 92, 93, 95, 244, 258

Gottskálks Annals 242

Graderne (Norway) I 28

Grágás ('Gray Goose Laws') I I, 58, I 8 I, I 82-3, I 84, I 85 , I 87, I95, $300 \mathrm{~g}$

on booths I $87-8,274$

court circles I9I

on meeting times 254

on opening rituals 256

trade regulations $233,234,237$

Greenland I3, I7, 2I-2, I92, 275

Grimm, Jacob 33, 36

Grimnir's Sayings (Eddic poem) 2 I I

Grímr Goatbeard I 86

Gulathing Law 58, I73

arrow summons I 57

and Norse colonisation I80-I

ship-districts 163

timing of assemblies 78

Gulathing (Norway) 44, I05, I06, I 26, I39 administrative organisation I $70-2$, I $76-7$, I 78 topography and archaeology

Føyno $175-6,176$

Tinghaugane $\mathrm{I} 72-3,173, \mathrm{I} 77$

Tønjum I73-5, I74

Guta Law 8I

Haakon the Good, King 4I, I36, I4I

Haakon Haakonsson, King I05, I06, I16, I26, I 27, 23 I

Halfdan the Black I I 5

Halikeld (North Yorkshire) 22 I, 222

Halland (modern Sweden) 98, 99

Harald Fairhair, King I 54

Harald Gille, King I 54

harbours, and accessibility 264-5

Harthacnut, King I 23

Hastrup, Kirsten 254

Haugathing (Norway) I 8, I 25, I34, I45, I 54-6, I $55-6,285$

Hazelius, Artur 33

hearths see cooking-pit sites

Hegranes (Iceland) I 89-90, I9I, I92, 254-5

Heimskringla I 24

Helgeland (Norway) I64, I65-6

Helle, Knut Io6

henge monuments $2 \mathrm{I} 2$

Henry of Orkney, Earl 2I4

Hibbert, Samuel, Description of the Shetland Islands 34

hierarchies of assembly 3, 2O-I, 2I-2

hillforts 7I, I4 I, 267

Hirdskråen I 29

Historia Norwegiae I 37

historical sources see documentary sources

Hlothere 8, I0

horses, and assemblies I92, 257, 276
Housesteads (Cumbria), Mars Thinscus altar 8, 9

Hundabrævið 273

Hålogaland (Norway) 73-4, 77, I03, I05, II0, I I 2, I 39, I 69

administrative organisation $163-4,163,178$

courtyard sites I 59-63, I60-I

levels and functions of sites I64-9, I67-8

Hälsingland (Sweden) $83,83,84,86,87-8$

Iceland 2, I I, I 8, 2I, 227, 273

accessibility of sites 265

activities at meetings 258

administrative organisation $182-3,230,275$

archaeology and topography I85-95, I85, I87-

$8, I 90-I, I 93-4,265$

documentary sources I 82

levels and functions of sites I $83-5$

meeting times 254

nationalism 34, 35

participants $260,26 \mathrm{I}$

terminology $2 I-2$

trade 236-4I, 237, 239-40, 246, 247

regulations 232-6

see also Pingvellir

identity 283,297

inauguration $3,3 \mathrm{I}-2$, II6-I7, I28-30, 262-3, 286

Denmark 99, I I 5, I I6, I 2 I-3, I 22

Ireland 262

Norway I 54, I 56

Scandinavia I I 6-I 7

Scotland $30,47,262$

Sweden II6, II7-20, I I 8-I9, I 2 I

indoor meetings I $3 \mathrm{I}, \mathrm{I} 34$

Indrebø, Gustav I03, I IO, I4 I

Ingolf Arnarson 256

inscriptions 25, 26, 47, 58, 263

Denmark 97

England 8, 9

Faroe Islands I98, 200, 274

Sweden I I, I 2, I 33

Ireland 2, 2, I3, I32, 250, 276, 280

antiquarianism 29-3I

feasting 257

Gaelic Revival 37-8

games and competitions 25, 257

inauguration 3-4

land ownership 268

location and topography 262, 266

research/excavation $47-8,5 \mathrm{I}-3$

Iron Age 4, 5-IO, 7, 53-4, 55, 252, 253, 277-8, 283

burials I74, I75, 229

hillforts I4 I

monuments 84,85

islands, as locations of assemblies 26, 65, I3 I, I95, 263, 264

Isle of Man I3-I4, I5

Íslendingabók ('Book of the Icelanders') I 8 I, I 86, 235, 258 
isthmuses 65, II2, II 5, I 3 I, 208-9, 2 I I , 227, 263,264

Isøre (Denmark) I 2I-3, I 22

Jakobsson, Sverrir 234

Jarnsiða (legal reforms) 236, 30 Ig

Jelling (Denmark) 25, 25, 274

Jolliffe, J E A 227

Jónsbók (legal reforms) 236, 237, 273

Jónsson, Brynjúlfur 34

Julius Caesar, Bello Gallico 5-6

Jutland (Denmark) 95, 96, 97, IOI-2 timing of assemblies 78

Jämtland (Sweden) I I 2, I I3

Jørgensen, L 45

Kalmar Union 75, I I 7, I 29, I3 I, I34, 294

Kaupang (Norway) 45, 243, 246

Kaupangur (Iceland) 237, 238, 239, 240

Keatings, Geoffrey, History of Ireland 30

kings/kingdoms I, 2, 284-5, 286, 287-9 see also chieftains; inauguration

Kirkwall (Orkney) 206, 208, 209

churches 2I 5, 229

market cross 233

trade I 44-5

Kjula ås (Sweden) 65, I33, 229, 274

Kolberg (Norway) I45, I 57-8, 158

Kristian IV of Denmark I7

Kungavägen (Royal Road) 97

Lambarde, William, Archaionomia, sive de priscis Anglorum legibus libri 29

land-holding 3, 268, 280-I, 282, 290, 291, 297

Landscapes of Governance (project) 5 I

Larsen, Jan Henning I I 5

Larsson, Mats G 46

Lausavísur (poem) I I

Law of Dalarna 79,82

Law of Jutland 77,78

Law Rock (lögberg) (Iceland) I 87, I 89, $362 \mathrm{~g}$

Law of Skåne 96

'Law of Ten Hundreds' 8I

Law Ting Holm (Shetland) I 8, 67, 206, 209-Io, 2II, 2 I2, 258, 263, 270

Law of Uppland $80,8 \mathrm{I}-2$ on the Eriksgata I 2 I markets 244

law-making and codes 5, IO-II, I6, 58-9, 29I, 296, 298

Commonwealth period 232

Danelaw 220-I

England 29, 35-7

Iceland I 98

Norway 283

Scandinavia $72-9$, I3 I

and trade $232-7$

Leges Edwardi Confessoris 22I

Leges Henrici Primi 224

Leland, John 26

levels see hierarchies of assembly
Lex Romana Burgundionum Io

Lex Salica Io

Liebermann, Felix 36-7

Lolland (Denmark) 98, IOI

Lund (Denmark) 97, 98, 99, I 23, 285

Lund, Harald Egenæs 44, I I 2, I 62

Lunde (Norway) I 5O-2, I 52-3, 252

Maeshowe (Orkney) 206, 208, 2I 2, 2I3, 2I4, 270

Magnus Eriksson, coronation of I I 7

Magnus Eriksson's Law 74, 75, 8I

Magnus Erlingsson, King I 27

Magnus the Good I 27

Magnus, Olaus 263

Historia de Gentibus Septentrionalibus 26

Magnus VI Hakonsson (the Law-Mender) 74, I 56, I 8 I, I 83, 23 I, 236, 273

Maitland, Frederic William 35, 36, 22 I

mallus 20, 279, 280

mapping sites $37,49,59,60,62-9,63$

Maríuhöfn (Iceland) 237, 24 I, 242, 243

markers 268, 269, 270, 276

Danelaw 226, 264

Faroe Islands 203

Iceland 228

Sweden 9I, I32, I33

market peace 233

markets 5, 232

Denmark 97, I02

Iceland 236-4I, 237, 239-40

von Maurer, Konrad 35

measurement units 195

memory

creation of 256

oral 28

and sites 30, 252, 254, 270, 27I, 283, 297

metal-detecting

England 49

methodology 295

limitations of the $69-70$

mapping sites $62-9,63$

survey and excavation $I 8,68-9$

written sources 58-62, 6I

migration IO, 7I, 95, 249, 283

military organisation $4,253,279,284,292-3$

Francia 4,278

Scandinavia 44, 7I, 76, I62, I69, I70, I78, 253

Millum Vatna (Faroe Islands) I97, 200, 20I, 203

monasteries 287

Denmark IO2

Iceland I95

York 223

money systems 232

Montesquieu, Charles-Louis de Secondat 29

monuments/monumentalisation I 4, 55, 65, 66, I32-3, 265-7I, 272, 290, 294, 296, 297 antiquarian study 37

Danelaw 224, 229

Faroe Islands 228 
Iceland 228

Orkney 208, 2 I I

reuse I6, 55, 2II-I2, 2I4, 228, 229, 267-9, 282,294

Sweden $93-4$

Mora thing (Sweden) I I7-I 8, I I 8-I9, I 20, I 29, I33-4, 264, 286

mounds I $30, \mathrm{I} 32, \mathrm{I} 34,254,262,265-8,270$,

282

court 48

Danelaw 2I 8, 222, 223, 224-5, 270

Denmark I03, I 23, 266

Norway I IO, I I2, I I2, I I 5, I 59, 266

Berg in Eiker I 57

Haugathing I 54, I 55-6

Kolberg site I $57-8,158$

Tinghaugane $\mathrm{I} 72$

Shetland and Orkney 2I I-I 2, 228

Sweden I I 8, 270

Munch, P A 34

Møllerop, Oddmund 44, 259

Møn (Denmark) 98, IOI

National Socialism $4 \mathrm{I}-3$

nationalism 29, 32-7, 57

Niklis Tuesson of Hardeberga 97

nominated men $76,77,82$, IOI

Northern Isles see Orkney Islands; Shetland Islands

Norway I, 2, 3, I8, 2I-2, I03-5, I04, I07-9, I I I-I 4, 250, 279

activities at meetings 259

administrative organisation $58,73-4,73$, I035, I 35-9, I37, I77-9, 235-6, 236, 25 I

birk 287

cooking pit sites I 27, I 34, I 50-2, I 52-3, 252, 257

courtyard sites $44-5,45,253$

election and inauguration of kings I $16, \mathrm{I}_{2}-8$, I 24-6, I 29, I33

locations/archaeology/topography I04, I05-I6, IO7-9, III-I 4, I 59, 266

nationalism 33-4

participants $260,26 \mathrm{I}$

recent historical research $44^{-5}$

resources 272

royal farms/estates IO6, I 54, I 56, 285

timing of assemblies 78

trade $236,243,244,246,247$

urbanism 294

see also Borgarthing (Norway); Gulathing law province (Norway); Hålogaland (Norway)

Närke (Sweden) 79, 93

Olaf Haakonsson, King 243

Olaf the Holy I 27

Older Law of Västergötland I 29

oppida 5-6, 54, 278

Ordericus Vitalis 286

Ordnance Survey 37

Orkney Islands I 3, I 8, 205, 227, 293 administrative organisation $205-6,230-I$

levels and functions of sites 206

location/archaeology/topography 206-I 5 , 208-9, 2I3, 270

participants 260

trade 247

Öland (Sweden) 79, 8I, 93, 95 Östergötland

(Sweden) 79, 8I, 272

Ölkofra páttr 256

Öxará (river, Iceland) I 86-7, I90, I95, 258

Øyrathing (Norway) I I0, I 25, I 25, I 26-7, I 29, 285

palaces, royal 284

Pantos, Aliki 219, 229, 257, 259

participants of assemblies 23, I30, 25 I, 259-6I,

$277,283,290,294$

Faroe Islands I95, I98

Iceland I 82, I 87-8, 24I, 254-5, 256, 274-5

Norway 74, I 28, I38-9, I47, I 52

Shetland 2 I I

peace

market/trade 95, 233

thing 106, I07

Petersson, Aslak 105

Petrie, George 38

Picts 2 I I

pillars, high-seat 238

place-name studies I3, I4, 49, 59-60, 65, I 82,

219, 249, 250

and catalogues 39-4 I

Danelaw 22I, 226

portages 263

power of elites $277-8$

prehistoric archaeology 53-4, 55

price fixing $233,234,238,240,246$

promontories 49, IO8, IIO, I3I, 262, 28 I-2, 282

\section{Rannsakningarna 59}

Reformation 96

Regesta Imperii 284

Rekneskap for dei nordlandske lena og Finnmark I 63

research traditions $38-9,54-5$

catalogues and place-names 39-4I

National Socialism 4I-3

prehistoric archaeology 53-4

Scandinavia since I940 43-7, 45-6

see also antiquarianism

resources, management of 65, 27I-2, 28I-2, 290, 29I, 292, 293, 297

Ridings of Yorkshire see Yorkshire

Ringsted (Denmark), thing stones I 23, I 24

ritual

deposition I I 7, 2 I I

feasting and drinking 256-7, 283

Iceland 256

Norway 178

Orkney $2 \mathrm{I} 4$

sacrifice $162,258-9,259$

and site location 264 
see also inauguration

rivers 263

River Ôxará (Iceland) I 86-7, I 95, 258

see also water

roads, Roman 22I, 226, 228

Rolfsen, Perry I I 5

Roman period 4, 5-7, 7, 8-9, 296

authors $7,7,9,24,33,55,248-9$

Romantic Movement 33, 38

Ireland $37-8$

royal assemblies 78, 89, I05, I 24, I39

see also inauguration

royal centres 52, 56, 284, 285

royal manors $94-5,285$

Royal Road 97

Rudston Monolith 225, 226

rune-stones 26, 40, 58, 64, I33, I34, 274, 276

Anundshög (Sweden) 46, 84, 85-6

Aspa Löt (Sweden) I 2, 26

Hälsingland (Sweden) 87-8

Jelling (Denmark) 47

Sweden 9I, I I 8, I I 9

see also inscriptions

Ryfylke (Norway) I06, I3 8, 259

Rønneseth, Ottar 44

sacrifice 2 I 4, 258-9, 293

sagas 59

Bandamanna saga $24 \mathrm{I}$

Egil's Saga 106, I78, I87, 258, 273

Eyrbyggia saga I 87, 238, 258

Foreyinga Saga I 8 I, I98

Fagrskinna saga I4 I

Guta saga 8I, 256

Haakon Haakonsson's saga I05, I42

Heimskringla 124

Knýtlingasaga 99

Kormáks saga 24I, 258

Ljósvetninga saga 238, 239

Nial's saga 59, I87, I92

Orkneyinga Saga I60, 206, 208, 244-5

Saga of Gisli the Outlaw 238

Saga of Magnus the Blind and of Harald Gille I 54

Saga of Olav Haraldsson I 44

Saga of Olav the Holy II7, I4I, 243

Saga of the Sword Brothers (Fóstbroeðra saga) 235

Sturlunga saga 234, 237

Sverri's saga 105

Víga-Glúms saga 238

St Benedict's Church (Ringsted, Denmark) I23, I 24

Salmonsbury (Gloucestershire) 40

Sandnes, Jørn I 27

Sanmark, Alexandra 46-7, 62, I32, 269

Saxo Grammaticus 26, 97, I2 I, I 22

Saxony 280

Sámi I 36, I37

Scandinavia I, 3, 20-I, $2 I-2,7 \mathrm{I}-3, \mathrm{I} 3 \mathrm{O}-4,278-9$ administrative organisation IO-I I, 58, 72-9, 73,287

antiquarianism $24-7,25,27$

'central places' 45

inauguration I I 6-I7

location $262,263,264-5,268$

research traditions since I $94043-7,45-6$

royal/elite involvement 285-6

trade $236,246-7$

urbanism 286

see also Denmark; Norway; Sweden

Scotland I, 2, I 3, 2I, I 80, 259

antiquarianism $3 \mathrm{I}$

location of sites 262,266

nationalism $34-5$

research/excavation $47-8,5 \mathrm{I}-2$

terminology $2 I-2$

see also Orkney Island; Shetland Islands

seasonality 5, I6, 292

see also timing of assemblies

Seip, J A IO3

Seldon, John 29

Sem (royal farm) I 57

Shetland Islands I 3, I 8, 205, 227, 273

administrative organisation 205-6, 230-I, 293

court circles I92

and horses 192

location of meetings 263

location/archaeology/topography 206-I 5, 207, $2 I 0,2 I 2,2 I 4,263,266$

nationalism 334

research/excavation 48

trade $245,245,247$

shields I 29, I30, I32, 235

ship-settings 84, 859I, 93, I32, 267, 274

ships, laws at sea 235

Sigar's mound I I 2 , I 12

Sjaelland (modern Sweden) 98

Skåne (modern Sweden) 95, 97, 97-8, 244

Skipan um tingfaratoll (document) I98, 200

slaves $78,255,260$

slopes, thing, Iceland 187

Snorri Narfason 273

Snorri Sturluson 25,89

Chronicle of the Kings of Norway 24-5

on Haakon the Good I36

on Halfdan the Black I I 5

on the 'Law of Uppsala' 75

Saga of Olaf the Holy 243

Spain 280

Speed, John, History of Great Britaine, The $3 \mathrm{I}$

Spellow Clump (Yorkshire) 63

Spelman, Henry 29

Spenser, Edmund, View of the Present State, A 30

Sperra, Malise 2I 4

standing stones $267,274,276$

Danelaw 225, 226

Orkney and Shetland 2I 2, 2 I 4

status 260-I

Steigen (Norway) I Io, I I 2, I 39, I64, I66, I67, I 69, I 78 
Stewart, Lord Robert 208

Stobaeus, Kilian I 23

Stone of Destiny 30, 30-I

stone-circles I IO

stones I 29, I3O, I 32-3, 274

Denmark I 23, I 24

see also rune-stones; standing stones; stonecircles

structures at the thing 272-7

Stubbs, William 36, 38

Styffe, Carl Gustaf 83

Stånga (Sweden) $89,9 \mathrm{I}$

succession laws I 24-6, I 27

Sutton Courtenay (Oxfordshire) 49, 5 I

Svein, King I 27

Sverre, King 105

Sweden I, 2, 3, I 8, 2I-2, I3 I, 250

administrative organisation $73,73,74,75,78$, $79-84,83,285$

assemblies location/archaeology/topography

$84-95,85-8,90-2,94,267$

election and inauguration of kings I 6 , I I720, II8-I9, I2I, I 29, I3O, I34

nationalism $33-4$

trade 243-4, 247

Södermanland (Sweden) 65, 76, 79, 82, 93, 272

Aspa Löt I2, I8, 46-7, 93

Tacitus, Publius Cornelius 55, 28 I

Germania 7, 7, 9, 24, 33

Tara (Ireland) 3, 29-30, 3 I, 38, 47, 52, 53

Taranger, Absalon I 23-5, I 27

tax

Iceland 183

Norway 76, I36, I3 8,285

Shetland and Orkney 205

Sweden, taxation map 92

tents $272,274,275$

terminology

administrative districts $20-\mathrm{I}, 2 \mathrm{I}$

assemblies 8, I9-20, 22, 60, 6I, 62, I3 I, 25I-2

glossary 299-303

Theoderic I Io

thing

origins IO-I 4, I2-I3, 293

term/terminology 3, 8, 22, 6I, 25I, 279-80

thing cottages 77, IOI, I3I, I73, I75

thing peace 106, 107

Thing plays (Thingspiele) 42-3, 43

thing slopes 187

thingmen I 82, I 84, I 89, 233-4, 238, 255, 260, 26I, 265

Thoresby, Ralph 21 5, 225

Thorsteinsson, Arne 196

timing of assemblies $77-8,254-5$

Faroe Islands 196

Iceland I 84, I 86, 236-4 I, 237, 239-40

Norway 259

Tinganes (Tórshavn, Faroes) 27, I89, I96, I98, I 99-200, 203, 227, 244, 275

Tingfaratoll (document) I98, 200
Tinghaugane (Norway) I 72-3, I73, I77

Tingley (West Riding of Yorkshire) 2I 5, 22 I, 223, 224-5, 23 I

Tingvalla (Sweden) 93, 94

Tingwall (Shetland) 34, 67, I92, 206, 207, 208IO, 2IO, 2II, 2I 2, 2I3, 2I 4, 245, 245, 266 and churches I95, 2I 5, 229

duels 258

location 227

trade 245,245

Tiohärad (Sweden) 79, 8I, 93

Tjølling (Norway) I8, I05-6, I 50-I, 243, 252, 272

Tjøtta (Norway) I 64, I65, I 66

Tórshavn (Faroe Islands) 27, I 8 I, I96, I97, I98, I99-200, 229, 244, 245

trade $232,242-7$

Faroe Islands 203

and foreign traders $232-3,234-5,238,246$, 247

regulation/laws $74,75,232-7,246$

tradition, invented 52, 55, 57, I30, I32, I34, 25I, 264, 270, 289, 296, 297

England 270

invented, Wales 32

Norway I 58 , I 59

Scotland and Ireland 34, 52, 55-6, 289

Sweden 270

Treaty of Alfred and Guthrum 216

trees 226, 263-4, 273

'truth men' 76

Trøndelag (Norway) 73, I IO, I24, I27, I35, I38, I 54, I 60, I62, 266 Tunberg, Sven I 40

Tynwald Hill (Isle of Man) I3-I 4, I 5, 53, 273

Tønjum (Norway) I73-5, I74

Ulfjlót I 8 I

Ullunda (Sweden) 9 I

Uppi millum Stovur (Faroe Islands) I97, 200, 203, 262

Uppland Law, on elections of kings I 8

Uppland (Sweden) 79, 86, 89, 90, 258, 273, 285

Uppsala law 75

urbanism I3 I, 286, 294

Vaðlaping (Iceland) 34, I 85, I85, 237, 238-9, 240,265

Vésteinsson, Orri I 88-9, I92, 275

Viborg (Denmark) 95, 96

inauguration IOI-2, I2I, I22-3, I29, I33, 286

Vigfússon, Sigurður 34, I 89

Viken (Norway) see Borgarthing (Norway)

Värmland (Sweden) 79, 93, 94

Västergötland (Sweden) 79

Västmanland (Sweden) 79, 82, 84, 85

Wales I, 2, 32, 5 I, 28I

Wantage decree/code I 8 I, 2 I 5, 2I6-I 7, 2 I 8

warehouses, Faroe Islands 203

water association with sites I3 I, 263, 265

Danelaw 221, 222, 228 
Danish sites and 102

Faroe Islands 203

Iceland I95, 265

Norway I I 5

Shetland/Orkney Islands 209, 265

Swedish sites and 88, 93, II 9

weapon things I I, 6I, I42, I 56-7, I6I

weapons 165,234

weights and measures 237

Wihtbordesstan code I $8 \mathrm{I}$

Wildte, Fridolf 40

William of Malmesbury 28

Williams, Edward 32

women, and assembly attendance 26I

Worm, Ole 26, IO2

Danicorum Monumentorum Libri Sex 25

Wulfstan 95

Yeavering (Northumberland) 49, 50, 27I, 276, 288

Yorkshire 60, 2I 8, 2I9, 220, 262, 270, 293, $302 \mathrm{~g}$

Younger Law of Västergötland 79

Zealand (Denmark) 95, 97, I00-I

Pingeyrar (Iceland) I 85, I85, I86, I93, I93-5, I93-4, 237

Pingeyri (Iceland) 238, 239

Pingvellir (Iceland) I I, 27, 28, 34, I 83, I 84, 262 activities 258

archaeology and topography $185,185,186$, I 87, I 89, I90

church 195

founding of 238

modern 56

trade $234,24 \mathrm{I}-2,242,246$

Pórðr Sturluson 234

Porolf Mosterbeard I 82

Pórsnes thing (Iceland) 60, I 82, I $85-6$, I 85 , I 87 , 2I $4,237,258$

sacrifice 258

trade 237

Porsteinsson, Björn 24I 


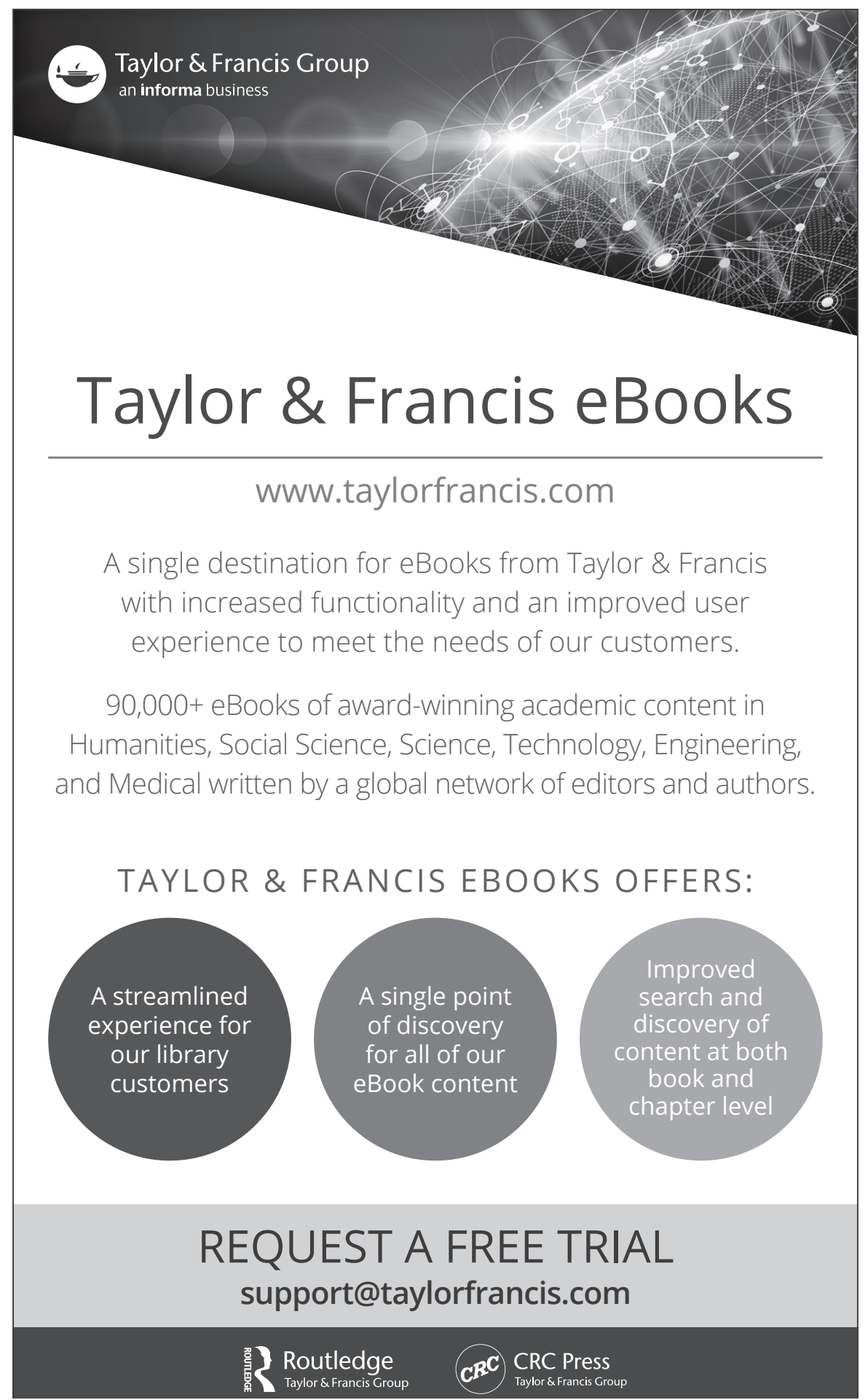

